Science, Technology, and Medicine in the Modern Japanese Empire

Edited by

David G. Wittner and Philip C. Brown

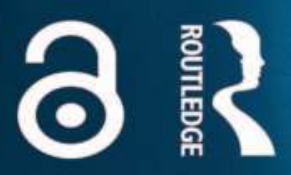




\section{Science, Technology, and Medicine in the Modern Japanese Empire}

Science, technology, and medicine all contributed to the emerging modern Japanese empire and conditioned key elements of post-war development. As the only emerging non-Western country that was a colonial power in its own right, Japan utilized these fields not only to define itself as racially different from other Asian countries and thus justify its imperialist activities, but also to position itself within the civilized and enlightened world with the advantages of modern science, technology, and medicine.

This book explores the ways in which scientists, engineers, and physicians worked directly and indirectly to support the creation of a new Japanese empire, focusing on the eve of World War I and linking their efforts to later post-war developments. By claiming status as a modern, internationally engaged country, the Japanese government was faced with having to control pathogens that might otherwise not have threatened the nation. Through the use of traditional and innovative techniques, this volume shows how the government was able to fulfil the state's obligation to protect society to varying degrees. The contributors push the fields of the history of science, technology, and medicine in Japan in new directions, raising questions about the definitions of diseases and the false starts in advancing knowledge and highlighting the very human nature of fields which, on the surface, seem to non-specialists to be highly rational.

Challenging older interpretative tendencies, this book highlights the vigor of the field and the potential for future development. Therefore, it will be of huge interest to students and scholars of Japanese history, Asian history, the history of science and technology, and the history of medicine.

David G. Wittner is a professor of East Asian history and Director of the Center for Historical Research at Utica College, USA.

Philip C. Brown is a professor at The Ohio State University, USA, specializing in early modern and modern Japanese history. 


\section{Routledge Studies in the Modern History of Asia}

1. The Police in Occupation Japan Control, corruption and resistance to reform

Christopher Aldous

2. Chinese Workers

A new history

Jackie Sheehan

3. The Aftermath of Partition in South Asia

Tai Yong Tan and

Gyanesh Kudaisya

4. The Australia-Japan

Political Alignment

1952 to the present

Alan Rix

5. Japan and Singapore in the World Economy

Japan's economic advance into

Singapore, 1870-1965

Shimizu Hiroshi and

Hirakawa Hitoshi

6. The Triads as Business

Yiu Kong Chu

7. Contemporary Taiwanese

Cultural Nationalism

A-chin Hsiau
8. Religion and Nationalism in India The case of the Punjab

Harnik Deol

\section{Japanese Industrialisation}

Historical and cultural perspectives Ian Inkster

10. War and Nationalism in China 1925-1945

Hans J. van de Ven

11. Hong Kong in Transition

One country, two systems

Edited by Robert Ash,

Peter Ferdinand, Brian Hook

and Robin Porter

12. Japan's Postwar Economic Recovery and Anglo-Japanese Relations, 1948-1962

Noriko Yokoi

13. Japanese Army Stragglers and Memories of the War in Japan, 1950-1975

Beatrice Trefalt

14. Ending the Vietnam War

The Vietnamese communists' perspective Ang Cheng Guan 
15. The Development of the Japanese Nursing Profession Adopting and adapting Western influences Aya Takahashi

16. Women's Suffrage in Asia Gender nationalism and democracy

Louise Edwards and Mina Roces

17. The Anglo-Japanese

Alliance, 1902-1922

Phillips Payson O'Brien

18. The United States and Cambodia, 1870-1969

From curiosity to confrontation

Kenton Clymer

19. Capitalist Restructuring and the Pacific Rim

Ravi Arvind Palat

20. The United States and Cambodia, 1969-2000

A troubled relationship

Kenton Clymer

\section{British Business}

in Post-Colonial

Malaysia, 1957-70

'Neo-colonialism' or

'disengagement'?

Nicholas J. White

22. The Rise and Decline of Thai Absolutism

Kullada Kesboonchoo Mead

23. Russian Views of Japan, 1792-1913

An anthology of travel writing David N. Wells
24. The Internment of Western Civilians under the Japanese, 1941-1945

A patchwork of internment Bernice Archer

25. The British Empire and Tibet 1900-1922

Wendy Palace

26. Nationalism in Southeast Asia If the people are with us Nicholas Tarling

27. Women, Work and the Japanese Economic Miracle The case of the cotton textile industry, 1945-1975

Helen Macnaughtan

28. A Colonial Economy in Crisis

Burma's rice cultivators and the world depression of the 1930s

Ian Brown

29. A Vietnamese Royal Exile in Japan

Prince Cuong De (1882-1951)

Tran My-Van

30. Corruption and Good

Governance in Asia

Nicholas Tarling

31. US-China Cold War

Collaboration, 1971-1989

S. Mahmud Ali

32. Rural Economic Development in Japan

From the nineteenth century to the Pacific War

Penelope Francks 
33. Colonial Armies in Southeast Asia Edited by Karl Hack and Tobias Rettig

34. Intra Asian Trade and the World Market

A. J. H. Latham and

Heita Kawakatsu

35. Japanese-German Relations, 1895-1945

War, diplomacy and public opinion Edited by Christian W. Spang and Rolf-Harald Wippich

36. Britain's Imperial Cornerstone in China

The Chinese maritime customs service, 1854-1949

Donna Brunero

\section{Colonial Cambodia's}

'Bad Frenchmen'

The rise of French rule and the life of Thomas Caraman, 1840-1887

Gregor Muller

38. Japanese-American Civilian Prisoner Exchanges and Detention Camps, 1941-45

Bruce Elleman

39. Regionalism in Southeast Asia Nicholas Tarling

40. Changing Visions of East Asia, 1943-93

Transformations and continuities R. B. Smith, edited by

Chad J. Mitcham

41. Christian Heretics in Late Imperial China

Christian inculturation and state control, 1720-1850

Lars P. Laamann
42. Beijing - A Concise History

Stephen G. Haw

43. The Impact of the

Russo-Japanese War

Edited by Rotem Kowner

44. Business-Government Relations in Prewar Japan

Peter von Staden

45. India's Princely States

People, princes and colonialism Edited by Waltraud Ernst and Biswamoy Pati

46. Rethinking Gandhi and Nonviolent Relationality

Global perspectives

Edited by Debjani Ganguly

and John Docker

47. The Quest for Gentility in China Negotiations beyond gender and class

Edited by Daria Berg and

Chloë Starr

48. Forgotten Captives in Japanese Occupied Asia

Edited by Kevin Blackburn and Karl Hack

49. Japanese Diplomacy in the 1950s From isolation to integration Edited by Iokibe Makoto, Caroline Rose, Tomaru Junko and John Weste

50. The Limits of British Colonial Control in South Asia

Spaces of disorder in the Indian Ocean region

Edited by Ashwini Tambe and Harald Fischer-Tiné 
51. On The Borders of State Power Frontiers in the greater

Mekong sub-region

Edited by Martin Gainsborough

52. Pre-Communist Indochina

R. B. Smith, edited by

Beryl Williams

53. Communist Indochina

R. B. Smith, edited by

Beryl Williams

54. Port Cities in Asia and Europe

Edited by Arndt Graf

and Chua Beng Huat

55. Moscow and the Emergence of Communist Power in China, 1925-30

The Nanchang Rising and the birth of the Red Army

Bruce A. Elleman

56. Colonialism, Violence and Muslims in Southeast Asia

The Maria Hertogh controversy and its aftermath

Syed Muhd Khairudin Aljunied

57. Japanese and Hong Kong

Film Industries

Understanding the origins of

East Asian film networks

Kinnia Shuk-ting

58. Provincial Life and the Military in Imperial Japan

The phantom samurai

Stewart Lone

59. Southeast Asia and the Vietnam War Ang Cheng Guan
60. Southeast Asia and the Great Powers

Nicholas Tarling

61. The Cold War and National Assertion in Southeast Asia

Britain, the United States and

Burma, 1948-1962

Matthew Foley

62. The International History of East Asia, 1900-1968

Trade, ideology and the quest for order

Edited by Antony Best

63. Journalism and Politics in Indonesia

A critical biography of Mochtar Lubis (1922-2004) as editor and author

David T. Hill

64. Atrocity and American Military Justice in Southeast Asia

Trial by army

Louise Barnett

65. The Japanese Occupation of Borneo, 1941-1945

Ooi Keat Gin

66. National Pasts in Europe and East Asia

P. W. Preston

67. Modern China's Ethnic Frontiers A journey to the West Hsiao-ting Lin

68. New Perspectives on the History and Historiography of Southeast Asia Continuing explorations Michael Aung-Thwin and Kenneth R. Hall 
69. Food Culture in Colonial Asia A taste of empire

Cecilia Leong-Salobir

70. China's Political Economy in Modern Times

Changes and economic consequences, 1800-2000

Kent Deng

71. Science, Public Health and the State in Modern Asia

Edited by Liping $\mathrm{Bu}$,

Darwin Stapleton and Ka-che Yip

72. Russo-Japanese Relations, 1905-1917

From enemies to allies

Peter Berton

73. Reforming Public

Health in Occupied

Japan, 1945-52

Alien prescriptions?

Christopher Aldous

and Akihito Suzuki

74. Trans-Colonial Modernities in South Asia

Edited by Michael S. Dodson and Brian A. Hatcher

75. The Evolution of the Japanese Developmental State

Institutions locked in by ideas

Hironori Sasada

76. Status and Security in Southeast Asian States

Nicholas Tarling

77. Lee Kuan Yew's

Strategic Thought

Ang Cheng Guan
78. Government, Imperialism and Nationalism in China

The Maritime Customs Service and its Chinese staff

Chihyun Chang

79. China and Japan

in the Russian

Imagination, 1685-1922

To the ends of the Orient

Susanna Soojung Lim

80. Chinese Complaint Systems

Natural resistance

Qiang Fang

81. Martial Arts and the Body

Politic in Meiji Japan

Denis Gainty

82. Gambling, the State and Society in Thailand, c.1800-1945

James A. Warren

83. Post-War Borneo, 1945-1950

Nationalism, Empire

and state-building

Ooi Keat Gin

84. China and the First Vietnam

War, 1947-54

Laura M. Calkins

85. The Jesuit Missions to China and Peru, 1570-1610

Ana Carolina Hosne

86. Macao - Cultural Interaction and Literary Representations Edited by Katrine K. Wong and C. X. George Wei

87. Macao - The Formation of a Global City

Edited by C. X. George Wei 
88. Women in Modern Burma

Tharaphi Than

89. Museums in China

Materialized power and

objectified identities

Tracey L. $-D$. Lu

90. Transcultural Encounters

between Germany and India

Kindred spirits in the 19th and

20 th centuries

Edited by Joanne Miyang Cho,

Eric Kurlander and

Douglas T. McGetchin

91. The Philosophy of Japanese

Wartime Resistance

A reading, with commentary, of the complete texts of the Kyoto School discussions of "The Standpoint of World History and Japan"

David Williams

92. A History of Alcohol and Drugs in Modern South Asia

Intoxicating affairs

Edited by Harald Fischer-Tiné and Jana Tschurenev

93. Military Force and Elite Power in the Formation of Modern China Edward A. McCord

94. Japan's Household Registration System and Citizenship

Koseki, identification

and documentation

Edited by David Chapman

and Karl Jakob Krogness

95. Itō Hirobumi - Japan's First

Prime Minister and Father of the Meiji Constitution

Kazuhiro Takii
96. The Non-Aligned Movement and the Cold War

Delhi - Bandung - Belgrade

Edited by Nataša Mišković,

Harald Fischer-Tiné, and

Nada Boškovska

97. The Transformation of the

International Order of Asia

Decolonization, the Cold War,

and the Colombo Plan

Edited by Shigeru Akita,

Shoichi Watanabe and

Gerold Krozewski

98. Xinjiang and the Expansion of

Chinese Communist Power

Kashghar in the early

twentieth century

Michael Dillon

99. Colonial Counterinsurgency and

Mass Violence

The Dutch Empire in Indonesia

Edited by Bart Luttikhuis and

A. Dirk Moses

100. Public Health and

National Reconstruction in

Post-War Asia

International influences, local transformations

Edited by Liping $\mathrm{Bu}$

and Ka-che Yip

101. The Pacific War

Aftermaths, remembrance

and culture

Edited by Christina Twomey

and Ernest Koh

102. Malaysia's Defeat of Armed Communism

The second emergency, 1968-1989

Ong Weichong 
103. Cultural Encounters and Homoeroticism in Sri Lanka

Sex and serendipity

Robert Aldrich

104. Mobilizing Shanghai Youth

CCP internationalism,

GMD nationalism and

Japanese collaboration

Kristin Mulready-Stone

105. Voices from the Shifting

Russo-Japanese Border

Karafuto / Sakhalin

Edited by Svetlana Paichadze

and Philip A. Seaton

106. International Competition in

China, 1899-1991

The rise, fall, and restoration of the Open Door Policy

Bruce A. Elleman

107. The Post-war Roots of Japanese Political Malaise

Dagfinn Gatu

108. Britain and China, 1840-1970

Empire, finance and war

Edited by Robert Bickers and

Jonathan Howlett
109. Local History and War

Memories in Hokkaido

Edited by Philip A. Seaton

110. Thailand in the Cold War

Matthew Phillips

111. Early Modern Southeast

Asia, 1350-1800

Ooi Keat Gin and Hoang Anh Tuan

112. Managing Famine, Flood and Earthquake in China

Lauri Paltemaa

113. Science, Technology, and Medicine in the Modern Japanese Empire

Edited by David G. Wittner

and Philip C. Brown

114. Street Performers and Society in Urban Japan, 1600-1900

Gerald Groemer 


\section{Science, Technology, and Medicine in the Modern Japanese Empire}

Edited by

David G. Wittner and Philip C. Brown 
First published 2016

by Routledge

2 Park Square, Milton Park, Abingdon, Oxon OX14 4RN

and by Routledge

711 Third Avenue, New York, NY 10017

Routledge is an imprint of the Taylor \& Francis Group, an informa business

(C) 2016 David G. Wittner and Philip C. Brown

The right of the editors to be identified as the authors of the editorial material, and of the authors for their individual chapters, has been asserted in accordance with sections 77 and 78 of the Copyright, Designs and Patents Act 1988.

With the exception of Chapter 14, no part of this book may be reprinted or reproduced or utilised in any form or by any electronic, mechanical, or other means, now known or hereafter invented, including photocopying and recording, or in any information storage or retrieval system, without permission in writing from the publishers.

Chapter 14 of this book is available for free in PDF format as Open Access at www.tandfebooks.com. It has been made available under a Creative Commons Attribution-Non Commercial-No Derivatives 3.0 license.

Trademark notice: Product or corporate names may be trademarks or registered trademarks, and are used only for identification and explanation without intent to infringe.

British Library Cataloguing in Publication Data

A catalogue record for this book is available from the British Library

Library of Congress Cataloging in Publication Data

Names: Wittner, David G., editor. | Brown, Philip C., 1947- editor.

Title: Science, technology, and medicine in the modern Japanese Empire / edited by David G. Wittner and Philip C. Brown.

Description: New York, NY : Routledge, [2016] I Includes bibliographical references and index.

Identifiers: LCCN 2015026491| ISBN 9781138905337 (hardback) | ISBN 9781315695914 (ebook)

Subjects: LCSH: Japan--History--1868- | Medicine--Japan--History. | Science--Japan--History. | Technology--Japan--History.

Classification: LCC DS881.9 .S34 2016 | DDC 509.52--dc23

$\mathrm{LC}$ record available at http://lccn.loc.gov/2015026491

ISBN: 978-1-138-90533-7 (hbk)

ISBN: 978-1-315-69591-4 (ebk)

Typeset in Times New Roman

by Taylor \& Francis Books 
To James R. Bartholomew, educator, mentor and friend, whose work has inspired a new generation of historians of Japanese science, technology, and medicine. 
This page intentionally left blank 


\section{Contents}

List of figures $\quad$ XV

List of contributors $\quad$ xvi

Acknowledgement xxi

Note on transliteration $\quad x$ xii

Introduction 1

DAVID G. WITTNER AND PHILIP C. BROWN

1 On science and faith in the life of a Meiji engineer 17 ALEKSANDRA KOBILJSKI

2 Academia-industry relations: interpreting the role of Nagai Nagayoshi in the development of new businesses in the Meiji period and beyond

JULIA S. YONGUE

3 An emperor's chemist in war and peace: Sakurai Joji during the Russo-Japanese War and World War I KIKUCHI YOSHIYUKI

4 Buddhism contra cholera: how the Meiji state recruited religion against epidemic disease WILLIAM D. JOHNSTON

5 The influenza pandemic of 1918, Taishō Democracy and freedom of the press during the Siberian Intervention SUMIKO OTSUBO

6 The politics of manic depression in the Japanese empire JANICE MATSUMURA

7 A colony or a sanitorium? A comparative history of segregation politics of Hansen's disease in modern Japan 


\section{xiv Contents}

8 "They are not human": Hansen's disease and medical responses to Hōjō Tamio

KATHRYN M. TANAKA

9 Dr. Baelz's Mongolian spot: German medicine, discourse of race in Meiji Japan, and the local response

ROTEM KOWNER

10 When precision obscures: disease categories related to cholera during the Sino-Japanese War (1894-1895)

ROBERTO PADILLA

11 Kampō in wartime Sino-Japanese relations: the Association of East Asian Medicine and the search for a tripartite medical partnership

NORIHITO MIZUNO

12 The question of research in prewar Japanese physics ITO KENJI

13 Architects of $\mathrm{ABC}$ weapons for the Japanese empire:

microbiologists and theoretical physicists

TOMOKO Y. STEEN

14 The science of population and birth control in post-war Japan HOMEI AYA

Afterword: is there anything unique about modern Japanese science? JAMES R. BARTHOLOMEW 


\section{List of figures}

2.1 Nagai's sketch of Dainippon's first production site

2.2 Nagai Nagayoshi and the 21 founders of the "new" Dainippon (Osaka) 39

2.3 Photograph of one of Nagai's visits to the Naikoku laboratory 41

2.4 Nagai's visit to Merck's Japanese garden 45

4.1 Kimura Takejirō, Defeating cholera (Korera taiji), 1886

4.2 Utagawa Kuniyoshi, Effective medicines for treating the epidemic (Hayari yamai kusuri no chikamichi), 1858

4.3 Admonitions regarding cholera prevention (Korera yobō no satoshi) - cover and first page of woodblock print edition

4.4 Admonitions regarding cholera prevention (Korera yobō no satoshi) - first page of sutra chapbook edition

5.1 Ambulatory patients disembarking the Japanese Red Cross hospital train

5.2 Patients leaving the Vladivostok Army Hospital returning to Japan

5.3 Censored coverage of the Rice Riots in the Osaka Asahi (August 15, 1918)

5.4 A proposal to discontinue regulations on newspaper reporting, originally suggested by the Ministry of the Army in 1914

5.5 "The formidable enemy of the expeditionary troops: Turning from influenza to malignant pneumonia, a thousand and some hundreds in field hospitals"

8.1 Hōjō Tamio, by Tojo Koichi (1936) 132

8.2 Hōjō Tamio upon institutionalization (1934)

8.3 Medical staff and sufferers who were light cases provide care for seriously ill sufferers, Zensei Hospital (1919). Note the nurse's mask and head covering to prevent contagion

$\begin{array}{lll}\text { 8.4 A ward for seriously ill cases, Zensei Hospital (1933) } & 141 \\ \text { 9.1 Erwin Baelz: a bust at the University of Tokyo } & 149\end{array}$

9.2 "The Mongol spot seen in a seven-year old Japanese girl" 151

9.3 Baelz's typology of the Japanese "race": the Manchu-Korean type, the Malayan-Mongol type, and the Ainu type 


\section{List of contributors}

James R. Bartholomew taught modern Japanese history in the Department of History at The Ohio State University from 1971 to the end of 2012 and is now Professor Emeritus. The history of medicine and science in Japan has been his principal research focus for many years. Recent publications include "Toward a History of Christian Scientists in Japan," in Kevin M. Doak, ed. Xavier's Legacies: Catholicism in Modern Japanese Culture (Vancouver: UBC Press, 2011, 47-63) as well as an essay about Japan's first Nobel Laureate in Chemistry, Ken'ichi Fukui. See "Ken'ichi Fukui," in Noretta Koertge, ed. New Dictionary of Scientific Biography (Farmington Hills, MI: Charles Scribners/Thomson Gale, 2007, vol. II, 85-89). He is presently working on a book about Japanese candidates for the Nobel prizes in physiology or medicine, physics, and chemistry during the first half of the twentieth century, including the joint German-Japanese project (1910-1915) of Paul Ehrlich and Sahachiro Hata that introduced chemotherapy to modern clinical medicine.

Philip C. Brown is Professor of Japanese and East Asian history at The Ohio State University. He has published widely in both Japanese and English on the history of rural Japan, landholding, state-society relations, environmental history and the history of technology in early modern and modern Japan. His most recent book is Cultivating Commons: Joint Land Ownership in Early Modern Japan (University of Hawaii Press, 2011). He is a co-editor, with Bruce Batten, of Environment and Society in the Japanese Islands: From Prehistory to the Present (Oregon State University Press, 2015). His current research on Japan's changing responses to flood risk during the nineteenth and twentieth centuries has been supported by grants from the National Endowment for the Humanities, the National Science Foundation, the Fulbright and Fulbright-Hays programs.

Hirokawa Waka is an Associate Professor of medical history at Senshu University. Her work is focused on community responses to state policies targeting Hansen's disease in the first half of the twentieth century. She is the author of Kindai Nihon no Hansen-byō mondai to chiiki shakai (The Problems of Hansen's Disease and Regional Communities in Modern 
Japan, 2011), and the co-translator of Ann Janetta's The Vaccinators (Shutō Denrai, 2013). Among her current projects are studies titled "Rethinking the Relationship Between Poverty, Social Status and Disease in Modern Japan's Regional Communities" and "Constructing a New Archival Science Theory Based on Medical Materials."

Homei Aya is a Wellcome Trust Fellow at the University of Manchester. She received her Ph.D. at the Centre for the History of Science, Technology and Medicine at the University of Manchester and has worked on midwifery, fungal infection and radiation sickness. She is the co-author with Professor Michael Worboys of Fungal Disease in Britain and the United States 1850-2000: Mycoses and Modernity (Palgrave Macmillan, 2013). Currently, Aya is working on the research project funded by the Wellcome Trust titled "Family Planning, Health Promotion and Global Medicine, 1945-1995: The Activities of Japanese Health Campaigners Around the World."

Ito Kenji is an Associate Professor of the Department of Evolutionary Studies of Biosystems at SOKENDAI (the Graduate University for Advanced Studies), Hayama, Japan. He earned his Ph.D. in 2002 at Harvard University in the history of science. His main area research is the cultural history of physical sciences and technology in twentieth-century Japan. He has published articles on the history of quantum physics in Japan, the dissemination of the Feynman diagrams, cultural images of robots and atomic bombs, and amateur videogame culture in contemporary Japan. He is currently working on a biography of Nishina Yoshio and a book on the introduction of quantum mechanics into Japan.

William Johnston received his BA from Elmira College in Elmira, New York, and his MA in Regional Studies East Asia and Ph.D. in history and East Asian languages, both from Harvard. He is Professor of History, East Asian studies, and science in society at Wesleyan University, where he was also a faculty fellow at the College of the Environment for the 2012/13 academic year. Most of his publications focus on the history of disease and medicine in Japan.

Kikuchi Yoshiyuki is an Associate Professor at SOKENDAI (The Graduate University for Advanced Studies), Hayama, Japan. He earned a Ph.D. in the history of science, technology and medicine at the Open University, Milton Keynes, UK, and held postdoctoral positions at the Chemical Heritage Foundation, MIT, Harvard University, and the International Institute for Asian Studies, Leiden. Kikuchi's research has focused on the history of chemistry, laboratory design, higher education, and international cooperation for science in modern Japan, Britain, and the United States. He is the author of Anglo-American Connections in Japanese Chemistry: The Lab as Contact Zone (Palgrave Macmillan, 2013).

Aleksandra Kobiljski is an Associate Professor at the French National Center for Scientific Research (CNRS). She is based at the Center for Research of 
China, Korea, and Japan at the École des Hautes Études des Sciences Sociales in Paris. Since 2011 she has been researching and writing on technology and material aspects of the Meiji period. Tentatively entitled "Engineering the Restoration," the work draws on production and government archives as well as memoirs of engineers involved in literarily building the new Japan or atarashi nippon. Kobiljski's research has been funded by the Japan Foundation, Social Science Research Council (SSRC), and D. Kim Foundation.

Rotem Kowner is Professor of Japanese history and culture at the University of Haifa, Israel. His research focuses on the cultural and racial nexus between Japan and the West since the early modern period as well as wartime behavior and attitudes in modern Japan. Among his recent books are From White to Yellow: The Japanese in European Racial Thought, 1300-1735 (McGill Queen's University Press, 2014) and the co-edited volumes Race and Racism in Modern East Asia: Western and Eastern Constructions (Brill, 2013) and Race and Racism in Modern East Asia: Interactions, Nationalism, Gender and Lineage (Brill, 2015).

Janice Matsumura is an Associate Professor at Simon Fraser University, Canada, specializing in twentieth-century Japanese history. The focus of her past research has been on the relationship between state propaganda and medical policies, and she has contributed to such journals as Gender and History, Modern Asia Studies, and the Bulletin of the History of Medicine. She is currently conducting a study of Japanese colonial psychiatry.

Norihito Mizuno is Professor of East Asian studies in the Global Studies Program at Akita International University, Akita, Japan. His research interests are broadly Japanese-East Asian relations. He currently focuses on Japanese communities in China in the modern period before 1945, especially on educational institutions for Japanese children in overseas Japanese communities, and some related issues to Japanese overseas education in the past and present. His latest publications include "The Search for Educational Betterment in a Foreign Land: A Study of the North China Japanese Elementary School Principals' Conference," International Journal of Social Science and Humanity, 4: 1 (January 2014), 74-82; "The Japanese Overseas Educations: Its Current State and Problems," International Proceedings of Economic Development and Research, 64: (April 2013), 45-50.

Sumiko Otsubo is Professor of history at Metropolitan State University, St. Paul, Minnesota. Her recent publications include "Fighting on Two Fronts: Japan's Involvement in the Siberian Intervention and the Spanish Influenza Pandemic of 1918" in The Decade of the Great War: Japan and the Wider World in the 1910s, edited by Tosh Minohara, Tze-ki Hon and Evan Dawley (Leiden, the Netherlands: Brill, 2014), "Nichibei yūseigaku no setten: Shokubutsu gakusha Yamanouchi Shigeo o chūshin to shite" in Seimei no rinri, edited by Kiyoko Yamazaki, vol. 3 (Kyūshū Daigaku 
Shuppankai, Fukuoka, Japan, 2013), 131-160, and "Emperor, Family, and Modernity: The Passage of the 1940 National Eugenics Law" in Tumultuous Decade: Japan's Challenge to the International System, 1931-41, edited by Kimura Masato and Tosh Minohara (Toronto: University of Toronto Press, 2013), 69-100.

Roberto Padilla is an Associate Professor and Director of Graduate Studies in the Department of History at the University of Toledo in Toledo, Ohio. He works on the history of medicine in nineteenth-century Japan, with an emphasis on the intersections between policy, identity, medical institutions, nursing, and disease. He is currently working on a monograph-length work on cholera during the Sino-Japanese War (1894-1895).

Tomoko Y. Steen is currently an Adjunct Professor at Georgetown Medical School while holding a tenured position with Library of Congress. She has a Ph.D. from Cornell University from the Department of Science and Technology Studies jointly with the Section of Ecology and Evolution and affiliated with Asian Studies. Her dissertation was on nearly neutral evolution and the work of Tomoko Ohta. Steen's postdoctoral training is on antibiotic resistant strains and was conducted at Emory and Harvard universities. Her current project is on the biological effects of radiation, both historically and scientifically. Steen is an associate editor for the Journal of Heredity (Oxford University Press) and also an advisor to the Schull Institute.

Kathryn Tanaka is Lecturer in the Department of Cultural and Historical Studies of Otemae University. A scholar of Japanese and comparative literature, her current research interests explore community creation through writing and the intersections of medicine and literature. Her publications include "Contested Histories and Happiness: Leprosy Literature in Japan," in Health, Culture and Society, 5: 1 (2013) and "Senzen Nihon no Hansenbyō no ryōyōjo ni okeru tanka ni yoru koryū-Kyushu ryōyōjo no "Hinokagekai"wo chūshin ni" in Hansen-byō shimin gakkai nenpō 2013 (July 2014). She is at present finishing her book manuscript, Through the Hospital Gates: Hansen's Disease and Modern Japanese Literature.

David G. Wittner is Professor of East Asian history and Director of the Center for Historical Research at Utica College in Utica, New York. His work focuses on questions of industrial technology transfer, technological choice, and cultural perceptions of technology in late nineteenth and early twentieth-century Japan. He is the author of several articles and books including Technology and the Culture of Progress in Meiji Japan (Routledge, 2008) that look at the modernization of Japan's iron smelting and silk reeling industries.

Julia S. Yongue is Professor in the Faculty of Economics of Hosei University in Tokyo, Japan. Her research focuses on the development of the Japanese pharmaceutical industry including the policies and regulations that have 


\section{$\mathrm{xx} \quad$ List of contributors}

shaped it from the Meiji period to the present. She has written on a variety of themes such as the introduction of clinical trial regulations via $\mathrm{ICH}$ (International Conference on Harmonization of Technical Requirements for Registration of Pharmaceuticals for Human Use) and their influence on industry; the globalization of Japanese pharmaceutical firms; and the Japanese vaccine industry. She and other members of the Japanese Society for the History of Pharmacy are currently writing an encyclopedia on the history of pharmacy_-both Western and traditional - in Japan. 


\section{Acknowledgement}

While an edited volume such as this cannot note the many people who contributed to the research presented in each article, we would be remiss if we did not acknowledge the generous financial support of the Northeast Asia Council of the Association for Asian Studies, and the Mershon Center for International Security Studies, the Office of International Affairs, the College of Humanities, the East Asian Studies Center, the Institute for Japanese Studies and the Department of History, all of The Ohio State University. Finally, each of the editors wishes to acknowledge the contribution of the other to this entire effort and the writing of the jointly authored introduction. Each has brought different perspectives and talents to the project from its inception, without which none of this would have come to fruition. Throughout the contributions of each editor have been on a very even par with the other.

Philip C. Brown David G. Wittner 


\section{Note on transliteration}

We have followed East Asian convention, listing family names before given names. Unless typically found otherwise, Romanization is according to the modified Hepburn system. Japanese words commonly used in the English language such as Tokyo or Kyoto are neither italicized nor contain macrons. 


\title{
Introduction
}

\author{
David G. Wittner and Philip C. Brown
}

The histories of science, technology, and medicine (STM) in Japan are small but important fields, writings of which have often been subsumed under the auspices of other sub-disciplines such as economic or labor history. Given Japan's reputation for technological innovation plus solid record of Nobel Prize laureates in both science and medicine, and nearly one hundred nominees, this is surprising. Yet until recently historians writing for an English language audience have largely neglected or stereotyped the histories of STM in Japan.

There is no simple explanation for the lack of scholarly attention to Japan's accomplishments in science, technology, engineering, and medicine. One suggestion is that the historic lack of attention to Japanese STM in Western language literature resulted from the fields having no unifying authority like Joseph Needham or corpus of knowledge such as that he accumulated in the fields of Chinese science, technology, and medicine through his monumental History of Science and Civilization in China project. Perhaps this neglect derives from the comparatively late correction of the erroneous belief that Japan lacked fundamentally innovative scientific, medical, and technological traditions. Regardless, a reputation for imitation and marginal innovations, ${ }^{1}$ occasionally punctuated by more important developments, long dominated academic and popular images of the nation's contributions to fields considered essential to the rational understanding of our universe and that could help humans manipulate their environment. Early on, advances in consumer electronics were recognized with jibes: Charles de Gaulle referred sarcastically to Prime Minister Sato Eisaku as a "transistor salesman." Japan's increased visibility in the global economy was recognized as partly built on innovations in quality control, but opprobrium for such accomplishments was often buried under a broader disparaging reputation of Japanese as "economic animals" and the country as a whole as "Japan, Inc." When Japanese scientists were nominated for Nobel awards, the press, of course, focused on winners, not also-rans.

Such a stereotyped view may still dominate sectors of popular consciousness, but it has become increasingly untenable in the context of our contemporary consumer society, and certainly in the academic world. Japanese scientists now appear regularly among the annual lists of Nobel winners. 


\section{David G. Wittner and Philip C. Brown}

Since 1949, some fourteen Japanese have been Nobel laureates in chemistry and physics: Yukawa Hideki, Tomonaga Sin'itirō, Kobayashi Makoto, Masakawa Toshihide, and Nambu Yoichirō, Fukui Kenichi, Shirakawa Hideki, and Tanaka Koichi, to name some of the best-known among them. Product innovation, medical research, and engineering prowess from Japan earn accolades without the sarcasm of the 1960s, 1970s and early 1980s. Ubiquitous consumer products such as the compact disc player, the Sony Walkman and Discman, Blu-ray discs, pocket calculators, quartz watches, flat panel displays, and SLR digital cameras are all Japanese inventions. The portable electrocardiograph and esophagogastroduodenoscope are just two ground-breaking medical devices of Japanese origin, and Japanese developed industrial devices such as the power loom and new industrial materials like KS non-magnetic steel.

Studies of Japanese science and medicine shared similar trajectories. Initially they read as studies of exceptions to an undistinguished norm. Japan, it seemed, had no science until the modern era. To that time, Japanese medicine was an admixture of Chinese and outdated Western medicine gleaned through trade with the Dutch. ${ }^{2}$ Of course there were breakthroughs, the exceptions, such as Hanaoka Seishu's first documented surgery under general anesthesia in 1804, or Takamine Jōkichi's discovery of epinephrine in $1900{ }^{3}$ These histories read as lists of firsts, discoveries of isolated scientific or medical bits rather than explorations of Japan's larger corpus of scientific or medical knowledge. This long-standing, broad trend in the field of STM studies has now come under sharp criticism. ${ }^{4}$

Marginalization of Japan's experience began to recede with the works of historians such as the late Nakayama Shigeru in Japan and James Bartholomew in the English language world. Both took Japanese science and medicine out from under the lens of discovery and lists of "firsts" and situated them within the context of the greater scientific and medical communities. ${ }^{5}$ They helped to institutionalize the history of Japanese science and medicine as legitimate fields of study. Yet these efforts long remained sparse exceptions and did not lead quickly to an expansion of the field.

The history of Japanese technology has suffered a fate similar to that of science and medicine. For many historians writing prior to the 1980s, Japan is portrayed as a country of imitators, adapters at best but rarely innovators. ${ }^{6}$ The story is familiar. Following Japan's opening to the West in the mid-nineteenth century, Japanese officials sought the latest technologies in order to modernize the new nation. The government simultaneously hired foreign advisers and imported what it thought were the most modern Western technologies, which often failed to perform as expected. ${ }^{7}$ Here the story bifurcates. One trend describes how, after years of imitation-based trial and error, the Japanese gained sufficient experience with their imported technologies to adapt them to local circumstances and eventually achieve success in production but not in technological development. ${ }^{8}$ A second albeit somewhat more nationalistic rendition describes Japanese engineers as realizing they were sold a bill of goods by greedy foreigners and then turning to indigenous technologies that 
led to success in manufacturing through diligence, hard work, and the adaptation of foreign technologies to unique Japanese circumstances. ${ }^{9}$ Regardless of the approach, histories based on these assumptions were neither wholly accurate nor did they help us understand how a society could rather quickly adopt and adapt to its own cultural framework a set of sophisticated methods, frameworks of thought and institutions that provided a foundation for broadly independent modern technological and engineering development. ${ }^{10}$

It would be nice to say that a publication or select set of publications had resulted in an immediate stream of new approaches that advanced the field, but developments have moved more slowly. It may not be especially surprising that in the realm of Japanese history, where the challenges of language loom so large, a rapid change did not occur outside Japan. That said, the histories of science, technology, engineering and medicine have witnessed a steady growth since the 1950s, a trend apparent in both journal articles and monographic publications.

One measure of a change after the 1960s is the growth of academic journals that devote significant attention to the history of science, medicine, technology, and engineering in Japan. Although the subject range of these journals extends well beyond coverage of a single culture, articles focused on Japan have appeared with regularity. Historia Scientiarum, the journal of the History of Science Society of Japan, began publication in 1962, part of an effort of a small but dedicated group of Japanese historians of science, technology, and medicine to link their work to the broader concerns of the field elsewhere in the world by publishing in English, French, and German. The journal formerly known as Chinese Science began to actively broaden its focus to include Japan in the late 1980s under the leadership of Nathan Sivin. ${ }^{11}$ Reflecting the effort to expand its coverage, in 1999 the journal changed its title to East Asian Science, Technology, and Medicine (published by the International Society for the History of East Asian Science, Technology, and Medicine). While staying close to its roots in the Chinese experience, increasingly EASTM publishes work on Japan. East Asian Science, Technology, and Society: An International Journal published its first issue in December of 2007. Its pages largely balance treatments of China, Japan, and Korea, as well as containing articles on history of colonial and Southeast Asian STM. ${ }^{12}$

The increase in specialized journals tells only part of the story, one matched by the growing number of scholarly monographs in the history of STM in Japan. These works cut across fields, engaging people in Japanese studies on the one hand and the history of science, technology, engineering, and medicine on the other. For practitioners of Japanese studies, such research represents a useful way to understand more about Japanese history and society. They are less interested in contemporary issues in the history of science, technology, and medicine and are likely to refer to specialized STM journals only on occasion. Conversely, the latter group are interested in the contribution that Japanese history studies can make to their special interests in the history of medicine, the history of technology, or the history of science. They are much 


\section{David G. Wittner and Philip C. Brown}

less interested in more limited studies that focus on Japan or even East Asia per se.

Beginning in the 1980s, historians such as Penelope Francks started to take a more broadly based and nuanced approach to Japan's technological development. ${ }^{13}$ While it could not be denied that the Japanese had imported and borrowed Western technological artifacts and hired foreign advisers, the history of indigenous technological developments and indigenous technological traditions could not be ignored. Japanese technology was placed in its social and cultural settings. ${ }^{14}$ Historians looked for Tokugawa roots to Meiji technological developments, examined social networks, and discovered a tradition of Japanese craftsmanship and engineering that flourished independent of Western influence. ${ }^{15}$ By sending promising students abroad, the Japanese government and businessmen created their own sources of technological know-how as opposed to importing foreign experts. Whether working with Western or indigenous technologies, these men created a tradition of technological innovation in Japan. ${ }^{16}$

Among the early works that adopted this approach, one work drew particular attention in the realm of the history of science: The Formation of Japanese Science by James R. Bartholomew, won the 1992 Pfizer Award of the History of Science Society and marked a new high point for the field of the history of Japanese science by earning accolades beyond the realm of Japan specialists. ${ }^{17}$ Focused on the career of bacteriologist Kitasato Shibasaburō, Bartholomew deftly shows how, in the decades following 1854, the Japanese were able to create a modern scientific research tradition under the influence of Confucian social and cultural values of the Tokugawa period.

The history of medicine has remained a site of significant activity since the 1990s, especially at the strategic intersections of disease and society. Ann Jannetta's 2009 prize-winning study, The Vaccinators, is a perfect example of a STM history that is more than a simple study of a disease or its treatment. ${ }^{18}$ Jannetta shows how physicians changed the institutional face of Japanese medicine prior to the Meiji Era. Working across the Tokugawa-Meiji divide Ellen Gardener Nakamura (Practical Pursuits) focuses on the local significance of the introduction of Western medicine into Japan. ${ }^{19}$ As with Jannetta, we see the indigenization of foreign medicine. Historians such as Alexander Bay (Beriberi in Modern Japan) have shown the role of medicine and science in empire building in the nineteenth and twentieth centuries. ${ }^{20}$

In the history of physics, two recent studies exemplify the application of a more holistic approach to understanding the evolution of science in Japan. Dong-won Kim has done for Japanese physicist Nishina Yoshio what Bartholomew did for Kitasato. Yoshio Nishina: Father of Modern Physics in Japan is an important study of physics and a scientist's role, albeit controversial, within the scientific community and state, especially in the immediate post-war era. ${ }^{21}$ Following Kim's lead, Morris F. Low examines the lives of seven physicists in Science and the Building of a New Japan and their relationship to the state, national rebuilding, and the formation of their own identities. ${ }^{22}$ The intention of these 
studies is not simply to celebrate great men and their achievements but rather to situate the men and their science into the socio-cultural and political factors from which they arose. Through the studies of key individuals, some of whom were Nobel Prize laureates, these authors also succeed in connecting science and state.

Exhibiting a trajectory that parallels growth in the history of science and medicine, the last twenty years have also seen a transformation in the way historians of technology ply their craft. Alongside studies that make technology their central focus are numerous works that reflect the broad contexts to which authors link their treatment of technology. Publishers and others have even categorized a number of such works as belonging to other fields, e.g. economic, business, environmental history, or material culture, Jeffrey Alexander's Japan's Motorcycle Wars is just one example. ${ }^{23}$ A cutting-edge business history of the industry, Alexander traces the lineage and social significance of this technology from its Meiji-era introduction through the Pacific War, tying together industry, government, and research institutions. Brett Walker's Toxic Archipelago typically considered environmental history, is a study of the interaction between technology, man, and the environment. ${ }^{24}$ Some authors, taking a path similar to that of Bruno Latour, explore very rudimentary technologies. ${ }^{25}$ For example, Martha Chaiklin has looked at everything from shoes to hair combs and plate glass, situating everyday objects in their greater cultural and political contexts. $^{26}$ David G. Wittner (Technology and the Culture of Progress) has looked at the physical technologies of the iron and silk reeling industries, arguing that technology transfer and choice of technique were infused with cultural and political attitudes toward the nature of machines and buildings rather than a particular technology's utility. ${ }^{27}$

A number of recent Japan-centered histories of STM monographs attract attention from broader audiences because of their subject. At least five recent books deal directly with the link between science, technology, medicine and the establishment and control of the Japanese continental empire, and another deals with Japan's secret weapons during World War II: Louise Young devotes some attention to science and technology as part of an overall treatment of the "culture of Imperialism" in Japan's Total Empire, and Janice Mimura's Technocratic Visions of Empire looks at the bureaucratic forces that controlled the broad links connecting science, technology and medicine to the colonies in the broad context of colonial administration. More directly addressing science and technology are Hiromi Mizuno, whose Science for the Empire addressed those links specifically in the realm of science, and Daqin Yang, who did so in the realm of telecommunications in his 2010 monograph Technology of Empire. Aaron S. Moore's Constructing East Asia tackled the broad array of academic, engineering, policy, bureaucratic, and other interests that underlay large-scale, even utopian Japanese development exercises in Manchuria and Korea. Finally, Michael Shiyung Liu examined medicine in the Japanese colonies in Prescribing Colonization. Wartime military technology lies at the center of Walter Grunden's Science Under the Rising Sun. ${ }^{28}$ 
English-language scholars continue to build on these earlier developments and follow the decades-old movement in STM history to situate scientific, technical and medical developments in their socio-cultural contexts. That is to say, they explore how these developments connect with other trajectories in modern Japanese history and society. To take but one recent example, Takashi Nishiyama's new study of the development of Japan's "bullet train" examines not only the process of technological innovation but elements of the nature of engineering education, the career trajectories of key technical actors assembled to address the challenges of high speed rail travel, the economic contexts of rebuilding Japan's economy after World War II, and more. Studies demonstrate the myriad ways that these modern traditions grew out of Japan's historical experiences, whether indigenous or influenced by contact with the West or other countries in East Asia.

The increased prominence of STM historical, English-language research is rooted in multiple sources. Some who have published in the field were people trained by Professor Bartholomew, of course. Another source, however, has been people with an interest in the history of these fields whose training took place at institutions where history of science programs were strong and the STM orientation, as much or more than a Japanese studies approach, sparked the research. Gregory Clancy, whose work on the world of seismological studies in Japan has attracted considerable attention, is a case in point. ${ }^{29}$ Trained at M.I.T., his lead advisers were in the history of technology, and that was supplemented by work with renowned modern Japan specialist John Dower, who is not a specialist in the history of science or technology. A clutch of younger scholars fall into this pattern of training. Still others, like William Johnston, carved out a path by which to study and write the history of Japanese medicine - disease, epidemics, and public health — when the field barely existed in the West. These pioneering scholars moved into one or more of the STM fields as interest in one subject raised questions that spanned the intersection of science, medicine, and the like with other fields such as religion. Nor are younger scholars solely approaching these issues from the perspective of the historical disciplines. As Tanaka's essay in this volume shows, specialists in other fields such as literature are also addressing STM-related issues in historical contexts. ${ }^{30}$

In sum, a confluence of personal, professional, and cross-disciplinary developments has yielded an increasing volume of works on the development of science, technology, and medicine in Japanese history. This trajectory follows an increase in interdisciplinary research in the field of science and technology studies more generally. The object of National Science Foundation grant programs, the formation of professional organizations such as the Society for the Social Study of Science, and policy debates in a variety of contexts (e.g. technology's role in disasters), interest in the fields of science, technology, and medicine and their links to other elements in society extends beyond the narrow world of academics to larger social concerns. As in the case of studies in other regional/national contexts, examination of Japan's historical 
experience has much to contribute to understanding of the interplay between these technical fields, society, economic development, and power.

$$
* * * * *
$$

The essays in this volume serve as something of a marker of the current state of studies in the history of science, technology, and medicine in Japan. The contributions span multiple fields, although contributions associated with biology and medicine are most numerous. They present a sampling of some of the most innovative approaches to STM history research to date. This volume's chapters come from an array of international scholars who span generational divides. All were part of a major conference (more than forty papers were presented) held in October 2011 to explore current issues in the field as well as to mark the contributions of James Bartholomew as a scholar, teacher and colleague.

All contributions treat science, technology and medicine in the context of the emerging, late nineteenth century Japanese empire and its immediate aftermath. The term empire has numerous meanings. It can conjure notions of conquest and territorial acquisition, business monopolies, or authoritarian rule. Empire is a controversial term being either compliment or curse depending on the century or who uses the term. In the present volume, the idea of empire, a modern Japanese empire, should be considered in its broadest sense. Herewithin, we are not simply describing the relationship between STM and empire building as a territorially expansive process. Although some essays discuss STM's contributions to empire building in the traditional sense, e.g. forging the tools of conquest, others examine STM within the context of empire and how STM practitioners were subsumed in the discourse of state building within an explicitly self-styled imperial regime that first formally incorporated key lands - Hokkaido and the Ryukyu Islands - now treated as part of Japan.

As a case study of the transfer of science, technology and medicine, Japan is particularly interesting, especially during the period between more intensive contacts with the West in the mid-nineteenth century and the middle of the twentieth century, both because it was not a colony of another country and because it became the first non-Western colonial power in the modern world. The former circumstance provided Japan greater latitude in making choices about what and how to adopt/adapt elements from other contexts and to set its own course. ${ }^{31}$ In the latter context, it filtered both its own ideas and practices and many of those developed in the West to its colonies, matching them to different objectives and priorities than in Euro-American cases, notably the United Kingdom, that form the basis of much of our understanding of cross-cultural movement of science, technology, and medicine.

The essays in this collection are particularly strong in dealing with issues that illuminate the independence with which Japan developed its abilities, institutions, and policies in regard to science, technology, and medicine, but several also address elements of Japan's imperial presence on the Asian 
mainland. Examples of the former include adaptation of Western racial thinking, innovations that adapted iron processing to Japanese circumstances, and more. Examples of the latter address efforts to organize professionals of traditional Chinese medicine on the mainland and techniques for identifying cholera among Chinese and Japanese populations during the Sino-Japanese War.

Within the context of Japan's emergence as a modern imperial state, our authors address the following themes that cut across the sections into which the essays are divided.

Science, technology and medicine was affiliated with a strong sense of national pride and image. As might be anticipated by readers, much of the scholarship here that engages this theme focuses on the development of Western-based ideas of the time. Some of these had lasting impacts, but not all of them survived in the post-war world (e.g., the medical involvement with making hierarchical racial distinctions). Just as interesting, however, was the impact of Western organizational practices on more traditional endeavors in these fields. The most striking example may be the case of Japanese practitioners of traditional East Asian medicine and their efforts to create a regional professional association, an effort that combined pride in past practices with strong undertones of nationalism.

A second theme concerns the degree to which the state was directly involved in promoting any particular scientific, medical or technical endeavor. Given the heavy emphasis in English-language historiography on the role of the state in building a modern economy with its scientific, technical, and medical accoutrements, the diversity of stimuli presented by our authors stands out. Clearly defense/ military-related efforts got state funding, but some of studies here suggest an increasing state involvement with the passage of time, including not only issues of nuclear development but also population management, and the trend shows something of a globalization of concerns as the Cold War emerges. Equally important for technical and scientific development, our authors show clearly that key centers of activity were located in the world of business or the interstices of business and science, not the rarified atmosphere of academic labs or in the halls of central bureaucrats. Here, demands of the market and opportunities to create markets for new products and processes pushed and pulled both researchers and businessmen - sometimes one and the same - to explore new frontiers. Even the academic pursuit of science bled into the commercial realm. Unplanned by the state, many of these activities still promoted economic growth and the scientific and technical foundations that supported long-term state objectives. Finally, at least two essays raise questions about either the ability or the will of the government to effectively and unwaveringly implement its policies. Potential conflicts between the interests of the state (strategic secrecy, promotion of a hierarchical view of Japan and colonial peoples) show what was often a sensitive negotiation between professional interests (primarily medical professionals, but also news professionals reporting on medical issues) and those of the state.

At a popular level, and perhaps at the level of assumptions about science, technology, and medicine more generally, a widespread impression remains, 
one in which these fields are opposed to religion and push it - along with popular beliefs - back from the main explanations of the workings of our world. Some of our authors, Johnston and Kobiljski in particular, show interesting ways in which religion shaped both individual and administrative choices in research and public health policy. Further, Kathryn Tanaka and Hirokawa Waka show ways in which older beliefs and understandings persisted, sometimes for ill, sometimes for the better. Conversely, Padilla demonstrates the limitations of science and medicine - creating impractical standards for diagnosis that turned some scientific approaches to unintentionally destructive ends: misdiagnosis of disease and failure to treat it properly.

While "originality" of Japanese research is something of a bone of contention today, several of our essays clearly show that in the pre-War era Japanese scientists and medical personnel were able to effectively create domestic professional organizations and contacts that earned Japan a respected, if not prominent, place in international circles. In addition, multiple essays show innovations and new perspectives that developed from Japanese research. Finally, they widely address a different kind of creativity than the lofty achievements of Nobel awards by acknowledging that originality was embodied in the very act of transferring patterns of thought, investigation and development from one cultural context to another. Cross-cultural transit of an idea or process was often undertaken for purposes different to those of their original context. Such intellection movements necessarily embraced modification and adaptation into the Japanese social, economic, and material world. In the Japanese response to Western ideas such as smelting technology or German concepts of identifying physical differences thought meaningful in racial discourse and other instances, several authors (including Kobiljski and Kowner, to follow these two examples) show the inapplicability of presuming an unfiltered transmission of Western ideas and techniques to Japan. Adaptation to local supplies of materials, etc., as well as local patterns of thinking modified and transmuted "received knowledge" in important ways. This new "knowledge" was then transmitted by Japan to its growing colonial empire as well as back to Europe, including ways by which Japanese researchers helped to define what it meant to be Japanese and not some other "Asian," to Westerners.

Although there are some ways in which the conclusion of World War II marked important transitions (e.g., a move away from funding military research), several of our authors show that common concerns transcended the war: how to handle population pressures and issues and the transcendence of research in the realm of physics, to name just two with rather positive benefits. Steen shows, too, however, that those highly placed people associated with infamous chemical and biological weapons development likewise survived the transition to post-war Japan in very good shape.

More specifically, each section of this volume reflects a different aspect of empire and empire building and its relationship to science, technology, and medicine. Part I, "Science, Technology, and Industry in the Creation of a New Japan," examines the lives and careers of scientists whose work directly 
or indirectly contributed to building the Japanese Empire. In Chapter 1, Aleksandra Kobiljski discusses Shimomura Kōtarō's conversion to Christianity as tied to his desire to pursue a career as a chemical engineer, treating both as ways of dealing with personal crises of identity and social value created by the changes the Meiji Restoration and its ensuing policies sparked. Although his standing vis-à-vis Christianity changed over his career, he did much to serve the national interest by creating a coking protocol that was efficient and made possible the use of low-quality Japanese coal for coke. Coke, the fuel used in industrial iron production, an essential element at the government's new ironworks at Yawata, relied on Shimomura's battery of coke ovens as the country began mobilizing for the Russo-Japanese War. Shimomura's commitment to science, state, and faith (Christianity or the religion of Jesus, but also other religious ideas) were strengthened after a laboratory accident on the eve of the First World War while working incautiously to recreate chemical processes for Japan to stem future shortages of dyestuffs that he recognized would arise because of the advent of war with Germany, Japan's main supplier. Kobiljiski's combination of history of religion and history of science reveals a striking blending of traditional and practical influences as Japanese sought to adapt to a new world in the late nineteenth and early twentieth centuries, challenging any idea of a facile transformation to completely Western practices of science at both individual and national level.

Julia Yongue examines the career of Nagai Nagayoshi, a pharmaceutical chemist, during the Meiji and Taisho eras. She notes that Nagai, like Shimomura, did not set out to be one of the "Emperor's chemists," but his work in pharmaceuticals contributed to empire building because the drugs he developed worked within the scheme of Japanese imperial expansion, preventing and/or treating diseases in soldiers overseas. As was the case with Shimomura, Nagai also worked for Japanese chemical independence during World War I. His efforts to create private pharmaceutical companies were aided by the Taisho government, which promoted a policy of self-sufficiency through import substitution of dyestuffs and pharmaceutical products. Nagai's career was not just that of a scientist but also that of a multi-talented individual whose activities crossed both intellectual and commercial realms.

The final chapter in this section rounds out the discussion of chemists and empire through Kikuchi Yoshiyuki's examination of Sakurai Jōji, the "Emperor's chemist," who, he argues, bridged the gap between civilian and military through the creation of dual purpose institutions for basic and applied chemical research. Straddling the Russo-Japanese War and World War I, Sakurai parted ways with other chemists to build a scientific tradition intended for use in war and peace. Rather than finding strictly internal stimuli for war-related research, Kikuchi identifies important international linkages that still left plenty of room for Japanese innovation in tactical weapons. Sakurai continued to work his international connections even as he retained considerable nationalist sentiments.

Part II, "State, Experts, and Imperial Medical Policy," explores the varied reactions of the Meiji and Taisho governments and medical practitioners to 
diseases such as cholera, influenza, leprosy, and manic depression that threatened the empire from within and without. William Johnston examines the intersection of disease, religion, and state as the Meiji government enlisted Buddhist organizational and communications media to help fight the spread of cholera in the 1880s. Johnston rightly argues that this was a disease that required state intervention and in his story we see an early manifestation of public health policy at a time when the concept of public health did not yet exist. Yet this effort was one that the state had limited capacity to implement on its own, and therefore relied on private, even recently disparaged, religious organizations.

Sumiko Otsubo focuses her attention on the 1918 influenza pandemic and press censorship, arguing that, unlike many European countries, which censored information related to the spread of the disease, under so-called Taisho democracy the Japanese state did not censor information regarding deaths from influenza among soldiers in the Siberian Expeditionary Force, local peoples whether in Siberia or Japan, allied forces in Siberia, or ships coming to Japan. Given that the Japanese government censored information such as troop locations and ship names, this may be somewhat surprising. Nonetheless, this chapter forces us to reconsider the relationship between state, press, disease, and censorship in the growing empire, arguing that in this instance, openness was a counterpart to Japan's role as an ally of the West in a collaborative military venture that promised a short, easy victory.

In Chapter 6, Janice Matsumura looks at the relationship between manic depression, race, and empire. A less virulent disease than cholera or influenza, Matsumura argues that manic depression nonetheless became integral to the debate over Japanese cultural superiority and national character. Psychiatrists provided evidence to the state that supported notions of "mental fitness" in Japan and her drive for imperial expansion over "less fit" people. Initially seen as a relatively unimportant disease, manic depression later took on greater significance, in part because it helped medicalize problems in Japan's colonies.

The final two chapters in this section examine Hansen's disease, more commonly known as leprosy, and state reactions to the disease. Hirokawa Waka looks at the evolution of state policy toward Hansen's disease sufferers and argues that pre-war and wartime laws and the links between central imperial government and local governments were structured in such a way as to make government incapable of creating a policy of total isolation, as historians once commonly believed (encapsulated in their descriptive term, sakoku, "closed country"). Disease sufferers often self-segregated, creating their own colonies and providing themselves with alternate treatment and living arrangements. State efforts to theoretically limit the spread of the disease restricted these options and eventually supported a policy of total segregation of Hansen's sufferers from society. In Chapter 8, Kathryn Tanaka takes a different approach to the question of Hansen's disease, state, and society by examining Hōjō Tamio's writings as part of the genre of patient writing known as "leprosy literature." Through Hōjō, Tanaka demonstrates the competition between medical staff and the state apparatus on the one hand and on the other the 
perspectives of patients in defining the dominant characteristics of hospitals for Hansen's disease patients. Even the literary world was drawn into debates about the degree to which Hōjō's writings could be validated as literature as opposed to "just" a form of social documentary.

Looking at the evolving empire, Part III, "Medical Specialists and Scientists at Work: Imperialism and War," focuses on defining race, disease, science, and colony and their relationship to the metropole. Chapter 9 examines Japanese and German scientists and the construction of racial identities based on a temporary birthmark known as the Mongol spot. Rotem Kowner demonstrates that Erwin Baelz's theories of Japanese ethnic identity based on the Mongol spot were challenged by Japanese scholars and the Meiji state, both of which sought to distance Japan from its Asian neighbors whose infants shared this same phenomenon. Kowner's chapter illuminates the differing agendas and interests held by both foreign and Japanese scientists in the construction of race during the late-Meiji era, with Japanese trying aggressively to render themselves similar to Europeans, not Asians.

Roberto Padilla continues the discussion of race with his examination of cholera during the Sino-Japanese War. He argues that Japanese physicians' understanding of disease causation changed over time. While leading physicians were aware of bacteriological tests to absolutely confirm cholera, medical personnel generally were unable, and even unwilling, to rely on these tests, choosing instead to treat cholera-like symptoms among non-Japanese Asians as cholera and as catarrh when they appeared among Japanese. Following these policies designed to distinguish Japanese from less "civilized" Asians, military doctors inadvertently concealed the extent of the epidemic and ultimately, even tragically, allowed soldiers to spread cholera back to Japan.

The third section concludes with an examination of state and traditional medical communities in Japan, China, and Manchukuo. Japanese kampō doctors founded the Association of East Asian Medicine in an attempt to forge peace in East Asia through medical partnership. Mizuno Norihito demonstrates that the idealism of the group's founders was frustrated in no small part by their personal limitations of training or experience in foreign languages, and argues that the Association was ultimately unable to achieve its regional objectives as it was co-opted under the banner of Japan's "New East Asian Order." Despite claims that members were part of a greater community of kampō practitioners, Japan's East Asian neighbors became ranked as part of a racial hierarchy beneath Japanese practitioners.

The fourth section, "Scientific Weapons, Technology, and the Transformation of Pacific War Aims," brings together essays that examine the role of scientists from the pre-war era through post-war eras. Ito Kenji begins in Chapter 12 with a study of physicists and their desire to establish a research traditionbasic and applied - in Japan. Positing four realms for consideration (possibility of establishing physics, the legitimacy of the enterprise, strategies for pursuing research and, finally, originality in research), Ito argues that Japanese physicists were successful in legitimating their efforts, capable intellectually of pursuing 
physics, and chose strategies for research and research environments that provided opportunities for them to do important and original work. Struggling to counter prevailing Western beliefs that Japanese were not capable of original research, each of the figures he examines made valuable contributions to the establishment of a research tradition in the field, yet few were recognized for their research achievements per se, in part due to relative isolation from the global activities of physicists elsewhere.

In Chapter 13 Tomoko Steen moves from developing research traditions to applied research in her study of Japan's efforts to build biological, chemical, and atomic weapons during the Pacific War. Steen examines the roles and motivations of two groups of researchers, biologists and physicists, groups that adopted entirely different and significantly contrary agendas vis-à-vis the state. The former group enthusiastically embraced its role producing biological and chemical weapons for the imperial government and war effort. The latter joined the government's cause but with the aim of keeping young physicists from going to war and maintaining their already well-established basic research agenda.

The final chapter examines population science in the service of the state as an outcome of the war. Homei Aya argues that within the context of the collapsed Japanese empire and American imperial expansion, Japanese and American occupation policymakers relied on population science to support post-war reconstruction and created a policy of birth control that could not have been predicted at the time when post-war population was recognized as a problem. Post-war democratization and demilitarization rested in part on developing policies for population control in place of lebensraum.

The volume concludes with an adaptation of the plenary address given by James Bartholomew at the 2011 conference mentioned above. Bartholomew's address touches on a number of themes addressed in this volume, including the problems of validity and recognition, scientific imperialism and issues of racial characterization. These issues are reflected in his discussion of the importance attached to Nobel Prizes in Japan, the effect of international scientific politics on the awarding of the prize, and the balance between notions of particularism and culture in Japanese science. Bartholomew argues that while there may be aspects of Japanese culture that contributed to the successful careers and Nobel candidacies of Yamagiwa Katsusaburō and Yukawa Hideki, beliefs in Japan's "otherness" may have disadvantaged many Japanese nominees.

The studies in this volume push the field in new directions, especially in the realm of biology and medicine, raising questions about the definitions of diseases and false starts in advancing knowledge and highlighting the very human nature of fields that, on the surface, seem to non-specialists as highly rational, logical, and free from many of the predispositions that afflict other social enterprises. Where individual histories of Japanese science, technology, and medicine tend to take up individual phenomena largely on their own terms but perhaps considering their relationship to government policy or economics, our authors go well beyond traditional alignments to demonstrate the myriad 
ways that science, technology, and medicine interact and influence social and cultural assumptions related to religion, race, and prestige as well as empire. All of the studies presented here undermine older interpretative tendencies. Simultaneously, they suggest both the vigor of the field and its future potential.

\section{Notes}

1 Boye De Mente uses the term yokonarabi to describe Japan's "copycat syndrome." See Boye De Mente, Japan's Cultural Code Words: 233 Key Terms That Explain the Attitudes and Behaviour of the Japanese (Tokyo: Tuttle Publishing, 2004), 311-12; Günter Heiduk and Kōzō Yamamura, eds, Technological Competition and Interdependence: the Search for Policy in the United States, Germany, and Japan (Washington, DC: University of Washington Press), 24-63.

2 See John Z. Bowers, Medical Education in Japan, from Chinese Medicine to Western Medicine (New York: Hoeber, 1965); Takeshi Hayashi, The Japanese Experience in Technology: From Transfer to Self-Reliance, Technology Transfer, Transformation, and Development (Tokyo: United Nations University Press, 1990); Christopher Freeman, Technology, Policy, and Economic Performance: Lessons from Japan (London and New York: Pinter Publishers, 1987); Hiroyuki Odagiri and Akira Gotō, Technology and Industrial Development in Japan: Building Capabilities by Learning, Innovation, and Public Policy (Oxford and New York: Clarendon Press and Oxford University Press, 1996).

3 On these cases, see Masaru Izuo, "Medical History: Seishu Hanaoka and His Success in Breast Cancer Surgery Under General Anesthesia Two Hundred Years Ago," Breast Cancer, 11: 4 (2004); Akimoto Motsuki, "Seishu Hanaoka, a Japanese Pioneer in Anesthesia," Anesthesiology, 32: 5 (1970); Nobuko Iinuma, Takamine Jōkichi to Sono Tsuma (Tokyo: Shin Jinbutsu Öraisha, 1993); Kiyoshi Karl Kawakami, Jōkichi Takamine; a Record of His American Achievements (New York: W. E. Rudge, 1928).

4 David Edgerton, The Shock of the Old: Technology and Global History Since 1900 (London: Oxford University Press, 2006) makes an extended critique of the history of technology, arguing the intellectual poverty and incompleteness of treating STM history in terms of first invention rather than post-invention trajectories of a technology which can more fully and dramatically reveal not only the impact of a development but also the different social relationships it comes to entail.

5 Shigeru Nakayama, A History of Japanese Astronomy; Chinese Background and Western Impact, Harvard-Yenching Institute Monograph Series (Cambridge, MA: Harvard University Press, 1969); Science, Technology, and Society in Postwar Japan, Japanese Studies (London and New York: Kegan Paul International; Routledge, Chapman \& Hall distributor, 1991); Shigeru Nakayama, Kunio Gotō, and Hitoshi Yoshioka, A Social History of Science and Technology in Contemporary Japan, Japanese Society Series (Melbourne and Portland, OR: Trans Pacific Press and Distributors, USA and Canada, International Specialized Book Services, 2001); James R. Bartholomew, "Science and Technology as Cognitive Domains in Japan: A Comparative Perspective," Senri Ethnological Studies (1998).

6 See for example, Hideomi Tuge, Historical Development of Science and Technology in Japan, Series on Japanese Life and Culture (Tokyo: Kokusai Bunka Shinkokai, 1961).

7 Hayashi, The Japanese Experience in Technology.

8 Terutomo Ozawa, Japan's Technological Challenge to the West, 1950-1974: Motivation and Accomplishment (Cambridge, MA: MIT Press, 1974) is an example of later technology transfer that follows this argument only to go on and ignore favorable 
post-war US policy on Japan's technological development only to ascribe gains to national character. Ian Inkster, Japan as a Development Model? Relative Backwardness and Technological Transfer (Bochum: Studienverlag Dr. N. Brockmeye, 1980) also follows this line and argues that Japan's case is inapplicable to other "underdeveloping" countries.

9 See for example, Seiichiro Yonekura, The Japanese Iron and Steel Industry, 1850-1990: Continuity and Discontinuity (New York: St. Martin's, 1994); Tetsuro Nakaoka, Science and Technology in the History of Modern Japan: Imitation or Endogenous Creativity? (Tokyo: UN Press, 1980).

10 At a theoretical level there were notable contributions outside the Japan field, notably the idea that late developers actually had advantages over their earlier counterparts, thus painting late adopters in a rather positive light. See for example, Alexander Gerschenkron, Economic Backwardness in Historical Perspective: A Book of Essays (Cambridge, MA: Belknap Press of Harvard University Press, 1962).

11 Although Nakayama Shigeru and others were long associated with the journal, the movement to greater inclusiveness proceeded unevenly. One result of editor Nathan Sivin's efforts to broaden the field was a publication on Japanese land survey techniques: Philip C. Brown, "Never the Twain Shall Meet: European Land Survey Techniques in Tokugawa Japan," Chinese Science, 9: (1989).

12 Since its inception in 2007, EASTS has published roughly the same number of articles on China and Japan, the latter in slightly greater numbers. General Asia or STS articles number approximately the same as China and Japan, Korea, Taiwan (colonial and post-colonial) are roughly matched, as is the distribution of material related to Indonesia, Thailand, Vietnam, and Singapore.

13 Penelope Francks, Technology and Agricultural Development in Pre-War Japan (New Haven, CT: Yale University Press, 1984).

14 Although largely a discussion of evolutionary economic theory, Odagiri Hiroyuki and Goto Akira early on, identify Tokugawa roots to Japan's technological and industrial development during the Meiji Era and beyond. See Odagiri and Gotō, Technology and Industrial Development in Japan: Building Capabilities by Learning, Innovation, and Public Policy.

15 For treatment of these three themes, see, e.g., Tessa Morris-Suzuki, The Technological Transformation of Japan: From the Seventeenth to the Twenty-First Century (Cambridge and New York: Cambridge University Press, 1994); Masayuki Tanimoto, The Role of Tradition in Japan's Industrialization: Another Path to Industrialization, Japanese Studies in Economic and Social History (Oxford and New York: Oxford University Press, 2006).

16 See for example, Miwao Matsumoto, Technology Gatekeepers for War and Peace: The British Ship Revolution and Japanese Industrialization (Basingstoke and New York: Palgrave Macmillan, 2006); David G. Wittner, Technology and the Culture of Progress in Meiji Japan, Routledge/Asian Studies Association of Australia (ASAA) East Asia Series (London and New York: Routledge, 2008).

17 James R. Bartholomew, The Formation of Science in Japan: Building a Research Tradition (New Haven, CT: Yale University Press, 1989).

18 Ann Bowman Jannetta, The Vaccinators: Smallpox, Medical Knowledge, and the "Opening" of Japan (Stanford, CA: Stanford University Press, 2007).

19 Ellen Gardner Nakamura, Practical Pursuits: Takano Chōei, Takahashi Keisaku, and Western Medicine in Nineteenth-Century Japan, vol. 255 (Cambridge, MA: Harvard University Council on East Asian, 2005).

20 Alexander R. Bay, Beriberi in Modern Japan: The Making of a National Disease, Rochester Studies in Medical History (Rochester, NY: University of Rochester Press, 2012). 


\section{David G. Wittner and Philip C. Brown}

21 Dong-Won Kim, Yoshio Nishina: Father of Modern Physics in Japan (Boca Raton, FL: Taylor and Francis, 2007).

22 Morris Low, Science and the Building of a New Japan, 1st edn, Studies of the Weatherhead East Asian Institute, Columbia University (New York: Palgrave Macmillan, 2005).

23 Jeffrey W. Alexander, Japan's Motorcycle Wars: An Industry History (Vancouver: UBC Press, 2008).

24 Brett L. Walker, Toxic Archipelago: A History of Industrial Disease in Japan, Weyerhauser Environmental Books (Seattle, WA and London: University of Washington Press, 2010). See also Timothy S. George, Minamata: Pollution and the Struggle for Democracy in Postwar Japan, Harvard East Asian Monographs (Cambridge, MA: Harvard University Asia Center, 2002).

25 Bruno Latour, "Where Are the Missing Masses? The Sociology of a Few Mundane Artefacts," in Technology and Society: Building Our Sociotechnical Future, ed. Deborah G. Johnson, and Jameson M. Wetmore (Cambridge, MA: MIT Press, 2009) takes a door as his exemplar.

26 Martha Chaiklin, "Up in the Hair: Strands of Meaning in Ornamental Hair Accessories in Early Modern Japan," in Asian Material Culture in Context, ed. Elizabeth Bedford, Marianne Hulsbosch and Martha Chaiklin (Amsterdam: University of Amsterdam, 2009); "Traditional Japanese Footwear: Purity and Pollution," in Shoes: A History from Sandals to Sneakers, ed. Peter McNeil and Giorgio Riello (Oxford and New York: Berg Publishers, 2006); "A Miracle of Industry: The Struggle to Produce Sheet Glass in Modernizing Japan," in Building a Modern Japan: Science, Technology, and Medicine in the Meiji Era and Beyond, ed. Morris F. Low (New York: Palgrave Macmillan, 2005); Andrew Gordon, Fabricating Consumers: The Sewing Machine in Modern Japan (Berkeley, CA: University of California Press, 2011).

27 Wittner, Technology and the Culture of Progress.

28 Louise Young, Japan's Total Empire Manchuria and the Culture of Wartime Imperialism (Berkeley, CA: University of California Press, 1999); Hiromi Mizuno, Science for the Empire: Scientific Nationalism in Modern Japan (Stanford, CA: Stanford University Press, 2009); Daqing Yang, Technology of Empire: Telecommunications and Japanese Expansion in Asia, 1883-1945 (Cambridge, MA: Harvard University Asia Center; distributed by Harvard University Press, 2010); Janis Mimura, Planning for Empire: Reform Bureaucrats and the Japanese Wartime State (Ithaca, NY: Cornell University Press, 2011); Michael Shiyung Liu, Prescribing Colonization: The Role of Medical Practices and Policies in Japan-Ruled Taiwan, 1895-1945, Asia Past \& Present: New Research from A.A.S. (Ann Arbor, MI: Association for Asian Studies, 2009); Walter E. Grunden, Secret Weapons and World War II: Japan in the Shadow of Big Science, Modern War Studies (Lawrence, KS: University Press of Kansas, 2005); Aaron Stephen Moore, Constructing East Asia: Technology, Ideology, and Empire in Japan's Wartime Era, 1931-1945.

29 Gregory K. Clancey, Earthquake Nation: The Cultural Politics of Japanese Seismicity, 1868-1930 (Berkeley, CA: University of California Press, 2006).

30 Examples of other notable studies of Japanese science and technology by nonhistorians are (anthropology) Samuel Coleman, Japanese Science: From the Inside (London: Routledge, 1999) and (political science) Saadia M. Pekkanen, Picking Winners? From Technology Catch-up to the Space Race in Japan (Stanford, CA: Stanford University Press, 2003).

31 David Edgerton, Shock of the Old, treats examples of this in the context of, e.g., technologies of abattoirs moving from (e.g.) the U.S. to Brazil, but we are concerned with much broader patterns here. 


\title{
1 On science and faith in the life of a Meiji engineer
}

\author{
Aleksandra Kobiljski
}

\section{Introduction}

In a recent article, James Bartholomew raised a fundamental question regarding research and writing the history of Japan's scientists with Christian affiliations. ${ }^{1}$ The irony of an article on Catholic scientists starting with "a confession" by the author can hardly be lost on readers, yet it reveals the intellectual integrity of the scholar whose work this volume honors. "It is with some trepidation that I write ... on Japan's Christian scientists," writes Bartholomew. "I have had misgivings ... because the topic poses serious intellectual challenges of definition and explanation...." ${ }^{2}$ This article has been an encouragement and a challenge because I share Bartholomew's misgivings about writing on Japan's Christian scientists.

That I now address the intersections of religiosity and science here resulted from a particular event in my own research. In spring 2009, while doing dissertation research, I was given access to 25 boxes containing the uncatalogued papers of Shimomura Kōtarō (1863-1937). This turned out to be a remarkable wealth of material on an engineer who was a member of Dōshisha's first graduating class and went on to become first the dean of the Harris School of Science before a remarkable career in the chemical industry. This rich and hitherto unknown pool of sources removed one of two obstacles identified by Bartholomew-an absence of sources.

The intellectual challenge of articulating the stakes of such an inquiry remains. What can an examination of the relationship between religion and science (and technology) mean in Meiji Japan, knowing that the very notion of these categories was in flux? In addition, "religion" in Meiji Japan was not solely an intellectual category but also a legal concept. The word (shukyō 宗教) was elaborated in the context of political and legal negotiations for revision of the unequal treaties, which installed extraterritorially and limited Japan's power to make legal decisions about its tariffs, customs, and trade transactions. The elaboration of the notion of religion also resonated with domestic reconfiguration of religious sites to create a version of Shinto as a dominant state religion. ${ }^{3}$ What is the relevance of a study limited to Christian scientists, a fraction of the 1 percent of Japanese who had any affiliation with Christian institutions at the time? 


\section{The school and the congregation}

Meiji Japan was the theater for a peculiar connection between classroom and congregation. Three groups of converts - the Yokohama, Sapporo, and Kumamoto "bands"-embodied the strong link between class and congregation: two out of the three groups of converts literarily came out of a classroom. The Kumamoto and Sapporo bands, which emerged in the first half of the 1870s, were both inspired and led by two teachers, not missionaries, hired by the local government. Both were veterans of the American Civil War and were chosen with an expectation that they would emanate an atmosphere resembling the training of military cadets to strengthen the students physically as much as intellectually. Both were practicing Protestants. Both were hired to teach modern science, and in Sapporo, civil engineering. The program of study at both the Kumamoto School for Western Learning and the Sapporo Agricultural College were similar in spirit and both teachers built a strong personal relationship with students.

Irwin Scheiner showed that becoming a Christian was a way of making sense of the socio-political earthquake that was the Meiji Restoration and the start of the modern nation-state. This was particularly so for former samurai who lost privilege and their sense of purpose. For this group, a turn towards Christianity was a way of dealing with a crisis of identity. Men from former feudal domains who had no natural allegiance to the new Meiji government. Christianity was a way to structure their relationship to the new order and their horizontal and vertical social relationships within it. In a world in which their former rank mattered little, a congregational affiliation put new ground under their feet.

To Scheiner's analysis, I would add a more practical set of concerns. PreRestoration institutions had, to a degree, secured the livelihood of samurai. The new order left many middle and lower-ranking samurai in a state of economic deprivation. ${ }^{4}$ For young and disoriented samurai youth, a connection to Christian missionaries or lay Christian teachers could serve also as a pathway to new skills and an education that was both a metaphorical and material toolkit for weathering the transition. Language skills and training thus acquired constituted a ticket to new, modern professional possibilities.

What stands out about early Imperial Meiji Japan is that mastery of modern science and technology was often paved with Bible instruction and prayer meetings. It may be tempting to draw parallels to the way the work of some European luminaries of modern science was structured by theological concerns. But this was not comparable with the situation in Meiji Japan. At first connections between the Bible and scientific knowledge were less organic. Scores of impoverished young men pursued Western science and technology to restore their family's livelihoods without needing an explanation for Biblical miracles. However, the path to that knowledge often went through reception rooms, homeroom schools, and formal academies run by foreign missionaries. Hence, ambitious and curious Japanese youth without connections or the 
knowledge necessary to obtain scholarships in rare government high schools found themselves learning English by reading the Bible and taking an interest in the precepts that ostensibly shaped the conduct of their foreign teachers, a sign of respect and courtesy as much as curiosity. Missionaries were in fact busier teaching than preaching. Those who received baptism while attending high school or college are often referred to as "student Christians" because of the time and site of conversion and because their commitment to Christianity faded later in life. This tendency reinforces the sense that Christian affiliation had a stronger connection with the figure of the teacher than with the acquisition of guiding principles for life.

We need to labor towards a more subtle and nuanced understanding of what it meant to be a Christian and a scientist or an engineer in the Meiji period as we write histories of science and technology and histories of Christianity in modern Japan. A good start may be to grasp the possibility or likelihood that some "student Christians" embraced Christianity in the same way one mimics the intellectual habits of a beloved teacher and mentor. Furthermore, it may be useful to view the turn to Christianity in terms of it being not only a new value system with some structural similarities to the past order but also a means to make sense of the new Japan by acquiring new skills and social networks consistent with the emerging conceptualizations of "civilization." For most, conversion was a result of multiple factors in a range of motivations. Further, positioning the conversion as the pivotal moment would be misguided in as much as it would render invisible many who did not technically convert or who distanced themselves from Christianity but cultivated relationships with Christian mentors and friends and manifested commitment to certain Christian institutions. Such was the complex and nuanced world of the overlap between Meiji Protestant and scientific milieus, and this ostensibly odd configuration of the science-religion trope during the last third of the nineteenth century constitutes an instance of Meiji's lost possibilities. ${ }^{5}$ As the dust of the Meiji earthquake settled, it became increasingly difficult to manifest oneself as a Christian scientist.

Beyond the question of availability of sources, one reason why little attention has been paid to early Meiji converts with careers in science and engineering has to do with the fact that their existence was recast as an oxymoron. On a personal level, for an engineer to make public his religious affiliation seems to have been as unproductive as early Meiji geishas' attempts to associate themselves with enlightenment ideas of femininity. On an intellectual level, the small but rich (and complicated) world of Meiji Christian scientists is often relegated to the margins of historical interest. To the historians of Christianity, scientists are of limited interest because they were discreet or less public about their faith, and because making sense of their careers requires the ability to digest its technical aspects.

A final complicating point is the tendency of Meiji engineers to keep a low profile even when their work was staring everyone in the face. As Ken Alder has shown in France, the nature of technocratic rule led engineers to deny 
that their activities involved political judgments and power. The resulting cloak made engineers appear transparent, mere conduits for external forces. Beyond the question of visibility what is most interesting about Meiji Christian engineers may be precisely the context which enabled them to emerge and remain a category of actors - a generation of young men embracing configurations of ideas which, although defunct today, were productive at the time.

Meiji Christian engineers' interesting role and connection to building the new Japan can only be captured if the history of engineering and history of Christianity are joined. Concern with engineering is central to the renewed interest in understanding the materiality of how the Meiji transformation actually worked. By shifting attention from intellectual and cultural aspects of the period, engineers invite us to the world of those who were literally building the new Japan while often eschewing the limelight.

\section{The Kumamoto School for Western Learning: catching up with the Restoration}

In January 1875, a group of about forty young men, students of the Kumamoto School for Western Learning, climbed Mt. Hanaoka on the island of Kyushu, read a covenant and proclaimed their faith in the Lord Jesus Christ. Accompanied by American teacher Captain Leroy Janes, they descended the mountain and met the wrath of parents and school authorities. Many of them nonetheless remained steadfast in their new faith and came to be known as the Kumamoto boys, one of three groups of converts that marked the birth of Protestant Christianity in Japan. Several months later, most moved to Kyoto to continue their studies at the newly founded, ambitious missionary endeavour, Dōshisha English School. Among them were future journalists, social reformers, men of letters, one banker, and two scientists, one of whom was Shimomura Kōtarō, our protagonist.

In September 1872, at age nine, Shimomura was given the exceptional opportunity to attend the Kumamoto School for Western Learning. There, he was guaranteed an intellectual encounter with the basic science curriculum as taught to comparably aged children in the United States. Shimomura was four years younger than the average student and, as with many of his peers, Janes was the first foreigner he had encountered. The school was a fresh invention, the result of an initiative of the Kumamoto domain's neo-Confucian scholars and proponents of "practical learning" with the support of their reformminded daimyō. It sought to combine Japan's Confucian ethics with Western science and technology, especially military strategy and tactics, to provide a stronger foundation for Kumamoto, in the post-Restoration order.

A graduate of West Point and a Civil War veteran, Janes had accepted a tall order: live in the Japanese interior, as only a handful of foreigners could, and teach the brightest of one of Japan's conservative domains, which aimed to catch up with the times and claim a reform image by seeking to uphold the "Eastern Ethics, Western Science" objectives of domain intellectuals. In following 
this prescription, Janes was to bring a set of competencies indispensable in a cocktail intended to immunize Japan from military and technological weakness. Teachers of the "Eastern ethics" were in good supply in Kumamoto in the 1870s; Janes was to deliver the science component. Accordingly, students' days were divided between instruction in English language, physics, astronomy, chemistry, mathematics, geography, and military drills on the one hand, and a relatively classical, abridged Confucian curriculum on the other.

This mission of grafting modern science onto Confucian ethics did not proceed as smoothly as planned. Captain Janes and Takezaki sensei, the school's famous Confucian scholar, found themselves in competition. Each knew little of the other and each was prejudiced against the world of the other. Takezaki referred to Christianity as an evil religion. ${ }^{6}$ Janes went into his students' dormitory rooms and snatched their "Chinese books." Janes never learned much Japanese and spoke only English to his students, regardless of their level of comprehension. While his Japanese counterparts tried to monitor and restrain Janes' influence, he pursued the English section of the curriculum as if the Confucian classics section did not exist. Thus, his students were living and learning in two languages, each with its own cultural logic that they had to try to harmonize.

In practice, there were also two visions of the place of science and technology in culture at work in the school. Japanese scholars argued that it was possible (and necessary) to take one aspect of American intellectual culturemilitary academy-style science - and add it to a curriculum based on neoConfucian precepts without destabilizing the latter. Janes, however, came to believe that one simply could not learn and apply Western technology without understanding what he believed was at its core: Christian faith and morality. Very few Japanese ever subscribed to the idea that Japan had to Christianize to be counted among the civilized nations, and by the end of the nineteenth century, a number of visiting and resident Anglo-American writers "believed that Japan has nothing to gain by Christianity." "7 Yet at Kumamoto, Janes stood firmly by the idea that learning science and English alone could not strengthen Japan. While he worked hard to convince his students that there was an unbreakable link between technology and ethics, his Japanese colleagues were policing the border between the two. Like every border, this one was too fluid to police and, with time, Janes' vision won at Kumamoto, at least temporarily.

Janes initially neither preached nor explicitly mentioned Christianity. Teaching the basics of English language to his students was a far more pressing matter. Over time, the mix of isolation and confrontation with a different culture led Janes to experience a revival of his religious sentiment and the emergence of an evangelical impulse. The students, too, changed. Intense, daily contact with their American teacher, typical of small classrooms, chipped away at cultural prejudices and replaced them with an earnest engagement with their teacher's intellectual universe. Gone were the efforts to bombard him with arguments of Confucian superiority. ${ }^{8}$ The more they got to know Janes, the 
more he looked to them like an American samurai, enabling his newly found religious zeal to resonate with many students. In his fifth year at the school, after considerable intellectual interrogation and spiritual torment, Kozaki Hiromichi, who had tried to teach Janes Confucian classics, received his baptism along with the much younger Shimomura. ${ }^{9}$

\section{Jesus the magician: conversion and misunderstanding}

Many of the Kumamoto boys later wrote about their conversion in terms of the connection between Christianity on the one hand and science, technology, and progress on the other. Some used startlingly scientific metaphors. Ebina Danjō, a renowned bando member and pastor, described his conversion as a shift from the geocentric to the heliocentric understandings of the universe:

Up till then my way of thinking had resembled the theory that the earth was at the center of the universe ... . I had thought that Gods revolved around me, but now God was at the center and I was like a planet revolving around the perimeter of the Sun. ${ }^{10}$

Shimomura too, made the science-Christianity connection, inspired by the belief that "there is a chain connection between Christianity and Western learning." $11 \mathrm{He}$ and the other Kumamoto boys were some of the many Protestant converts whose path to Jesus was prepared by their teachers and forged by curiosity about science.

Nonetheless, Shimomura's path to conversion was uncommon in nineteenthcentury Japan. First, his parents did not object to his conversion. Some of his fellow students passed days in confinement orchestrated by their families; others were deprived of food and water for weeks. Parental disapproval was taken for granted by school authorities during their interrogation of students after their conversion. The headmaster, a Mr. Morita, reproached Shimomura for "neglecting the advice of his parents, abandoning wise ways, and straying onto the path of the evil Christian faith." He concluded his reprimand by urging Shimomura to listen to his parents presupposing that they too, urged him to forget the Mt. Hanaoka episode. When Shimomura calmly answered that, as filial piety would demand, he asked and obtained his father's permission to convert, Morita was dumbstruck. ${ }^{12}$

The main thrust of Shimomura's exceptionality vis-à-vis the common Meiji conversion narrative lies in the fact that he was first drawn to Christianity because he (mis)understood that the Bible was a book of sorcery and Jesus was a powerful sorcerer. In an account of his school days, Shimomura did not shy away from explaining that his initial interest in Christianity came from his desire to master magic. Through reading Takizawa Bakin's magic-infused early modern classic The Eight Dog Chronicle to his bed-ridden mother, Shimomura encountered a wide range of demons and sorcery. These reading sessions led him to yearn to master the magic that made possible the 
adventures described in the novel. Later, at the Kumamoto school, a fellow student suggested that Christian literature was where to learn about Western alchemy and magic. It seems that both boys were searching for the secrets of alchemy, notably how to turn leaves into gold.

Although he failed initially at alchemy, Shimomura continued reading. He found a woodblock print of the Gospel of Matthew - the miracle of the five loaves, two fish, and thousands of hungry people - which confirmed his understanding of Jesus as a magician. While it may contradict common reading of that episode, his reading of the miracle of the "Feeding of the 5,000" as magic was not beyond comprehension. It was the first miracle Shimomura encountered, a promising start for an alchemy book. It became a launch pad for an eager student of magic interested in Western learning.

Thus, unlike many early Meiji converts, Shimomura did not come to Christianity in search of Western learning, modern science, and language acquisition. He came to his first prayer meeting inspired by the productive misunderstanding of Christian miracles. Captain Janes looked up to the sky and offered thanks before each session. Thus, Shimomura had every reason to believe that at the prayer meeting Janes could teach him about Jesus and advance his knowledge of Western magic. And about Jesus he did teach him. This is not to say that Shimomura was uninterested in the latest scientific developments. During his Kumamoto days he was also curious about astronomy. Janes often prayed looking up to the sky and here too, the bodily manner of his prayer helped spread a rumor "that the study of Christianity enables one to learn the way of going to the moon."13 This too, was just what Shimomura wanted to learn.

Shimomura came to attend the prayer meetings, which took place in the intimacy of Janes' home, because he made two (mis)connections. On the one hand, coupling Christianity with magic and Jesus (the magician) with Janes (his disciple). On the other, Shimomura connected "going to heaven," which Janes talked about, and "going to the moon," about which he wanted to learn more.

\section{Fighting against scientific atheism: the making of a Christian scientist?}

With his interest in magic and science, how did Shimomura experience the science curriculum in the religiously infused atmosphere of the Kumamoto School? The best source for understanding this question is his autobiographic poetry, notably a poem titled "The Dream of Three Nights" (published 1914). The poem is divided into three parts. The metaphor, found in the portion of the poem describing the "Commonwealth of Science," was that of being handed a pair of glasses. Once he put them on, the world was no longer the same: "transparent had become all things opaque" and "their insides could be seen." The powerful energy of this encounter was followed by fear. "Fear came on me, I dropped the magic glass/And instantly the same old world returned." But fear did not put an end to the pursuit. The old man who was his guide in this part of the poem took him high above the clouds and 
explained two grand rules. First: hate, love, fear and all emotions, were trodden upon and forbidden in that kingdom. Second: a man of science believes only what his eyes can see and his hands can touch. ${ }^{14}$ In this "grand republic" intellect reigns supreme and all men are "kings by right," but there were limits to its power, and the boundaries of the kingdom of science lay at the limit of the tangible, beyond which lay the chasm, off-limits to mankind. Shimomura was "a profound thinker" and the fluid mix of interest in magic and science that brought him to Christianity lay at the heart of his brand of scientific piety. However, unlike many Meiji bureaucrats and scientists who believed that science and technological advancement were a panacea for Japan, and Christianity an impediment to scientific thought, Shimomura was keenly aware of the limits of scientific tangibles and the necessity of faith to guide contemplation about what lay beyond. ${ }^{15}$

Despite all the references to the importance of Western technology and hours spent poring over science textbooks, only two of four Kumamoto boys went on to scientific careers, Shimomura the more prominent of the two. His life as a Christian may have started in Kumamoto, but his career as a science educator started a few years later in Kyoto as a teacher at Dōshisha. Shimomura graduated in 1879 with Dōshisha's famous first class. Three years later, Shimomura assumed a teaching position at his alma mater. Like all Dōshisha teachers, he taught a wide range of subjects, from Japanese composition and American civilization to mathematics and chemistry. Because of a combination of self-study and talent, he gradually became the science teacher. By 1885 , the school's catalogue listed him as professor of chemistry, physics, and mathematics. ${ }^{16}$ By the mid-1880s, Shimomura had found his calling: he was a Christian scientist, an identity of extreme importance in his young mind as well as in the intellectual landscape of mid-Meiji Christianity.

In the 1870s he came to believe that there was a "chain connection" between Christianity and science. A decade later, when this link was threatened by the introduction of a Spencerian version of Darwinism to Japan, Shimomura and others at Dōshisha were ready to defend their faith. "A religion which conflicts with science is no religion," he wrote to a teacher, adding, "a science jarring with religion is no science." ${ }^{17}$ For Shimomura nurturing Christian scientists was urgent; the future of Japanese Christianity depended on it. "The one great need of the present day, I think, is found in the lack of Christian scientists," he wrote in 1884 to Dōshisha president Niijima Jō. In due course it became clear that the best way to fight for a Christian cause in Japan was to become a scientist and be living proof of its value. The "main enemy" in his mind was neither Japan's Buddhist establishment nor the Meiji government's Shinto policy, but rather "scientific atheism." Shimomura was eager to advance this agenda by going to the United States for further study "in some scientific school." His usefulness to Dōshisha and the Japanese Christian community, he argued, depended on further study abroad. ${ }^{18}$

With some effort, he succeeded in overcoming the reluctance of American missionaries at Dōshisha, whose blessing and connections were important to 
realize such a trip. In the summer, 1885, he left for Worcester Polytechnic Institute (WPI) in Massachusetts. There, Shimomura found that he was behind in his "knowledge of technical and scientific terms." Initial hurdles were quickly overcome and "he applied himself so diligently that he soon took high rank in one of the best classes the [Worcester] 'Tech' ever had."19

Many young Japanese converts went to the United States eager to experience the Christian society missionaries talked so enthusiastically about, only to return feeling disappointed, allowing their passion for Christianity to fade. Unlike them, Shimomura cultivated his faith. He joined the YMCA and merited an invitation to the founding meeting of the College Y (July, 1886). Some 251 carefully selected male students from 89 colleges in the United States and Canada met in Northfield, Massachusetts, discussed student evangelical work overseas, and formed the Student Volunteer Movement for Foreign Missions. ${ }^{20}$

At the same time, in a struggle to become a scientist, the Christian part of becoming a Christian scientist faded into the background. In an essay he wrote while at Worcester, "The Aim of My Life," Shimomura did not speak of wanting to be a Christian scientist, but his religious sentiments were not hidden. "I would like to be a man of broad views" he wrote, adding, "What is milder and kinder than religion?" He went on to make an argument for intellectual and religious tolerance.

Men say, "The age of persecution is gone, and the bright sun of toleration is shining." If so, we were born in the happy days of the earth but it seems to me that ... whenever a new difficulty occurs and some cherished beliefs are endangered, strong passions are aroused, and things are said and words are uttered unworthy of the "peace makers" of the earth. ${ }^{21}$

In 1888, Shimomura earned his B.Sc. writing a thesis on theories of the formation of chemical elements and graduating second in his class. Instead of returning to Japan, Shimomura decided to stay in the United States. He went to study with Ira Remsen, founder of the American Chemical Journal, one of the original faculty members at Johns Hopkins. In 1889, Shimomura obtained his Ph.D. in chemistry. Beyond his studies, his reasons for staying were intimately tied to doing the more mundane work he considered essential to Dōshisha-fundraising. ${ }^{22}$ Thanks to introductions from friends and acquaintances, he engaged in prospecting wealthy New Englanders and hit a lucky strike when he met Jonathan Newton Harris of New London, Connecticut, who gave a \$250,000 endowment (some six million dollars in 2012 values) to underwrite the establishment of a new department for scientific work at Dōshisha - the Harris School of Science - opened in September 1890, the first of its kind at a private college in Japan.

\section{Theory and practice: from science teacher to chemical industry}

The Harris School of Science became a beacon of science in a sea of Christianity and Shimomura was happy to pursue his ideal of working against 
scientific atheism, but the partnership between Shimomura and Dōshisha, however, did not last. After only five years, because of a conflict about what he thought was a misappropriation of the Harris endowment and hence a breach of trust, Shimomura left Dōshisha. He found himself with virtually no prospect of continuing his career as a science educator.

For a student of Ira Remsen, a great advocate of basic research who disregarded research intended for industrial application, and for a young man who wanted to help educate generations of Christian scientists, Shimomura was faced with the prospect of going from education to industry. This was a drastic change which Ukita Kazutami, a fellow Kumamoto graduate and Shimomura's brother-in-law, described many years later as the difference between teaching tactics and entering an actual battle. "There, the question of success or failure becomes the question of life and death." ${ }^{23}$ To make matters worse, by virtue of the strength of his personal ties to Kyoto, Shimomura was geographically limited in his job hunt. Finally, two years after leaving Dōshisha, he was recruited by Osaka Chemical Works Company where he was assigned to work on coking technology. One of his first tasks was to take an extended study trip to visit Belgium's Semet-Solvay Company.

Shimomura may have been hesitant about entering the world of industry, but once there he thrived. His first breakthrough, in 1898-99, was the successful installation of the first byproduct coking plant in Japan, a few years after the technology was patented in Europe. He topped this technological feat shortly thereafte when he developed a protocol for coking poor quality Japanese coal. This was no small feat. Solvay coke ovens were designed to coke coal with relatively low ash and sulphur content abundant in Belgium and elsewhere in Europe. Most Japanese coal, however, had a high volatile content which when coked in imported ovens resulted in a spongy, porous matter, unusable in blast furnaces. The "Shimomura procedure," was a game changing technology. ${ }^{24}$ This kind of high quality fuel was indispensable for the budding Japanese steel industry and Shimomura was quickly called upon by the Imperial Japanese Army to implement his protocol at the Meiji government's Yawata Steel Works.

Despite the utility of his coking process, Shimomura was personally quite critical of the government's attitudes and dealings in China as indicated by an undated, handwritten note from his private papers:

The international community is well aware of the fact that Japanese secret agents assassinated Queen Min to annex Korea. And the Chinese know that that Zhang Zuolin [1928] was killed by Japanese agents in Manchuria. If [all of] this is an open secret which both the international community and Chinese know very well, even if the Japanese government is repeatedly calling for friendly relations, the Chinese must know that this is not the true meaning of friendly relations. ${ }^{25}$

Regardless of his personal misgivings about Japanese activities in Manchuria, the techniques of preparing coal for coking that he developed were at the 
heart of Japan's capacity to make the best out of Manchurian coal-which, despite much bluster, was as poor quality as Hokkaido coal—virtually unusable in the iron and steel industry without the technology initially developed by Shimomura.

\section{Working pressure}

By the turn of the century, Shimomura was deeply immersed in pushing the limits of byproduct coke oven chemistry. Unlike ovens that were not designed to capture chemical substances released during the coking process, Solvay ovens could recuperate a portion of gas, coal tar, ammonia, and benzene that previously escaped into the atmosphere. Although he kept close ties with Dōshisha, serving as a trustee and later president, marrying a Dōshisha Women's College graduate and convert, and maintaining a "Christian home," Shimomura's life largely became a battle to find new applications for coking byproducts and to increase byproduct recuperation rates.

Pushing the limits of what is possible may be an accurate definition for what chemical engineers do, but one night, however, he pushed too far. On a Friday evening, 14 August 1914, while conducting an experiment on dyestuff production in his private home laboratory in Kyoto, an explosion took place. Shimomura suffered burns to his hands and face and most seriously, both his eyes were injured.

The work in his laboratory was linked to his knowledge that immanent war with Germany meant loss of dyestuff imports essential for Japan's textile industry. By early August, 1914, Japan received an official request from Great Britain, its military ally since the 1902 Anglo-Japanese Alliance, to help destroy German naval raiders in Chinese and Japanese waters. A few hours before Shimomura confined himself to his laboratory on that Friday evening, Japan had issued an ultimatum to Germany to remove its forces from the waters surrounding Japan and to deliver the entire Kiaochau lease territory to Japanese authorities. That meant Japan was going to war with Germany. It was probably the urgency of this situation, which only a handful of Japanese scientists and businessman could grasp at the time that pushed Shimomura to disregard caution as he experimented in his home laboratory.

Did this Christian scientist think of this accident as punishment for his hubris? Shimomura did not write directly about the accident, but a long three part poem in English, written on Christmas day 1919 and dedicated to his son who was leaving to study engineering in the US, is telling. ${ }^{26}$ The poem has a metaphorical description of his accident. ${ }^{27}$ On three separate nights, in his dreams, the poem's protagonist travels to three kingdoms; first that of philosophy where he finds heaps of bones and skulls, inflated words, vacant sounds, deceit, and death. The accident is found in the description of the second night, spent at the commonwealth of science, where "intellect reigns supreme." With the help of a magnifying glass he was able to see atoms and molecules and was overwhelmed by "Nature's secrets ... to sight exposed." An old man, his guide 
of the domain, took the protagonist on a trip onboard a big bird to "what was supposed/To be the limits of the Tangible." There "lay a Chasm" which extended beyond human knowledge and which he was told was forbidden to mankind. The old man warned the protagonist that "the realm of science has its boundaries/beyond which it is fatal to e'en to (sic) peep." The old man retired. Knowing that there is some place he is not allowed is what a young man needs to hear to promptly head there. Against all warnings, the protagonist jumps on the bird and heads to the outer limits. Stopping at the brink, he makes "the last resolve to stake all on this leap." No sooner than they try to cross the abyss, "Then all was wrecked, the Monster Bird and I." 28

\section{The Religion of Jesus, spirits, and reincarnation}

During Shimomura's painful recovery, faced with the prospect of lifelong blindness, and after two decades of "living in the world of engineering and dealing only with materiality," Shimomura returned to some of the key spiritual and religious questions of his youth. ${ }^{29}$ Interestingly, he first expressed his thoughts in verse. Although he was passionate about waka, he also wrote in English. His poetry was a way of pursuing knowledge, as his themes ranged from common waka themes of nature to discussions of ambition, labor, and time. These poems resulted from the intersection of poetry and monthly study group meetings, at which seven friends studied Japanese poetry master Yamamoto Ryōkan and the writings of Thomas Huxley and William Crooks.

The publication of Shimomura's poetry collection, Fallen Leaves, in 1914 was followed by a collection of reflections entitled The Immortality of the Soul (1922), dealing with the aging of the body and mind and questions of life after death. In 1933, he published his final work, a combination of biographical and contemplative notes on space, time, Christianity and his life entitled My View of Religion.

All three published works, while treating slightly different topics and of differing genres, are united in the idea that a man is a being of thought, as well as a being of feeling. In the realm of thought, all men are skeptics and in the end are likely to be agnostic. Religious experience, however, belongs to the sphere of emotions and love. To give an example of how scientific skepticism had its palpable limits in the world of human emotion, Shimomura gave a simple example: "Suppose your only son is dying in the next room, and do you feel any skeptical (sic) of that fact?" ${ }^{30}$ Prayer, as a religious practice, and its efficacy as judged in scientific terms was also on Shimomura's mind. He wrote:

[Prayer is a] very difficult problem. I believe in its efficacy, though it is impossible to tell how far. Of all the natural manifestations of the Religious Sense, the impulse to prayer is the most natural and most essential to the existence of practical religion. And yet, it is most different [sic] to believe, while it is most widely believed in. This is a paradox. ${ }^{31}$ 
By far, the most controversial part of his religious thought, and the reason Shimomura is studied neither by historians of Japanese Christianity nor historians of science, was his belief in reincarnation and interest in scientific study of psychic phenomena. Much of his inspiration came from the work of Sir William Cook, renowned British chemist who was also interested in spiritualism. Thus, Shimomura joined a group of established scientists, such as British naturalists Alfred Russel Wallace and German astrophysicist Johann Karl Friedrich Zöllner, who expressed interest and various degrees of support for the spiritualist cause. Unlike most of them, however, Shimomura was still a believing Christian. Thus, to declare his belief in spirits Shimomura first had to dispense with the Christian doctrine of heaven and hell and embrace the concept of reincarnation. Written on a loose piece of paper, found amidst his notes on chemical elements, he writes: "Belief in immortality: The modern wording is Survival of man. Do you believe in reincarnation or in the Christian doctrine of Heaven and Hell? The reincarnation is more plausible and scientific then [sic] the other as it seems to me." 32

Dispensing with heaven and hell was a departure from the version of Christian thought preached by American Protestant missionaries in Japan at the end of the nineteenth century. One could address one's Lord, Jesus Christ, in prayer, but he was to be feared. By the time Shimomura's own sense of Christianity matured, his view of what should be Christian doctrine had evolved. "As I grow older," he wrote friend and former student Murai Tomoyoshi, "my thought is growing more open and free. I may no longer be a believer in Christianity but I am a believer in the Religion of Jesus. In my old age, I lost my Christian faith but my faith in Religion of Jesus was revived." 33

This is a reference to Shimomura's contemplation of the Bible in which he agreed with some theologians of the early twentieth century that there were two different kinds of religious teaching in the Bible: Pauline Christianity and the Religion of Jesus. The assumption was that Paul's teaching subverted the real message of Jesus. Shimomura was quick to recognize the problems inherent in the embrace of the teachings of Jesus. To another friend, he wrote:

Having discarded the Pauline Christianity, I took refuge in the Religion of Jesus. But where is the Religion of Jesus to be found? It is said that one can find it in the synoptic Gospels. But a question arises, How far are these gospels true? It is difficult to see where the genuine Jesus begins, and where the imaginary Jesus ends. ${ }^{34}$

Finally, in his considerations of Jesus, his nature and his historicity, Shimomura's early interest in and understanding of Jesus as a magician came together with his later interest in spiritualism and mediums. On a small piece of paper, perhaps another meeting agenda, he jotted three questions: "Was Jesus a historical personage? Did he perform the miracles as described in St. Mark? Do you think that the teachings of Jesus show the supernatural elements in him?" 35 Two points, that his capture and crucifixion were a blow to his disciples, and 
that they "saw or rather believed they saw Jesus in the risen form," Shimomura argued could be taken as historical fact. ${ }^{36}$ But how could a scientist explain the resurrection? Shimomura concluded: Jesus was born with a psychical body, that is, a material body with powers to dispense with ordinary laws of matter. Because it was psychical, the usual law of birth was dispensed with, and naturally the usual law of death was dispensed with. ${ }^{37}$

Shimomura admitted that because we do not have enough evidence of "socalled materialisation in metapsychic" there is not enough to consider this line of explanation final. But for the time being, "we may take Jesus to have been a great medium endowed with the noblest moral sentiments ... . A man of this type would be exceedingly human and at the same time powerful enough to perform the so called miracles." ${ }^{38}$ Jesus, the sorcerer, became Jesus the superman, able to do things ordinary human beings could not.

\section{Conclusion}

Speaking at the first anniversary of Shimomura's death, Ukita Kazutami, declared: "For him, science and faith were parts of the same path." Within the engineering community, Shimomura was recognized through his work with Yawata Steel Works and his continued employment in high-ranking positions at Osaka Gas. The best proof of Shimomura's standing in Japan's Christian community was his appointment to the Presidency of Dōshisha from 1904 to 1908. After two turbulent decades following the death of the college's founder, it was the engineer who was charged with steering the school into calmer waters. Yet the two sides of his career have yet to meet in a biography of a man whose trajectory started as a quest to understand the sources of Western sorcery and the secrets of the stars, which first found expression in conversion to Christianity and in later years solace in study of physic phenomena. The embrace of the new faith was in part inspired by belief in a causal connection between Christianity and science, but we must recognize his interest in magic that brought him to study Christianity and science. The goal of his youth was to become a Christian scientist who could help fight scientific atheism, but in later years his interest in the overlap between science and magic was manifested by his interest in the scientific study of psychic phenomena and readings on metapsychic materialization. His intellectual career and religious life were infused by systematic grappling with the boundaries between science, magic, and faith, as well as what was possible and what was not. In a sense, just as he pushed the boundaries of what could be a good coking coal, he thought it would be possible to one day explain and manipulate other forces and objects in a way that was considered childish phantasy, such as going to the moon, but which a century later became reality. Shimomura's career as scientist and religious thinker further illustrates broader trajectories through which, individuals adapted to a new imperialist world view, survived and prospered in the era of "civilization and enlightenment." 


\section{Notes}

1 James R. Bartholomew, "Towards a History of Meiji Scientists in Japan," in Xavier's Legacies: Catholicism in Modern Japanese Culture, ed. Kevin M. Doak (Washington, DC: University of Washington Press, 2011), 47.

2 Bartholomew, "Towards a History," 47.

3 See Jason Ananda Josephson, The Invention of Religion in Japan (Chicago, IL: Chicago University Press, 2012). On the reconfiguration of the religious geography of Meiji Japan, see Sarah Thal, Rearranging the Landscape of the Gods: The Politics of a Pligrimage Site in Japan, 1573-1912 (Chicago, IL: Chicago University Press, 2005).

4 Harry D. Harootunian, "The Economic Rehabilitation of the Samurai in the Early Meiji Period," Journal of Asian Studies, 19: 4 (1960), 433-44.

5 Amy Stanley, "Enlightenment Geisha: The Sex Trade, Education, and Feminine Ideals in Early Meiji Japan," Journal of Asian Studies, 72: 3 (2013), 539-62.

6 Shimomura Kōtarō, My View of Religion (Kyoto, 1933), 9.

7 Hearn to Chamberlain, January 19, 1893 in Lafcadio Hearn, The Writings of Lafcadio Hearn, 16 vols (Boston, MA: Houghton, 1922), vol. 15, 359.

8 Kozaki Hiromichi, Reminiscences of Seventy Years (Christian Literature Society of Japan, Kyo Bun Kwan, 1933).

9 See Helen Ballhatchet, "Confucianism and Christianity in Meiji Japan: The Case of Kozaki Hiromichi," Journal of the Royal Asiatic Society of Great Britain and Ireland, 2: (1988), 349-69.

10 Quoted in Tsuenekichi Watase, Ebina Danjō sensei (Tokyo: Ryūginsha, 1938), 97, see also 1-54; Fred G. Notehelfer, Ebina Danjō: a Christian Samurai of the Meiji Period (Cambridge, MA: Harvard University East Asia Center Japan Papers, 1963), 46-7.

11 Shimomura, My View of Religion, 7.

12 Ibid., 9.

13 Kiristosha retsuden: shinkō sanjūnen [Christian Lives: Thirty Years of Faith] (Tokyo: Keiseisha Shoten, 1921), 56.

14 Shimomura Kōtarō, Fallen Leaves (Kyoto: William Blackwood \& Sons, 1914), 35.

15 Isō Abe, Diary of Isō Abe (Kyoto: Doshisha Archives, 2009), entry October 13, 1883.

16 Circular of the Dōshisha Collegiate and Theological School (Kyoto and Yokohama: R. Meiklejohn \& Co. Printers, 1885), 4.

17 Kōtarō Shimomura to Jō Niijima, Kyoto, September 25, 1884.

18 Ibid.

19 Homer T. Fuller, "Kotara M. Shimomura," Journal of the Worcester Polytechnic Institute, 7: (1903-4), 312; J. M. Goodell and C. L. Griffin et al. (eds), The Log of '88 Published by the Senior Class of the Worcester Polytechnic Institute (Worcester, MA: Worcester Polytechnic Institute, 1888), 64.

20 Ian Tyler, Reforming the World: The Creation of America's Global Empire (Princeton, NJ: Princeton University Press, 2010), 56, 61.

21 "The aim of my life," Unnumbered folder, Shimomura Kōtarō Papers, Dōshisha Archives (hereafter $S K P$ ).

22 Shimomura to Niijima. April 15, 1888.

23 Wakamatsu Usaburō (ed.), Shimomura sensei tsuioku roku (Kyoto, 1938), 4-5.

24 "Shimomurashiki sekitann teion kanryūhō-yūryō gaitan wo seizo" (Shimomura Process of Low Temperature Carbonisation-Method of Producing Superior Coke), uncatalogued material $S K P$, box 7 of 21 .

$25 S K P$, handwritten note, RG: Y.SK-6 S 2, folder 7.

26 This dedication is absent from the published version and can be found in the typescript of the poem SKP, RG: Y.SK-6 S 2, folder 3. 


\section{Aleksandra Kobiljski}

27 Ibid., folder 3.

28 Shimomura, Fallen Leaves, 37-8: Shimomura Kōtarō, Reikon fumetsukan (Tokyo: Dairinsha, 1939), 2.

29 SKP, RG: Y.SK-6 S 2: folder 8, various notes.

30 Ibid.

31 Ibid.

32 Wakamatsu, Shimomura sensei tsuioko roku.

33 Ibid.

34 Ibid., RG: Y.SK-6 S 2, folder 7, loose note "On the Resurrection of Jesus."

35 Ibid.

36 Ibid.

37 Ibid.

38 Ibid. 


\title{
2 Academia-industry relations \\ Interpreting the role of Nagai Nagayoshi in the development of new businesses in the Meiji period and beyond
}

\author{
Julia S. Yongue
}

\section{Introduction}

As emphasized in the pioneering work of James Bartholomew, in the Meiji period the transfer of knowledge from scientists who had studied overseas was vital to the formation of science at Japanese universities and requisite to the emergence of modern industries. ${ }^{1}$ This was especially true in the case of the pharmaceutical industry, which employed what was then a new discipline, chemistry - particularly its practical applications - in the production of Western medicines. As aspiring entrepreneurs lacked practical knowhow, direct scientific supervision and guidance were of utmost importance to the emergence of pharmaceutical enterprises in the Meiji and Taisho periods, though only a few of these scientists actually offered any hands-on assistance at production sites. At the same time, they provided indirect assistance through informal academiaindustry ties which also served as an important modernizing force. Both types of assistance contributed to the building of the economic and productive foundations of the modern Japanese empire.

This chapter examines the salient characteristics of the earliest academiaindustry relations during the Meiji period and beyond by assessing the underappreciated role of one key scientist, Nagai Nagayoshi, and his efforts to assist in the development of pharmaceutical chemicals businesses. Best known today for his discovery of ephedrine, Nagai is also credited with having introduced pharmaceutical science to Japan, a focus that distracted from a deeper appreciation of his business involvement. ${ }^{2}$ As the first president of the Pharmaceutical Society of Japan, he did much to promote the study of pharmacy and educate pharmacists, a new vocation, while also endeavoring to raise their status vis-à-vis physicians. ${ }^{3}$ Given these exceptional achievements, studies of Nagai have tended to emphasize his contributions to science, especially pharmacy, rather than his role in assisting the development of new businesses. ${ }^{4}$ Yet Nagai's early career expertise in the production of biomedicines was the principal reason why the Meiji government's chief of medical affairs, Nagayo Sensai, summoned him to return to Japan from his studies in Berlin.

The second reason why studies of Nagai's contributions to business have received less attention than those to science is that on the whole the fruits of 
his commercial endeavors were-at least in the short term-mixed. The government-backed pharmaceutical companies, Dainippon and Naikoku, which received Nagai's direct guidance and supervision both failed and were sold to the private sector. However, these failures were not due to any shortcomings on Nagai's part but to poor government oversight. Once these enterprises were turned over to the private sector their performance improved, and one reason for Dainippon's success in the long term is that while Nagai officially resigned from the company in 1893, his ties with management and hands-on assistance at production sites never ceased.

A third reason why Nagai's contributions to industry have not been explored in depth is because historians have tended to focus on his direct participation in major projects formulated by the central government while making little if any mention of his efforts to provide scientific guidance to either existing businesses or new ones initiated by the private sector. ${ }^{5}$ One of the cases examined in this chapter describes Nagai's attempt to rescue an indigenous industry, the Awa dye business, from foreign competition through technological innovation. Nagai also had informal ties during the Taishō period with the founder of another Tokushima enterprise, Tomita Pharmaceutical Company, which has not been mentioned in any previous studies of Nagai. This enterprise is of note not simply for its connection to Nagai but because it provides a rare example of a successful business established by a private-sector entrepreneur that survived both the Meiji and Taishō periods and remains a profitable firm today.

Throughout his lifetime, Nagai became directly and indirectly involved in a wide range of business activities, especially in Tokushima, his birthplace. Because his reasons for aiding businesses in Tokushima were in part personal, his role differed from the one he played in service of the central government. Nonetheless, one can find much continuity in all his relations with businesses - both new and existing - and his motivations for assisting them through science and innovation. While previous studies of Nagai have drawn conclusions regarding his character and personality, few of these assertions have been based on his relations with business. ${ }^{6}$ Through an examination of accounts of persons with whom Nagai came into contact I will assess Nagai's motivations and aspirations for aiding in the development of business. In addition, I analyze some of the economic and political changes occurring during Nagai's lifetime and the influence they had on his interest in both business and the formation of science in Japan.

\section{Nagai's Meiji period industry role: Dainippon Seiyaku}

According to the History of the Ministry of Health and Welfare, demand for biomedicines rose from the start of the Meiji period. ${ }^{7}$ Carbolic acid was in particularly high demand due to frequent cholera outbreaks in the late 1870 s and 1880 s, which posed a threat to public health and were a burden on the economy. As the demand burgeoned, competition intensified and prices increased precipitously. With little domestic production, Japan had no choice 
but to purchase foreign medicines at highly inflated prices. Unscrupulous businesses, both foreign and domestic, perceived the sale of pharmaceutical chemicals as a lucrative opportunity, and this generated a significant parallel trade in poor quality and counterfeit products. The unequal treaty system only aggravated the situation since the government could not impose protective tariffs on foreign imports as a means of fostering local production. For those reasons, establishing a viable domestic pharmaceutical industry capable of producing high quality products at competitive prices was vital to achieve self-sufficiency.

The instigator of an industrial policy for manufacturing pharmaceutical chemicals in the Meiji period was Nagayo Sensai. Before becoming chief of medical affairs at the Ministry of Education (later part of the Ministry of the Interior), Nagayo left Japan in 1871 on a two-year journey to Europe and the United States as a participant in the Iwakura Mission. After returning to Japan, he introduced the notion of hygiene along with a system of public health inspired mainly by the Dutch model. ${ }^{8}$ Nagayo's hygiene policies encompassed an array of fields ranging from sanitation and public health to water supply regulation, disease prevention, hospital inspection, and welfare services. All of his measures were highly regulatory in nature. ${ }^{9}$ Examples of his industryrelated policies included the establishment of the first hygienic testing stations to evaluate all medicines for both quality and authenticity. The first station, the precursor of the National Institute of Health Sciences, opened in Tokyo in 1874. After issuing the first Japanese Pharmacopeia in 1886, which established standards for ingredients and production, the government put in place a strict set of regulations in 1889 governing the handing and production of medicines, the precursor of the Pharmaceutical Affairs Law.

Nagayo also drew up a plan for the founding of a joint-stock company for the production of pharmaceuticals with equal ownership by the public and private sectors. Officially registered in 1883, Dainippon Seiyaku Kabushiki Gaisha was capitalized at 10,000 yen and opened for business in Tokyo in 1885. The success of the company would depend on sufficient financial support from both the public and private sectors, as well as expert technical guidance. To achieve the latter, Nagayo made it his mission to appoint Nagai Nagayoshi, whom he had met in Berlin during the Iwakura Mission, as scientific advisor.

Nagai Nagayoshi was born in Awahan (present-day Tokushima prefecture). Like Nagayo, he was the son of a prominent domain physician. On the eve of the Meiji restoration, he left for Nagasaki to study medicine, although his true passion was a completely new discipline to Japan, chemistry. ${ }^{10}$ In Nagasaki, he had hoped to study under the Dutch chemist, K. W. Gratama; however, by the time he had arrived, Gratama had already departed for Edo, the Shogun's castle town. While in Nagasaki, Nagai did not abandon his aspiration to study chemistry. He went to live at the home of a former student of Gratama, Ueno Hikoma, who had opened Japan's first photography studio. Ueno employed chemistry in his work as a photographer, a craft he had studied at Nagasaki Medical College under Pompé van Meerdervoort. Nagai's experience developing photographs undoubtedly shaped his career: even after becoming a professor at 
Tokyo Imperial University, he continued to emphasize the importance of practical as opposed to theoretical chemistry.

Shortly after the start of the Meiji period, Nagai left Nagasaki and moved to Tokyo to study medicine. Because the Meiji government had recently decided to abandon the English model of medicine in favor of the German, the government dispatched Nagai along with eight other scholars to Berlin, where he would spend 13 years at the University of Berlin. It was during his stay in 1875 that Nagai received a missive from Nagayo summoning him to return to Japan to head Dainippon's production operations. Nagai declined, even though this meant that the government would no longer support his activities. Unlike many of the scholars whom the Japanese government had sent overseas for study, Nagai was able to support himself financially using his savings and an assistantship in Professor August Wilhelm von Hofmann's laboratory. ${ }^{11}$ Given these financial circumstances, Nagai was in a position to make independent decisions about his studies and career. There were also personal reasons for remaining in Berlin; during his stay, Nagai became engaged to Therese Schumacher, the daughter of a prominent merchant, whom he married in 1886.

Nagayo and others did not easily relinquish their objective of persuading Nagai to return to Japan. Nagayo's request was followed by a visit by two government representatives, Shibata Shōkei, who would become Nagai's colleague at Tokyo Imperial University, and Baron Nitta Tadasumi, the first president of Dainippon Pharmaceutical Company. According to Shibuya Masayuki, professor emeritus at Tokushima University's faculty of pharmaceutical sciences, for ten years starting in 1874, they "resorted to any kind of trick" to convince Nagai to return, including promises of a university appointment with an exorbitant salary and even a Japanese wife. As pointed out by Shibuya, most of the promises they made in their letters to Nagai were never fulfilled. ${ }^{12}$ (Nagai did receive a professorship at Tokyo Imperial University, though it was some years after he had returned to Japan).

The deciding factor in Nagai's return is unknown. According to the work of one of Nagai's fiercest critics, the late Yasue Masa'ichi, professor emeritus at Nagoya City University, Nagai must have known that his chances of obtaining a professorship in Germany were bleak and that returning to Japan was his best option. ${ }^{13}$ Though there is no documentation to support or refute this assertion, there is evidence shown in the Naikoku case discussed below that Nagai's participation in state-sponsored projects came from his sense of duty and a strong desire to acknowledge the opportunity the Japanese government had given him by permitting him to study overseas. Given the knowledge Nagai had acquired during his 13 years in Berlin, he must have realized that he was the most suitable candidate to assist in building the foundations for the production of biomedicines based on chemistry. ${ }^{14}$ Nagai emulated his professor, August Wilhelm von Hofmann; he even adopted "Wilhelm" as his first name in his signature. Hofmann had close ties to the German chemical industry and had contributed to its development during his career as a university scientist. ${ }^{15}$ It is likely that Nagai's observations of his professor's activities, particularly 
his close relationship with industrialists, influenced his positive stance toward business and his decision to leave Berlin to aid the government in establishing a new enterprise, Dainippon.

Once Nagai had resolved to return to Japan for this purpose, he devoted himself fully to the cause. Nagai personally drew the sketches for the company layout as illustrated by his notations in both German and Japanese (Figure 2.1). In 1888, Dainippon's factory was erected according to his specifications in Kobiki-chō, located in the Kyōbashi area of Tokyo, next to the Japanese Naval Academy. It was on this factory site that he and his newly wedded wife, Therese, took up residence after arriving in Tokyo. Prior to his departure from Germany, Nagai was commissioned to make purchases of the latest equipment for pharmaceutical production which arrived at the Port of Yokohama in 1884. (One piece of this original equipment, a distillation still, is still on display in the company's headquarters.)

Under Nagai's guidance and supervision, Dainippon was able to begin production on a scale unprecedented in Japan. The company's products included a large assortment of pharmaceutical chemicals, a few cosmetics such as fragrances and skin creams, as well as ramune, a carbonated lemonade, then used as a cholera remedy and still sold today as a beverage. ${ }^{16}$ Dainippon was clearly in a class of its own as most of the other early pharmaceutical producers were

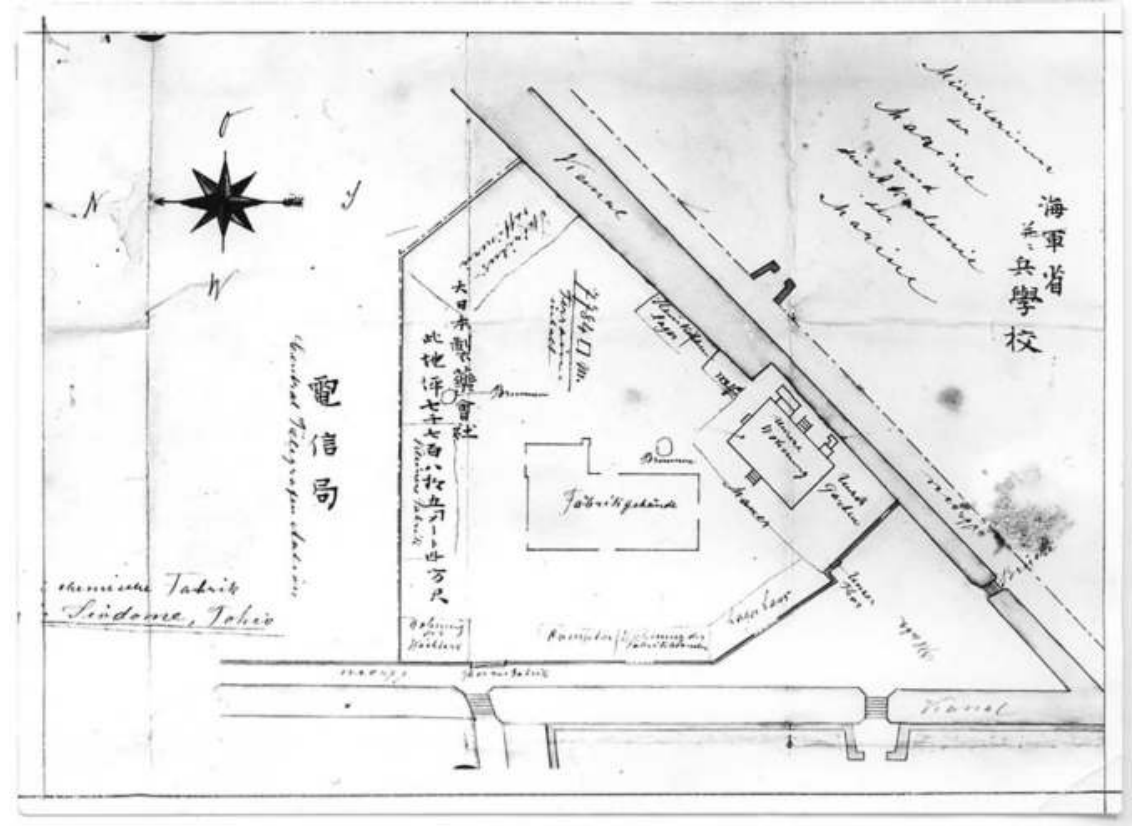

Figure 2.1 Nagai's sketch of Dainippon's first production site

Source: Image courtesy of the Faculty of Pharmaceutical Sciences, Tokushima University. 
still experimenting with new manufacturing techniques and only ran small-scale operations. $^{17}$

Although Dainippon got off to a strong start, its success was short-lived. Apart from the company's official histories, little is known of the actual causes of Dainippon's failure or the reasons for the government's decision to sell the company to the private sector. Nagayo's memoirs and Nagai's official biography mention the founding of Dainippon but offer no information on Osaka Pharmaceutical Company, the company that purchased Dainippon, managerial problems or the financial circumstances that led to the sale. According to the 60 -year history of Dainippon, the reason for its demise was the company's rigid bureaucratic management that impeded change. Dainippon was not able to adapt to fluctuations in the market and its profits stagnated. ${ }^{18}$ Other corporate accounts offer similarly brief explanations of Dainippon's poor performance and subsequent merger. ${ }^{19}$

Dainippon was purchased in 1897 by a group of 21 investors, who were joint owners of Osaka Pharmaceutical and former members of what had once been Japan's largest medicinal guild. Indeed, prior to the dissolution of the guild in the early Meiji period, the merchants of Doshōmachi in central Osaka had for centuries dominated Japan's most extensive trade network for medicinal herbs of Eastern and indigenous origin. The purchase of the company included Dainippon's trademark as well as the valuable equipment that Nagai had shipped from Germany; its headquarters were moved from Tokyo to Osaka. Nagai had resigned from Dainippon in 1893, the same year that he was awarded a professorship at Tokyo Imperial University. Despite having officially left the company, however, he occasionally made visits to Osaka to provide guidance and scientific support to the new owners of Dainippon and sent two of his graduates to supervise production on a more regular basis. The photograph below (Figure 2.2), taken of the 21 new owners seated in front of the company's production site in Osaka in 1902, provides evidence of Nagai's ties to the nascent pharmaceutical industry even after his resignation.

Seated front row, center, is Nagai. Because he is wearing a laboratory coat it is likely that he provided direct supervision on the factory floor. To his left and right respectively are the owners of Tanabe and Shionogi Pharmaceutical Companies, Tanabe Gōhei and Shiono Gizaburō. All of the individuals in the photograph were joint owners of Dainippon, and they included the founders of such well-known pharmaceutical manufacturers as Takeda and Ono. Dainippon, which became Dainippon Sumitomo Pharmaceutical Company after a merger in 2005 , is still in operation today.

\section{New businesses in the Taishō period: Naikoku Pharmaceutical Company}

The government's role in promoting the development of a domestic pharmaceutical chemicals industry gradually evolved during the Meiji and Taishō periods. Meiji-period policy had the dual focus of providing a regulatory 


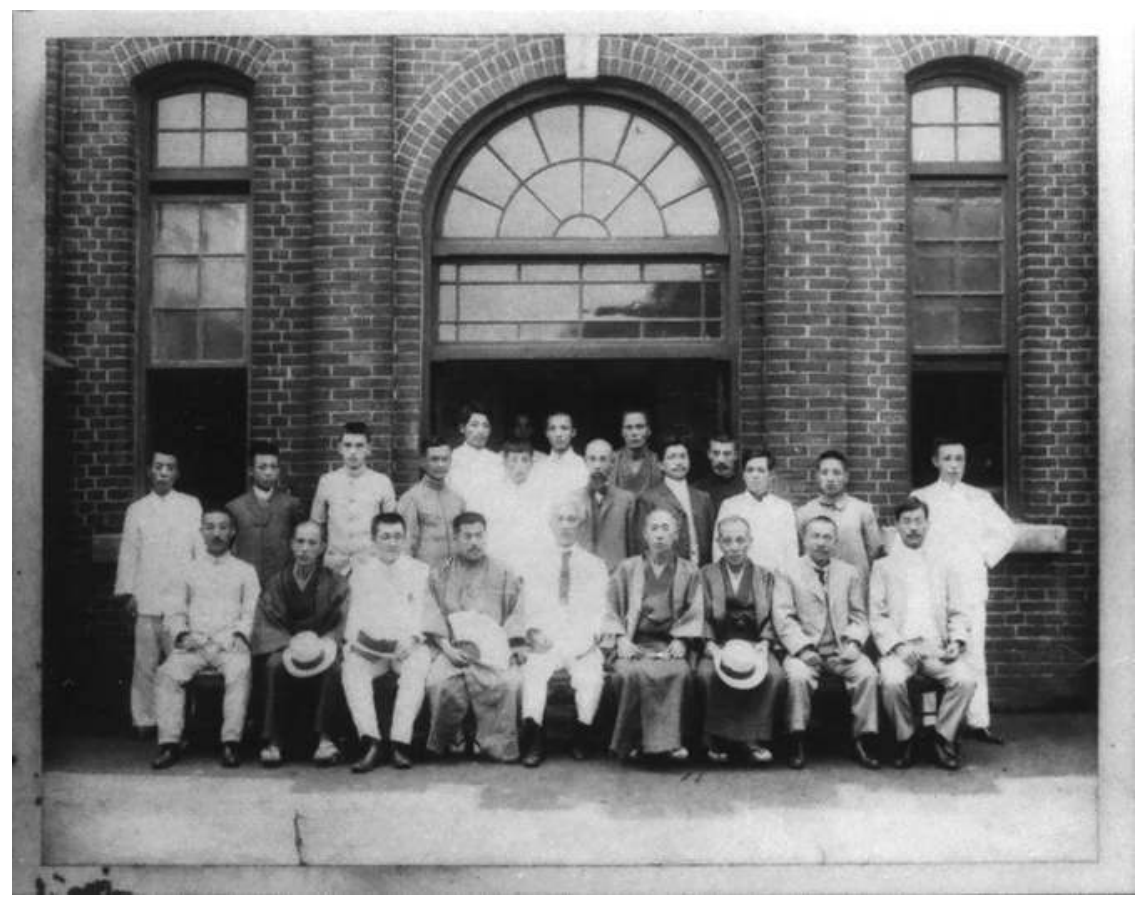

Figure 2.2 Nagai Nagayoshi and the 21 founders of the "new" Dainippon (Osaka) Source: Image courtesy of Faculty of Pharmaceutical Sciences, Tokushima University.

framework to improve the quality of biomedicines in circulation while also supporting the establishment of a modern, large-scale enterprise, Dainippon. In the Taishō period, policy goals shifted from improving quality with a view of achieving economic and political autonomy to obtaining full self-sufficiency through import substitution so as to contribute to the building of a modern empire. The main impetus for policy change was war, which caused a sharp rise in demand for pharmaceutical chemicals.

Although Japan's direct involvement World War I was limited, it was a major importer of German chemical products. In 1913, of the 5,700 tons of imports to Japan, 90 percent were German dyes. ${ }^{20}$ Consequently, when German imports were cut off at the start of the war, there were severe shortages of all types of chemical products, including pharmaceuticals, accompanied by a marked increase in price. In response to this crisis, the Taishō government began to implement regulations in 1914 to limit the export of medicinal products whilecontinuing to promote self-sufficiency. In the following year, a nine-article Law to Promote the Production of Dyes and Medicines was implemented to aid industry by providing subsidies to dye and pharmaceutical-producing enterprises capitalized at over $¥ 500,000$. This law also provided for the creation of another pharmaceutical manufacturer, Naikoku, followed by Tōyō. 
As part of government plans for self-sufficiency, Naikoku's financing came from both the public and private sectors. However, unlike Dainippon, which had equal public and private investment, Naikoku's ownership was almost entirely private. Naikoku's largest shareholder was the renowned scientist Takamine Jōkichi. Takamine was also president in absentia of Sankyō Shōkai, which in 1913 would become the joint-stock company, Sankyō Pharmaceutical Company, and the developer of two of Sankyō's best-selling products, takadiastase and adrenaline. According to Sankyō's 100-year history, at the time of the founding of Naikoku, Takamine wished to obtain full ownership. It was decided, however, that the heads of existing companies would not be permitted to obtain a 100 percent stake in the new company. Thus, Takamine became the majority shareholder of Naikoku with 19,000 of the total 20,000 shares. ${ }^{21}$ Though Takemine did not have full ownership, Sankyō's management under Shiobara Matasaku exercised direct influence over daily operations. Naikoku's headquarters were situated on the same premises as Sankyō, in Nihonbashi in central Tokyo, while production took place on Sankyō's factory site in Shinagawa. ${ }^{22}$ Fukuhara Arinobu, a prominent pharmacist and founder of the cosmetics firm Shiseidō, had close ties to Sankyō and became Naikoku's first president.

Nagai, aged 71 and just retired from Tokyo Imperial University, became its advisor. Nagai already had loose connections with Sankyō, as he had become one of the numerous shareholders at the time of its incorporation in 1913. One might be tempted to think that because of Nagai's advanced age his position would be merely honorary; however, this was not the case- he visited the company's laboratory three times a week. ${ }^{23}$ The photograph below (Figure 2.3) taken during one of his visits to Naikoku confirms his direct assistance.

It is clear that Nagai was enthusiastic about contributing to Naikoku's scientific development. In an interview published in the Tokyo Asahi Newspaper, he denied that his age would in any way hinder his assisting in the scientific operations of the company. Further, he strongly expressed his willingness to share his knowledge and expertise to help the nation, as his way of repaying the Japanese state for permitting him to go to Berlin for study. ${ }^{24}$ Although he was eager to assist in Naikoku's medicinal manufacturing activities, his role was much less significant than at Dainippon and consisted mainly of overseeing the production of one medicine, ephedrine, for which he is best known. Ikeguchi Keizō, a doctor of pharmacy and head of the Hygienic Laboratory of the National Police, became Naikoku's executive director and laboratory chief. Naikoku produced an impressive list of some thirty pharmaceutical chemicals including aminopyrine and carbolic acid, substances for which Japan was heavily dependent upon imports. ${ }^{25}$ The government also granted special permission to Naikoku, as well as two other companies, Dainippon and Hoshi, to produce opium and morphine, while Naikoku, Kōtō, Hoshi, Takeda and Shionogi became the official manufacturers of cocaine.

Naikoku was unprofitable despite substantial subsidies which became an increasingly onerous burden to the government. In 1920, a deal was negotiated whereby Sankyō was granted permission to purchase all remaining Naikoku 


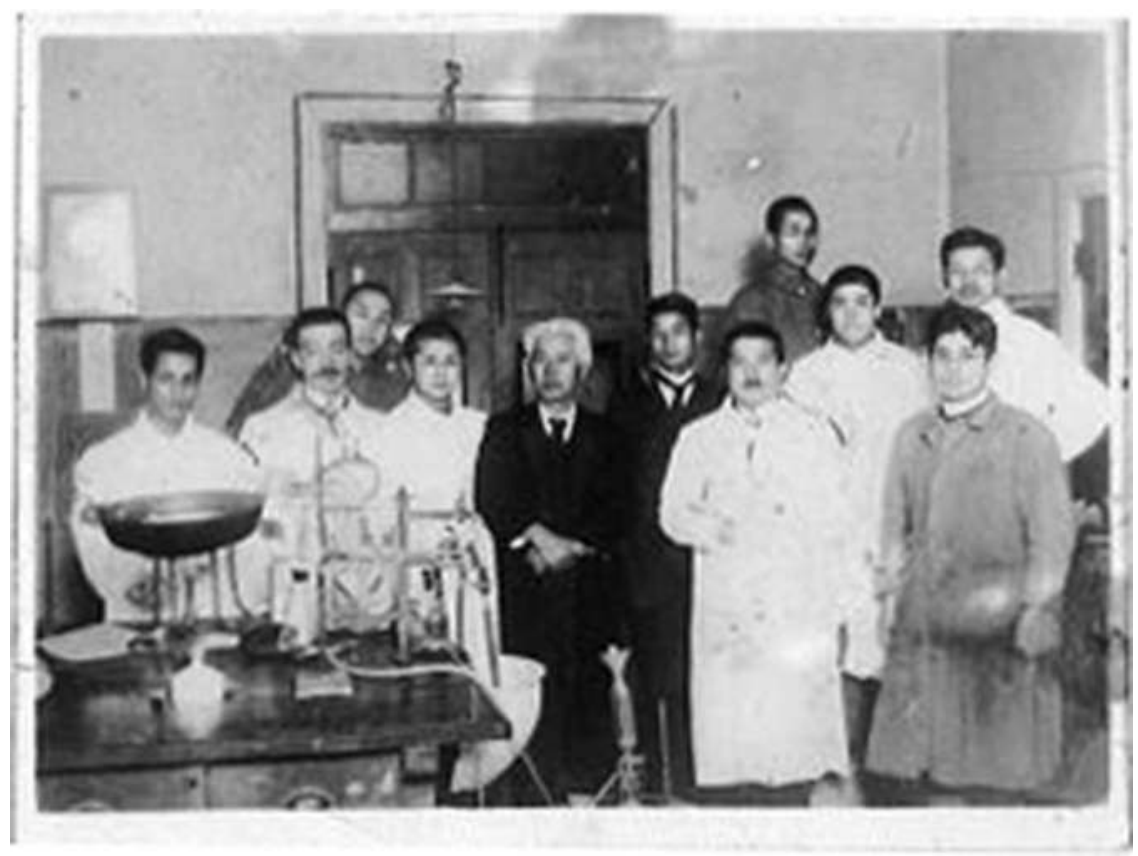

Figure 2.3 Photograph of one of Nagai's visits to the Naikoku laboratory

Source: Image courtesy of the Faculty of Pharmaceutical Sciences, Tokushima University.

shares. In addition, Sankyō obtained the coveted rights to manufacture and market narcotics, a privilege it still retains today. As was the case with Dainippon, little is known of Naikoku's daily operations or the negotiations between Sankyō and the Taishō government. ${ }^{26}$ According to Sankyō's corporate history, Naikoku's failure can be blamed on unstable economic conditions. ${ }^{27}$ Thus, despite government subsidies, expert technical assistance and novel technologies introduced by Nagai and others to produce pharmaceutical chemicals for which there was considerable demand, this state-sponsored enterprise followed a similar pattern of failure to its predecessor, Dainippon.

\section{Technological innovation at local businesses: the case of the Awa indigo business}

The cultivation of indigo in Awa (present-day Tokushima prefecture) can be traced to the Heian period, although it did not begin to flourish as a business until 1585 when measures were introduced to encourage its development. Thanks to the implementation of a monopoly and other protective measures, Awa indigo production reached its zenith in the Edo period (1600-1868) and became one of the main pillars of the Awa economy. From 1882, however, the industry's long dominant position throughout Japan began to wane due to 
competition from imported natural indigo from India. Then, from 1902, producers were dealt a further blow by imports of synthetic dyes from Germany. After a short reprieve during the First World War when German imports abruptly ceased, by 1926, production of natural Awa indigo once again plummeted, having been completely overtaken by synthetic dyes. ${ }^{28}$

Between 1899 and 1901, Nagai made several visits to his home prefecture in large part to assist dye producers in dealing with mounting international competition. Between July 6 and 23, 1901, Nagai gave a total of 14 hours of lectures. ${ }^{29} \mathrm{He}$ began his series by urging his audience, which included indigo growers, dyers and sellers, to organize themselves by forming a production association. ${ }^{30}$ Nagai also provided relevant explanations of the technological innovations in synthetic dyeing that had been taking place in Germany. He mentioned the work of German chemists involved in the recent discoveries, some of whom he had met during his studies, while underlining the contributions of his former mentor, August Wilhelm von Hofmann.

The purpose of his lecture series was to describe in simple terms the chemistry for an improved dye production process that he had developed expressly to aid the Awa indigo businesses. Nagai patented his discovery, for which he was awarded a gold medal at the Paris Exposition in $1900 .{ }^{31}$ In addition to his explanations, Nagai also offered producers a wide range of suggestions to enhance dye quality, including the use of specific fertilizers to improve the dyeing properties of the indigo leaves. ${ }^{32}$

In his lecture notes, Nagai clearly stated his motivations and aspirations for assisting this local industry. First, he wished to give his support to the many dye-related businesses that for centuries had been so important to the livelihood of the people of Tokushima. Second, he stated that through scholarship he aspired to contribute in some small way to the development of the Japanese nation. ${ }^{33}$ Thus, in the case of Awa indigo, Nagai's goal of contributing to economic growth through science, notably chemistry, was consistent with the goals he espoused when assisting Dainippon and Naikoku.

\section{Industry-academia ties in Tokushima prefecture: Tomita Pharmaceutical Company}

Nagai's involvement in the development of businesses went beyond large government-sponsored projects to include small privately owned enterprises. One such enterprise is Tomita Pharmaceutical Company. Today the company is managed by a direct descendant of the founder, Tomita Kyūzaburō (1852-1937) and manufactures many of the same pharmaceutical chemicals that it produced at the time of its establishment in $1893 .^{34}$ The company first opened for business not in Tokushima but in what is now Shizuoka prefecture, the birthplace of its founder. In order to enjoy a more plentiful source of raw materials, Kyūzaburō moved the headquarters to the coastline of Naruto in Tokushima prefecture, where they remain today. 
Kyūzaburō shared Nagai's interest in applying the principles of chemistry to business. During much of his lifetime, Kyūzaburō worked in Tokushima as a successful scientist, business owner and local politician. Although he was never dispatched overseas for studies, he was exposed to Western knowledge from an early age. Yasugorō, Kyūzaburō's grandfather, studied rangaku (Western Learning), including chemistry and medicine, and passed this knowledge on to his son and grandson. From 1869 to 1871, Kyūzaburō lived in Nagoya at the home of a physician trained in Dutch medicine. There he was able to pursue his study of Western science while also beginning to learn about biomedicine production. After returning home from Nagoya in 1871, Kyūzaburō embarked on a long search for a process for producing magnesium carbonate. His goal was to produce large quantities of this substance cheaply by using a by-product of the salt-making process, bittern, which is composed of magnesium chloride, magnesium sulfate, potassium chloride and sodium chloride. At that time, Japan had not achieved self-sufficiency in the production of magnesium carbonate and had to rely on imports from England. Kyūzaburō experimented with a number of different production methods, all of which failed. Consequently, he returned to Nagoya for a second time to study under Itō Keisuke, a physician who trained in botany under Philipp Franz von Siebold in Nagasaki.

Two examples of Kyūzaburō's ability to combine modern science and business are particularly noteworthy. First, in 1877, he succeeded in developing his own production method and began manufacturing magnesium carbonate. In 1881, the Meiji government granted Kyūzaburō an official license to produce magnesium carbonate according to the standards of the British pharmacopoeia as well as permission to manufacture ether and a number of other pharmaceutical chemicals. Then, in 1884, he received a second license to produce other substances such as ammonia according to the German Pharmacopeia, dilute acetic acid, opium tincture, and more. In 1887, the Meiji government issued the first Japanese Pharmacopeia, which listed magnesium carbonate. Then, in 1890, Kyūzaburō became the first person in Japan to successfully extract potassium chloride from bittern, an accomplishment that brought acclaim from both business and academia. ${ }^{35}$ As was the case with magnesium carbonate, Kyūzaburō's discovery of a new method to extract potassium chloride with a high level of purity contributed to the nation's efforts to achieve import substitution. With the financial success that ensued, Kyūzaburō decided to move his growing business operations to Tokushima in order to have an abundant supply of bittern. More successes followed: in 1896, he also discovered a method to produce refined sodium chloride and became the official supplier to the Meiji government.

Despite similarities in their interests, Nagai's ties with Kyūzaburō were much more indirect than in the cases mentioned above; furthermore, Kyūzaburō's first academia-industry relations involving Tomita were not with Nagai but with one of his colleagues from Tokyo Imperial University, Shimoyama Jun'ichirō. Like Nagai, Shimoyama also provided assistance to industry. ${ }^{36}$ Tokyo Imperial University did not yet have a faculty of pharmacy; instead there was a department of pharmaceutical production, affiliated with the school of medicine. ${ }^{37}$ The 
interest of some academic scientists such as Shimoyama in the pharmaceutical chemicals industry stemmed from the department's focus on practical chemistry applied to the production of medicine. In 1890, he and some of his students visited Tomita's Shizuoka factory, whose products had gained a reputation both for their high quality and purity. Given the fact that chemistry was still a new science in Japan, Kyūzaburō's discoveries were extraordinary-particularly for someone who had never studied overseas - and attracted great attention.

Kyuzzaburō's first contacts with Nagai came at the end of Nagai's life and career. In 1920, a group of some 708 medicinal businesses in Tokushima prefecture decided to form a prefectural trade association that Kyūzaburō, then a local politician, joined as an advisor. ${ }^{38}$ As president of the Pharmaceutical Society of Japan, Nagai was invited in 1921 to give a lecture in Tokushima, organized in part by the members of this association. Then, in 1923, the Pharmaceutical Society of Japan and the Shikoku Chemical Manufacturers' Association decided to hold a joint general assembly meeting in Tokushima, which Nagai and a number of prominent bureaucrats attended, notably the chief director of the Hygiene Bureau of the Ministry of Home Affairs. At this meeting, Nagai invited Kyūzaburō to join him on an eight-month trip to Germany with members of Nagai's close family and former students including one future president of Dainippon, Takino Osamu. ${ }^{39}$

In 1927, Kyūzaburō departed with Nagai for Germany, the last of several trips Nagai made there during his lifetime. Nagai, aged 83, and Kyūzaburō, aged 76, developed an affinity for one another. ${ }^{40}$ While in Germany, Kyūzaburō attended a joint reception hosted by the German Chemical and German Pharmaceutical societies, where Nagai gave a speech on Japan's progress in these two disciplines. Kyūzaburō joined Nagai, Takino and others on their visits to Siemens, the Kaiser Wilhelm Institute, and Bayer, where they were able to meet with a number of corporate scientists. They also visited Merck's pharmaceutical and chemical production sites where the photograph below (Figure 2.4) was taken in the company's Japanese garden (Kyuzzaburō is standing to Nagai's right; Takino is on his left, wearing a vest).

Kyūzaburō was deeply impressed by the many places he visited, particularly the orderliness and cleanliness of the production sites. He believed that it was essential for Japan to emulate German factories to ensure high levels of safety and hygiene, which would in turn lead to improvements in production quality. ${ }^{41}$

Although Tomita's corporate history provides a description of some of Kyūzaburō's impressions, there is no remaining archival evidence to prove that he made specific changes to his business organization as a result of his observations of German companies or direct advice from Nagai. ${ }^{42}$ As illustrated through his long quest for a method to produce magnesium carbonate, it is clear that Kyūzaburō had a strong desire to engage in research-based product development even before his trip overseas. According to an interview at the Tomita headquarters in Tokushima, Kyūzaburō aspired to construct a corporate laboratory at a time when investment in research and development was rare. ${ }^{43}$ Kyūzaburō 


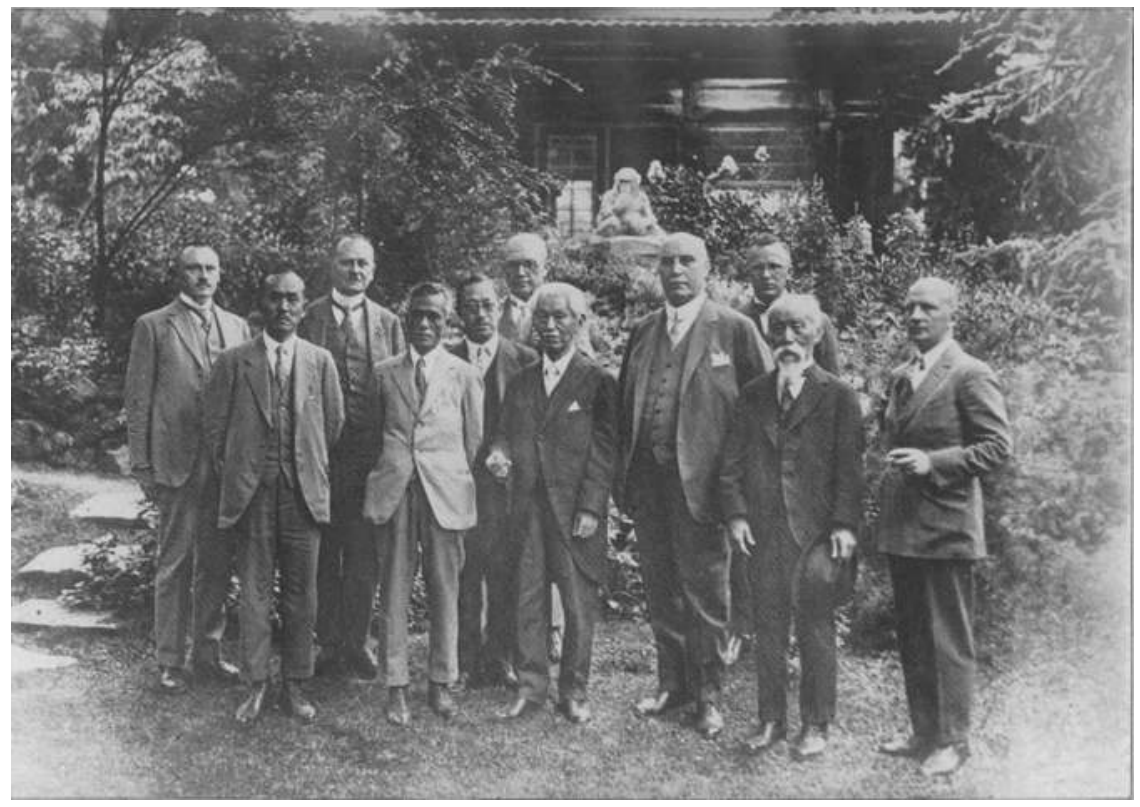

Figure 2.4 Nagai's visit to Merck's Japanese garden

Source: Image courtesy of Tomita Pharmaceutical Company, Tokushima, Japan.

may have been influenced by Nagai's willingness to share his scientific knowledge and practical know-how with others and, like Nagai, freely gave information to potential competitor firms as well as his Osaka-based distributor, Fujisawa Pharmaceutical Company. ${ }^{44}$

Nagai's relationships with the many business representatives he assisted continued to the final days of his life. Nagai's last trip to Tokushima, just before his death, took place in November 1928. During his stay, he paid a visit to Kyūzaburō's home where a gathering of those who had made the trip to Germany, along with prominent members of the Tokushima business community, took place. Takino Osamu, future president of Dainippon and head of the Awa Indigo Production and Sales Association, were both present at the celebration.

\section{Conclusions}

The cases of Dainippon and Naikoku, which both received direct technical assistance from Nagai, bring to light the different objectives and roles of the Meiji and Taishō governments in fostering the development of pharmaceutical enterprises, as well as the similar patterns by which the state, academia, and private sector endeavored to build a viable and enduring domestic industry. Although Dainippon failed in the short term under state management, in the long term it provided a business model for the owners of existing medicinal enterprises in Doshōmachi who were also beginning to embark on the 
production of biomedicines. The long and laborious process of building the foundations of a domestic pharmaceutical industry had only gotten underway in the Meiji period. By the end of the First World War, however, Japan possessed two large-scale enterprises founded by the state-later purchased and managed by the private sector: Dainippon in the Kansai region and Sankyō in the Kantō. These enterprises were essential to the nation's aspirations to achieve economic autonomy and build a modern Japanese empire.

Although bureaucrats were largely unsuccessful in their efforts to manage these pharmaceutical enterprises, the state's initial involvement was indispensable. Had there not been any measures introduced, self-sufficiency in the production of pharmaceuticals would have taken much longer for Japan to achieve. With the foundations for the production of pharmaceuticals in place, combined with expert assistance and a series of new discoveries by Japanese scientists such as Nagai (ephedrine), Takamine (adrenaline), Suzuki Umetarō (vitamin B1), the two largest enterprises of the Meiji and Taishō periods, Dainippon and Sankyō, could begin to consolidate and expand their operations.

The four cases examined in this essay illustrate the pivotal role that one individual scientist, Nagai, played - not only in the service of the state but also on his own initiative - in transferring Western science and technology from academia to industry. Nagai was not the only Japanese scientist to provide assistance to industry at production sites. However, his degree of involvement and commitment, as well as the sheer diversity in the type of guidance he provided - be it direct, indirect, national, or local — were unparalleled by his peers. These cases also offer new insights into the many patterns and characteristics of the earliest academia-industry relations in Japan and provide a useful resource for comparative studies of East Asian countries as well as other parts of the world.

What can also be considered characteristic of Nagai is that his contributions went beyond the creation of new businesses. He developed and patented an improved technology to aid in the modernization of a longstanding indigenous industry, Awa indigo dyeing. His concern for the economic and scientific development of his birthplace during a period of history when the state was making great efforts to unify the nation by centralizing all activities in Tokyo is unique to Nagai and illustrates a side of his personality that few if any scholars have explored. His ties to businesses in Tokushima and industrialists in Osaka spanned several decades through the last year of his life.

Though Nagai was one of the first, he would not be the last scientist to have close ties to corporate science. Another well-known example is Umezawa Hamao, who worked with officials to facilitate the transfer of mass production technology for penicillin to industry during the early Occupation and continued to provide pharmaceutical companies with technologies for new antibiotics in the decades to follow. Such formal and informal ties between academia and industry contributed to the formation of science in the pharmaceutical industry, the development of the economy, and the improvement of public health in the long term. By absorbing and then building on the 
practical knowledge acquired from Nagai and later academic scientists, Japan's corporate scientists could begin their quest for innovation and the discovery of their own novel in-house drugs.

\section{Notes}

1 This phrase is borrowed from the title of James R. Bartholomew's book, The Formation of Science in Japan (New Haven, CT: Yale University Press, 1989).

2 Hiromu Nohara, Roman to Jyōnetsu ni ikita yakugaku no chichi, Kono hito Nagai Nagayoshi (Tokyo: Creative Books, 2008).

3 Nagai and others fought unsuccessfully to introduce a modern system of pharmacy (iyaku bungyō) to Japan. Takashi Nishikawa, Kusuri no shakaishi: Jinbutsu to jiji de yоти 33 wa (Tokyo: Yakuji Nippō-sha, 2010), 44-50. Had this system been implemented it would have given pharmacists greater autonomy vis-à-vis physicians and higher status in the medical system.

4 The Japan Society for the History of Pharmacy published a considerable number of articles on Nagai that focus on his discovery of ephedrine, education of pharmacists, separation of dispensing and prescribing of medicine, etc. Few explore his role in the development of business. The same is true of Nagai's official biography published by the Pharmaceutical Society of Japan. Kaneo Seizō, Nagai Nagayoshi den (Tokyo: Nihon Yakugakukai Hachijūnen Kinengyōji, 1960).

5 Kaneo, Nagai Nagayoshi den. Even in Nagai's biography the focus is his official scientific/academic achievements rather than his contributions to industrial development.

6 Shibuya Masayuki, professor emeritus of pharmaceutical sciences at Tokushima University and Japan's foremost specialist of Nagai, was instrumental in establishing and cataloging the information housed in the Nagai archive in Tokushima. Shibuya stresses Nagai's passion for chemistry and drive to contribute to education and business. See Shibuya Masayuki, Yakugaku to yakurigaku no bun'ya ni okeru Nagai no yakuwari to jūyōsei-Tokuni Nihon ni oite (Nichidoku Ishizuze no Rekishi, 2002).

7 Kōseisho Imukyoku, eds., Koseishō gojūshūnenshi (Tokyo: Gyōsei, 1976), 178.

8 Tadayasu Ban, Tekijuku to Nagayo Sensai: eiseigaku to Shōkō shishi (Osaka: Shōgensha, 1987).

9 Nagayo is known as the father of public welfare (福祉の祖), Mikio Toyama, Iryōfukushi no So Nagayo Sensai (Kyoto: Shibunkaku Shuppan), 2002. Toyama also credits Nagayo as being the creator of modern regulatory policy in healthcare. See also Ann Jannetta, From Physician to Bureaucrat: The Case of Nagayo Sensai, in New Directions in the Study of Meiji Japan, ed. Helen Hardacre and Adam L. Kern (Leiden, New York and Köln: Brill, 1997), 151-61.

10 Shibuya, Yakugaku to Yakurigaku, 1-3.

11 Nagai received word from Aoki Shūzō shortly after his arrival that he would have to return to Japan. Because Nagai had saved $¥ 2,000$ to $¥ 3,000$ that he would use with extreme frugality for the following two to three years, he was able to continue his studies in Berlin. Nagai Nagayoshi Berurin tsūshin, Tokushima School of Pharmaceutical Science (Nagai Nagayoshi Shiryō Iinkaihensū, 2006), 139.

12 Descriptions of some of the outlandish promises contained in Nagai's letters can be found in Shibuya, 6-7.

13 Yasue Masa'ichi, Kagakusha Nagai Nagayoshi no gyōseki saiginmi: Densetsuteki jinbutsu hyōron o hihansuru (Tokyo: Kagakushi Kenkyū, 1986), 163.

14 Kaneo, Nagai Nagayoshi, 132-4. 
15 Nagai so loved the name Wilhelm that he gave the name, Willy, written in Chinese characters, to one of his sons.

16 An account of Dainipppon including the products the company manufactured can be found in Mishima Yūichi, Kusuri no Osaka Doshōmachi ima mukashi (Osaka: Izumi Shoin, 2006), 98-106.

17 See the corporate histories of Tanabe, Shionogi and Takeda Pharmaceutical companies for description of their struggles.

18 Dainippon Seiyaku (ed.), Dainippon seiyaku rokujūnenshi (Osaka: Dainippon Publishers, 1958), 25.

19 Ibid., 17-8; Dainippon Seiyaku (eds), Dainippon seiyaku hachijūnenshi, 6-7. The 60-year history states that no records exist to confirm the reasons for Dainippon's failure. During an interview at the Dainippon headquarters in Osaka, the former president stated that most of the company's archives were lost during World War II. Whether there were ever any records remains a mystery. It is likely that any evidence of poor management was discarded at the time of the merger.

20 Yamamoto Akio, Nihon no kagaku no rekishi, Kagaku aakaibusu-kagaku sōgō shiryōkan no setsuritsu e; Chemical Society of Japan, Kagakukyōiku Kyōgikai, Kagaku archive working group (25 March 2004), 56.

21 Sankyō Hyakunen-shi Henshūiinkai (eds), Sankyō hyakunenshi (Tokyo: Dainippon Publishers, 2000), 52.

22 Ibid., 51-3.

23 Kaneo, Nagai Nagayoshi, 214.

24 Tokyo asahi shinbun, "Nagai hakushi daigaku wo shirizokute, minkan no seiyaku ni tsukusu" (December 6, 1917), 5.

25 Sankyō Hyakunenshi, 61-2.

26 An account written by Hoshi Shin'ichi, son of the founder of Hoshi Pharmaceutical, provides a far more critical assessment of Naikoku's incompetent management and the role of the state, which is omitted from Sankyō's corporate history. The book's title, Minjin wa yowashi kanri wa tsuyoshi, can be translated as "Bureaucrats are powerful; the people are weak" and alludes to the reason for the failures of Naikoku's and Hoshi's pharmaceutical business. Hoshi Shin'ichi, Minjin wa yowashi kanri wa tsuyoshi (Tokyo: Shinchōsha, 1978).

27 Sankyō hyakunenshi, 61.

28 Yasuhiro Izumi, Ai no gōshō-keiei senryaku to seisui (Tokushima: Tokushima Shinbunsha, August 21, 1991), 54 and 87.

29 A copy of Nagai's lectures, Awa ai kairyōdan was obtained courtesy of the Faculty of Pharmaceutical Sciences, Tokushima University, Nagai Nagayoshi Archives.

30 Awa ai kairyōdan, 5-6.

31 The original patent (number 3767) can be found at the Industrial Property Digital Library, online at: www6.ipdl.inpit.go.jp/Tokujitu/tjsogodbk.ipdl.

32 Awa ai kairyōdan, 4.

33 Awa ai kairyōdan, 75.

34 Tomita is a producer of finished and bulk pharmaceuticals, food additives, mineral supplements, and various chemicals derived from seawater, online at: www.tomitap h.co.jp/english/.

35 Tomita Seiyaku Kabushiki Kaisha, Tomita seiyaku hyakunenshi no ayumi (Naruto-shi: Tomita Seiyaku Kabushiki Kaisha, 1992), 31-2.

36 Ibid., 31; Sankyō hyakunenshi, 19.

37 Nagayo established the Department of Pharmaceutical Production to train students to produce and evaluate the quality of medicine. The Faculty of Pharmaceutical Sciences did not become separated from the Faculty of Medicine until 1958.

38 Tomita seiyaku hyakunenshi, 85.

39 Ibid. Takino also served as Dainippon's fourth president.

40 Ibid., 115. 
41 Ibid., 118.

42 According to an interview with Murakami Kazuyuki, Personnel Department, Headquarters of Tomita Pharmaceutical Company, November 17, 2011, virtually all of the company's archival information was lost during a typhoon. This is not surprising given the company's coastal location.

43 Ibid.

44 Fujisawa Pharmaceutical Company merged with Yamanouchi Pharmaceutical Company in 2005 to form Astellas, Pharma. 


\title{
3 An emperor's chemist in war and peace
}

\section{Sakurai Jōji during the Russo-Japanese War and World War I}

\author{
Kikuchi Yoshiyuki
}

\section{Introduction}

Sakurai Jōji (1858-1939) is now recognized as a highly significant person in the history of science in Japan due in no small part to the extensive discussion of his career in James Bartholomew's Formation of Science in Japan. ${ }^{1}$ He was an organic and physical chemist by training with some reputation as a research scientist and skilled teacher during the Meiji period. ${ }^{2}$ However, it was above all as an organizer and diplomat of science in Japan, particularly active during the interwar period, that he gained recognition. Sakurai was involved in establishing three principal organizations for scientific research, all eventually utilized to some extent for the mobilization of scientists for colonial exploitation and war efforts during World War II: the Institute for Physical and Chemical Research (Rikagaku Kenkyüjo or RIKEN, est. 1917), the National Research Council of Japan (Gakujutsu Kenkyū Kaigi or GAKKEN, est. 1920), and the Japan Society for the Promotion of Science (Nihon Gakujutsu Shinkōkai or GAKUSHIN, est. 1932). ${ }^{3} \mathrm{He}$ also assumed the presidency of the Imperial Academy (Teikoku Gakushiin) and the office of privy councilor from 1926 until his death in 1939. He stood quite literally at the crossroads of science and empire-building in interwar Japan. This essay addresses two questions: to what degree did Sakurai's vision of science and empire, if any, shape the development of science in Japan? To what extent was he an unwitting accomplice to empire-building?

Two relevant elements of Sakurai's career and personality have already been noted by historians: his strong British connections and his sense of inferiority to Euro-American scientists. ${ }^{4}$ The former is particularly pertinent to the second question in light of the deterioration of Anglo-Japanese relations after the Manchurian Incident (1931) and the fact that the very research organizations he was instrumental in building were utilized against Britain and the United States. The question here is to what extent he felt the dilemma of such a seemingly charged situation.

Less discussed but even more relevant to the theme of this chapter is Sakurai as a "great patriot." ${ }^{5}$ On Sakurai's patriotism and that of other Meiji scientists involved with the establishment of RIKEN, Hiroshige Tetsu observed that 
"they all grew up together with the Meiji government and strongly identified themselves (ittaika shita) with the 'establishment,' both subjectively and objectively." I am not of the opinion that the whole spectrum of Sakurai's visions was predetermined by Meiji patronage. However, I do agree with Hiroshige that we have to go beyond the chronological framework of the interwar period to really understand the genesis of patriotism in Japanese scientists of Sakurai's generation.

I focus here on the Russo-Japanese War and World War I, which played important but quite different roles in the development of Sakurai's visions of science, the military, and empire. In Western historiography of twentieth-century science, technology, and society (STS), World War I has been identified as the starting point of the organized mobilization of science for military purposes. Hiroshige's Kagaku no shakaishi and Bartholomew's Formation of Science in Japan both devoted a chapter to World War I but not the Russo-Japanese War, and Hiromi Mizuno's more recent Science for the Empire similarly started the whole story of "scientific nationalism" in Japan with it. ${ }^{7}$ In Japanese history, by contrast, the Russo-Japanese War outweighed the role of the First World War in heralding the rise of Imperial Japan. ${ }^{8}$ By scrutinizing Sakurai's career as an "Emperor's chemist," this chapter aims to bridge these two "starting points."

As clarified below, Sakurai participated in both wars as a scientist, which suggests that the two wars helped him play an early yet major role in bridging science, empire-building, and the military. I therefore analyze how his visions evolved between the 1890s and 1930s and discuss their ramifications for science in Japan. In other words, I shall look at how he self-transformed from a chemistry professor into a national figure at the crossroads of science, technology, and the military and determined the basic character of the Japanese scientific organizations he helped create as "dual-use" agencies for wartime as well as peacetime.

\section{Nationalism/patriotism echoed: Sakurai and William Ramsay at University College London}

Sakurai Jōji became one of the first Japanese professors of chemistry in Japan at Tokyo Imperial University in 1881 after being trained at the Tokyo Kaisei Gakkō with the English chemist Robert William Atkinson and at University College London with Alexander William Williamson. Williamson was succeeded by William Ramsay in 1887. In this capacity, Ramsay developed both connections and friendship with Sakurai.

The earliest sign of Sakurai's development as an "emperor's chemist" emerged in the 1890s. By then, the nation-making project of the Meiji government based on patriotism and ideological integration was well underway. For example, in 1890 the Imperial Rescript on Education was promulgated, which soon dominated elementary school education with its moral emphasis on the loyalty and piety of the nation to the emperor. The Sino-Japanese War (1894-1895) likewise inspired the spirit of national unity and patriotism among the Japanese 


\section{Kikuchi Yoshiyuki}

populace. ${ }^{10}$ In this context, Sakurai delivered a popular lecture "The State and Science [Kokka to rigaku]" at the Tokyo Academy in December 1898, which was published in January the following year. ${ }^{11} \mathrm{He}$ argued for the relevance of science (rigaku) to the state (kokka) in terms of its role in training the nation (kokumin) in the scientific method to better prepare the people for their occupations: "Politicians, soldiers, or merchants: regardless of occupation, anyone has to practice the scientific method to avoid misjudgment in his daily life." 12

Sakurai's statement is an interesting combination of state education's role in nation-making and English-style "science as liberal education," advocated by, among others, Sakurai's mentor, Williamson, and biologist Thomas Henry Huxley. These two formed Sakurai's earliest version of scientific nationalism defined as "the kind of rhetoric claiming science's relevance to nation-making." 13 It is important to note that, though he chose the term kokumin (the civic or political nation) instead of shinmin (subjects) as specified in the 1889 Meiji Constitution, Sakurai did so only to argue for the value of science for the state, i.e., empire, as the title of his address shows. Simply put, for Sakurai nation-making was inseparably connected to empire-building. ${ }^{14}$ At this stage, emphasis was on the pedagogical value of science and there was no mention to potential use of the outcomes of scientific research for military purposes.

It is probably while Sakurai held this version of scientific nationalism that he met William Ramsay in 1901. Unfortunately, there is no record of their conversation, but in June 1902, Ramsay wrote to Sakurai:

You have made a most favourable impression on my women-folks, who have now the highest opinion of you as a nation. They regard you as a "man and a brother" in quite a different light, for example than our Indian fellow-subjects. ${ }^{15}$

Again, timing is a key to understanding Ramsay's attitude towards Japan. The Anglo-Japanese Alliance was being negotiated during Sakurai's stay in London in 1901. Signed in January the following year and announced in Februaryperfect timing for Ramsay to recognize his Japanese colleague as part of "a nation." Ramsay's friendly attitude towards Japan as an independent, Asian nation-state, as well as imperialist attitude towards India, are apparent in the quotation. ${ }^{16}$ On its own it may sound like a complimentary remark to a foreign colleague, but Ramsay's extraordinary action during the Russo-Japanese War would show his sincerity.

\section{Turning point: Sakurai during the Russo-Japanese War}

The Russo-Japanese War was the biggest war the Meiji government had ever fought, with over 50,000 casualties on each side. ${ }^{17}$ Probably because of the unprecedented scale of the war, on December 23, 1905, the Ministry of War ordered each department $(k a)$ and bureau $(b u)$ to submit a detailed report of 
their wartime accomplishments by May 1906 "to compile a history of [our] services during the war for future reference," adding that "opinions should be attached to the description of major topics of our services." 18

One of the outcomes of the Ministry of War's efforts to preserve lessons of the war for later generations was "A Detailed Report of the Work done by the Artillery Department during the 1904-5 Campaign." ${ }^{19}$ It is in this report that Sakurai and Ramsay are mentioned:

On December 21, [1904,] Dr. Ramsay in Britain explained about a kind of gas which is not deleterious but the use of which would force soldiers to leave the battle position they are defending. He added that Dr. Sakurai knows the details of how to prepare this gas. Accordingly, our department gave an order for the Army Technology Review Board to produce it. ${ }^{20}$

This report is thin in technical details, but according to Sakurai's own reminiscence given 30 years later to the Tokyo asahi shinbun on the Navy Anniversary Day (commemorating the Battle of Tsushima), May 27, 1935, the gas mentioned was acrolein, a colorless or yellowish irritant best known among organic chemists as a starting reagent to synthesize sugars. ${ }^{21}$

According to his newspaper reminiscence, Sakurai and his assistant (and future son-in-law) Suzuki Tsuneo (Yōsei, 1877-1941) had "no difficulty in preparing acrolein but found that it soon underwent chemical reaction and lost its lachrymatory effect. Because during wartime there was not enough time to find the cause of such change, we simply diluted it to reduce the reaction and produced a certain amount ... in two days, night and day," for testing, which was successfully carried out at the Aoyama Parade Ground (renpeijō) in Tokyo. ${ }^{22}$ Indeed, official correspondence between the Army Technology Review Board, the army, and Tokyo Imperial University inviting Sakurai, referred to his proposed mission simply as "the examination of ammunition" (dan'yaku no shinsa) but discussed the possible danger caused by the reaction between a dissolved "yellow chemical" (kiiro yaku) being loaded into a shell and the paint applied to the shell's interior, thus explaining why a chemical specialist (kagaku senmonka) was needed to examine such danger. ${ }^{23}$ However, we do not know any case where acrolein, or any other gas, was used during the war.

Sakurai's reminiscence explained the reason something like this: "The seizure of Lushun [Port Arthur] took place when the army was about to start producing acrolein on a large scale" and therefore the objective of his project simply disappeared. ${ }^{24}$ The artillery report, however, suggests a more political reason. The problem started when the artillery department was about to send shells filled with acrolein to the battlefield:

A legal question about its use in battlefields was raised just before we were about to send this gas there. An enquiry into this question made it clear that, because this gas is not deleterious, its use in battlefields would be defensible in light of international laws. However, if we had ever used it, 


\section{Kikuchi Yoshiyuki}

the enemy would surely have propagandized that we used deleterious gas, and international voices would have blamed us. We therefore terminated this project and could not use the gas Dr. Sakurai and his assistant had researched. Port Arthur fell soon afterwards, and all shells filled with this gas were eventually discarded. ${ }^{25}$

In short, the Japanese army's restraint finally came neither from moral nor from legal issues: it came from the fact that this war was seen and judged by many spectators, not least by the United States, who mediated peace negotiations between Russia and Japan.

Nonetheless, Sakurai's experience highlighted the importance of technoscientific intelligence for military purposes. The artillery report, cited earlier, recommended that the Japanese army "dispatch experienced experts in military technology to European and American countries as military attachés to Embassies or Legations, correspondents, or observers, and to assign them to report not only disclosed, but also secret information about arms while staying there." ${ }^{26}$ It never mentioned the possibility of hiring civilian scientists to domestically create new weapons. This may have been because of military officials' fears that the "national economy would not withstand" the strain if they were to "renew weapons every year to catch up with rapid technological development." 27 It was also a perfectly logical recommendation: the first impetus for acrolein R\&D came from England, not from inside Japan. Indeed, Sakurai paid considerable attention to the international exchange of techno-scientific intelligence for military purposes in his later organizational and diplomatic activities.

The second impact of this incident from the Russo-Japanese War is related to Sakurai's feelings of personal "failure," recorded in his autobiography. ${ }^{28}$ As mentioned earlier, Bartholomew has long argued that Sakurai's sense of inferiority as a research scientist persisted throughout his whole career. ${ }^{29}$ Actually, from this source alone it is impossible to know when this crisis began; however, it is possible to know when his psychological struggle ended and what came of it: Sakurai came up with a purpose for his subsequent life, i.e., "atoning for my sins," by promoting scientific research for "industrial development and national defense" and by contributing to "international cooperation in science"- several years before World War I. ${ }^{30}$

My concern here is with the temporal specificity of his rhetoric and with the added mention of "national defense." The latter stands in marked contrast to Sakurai's pedagogy-oriented view of the state and science in 1899. I suggest that Sakurai's new focus was essentially due to his new sense of scientists working for military purposes during the Russo-Japanese War. He repeated this theme of "atoning for my sins" again and again, essentially unaltered, for the remainder of his life.

It would be a mistake to consider the impact of this wartime research on Sakurai alone. His assistant, Suzuki Tsuneo, took the major experimental part of the acrolein research and embarked later on a career as a chemist with Manchurian connections made possible by the Russo-Japanese War. ${ }^{31}$ The 
branches south of Changchun (Chōshun) of the Chinese Eastern Railway were transferred to Japanese control under the terms of the Treaty of Portsmouth. To operate railways and to develop the so-called Railway Zone (fuzokuchi) attached to them, the South Manchuria Railway (SMR) was instituted in Dalian (Dairen) in 1906 as a semi-private, semi-governmental company of the Japanese Empire. ${ }^{32}$ After overseas study in Germany (1907-1910), Suzuki was hired by the SMR in 1910 and became head of the applied chemistry department of the SMR Central Laboratory in $1912 .{ }^{33}$ In 1923, he was appointed senior researcher (shunin kenkyüin) at RIKEN. ${ }^{34}$ His research activities at the SMR Central Laboratory and RIKEN were mainly concerned with the exploitation of natural resources with military and economic potential in Manchuria such as oil shale, aluminum, and soy oil. ${ }^{35}$

Suzuki's career deserves more serious attention by historians than it has received and resolution of questions such as exactly how Sakurai affected his subsequent career awaits fuller scrutiny. In the context of the time, however, it seems safe to assume that Sakurai took care with fostering Suzuki's career development. Though not explicitly mentioned, Sakurai's plea for scientific research for "industrial development and national defense" very likely included any areas from which mainland Japan might benefit.

\section{Sakurai during the First World War}

If the Russo-Japanese War for the Japanese was a war with many spectators, what then was World War I? ${ }^{36}$ Japan declared war against Germany in August 1914, under the terms of the Anglo-Japanese Alliance, and technically remained a belligerent on the Allied side throughout the war. Japan's participation largely ended after capturing the German-held Shandong peninsula and a group of South Pacific islands in November 1914. Its efforts thereafter focused on securing Japanese colonial interests through diplomatic means. Most Japanese subjects thus "experienced" world war through economic hardships and opportunities brought by the Allied blockade of German products and as news from abroad, observation, and discourse. These circumstances required the Japanese to have a lot of imagination in order to feel that they were at war and to think that their scientists were working for the war effort.

Sakurai had both. With many friends and colleagues in England, he very much felt himself to be a belligerent, and had acquired the capacity to imagine scientists working for the war. It is essentially for these reasons that Sakurai became a central figure in the movement to establish RIKEN soon after the war's outbreak. His basic rhetoric was that "war is the enemy of humanity but the mother of progress" and "today's war is a war of applying physics and chemistry." ${ }^{37}$ The former referred to Japan's economic hardships and opportunities engendered by the war. The latter came not from Japanese experiences but from abroad. Nevertheless, both were effective tools in his lobbying politicians and fundraising from industrialists to support his proposals to 


\section{Kikuchi Yoshiyuki}

establish RIKEN and define its mission. When RIKEN was established in March 1917, he assumed the office of its first vice-president.

Sakurai's second project, the National Research Council of Japan, arose from his diplomatic activities during the Inter-Allied conferences in October and November 1918 in London and Paris. He strove to end the disruption of international cooperation caused by the war. Discussion at these conferences was centered on the proposal by US representative George Ellery Hale, who deliberately delineated an "Inter-Allied Research Council" as a "dual use" agency, i.e., an organization for war purposes which could also be used in peacetime, based on his brainchild, the National Research Council (NRC) and Research Information Committee. ${ }^{38} \mathrm{He}$ treated international cooperation in science as a problem of scientific intelligence service for military purposes, something Sakurai was familiar with through his experience during the RussoJapanese War. He therefore, strongly seconded Hale's proposal of establishing an Inter-Allied Research Council composed of research councils at the national level.

The establishment of RIKEN and Sakurai's scientific diplomacy were tightly connected. Before the Inter-Allied conferences, Hale had no idea whatsoever about scientific developments in Japan. Sakurai's support of Hale's plan during the London conference did not actually make an impression on Hale. It was after he talked with Sakurai and Tanakadate about a "large national physical laboratory" in Japan, i.e., RIKEN, between the conferences in London and Paris, that he changed his attitude towards the Japanese delegates, calling Sakurai "a very able Japanese representing the Tokio Academy." ${ }^{39}$ Arguably this is an early example of a Japanese scientific research institute using "soft power," as an institute which had not (yet) created any scientific knowledge, wealth, or military power but the visibility of which made the Japanese nation one to be reckoned with in international negotiations. ${ }^{40}$

In "selling" the concept of a NRC to the Japanese scientific community and general public, Sakurai emphasized its function as an information hub for military-related scientific research around the world and insisted on including military officers in its membership. ${ }^{41}$ This time, however, the rhetoric of war mobilization proved divisive rather than unifying for Japanese scientists who had "experienced" the war differently than Sakurai. For Sakurai, World War I was a veritable war in which Japan took part, but for the vast majority of other Japanese scientists, there was hardly any war that directly involved Japan. It is well known that they were outraged by the fact that Sakurai showed a willingness to cast a "yes" vote for German exclusion from the proposed Interallied Research Council. More important from my perspective was the fate of Sakurai's key ideas, such as the inclusion of military officers in its membership and a powerful role for the office of prime minister in its management. The latter was eventually discarded, probably because of the prime minister's limited power within the Japanese state system. ${ }^{42}$ The idea of including military officers in NRC membership was considerably watered down, but survived. According to GAKKEN rosters, as of June 1925, among 99 members, seven were from 
either the army or navy whereas the vast majority, 73, were from universities and 13 from non-military government agencies. ${ }^{43}$ This was a humble, inauspicious, but consequential, beginning of civilian-military cohabitation at GAKKEN.

\section{Conclusions}

As Dick Stegewerns pointed out, in academic debate there has been the trend since the mid-1990s to see nationalism and internationalism not as two opposite forces but as compatible. ${ }^{44}$ Indeed, the above discussion of the relationship between science, nation, and empire also addresses how and why scientists in early twentieth-century Japan tried to connect themselves to the international scientific community, a key question of another section of this volume. I start with this question to wrap up this chapter.

This chapter first examined the involvement of civilian chemists with chemical warfare research activities in Japan, a development which began much earlier than its Euro-American counterparts, during the Russo-Japanese War. I have shown how Sakurai's British connections, especially with UCL chemist William Ramsay, functioned as a context in which nationalistic feelings on both sides "resonated," and were a "conduit" of military intelligence that led to Sakurai's wartime research. The use of "resonance" in cross-national history of science has been pioneered by Ito Kenji, and I find this metaphor useful to characterize this first function of the Sakurai-Ramsay connection. ${ }^{45}$ It should not, however, obscure the second, undeniable one-way transfer of an idea. Unlike the learning process that typically took place in the early Meiji period, this did not transfer chemical expertise of any sort. It was the transfer of the novel tactical idea of using chemicals for a particular military purpose. These two functions complemented each other in the co-production of what was arguably the first chemical warfare $R \& D$ project in the world. This experience, together with the opportunities afforded by World War I, crystallized Sakurai's visions as a promoter of both national scientific research and international collaboration for the same overall purpose, for "industrial development and national defense."

To what degree were his visions of science, empire, and military relevant to the subsequent development of science in Japan? Sakurai's organizational and diplomatic efforts at international cooperation in science during the 1920s are a good starting point to examine this question. They were in the main based in GAKKEN and culminated in his successfully organizing the Third PanPacific Science Congress in Tokyo in 1926, which marked the establishment of the permanent Pacific Science Association. ${ }^{46}$ Its biggest aim was arguably to present the image of Japan as a "scientific," "modern," "civilized" empire to international society. ${ }^{47}$ Sakurai's inaugural address was peppered with such words as "cooperation," "brotherhood," and "friendship" and even asserted that "an association like this composed of scientists all working in harmonious cooperation and cherishing a strong feeling of brotherhood must and will make its influence felt in wider spheres," by which he meant forging "cultural 
alliances" through cooperation in science. ${ }^{48}$ However, a political dimension of "Scientific Japan" is apparent in the 1923 statement attributed to Japanese seismologist Ömori Fusakichi, who presided over the planning committee of the Tokyo congress:

When the First [Pan-Pacific] Congress was held [in Honolulu], US-Japan sentiments towards each other were not necessarily good. In Australia in particular, there were many people casting a suspicious eye on Japan. In addition to scholarly outcomes, the Honolulu congress was able to create goodwill between nations. ${ }^{49}$

In short, "scientific Japan" was used as "soft power" to counter propaganda and to legitimize Japanese colonialism to ease tensions between Japan, the United States, and Australia.

As discussed above, Sakurai's key concept was that an NRC was a "dual use" agency, i.e., an organization for wartime purposes which could also be used in peacetime, and that was exactly how GAKKEN functioned. Much as it might sound idealistic and grandiose, the above quotation from Sakurai's address, together with Ōmori's earlier remark, reveals continuity in his thinking about the use of science as a source of power, "soft power" this time, for world politics.

Sakurai's reaction to the circumstances of the 1930s seems more complex. For the better part of the 1930s Sakurai kept close ties with Britain, the United States and Australia, both in Japan and overseas, culminating in his visit to London between April and June 1937 to attend the International Council of Scientific Unions (the organization which succeeded IRC in 1931), to attend the coronation of King George VI of Great Britain, and to be awarded an honorary fellowship from his alma mater, UCL, in June $1937 .^{50}$ Sakurai, however, clearly served the colonial and imperialist purposes that increasingly antagonized Britain and especially the United States. According to Hiroshige, he worked tirelessly to launch the Japan Society for the Promotion of Science in 1932, which had a strong emphasis on mission-oriented research involving academic, industrial, and military personnel. Its special committees created between 1933 and 1936 coordinated research on flagrantly colonial and war-related topics such as the "economic problem in Manchuria, Mongolia, and China," the "long-term rise and fall of Pacific Islands," "mining methods based on geophysics," and "airplane fuel." $51 \mathrm{He}$ was also personally involved in selecting scientists for a Manchuria and Mongolia Scientific Expedition (Manmō gakujutsu chōsadan) co-sponsored by Manchukuo and the Japanese Empire "as a basis for the exploitation of natural resources in Manchukuo." 52

Today's historians would doubtlessly see contradictions in Sakurai's actions during the 1930s, but the guiding principles of Sakurai's second career were remarkably constant: promoting scientific research for industrial development and national defense, and regarding organizations that support scientific 
research as dual-use agencies. The assumption that something like GAKKEN should be able to work as a dual-use institution rested on the unspoken premise that Japan's friends and foes would remain the same. Indeed, the participating countries and regions of the Third Pan-Pacific Science Congress were allied or neutral countries during World War I: Britain, the United States, the Netherlands, and their colonies and dominions. ${ }^{53}$ The fact that Sakurai's diplomatic activities came to a complete halt at the outbreak of the Second Sino-Japanese War in July 1937, soon after he returned from London, suggests that his visions, in their entirety, were ultimately flawed, though he never seems to have admitted that. ${ }^{54}$ It is only in this sense that Sakurai can be considered an unwitting accomplice to Japanese expansion from this time.

\section{Notes}

1 Sakurai is the second most cited scientist next to Kitasato Shibasaburō in James R. Bartholomew, The Formation of Science in Japan: Building a Research Tradition (New Haven, CT: Yale University Press, 1989).

2 For Sakurai during the Meiji period, see Kikuchi Yoshiyuki, Anglo-American Connection of Japanese Chemistry: The Lab as Contact Zone (New York: Palgrave Macmillan USA, 2013), Chapters 3-6.

3 Hiroshige Tetsu, Kagaku no shakaishi: Kindai Nihon no kagaku taisei (Tokyo: Chūō Kōronsha, 1973), 84-130 and 153-75. On the role of the National Research Council of Japan during World War II, see Sawai Minoru, "Research and Development in Wartime Japan: Mobilization of Science \& Technology and Intensification of Joint Research (in Japanese)," Osaka Daigaku keizaigaku, 54: (2004), 383-409; and Aoki Hiroshi, "Dai niji sekai taisen chū no kagaku dōin to Gakujutsu Kenkyū Kaigi no kenkyū han," Shakai keizai shigaku, 72: (2006), 331-53.

4 Kikuchi Yoshiyuki, "Joji Sakurai and his British Connections (in Japanese)," Kagakushi, 31: (2004): 239-67; Barthomew, Formation of Science, 238-63.

5 The quotation is from Sakurai's obituary by the British physical chemist, F. G. Donnan: "Baron Joji Sakurai," Nature, 144: (August 5, 1939), 235.

6 Hiroshige, Kagaku no shakaishi, 94.

7 Ibid., Chapter 3; Bartholomew, Formation of Science, Chapter 7; and Hiromi Mizuno, Science for the Empire: Scientific Nationalism in Modern Japan (Stanford, CA: Stanford University Press, 2009).

8 Rotem Kowner (ed.), The Impact of the Russo-Japanese War (London and New York: Routledge, 2007), xvi.

9 Adapted from Jeffrey Allan Johnson, The Kaiser's Chemists: Science and Modernization in Imperial Germany (Chapel Hill, NC: University of North Carolina Press, 1990).

10 Carol Gluck, Japan's Modern Myths: Ideology in the Late Meiji Period (Princeton, NJ: Princeton University Press, 1985), 102-56.

11 Sakurai Jōji, "Kokka to rigaku," Tōkyō gakushikaiin zasshi, 21: (1899), 1-20.

12 Ibid., 5.

13 There has been considerable recent interest in scientific nationalism worldwide among historians and particularly in twentieth-century East Asian countries, and naturally they have used the term differently. It seems to me that the common denominator is the utilization of science for the nation. Differences in definition come largely from the different historical contexts in which the term was used. Here I define scientific nationalism in deliberately broad terms to encompass different phases of Sakurai's visions. 


\section{Kikuchi Yoshiyuki}

14 That Sakurai mentioned kokumin in the context of kokumin kyoiku (education of the nation) (Sakurai, "Kokka to rigaku," 8) but never talked about popular participation in politics underscores my point. In many ways, he behaved like a postconstitutional government official (that indeed he was as an imperial university professor) employing "the rhetoric of kokumin as a mechanism for ideological integration of the people into the state, while maintaining the legal and constitutional reality of monarchical sovereignty." Kevin M. Doak, A History of Nationalism in Modern Japan: Placing the People (Leiden: Brill, 2007), 193-4.

15 Letter from William Ramsay to Sakurai, June 12, 1902. Sakurai Correspondence with Foreign Colleagues, Chemical Society of Japan, Tokyo. Transcribed in full in Kikuchi, "Joji Sakurai and his connections with British chemists," 260-1.

16 Ramsay's negative attitude towards university science education in contemporary India is discussed in Kim P. Sebaly, "The Tatas and university reform in India, 1898-1914," History of Education, 14: (1985), 117-36, on 124-5.

17 On recent reappraisals of the Russo-Japanese War, see John W. Steinberg, Bruce W. Menning, David Schimmelpenninck van der Oye, David Wolff, and Shinji Yokote (eds), The Russo Japanese War in Global Perspective: World War Zero, vol. 1 (Leiden: Brill, 2005) and David Wolff, Steven G. Marks, Bruce W. Menning, David Schimmelpenninck van der Oye, John W. Steinberg, and Yokote Shinji, The Russo Japanese War in Global Perspective: World War Zero, vol. 2 (Leiden: Brill, 2007); and Kowner, The Impact of the Russo-Japanese War.

18 "Meiji sanjūnana-hachinen sen'eki Rikugunshō gyōmu shōhō chōsei yōryō" (Gunmukan-zatsu-M1-29-29. JACAR Ref. C09080546100), Military Archives, National Institute for Defense Studies, Ministry of Defense, Tokyo, Japan.

19 "Meiji sanjūnana-hachinen sen'eki Rikugunshō Gunmukyoku Hōheika gyōmu shōhō" (Rikugunshō-Nichiro Sen'eki-M37-11-132. JACAR Ref. C06040172100), Military Archives. Hereafter this source is referred to as "the artillery report."

20 "The artillery report," Sheet 124 (JACAR ref. C06040180000).

21 Tokyo asahi shinbun, 28 May 1935 (Morning): 11. See also Majima Toshiyuki (Rikō), "Waga shōgai no kaiko," Kagaku no ryōiki, 8: (1954), 6.

22 Tokyo asahi shinbun, May 28, 1935 (morning edition), 11.

23 Letter from Arisaka Nariakira (Technology Examination Board Director) to Ishimoto Shinroku (Under-Secretary of the Army), November 27, 1904. "Sakurai rigaku hakushi shōhei no ken" (JACAR Ref. C03027762500), Military Archives.

24 Tokyo asahi shinbun, 28 May 1935 (Morning), 11.

25 "The artillery report," Sheet 124.

26 Ibid., Sheets 153-54 (JACAR Ref. C06040181900, C06040182000).

27 Ibid., Sheet 152 (JACAR Ref. C06040181900).

28 Sakurai Jōji, Omoide no kazukazu: Danshaku Sakurai Jōji ikōo (Tokyo: Kyūwa kai, 1940), 18-20. Hereafter referred to as Omoide no kazukazu.

29 Bartholomew, Formation of Science, 263.

30 Omoide no kazukazu, 20.

31 As Suzuki later told a colleague at the SMR Central Laboratory: Tanaka Yasuo, "Sakurai Jōji sensei kara kiita koto nado,” Kagakushi, 18: (1991), 232-4, on 232.

32 On SMR and its significance in the Japanese colonization of Manchuria, See Yoshihisa Tak Matsusaka, The Making of Japanese Manchuria, 1904-1932 (Cambridge, MA: Harvard University Asia Center, 2001).

33 Suzuki's biographical data is much harder to come by than Sakurai's. See, for example, Minami Manshū tetsudō kabushiki kaisha jūnenshi (Dairen: Minami Manshū Tetsudō Kabushiki Kaisha, 1919), 91; and Hirota Kōzō, Mantetsu no shūen to sono go: Aru chūō Shikenjo shoin no hōkoku (Tokyo: Seigensha, 1990), 125.

34 Riken gojūnen (Tokyo: Rikagaku Kenkyūjo, 1967), Appendix 4 "Kenkyūshitsu no keitōzu." 
35 Hirota, Mantetsu no shūen, 136, 138, 152, and 158; Sugita Nozomu, Mantetsu chūō shikenjo: Tairiku ni yume o kaketa otokotachi (Tokyo: Kōdansha, 1990), 46-7, 64.

36 Based on Kikuchi Yoshiyuki, "World War I, International Participation and Reorganisation of the Japanese Chemical Community," Ambix, 58: (2011), 136-49.

37 Ibid., 137, 139.

38 Daniel J. Kevles, “'Into Hostile Political Camps': The Reorganization of International Science in the First World War," Isis, 62: (1971), 47-60, on 52-3.

39 Kikuchi, "World War I," 143-4.

40 Here I am broadening the meaning of "soft power" to embrace international politics of science. For its original meaning, see Joseph S. Nye, Jr., Soft Power: The Means to Success in World Politics (New York: Public Affairs, 2004).

41 Kikuchi, "World War I," 148.

42 Ibid.

43 Ibid.

44 Dick Stegewerns (ed.), Nationalism and Internationalism in Imperial Japan: Autonomy, Asian Brotherhood, or World Citizenship? (London: RoutledgeCurzon, 2003), 4-5.

45 Kenji Ito, "The Geist in the Institute: The Production of Quantum Physicists in 1930s Japan," in Pedagogy and the Practice of Science: Historical and Contemporary Perspectives, ed. David Kaiser (Cambridge, MA: MIT Press, 2005), 175.

46 On the history of the Pan-Pacific congresses and the Pacific Science Association, see Philip F. Rehbock, "Organizing Pacific Science: Local and International Origins of the Pacific Science Association," in Nature in Its Greatest Extent: Western Science in the Pacific, ed. Roy MacLeod and Philip F. Rehbock (Honolulu, HI: University of Hawaii Press, 1988), 195-221. The Pan-Pacific congresses' impact on anthropology and seismology in Japan are discussed in Sakano Tōru, Teikoku Nihon to jinruigakusha: 1884-1952 nen (Tokyo: Keisō Shobō, 2005), 398; Kim Boumsoung, Meiji Taishō no Nihon no jishingaku: "Rōkaru saiensu” o koete (Tokyo: Tokyo Daigaku Shuppankai, 2007), 129 and 138-9.

47 Gakujutsu Kenkyū Kaigi (ed.), Scientific Japan: Past and Present. Prepared in connection with the Third Pan-Pacific Science Congress, Tokyo, 1926 (Kyoto, 1926). On how the rhetoric of science as a basis of modern civilization was used for this congress, see Prince Kotohito of Kan-in, "Opening Address," in Proceedings of the Third Pan-Pacific Science Congress Tokyo, October 30-November 11 1926, ed. National Research Council of Japan (Tokyo: 1928), 65-6; and R. Wakatsuki, "Address of Welcome," ibid., 66-8.

48 Joji Sakurai, "Inaugural Address," in Proceedings of the Third Pan-Pacific Science Congress Tokyo, 68-75, on 74. See also Omoide no kazukazu, 282-95.

49 Tokyo asahi shinbun (Morning), 13 June 1923, 5. Due to his death in November 1923, Omori actually did not participate in the actual planning of the Tokyo congress. Kim, Meiji Taishō, 132-3.

50 Tokyo asahi shinbun (Morning), 12 July 1935 (Japan-Australian friendship), 25 April 1936 (Anglo- and American-Japanese Solar Eclipse Expedition), and 21 April 1937 (London visit). For Sakurai's visit to London in 1937, see Kikuchi Yoshiyuki, "Sakurai Jōji (1858-1939): Leading Chemist and Nō Drama Specialist," in Britain \& Japan: Biographical Portraits, vol. IX, ed. Hugh Cortazzi (Folkestone: Renaissance Books, 2014), 434.

51 Hiroshige, Kagaku no shakaishi, 123-8.

52 Tokyo asahi shinbun (Morning), (January, 26 1933), 3.

53 Proceedings of the Third Pan-Pacific Science Congress Tokyo, 8-20.

54 On his deathbed, he is said to have talked about a plan for the Sixth Pan-Pacific Science Congress scheduled to be held in Berkeley and San Francisco in July 1939, showing his intension to continue participating in scientific diplomacy. Tokyo asahi shinbun (Morning), (January 29, 1939), 11. 


\title{
4 Buddhism contra cholera \\ How the Meiji state recruited religion against epidemic disease
}

\author{
William D. Johnston
}

\section{Introduction}

Imagine a disease of uncertain origin that strikes one in eight or ten persons in a community. It is unlike anything people have known. The main symptoms are malaise, headache, and vomiting, followed by violent diarrhea. Six to ten liters of fluid can be purged from the body in a very short time resulting in sunken eyes, leathery, bluish skin, lethargy, disorientation, and death. Between six and eight out of ten patients die, many within a day or less of their initial symptoms, some within hours. Nobody knows what to do.

Many Japanese people experienced something like this when such a disease first appeared in 1822. The disease was given many names, one being mikka korori, the three-day collapse. It described a common unfolding: three days of illness followed by death. Soon people called it simply korori, a name that also echoed what Dutch physicians had called it: cholera. The disease started in the southern parts of Japan and traveled north but never reached Edo, after which it disappeared. It struck again in 1858, this time reaching Edo with disastrous consequences. The estimates of dead varied widely. A Bakufu document published in 1862 estimated the total number of deaths at over $28,421 .{ }^{1}$ The epidemic had profound consequences on families, businesses, government, and the social order. It left the city and most of the country enervated during the two years before it disappeared.

Well before this time, the Tokugawa Bakufu realized the political and social importance of marshaling its resources in the face of epidemic disease. One result was the establishment of the Igakusho (literally "medical school") for studying Western medicine. Its faculty was instrumental in creating widespread vaccination programs against smallpox. ${ }^{2}$ Faced with the enormous 1858 cholera epidemic, the Bakufu turned to Western medical understandings of the disease but lacked any kind of public health infrastructure with which it could enact control measures beyond issuing advice and recommending medicines to villages under its direct control. ${ }^{3}$ Anticipating that the disease could return, the Bakufu developed further control strategies. In 1862, it published a manual edited by Matsumoto Ryōjun for cholera control based on European sources. ${ }^{4}$ It recommended dietary and behavioral measures similar to those found in 
contemporary health maintenance texts that individuals could implement, as well as quarantine measures for both diseased individuals and infected ships' crews. Through such efforts the Bakufu developed a groundwork of ideas, personnel, and policies that laid the groundwork for the Meiji government's later measures.

Still, without a definitive explanation for the cholera's cause, the government was hard pressed to develop specific, effective control measures. Japanese scholars, like those in Europe, could not settle on an explanation. During the 1858 epidemic, Ogata Kōan, a preeminent Japanese practitioner of European medicine, noted that the disease had originated in Arabia, spread to China, America, and England, and was carried in the atmosphere. ${ }^{5}$ Thirteen years later (1871), Ishiguro Tadanori authored a book on cholera based on the current ideas of Max von Pettenkofer and Ernst Delbrück. Although an Italian anatomist, Filippo Pacini, had discovered the cholera bacillus in 1854, the idea that bacteria caused the disease did not gain serious attention until Koch's rediscovery of it in 1883 . Moreover, germ theory was not universally recognized until considerably later. Pettenkofer, in particular, opposed Koch's theory. He and Delbrück both claimed that cholera toxin was present in feces but in some cases could be carried in the atmosphere. ${ }^{6}$ Ishiguro also noted that cholera toxin was spread through feces and that German scientists recommended sulfurous acid as a disinfectant. ${ }^{7}$ The idea that acidic solutions could disinfect the cholera toxin entered Japanese medical discourse just three years after the Tokugawa regime collapsed; it quickly became one of the pillars of cholera control.

For a while, Japan was lucky. Between 1863 and 1877 cholera was either absent or caused only minor, local outbreaks. In 1877 it reappeared but caused a relatively small number of deaths (just over 8,000 nationally). Troops returning from the Satsuma Rebellion contributed to its spread. ${ }^{8}$

The post-Satsuma Rebellion cholera outbreak prodded the new government's leaders into considering how to control the potentially catastrophic disease. Home Minister Ōkubo Toshimichi urged preventive measures, in particular the use of quarantine. Nevertheless, perhaps picking up on a thread of thought that Ishiguro had advocated, disinfection, the idea that chemical substances could neutralize what specialists vaguely called the cholera pathogen - literally the "cholera sickness poison"-also became a focus of government policy. ${ }^{9}$

The repercussions of these efforts were profound and long lasting, and there is no avoiding the fact that of the many agents speeding societies toward modernity during the nineteenth century, one of the most powerful was cholera. It instigated state policies that ranged from the coercive to the mundane. The goal was to save lives and maintain the social and economic order. Cholera was central to the creation of public health measures worldwide. The disease combined a mix of rapid onset, dire symptoms, and high rates of mortality that made it impossible to ignore. Globally, cholera killed far more people than warfare during the 1800s. Anti-cholera and other public health measures in turn contributed to economic growth. Yet when compared to the creation of modern armies, navies, and factories, historians shunt cholera control and 
emergence of modern public health systems to the sidelines. In no small part this is because the subject raises an issue that still makes people squeamish: the disposal of human waste. ${ }^{10}$

Without the threat of coercion, it was difficult to ensure that people disposed of their waste appropriately and protected water supplies from contamination, the most important way of preventing the spread of cholera and many other afflictions. Garrett Hardin noted that restrictions against the disposal of human waste in common spaces-rivers, streams, open-pit cesspools, and the like - were an early example of "mutual coercion, mutually agreed upon." 11 In many respects incipient public health measures depended on this formula, placing limitations on individual freedoms for the good of society.

Yet public health measures also include much more subtle and refined methods in addition to those aimed at waste disposal and pure water supplies; it was here that the confluence of Buddhism and state hygiene occurred. Efforts included education to change how people understood the relationship between health, disease, and their environment. In Japan, where the disposal of human waste in urban areas was less of a problem than in Europe and the United States, efforts aimed at changing peoples' thinking about disease were central to government attempts to control cholera. ${ }^{12}$

Central to government education efforts was the creation of networks of knowledge that integrated Japanese and European understandings of cholera. ${ }^{13}$ Even before the Meiji Restoration Japanese leaders understood the value of public health measures, as demonstrated by the Bakufu's vaccination measures against smallpox. Yet the concept of public health — or more accurately at this time, state hygiene - was new. Further, when considering the history of cholera in Japan, we must remember that the disease category as understood today did not come into existence until after Koch demonstrated that the bacillus Vibrio cholerae caused the disease in 1883, and, as in the case of Pettenkofer, not even Koch's discovery immediately established the modern concept of cholera.

To understand the history of how people responded to cholera we must keep in mind the differences between their understandings of the disease and today's scientific understanding. Even when Japanese health officials wrote about "cholera" in the 1870s and early 1880s, they were not discussing the disease we know today. It was "scientific" but only in the way that anti-contagionism and the use of medicinal mercury were "scientific." In short, it is more useful to look at how Japanese health officials integrated their thinking into networks of European ideas rather than to analyze their efforts in terms of "modern science."

Similarly, indigenous networks of ideas should be considered on their own terms and as an important basis for transmitting new understandings throughout Japan. By the eighteenth century, common medical thought included schools that had established sophisticated systems of observational methods unrelated to European thought. Medical thought, which includes what can be called "folk medicine," interpreted disease according to contemporary networks of semiotics that shaped reality for those who had no alternatives. Whether those 
widely known understandings are best called "religious" or "superstitious" is irrelevant. For Japanese health officials who wanted to make European approaches to cholera control accessible to medical specialists and the population at large, they had to find ways to hook the new on the old, the unfamiliar on the familiar. A relatively obscure publication with a hybrid genesis reveals at least one way in which they did this.

\section{A peculiar publication}

In 1880, the Japanese Home Ministry produced a pamphlet under the title Korera yobō no satoshi [Admonitions Regarding Cholera Prevention] (hereafter, Satoshi). Editorial credit was given to the Home Ministry Bureau of Shrines and Temples and Bureau of Hygiene and publication credit to the Bureau of Shrines and Temples. The major Buddhist sects, however, printed and distributed at least fourteen versions of it nationally. They varied in layout but had identical wordings. They recalled the previous year's widespread epidemic and presented instructions for preventing both cholera and other acute infectious diseases.

The document itself manifested a network of top-level government leaders, including administrators from the Bureau of Hygiene and the Bureau of Shrines and Temples. Together they created the text and enlisted Buddhist organizations to print and distribute it. This symbiotic relationship lasted only briefly. There is no record of further cooperation between the bureaus of Shrines and Temples and of Hygiene to control infectious diseases. The authors were anonymous. At the time Nagayo Sensai was the head of the Bureau of Hygiene; the head of the Bureau of Shrines and Temples was Sakurai Nōkan. In that position, Sakurai moderated previous policies antagonistic toward Buddhism and ended the dissemination of state Shinto by missionaries. Both Nagayo and Sakurai would have had to consent to the project for their bureaus to be given credit on the document. While it is tempting to say that this represents the intersection of public health and religious policies, to do so is anachronistic - "public health" and "religion" were nascent concepts at the time. It was only five years later that the term for public health, kōshì eisei, first appeared in print. The initial use of that term in the title of a work was in Okudaira Hiroshi's Kōshū eisei sankō yōsho (Essential Reference for Public Health). ${ }^{14}$ The term shūkyō in the sense of "religion" had been coined by Mori Arinori as early as 1866, but as late as 1873 , members of the Meirokusha cultural society discussed concerns regarding "religion" under various terms, including hōkyō, kyōmon, kyōdō, and kyōhō. ${ }^{15}$ Even today, popular conceptions of shiukyō do not always coincide exactly with the English language term "religion."

What is important here, however, is the integration of ideas that emerged from European public health literature with contemporary Shinto and Buddhist ideas dealing with disease. Although the Meiji government's use of Buddhist sects for promotion of public health was ephemeral, the intersection 
of networks that produced this text reveals a messy complex of practices that illuminate how that moment in Japanese history differed from what came before and after. The key issue here is how these materially heterogeneous relations - cholera, Buddhism, and the Meiji government's early public health policies - intersected at this time.

\section{Cholera in Japan to $\mathbf{1 8 8 0}$}

Most discussions of cholera before 1883 are anachronistic. Until that year the concept of cholera as we know it did not exist. What existed were ideas of how a particular set of disease characteristics intersected with climactic change, earthquakes, comets, soil and topographical features, miasmas, contaminated food and water, general filth, the disposal of corpses, alcohol consumption, sexual morality, poverty - and more. This was the case in Japan, Europe, and the United States. And most of these elements associated with cholera before 1883 were not immediately disassociated simply because Koch demonstrated that Vibrio cholera was a necessary cause of cholera. Changes in conceptions of etiology are both slow and messy, an essential point when observing the intellectual and cultural traces that cholera left in nineteenth-century Japan.

Nevertheless, anachronisms have their uses. It is helpful to assume that the genetically structured organism that defines Vibrio cholera has a durability that allows us to associate this microbe in the past with its specific signs and symptoms in the present. This point is not self-evident. The Black Plague of medieval Europe manifested signs and symptoms that modern scientists do not associate with the plague bacillus, Yersina pestis, although the medieval and modern genetic materials seem nearly identical. ${ }^{16}$ Microorganisms evolve quickly. In the case of cholera, only two serotypes, $\mathrm{O} 1$ and $\mathrm{O} 139$, are associated with epidemic disease but over two hundred exist. Nevertheless, it is useful to assume that cholera as understood today can be identified with the disease reported under the same name from the early nineteenth century.

Before the eighteenth century, cholera was endemic to India's Ganges Delta. The cholera bacillus established itself there in estuarine waters where no host, either human or animal, was necessary. Rather, it depended on an ecological balance between temperature, alkalinity, salinity, and organic matter that allowed indefinite survival. ${ }^{17}$ Disease occurs once the bacillus enters the body and proliferates in the small intestine. Proliferation is key, as exposure by itself is not sufficient to cause disease. When the bacillus flourishes it emits a toxin that initiates an imbalance of sodium in intestinal cells, causing prolific diarrhea and sometimes nausea. The body becomes dehydrated and leached of vital electrolytes. Untreated, it leads to a thickening of the blood and cyanosis - hence the discoloring of many of its victims. In 25 to 50 percent of untreated cases death rapidly follows 24 to 72 hours after the appearance of symptoms. Historically, mortality rates have reached from 50 to over 70 percent, and can be higher in children and the elderly. ${ }^{18}$ Disease transmission depends primarily on contamination of drinking water by infected feces. Even today, cholera remains widespread. In 2012, 
the World Health Organization estimated that three to five million cases occur annually, causing 100,000 to 130,000 deaths. ${ }^{19}$

Cholera did not spread far from the Ganges Delta until the early nineteenth century. ${ }^{20}$ The first recorded pandemic started in 1817; it reached Japan in 1822, well before its first appearance in Western Europe in 1831. Dutch physicians first informed the Japanese about the disease, calling it cholera morbus; it appeared in Java in 1821. By some accounts it reached Japan via Korea, by others via Java. Both may be correct. In any event, this epidemic was brief. It started in October (by the Western calendar) of that year but disappeared by the end of the next month, traversing from Tsushima and Kyushu to as far north as Shizuoka. Although the medical community took note of this new epidemic disease, it apparently made little public impression.

Most accounts of cholera in Japan begin with its next appearance, which made a profound mark on public memory. ${ }^{21}$ On the first of July 1858 (by the Western calendar), the U.S.S. Mississippi docked in Nagasaki with several sailors and officers on board who had become infected with cholera in China. Three afflicted officers disembarked for treatment. ${ }^{22}$ All three survived but their waste likely started the epidemic that continued intermittently until 1860 . Yet as in the previous epidemic, there was possibly more than one entry point.

Where Japan's first cholera epidemic was relatively mild, the second was ferocious. During September and October, over 12,000 persons were recorded as having died in the city of Edo alone, although accurate epidemiological records are lacking and this certainly represents a low estimation. ${ }^{23}$ After 1858, the disease persisted with minor annual outbreaks, most notably in 1862 and possibly in 1863 .

The third major cholera outbreak came in 1877. The bacillus apparently entered Nagasaki and spread to Yokohama. It became a national epidemic, transported in part by soldiers during the Satsuma Rebellion. This was a relatively minor outbreak, with approximately 14,000 reported cases and just over 8,000 deaths. The following year the disease remained endemic, with just over 900 cases reported and 275 deaths. In 1879, Japan's second-worst cholera epidemic in modern times occurred (the worst was in 1886, with over 108,000 deaths). Over 162,000 cases were reported, resulting in almost 106,000 deaths. ${ }^{24}$

The 1879 epidemic convinced Meiji government leaders to implement extensive control measures to maintain the state's social and economic stability. These included the establishment of a well-structured public health bureaucracy, hospitals and other medical facilities, and the reformation of medical education. Above all, they fostered public education regarding the prevention not only of cholera but also of other acute infectious diseases.

\section{Cultural reflections of cholera}

In part, popular conceptions of cholera can be read from the names used to refer to the disease. During the Edo period several Japanese names appeared; their use, as might be expected, persisted well into the Meiji period. One of 
the most common names was mikka korori: roughly, the "three-day collapse." A common transliteration for cholera, or korera in Japanese, mixed a telling combination of Chinese characters. One combination was 虎狼痢 (korori), literally “tiger wolf diarrhea," while another was 虎狼狸, literally "tiger wolf tanuki.",25 The tiger was foreign and fierce; the wolf equally fierce and in Japanese culture had significance as a kami (deity) that could do both harm and good; the tanuki was a male trickster often symbolized by enormous testicles.

From the mid- to late nineteenth century, images such as Kimura Takejirō's 1886 woodblock print (Figure 4.1) illustrated these names, current concepts of cholera's etiology, and the modern technologies believed to provide means to control the disease. The mix of elements in Kimura's image are as much a cultural chimera as the cholera beast it depicts is a literal one. On the right side, the cholera "tiger-wolf-tanuki" has knocked over people dressed in Japanese clothing while a group calling itself the "Hygiene Army" led by a man in samurai armor fires a cannon in the shape of a bottle of carbolic acid at the beast. The text at the top is equally heterogeneous, explaining that the cholera pathogen can be killed using carbolic acid and that it should be used widely. Yet carbolic acid was not widely available, so the text then notes that pickled plums were effective in the past against enteric diseases so they, along with plum vinegar, could be effective against cholera.
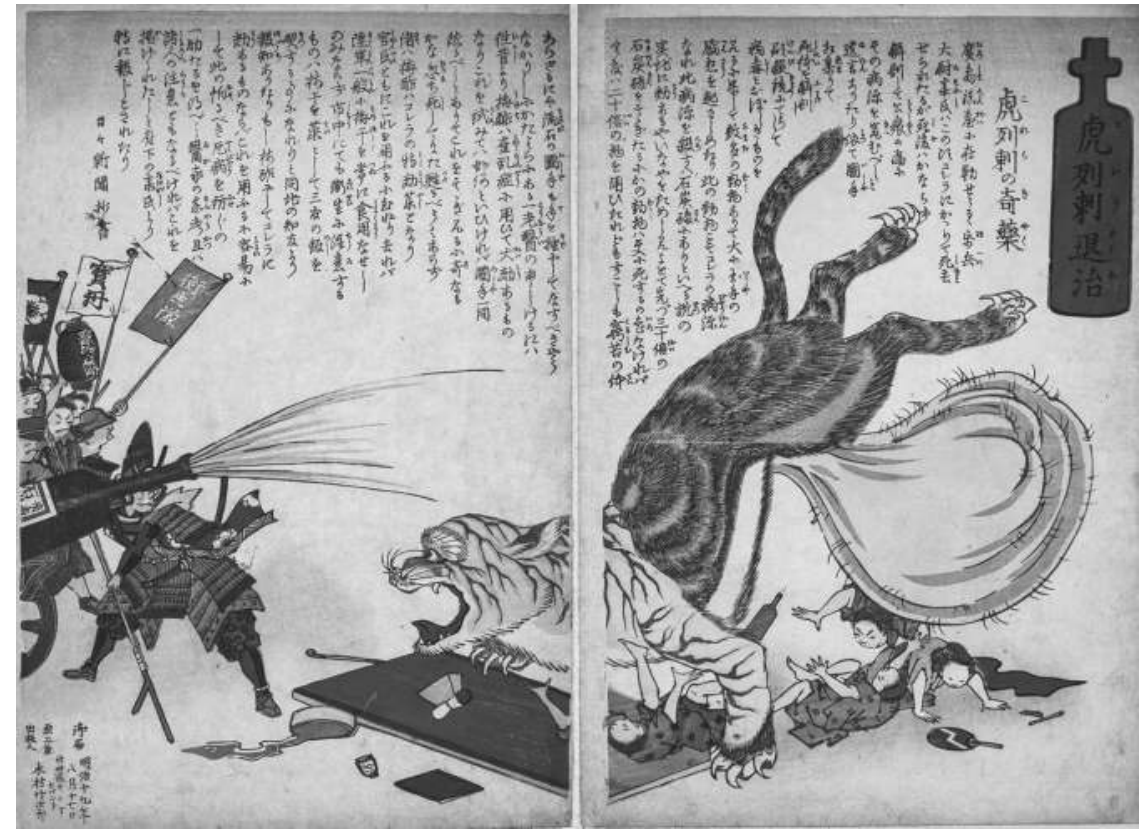

Figure 4.1 Kimura Takejirō, Defeating cholera (Korera taiji), 1886

Source: Image courtesy of Archives and Special Collections, Library and Center for Knowledge Management, University of California, San Francisco. 


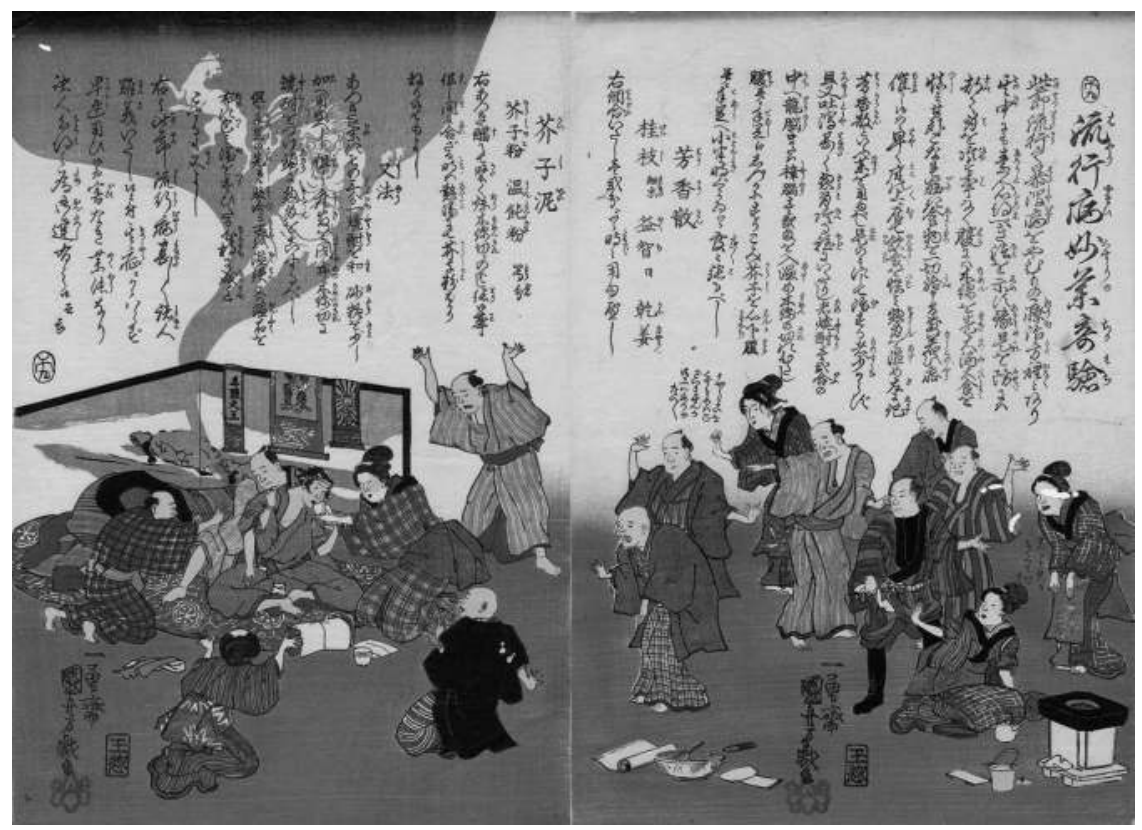

Figure 4.2 Utagawa Kuniyoshi, Effective medicines for treating the epidemic (Hayari yamai kusuri no chikamichi), 1858

Source: Photograph (C) Museum of Fine Arts, Boston.

Popular etiologies of the disease attributed it to fierce, angry spirits in the forms of kami, yōkai (supernatural monsters), and similar entities. ${ }^{26}$ Disease ensued when these spirits either attacked or possessed a person's body. An Utagawa Kuniyoshi woodblock print (Figure 4.2) published during the 1858 cholera epidemic shows a medicine curing the disease by driving off pernicious spirits; the text provides recipes for recommended medicines.

The key point here is the confluence of heterogeneous elements in both images: the first illustrating a mix of Western and Japanese; the second illustrating the use of medicine to rid the body of disease-causing spirits. When Satoshi appeared in 1880, a date these two images straddle, many Japanese thought of disease as both a physical and spiritual affliction. The government used both ways of thinking in its efforts to control cholera.

\section{Text and context of Korera yobō no satoshi}

The events that led to the production of Satoshi are not entirely clear. According to the preface, Home Minister Itō Hirobumi realized the need to educate people about the causes and prevention of cholera and other infectious diseases. He ordered the Home Ministry to compose this text for national distribution to become the basis for sermons by Buddhist and, ostensibly at least, Shinto priests. This narrative, however, raises more questions about the text's genesis than it 
explains. Based on Matsumoto Jun's autobiography, it is clear that Itō had been concerned with controlling cholera by 1875 so it is not surprising that he should have been looking for means to control the disease during the epidemic of $1879 .{ }^{27}$ It does seem likely that a team of two or more writers from the Bureau of Hygiene and the Bureau of Shrines and Temples composed this text as it uses the languages of both hygiene and religion. However, the author or authors remain obscure. Nagayo Sensai makes no mention of this text in his autobiography, although he pays considerable attention to other cholera control efforts. ${ }^{28}$ The text gives no hints beyond attribution of the two bureaus as "editors." Yet the roles of each are not consistently attributed. For example, in the version printed in Tokyo by Ikebe Kōzō, both bureaus appear on the front cover but only the Bureau of Shrines and Temples appears on the colophon page.

The Home Ministry's publication date of April 12, 1880, appears in most printings, suggesting that was the completion date. On April 17, 1880, the Home Ministry directed the Bureau of Shrines and Temples to order its printing and distribution, noting that it would become the basis of sermons throughout the country. ${ }^{29}$ On 25 April, the headquarters of the Sōto Zen Sect initiated the text's national distribution to its temples for use in sermons by priests who would instruct their congregations about cholera's prevention and treatment. ${ }^{30}$ The Pure Land Sect produced its own printing (Tokyo, 30 April), and in Shimane Prefecture, a Rinzai Zen priest, Seki Shōshū, printed the text — this being the only one explicitly listed as "not for sale." ${ }^{31}$ From other printings, it is clear that the text was indeed distributed widely, especially in western Japan. There was one printing in Yamagata, but otherwise it is unclear how widely distributed Satoshi was north and east of Tokyo. Moreover, although the directives for distributing this text were sent to Shinto and Buddhist organizations alike, there is no record of a Shinto printing. ${ }^{32}$

It is difficult to read absences. Nevertheless, the historical setting - the networks that linked Shinto and Buddhism before 1880 - can help. The rise of anti-Buddhist sentiments from the eighteenth century and their implementation into policy during the nineteenth century are well documented. ${ }^{33}$ There were several strands of anti-Buddhist thought. One emphasized the idea that Mahayana Buddhism, which included most schools of Japanese Buddhism, was not truly Buddhist because much of it emerged after the death of the historical Buddha. Nativist thinkers saw Buddhism as foreign and un-Japanese and called for its extrication. Confucianists depicted Buddhism as immoral and anti-Japanese because it called for people to forsake loyalties to family and state for what they considered a superstition-based salvation.

These strands of thought and practice coalesced in the late Edo Period and the early years of the Meiji with the rise of their supporters to positions of political power. "Abolish Buddhism and Destroy the Buddha" became a slogan for those who wished to subordinate Buddhism to Shinto or eliminate it entirely. In some regions, such as Kagoshima and Toyama, the result was the virtual eradication of Buddhist temples, priests, and icons - at least temporarily. 
Nationally, Buddhism was changed forever. The years between 1869 and 1871 witnessed the most violent anti-Buddhist activities. After that, peasants who saw this movement endanger their traditional ways of life rose in opposition to it, and the Meiji government, which simultaneously faced potential threats from foreign powers, pro-Tokugawa loyalists, samurai who opposed the abolition of their class, and supporters of liberal democracy, demoted the anti-Buddhists from positions of power. Some Buddhists even accepted assertions that Buddhism had become decadent and needed major reforms. ${ }^{34}$ The major Buddhist organizations subsequently implemented major reforms. Most avidly strove to demonstrate their patriotism and loyalty to Tennō (usually translated as "Emperor") and the state.

By 1879, the Japanese Sōtō Sect in particular clearly ingratiated itself sufficiently to the state that the Tennō bequeathed upon its founder, Eihei Dōgen, the honorary title of Jóyō Daishi: the Great Master Who Receives the Sun. Hence it is no surprise that this sect actively participated in the state's efforts to make Buddhist priests into proponents of cholera control. Yoshioka Shinkō, a Sōtō priest in Shimane prefecture, recorded some of the ways he spoke of cholera to his congregation. He wrote that the historical Buddha had received the moral precepts and that similarly, government officials spread knowledge for long life. Consequently, people owed a debt of gratitude to both. ${ }^{35}$ In his sermons, Yoshioka converted the language of Satoshi into colloquialisms more easily grasped by his audience. ${ }^{36}$ This is not surprising because to anybody who thought of disease primarily in terms of spirit possession or punishment by "kami and buddhas" (a single term in Japanese: shinbutsu), much of the hygienic language in Satoshi would have seemed foreign.

The Satoshi was divided into three chapters. The first, "The prevention and conquering of cholera and other infectious diseases," challenged traditional conceptions of disease. It started by explaining, "In this world there are visible enemies and invisible enemies." ${ }^{37}$ Visible enemies included wars, floods, famines, typhoons, fires, and earthquakes; the main invisible enemies were cholera and other infectious diseases. Of the two, the invisible were the more dangerous because one never knew where they might be lurking. Yet while fearsome, these invisible enemies did not appear simply by coincidence but according to laws of nature and needed to be understood in terms of "disease toxins." Diseases were not punishments because if they were, the innocent would never get ill - and clearly they did. Morally upright and evil persons alike were subject to infectious disease.

At this point, rather than focusing simply on the natural laws that governed epidemics, the authors deployed a strategy parallel to that visible in Utagawa Kuniyoshi's Hayari yamai kusuri no chikamichi (Figure 4.2). In the same way that this print advocated the use of medicine to exorcise disease-causing spirits, Satoshi advocated that people follow the natural laws of prevention in conjunction with appeals to the shinbutsu. Similarly, bearing in mind an audience familiar with farming, this chapter compares disease prevention and agriculture. For the sake of a plentiful harvest, people carefully planted and 
tended their fields while praying to the shinbutsu. In the same way, people should take care to prevent the spread of pathogens while appealing to the shinbutsu for good health and the avoidance of cholera and other infectious diseases. ${ }^{38}$ In another simile, cholera prevention by keeping the pathogen out of one's town or village was compared to crime prevention by keeping thieves from entering one's home. ${ }^{39}$

The second chapter explained how to keep a community disease-free by tending to the air, drinking water, food and drink, and social intercourse. ${ }^{40}$ The inclusion of these categories rather than a focus on drinking water alone reflected the multiple etiologies of cholera that appeared in European medical discourse. By 1854, the British physician John Snow had demonstrated that cholera was transmitted through water but opposition to this idea remained strong, especially in German medicine. Japanese writers did not take note of Snow's discovery until the 1880s and with the dominance of German medicine Snow's work received limited attention in Japan. ${ }^{41}$ The Satoshi made recommendations under the category of "air" that included cleaning houses and toilets and keeping sewage far from homes. Bad smells were unhealthy, according to long-held European conceptions of etiology. Yet the recommendations under the category of "water" reflected Snow's conclusions. The authors stressed that toilet and laundry waste be kept away from sources of drinking water and specified measures to ensure access to clean water. ${ }^{42}$ The section on food and drink advocated that people discard any foods, including fish, meat, and fruit, that had begun to rot or that smelled bad. This recommendation reflected a conflation of gastro-enteric diseases caused by rotting foods - often called cholera morbus in Western languages - and cholera as we think of it now-often called cholera asiatica.

Ideas of disease during the nineteenth century varied greatly from today. Many contemporary European medical theorists believed that distinctly different diseases could change from one into another. For example, the idea that tuberculosis could become cancer was not uncommon in late nineteenth-century Europe, so it is not surprising that people might have thought one form of cholera could become the other. Only when Koch's postulates, which required the isolation and cultivation of a particular bacillus and its experimental demonstration to be the cause of a disease, became a universal standard did such thinking disappear, generally during the last decade of the nineteenth century. ${ }^{43}$

The section on social intercourse had few specific recommendations, most of which revealed more about work conditions than cholera transmission. It urged that people who frequented crowded places such as theaters, restaurants, temples, shops, and factories also get plenty of fresh air. It suggested that men who pulled jinrikisha not exceed ten ri (approximately 24 miles) each day because longer distances were harmful. Women and children should be circumspect with regard to how many hours a day they worked in factories and should get plenty of fresh air and water. Finally, crematoria should be situated far away from residential areas and streets should be cleaned periodically. 
The breadth of recommendations for cholera control show how the disease came to be called the mother of public health. Because cholera was thought of as having diverse causes, its control called for a broad range of interventions. Had the main focus of cholera control been water alone, it would not have prompted the range of changes in public and personal hygiene that the government strove to implement. In short, what we now consider imperfect science became the basis of modern public health measures.

The third chapter focused on ways individuals could conquer cholera once it entered their communities and families. It instructed people to report any cases to the police and local authorities and to follow their instructions for moving people to quarantine hospitals. ${ }^{44}$ Highly unpopular, people saw hospitals as places where the state took the ill to die, separated from their families. Opponents sometimes rioted against them. ${ }^{45}$ The Satoshi strove to overcome these fears by describing hospitals as places where patients were treated. Moreover, family members would have visitation rights if properly disinfected upon leaving. (Despite these appeals the central government had little power to guarantee that local hospitals were well staffed, sanitary, or could provide any measure of treatment.) This chapter emphasized the need for cleanliness when dealing with patients' waste products; it advocated the liberal use of disinfectants, especially carbolic acid. Notably, it described contaminated water as the way cholera could enter a community and recommended boiling water or filtering it through sand. Calls for sanitary water supplies were juxtaposed with calls for wearing stomach wraps (haramaki) even in hot weather and admonitions against sleeping naked with windows open, this being the cause of intestinal catarrhs. This implied that a relatively mild "catarrh" could become cholera if care were not taken. Finally, the text specified measures for the care of cholera patients at home, but noted that deaths should be reported immediately to the local board of hygiene and the body quickly cremated.

The Satoshi ends with a warning that even the greatest of physicians could not be counted on to cure cholera once contracted, and as a consequence the disease presented a danger to entire family lineages. Government instructions regarding the prevention and management of cholera had to be followed in order to avoid such lamentable outcomes. Responsibility for prevention and proper treatment remained with the individual. People were admonished that they "must guarantee the safety of their own bodies." Failure to do this meant that neither the power of the government nor the power of the shinbutsu could care for people. ${ }^{46}$ The last paragraph spelled out the implied ideology: "If each person honestly heeds the points made in this admonition, we can pray for the safety of each and every one. If each individual is safe, then the household and the community also are safe and the peace of the land will be ensured."47

This final section reads as though it had been based directly on the "Book of Great Learning," which describes the cultivation of the individual as the basis for the order of the household, community, and state. ${ }^{48}$ It integrates a Neo-Confucian philosophical approach with contemporary Western medical and public health ideas. Yet even these ideas are by no means homogeneous 
or consistent, and the Satoshi integrates various schools of Western thought concerning cholera and acute infectious diseases into a single "admonition" that Buddhist priests could present to their congregations.

This work manifests a network of heterogeneous practices including science, politics, and religion. The scientific practices include various strains of European hygienic and medical thought; the political practices manifest the intersection of science with the policy directives of the Home Ministry and its subordinate bureaus of Hygiene and Temples and Shrines with the goal of maintaining order in the face epidemic disease and resulting social unrest. The religious practices include popular beliefs concerning shinbutsu, Confucian thought, and the yearnings of Buddhist organizations working to self-promote as patriotic and rational organizations. Together they formed a nexus that coalesced in this single work.

Yet it is not quite correct to call this a single work. Although the wording of the fourteen available texts is identical, the various printings of Satoshi further reveal heterogeneous practices. There seems to have been a prototypical edition produced by the Home Ministry, which might be one or both of two extant printings that include no other printing information other than the Bureau of Shrines and Temples. Among the fourteen available printings there are at least three distinctly different printing techniques: woodblock, metal block typeface, and metal semi-cursive typeface. In addition, there are three distinct formats: most are bound pamphlets. Yet there was a broadsheet-style printing that placed the entire text on one side of a single sheet of paper that was then folded into a binder. Another printed the text as a folding sutra book. At least for the main text if not for the preface, all provided phoenetic pronunciation guides. Prices, where listed, ranged from three to ten sen (a bowl of soba noodles cost approximately one sen). The printing illustrated in Figure 4.3 was attributed to Katō Mansaku in Mie Prefecture, and printed on 14 June 1880. It was typical of most printings in that it used a style similar to late Edo Period popular publications printed using woodblocks, with phoenetic pronunciations and folded sheets.

Only one printing, produced by the Pure Land Sect on April 30, 1880 presented an obvious religious affiliation. It condensed the typeface so that the entire pamphlet consisted of just eighteen pages (most were twice that length). Although there were no other mentions of religious affiliation in the printings themselves, the version printed in the form of a sutra chapbook, shown in Figure 4.4, assumed religious connotations unmatched by any of the other printings.

Yet even this Pure Land Sect version contained heterogeneous elements. The shape and accordion pages were like any standard sutra chapbook, and the title, printed on white paper, was placed on the outside cover, which was black, the common style of most sutra chapbooks. The inside title page, however, depicted a young man dressed in Western clothing with a broom and dustpan at his feet, a spray can for disinfectants in his right 


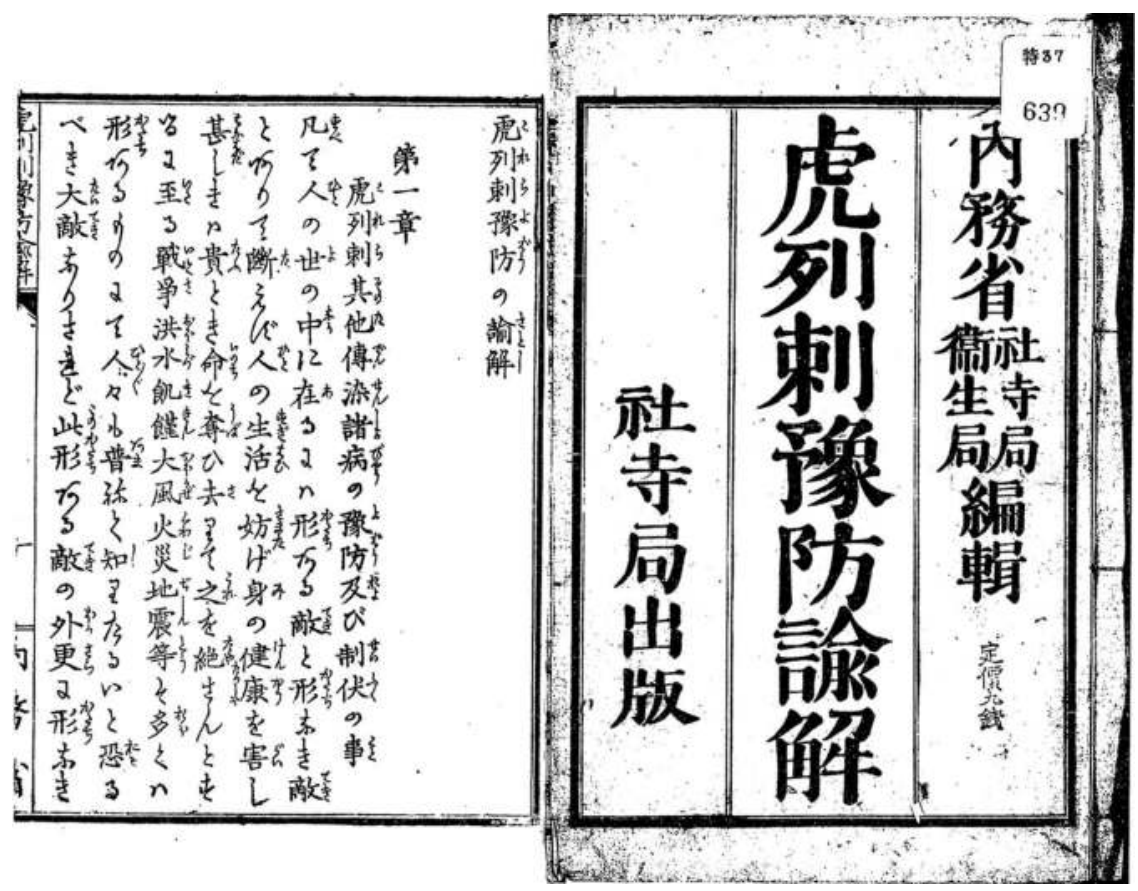

Figure 4.3 Admonitions regarding cholera prevention (Korera yobō no satoshi)—cover and first page of woodblock print edition

Source: National Diet Library Collection.
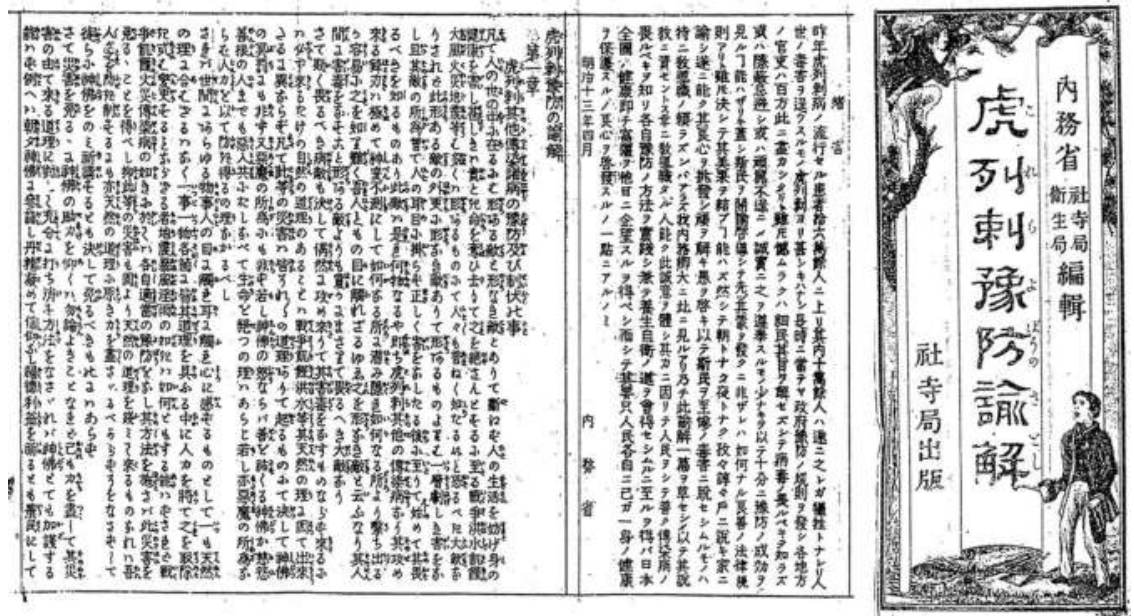

Figure 4.4 Admonitions regarding cholera prevention (Korera yobō no satoshi)—first page of sutra chapbook edition

Source: National Diet Library Collection. 
hand, and a bottle, presumably containing carbolic acid, in his left. This is, moreover, the only illustrated version. Its production would have been expensive but its sponsor was not identified.

The great variety of styles in which they appear suggest a loose but cooperative relationship between the central government that mandated them and the religious organizations that actually produced them. The Buddhist sects that participated in this project were not on their way to becoming governmental organizations in themselves, unlike their Shinto peers. This was not, however, the only attempt at cholera control that the central government implemented through Buddhist organizations. State regulations regarding cholera control promulgated in July 1880 called for the establishment of quarantine hospitals. Most communities did not have sufficient resources to do this themselves so they frequently used local temples as sites. This practice continued until the end of the nineteenth century, although not without protestations from some local clergy. ${ }^{49}$ Despite the difficulties this practice caused it did not incite organized resistance. To the contrary, efforts that the Buddhist establishment expended on printing and disseminating the Satoshi is an indication of a spirit of cooperation between Buddhist leaders and the government that set a broader tone of their relationship from this time until the end of World War II.

\section{Conclusion}

What this discussion makes clear is the impossibility of understanding a text such as the Satoshi with any kind of reductionistic approach. It is a document of surprising confluences and elements that do not fit most approaches to understanding either the history of public health or Buddhism in nineteenth-century Japan. A document such as this requires multiple contextualizations. As such, it presents not only a challenge but an engaging opportunity, one that calls for continued efforts at interpretation, one based roughly on actor network theory. ${ }^{50}$

The approach I have taken here is likely to be extremely promising for a broad range of subjects in modern Japanese history, where heterogeneities not only abound but can be taken as a given with nearly any topic, not just the history of Japanese medical and public health practices. The examination of objects as intersections of practices undertaken by individuals with disparate motivations allows a fuller understanding of observed objects and events. The Satoshi represents an ideal subject for this kind of approach, one that provides a lens for understanding larger issues in the histories of public health and religion in modern Japan, adding a new dimension to our understanding of emergent practices stimulated by contact with the West and the birth of a modern, centralized imperial state. 


\section{Notes}

1 Matsumoto Ryōjun et al. (eds), Kanpan ekibyō yobō setsu (Edo: Yōsho Shirabesho, 1862), 2 recto. For a general account, see Yamamoto Shun'ichi, Nihon korera shi (Tokyo Daigaku Shuppan Kai, 1982), 3-26.

2 Anne Jannetta, The Vaccinators: Smallpox, Medical Knowledge, and the "Opening" of Japan (Stanford, CA: Stanford University Press, 2007).

3 For example, Dosha ryūkō ji goyōjo korera yōyaku kokoroe, 1858, Yamazaki Bunko, Juntendō University.

4 Matsumoto, Kanpan ekibyō yobō setsu.

5 Ogata Kōan, Korori chijun (Osaka: Tekiteki Saizō, 1858), 1 verso.

6 Ishiguro Tadanori, Korera ron (Tokyo: Daigaku Tōkō, 1871), 2 verso-5 verso.

7 Ibid., 29 recto.

8 Yamamoto Shun'ichi, Nihon korera shi, 27-41.

9 Furukawa Seiichi, Korori no fusegikata (Tokyo: Furukawa Seiichi, 1877), 6 verso-11 recto.

10 See David Howell, "Fecal Matters: Prolegomenon to a History of Shit in Japan," in Japan at Nature's Edge: The Environmental Context of a Global Power, ed. Ian Jared Miller, Julia Adeney Thomas, and Brett L. Walker (Honolulu, HI: University of Hawaii Press, 2013), 137-51.

11 Garrett Hardin, "The Tragedy of the Commons," Science, New Series, 162: 3859 (1868), 1247-48.

12 Susan B. Hanley, "Urban Sanitation in Preindustrial Japan," Journal of Interdisciplinary History, 18: 1 (1987), 1-26.

13 Nagayo Sensai, "Hakkai shukushi," Dai Nihon Eiseikai zasshi, 1, (1883), 9.

14 Okudaira Hiroshi, Kōshū eisei sankō yōsho (Tokyo: Kyōeidō, 1885).

15 Yonei Teruyoshi, "Kindaika to shūkyō," Tokyo Daigaku shūkyōgaku nenpō, 17: (2000), 47-55.

16 Stephanie Haensch, Raffaella Bianucci, Michel Signoli, Minoarisoa Rajerison, Michael Schultz, et al. "Distinct Clones of Yersinia pestis Caused the Black Death," PLoS Pathogens, 6: 10 (2010), e1001134.

17 Rita R. Colwell, "Global Climate and Infectious Disease: The Cholera Paradigm," Science, New Series, 274: 5295 (Dec. 20, 1996), 2025-31; Rita R. Colwell, "Infectious Disease and Environment: Cholera as a Paradigm for Waterborne Disease," International Microbiology, 7: (2004), 285-9; Reinhard S. Speck, "Cholera," in The Cambridge World History of Human Disease, ed. Kenneth Kiple (Cambridge: Cambridge University Press, 1993), 643; Gerald Grob, The Deadly Truth: A History of Disease in America (Cambridge, MA: Harvard University Press, 2002), 104.

18 Speck, "Cholera," 642.

19 World Health Organization Cholera Fact Sheet No. 107, July 2012, online at: www.who.int/mediacentre/factsheets/fs107/en/index.html (accessed August 15, 2012).

20 Colwell, "Global Climate and Infectious Disease," 2025-6; for a narrative history of pandemic cholera see Christopher Hamlin, Cholera: The Biography (Oxford: Oxford University Press, 2009).

21 Yamamoto, Nihon korera shi, 3-13.

22 William F. Gragg, A Cruise in the U. S. Steam Frigate Mississippi, Wm. C. Nicholson, Captain, to China and Japan, from July 1857 to February 1860 (Boston, MA: Damrell \& Moore, 1860), 31-2.

23 Yamamoto, Nihon korera shi, 20. Yamamoto places deaths in the city during this period at over 280,000 , a quarter of the city's population, which seems unlikely.

24 Ibid., 27.

25 For example, see Ogata Kōan, Korori chijun, 1858, presents an example of 虎狼痢 (korori); Kanagaki Robun, Ansei korori ryūkō ki, 1858, for 虎狼狸 (korori). 
26 Tatsukawa Shōji, Kinsei yamai zōshi (Tokyo: Heibonsha, 1979), examines popular etiological concepts of cholera; see especially 182-91.

27 Ogawa Teizō and Sakai Shizu (eds), Matsumoto Jun jiden: Nagayo Sensai jiden (Tokyo: Heibonsha, 1980), 90.

28 Ibid., 168-78.

29 Kawaguchi Kōfū, Meiji zenki Sōtō shū no kenkyū (Kyoto, Hōzōkan, 2002), 505.

30 Ibid., 506-7.

31 The Shimane printing lists Seki as responsible for its production. Kawaguchi notes that Seki was a Rinzai priest. See Kawaguchi, 507.

32 A separate text, Ota Kōsaku's Korera yobō kokoro egusa (Tokyo: Tokyo Shinto Jimu Bun Kyoku, 1880) was produced under the auspices of the Tokyo branch of the main Shinto administrative office. This might have represented a Shinto effort parallel to the seemingly Buddhist Korera yobō no satoshi, the Home Ministry was uninvolved.

33 See especially Haga Shōji, Meiji Ishin to shukyō (Tokyo: Chikuma Shobo, 1994); and James Ketelaar, Of Heretics and Martyrs in Meiji Japan (Princeton, NJ: Princeton University Press, 1990).

34 Ibid., 77-86.

35 Kawaguchi, Meiji zenki, 509.

36 Ibid., 510.

37 Korera yobō no satoshi, edition printed in Tokyo by Ikebe Kōzō, 4/28/1880, 2

38 Ibid., 5-6.

39 Ibid., 7.

40 Ibid., 7-8.

41 An informative explanation of Snow's cholera research is Howard Brody et al., "Map-making and Myth-making in Broad Street: The London Cholera Epidemic, 1854," The Lancet, 356: (July 1, 2000), 64-8. Two informative popular accounts are Sandra Hempel, The Strange Case of the Broad Street Pump: John Snow and the Mystery of Cholera (Berkeley, CA: University of California Press, 2007), and Steven Johnson, The Ghost Map: The Story of London's Most Terrifying Epidemic and How It Changed Science, Cities, and the Modern World (New York: Riverhead Books, 2006). Snow's work was rarely cited in Japanese works on cholera. See, e.g., Katō Susumu, "Korera kokoroe," Tokyo iji shinshi, 443 (1886), 1302.

42 Korera yobō no satoshi, Ikebe edition, 13-5.

43 William F. Bynum, Science and the Practice of Medicine in the Nineteenth Century (Cambridge: Cambridge University Press, 1996), 130.

44 Korera yobō no satoshi, Ikebe edition, 24.

45 Tatsukawa Shōji, Meiji iji ōrai (Tokyo: Shinchōsha, 1986), 67-73.

46 Korera yobō no satoshi, Ikebe edition, 36.

47 Ibid., 36.

48 Hattori Unokichi (ed.), Kanbun taikei, vol. 1, Daigaku setsu, chūyō setsu, rongo shū, Mōshi teihon (Tokyo: Fusanbō, 1972), 1-2.

49 Kawaguchi, Meiji zenki, 512-14.

50 There is an extensive literature on actor network theory, but an excellent overview can be found in John Law's "Actor Network Theory and Material Semiotics," in The New Blackwell Companion to Social Theory, ed. Brian S. Turner (Chichester: Wiley-Blackwell, 2009), 141-58. 


\title{
5 The influenza pandemic of 1918 , Taishō Democracy and freedom of the press during the Siberian Intervention
}

\author{
Sumiko Otsubo
}

The 1918 influenza pandemic played a major role during the last months of the Great War in Europe. The pandemic crippled armies on battlefields and support operations. Military historian Hew Strachan relates, "During the summer the first wave of the influenza epidemic that was to ravage Europe in 1918-19 hit the German army in the west. At home munitions production was throttled back for lack of men to use its output in the field."1

In the summer of 1918, Germany was about to win the war. Russia had signed a peace treaty in March fulfilling Lenin's revolutionary promise of "Peace, Land, and Bread." However, German commander, Erich von Ludendorff noted, "it was a grievous business having to listen every morning to the chiefs of staff's recital of the number of influenza cases, and their complaints about the weakness of their troops if the English attacked again."2 Though the pandemic affected both Allies and Central Powers, inability to mobilize soldiers effectively because of the flu at a crucial moment, Germany's July offensive, cost the Central Powers their triumph. ${ }^{3}$

The 1918 pandemic is widely known as "Spanish Influenza," according to Alfred Crosby, "not because it originated there, but probably because Spain, still a nonbelligerent, had no wartime censorship to keep its health problems secret from the world." 4 Stephen G. Fritz argued that, "In Germany, the government suspended publication of many classifications of health and social statistics during the war. In addition, wartime censorship tightened considerably during the course of the war, making even accurate local reporting of negative events problematical." 5

In the fall of 1918, Japan faced a similar challenge of illness and concern about its strategic importance in Eastern Asia. The Imperial Japanese Army (IJA) sent 70,000 troops to eastern Siberia and Manchuria in order to participate in the Allied Siberian Intervention. While the western part of the Eurasian continent transitioned from war to peace, the eastern part experienced continued warfare. Further, while the sheer number of Japanese troops, far greater than any other Allied nation's, suggests Japan's ambition to further imperial expansion, Japan also launched international humanitarian aid to Siberia.

Unlike Japan's earlier wars, which attempted to build an empire by force, the Siberian Intervention was designed to promote Japan's international 
image among the allies and increase Japan's "soft power" through medical aid and food distribution; at least in the beginning, efforts to control disease and openness regarding disease casualties developed on site, not in a national bureaucracy. ${ }^{6}$ Japan's humanitarian initiatives, especially medical care, as a way to gain trust from local residents was prompted by its competition with the Allies in the intervention, especially the United States, which effectively mobilized the American Red Cross for comprehensive humanitarian programs. The Japanese army in Siberia was compelled to provide clinical care for Russians and share medical supplies with Russian doctors as early as October 9, before Tokyo planned extending systematic public health aid. Policies of medical assistance were formulated from the bottom up, reflecting local army physicians' efforts to cope with the burgeoning patient numbers on the battlefield. ${ }^{7}$

Keeping the contradictory factors of war and humanitarian activities in mind, Japan exhibited a mixed and nuanced pattern of press censorship during the intervention, one further conditioned by the period of so-called Taishō Democracy during which the press demanded its freedom to report without strict imposition of censorship. While virologist Nishimura Hidekazu speculated that the Home Ministry might have sought to limit access to confidential military information, demographic historian Hayami Akira observes that military damage caused by the pandemic in Siberia was reported by newspapers as simple fact. Hayami associates this expansion of expression with the Taishō Democracy. ${ }^{8}$ Supporting these contradictory assessments, historian Andrew Gordon treats "Taishō Imperial Democracy" as a period of conflicting developments. I find similarly paradoxical trends in Taisho-era censorship and in studies of censorship that concentrate on the state's control of expression that it believed would compromise public order-politically, ideologically, and morally_but neglect the state's handling of public health information. ${ }^{9}$

In addition to pointing out Japan-specific factors I argue that much of policy resulted from "indeterminacy," by which I mean the Japanese faced an uncertain situation that they did not have the ability to accurately appraise. Contrary to Crosby's oft-cited theory, there were no detectable efforts in Japan to conceal pandemic information about expeditionary forces in Siberia. Although historians know the outcome of the 1918 pandemic, people at all levels failed to appreciate the flu's impact at the time. Consequently, officials did not formulate plans to prevent the spread of influenza or conceal the number of influenza casualties.

\section{The 1918 pandemic}

In the spring of 1918, an unusually infectious strain of influenza broke out in the United States and quickly swept through many parts of the world. Within two years, the number of flu victims totaled some hundred million, including 450,000 Japanese, easily outdoing the Great War's mortality (about ten 
million soldiers). ${ }^{10}$ In August 1918, Prime Minister Terauchi Masatake began sending the first of over 70,000 troops to Siberia as part of the Allied effort to support White Russians against the Bolsheviks. Japanese soldiers arrived at their battlefronts after traveling through Vladivostok and Guandong, about two weeks before the first cases of the fall outbreak were reported in France. This second wave of flu in fall 1918 was much more deadly than the first wave. As I have discussed elsewhere, the IJA's medical records, Shiberia Shuppei eisei shi, had detailed statistical data of influenza patients. ${ }^{11}$ The earliest flu outbreak took place among Russians around Konduy and Borzha near the border of Siberia and Manchuria in early September. On the east coast, the first flu outbreak was recorded in Spasskoye, north of Vladivostok in late September. Soldiers hospitalized in Siberia because of the flu declined in numbers from 495 in October to 246 in November. ${ }^{12}$ The fall influenza in northeast Asia moved from west to east along the Trans-Siberian Railroad, then from Vladivostok to Japan via the steamship Hozan-maru. Japan's large-scale wartime mobilization allowed the virus to travel much more quickly by putting soldiers in contact with local peoples and foreign forces. Among 102,329 patients on the Siberian Intervention fronts, 956 died (0.93 per cent). Influenza (ryūkōsei kanbō) killed the largest number, 330 of them (34.52 per cent). (Figures 5.1 and 5.2) ${ }^{13}$

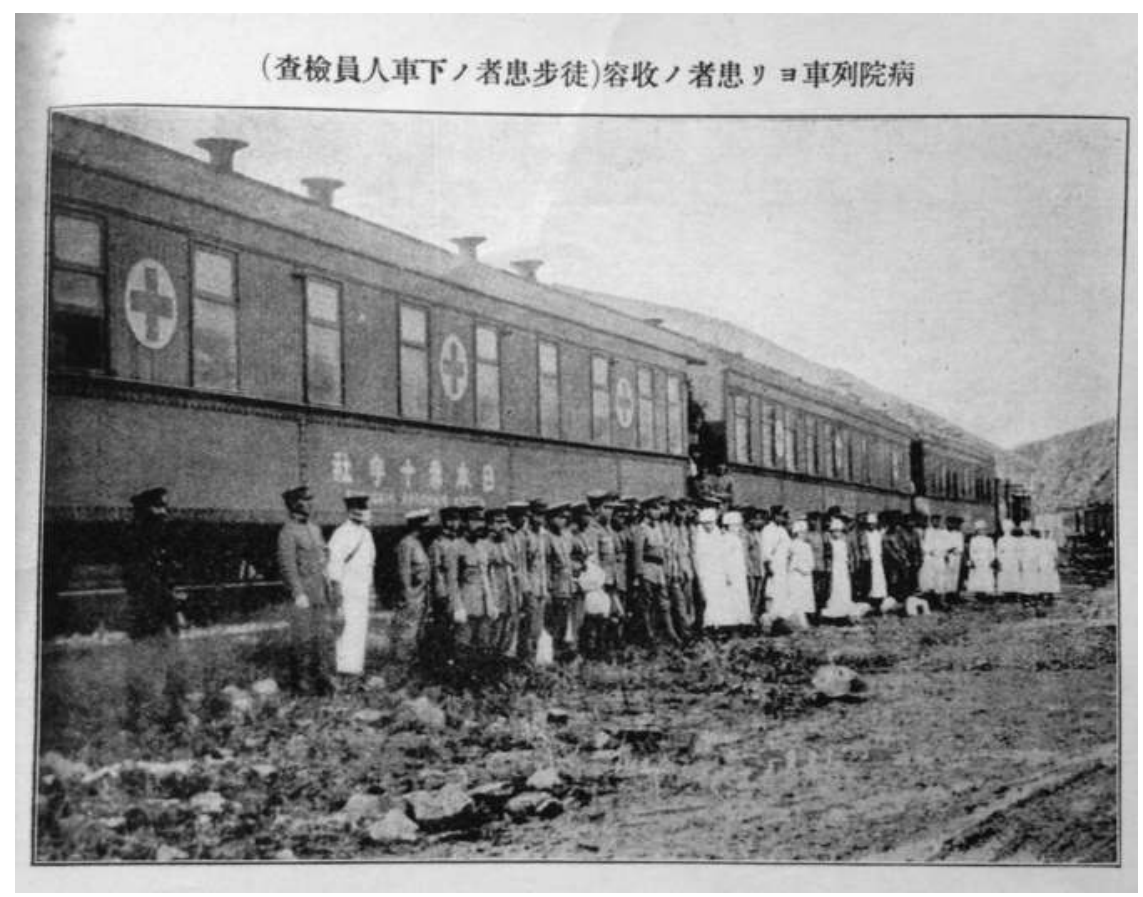

Figure 5.1 Ambulatory patients disembarking the Japanese Red Cross hospital train Source: Shiberia shuppei eisei shi, vol. 1, Eisei kinmu, Ge (Tokyo: n.p., 1924). Courtesy of the Tokyo University Institute for Advanced Studies on Asia. 


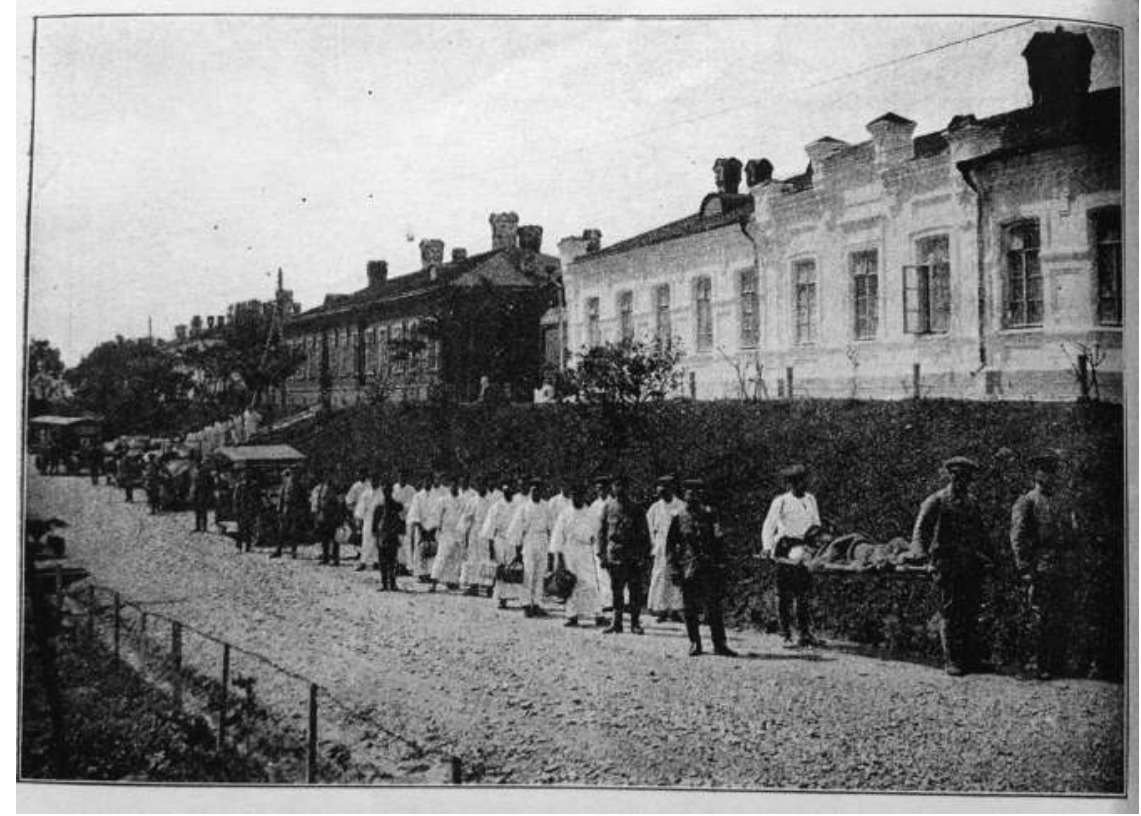

Figure 5.2 Patients leaving the Vladivostok Army Hospital returning to Japan Source: Shiberia shuppei eisei shi, vol. 1, Eisei kinmu, Ge (Tokyo: n.p., 1924). Courtesy of the Tokyo University Institute for Advanced Studies on Asia.

\section{Taishō Democracy, the Osaka Asahi and the growth of press censorship}

As the 1918 influenza pandemic killed millions and the Allies requested its involvement in Siberia, Japan was experiencing Taishō Democracy (1905-32). This trend, allowing ordinary people to question the monopoly of power, had a great impact on the freedom of the press. In 1916, the Osaka Asahi began promoting "democracy" and encouraging a cabinet made up of elected political party members, the allies of people and workers. The Osaka Asahi spearheaded a campaign against Terauchi Masatake's so-called transcendent cabinet, largely composed of bureaucrats, excluding figures elected by the people. Tensions between the Osaka Asahi and the administration continued over such issues as the Russian Revolution, Terauchi's policy against hyperinflation and the Siberian Intervention. The Osaka Asahi clearly opposed the intervention. In this context, the Home Ministry expanded its staff in charge of censoring newspapers, magazines, and books in the summer of 1917. The Terauchi cabinet banned the publication of the Osaka Asahi's morning editions on April 23 and May 13, 1918. In July, anticipating the beginning of the Siberian Intervention, the Home Ministry attempted to establish a newspaper section within its police section. ${ }^{14}$ Although this consolidation plan never materialized, Terauchi 
tightened press controls and banned the publication of many newspapers on July 30 , immediately before the dispatch of troops to Vladivostok. ${ }^{15}$

Press-government tension was further aggravated by the outbreak of the Rice Riots (1918). The resulting Hakkō censorship incident epitomized the irony that the expansion of government efforts at press suppression led to newspapers' sharpened desire for freedom of the press. During World War I, the need to meet the demand for textiles, goods, and ships for the world market vacated by European industrial powers busy fighting combined to accelerate industrialization and urbanization in Japan. The vast majority of Japanese suffered from a severe decline in material well-being as pay raises were grossly outpaced by the rapid inflation accompanying economic growth. Rice riots against inflation and speculation broke out. When the uprisings were reported locally and nationally, the government responded with military suppression. Terauchi banned the publication of newspapers carrying sensational reports sympathetic to the rioters (see Figure 5.3). When Home Minister Mizuno Rentarō prohibited the media from reporting anything related to the Rice Riots on August 14, based on the Newspaper Act of 1909, journalists immediately called for the repeal of these bans as they imperiled freedom of speech. Osaka asahi's August 26 report on the meeting of newspaper representatives against excessive press control included the Chinese classical expression, "Hakkō hi o tsuranukeri (A white rainbow pierces through the sun)." 16 As it implied a warning of a rebellion against the ruler, the Home Ministry officially indicted the officers of the Osaka asahi. However, persistent resistance and pressure from newspapermen forced Mizuno to compromise. He allowed media reports of the Rice Riots as long as they were based on facts from official presses, without exaggeration or sensationalism. In the end, the breakdown in civil order forced Takeuchi to step down, to be replaced by the Seiyūkai party leader, Hara Takashi, on September 29. ${ }^{17}$ For the first time, the public display of defiance by news media forced authorities to back down.

By nature, censorship leaves few records. ${ }^{18}$ Studies of military censorship seem very limited perhaps because of the paucity of documents. ${ }^{19}$ However, laws and regulations help to establish enabling frameworks.

The legal or policy framework in which wartime press freedom was both guaranteed and repressed was most importantly embodied in article 29 of Japan's 1889 constitution. "Japanese subjects shall, within the limits of law, enjoy the liberty of speech, writing, publication, public meetings, and associations." "Law" was supposed to be established only by both houses of the Diet, not by administrative ordinances, so the constitution appeared highly liberal. Yet the Meiji constitution allowed emergency imperial intervention at the time of a foreign war or domestic insurrection (article 14). ${ }^{20}$

Furthermore, other laws restricted freedom of the press. The legal framework for press censorship that facilitated Japan's nation- and empire-building sought to establish order while discouraging the public from questioning authorities. Those laws included the 1875 Newspaper Ordinance, revised in 1883 and 1887 and replaced by the 1909 Newspaper Act and the 1893 Press 


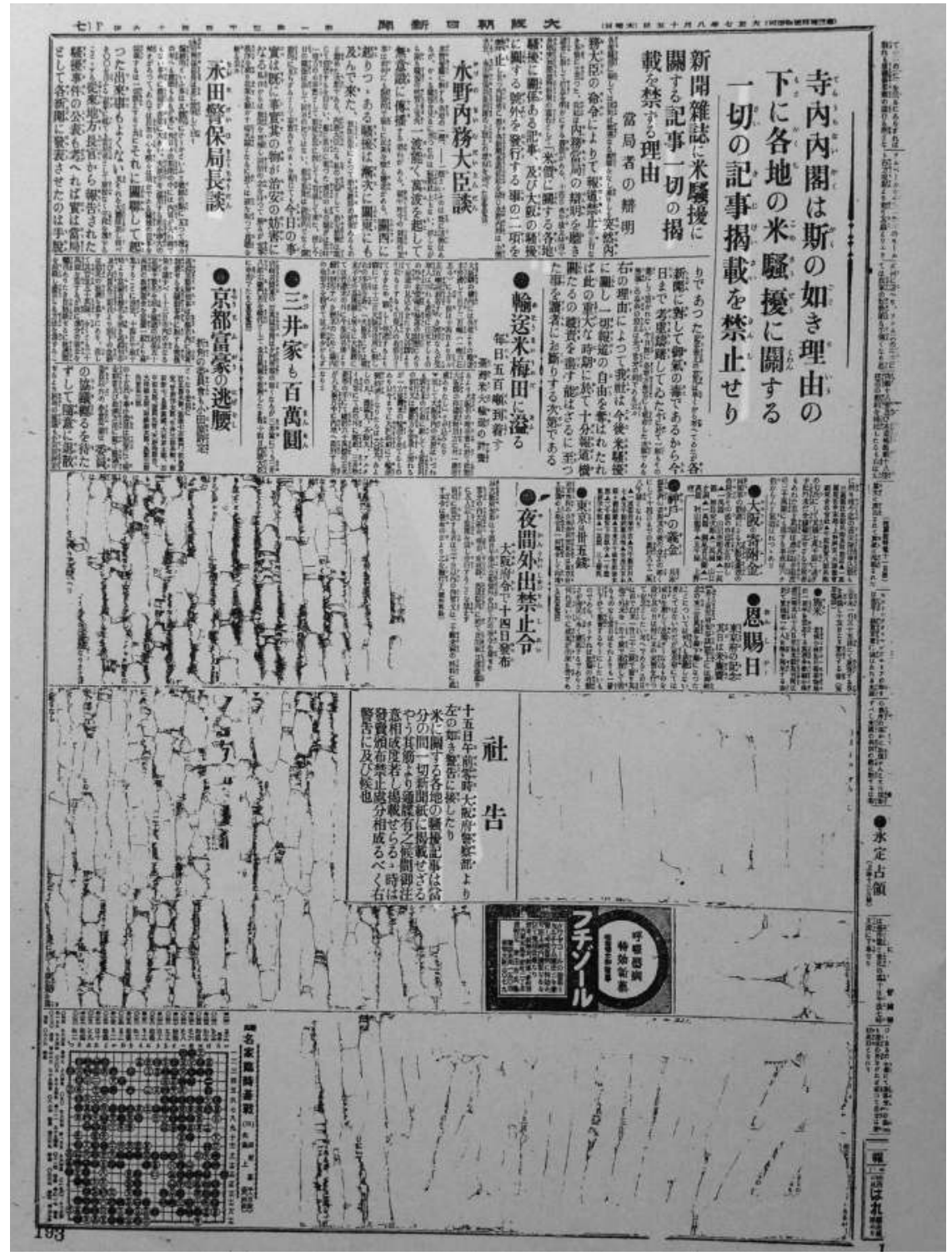

Figure 5.3 Censored coverage of the Rice Riots in the Osaka asahi (August 15, 1918) Source: Osaka asahi, August 15, 1918, morning edition, 7. 
Act. Under these ordinances, the Police Bureau of the Home Ministry regulated publications that might breach public order and corrupt public morals. Army and navy ministers were given authority to ban the report of a deployment as well. The 1887 version of the Newspaper Ordinance allowed army and navy ministers to ban the publication of news and listed the banned subjects (article 22). For example, shortly before the Russo-Japanese War began, the army and navy ministers began inspecting manuscripts dealing with strategically sensitive matters in newspapers and magazines. While the army and navy were directly involved in censorship in Tokyo, the police acted as their proxy elsewhere. ${ }^{21}$ Similar military authority can be found in article 27 of the 1909 Newspaper Act. ${ }^{22}$ Both acts prevented the mass media from freely reporting classified military information.

While these restrictions were based press laws, a separate Military Secrecy Protection Law, established in 1899, reinforced their provisions. It aimed to protect from public exposure "operations, tactics, mobilization, dispatches and other matters and documents which would require military confidentiality." 23 Casualties caused by infectious diseases were not included specifically but could be part of "other matters."

Based on the broad array of censorship laws, the Japanese military developed a mechanism for media control during the Russo-Japanese War (1904-5) that is considered the world's first modern press pool. The IJA's censorship system was the most restrictive in the world at that time. American journalists who covered the Russo-Japanese War complained that Japan's military censorship was considerably tighter than elsewhere. These reporters, who wanted to witness action at the front, "were not permitted within four miles of combat" and "were not allowed to wander without a military escort, print anything that might disturb morale, file any information to the telegraph without getting a censor's stamp ... or attempt to circumvent the censorship system ... ."24

An IJA-designated spokesman gave war news to one reporter who was to share that information with other journalists. The IJA controlled the media by circulating only desirable news and was effective in boosting war support at home and encouraging further foreign investment. ${ }^{25}$

When Japan took over the German colonial concession at Qingdao at the beginning of World War I (1914), the IJA revised regulations regarding news cables developed originally for the Russo-Japanese War. The regulations established a group of approved correspondents, set guidelines regarding censorship, languages of publication, message length, and what information could be sent via cable. ${ }^{26}$ In preparation for the siege, the IJA enlisted local Chinese police to close post offices and cable stations because mail from occupied areas often contained militarily sensitive information, and the IJA kept post offices, imposing censorship. ${ }^{27}$

Incidents described in the classified Military Police (M.P.) records of the siege reveal how press censorship worked. There were 18 war correspondents who covered the initial stage of the siege. One correspondent, who competed on how quickly he could send information from the warfront in Shandong 
province (where Qingdao was located) was Midoro Masuichi (1886-1973) of the Osaka asahi. Midoro managed to send information without the military headquarters' approval. He hired local Japanese merchants, who cabled information to Dalian, Liaodong peninsula, using their business network. Apparently, it was easy to send cable messages from non-belligerent Dalian to Japan. Consequently, the Osaka asahi could print news two to four days earlier than its rivals. His strategy was exposed when journalists outdone by Midoro reported Osaka asahi's non-compliance with censorship rules to the M.P. Midoro was penalized and sent back to Japan on October 26, $1914 .^{28}$

While the M.P. was active in enforcing press regulations in Qingdao, during the Siberian Intervention its objectives were different. They included maintaining military discipline, peace, and public order and preventing revolutionary thought from pouring into Japan. ${ }^{29}$ The IJA's Military Police compiled their own history of the Siberian Intervention and described policies issued during the Intervention in its supplement. One of these confidential documents describes censorship regulations for both telegrams and mail. The former was to prevent radicals from undermining the Allied Powers to maintain peace and order in Siberia. Russian officials were primarily in charge of inspecting telegraph messages to and from Vladivostok, although a few representatives from the U.S., Japan, and the Czech Legion played a supporting role inspecting messages in their own languages. The Japanese M.P. sent one noncommissioned officer and two privates for this task. Anyone who attempted to send coded cable messages was summoned to clarify message content. Military and diplomatic messages had to be processed promptly. Reading messages protected by international rules was not permitted. ${ }^{30}$ Unlike earlier wars, no specific documents concerning war correspondents were listed.

\section{Censorship, influenzas, and the Siberian Intervention}

Censorship of the press existed during the Intervention. Press censorship rules were presumably the same as the ones revised for the Siege of Qingdao (no further IJA revisions were recorded until 1922 [Figure 5.4]). ${ }^{31}$ The July 21 evening edition of the Tokyo-based Jiji shinbun plainly reported that the Ministry of War created a new censorship section, ordering journalists not to write details concerning such issues as weapons, mobilization, departure schedules, and airplanes starting on July $20 .{ }^{32}$ The press pool system, in which the military headquarters announced battlefront news twice a day, remained intact. In his article printed on September 3, 1918, Osaka asahi reporter Suzuki Bunshirō wrote disappointedly about receiving no new information since the first deaths among Japanese troops on August 24. (There was no suspense required in war news since everyone anticipated the victory of the Allies.) ${ }^{33}$ A few days later, another Osaka asahi correspondent Taniguchi Tokujirō, bored from the lack of exciting news, sought and received special permission to travel inland to battlefronts. ${ }^{34}$ War coverage rules seemed to have been relaxed in the face of a prospective victory. Considering the special access to the front for reporters and the 


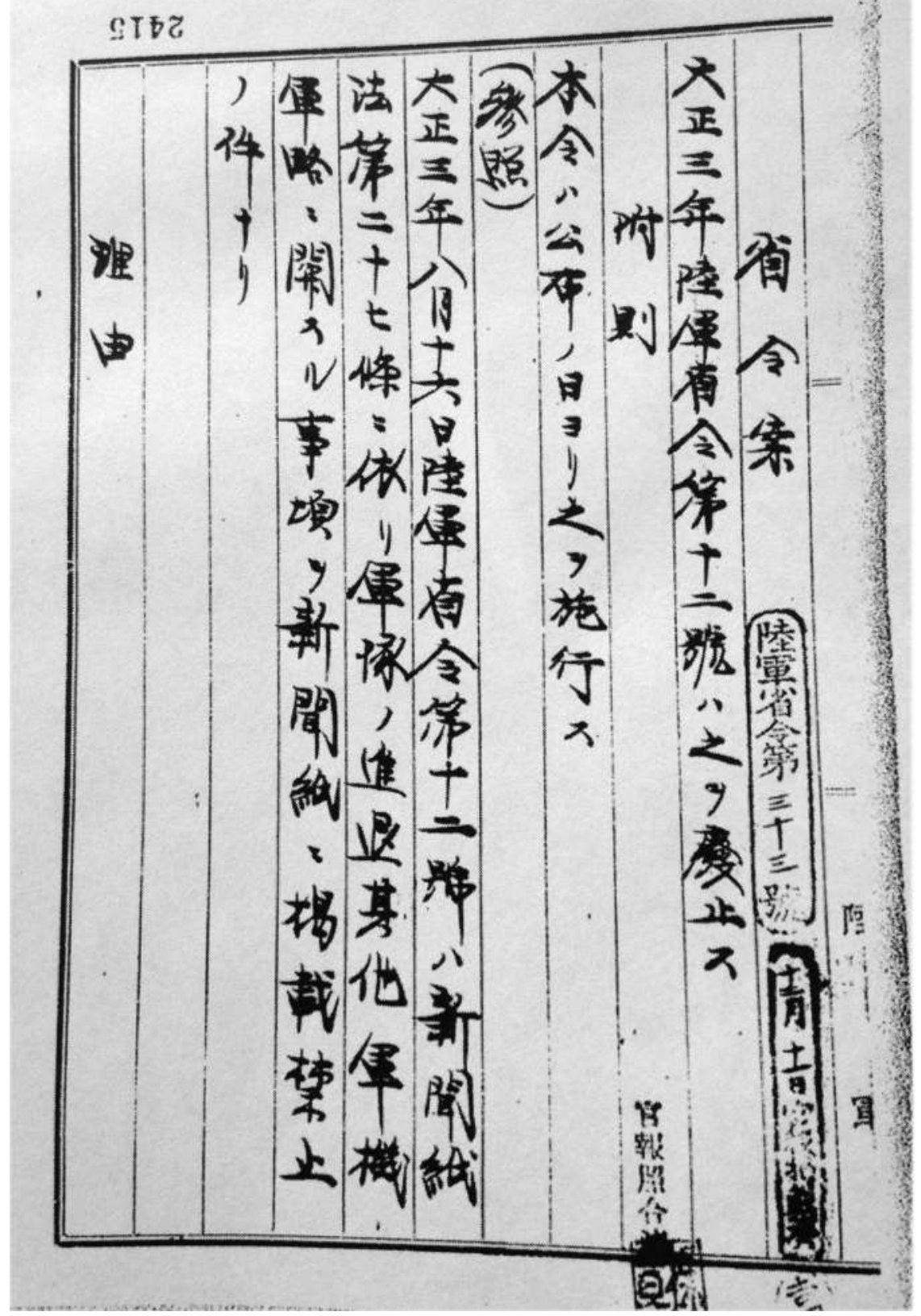

Figure 5.4 A proposal to discontinue regulations on newspaper reporting, originally suggested by the Ministry of the Army in $1914^{35}$ 
small number of censorship staff, it appears that writing about the Siberian Intervention was less restricted than earlier.

How did various newspapers report the fall wave of the 1918 influenza pandemic, especially in relationship to the intervention? By mid-October, influenza outbreaks began to be reported in many places in Japan. ${ }^{36}$ Many included sensitive information, but some were compliant with - or at least sensitive tothe security issues raised by the information. These reports indicate that neither the journalists nor the army physicians who provided information to the journalists were generally careful about discussing "operations, tactics, mobilization, and dispatches" as specified in the Military Secrecy Protection Law. It apparently did not immediately occur to them that the alarming increase of influenza casualties within the army and related information could be protected by "military confidentiality."

Newspapers displayed a curious co-existence of sensitivity and insensitivity toward what historians might classify as confidential matters. The Tokyo asahi, though associated with the Osaka asahi, had separate news coverage focusing on eastern Japan; it carried its first article on the fall wave of influenza in Japan on October 22. More intriguing, it casually mentioned that many in the army had been infected, but provided little information about locations, numbers, or dates. ${ }^{37}$ Another Tokyo asahi piece, published on October 24, made little effort to conceal the flu outbreak in Siberia. Its writer, based in Kyūshū, identified his source as information sent to the medical director of the Twelfth Division stationed in Kokura from the head of the IJA's Second Field Hospital in Siberia. The article noted that the army doctor in Siberia was concerned with the arrival of the vicious flu, which coincided with the arrival of the cold Siberian winter. If patients in four field hospitals in Siberia were combined, there were more than a thousand and several hundred patients. Each field hospital worked hard to come up with effective preventive measures. ${ }^{38}$ The writer apparently had direct access to an army physician who was fighting the flu and had not processed information for release by the press. The tone of the news was sympathetic to the doctor but not particularly critical of the army or authorities. Further, in its October 24 morning edition, the Osaka asahi described simultaneous flu outbreaks in Tokyo, Siberia, Sasebo, and on a ship returning to Japan from San Francisco. The space covering Siberia was small but listed the names of two soldiers who died without specifying their unit. Its evening edition on the same day detailed information obtained from the director of the Second Field Hospital in Siberia, which had admitted 300 patients, 18 of whom died (Figure 5.5). As noted in the Tokyo asahi report, inpatients in the four Siberian field hospitals numbered a thousand and several hundred. ${ }^{39}$ Although the headlines, expressions, and some details differed, both the Tokyo asahi and Osaka asahi had the same source.

The similar mix of censorship, self-censorship, transparent publication, and selective publication can be found in a local newspaper in Fukuoka on October 24. The Kokura-based Twelfth Division was of major interest to the Fukuoka nichinichi. It reported significant details provided by an army doctor 


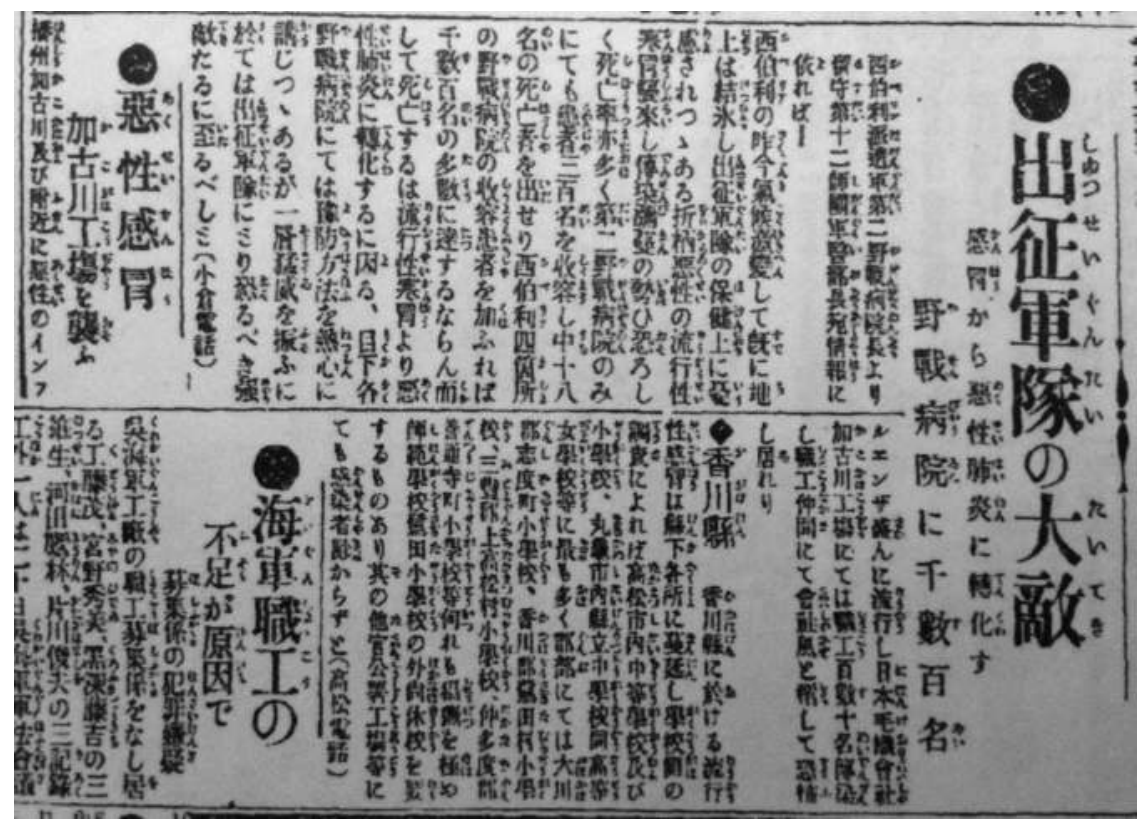

Figure 5.5 "The formidable enemy of the expeditionary troops: Turning from influenza to malignant pneumonia, a thousand and some hundreds in field hospitals."

Source: "Shussei guntai no taiteki, kanbō kara akusei haien ni tenka, yasen byōin ni sen sūhyaku mei," Osaka asahi, October 24, 1918, evening edition, 2.

named Yada (apparently in Kokura) and indicated that more information would soon arrive from another army doctor returning from Siberia together with 28 sick or injured soldiers on the hospital ship, Taichū-maru, October $29 .{ }^{40}$ Although some strategically important information was missing, the amount of statistical information reported in these articles was very specific and perhaps excessive. As the army physician provided information, the IJA apparently considered its release acceptable (there were no records of punishing this doctor). Or perhaps military or government authorities had not fully grasped the impact of the epidemic to appropriately judge what policies would be necessary in the midst of this highly infectious, deadly epidemic.

The Home Ministry's indeterminacy and the army's general indifference toward influenza likely had much to do with the absence of any systematic policy for the pandemic until January 1919, by which time the fall wave was largely over. The Home Ministry sent a notification on October 23, 1918 to the superintendent-general of the Tokyo Metropolitan Police and prefectural governors regarding the pandemic's serious threat, but left regional authorities to take appropriate preventive measures. Another notification directed to prefectural governors, issued on November 13, described successful regional measures as exemplars, such as emergency funding for clinical care and medical 
supplies and dispatching doctors and nurses to areas where they were in short supply. Only in January and February 1919, when the fall wave was already over, did the Home Ministry transmit systematic preventive measures.

The army's response was no quicker than the Home Ministry's. Within the IJA, there was a Twelfth Division report referencing the severe influenza epidemic in eastern Siberia observed between October 9 and 29. But there was no mention of any remedial plan. In fact, the report noted nonchalantly, "there had been quite a few deaths from pneumonia, developed immediately after contracting influenza, but other than that, there were no health-related concerns." ${ }^{41}$ Major General Sugawara Sagae's 1925 history of the Intervention did not mentioned the fall influenza either, indicating only that the IJA had promptly pacified the Maritime, Amur, and Transbaikal provinces in Siberia within 45 days of the war's onset. According to him, the army was eager to manage the discontent regarding the war among sympathizers of the Rice Riots and labor unionists by sending back approximately 14,000 soldiers between late October and late December, coincident with the peak of the influenza epidemic. ${ }^{42}$ Army authorities feared the spread of communism more than the spread of influenza. Health officials and military leaders had limited insight into the uniqueness of the fall 1918 influenza epidemic.

Clearly sensitive information which could be exploited to undermine political leaders and the IJA was published without close scrutiny. Even news reporters were not fully aware of the political value of some of the information they circulated. For example, the Osaka asahi missed the opportunity to point out that the Siberian Intervention, started by the illiberal Terauchi cabinet, was responsible for establishing contacts among local residents, revolutionaries, and multi-national forces and creating a microbiological link between northeastern Asia and Japan. A November 2 Tokyo asahi article stated that a Home Ministry inspector linked the October 9 influenza epidemic in Tsuruga (Fukui prefecture) to the arrival of a civilian ship, Hozan-maru, from Vladivostok. ${ }^{43}$ Thus, the Tokyo asahi informed its readers that the steamship picked up the influenza virus, already prevalent on the Siberian coast in early October, and brought it to Japan. Unlike its sister company, however, the Osaka asahi only reported when inspectors had been dispatched. ${ }^{44}$ Whether deliberate or not, the Osaka asahi failed to make the connection that Siberia was the original source for Japan's influenza (without consulting the coverage by others) and the return of sick soldiers was potentially dangerous.

If the Osaka asahi had identified the Siberian Intervention as an important feeder of Japan's flu, it could have blamed political leaders for the many deaths of soldiers and people in Japan, but it did not, in spite of the particularly contentious history between this company and the state - and this was not an isolated circumstance of sensitivity to political concerns. Consider the following episode. On November 5, 1918, the Osaka mainichi reported that an unnamed transport ship arrived at Moji the previous day from Vladivostok, carrying 11 bodies, all influenza casualties. Among the victims, seven belonged to the Twelfth Division, including an army physician. Victims, 
whose names were identified in the article, were offloaded at Moji and after a Buddhist ceremony, were taken to their division's headquarters at Kokura. Two Buddhist monks accompanying these bodies commented on the virulent nature of the influenza outbreak on the continent, "On the 26th of last month, as many as 27 died of flu. We have been busy with funerals every day." ${ }^{45}$ No comparable article can be found in the Osaka asahi, the paper published in the same city as Osaka mainichi; however, the Osaka asahi reported on an officer who had returned from the war fronts in eastern Siberia, Usuri and Amur. He commented on the serious influenza outbreak in northern Manchuria. ${ }^{46}$ The Osaka asahi also reported the frustration of a dispatched soldier's wife on October 29. She noted that she was unable to send warm clothes because of censorshiporiented wartime mail restrictions even after learning that in her husband's subunit 17 out of 23 had caught the flu, six of whom were admitted to hospital. ${ }^{47}$ Clearly, personal mail with sensitive news from Siberia reached Japan even while censorship rules prevented packages from being shipped from Japan to quiet battlefronts. ${ }^{48}$ Moreover, the Osaka daily wrote, most soldiers in the first group returning to Japan on November 10 got influenza during a long march when the temperature had already dipped to $-28{ }^{\circ} \mathrm{C}\left(-18{ }^{\circ} \mathrm{F}\right)$ in October. ${ }^{49}$ On November 23, the Osaka asahi reported the official news that among the troops sent to Vladivostok, 97 died in battle or of diseases between August 23 and October 20 (causes of death were unspecified.), In Osaka, influenza deaths peaked on November 12; by the end of the month news on the pandemic declined, reflecting the end of the fall outbreak linked to Siberia. ${ }^{50}$

These news articles embody contradictory tendencies because information about influenza among Japanese troops was made publicly available but there were restrictions on reporting and shipping in line with routine wartime censorship. Although the Osaka asahi had a history of conflicts with the authorities over censorship and was known for its anti-Siberian Intervention position, the newspaper did not connect the IJA and the Intervention to the introduction of an influenza-causing agent from the Eurasian continent or to the fact that the army failed to protect its soldiers properly. ${ }^{51}$ Of course, by the time the pandemic ravaged Japan, especially between mid-October and mid-November, Osaka asahi's principal enemies, Prime Minister Terauchi Masatake and Home Minister Mizuno Rentarō, had stepped down. The new Hara administration was careful to restore relationships with the press. The Osaka asahi viewed favorably Hara's invitation to journalists for an afternoon party after his inauguration. ${ }^{52}$ While Mizuno was in office, the Osaka asahi criticized censorship and the delay in cable communications; apparently, the newspaper was satisfied by the efforts of Hara's communication minister to speed up the processing of cable messages. Moreover, the newspaper approved of the new chief of the Home Ministry's Police Section as he tried to foster understanding between his office and the press. ${ }^{53}$ After Hara replaced Terauchi at the end of September, the Osaka asahi no longer had a strong motive to attack censorship or the administration's decision to involve Japan in Russia's civil war. 


\section{Sumiko Otsubo}

\section{Limited censorship: Taishō Democracy or special circumstances?}

Evidence indicates there was no systematic plan to control the spread of the epidemic or to conceal influenza casualties by the army or Home Ministry in the fall of 1918. As we have seen, the enforcement of the Military Secrecy Protection Law and related media policies were more relaxed than before the Intervention. There seemed no dire need to conceal wartime casualty information, including that relating to influenza, since suppressing disorganized revolutionaries was expected to be easy. ${ }^{54}$ In addition, IJA's humanitarian aid initiatives in Siberia necessitated a certain degree of international medical information-sharing.

This situation requires us to rethink the association between both the pandemic and censorship and Taishō Democracy and the relaxation of censorship. Unlike Germany, where influenza casualty information during the prolonged engagement in war was kept secret, Japan did not have policies to guard information concerning patient and death numbers in the fall pandemic, even though the bureaus in charge of censorship and that overseeing public health belonged to the Home Ministry. The military and state authorities were unconcerned that the killer pandemic would alter Japan's dominant position versus Russian revolutionaries.

For people who experienced the pandemic the impact of the flu was indeterminate, developing rapidly but with unclear outcomes. Policies to cope with the pandemic did not keep up with the pace of its swift diffusion. ${ }^{55}$ It may be unfair of historians who have the benefit of knowledge of how different this influenza was in its speed of transmission, lethality, and global simultaneity to expect consistent government action as contemporaries sought to comprehend the causes and effects of the overwhelming number of deaths caused by a seemingly casual illness - influenza.

Besides indeterminacy, when we consider why there is limited evidence of Japan's wartime censorship regarding battlefront influenza victims, we must consider the coincident timing of the disease in relationship to Japan's domestic politics. Close examination shows how the Osaka asahis strong desire to protest official censorship and the administration's decision to join the Intervention quickly disappeared when its archenemy Terauchi Masatake was replaced by Hara Takashi, just before influenza swept Japan. The timing was important. Although mobilized troops in Siberia and Manchuria constituted one of the major routes through which the fall strain of influenza arrived in Japan, simultaneous outbreaks in a short time obscured this fact. Consequently, there was no political reason to censor news of flu casualties in Siberia, nor was there reason to expose deaths and the role of the Siberian Intervention in the pandemic to discredit political leaders. Perceptions of the pandemic were shaped by changing press-state relationships, war aims, and incomplete knowledge. Belligerency and the pandemic alone were inadequate conditions to establish censorship. 
Nonetheless, this study shows that censorship was not necessarily relaxed during the Taishō Democracy. As evidenced by the expulsion of Midoro Masuichi from Qingdao and the Home Ministry's efforts to control the newspapers, press censorship existed, expanded, and was enforced long before the 1925 Peace Preservation Law, which signaled the waning of democracy.

It should also be noted that this idea of limited freedom co-existed with the desire for greater information circulation. Consider the observation made by the editorial staff of the IJA's Shiberia shuppei eisei shi:

In the past the IJA's medical history was classified and it was troublesome to go through the process for perusal, which resulted in the materials being unused. However, there was much necessary information among the classified and buried. Therefore, we have been careful to distinguish between information that could be made public and that which should be withheld. $^{56}$

When this was written in September 1920, these army doctors were unusually critical of confidentiality and were highly conscious of the need of information circulation. The official history, the history of the military police, and the medical history all describe the Siberian Intervention from a rather detached viewpoint. This uncharacteristically personal opinion was added after the editors put together the manuscripts of Eisei shi for the second time after the original burned in the Great Kantō Earthquake (1923). ${ }^{57}$

What I have presented above - that is, the co-existence of both guarantees of freedom of the press and restrictions of it - accords with Andrew Gordon's argument that the period between 1905 and 1932, the era of "Taishō Democracy," exhibited contradictory tendencies. While a dramatically democratic change, the beginning of political rule by elected politicians like Hara, took place during the Taishō era, leaders including Terauchi Masatake and Hara himself continued to support the emperor and Japan's imperial expansion. This essay confirms his observation that labels such as "conservative" and "liberal" are inadequate since the desire to disseminate sensitive medical casualty information existed within the supposedly conservative military. ${ }^{58}$

This chapter has explored an important but overlooked aspect of military medical casualty information censorship, focusing on news reports about the lethal influenza pandemic in Siberia in fall 1918, and, contradicting prevalent notions, has shown that the Japanese media coverage of the 1918 pandemic in northeast Asia was not highly restricted by wartime censorship policies. This was true even at the height of the tension between state and media. In addition to presenting another example of Gordon's "Taishō Imperial Democracy," this essay suggests that it may be worthwhile to re-examine Crosby's premise. Perhaps historians analyzing the 1918 influenza in other regions ought to pay more attention to central authorities' indeterminacy when considering links between the 1918 pandemic, belligerency, and censorship. 


\section{Sumiko Otsubo}

\section{Acknowledgements}

I would like to thank James Bartholomew for his continued mentorship and am indebted to Kevin Doak, James Huffman, Janice Matsumura, and Akihito Suzuki for helpful comments on earlier versions of this chapter. Finally, I want to express my sincere gratitude to the editors of this volume, Philip Brown and David Wittner.

\section{Notes}

1 Hew Strachan, The First World War (New York: Penguin Books, 2003), 298.

2 Carol R. Byerly, Fever of War: The Influenza Epidemic in the U.S. Army during World War I (New York: New York University Press, 2005), 73; Alfred Crosby, America's Forgotten Pandemic: The Influenza of 1918, new edition (1989; New York: Cambridge University Press, 2003), 26-7; and Hayami Akira, Nihon o osotta Supein Infuruenza: Jinrui to uirusu no Dai-ichiji Sekai Taisen (Tokyo: Fujiwara Shoten, 2006), 92; Stephen G. Fritz, "Frankfurt," in The 1918-1919 Pandemic of Influenza: The Urban Impact in the Western World, ed. Fred R. van Hartesveldt (Lewiston, NY: Edwin Mellen Press, 1992), 13-32.

3 Anne Rasmussen, "Prevent or Heal, Laissez-Faire or Coerce? The Public Health Politics of Influenza in France, 1918-1919," in Influenza and Public Health: Learning from Past Pandemics, ed. Tamara Giles-Vernick and Susan Craddock (London: Earthscan, 2010), 69-83.

4 Crosby, America's Forgotten Pandemic, 26. Crosby bases this inference on two sources. Neither links the circulation of flu information to the absence of wartime censorship directly. See Ward J. MacNeal, "The Influenza Epidemic of 1918 in the American Expeditionary Forces in France and England," Archives of Internal Medicine, 23: 6 (June 1919), 657-88, esp. 676. See also Ministry of Health, Reports on Public Health and Medical Subjects No. 4: Report on the Pandemic of Influenza, 1918-1919 (London: His Majesty's Stationery Office, 1920), 236-7, which describes the presence of information suppression in Spain.

5 Fritz, "Frankfurt," 14.

6 Hara Teruyuki discusses IJA's vision of securing Japan's economic and military spheres of influence as an objective of the Siberian Intervention and American reservations regarding Japan. See his Shiberia shuppei: Kakumei to kanshō 19171922 (Tokyo: Chikuma Shobō, 1989), 77-97. On Japan's humanitarian aid, see Izao Tomio, Shoki Shiberia Shuppei no kenkyū: "Atarashiki kyūseigun” kōsō no tōjō to tenkai (Fukuoka: Kyūshū Daigaku Shuppankai, 2003), 141-83.

7 The reason for this initiative was "deteriorating medical care in Russia." Izao, Shoki Shiberia shuppei, 158.

8 Nishimura, "Kaisetsu," in Ryūkōsei kanbō: "Supein kaze" dai ryūkō no kiroku, Tōyō Bunko ed. Naimushō Eiseikyoku, (1922; Tokyo: Heibonsha, 2008), 444-54; and Hayami, Nihon o osotta Supein Infuruenza, 293.

9 For example, see Uchikawa Yoshimi, Masu media tōsei, 2 vols (Tokyo: Misuzu Shobō, 1973-75); and Ariyama Teruo, Senryō-ki mediashi kenkyū (Tokyo: Kashiwa Shobō, 1996). In English, see Richard H. Mitchell, Censorship in Imperial Japan (Princeton, NJ: Princeton University Press, 1983); Jay Rubin, Injurious to Public Morals: Writers and the Meiji State (Seattle, WA: University of Washington Press, 1984); and Jonathan E. Abel, Redacted: The Archives of Censorship in Transwar Japan (Berkeley, CA: University of California Press, 2012).

10 John M. Barry, The Great Influenza: The Story of the Deadliest Pandemic in History (New York: Penguin Books, 2005), 4; Strachan, The First World War, 337; and Hayami, Nihon o osotta Supein Infuruenza, 426. 
11 Sumiko Otsubo, "Fighting on Two Fronts: Japan's Involvement in the Siberian Intervention and the Spanish Influenza Pandemic, 1918-1920," in The Decade of the Great War: Japan and the Wider World in the 1910s, ed. Tosh Minohara, Tze-ki Hon and Evan Dawley (Leiden: Brill, 2014), 461-80.

12 Shiberia shuppei eisei shi, vol. 2, Kanja tōkei (Tokyo: n.p., 1924), 159. Publication date and location of Shiberia shuppei eisei shi (hereafter SSE) volumes are officially catalogued "unknown" because of confusion caused by the Great Kantō Earthquake.

$13 S S E$, vol. 5, Senbyō, 1-5. These numbers seem small. A January 1920 report indicated the number of flu patients in the IJA totaled 5,512 as of January 19, 1920. "Rikugun no kanja ruikei niman gosen, shibō kyūhyaku," Tokyo asahi, January 22, 1920, ed. Taishō nyūsu jiten henshū iinkai, Taishō nyūsu jiten, vol. 4 Taishō 8-nen-Taishō 9-nen (Tokyo: Mainichi Komyunikēshonzu, 1987), 720. (Hereafter $T N J)$

14 "Shinbun-kyoku no secchi," Osaka asahi, August 10, 1918, 1.

15 Ariyama Teruo, Kindai jānarizumu no kōzō: Osaka asahi shinbun Hakkō jiken zengo (Tokyo: Tokyo Shuppan, 1995), 190-262.

16 "Terauchi naikaku no bōsei o seme mōzen to shite ketsugi shita Kansai kisha taikai no tsūsetsu naru kōgeki enzetsu," Osaka asahi, August 26, 1918, evening edition, 2.

17 Ariyama, Kindai jānarizumu no kōzō, 263-305. Uchikawa Yoshimi, "Terauchi naikaku no genron tōsei," in TNJ, vol. 3, Taishō 6-nen-Taishō 7-nen (Tokyo: Mainichi Komyunikēshonzu, 1987), 34-7. See also Mastsushima Eiichi, "Shiberia shuppei, kome sōdō, sekai taisen shūketsu," in ibid., 28-33.

18 Takeyama Kyōji, Hōdō denpō ken'etsu hishi: Marugame yūbin kyoku no Nichiro Sensō (Tokyo: Asahi Shinbunsha, 2004), 36 (hereafter HDK).

19 See Anno Kazuyuki, "Itsu, dare ga, nan no tame ni ken'etsu shita no ka," Kanda Zatsugaku Daigaku, online at: www.kanda-zatsugaku.com/110128/0128.html (accessed June 25, 2012) on materials lost in the 1923 earthquake. Exceptions to the paucity of pre-1930s studies include Hwang Min Gi's Tadaima sensō hajime sōrō: Meiji 10-nen no sukūpu gassen (Tokyo: Yōsensha, 2006) and Takeyama, $H D K$, 36. See also Kobayashi Hideo and Zhang Zhi Qiang (eds), Ken'etsu sareta tegami ga kataru Manshūkoku no jittai (Tokyo: Shōgakkan, 2006) for censorship by the Guandong Army 1937-1945. See James L. Huffman, Creating a Public: People and Press in Meiji Japan (Honolulu, HI: University of Hawaii Press, 1997), 271-309, on state-press relationships during the Russo-Japanese War.

20 Gregory J. Kasza, The State and the Mass Media in Japan 1918-1945 (Berkeley, CA: University of California Press, 1988), 13.

21 Takeyama, $H D K, 40-6$.

22 Okudaira Yasuhiro, Hyōgen no jiȳu, vol. 1 (Tokyo: Yūhikaku, 1983), 138-40, and 144; Huffman, Creating a Public.

23 Hata Ikuhiko (ed.), Nihon riku kaigun sōgō jiten, 2nd edn (Tokyo: Tokyo Daigaku Shuppankai, 2005), 722 and Takeyama, HDK, 42-4; and Hidaka Minoo, Gunki hogo hō (Tokyo: Hata Shoten, 1937).

24 Michael S. Sweeney, The Military and the Press: An Uneasy Truce (Evanston, IL: Northwestern University Press, 2006), 3-4.

25 Ibid. A similar press pool had already been established in the 1870s. See Hwang, Tadaima sensō hajime sōrō, 109-10, and 130-1.

26 Rikugun Daijin Kanbō, Rikugun seiki ruijū dai jūsan rui basei, dai jūyon rui un'yu, tsūshin, dai jū-go rui keiho, chōhatsu (Tokyo: Rikugun Daijin Kanbō, 1929-40), 39-42.

27 Kenpei Shireibu, Nichi-Doku sen-eki kenpeishi (Tokyo: Kenpei Shireibu, 1914), 59 and 83; and Zenkoku Ken'yūkai Rengōkai Hensan Iinkai (ed.), Nihon Kenpei seishi (Tokyo: Zenkoku Ken'yūkai Rengōkai Honbu, 1976), 155 (hereafter NKS). 


\section{Sumiko Otsubo}

28 Kenpei Shireibu, Nichi-Doku sen-eki kenpeishi, 85-6. For alternative explanations to the military police version see Midoro Masuichi, "Sōkōgeki o mae ni taikyo meirei," in Nihon sensō gaishi Jügun kisha, ed. Okamoto Kōzō (Tokyo: Shinbun Jidaisha, 1965), 67-74.

29 NKS, 162.

30 Kenpei Shireibu, Shiberia shuppei kenpeishi furoku (Tokyo: Kenpei Shireibu, 1928), 86-7.

31 "Shinbun kiji torishimari no ken,” Bōeishō Bōei Kenkyūjo, Rikugunshō Dainikki. Dai nikki kōshū, Taishō 11-nen (December 1922): Dai nikki kōshū (C02031073800), Ajia Rekishi Shiryō Sentā (accessed May 28, 2015).

32 "Rikugun-shō, senji taisei, dōin nado no kiji kinshi," Jiji, July 21, 1918, evening edition, in TNJ, vol. 3, 276-7.

33 Suzuki Bunjirō, "Shiberia jūgunki (Dainikai): Shushō mo kafē de takabanashi, kinchō senu Urajio no sensō kibun, katsu ni kimatte iru no de senpō ni wa ikkō hariai ga nai," Osaka asahi, September 3, 1918, 7.

34 Taniguchi Tokujirō, "Shiberia jūgunki (Dairokkai): Sensen o shisatsu shite, Urajio kara Shimakofusuka made, shūsō ryōran taru heiya ni kenkō bōei," Osaka asahi, September 7, 1918, 7. Midoro Masuichi, Meiji Taishō shi, vol. 1, Genron-hen (Tokyo: Asahi Shinbunsha, 1930) provides the most comprehensive list of press censorship regulations prior to 1930 .

35 "Shinbun kiji torishimari no ken," Bōeishō Bōei Kenkyūjo.

36 See, e.g., "Kanbō ryūkō: Shōgakkō heisa, Shiga kenka no kakusho," Osaka asahi, October 15, 1918, evening edition, 2, and Hayami, Nihon o osotta Supein infuruenza, 101.

37 "Dairyūkō no kanbō: Nani mo tokushuna mono de wa nai, kisoku tadashii seikatsu ga yobō-hō," Tokyo asahi, October 22, 1918, 5.

38 "Shiberia ni mo kanbō ryūkō, sensūhyaku-mei no kanja o dasu," Tokyo asahi, October 24, 1918, 5.

39 "Densen ga hageshii, kakuchi o osou ryūkōsei kanbō, Tokyo ya senchi ya, kōkai chū no fune made mo," Osaka asahi, October 24, 1918, 5 and "Shussei guntai no taiteki, kanbō kara akusei haien ni tenka, yasen byōin ni sen sūhyaku mei," Osaka asahi, October 24, 1918, evening edition, 2.

40 "Zen sensen ni akueki ryūkō: Shōsotsu kanja issen yomei ni tassu," Fukuoka nichinichi, October 24, 1918, reprinted in Hayami, Nihon o osotta Supein infuruenza, 286 and 290.

41 Naimushō Eiseikyoku, Ryūkōsei kanbō, 136-46. See Naimushō Eiseikyoku (ed.), Eiseikyoku nenpō Taishō 7-nen (1918), 55; and "Dai jūni shidan shotai no ichibu shisatsu ni kansuru shoken (Tōjō Taii)," Bōeishō Bōei Kenkyūjo, Rikugunshō Dainikki, Seimitsu-uke, sei-uke dai nikki, Taishō 7-nen, 12-gatsu (December 1918), Sei-uke Dainikki (C07060610100), Ajia Rekishi Shiryō Sentā, accessed April 21, 2015.

42 Sugawara Sagae, Shiberia shuppeishi yō (Tokyo: Kaikōsha, 1925), 59-66; and Otsubo, "Fighting on Two Fronts," 476.

43 "Kanbō no sanjō o shisatsu seru bōekikan no hōkoku," Tokyo asahi, November 2, 1918, 5 and "Kanbō ryūkō kakuchi ni bōekikan o haken, naichi de mokka shiretsu na no wa Aichi, Fukui, Saitama no kakuken, nijūnenme no daishōketsu, Eisei Kyokuchō Sugiyama Shigorō shi dan,” Tokyo asahi, October 26, 1918, 5. See also Geoffrey W. Rice and Edwina Palmer, "Pandemic Influenza in Japan, 1918-19: Mortality Patterns and Official Responses," Journal of Japanese Studies, 19: 2 (Summer 1993), 389-420; and Geoffrey W. Rice, "Japan and New Zealand in the 1918 Influenza Pandemic: Comparative Perspectives on Official Responses and Crisis Management," in The Spanish Influenza Pandemic of 1918-19: New Perspectives, ed. Howard Phillips and David Killingray (London: Routledge, 2003), 73-85, esp. 74. For Fukui, see "Kansai hōmen de mōi, shisha zokushutsu," Jiji, October 29, 1918, TNJ, vol. 3, 354. 
44 "Kesshite yudan suruna, tōkyoku de wa kakuchi ni bōekikan o haken (Sugiyama Eiseikyoku Kyokuchō no dan)," Osaka asahi, October 26, 1918, 7.

45 "Shiberia shuppei no heishi mo gisei," Osaka mainichi, November 4, 1918, TNJ, vol. 3, Taishō 6-nen-Taishō 7-nen, 355.

46 "Go-imonshi kito su, Bitō shōshō no dan," Osaka asahi, October 29, 1918, evening edition, 2.

47 "Hyaku zassai: rusutaku yori," Osaka asahi, October 29, 1918, evening edition, 2.

48 Letters containing sensitive information sent by a solider, Matsuo Katsuzō, from Siberia are compiled in Matsuo Katsuzō, Shiberia shussei nikki, ed. Takahashi Osamu (Nagoya: Fūbaisha, 1978).

49 "Senku o kataru gaisentai: Ujina Futō ni jōriku shite, secchū roei no jōkyō to kanbō," Osaka asahi, November 11, 1918, 7.

50 "Urajio hakengun no senshisha, byōshi tomo kyūjūnaname," and "Ryūkō kanbō no shibōritsu zōka su," Osaka asahi, November 23, 1918, evening edition, 2. "Akusei kanbō hotondo shūsoku, Osaka-shi no shibō-sū hotondo heijō ni fukusu," Osaka asahi, November 30, 1918, 7.

51 Scientists discovered that a virus, rather than a bacterium, caused influenza in 1933. At the time of the 1918 influenza outbreak, however, the most influential theory indicated Pfeiffer's bacillus as the causative agent. Like their counterparts in Europe and the U.S., Japan's medical experts were well trained in bacteriology and reluctant to question germ theory. See James R. Bartholomew, The Formation of Science in Japan: Building a Research Tradition (New Haven, CT: Yale University Press, 1989) and Alexander R. Bay, Beriberi in Modern Japan: The Making of a National Disease (Rochester, NY: University of Rochester Press, 2012).

52 "Kisha seien," Osaka asahi, October 5, 1918, evening edition, 1, and "Shushō kisha seitai," Osaka asahi, October 7, 1918, evening edition, 1.

53 "Mu denshinkoku," Osaka asahi, August 3, 1918, 1, "Tsūshin kikan no fukanbi," Osaka asahi, October 29, 1918, 5, and "Shin Keiho Kyokuchō to shinbun zasshi, ryōsha no aida ni rikai no hōhō," Osaka asahi, October 7, 1918, 7.

54 Regarding the promotion of Japan's international image, see Izao, Shoki Shiberia shuppei no kenkyū.

55 On indeterminacy experienced by people and historians' wide angle knowledge of events' outcomes, see Paul A. Cohen, History in Three Keys: The Boxers as Event, Experience, and Myth (New York: Columbia University Press, 1997).

56 SSE, vol. 1, Eisei kinmu, Ge (Tokyo: n.p., 1924), Attachment 1-2.

57 Ibid.

58 Andrew Gordon, Labor and Imperial Democracy in Prewar Japan (Berkeley, CA: University of California Press, 1991), 13-25; and Andrew Gordon, A Modern History of Japan: From Tokugawa Times to the Present (New York: Oxford University Press, 2003), 161; also Mitchell, x. 


\title{
6 The politics of manic depression in the Japanese empire
}

\author{
Janice Matsumura ${ }^{1}$
}

Since the last decade, scholarship on colonial psychiatry has become extensive enough to allow for comparative research. ${ }^{2}$ Although Japan has often been overlooked in such studies, imperialism certainly shaped discussions of mental health in the country. Beginning in the late nineteenth century, Japan acquired an extensive and multiethnic empire, gaining control over Hokkaido (1873), the Ryukyu Islands (1879), Taiwan (1895), Korea (1910), and Manchuria (1932). As in other empires, ideas about racial and ethnic hierarchies were used to justify rule. Unlike its European counterparts, however, Japan often shared physical traits and cultural traditions of the peoples whom they colonized. There was thus a greater reliance on other methods of setting colonizers above the colonizedmethods that psychiatrists were demonstrably eager to provide through the depiction of mental disorders and differences in susceptibility based on race and ethnicity.

Following James R. Bartholomew's lead, specifically his attention to the various social, economic, and political factors that interacted with scientific research, this chapter examines a purportedly minor condition for Japanese in illustrating the extent to which psychiatric discourse reflected professional interests and concerns about the maintenance, expansion, and defense of empire. ${ }^{3}$ Like Bartholomew, historians who have charted the development of psychiatry in various European countries effectively contested the view of medical knowledge as value-free or "derived from supranational scientific principles and hence ... impervious to such influences as culture, politics, or individual idiosyncrasy." 4

By no means unique to Japan and psychiatry, professional interests influenced the identification and interpretations of illnesses - their prevalence, seriousness, and significance socially and politically. Although psychiatry as a distinct medical specialty was established in late nineteenth-century Japan, the almost universal and constant complaint of psychiatrists was that officials and the public remained ignorant of their profession's significance. In the opinion of Kure Shūzō, "the father of Japanese psychiatry," this was made painfully obvious by the failure of Ministry of Education officials in 1905 to include psychiatry as a mandatory subject in the certification examinations for physicians. $^{5}$ 
Practitioners were conscious of the need to combat the view that psychiatry was a secondary field of medicine with little relevance, and, like members of countless other interest groups, became attracted to issues of race. As Bartholomew, Sumiko Otsubo, and other scholars have demonstrated, although scientific racism at the time privileged so-called Caucasians in a hierarchy of peoples, individuals in Japanese scientific circles remained receptive to research that could be used in the operation of Japan's colonies. ${ }^{6}$ In the metropole and the formal and informal colonies of Taiwan, Korea, and Manchukuo, psychiatrists politicized their research on manic depression by relating it to issues of racial hygiene and cultural superiority, theories of individual and national character and their relationship to criminal behavior, and even wartime strategic policies. Manic depression thereby became a means of measuring the competitive edge of Japanese over other peoples. Although early Japanese psychiatrists like Kure more often attempted to increase official and public appreciation of the profession by drawing attention to the dangers posed by the mentally ill, he and other psychiatrists provided quite reassuring interpretations about the mental fitness of the Japanese by emphasizing manic depression's low rates among this group. $^{7}$

The trajectory of medical opinion on manic depression in Japan thus differed from diagnoses in European and North American countries where psychiatrists revealed little initial interest in the condition but gradually began to take more notice and to express concern about its incidence. In his 1899 edition of Clinical Psychiatry, the German psychiatrist Emil Kraepelin introduced the new medical concept and identified various depressive and manic states, which could occur in alternating cycles as well as simultaneously: whereas depression was a "gloomy hopelessness" or "somber and sad melancholy," mania involved not just an "exuberant, unrestrained mood" and "increased busyness" but "delusions and hallucinations." " According to psychiatrist David Healy, Kraepelin had simply used manic depression as a contrasting disorder that did not result in cognitive decline, a "foil" for the far more debilitating dementia praecox (later renamed schizophrenia), and the response of Kraepelin's colleagues in the West to his new concept was more than just "muted." Manic-depression remained "all but ignored" for decades, and, as a consequence, Healey asserts, "there were few if any patients in the Western world described as having manic-depressive disorder before the 1920s." 9

In Japan, while psychiatrists eventually came to view the disorder as a comparatively minor condition for the Japanese when the concept of manic depression was introduced into the country around 1906, its impact was quite immediate and dramatic. ${ }^{10}$ Anthropologist Junko Kitanaka has revealed how manic depression, which Kraepelin attributed to "hereditary taint," changed attitudes toward utsubyō, the Japanese term for unipolar depression. ${ }^{11}$ Prior to the introduction of neuropsychiatry, utsubyō had signified something similar to the Western notion of melancholia, a condition not divorced from normality. But, once it became associated with one pole of manic depression, "[u]tsubyō as such signaled a hidden, dangerous psychosis, even doomed heredity, which 
had devastating effects on the afflicted individuals and their families." ${ }^{12}$ Wishing to spare individuals from being ostracized as hereditary deviants, Japanese psychiatrists might have reserved a diagnosis of manic depression for extreme cases, thereby helping to create the appearance of low incidence, especially in comparison to other countries where psychiatrists were less restrained in using the term to describe patients. Moreover, unlike American asylum superintendents and eugenicists, Japanese psychiatrists, including Kure Shūzō, did more to counter arguments that manic depression could corrupt the genetic composition of populations.

\section{Manic depression and degeneration}

Instrumental in establishing Kraepelinian neuropsychiatry in Japan, Kure investigated manic depression's connection to heredity and "degeneration," an influential psychiatric concept in the late nineteenth and early twentieth centuries that held that certain illnesses were indicative of a steady generational decline in mental functioning and social adaptation. ${ }^{13}$ In 1916, in an article published in the professional journal he established, Shinkeigaku zasshi, Kure referred to Kraepelin's findings, which revealed hereditary causes for 80 per cent of German manic-depressive patients, and concluded that the disorder was an inborn condition. As an example of "degeneration," Kure discussed the family history of one of his own manic-depressive patients, which included a heavydrinking father, an epileptic sister, and other siblings who died prematurely. Although hospitalized in 1913 at the age of 52 for pathological alcoholism, this patient soon exhibited signs of mania. ${ }^{14}$

For Social Darwinists and eugenicists both in and outside of medical circles, whose pessimistic views on therapeutic efforts and asylums were gaining ground in many countries, manic depression was clearly among the sicknesses that were exerting a retrogressive impact on societies. ${ }^{15}$ Kure shared with eugenicists an understanding of manic depression as symptomatic of degeneration. ${ }^{16}$ Unlike his European and North American counterparts, however, who had long worked within a system of mental institutions, Kure's acceptance of degeneration theory was not based on disillusionment over the failure of asylums and hospitals to cure most patients. ${ }^{17}$ Kure instead had to campaign to convince officials to establish such institutions. In 1918, he published a scathing report on the existing practice of confining the insane in caged cells in or near their homes. ${ }^{18}$ State mental hospitals were, in his opinion, the key to the profession's development, as they would provide employment and prestige for practitioners. A biologically deterministic model of insanity could encourage a belief that mental illnesses were untreatable and that hospitals were useless; under the circumstances, Kure had reason to mitigate the fears aroused by apparently innate psychiatric disorders.

When it came to manic depression, Kure disputed the views of asylum superintendents such as R. A. Stewart of Ohio's Independence State Hospital, who in discussing the dangers of hereditary illnesses in 1922 described manic 
depression as a "common type" of insanity. ${ }^{19}$ In a brief 1915 report in Shinkeigaku zasshi, Kure asserted that manic depression, while likely hereditary, was rare in Western countries as well as Japan. He also provided figures for Sugamo Mental Hospital, a teaching hospital associated with Tokyo Imperial University's Medical School, which showed a rapid decline in the number of manic-depressive patients. Comparing statistics for the period from 1887 to 1901 and the last ten years, presumably from 1905 to 1915 , the proportion of manic-depressives to all Sugamo patients dropped from 39.47 per cent to 11.95 per cent, which matched the $10-15$ per cent that Kraepelin recorded for German patients. ${ }^{20}$

Later Japanese psychiatrists provided data to further support Kure's observations about the low and declining incidence. In a 1937 statistical report on manic depression, Matsumura Hidehisa summarized the findings of previous studies, such as those of Takase Kiyoshi for the patients at Sugamo (later renamed Matsuzawa Mental Hospital) from 1902 to 1920 (551 cases) and Ishikawa Masakichi for a private clinic, Sugamo Brain Hospital, from 1913 to 1917 (381 cases). ${ }^{21}$ As for his own study of patients at Matsuzawa from 1926 to 1935, Matsumura identified an even smaller number of manic-depressives, 252 individuals out of a total of 4,151, which amounted to only 6 per cent of all patients. ${ }^{22}$

For Kure and other Japanese psychiatrists, manic-depressives may have been associated with degeneration, but they appeared to be a diminishing minority in the Japanese empire, notably in Korea. Colleagues in the colony provided data that the disorder was not only comparatively rare among the Japanese residents, it was even less evident among Koreans. By the early 1930s, the Korean population had exceeded 19 million and Japanese in the colony numbered about 500,000 . But, in 1929, whereas 64 individuals or 11.11 per cent of the 576 Japanese psychiatric patients in Keijō Imperial University's hospital were manic-depressive, 44 or 8.66 per cent of the 508 Korean patients were diagnosed with the disorder. ${ }^{23}$ For those who considered manic depression to be an indicator of degeneration, such low incidence rates indicated that the "ruling" Japanese enjoyed, or at least were beginning to enjoy, genetic superiority over a number of European populations but could not establish the superiority of Japanese over their own "subject" people, the Koreans. More so than their European counterparts, Japanese colonizers could emphasize similarities as well as differences between themselves and their colonized peoples. In accounting for what appeared to be a greater Korean immunity to the condition, the colony's leading psychiatrists Kubo Kiyoji and Hattori Rokurō preempted any suggestion that Koreans might enjoy some "racial" advantage over the Japanese by asserting that the two peoples shared the same origins. ${ }^{24}$

In a study published in 1930, Kubo and Hattori claimed that the contemporary cultural backwardness of Koreans was due not to some primordial flaw, as the people were descended from the same racial stock as the Japanese, but to a refusal to acknowledge the benefits of Western civilization. It was this refusal, they observed, that resulted in the decline of a culture that had once 
been more advanced than that found in Japan. Nonetheless, for these psychiatrists, it was because Koreans and Japanese were "similar" and because manic depression was suspected of having a genetic component inheritable in families that the lower incidence among Koreans was so intriguing. ${ }^{25}$ Venturing into the contemporary debate on eugenics in Japan and elsewhere in which proponents argued that selective reproduction was necessary to prevent the degeneration or decline of a people, Kubo and Hattori noted that Koreans had long practiced prohibition of marriage between individuals with the same last name and, as a result, benefited from reduced inbreeding. ${ }^{26}$

In raising the possibility that Koreans had over time acquired some possibly constitutional quality that reduced the incidence of certain genetic disorders, Kubo and Hattori also referred to the work of their junior colleague, Sugihara Manjirō, who had investigated a famous typology relating body and character types to mental illnesses - most notably, manic depression. ${ }^{27}$ Sugihara similarly countered fears of degeneration through the example of manic depression, but, unlike Kubo and Hattori, drew attention to the possibly positive attributes of those afflicted with the condition. Whereas Kubo and Hattori depicted manic-depressives as simply carriers of a hereditary condition, whose numbers were in decline, Sugihara found that manic-depressives could be treated, rehabilitated, and governed with greater ease. He seemed to suggest that these individuals, whom psychiatrists often described as "sociable, good-natured, friendly, genial," were clearly preferable to the more numerous anti-social character types that Sugihara identified in his examination of incarcerated Koreans. ${ }^{28}$

\section{Manic depression, character, and crime}

Using prison inmates and not just psychiatric patients as his test subjects, Sugihara linked a theory of the manic-depressive character to "Korean criminality," a topic that encompassed resistance to colonial rule and that had captured the attention of metropolitan and colonial writers after the First World War. Although the Japanese authorities experienced opposition to their interference in Korean affairs even before the country's annexation in 1910, they were nevertheless stunned by the ability of independence leaders in 1919 to establish organizations, mobilize exiles and students abroad to solicit international support, and inspire so many of their compatriots to run the risk of challenging colonial rule. The response of the Korean colonial government to the March First or Samil Independence Movement was to brutally suppress demonstrations and thereafter grant some concessions. ${ }^{29}$

In addition, after 1919, the governor-general's office reportedly sponsored extensive research on Korea and its people, whose subversive activities, in the opinion of one former colonial official, were puzzling in light of all the expenditures made to improve living conditions. In studies of the Korean character, such as a "confidential" colonial government publication, authors contended that independence was at odds with the history and character of 
the Korean people who, having been for centuries under the control of powerful neighboring countries, were incapable of advancing on their own. ${ }^{30}$ Arguments of this nature were not just produced in the colony. In Japan, studies of Korean criminality were the unfortunate byproduct of the increased presence of Koreans who had emigrated in search of work during the First World War economic boom. ${ }^{31}$

Although Japan-based research and newspapers seemed to focus on nonpolitical or petty crimes such as theft and pickpocketing, it was a 1927 work published in Japan by a legal specialist, Arai Ikuzō, which provided a detailed discussion of how aspects of the Korean character were reflected in the March First Movement. ${ }^{32}$ Korea's longstanding status as a tributary state, Arai argued, made the people less self-reliant and this tendency to depend on others to achieve their goals was evident when independence leaders, inspired by U.S. president Woodrow Wilson's call for national self-determination, attempted to gain the support of the Allied Powers at the close of the First World War. Depicting independence leaders as motivated by a love of fame, Arai also dismissed the establishment of the Korean Provisional Government in China as evidence of a Korean fondness for empty rituals or appearance over substance. In making his case for the role of national character in the commission of crimes, Arai nevertheless lamented the lack of source material for this research on Koreans, who, he observed, appeared physically no different from the Japanese. ${ }^{33}$

Like Arai and others, Sugihara promoted the view that the character of individuals exerted a greater influence on criminality and attitudes toward authority than exogenous factors such as government policies or developments that affected livelihood. In doing so, he helped colonial administrators to explain away the behavior of colonized peoples and rationalize punitive measures imposed on them. Appearing in 1931/2 as a series of articles in Shinkeigaku zasshi, Sugihara's research was inspired by the German psychiatrist Ernst Kretschmer's immensely popular theory that certain mental disorders were more common among individuals with specific body and character types. Kretschmer described three constitutional groups, the thin "asthenic," the muscular "athletic," and the rotund "pyknik." 34 While he was careful to point out that body types were not symptoms of mental illness, Kretschmer proposed that asthenic and athletic types were prone to schizophrenia and that pykniks were more likely to develop manic depression. In addition, he attributed certain character traits to the manicdepressive pyknik and schizophrenic asthenic. Like Emil Kraepelin, who had depicted manic-depressives as sociable, "closely attuned to social norms," and notably different from the often alienated and alienating schizophrenics, Kretschmer stated that manic-depressive patients "have usually something childishly goodnatured, trustful, and tractable about them, they are far more up to mischief than harsh acts of violence ... when their troubles give way to treatment, they are unassuming, friendly, and grateful." 35 In Japan, even a critic of Kretschmer's theory, Kyūshū Imperial University professor of psychiatry Shimoda Mitsuzō is said to have found manic-depressives honest, diligent, and possessing a strong 
sense of responsibility associated with exemplary youth or model employees. It was only under certain circumstances, such as when these individuals believed they were fighting for their rights, that their tenacity could become troublesome for others. ${ }^{36}$

Given his limited source material, only 312 Japanese and Korean psychiatric patients as test subjects, Sugihara stated that he could not make a definite pronouncement on the relationship between body type and mental illness. ${ }^{37}$ Sugihara had only been able to identify ten confirmed cases of manic depression, and two-thirds of these patients were Japanese rather than Korean. ${ }^{38}$ Yet, on the basis of these ten cases, he concluded that on the whole his study supported Kretschmer's theory. In Sugihara's opinion, nine of the patients possessed pyknik or variant of pyknik builds and manic-depressive characters, being docile, friendly, more willing to trust their doctors' advice, and, especially in the case of Japanese patients, often experiencing rapid improvement in their condition. $^{39}$

Supporting the character type that Kretschmer assigned to manic-depressives, Sugihara reinforced the perception that individuals afflicted with this disorder were ideal patients as well as prisoners. In various Western countries Kretschmer's theory was applied to the study of criminals, making it a tool in early attempts at profiling. ${ }^{40}$ For his data, Sugihara assessed the physiques and characters of 58 Japanese and 1,011 Korean male inmates who had been sentenced to a term of less than ten years in Seodaemun Prison, the facility where the colonial authorities incarcerated many members of the Korean independence movement. ${ }^{41}$ Sugihara took into consideration the effect of prison life on the physical build of inmates and the possibility that inmates would lie about themselves during interviews, and cautioned against ignoring the influence of education and environment on character. ${ }^{42}$ Still, he concluded that there was a notably small number of pykniks and variants of pykniks among Korean and Japanese inmates, the majority of whom were asthenics and variants of the athletic body type. ${ }^{43}$ With regard to character, he pointed out that among Korean inmates, only 151 or 19.1 percent could be described as manic-depressive; in comparison, 421 or 52.6 percent fell into the category of "schizoid," which, according to Sugihara, was the character type that most Western researchers associated with criminality. ${ }^{44}$ As described by Kretschmer, the schizoid was the polar opposite of the manic-depressive character, being "[u]nsociable, quiet, reserved, serious (humourless), eccentric," and exuding a "shy animosity." 45

In applying the theory of body and character types to presumably mentally healthy prison inmates in the colony, however, Sugihara transformed his medical research into a justification for the lengthy incarceration of most Korean political prisoners, who, in his estimation, lacked a manic-depressive character and, with it, a potential for rehabilitation. The compliant manic-depressive character in effect became the criteria for rehabilitation, which, Sugihara suggested, should be the condition for release from custody. Sugihara created two categories of crimes: minor ones that were undertaken impulsively by individuals whose delinquency was the result of poor socialization, and serious ones that were premeditated and usually perpetrated by so-called major degenerates, 
pathological troublemakers, innate criminals, and political prisoners. ${ }^{46} \mathrm{He}$ referred to researchers who claimed that few individuals with manic-depressive characters committed crimes, and he observed that inmates possessing this character and pyknik body type tended to commit minor crimes, such as stealing, burglary, and gambling. ${ }^{47}$ Sugihara explained that manic-depressive characters, being generally carefree, hedonistic, and talkative, were not likely to perpetrate political crimes, which required secrecy, patience, and a willingness to endure hardships. ${ }^{48}$ As they were more influenced by their emotions and by others, easily surrendering to threats or persuasion, they were instead inclined to commit crimes of passion. ${ }^{49}$ At the same time, they were good candidates for rehabilitation because they were follower types, sensitive to their environment, and open to guidance. ${ }^{50}$ According to Sugihara, in contrast to the 8.7 per cent schizoid inmates, 41.2 per cent of inmates with manic-depressive characters were successfully reformed. ${ }^{51}$

Sugihara noted the benefits of an extended period of incarceration, finding that the rate of recidivism was lower for so-called long-term as opposed to short-term inmates. ${ }^{52}$ His depiction of schizoid inmates indicated, however, that he held out little hope for their rehabilitation. He found that inmates with schizoid characters, which tended to make them far more introverted, were less influenced by their environment and included many whom Sugihara deemed innate or inborn criminals who repeatedly committed serious crimes. ${ }^{53}$ In contrast the opportunistic or impulsive crimes of those with manic-depressive character, the crimes of schiozoid characters were termed "intellectual" in that they required thoughtful and careful planning. ${ }^{54}$ Schizoid inmates thus possessed, in Sugihara's opinion, the cold, calculating intelligence useful for perpetrating crimes such as fraud, blackmail, and forgery, or the relentless determination to sacrifice themselves and others necessary for a political cause. ${ }^{55}$

Although Sugihara expressly stated that his and other studies on the post-release ability of criminals to adapt to society should help in determining prison policies, it is not known what, if any, impact his research had on officials. ${ }^{56}$ Still, he was able to disseminate his research through articles and at conferences such as that of the Korea Medical Association in 1927. Psychiatrists conducting later studies of manic depression or of Kretschmer's theory of body and character types frequently referred to Sugihara's work. Not all of Sugihara's colleagues supported his conclusions. Some colleagues raised doubts about the universality of Kretschmer's body types and contested Sugihara's suggestion that the athletic body type may be rare among the Japanese. Nonetheless, they did not challenge the character type assigned to manic depression. ${ }^{57}$ In further promoting the view of manic-depressives as generally docile and friendly, Sugihara's study allowed its readers to entertain the possibility that the Japanese might expect an easier time governing peoples reportedly more prone to the disorder, such as those in Taiwan or the puppet state of Manchukuo. 


\section{Manic depression and civilized status}

In their 1930 study, Keijō Imperial University professors Kubo Kiyoji and Hattori Rokurō referred to a debate among their European colleagues over whether the incidence of manic depression declined or increased as societies became "civilized." They noted the arguments of psychiatrists who used the example of higher rates among white-collar workers as opposed to manual laborers to prove that the disorder became more widespread in tandem with cultural development. ${ }^{58}$ Given the low rates among Japanese, however, it is not surprising that Kubo and Hattori supported the opposite position that the condition was rare among civilized peoples. Their work would prove useful to colleagues in Manchukuo, providing them with an example of Japanese superiority that could reinforce a colonizer-colonized hierarchy in the puppet state.

Following the establishment of the puppet state or informal colony in 1932, the Japanese state sponsored an unprecedented mass emigration project, which, as Louise Young has observed, was promoted by propagandists and the mass media as a "test of racial hardiness." an issue of national pride, the authorities in Manchukuo were prepared to support facilities and sponsor research on the natural and social environment of the region and the adaptation of the Japanese to it.

The opinions of medical researchers on the ability of Japanese colonizers to adapt to the Manchurian environment were not always positive. South Manchuria Medical College Professor of Hygiene Miura Un'ichi pointed out various obstacles to emigration, including those associated with mental conditions. ${ }^{60}$ Among the potential threats to the mental health of settlers, Miura included confinement indoors during the long winters, which could result in neurasthenia or nervous breakdowns, particularly among settlers' wives who, he assumed, would be less hardy in body and mind than men. ${ }^{61}$ Moreover, psychiatrists stationed in the cities of Dairen and Mukden also expressed concern about the higher rates of alcoholism and syphilis infection among Japanese residents than other ethnic groups in the region, proposing that these illnesses might be indicative of psychological difficulties in adjusting to unfamiliar environments. ${ }^{62}$

Still, through their studies of manic depression, colonial psychiatrists in Manchukuo as well as Korea were able to provide more positive assessments of the mental health of Japanese living abroad. ${ }^{63}$ In a 1936 two-part article published in the medical journal Tōkyō iji shinshi, Dairen Seiai Hospital psychiatrists Doi Masanori and Kuji Kōzō observed that many Japanese manic-depressive patients not only recovered and were soon discharged, but that the incidence rate for the disorder was lower among Japanese (10.6 percent) than among the few "Manchurian" patients ( 15.3 percent) that they had examined. ${ }^{64}$ (Although persons of Han Chinese ethnicity outnumbered any other group in Manchuria, the Japanese authorities preferred not to advertise this fact as it could be used to support China's claims to the region. It thus became somewhat conventional for Japanese researchers in the informal 
colony to use the blanket term "Manchurian" to refer to the Han Chinese and Tungusic peoples of the region.) Proposing that instances of mental illness could often go undetected among the non-Japanese population due to ignorance of medical science, making the Manchurian manic-depressives in their care just the most extreme examples of the disorder, Doi and Kuji also speculated that former Manchurian patients who had been diagnosed with psychogenic disorders might in actuality have been suffering from atypical forms of manic depression..$^{65}$

Yet, rather than offer their own explanations for the difference in incidence between Japanese residents and Manchurians, Doi and Kuji instead referred readers to earlier research on manic depression conducted by Kubo and Hattori. In Kubo's and Hattori's opinions, primitive peoples responded more emotionally to their natural environment, which promoted an excitable temperament, and when that response became mentally pathological, it was not unusual that it would take the form of manic depression. ${ }^{66}$ They noted that, whereas the Dutch colonial psychiatrist P. H. M. Travaglio found the disorder rare among the Javanese, Russian physicians N. Skliar and K. Starikowa claimed that 60 percent of their nomadic Kalmyk and Kirghiz patients suffered from manic depression. ${ }^{67}$ As an additional example of research suggesting a predisposition for manic depression in less civilized or "evolved" peoples, Kubo and Hattori cited the study of mentally ill African-Americans by the American psychiatrist William M. Bevis, who concluded that "[i]n a people naturally care-free, fond of excitement and motion, it is expected that their mental unbalance would ... find expression in the manic type of the manic-depressive group." 68

Kubo and Hattori cautioned their readers that an assumption of inherent inferiority of "colored" races could determine how Western researchers might interpret statistical figures for manic depression among other peoples. ${ }^{69}$ This bias was reflected in the skepticism expressed by the physician and pioneering British anthropologist C. G. Seligman in 1932 to the low rates of manic depression recorded by Kure Shūzō and another prominent psychiatrist, Miyake Köichi. While describing the Japanese as "one of the highest of the non-Caucasian races," Seligman was surprised at the greater incidence of schizophrenia "in view of the extravert temperament of the Japanese." The small number of hospitalized manic-depressives, Seligman contended, did not reflect the reality of the disorder's prevalence in the country but the possibility that "the culture of Japan offers no outlet for those with tendencies toward schizophrenia, but is less hostile to those with tendencies towards manic-depressive, i.e., folk of a cyclothyme disposition." 70

Japanese psychiatrists were aware that foreign researchers harbored doubts about the low incidence of manic depression among the Japanese and had to realize that the total number of mentally ill could not be derived from the figures of government- or university-affiliated hospitals, especially in Japan, where the vast majority of the insane remained under the care of their families or in private facilities. ${ }^{71}$ However, they never seriously disputed the figures for 
the disorder in Japan, Korea, and Manchukuo that, according to certain theories, could be taken as proof of both the mental fitness and civilized status of the Japanese. It was only in Taiwan, where the incidence rate for manic depression was the highest in the empire, that research was eventually conducted to determine if external factors such as a more tropical climate could make the Japanese more vulnerable to such mental illnesses.

\section{Manic depression, climate, and Nanshin policy}

After Japan acquired Taiwan in 1895, the island's reputation for "fatal epidemics and lethal miasmas" ensured that "acclimatization of the colonizers to the unhealthy Taiwanese environment would ... have first priority," a problem that took on greater importance after 1940 as Japan moved into Southeast Asia, but also included a mental dimension. Even into the 1930s, when the improved state of public health became part of the Taiwanese colonial authorities' selfcongratulatory propaganda, officials showed no signs of being complacent about the issue of acclimatization, continuing to point out in their reports the environmental foreignness of the colony. ${ }^{72}$ Researchers in Taiwan thus were at the forefront of tropical medicine studies in Japan. With the adoption of a nanshin doctrine of expansion toward Southeast Asia and the Pacific Islands as national policy in 1936, the authorities increasingly mobilized their expertise. ${ }^{73}$

The result was centers, most notably the Institute of Tropical Medicine, created in 1939 to support the "moving southward" policy, and publications, such as the Taiheiyo igaku ronsō, that in 1944 presented research on the possible health risks that a tropical climate could pose for Japanese personnel. ${ }^{74}$ Alongside the epidemiologists and other contributors to Taiheiyō igaku ronsō was Taihoku Imperial University professor of psychiatry Naka Shūzō, who assessed the arguments of geographer Ellsworth Huntington and other environmental determinists that the tropics had a negative impact on mental ability. ${ }^{75}$ Of the opinion that "mild winters with some frosts, mild summers with the temperature rarely above $75^{\circ} \mathrm{F}$, and ... moderate changes of weather from day to day" promoted physical and mental activity, Huntington declared that "white men who spur themselves to exert their minds as earnestly and steadily within the tropics as at home are in great danger of breaking down in health."76

Naka and other psychiatrists in Taiwan did not paint such a bleak picture for Japanese colonizers. Naka observed that mental ability might be affected by disorders or physiological responses common in the tropics, pointing out how the body's attempt to reduce its temperature through the dilation of blood vessels could affect an individual's mental as well as physical state. This link between the circulatory system and emotional volatility, Naka suggested, could explain the higher rates of manic depression and psychogenic disorders in warmer climates. ${ }^{77}$ According to Naka, most disorders considered unique to or endemic in the tropics were psychogenic, originating in the mind, and he cited the case of a group of physically and psychologically hardy European soldiers in East Africa to demonstrate how a strong sense of duty and high 
level of discipline and camaraderie could help individuals ward off mental and neurological disorders. ${ }^{78}$ Moreover, in an earlier 1941 Imperial Navy-sponsored study of tropical neurasthenia among Japanese laborers sent to the recently occupied island of Hainan, Naka and his co-authors contended that the disorder, the symptoms of which included physical and mental lethargy, was largely the product of widespread and essentially groundless fears of the ill effects of the climate. Besides noting that individuals were in more danger from their assumptions about the tropics, these psychiatrists recommended personality tests for potential laborers and psychological therapy for those already afflicted with psychogenic disorders. ${ }^{79}$

Naka's students at Taihoku Imperial University, such as Munemoto Naotoku and Okamura Nichiki, were able to publish in major Japanese medical journals their studies comparing disorders among the Japanese and Chinese in Taiwan that similarly functioned to allay concerns about mental health risks. Okamura conducted studies on neurosyphilis and hypochondria among Japanese in Taiwan. He concluded that life in a more tropical climate did not affect the incidence of neurosyphilis, with rates among Japanese in the colony showing no marked difference from that of their counterparts in Japan. ${ }^{80}$ As for hypochondria, besides noting that the disorder seemed more widespread among Chinese patients, Okamura asserted that the Japanese could take pride in the fact that the therapy developed by the Japanese psychiatrist Morita Shoma (1874-1938) was proving to be effective in treating a disorder that has been so difficult to combat in Western countries. ${ }^{81}$ Moreover, in his 1943 Seishin to kagaku articles, Munemoto declared that research such as his on manic depression would hopefully help to safeguard the mental hygiene of peoples in the southern regions of Japan's Greater East Asia Co-Prosperity Sphere. ${ }^{82}$ In examining the cases of 114 manic-depressives out of a total of 763 hospitalized psychiatric patients (414 Japanese and 349 Chinese), Munemoto noted that, while the number of manic-depressives among Japanese colonials (12.5 percent) was lower than Chinese (17.7 percent), the percentage for these Japanese was higher than that of their counterparts in all other parts of the empire. ${ }^{83}$

To account for a higher incidence among the Japanese in Taiwan than in Japan, Munemoto assessed the role of climate, a factor that earlier psychiatrists had only mentioned in passing. ${ }^{84}$ Although he did not discount the role of heredity, Munemoto not only discussed how the incidence rate for manic depression in Taiwan changed with the seasons, rising sharply in the spring when the weather was unpredictable and decreasing notably in the fall when conditions were relatively stable. ${ }^{85} \mathrm{He}$ argued that an examination of the disorder's geographic distribution in Europe and Asia revealed that the number of manic-depressives increased in southern, warmer regions. Using the statistics of mental hospitals in China, he revealed a north to south increase in numbers: in Manchuria, the percentage of institutionalized manic-depressives was 5.3 per cent, in Beijing, it was 16 per cent, and in Canton, it was 22.7 per cent. In the case of Japan, he relied on figures compiled by the psychiatric departments of universities to demonstrate a similar pattern: in Sendai, the percentage of 
manic-depressive patients was 5.3 per cent, in Tokyo, it was 10.8 per cent, and in Kyushu, it was 12.3 per cent. ${ }^{86}$

Although contending that manic depression could also be the result of environmental factors and thus a condition that could increase among Japanese living or moving into warmer climates, Munemoto was able to reduce concerns about this possibility by supporting Kraepelin's and other psychiatrists' arguments that manic-depressives had a good chance of recovery. ${ }^{87}$ In his 1919 article, for example, Ishikawa Masakichi stated that out of all of the Sugamo Brain Hospital patients, the manic-depressives had the lowest death rate and responded best to hospitalization. ${ }^{88}$ Munemoto presented equally positive findings for Taiwan, referring to the reports of psychiatrists in the colony that over 80 per cent of manic patients and more than 90 per cent of those suffering from depression had experienced improvement, if not full recovery, through continuous sleep therapy. ${ }^{89}$

The treatment was even more effective in dealing with symptoms of depression; consequently, the prognosis was especially positive for the colony's Japanese who, unlike the Chinese and manic-depressives in Japan, were more troubled by episodes of depression rather than mania. ${ }^{90}$ Moreover, while Munemoto was not as explicit as Naka Shūzō in declaring that the subjects of his examination were victims of their own excessive concerns, he did note that many of the Japanese patients in Taiwan were educated and may have been prone to depression because education could foster introspection and a skeptical, grave outlook on life. ${ }^{91}$ Psychiatrists, in short, depicted manic depression as no serious threat to the Japanese, many of whom, it seemed to be suggested, might be able to avoid the disorder or facilitate their recovery by adopting a more positive, optimistic attitude.

\section{Conclusion}

It is not just widespread or highly lethal illnesses that are worthy of historical inquiry, and an exploration of a supposedly minor medical condition provides a means of assessing the extent to which factors, such as professional interests as well as contemporary political concerns in a metropole or colony, can intrude upon interpretations of illness. As historian of medicine Charles E. Rosenberg observes, "every disease has a unique past," and Japanese research on manic depression clearly illustrates the plasticity of interpretations or what Rosenberg has described as the "time- and place-specific configuration of ideas, practices, and institutions" that operate in the production of medical knowledge. ${ }^{92}$

The trajectory or evolution of medical opinion on manic depression in Japan greatly differed from that in Western countries. European and North American psychiatrists demonstrated little interest in the condition but eventually, by around the 1920s, began to express concerns that it might be more widespread. As it was suspected of being hereditary, manic depression attracted the attention of Social Darwinists and eugenicists both among and outside of 
medical circles, who often cited it as an example of an illness that could have a degenerative or retrogressive impact on the health of entire societies. In Japan, attitudes toward manic depression shifted in the opposite direction: while the concept of manic depression may have provoked alarm when it was first introduced into the country, psychiatrists came to provide reassuring assessments about the condition.

Like their counterparts elsewhere, early twentieth-century Japanese psychiatrists addressed the question of degeneration, and Kure Shūzō accepted the Kraepelinian view that manic depression was the result of "hereditary taint." However, Kure could ill afford to overemphasize the genetic risk of mental illnesses, which could undermine faith in therapeutic measures and, ultimately, the campaign for public psychiatric hospitals. As noted above, although foreign researchers, such as British physician/anthropologist C. G. Seligman who worked with data compiled by Kure, suspected that many manic-depressives in the country were going undetected, Kure and his numerous protégés had little reason to dispute the disorder's low and declining incidence rate among the Japanese and some of their colonized peoples.

The incidence rate for manic depression among the Japanese not only served to counter the arguments put forth by members of eugenic movements about a looming threat of racial degeneration. It allowed psychiatrists working in Korea, Manchukuo, and Taiwan, explicitly or implicitly, to address and medicalize political and social issues that concerned colonial authorities. Maintaining distinctions between colonizer and colonized was certainly not a challenge unique to the Japanese authorities, but differences in the prevalence of illnesses functioned as a means of reinforcing a sense of superiority over subject peoples whose Otherness could not be so readily based on physical appearance or cultural traditions.

In post-1919 Korea, resistance to colonial rule prompted studies of Korean criminality, which functioned to shield the authorities from blame for failing to maintain law and order by reducing defiance of authority to an issue of the perpetrator's character. Research on manic depression contributed to this discussion, providing a justification for lengthy prison sentences for Korean political prisoners, who often did not conform to the so-called manic-depressive character. Adopting Ernst Kretschmer's typology of character and body types, Sugihara Manjirō seemed to propose that the relative absence of manic depression and, thereby, of individuals possessing the manic-depressive character meant a smaller number of "friendly," "tractable," and "grateful" Korean colonial subjects, and, when it came to prisoners, fewer individuals who could potentially be rehabilitated.

Still, other psychiatrists in Korea, such as Kubo Kiyoji and Hattori Rokurō, provided colleagues in Manchukuo, who were observing more cases of alcoholism, syphilis, and psychosomatic disorders among the Japanese than other ethnic groups in the puppet state, with theories of manic depression that could help bolster the colonizers' sense of superiority. While propagandists portrayed successful settlement in Manchukuo as a "test of racial hardiness," the state's 


\section{Janice Matsumura}

1936 adoption of a doctrine of southward expansion, focused medical researchers in Taiwan even more on the question of whether or not Japanese could acclimatize to tropical regions. Manic depression was again included in this investigation. In a study that provided statistics to illustrate a north-to-south geographical increase in manic depression, Munemoto Naotoku concluded that individuals in warmer climates had a greater risk of developing the disorder. He addressed this possibility, however, while referring to the success that psychiatrists in the colony had experienced in treating their manic-depressive patients, especially the Japanese.

As we have seen, Munemoto's study, as well as the research of the other psychiatrists examined here, demonstrates how imperialism shaped psychiatric discourse. The comparatively lower rates could be used to suggest that the Japanese enjoyed some genetic advantage over a number of European populations and, according to theorists who linked decreasing incidence to cultural advancement, were qualified to govern less "civilized" peoples whose lands had been incorporated into the empire. Moreover, in contrast to mental illnesses that were more difficult to treat and closely associated with anti-social behavior, manic depression was depicted as posing little danger to society, even less an obstacle to southward territorial expansion. Intent on demonstrating their usefulness to the authorities, psychiatrists related their discussion of the disorder to ideas about racial hygiene and cultural superiority, explanations for resistance to colonial rule, and even wartime strategic policy.

\section{Notes}

1 This study was supported by a research grant from the Social Sciences and Humanities Research Council of Canada. Thanks go to the editors, Yuki Terazawa, Paul Barclay, Peter Nosco, Diana E. Wright, Jie Yang, and Bidisha Ray, for their advice during the writing of various drafts of this work.

2 The following are examples of scholarship on colonial psychiatry: Dinesh Bhugra and Roland Littlewood (eds), Colonialism and Psychiatry (New Delhi: Oxford University Press, 2002); Sloan Mahone and Megan Vaughan (eds), Psychiatry and Empire (Basingstoke: Palgrave Macmillan, 2007); Ernst Waltraud, Mad Tales from the Raj: The European Insane in British India, 1800-1858 (New York: Routledge, 1991).

3 James R. Bartholomew, The Formation of Science in Japan: Building a Research Tradition (New Haven, CT: Yale University Press, 1989).

4 For example, see Julie V. Brown, "Revolution and Psychosis: The Mixing of Science and Politics in Russian Psychiatric Medicine, 1905-13," The Russian Review, 46: (1987), 284. For another notable example, see Jan Goldstein, Console and Classify: The French Psychiatric Profession in the Nineteenth Century (Cambridge: Cambridge University Press, 1987) who has demonstrated the role of diagnoses and hereditarian ideas in the drive for professional power among French psychiatrists.

5 Kure Shūzō shōden (Tokyo: Kure Hakushi Denkihen Sankai, 1933), 103; Kure Shūzō, "Monbushō shitei gakkō kisoku o yomu," in Kure Shūzō chosakushū, dai ni kan, ed. Okada Yasuo (Tokyo: Shibunkyaku Shuppan, 1982), 109 (hereafter KSC).

6 Sumiko Otsubo and James R. Bartholomew, "Eugenics in Japan: Some Ironies of Modernity, 1883-1945," Science in Context, 11: 3-4 (1998), 545-65; Tessa Morris-Suzuki, "Debating Racial Science in Wartime Japan," Osiris, 13: (1998), 
354-75; Robert Thomas Tierney, "Introduction," in his Tropics of Savagery: The Culture of Japanese Empire in Comparative Frame (Berkeley, CA: University of California Press, 2010), 1-37.

7 Mental disorders were, in Kure's words, a "national disease" that could potentially undermine the economic, political, and social order. Kure Shūzō and Kashiba Gorō, "Seishinbyōsha shitaku rangoku kanchi no jikkyō oyobi sono tōkeiteki kansatsu (shō)," in KSC, 180.

8 Emil Kraepelin, Manic-Depressive Insanity and Paranoia (Edinburgh: E. \& S. Livingstone, 1921), 54-98.

9 Healy, Mania, 64, 72, 74, 19-20.

10 Junko Kitanaka, Depression in Japan: Psychiatric Cures for a Society in Distress (Princeton, NJ: Princeton University Press, 2012), 35.

11 Kraepelin, Manic-Depressive Insanity and Paranoia, 165.

12 Kitanaka, Depression in Japan, 35-6.

13 Ihsan M. Salloum and Juan E. Mezzich (eds), Psychiatric Diagnosis: Challenges and Prospects (Chichester: Wiley \& Blackwell, 2009), 6.

14 Near the end of his life in 1932, Kure nevertheless appears to have become more skeptical of the hereditary nature of mental illness, countering a recommendation for sterilization laws by noting that there was no guarantee that the children of degenerates were doomed to become like their parents. Kure Shūzo, "Henshitsu-sōutsubyō," Shinkeigaku zasshi, 14: 9 (1916), 23-4, 27 (hereafter SZ).

15 The American eugenicist Harry H. Laughlin, for example, used a visual display of two individuals labeled "Mania Depressus" during his campaigns in the 1920s to drum up popular support for compulsory sterilization legislation. Lisa M. Hermsen, Manic Minds: Mania's Mad History and its Neuro-Future (Brunwsick, NJ: Rutgers University Press, 2011), 69-70; Frederick K. Goodwin and Kay Redfield Jamison, Manic-Depressive Illness: Biopolar Disorders and Recurrent Depression (Oxford: Oxford University Press, 2007), 413.

16 Fujino Yutaka, Nihon faashizumu to yūsei shisō (Kyoto: Kamogawa Shuppan, 1998), 191-2.

17 Allan Beveridge, "A brief history of psychiatry through the arts," in Mental Health, Psychiatry and the Arts: A Teaching Handbook, ed. Victoria Tsichler (Milton Keynes: Radcliffe Publishing, 2010), 16-7.

18 Kure Shūzō and Kashida Gorō, Seishinbyō shitake kanchi no jikkyō oyobi sono tōkeiteki kansatsu (Tokyo: Seishin igaku shinkeigaku koten kankōkai, 1973).

19 Hermsen, Manic Minds, 67-8.

20 Kure Shūzo, "Sōutsubyō ni tsukite," SZ, 13: 7 (1915), 54-5.

21 Takase Kiyoshi, "Sōutsubyō no ippanteki tōkei" (1-4), Seishin shinkeigaku zasshi (hereafter $S S Z$ ) [formerly $S Z$ ], 22: 2-5 (1922), 37-41, 9-20, 2-24, 20-38; Ishikawa Masakichi, "Seishinbyō ippan koto ni sōutsubyō no yogo ni tsuite," $S Z, 18: 2$ (1919), 28-34.

22 Matsumura Hidehisa, "Sōutsubyō no ippanteki tōkei," SSZ, 41: 1 (1937), 195.

23 Kubo Kiyoji and Hattori Rokurō, "Chōsen ni okeru seishinbyō ni kansuru (sono ichi) Sōutsubyō mahiseichihō tankan no ribyōritsu tōkei ni yoru hikaku seishinbyōgaku kōsatsu," Seishingaku zasshi, 32: 8 (1930), 36, 40-1.

24 Ibid., 34.

25 Ibid., 41.

26 For example, see Sumiko Otsubo, "Feminist Maternal Eugenics in Wartime Japan," US-Japan Women's Journal, English Supplement, 17 (1999), 39-76.

27 Kubo and Hattori, "Chōsen ni okeru seishinbyō," 36, 41, 34, 40.

28 Ernst Kretschmer, Physique and Character: An Investigation of the Nature of Constitution and of the Theory of Temperament, second edition revised with an appendix by E. Miller [Originally published in English in 1936] (New York: Cooper Square Publishers, 1970), 128. 


\section{Janice Matsumura}

29 Michael J. Seth, A Concise History of Modern Korea: From the Late Nineteenth Century to the Present (Plymouth: Rowman \& Littlefield Publishers, 2009), 46-9.

30 Murayama Satoshi, Chōsenjin no shisō to seikaku (Chōsa shiryō, dai nijū shū. Keijō: Chōsen Sōtokufu, 1927), 51.

31 Miki Kinji, Hōkoku shoshū: Naichi ni okeru Chōsenjin to sono hanzai ni tsuite. Shihō kenkyū, Dai 17 shū (Tokyo: Shihōshō Chōsaka, 1933), 1.

32 "Senjin suridan no dai oyabun tsuihō seiryoku arasoi no mikkoku kara," Yomiuri shinbun, July 26, 1932, n.p.

33 Arai, Hōkoku shoshū: Naichi ni okeru Chōsenjin to sono hanzai ni tsuite. Shihō kenkyū, Dai 5 shū (Tokyo: Shihōshō Chōsaka, 1927), 55-9, 91, 93. For similar views, see Murayama Satoshi, 45, 94.

34 Kretschmer, Physique and Character, 20, 108, 128-9, 155.

35 Emily Martin, Bipolar Expeditions: Mania and Depression in American Culture (Princeton, NJ: Princeton University Press, 2009), 198-9.

36 Shimoda's research is discussed in Mukasa Hiroji, "Sōutsubyō no byōzen seikaku ni tsuite," SSZ, 45: 6 (1941), 42; Munemoto Naotoku, "Taiwan ni okeru sōutsubyō no hikaku tōkeigakuteki kenkyū," part 1, Seishin to kagaku, 17: 1 (January 1943), 6, 8.

37 Sugihara's findings regarding body and character types of psychiatric patients did not always conform to those of Kretschmer. He could identify only what he called variants of the athletic physique, and also admitted that not all individuals with pyknik body types possessed the so-called agreeable manic-depressive character. Sugihara Manjirō, "Taikei to seishin to no kankei ni tsuite no chiken hoi," dai ikkai hōkoku, SZ, 31: 4 (1931), 478, 497, 495, 487-8.

38 Ibid., 490.

39 Ibid., 494-5.

40 While describing individuals suffering from manic depression and schizophrenia as "caricatures of certain normal types of personality," Kretschmer also asserted that "[a]mong them we find, in the first place, an enormous number of defective types, or sulky eccentrics, egoists, unstable idlers, and criminals." Kretschmer, Physique and Character, 215, 267-8; Sugihara Manjirō, "Taikei to seishin to no kankei ni tsuite no chiken hoi," dai nikkai hōkoku (Jukeisha ni okeru taikei to seishin ni tsuite no kansatsu), SZ, 34: 3 (1932), 257.

41 Sugihara, "Taikei to seishin," nikkai hōkoku, 258.

42 Ibid., 257, 278, 284, 288-9.

43 Ibid., 277.

44 Ibid., 282, 292; Sugihara Manjirō, "Taikei to seishin to no kankei ni tsuite no chiken hoi," dai sankai hōkoku (hanzai to taikei narabi ni seishin to no kankei), $S Z, 34: 5$ (1932), 432.

45 Kretschmer, Physique and Character, 151, 163.

46 Sugihara, "Taikei to seishin," sankai hōkoku, 424.

47 Ibid., 428, 430-33.

48 Ibid., $443-44$.

49 Ibid., 433.

50 Ibid., 436, 455.

51 Ibid., 453.

52 Ibid., 458.

53 Ibid., 448, 455, 457, 435.

54 Ibid., 435.

55 Ibid., 430-1, 447, 444-5.

56 Ibid., 452.

57 For example, Ōta Kiyoyuki, "Kuretchumeru shi santaikei no shisūteki hyōgen to honpō naichijin no taikei," SZ, 36: 5 (1933), 393-431.

58 Kubo and Hattori, "Chōsen ni okeru seishinbyō," 37. 
59 Louise Young, "Rethinking Race for Manchukuo: Self and Other in the Colonial Context," in Race, Ethnicity and Migration in Modern Japan, ed. Michael Weiner (New York: RoutlegeCurzon, 2004), 287-8.

60 Un'ichi Miura, "The Problem of Acclimatization of the Japanese in Manchuria," The China Medical Journal (1927), 797.

61 Miura Un'ichi, Waga kokumin no manmō imin to füdo tekigō mondai (Mukden: n.p., 1933), 2-3.

62 Doi Masanori and Kuji Kōzō, "Dairen ni okeru seishinbyō no tōkeiteki kansatsu: (1) Nihonjin seishinbyō ni tsuite," Tōkyō iji shinshi, 2999 (1936), 36-7; Tamura Yukio, "Manshū ni okeru shusei chūdoku no tōseiteki rinshōteki kansatsu" [originally in SSZ, 41: 11 (1937), 129-43], in Tamura Yukio (ed.), Chūgoku tōhoku kyū manshū ni okeru minzoku to seishinbyō: kyū manshū ika daigaku seishin shinkeika kyōshitsu gyōsekishū (Aomori: Tamurayukio, 1983), 232; Tokumaru Tateo and Nishimura Chūichi, "Manshū ika daigaku seishin shinkeika ni okeru mahisei chihō (shinkō mahi) no rinshōteki, tōkeiteki kansatsu" [originally published in 1940 in Ōnari Kiyoshi kyōju tsuitō ronbunsh̄̄] in Tamura, Chūgoku tōhoku kyū manshū ni okeru minzoku, 260, 275, 273.

63 Doi and Kuji, "Dairen ni okeru seishinbyō no tōkeiteki kansatsu, 36-7; Tamura Yukio, "Manshū ni okeru shusei chūdoku no tōseiteki rinshōteki kansatsu" [originally n SSZ, 41: 11 (1937), 129-43], in Chügoku tōhoku kyū manshū ni okeru minzoku, ed. Tamura Yukio, 232; Tokumaru Tateo and Nishimura Chūichi, "Manshū ika daigaku seishin shinkeika ni okeru mahisei chihō (shinkō mahi) no rinshōteki, tōkeiteki kansatsu," [originally published in 1940 in Ōnari Kiyoshi kyōju tsuitō ronbunshī] in Chūgoku tōhoku kyū manshū ni okeru minzoku, Tamura, 260,$275 ; 273$.

64 Doi and Kuji, "Dairen ni okeru seishinbyō no tōkeiteki kansatsu (1)," 37; Doi Masanori and Kuji Kōzō, "Dairen ni okeru seishinbyō no tōkeiteki kansatsu: (2) Manshūjin seishinbyō ni tsuite," Tōkyō iji shinshi, 3001 (1936), 29.

65 Doi and Kuji, "Dairen ni okeru seishinbyō no tōkeiteki kansatsu: (2)," 29-30.

66 Ibid., 30.

67 Kubo and Hattori, "Chōsen ni okeru seishinbyō," 39, 38.

68 Ibid., 39; W. M. Bevis, "Psychological Traits of the Southern Negro with Observations as to Some of his Psychoses," The American Journal of Psychiatry, 78, (1921-2), 76.

69 Kubo and Hattori, "Chōsen ni okeru seishinbyō," 35-6.

70 C.G. Seligman, "Anthropological Perspective and Psychological Theory," The Journal of the Royal Anthropological Institute of Great Britain and Ireland, 62: (Jul.-Dec., 1932), 224, n. 3; 224, 225, n. 1; 225.

71 For a study of private confinement in Japan, see Akihito Suzuki, "Family, the State and the Insane in Japan 1900-1945," in Psychiatric Confinement in International Perspective, ed. Roy Porter and David Wright (Cambridge: Cambridge University Press, 2003), 193-225.

72 Michael Shiyung Liu, Prescribing Colonization: The Role of Medical Practices and Policies in Japan-Ruled Taiwan, 1895-1945 (Ann Arbor, MI: Association for Asian Studies, 2009), 3. It was observed in a 1932 annual report by the Sanitary Department of the Government-General Research Institute that "[b]ecause of its location between tropical and subtropical zones, Taiwan differs from our country ... [and $t$ ]he prevention of infectious diseases is a prerequisite for our residence ...." Hsien-Yu Chin, "Colonial Medical Police and Postcolonial Medical Surveillance Systems in Taiwan, 1895-1950s," Osiris, 13: (1998), n. 5, 328.

73 Iwamoto outlines the development of the nanshin policy, which was integrated in government policy in 1936 when, at the Five Ministers Conference, the leadership agreed that Japan would advance south "peacefully." However, within months of the navy's occupation of Hainan and the Spratly Islands as basis for the advance to 


\section{Janice Matsumura}

Southeast Asia, the Imperial Headquarters in 1939 agreed that the war with China would likely necessitate the "use of force against [the] southern area." Hiromitsu Iwamoto, "Japanese Southward Expansion in the South Seas and its Relations with Japanese Settlers in Papua and New Guinea, 1919-1940," South Pacific Study, 17: 1 (1996), 36-8.

74 National Taiwan University, "The History Wall of the College of Public Health of Taiwan National University Inaugurated," 2006, online at: www.ntu.edu.tw/engv4/ spotlight/2011/e110823_1.html; Liu, Prescribing Colonization, 153.

75 Naka Shūzō, "Nettai shinkei suijaku oyobi seishinbyō mondai," in Taiheiyō igaku ronsō, dai isshū, ed. Taiheiyo kyōkai (Tokyo: Nankōdō Shuppan, 1944), 202-3.

76 Ellsworth Huntington, Civilization and Climate (New Haven, CT: Yale University Press, 1915), 15, 68.

77 Naka, "Nettai shinkei suijaku oyobi seishinbyō mondai," 210, 212.

78 Ibid., 221.

79 Naka Shūzō, Okamoto Hōsei, Yamagata Kunihiro, Hamasaki Kuiei, Gōhara Kōkichi, Sakakibara Katsushi, "Hainantō ni okeru nettai shinkei suijaku no kenkyū" Taiwan igakkai zasshi, 40: (December 1941), 55-7.

80 Okamura Nichiki, "Taiwan ni okeru nettai baidoku no mondai (hontōjin no hikaku seishinbyōgakuteki kenkyū I)," SSZ, 15: 11 (November 1941), 657.

81 Okamura Nichiki, "Taiwan in okeru shinkishō (shinkeishitsu) no tōkei (Hontōjin no hikaku seishinbyōgakuteki kenkyū II), SSZ, 15: 11 (November 1941), 665-6.

82 Munemoto, "Taiwan ni okeru sōutsubyō no hikaku tōkeigakuteki kenkyū," part 1, Seishin to kagaku, 17: 1 (January 1943), 2.

83 Ibid., 1: 4. According to one statistical study, manic-depressives constituted 11.29 percent of institutionalized mental patients in Tokyo in 1935. Kan Osamu, "Honpō ni okeru seishinbyōsha narabini kinsetsu seru seishinijōsha ni kansuru chōsa," SSZ, 41: 10 (October 1937), 836-9.

84 For example, Kubo and Hattori, "Chōsen ni okeru seishinbyō," 40.

85 Munemoto, "Taiwan ni okeru sōutsubyō," part 1, 5-6, 12-3.

86 Ibid., 3-4.

87 Ole Bratfosand and John Otto Haug, "The Course of Manic-Depressive Psychosis: A Follow-up Investigation of 215 Patients," Acta Psychiatrica Scandinavica, 44: 1 (1968), 89.

88 Ishikawa, "Seishinbyō ippan koto ni sōutsubyō," 28-9.

89 Munemoto Naotoku, "Taiwan ni okeru sōutsubyō no hikaku tōkeigakuteki kenkyū," part 2, Seishin to kagaku, 17: 2 (February 1943), 6.

90 Ibid., 2: 4, 8-9.

91 Munemoto, "Taiwan ni okeru sōutsubyō," part 1, 10.

92 Charles E. Rosenberg, "Foreward," in Mania: A Short History of Bipolar Disorder, David Healy (Baltimore, MD: Johns Hopkins University Press, 2008), xii-iii. 


\title{
7 A colony or a sanitarium? \\ A comparative history of segregation politics of Hansen's disease in modern Japan
}

\author{
Hirokawa Waka
}

\section{Introduction}

The problems of Hansen's disease (commonly known as leprosy) in modern Japan has been characterized by a continuous segregation policy for the 90-year period, from 1907 to 1996. Hansen's disease is an infectious disease caused by Mycobacterium leprae. The disease is not fatal in most cases, but its chronic nature tortured sufferers for many years if they did not receive proper treatment. This characteristic of the disease made the policies for its treatment more complicated since planners had to design a long-term recuperation program.

According to the records of Japan's Ministry of Health, Labor and Welfare, in 2014 there were 13 national sanitaria for Hansen's disease in Japan and approximately 1,800 residents who were cured decades ago yet continue to reside there as former patients. In 1998, a few years after the segregation law was abolished, some of the residents of a sanitarium in Kumamoto began to organize a damage compensation lawsuit against the government. In 2001, the Kumamoto District Court declared the continuance of the segregation policy after 1960 unconstitutional. It concluded that, based on the prevailing medical understanding, the government should have changed the policy and the Diet should have abolished the segregation law by 1965 in order to stop the violation of patients' human rights. Based on the court's decision, the government paid compensation to the former patients. ${ }^{1}$

Currently, the average age of the former patients who reside in the sanitaria is over 83 years old, and one of the most urgent problems is providing better care for these elderly former patients who are still suffering from the aftereffects of Hansen's disease and other illnesses. There is the additional problem of reintegrating sanitaria residents with the surrounding regional communities. Reintegration means that the government assists the sanitaria and the surrounding communities as they work together to turn the sanitaria into open facilities. Residents have pushed for their hospitals to be integrated into local communities because it is no longer as difficult for elderly inpatients who lack family or other connections to society to become part of the world outside the sanitaria. In order to solve these problems, the Act for the 


\section{Hirokawa Waka}

Promotion of the Resolution of Issues Related to Hansen's Disease was enacted in 2009. The government, former patients, and citizens are seeking ways to open the doors of the sanitaria to the general population by opening the hospitals as multipurpose facilities - for example, as treatment centers, special nursing homes for the aged, or kindergartens. This can be seen as a trial rehabilitation of the sanitarium and its integration into society. ${ }^{2}$

In order to realize these goals for the Japanese sanitaria, there needs to be a detailed examination of the historical relationship between the patients and local communities. An examination of Hansen's treatment prior to the implementation of government policy, which limited treatment to the single option of institutionalization, indicates that Japan had examples of relatively successful integration of Hansen's disease patients in society. This provides hints to approaches that might be useful today. The problems related to the rehabilitation of former Hansen's patients and their coexistence within regional communities has also been a matter of global interest and concern in such countries as Malaysia, the Philippines, India, and Brazil. ${ }^{3}$

Accordingly, I will first analyze laws and government policies for Hansen's disease sufferers in modern Japan. By the 1990s, most scholarship on Japan's policy traced a single path to "absolute segregation" under the 1931 act, a phrase that indicated the institutionalization of all sufferers until the end of their lives. ${ }^{4}$ Japan's policy for Hansen's disease patients was consequently considered a typical case among a set of medical policies based on Japan's fascist era, especially the era of "total war," because patients' human rights were violated most seriously during that period. Moreover, the Japanese government extended its segregation policies for Hansen's disease to its empire in Korea and Taiwan but applied regulations in a more rigorous way. ${ }^{5}$ This story of "the victims" of the policy often emphasizes the role of police authorities, which threatened the sufferers with physical brutality. The way in which Japanese policies targeted Hansen's disease patients was, however, not a simple continuous reinforcement of the segregation policy, but rather a series of complex interactions involving various actors, including the sufferers living in so-called "leper villages." Contrary to how it is often represented, although the police played an important role in enforcing the segregation policy, their legal authority was not omnipotent. To evaluate both the system itself and the actual process of treating patients requires an understanding of the entire system and its supporting legislation.

Second, I will examine the history of a "Hansen's disease sufferers' village" in the small hot-springs town, Kusatsu, in Gunma prefecture, as a case study. The idea of "leper villages" derived not only from American policies toward Hansen's disease patients in the Philippines and Hawaii but also from the patients' village which had already appeared in the local community. Other scholars have also examined the significance of this settlement. Susan L. Burns outlined the history of Japan's sanitaria system from the late nineteenth century until the 1930s, focusing on the process of dismantling "leper villages," including Kusatsu, and the transformation of the sanitaria into 
"total institutions." ${ }^{6}$ Her work emphasizes the impact of the Western concepts of race and nation on the politics of Hansen's disease in modern Japan. Though most studies tend to emphasize the international isolation of Japan's Hansen's disease policy and medicinal practices, which promoted continued segregation by ignoring prevailing medical knowledge, her comparative point of view shows how important Western concepts exerted great influence on Japan's segregation policy and the process of complete institutionalization. She also provides an objective description of the place Japan's policy holds in the history of international medicine. Japanese scholars' nation-centered approach to Hansen's disease up to this point has obscured points of both agreement and difference between Japan and other areas. ${ }^{7}$

In the following sections I examine why the specific policy of total isolation was chosen and consider the impact of that choice on Hansen's disease policies in Japan. Why was it that a policy of almost "total institutionalization" was chosen as a solution rather than one that would have provided support for communities of patients that had been historically embedded in Japanese villages? Certainly, these were not the only possible courses of treatment for Hansen's; in addition to the "sufferers' village" plan and the private institutions I introduce below, some medical institutions provided outpatient care for sufferers. ${ }^{8}$ Furthermore, I seek to reevaluate legislation on Hansen's disease treatment in prewar and wartime Japan, as well as the interplay between different plans for different forms of recuperation from the disease. As we shall see, the move towards greater segregation of Hansen's sufferers coincides with Japan's advance towards "total war" and increased restrictions on personal freedoms in general. Finally, I explore the realities of the sufferers' community in Kusatsu, as it was realities such as these that affected policy.

\section{Legislation on the treatment of Hansen's disease sufferers in prewar and wartime Japan}

Because the history of Hansen's disease policy has not been examined properly, I will begin with a brief review of the official policies on Hansen's disease in prewar and wartime Japan when there were two epoch-making changes in disease legislation. First was the passage of the Law Concerning the Prevention of Leprosy, in 1907; the second was the revision of this law promulgated as the Leprosy Prevention Law in 1931. By discussing how the general treatment of Hansen's sufferers was prescribed under these two acts, I emphasize the separate rules established in each prefecture. In order to comply with these acts in a way that was also compatible with their own aims and ideas, each prefectural government instituted its own ordinances. Only by recognizing this point can we understand the concrete processes and mechanisms that resulted in the exclusion of Hansen's disease sufferers in each area. In most historical studies up to the present, these laws have been misinterpreted. Scholars have typically regarded the 1907 act as the "beginning" of segregation policy; the 1931 act is considered "completion" of this "absolute 
segregation" policy. Yet these interpretations contain significant problematic elements. ${ }^{9}$

The 1907 act mandated the segregation and institutionalization of itinerant patients who had no means to provide for themselves and no family members who could be responsible for their support. Under this act, prefectures were divided into five groups, with each group establishing a shared, joint-prefectural sanitarium. A key criterion for institutionalization depended not on each sufferer's diagnosis but on his or her source of income. The act intended to basically provide "itinerant sufferers" with support and relief. It should be emphasized here that this act did not force the majority of sufferers who were being treated at home to enter one of the five joint-prefectural sanitaria. It did, however, require doctors who identified a case of Hansen's disease to notify the police, because at that time public health matters were under the control of the Ministry of Home Affairs. Therefore, patients who lived at home were monitored and overseen by the police who enforced patient isolation and disinfection of the room or home in which they lived.

The manner of dealing with sufferers who were treated at home varied widely among prefectures, as well as between cities and rural areas even though local governments provided no medical treatment. Patients at home endured the disadvantages of the policy, such as the forcible disinfection of their residences and police surveillance, in exchange for exemption from institutionalization. Regardless of these negative elements, however, the government intended to segregate and provide relief only for those who were regarded as high risk because of their status as itinerant patients. It still considered in-home care to be the standard form of treatment. This act can be regarded as similar to the acts addressing other chronic diseases that had become social problems, such as tuberculosis and mental illness during the 1900s and 1910s. Although such acts were generally insufficient in providing adequate care for the patients, they had a common aim of rescuing poor patients. ${ }^{10}$

In 1925, requirements for entering sanitaria were eased so that it became possible for Hansen's sufferers to enter sanitaria even if they had a person who was capable of providing them with support. This change represented a significant policy shift because under the 1907 act the criteria for entering sanitaria were based primarily on patient means as well as those of their legal guardians, rather than the patient's physical condition. Under the 1931 act, when a local government certified that the segregation of a patient was medically necessary, it could force a person to enter a joint-prefectural sanitarium regardless of economic status. Consequently, the medical doctor's evaluation of which patients had the potential to infect others became most important. When a doctor reported a high risk of infectiousness, the local administration certified that a patient was potentially infectious and sent him or her to a sanitarium. Therefore, the number of the targets for institutionalization increased under the 1931 act. The view that the law altered its characteristics as a relief act for poor, itinerant patients into an act which protected society from infectious patients based on scientific knowledge is correct in this sense. As Kathryn Tanaka 
describes in her contribution to this volume, it was in this situation that different types of patients who had belonged to various social classes and backgrounds, including the famous patient author, Hōjō Tamio, began to enter sanitaria and gradually changed the internal atmosphere. On the other hand, the new law provided benefits for patients who were denied admittance to the jointprefectural sanitaria because they were assessed as having a lower potential to infect others. Some of them qualified for monthly compensation under the 1931 act.

Even under the 1931 act, patients with mild cases could avoid entering sanitaria and were able to maintain normal patterns of social interaction when the local government allowed it. Therefore, we cannot regard this situation as the completion of "absolute segregation" as many have suggested. ${ }^{11}$ To be sure, under the 1931 act, prefectural governments aimed to institutionalize more sufferers than before, so if they had decided to regard all sufferers as "being at higher risk for infecting others," all of them would have been in danger of being institutionalized. The fact that the 1931 act did not target all sufferers is of great significance because it meant that alternative forms of treatment were still available after 1931 .

In order to continue their lives in society, some factors such as proper diagnosis by medical specialists and a specific system for allotting benefits required proper administrative management; however, no such system actually existed at that time and prefectural governments were unable to deal with the changes mandated by the 1931 act. Because prefectural governments remained in the position that determined how patients would be treated, they needed to change treatment process ordinances, which were enacted around 1907. Many of them, however, did not change their own ordinances to reflect the revision of the national law in 1931. Without revision of local ordinances or a change in local systems for proper treatment of patients in accordance with the new mandates, the national law was ineffective.

Because the prefectural systems for treatment were not revised to support the continued integration of patients with mild cases into local society, prefectural practices marked patients as infectious and this led to the widespread exclusion of Hansen's disease patients from regional communities. As a consequence, many of them had difficulties even in living in their own homes because they came to be regarded as a source of infection even though a significant portion of the general public still believed that the disease was hereditary. Therefore, an adequate residence, which was neither a sanitarium nor a regular residence, became necessary.

\section{Two proposed plans for the treatment of Hansen's disease sufferers}

On paper, the two laws appeared clear but the question of how they affected the actual treatment of people with the disease in prewar and wartime Japan is another matter. Notable differences between the 1907 act and the 1931 act came from a 1920 resolution, made by the Sanitation Investigation Council, 


\section{Hirokawa Waka}

which functioned under the Ministry of Home Affairs. This resolution, called "The Fundamental Principles for Preventing Leprosy," stipulated several points that were later put into practice under the 1931 act. It can thus be viewed as a bridge connecting the two acts. Of the six points outlined in the resolution, the two most important can be summarized as follows:

1 The creation of a national sanitarium to house patients who did not have permanent domiciles or who disrupted other patients' lives in local sanitaria-for example, through repeated escape attempts.

2 The establishment of a national or public "free area colony" for patients who had sufficient means to live autonomously in circumstances well equipped for their care. ${ }^{12}$

On the one hand, members of the Sanitation Investigation Council intended to send the worst-behaved patients from the joint-prefectural sanitaria to a newly created national sanitarium. As previously mentioned, Hansen's disease sanitaria had increased their patient diversity by the middle of the 1920s, in contrast to the earlier periods when only itinerant patients were hospitalized under the 1907 act. Consequently, trouble between patients increased. The national sanitarium was to be located on an isolated island off the coast of Honshu so that these patients would be unable to escape. Certainly the government had already examined the possibility and the availability of the use of an island on the empire's fringe-Iriomote Island, the largest of the Yaeyama Islands and the second largest in Okinawa prefecture - as a sanitarium exclusively for sufferers of Hansen's disease in 1916. Their secret research project, however, received strenuous objections from Yaeyama residents and failed. ${ }^{13}$ They also suggested the establishment of an area for sufferers being treated at home, so that they could carry on a lifestyle that was closer to that of an average citizen. These two plans were realized in the early 1930s in the form of two national sanitaria, Nagashima-Aisei-en (a prison-like facility located on an island) and KuriuRakusen-en (including "a free area colony"), although the actual outcomes were quite different from the purposes envisioned in the resolution. Through establishing both kinds of facilities, policy makers intended to make up for the deficiencies of the 1907 act. The primary problem was the situation created by the 1907 act under which the sanitaria reported repeated escapes by patients who had no means to support themselves on the outside, while sufferers with the means to remain self-sufficient had no options for hospitalization. Sufferers who had the means did not qualify for entrance into a sanitarium, but, practically speaking, they could not stay in their regular residences because of severe discrimination by the community.

These new plans were clearly inspired by global developments in the treatment of Hansen's disease. Their proposals included references to the Molokai Island Colony in Hawaii and the Culion Island Colony in the Philippines. Both institutions were established in the 1880s and 1900s on solitary islands far out at sea, in accordance with the policies of the United States. ${ }^{14}$ In 1918, 
the Sanitation Investigation Council resolved to inspect these Hansen's disease colonies as a foundation for drafting the 1920 resolution. ${ }^{15}$ In the Hawaiian and Philippine islands, patients who were deemed incurable were sent to these colonies, where they lived the rest of their lives isolated from society. In principle, the difference with Japan's two planned island communities seems clear: a prison-like sanitarium located on an island with the basic goal of protecting the rest of society from infection, on the one hand, and a free area where patients were permitted to carry on relatively unrestricted lives on the other. In reality, however, these plans represented two sides of the same coin: both focused on different aspects of the same models, Molokai and Culion. The nature of treatment still largely depended on a patient's "funds" because the proposed "free area" was limited to sufferers with financial means. This emphasis on means, however, shifted in the 1931 act to stress a patient's diagnosis regarding risk of spreading the disease.

Quite apart from those directly involved in the 1920 Sanitation Investigation Council resolution, other activists including medical doctors, Christian missionaries, Buddhists, and politicians frequently discussed forms of treatment from their respective viewpoints during the reform process between the passage of the 1907 and 1931 acts. In the 1920s and 1930s, these people pursued alternative forms of treatment that offered possibilities beyond blanket institutionalization in sanitaria. A range of proposals and petitions requesting the establishment of free areas for Hansen's sufferers were submitted to the Imperial Diet. $^{16}$ These activities often targeted a small mountainous village called Yunosawa, a Hansen's disease colony that had organically formed in Kusatsu 200 years earlier.

In 1925, a member of the House of Representatives, Kogure Sanshiro (elected from Gunma prefecture), proposed to the Imperial Diet that the government should improve the inadequate facilities in Yunosawa in order to help the sufferers who supported themselves there. Against his proposal, Ushizuka Torataro, a medical doctor and the governor of Gunma, claimed that Yunosawa should be relocated far from the town of Kusatsu on the grounds of the danger of infection. The Gunma prefectural assembly also proposed the removal of Yunosawa in accordance with Ushizuka's opinion. Even after the Ministry of Home Affairs seemed to have made the decision to break up Yunosawa in 1925 or 1926, many Diet members, including Kogure, submitted proposals for a free area for Hansen's sufferers to the Imperial Diet. The residents of Yunosawa also approached members of the Diet with the aim of continuing their lives in the community. ${ }^{17}$

\section{A free area for Hansen's sufferers had already appeared}

The existence of Yunosawa Village, a self-governed area located in Kusatsu, complicated the arguments concerning forms of treatment for Hansen's disease patients. The important difference between Yunosawa and the American island colonies was that Yunosawa was, for the most part, formed spontaneously and 


\section{Hirokawa Waka}

served as a refuge for sufferers. Therefore, any discussion of a "free area" plan in Japan often meant discussing Yunosawa's future management.

From the end of the seventeenth century, many sufferers had sought the supposed healing properties of Kusatsu's hot springs and became remarkably good customers at these baths. At the end of the nineteenth century, the sufferers' self-governed area, Yunosawa (also called the "Lower Village" in contrast to the "Upper Village," inhabited by regular residents), was formed. Some of the permanent settlers started to run inns and stores, or rented houses to other sufferers. Patients attempted to cure their disease with a combination of treatments that included the hot springs, chaulmoogra oil, moxibustion, and acupuncture. Their source of income was mostly from the funds the newcomers paid for recuperation. Other people engaged in manual labor around Kusatsu and earned some money that way. Yunosawa had a population of about 1,000 at its peak. ${ }^{18}$ The village was not a commune in which sufferers lived together equally; rather it was a regional society with a hierarchical structure formed by the different kinds of members, each with their own interests.

People with Hansen's disease in Yunosawa faced danger when their illness became too serious for them to work or their family cut off financial support. Some relief work on behalf of the worst cases was done in Yunosawa by a Christian mission called the "St. Barnabas' Mission to Lepers in Kusatsu." Its purpose was to care for just this kind of sufferer. It acted, therefore, as kind of a "safety net," helping people who developed complications such as blindness which limited their productivity and autonomy. An English missionary, Mary Helena Cornwall-Legh (1857-1941), started St. Barnabas' Mission in 1916 and was supported mainly by the Domestic and Foreign Missionary Society of the Protestant Episcopal Church in the United States, an organization in contact with a worldwide network of missionary activities for Hansen's sufferers. It provided free, gender-segregated homes for sufferers with a total capacity for 200 people. There was also a hospital with a Hansen's disease medical specialist, an elementary school for sick children, a church, and so on. ${ }^{19}$ Cornwall-Legh's policy for providing relief to sufferers can be seen in her letter to a Bishop of North Tokyo. She attached great importance to helping female sufferers - an emphasis not present in government sanitaria:

Even more than the men one longs to save the young women from a Kusatsu 'marriage', likely to end in being cast off as soon as the wife's hands become disabled or her eyesight fails. Here is O Seki San, whose husband divorced her, as most untainted husbands do, when she became a leper. She can work still and many of the men in Kusatsu want her. She has made up her mind not to marry again, but what is she to do with no money and subject to such temptations and importunities if she goes as [a] servant in an inn. She must be taken into St. Mary's, and so must poor Kimbo San, mother of four children, but who never hears a word from home. ${ }^{20}$ 
The mission also established good relations with Kusatsu's municipal authorities. Cornwall-Legh's devotion in Kusatsu had an affinity with numerous representations of Father Damien in Hawaii, as his arrival brought order, morality, and succor to the people residing there.

Sufferers supported by the mission led well-ordered lives in gender-segregated homes, admiring their "mother," Cornwall-Legh. The mission provided sufferers with a lifestyle characterized by the religious beliefs and practices of Christianity. Thus, the mission provided a unique option for patients, different from that of patients in sanitaria or in Yunosawa outside of the mission. The mission provided medicine and education for inpatients' children as well as non-Christian residents in Yunosawa. Moreover, the overseas missionary fund benefited the economies of both Yunosawa and Kusatsu and essentially supported the economic and social structure of the sufferers' community. ${ }^{21}$

At that time, people in Kusatsu regarded Hansen's disease as not infectious but hereditary, so they did not fear contact with their infected neighbors. Around 1930, an old headman's assistant of Kusatsu Town stated:

In 1869, Kusatsu was destroyed by a large fire and the townspeople were forced to live in poverty because no customers came to the town. In order to attract customers, we promoted the great hot springs as a cure for refractory diseases like leprosy and this strategy succeeded thanks to our advertising. Therefore, the customers at that time included a lot of leprosy patients. Innkeepers competed for these Hansen's disease patients, but all the inns were ill-furnished and innkeepers and patients often used to share everyday items such as bedding and clothes or ate at the same table for many years. No innkeepers and their families in Kusatsu, however, have contracted leprosy within these decades. So can you still define leprosy as an infectious disease? ? $^{22}$

Thus, the townspeople's concept of Hansen's disease developed as a result of experience rather than the imported medical knowledge on which the government's policies were based. Many people in Kusatsu, including Cornwall-Legh and the mission's staff, shared this belief.

I refer to this situation as an example of "folk epidemiology," even if the hypothesis was "scientifically" or "bacteriologically" incorrect. Their knowledge, based on personal experience of coexistence, was a major source of hope for the survival of the sufferers' village. It provided the foundation for a hospitable environment for patients outside the context of a sanitarium.

Although townspeople sometimes tried to hide sufferers from out-of-town guests, there were two reasons why the healthy people of Kusatsu and Hansen's sufferers could, on the whole, live together successfully. First, in all circumstances, patients who were financially independent were treated as "customers" of the hot springs town. Second, there had been no reported cases of infection among townspeople during their long history of living with Hansen's sufferers. The Yunosawa colony formed spontaneously and survived as a result of its 
connections to the outside world: for example, the economic interests of the townspeople were supported by sufferers' tourism and support from overseas through the Christian mission.

Unfortunately, this situation was far from the desirable closed-off "free area" which the national policy makers envisioned. A famous medical specialist on Hansen's disease, Mitsuda Kensuke, and a medical professional/bureaucrat, Takano Rokurō, were deeply troubled by the fact that the people of Kusatsu did not avoid contact with patients and tried to warn them of the possibility of infection. Takano stated in 1943:

The townspeople in Kusatsu do not hate leprosy so much, compared to average people. They gradually lost their concern about leprosy through their daily contact with the patients. For example, residents in the Upper Village go to a cafe in the Lower Village, and healthy children and sick children play together in Sunday school. They do not seem to believe that leprosy is infectious. As these people who come in contact with patients everyday do not fear leprosy, leprosy does not seem to be strongly contagious. We cannot, however, leave such a situation as it is. There is a real possibility that many leprosy patients will appear among the Upper Village residents in the near future. ${ }^{23}$

Doctors like Takano and Mitsuda maintained the basic idea that the disease was infectious and caused by the bacillus Mycobacterium leprae. They regarded Kusatsu people as ignorant - enslaved by a "false" hereditary theory. Mitsuda also believed that sufferers who received treatment in Kusatsu often traveled freely to Tokyo and other areas, spreading the disease on their journey. ${ }^{24}$ For a long time the doctors attempted to move Yunosawa farther away from the Upper Village; policy makers finally achieved this goal in 1941.

\section{Two plans by the Sanitation Investigation Council in 1920 and their consequences}

In 1932, the 1920 resolution by the Sanitation Investigation Council to establish two different types of institutions for Hansen's patients was actualized in the form of Nagashima-Aisei-en and Kuriu-Rakusen-en. Nagashima-Aisei-en, which was first planned as a prison-like institution, was built on a relatively accessible island in Okayama prefecture in the Seto Inland Sea. The first sufferers to reside there were not repeated escapees but model inpatients carefully selected by Mitsuda from among those living at the joint-prefectural sanitarium in Tokyo in order to make the new community easier to manage. By contrast, the site originally proposed by the Ministry of Home Affairs was Iriomote Island, located about $430 \mathrm{~km}$ southwest from mainland Okinawa. This plan ultimately proved to be impractical because it was impossible to establish and operate a sanitarium or a colony there with the necessary medical and administrative staff; thus, the less remote island of Nagashima was chosen. ${ }^{25}$ 
The other plan for a "free area" was actualized by establishing the Free Area inside Kuriu-Rakusen-en, built at the east end of Kusatsu. This "free area," however, was not a self-governing village like Yunosawa, but a site for inpatients to freely build houses at their own expense. The standard residence in sanitaria of the day was a gender-segregated hospital ward in which patients shared rooms. Many of the residents of Yunosawa lived with their families in their own houses, so the government here attempted to arrange the "free area" to accommodate these families as well. Although the original goals for the "free area" in the 1920 resolution had aimed at an independent and self-determined community, this path, while not realizing the original goal, resulted in a relatively freer space where patients with some economic means could enjoy a degree of privacy.

Both plans unrealistically presupposed the complete segregation of patients and therefore had to be modified into a form that enabled the government to maintain the sanitaria at a low cost under wartime conditions. The 1920 resolution was not carried out according to the original ideal but was instead based on the actual conditions facing patients at that time. The consequence of this was the building of several new national sanitaria which were quite similar to the existing joint-prefectural sanitaria, as well as nationalizing the prefectural sanitaria.

Yunosawa was gradually undermined by the government, and finally, in 1941, both Yunosawa Village and St. Barnabas' Mission were compulsorily broken up, leaving most of the remaining residents with no choice but to enter sanitaria. The mission refused the government's repeated offers to relocate within the area of Kuriu-Rakusen-en because the freedom of religious activities would be restricted to the grounds of the sanitarium. As a result, they were gradually forced to reduce activities in Yunosawa, including accepting new patients. The goal of St. Barnabas' Mission was in line with the goals of the 1907 act in that it offered relief to itinerant sufferers who had no means of self-support. The mission's activities to support underprivileged sufferers in Yunosawa and its ability to supplement the limited capacity of sanitaria established under the 1907 act were given official approval as part of the prior treatment system. Eventually, however, it became an obstruction to the government's process of clearing Yunosawa when it refused to move to Kuriu-Rakusen-en. Yunosawa was no longer sustainable as a self-governing colony and the patients began to enter the sanitaria since they were no longer able to provide for themselves. Despite this, Yunosawa survived for about ten years after the establishment of Kuriu-Rakusen-en.

\section{Conclusion}

The compulsory closure of private sanitaria in other areas marked a new movement toward greater segregation of Hansen's disease patients that coincided with the breakup of Yunosawa and St. Barnabas' Mission in the 1940s. The movement toward segregation came only as the war intensified and not earlier in the twentieth century. As we have seen, a variety of policies requiring patient segregation in the national sanitaria were strengthened as the Japanese 


\section{Hirokawa Waka}

government promoted a set of 'wartime social policies' to develop all human resources as soldiers ('kenmin kenpei'). ${ }^{26}$ Beyond the impact of prefectural administrations' tendencies in response to government directives, this influx of inpatients caused overcrowding and residents were forced to live in substandard conditions with insufficient medical care as facilities operated beyond maximum capacities in a time of "total war."

The revision of the 1907 act and passage of the 1931 act did not mean the completion of "absolute segregation" because the 1931 act did not itself necessarily aim at the institutionalization of all sufferers. Patients, however, sought to establish a settlement that was neither a sanitarium nor their own home because the support system for home care was insufficient and discrimination was often so severe that they could not realistically continue to live their lives within ordinary society. Yunosawa's ability to fulfill sufferers' needs elevated it to the status of one of the largest villages in the world spontaneously formed by people with Hansen's disease. The relationship between the people in Kusatsu and the sufferers is an unprecedented historical example of coexistence between a large group of patients and a regional community. It is also noteworthy from an epidemiological point of view. Coexistence of the disease and society developed independently from official medical policy, which still cast a long shadow on many former patients' lives. The destruction of existing alternatives and neglect of epidemiological facts, which could easily be observed in areas such as Yunosawa, were more problematic points in Japan's policy than the simple choice of a treatment path.

Although in the 1920s there remained some alternative lifestyle options for Hansen's sufferers, in the 1930s and early 1940s the government abolished most of these. Even so, a few small private sanitaria, as well as some outpatient care provided by a few medical institutions, remained as options. The Japanese government did not declare a single method for managing the disease, but its policies in the end severely impaired the possibility of alternative forms of treatment. These alternatives had been spontaneously created in Kusatsu, but revised polices limited sufferers' residence options by overestimating the risk of infection. This inflexibility in policy eliminated the existing refuges which had previously served as intermediaries between society and sufferers. The policy resulted in the single option of patients' institutionalization, especially in the postwar era. Even in former colonial areas, such as Korea and Taiwan, where the Japanese Empire established a similar system of segregating Hansen's disease patients, the legacy of Japanese policies still tortures former patients. This breakdown in communications between sufferers/survivors and society lessened the general public's understanding of and interest in the disease and became one of the chief reasons why the Hansen's disease segregation law was only abolished in 1996.

\section{Notes}

1 Tony Gould, A Disease Apart: Leprosy in Modern World (New York: St. Martin's Press, 2005), 373-4. 
2 Endō Takahisa, et al., "Kyōsei no ba to shite no ryōyōjo no "syakai-ka" wo kangaeru tame ni," Hansen-byō Shimin Gakkai Nenpō (2008), 40-77.

3 The establishment of the international network of former Hansen's patients, in 1994 stimulated the foundation of a domestic organization for former patients in such countries. These organizations have sought solutions for bettering patient lives based on the guidelines by the WHO (Guidelines for strengthening participation of persons affected by leprosy in leprosy services, 2011).

4 Fujino Yutaka, Nihon fashizumu to iryō: Hansen-byō wo meguru jisshō teki kenkyū (Tokyo: Iwanami Shoten, 1993).

5 Fujino Yutaka, Sensō to Hansen-byō (Tokyo: Yoshikawa Kōbun-kan, 2010).

6 Susan L. Burns, "From 'leper villages' to leprosaria: Public health, nationalism and the culture of exclusion in Japan," in Isolation: Places and practices of exclusion, ed. Carolyn Strange and Alison Bashford (Oxford: Routledge, 2003), 104-18.

7 Fujino emphasized the "Japanese style of segregation," which included forced segregation, forced labor, punishment, slaughter, and forced sterilization as well as abortion; he also argued that this form of segregation was different from internationally held treatment models. See Fujino, Hansen-byō to sengo minshu shugi (Tokyo: Iwanami Shoten, 2006), 11-7.

8 Waka Hirokawa, "Senzen senji ki Osaka ni okeru Hansen-byō sya no shogū," Kindai Nihon no Hansen-byō mondai to chiiki shakai (Osaka: Osaka Daigaku Shuppan-kai, 2011).

9 Many scholars have discussed the implications of the 1907 act. See Ikai Takaaki, "Sei no kakuri (sex segregation)" to kakuri seisaku: Hanna Rideru (Hannah Riddell) to Nihon no sentaku (Kumamoto: Kumamoto Shuppan Bunka Kaikan, 2005).

10 Ikeda Yoshimasa, Nihon shakai fukushi shi (Kyoto: Hōritsu Bunkasha, 1986), 392-401.

11 This view is largely based on Fujino's work, but little of the discourse supporting "absolute segregation" subjects the law or the treatment of Hansen's disease to careful examination.

12 Naimushō Eiseikyoku, Rai yobō ni kansuru ken (1921), 1-4.

13 Yamamoto Shun'ichi, Zōho Nihon rai shi (Tokyo: Tokyo Daigaku Shuppan-kai, 1997), 93-4.

14 Michelle T. Moran, Colonizing Leprosy: Imperialism and the Politics of Public Health in the United States (Chapel Hill, NC: The University of North Carolina Press, 2007).

15 Hoken Eisei Chōsa-kai, Hoken eisei chōsa-kai dai 3 kai hōkoku-sho (Tokyo, 1919).

16 Yamamoto, 162-8.

17 Hirokawa, 115-26.

18 Kuryū Rakusen'en Jichikai (ed.), Fūsetsu no mon: Kuryū Rakusen'en kanja 50-nenshi (Gunma: Kuryū Rakusen'en Jichikai, 1982), 1-101.

19 Nakamura Shigeru, Kusatsu “yorokobi no tani” no monogatari: Kon'uōru-rī (Cornwall-Leigh) to Hansen-byō (Tokyo: Kyōbunkan, 2007).

20 The Right Rev. McKim, John, D.D, "A Christ-like life among lepers in Japan," The Split of Missions, 12: (1927), 725-6. The emphasis is in the original text.

21 Hirokawa, 113-4.

22 Chujō Suketoshi, Rai densen no keiro (Tokyo: Zaidan Hōjin Rai Yobō Kyōkai, 1935), 8.

23 Takano Rokurō, "Kusatsu monogatari," Isha no kuroyaki (Tokyo: Kibundō Shobō, 1943), 53.

24 Naimushō Eiseikyoku (Hoken eisei chōsa kai Mitsuda Kensuke jutsu), Rai yobō ni kan suru iken, (1921).

25 Yamamoto, 98-9.

26 Takaoka Hiroyuki, Sōryokusen taisei to 'fukushi kokka': senjiki nihon no 'shakai kaikaku' kōsō (Tokyo: Iwanami Shoten, 2011), 228-9. 


\title{
8 "They are not human" \\ Hansen's disease and medical responses to Hōjō Tamio ${ }^{1}$
}

\author{
Kathryn M. Tanaka
}

\section{Introduction}

"You're certainly outstanding as a man of letters, and you have a brilliant hand for writing, but as a person you're nothing." 2 Fujimoto Toshi (19011987), an inmate at Tokyo's Zensei Hospital, heard this spoken by a doctor to fellow Hansen's disease patient Hōjō Tamio (1914-1937) in 1934. ${ }^{3}$ The attitude was not unusual. Many people believed that patients were in the hospital for the good of the nation, to prevent the spread of the illness, and to benefit from palliative care. For many medical professionals, the hospitals were a humane way to treat patients, providing them with a haven from social stigma. At the same time, a number of doctors viewed their patients as having little human value, without a claim to any agency with which to relate their own experience.

Doctors' attitudes towards Hansen's disease were underpinned by a complex global response to an illness implicated in projects of empire-building. Scholars have repeatedly demonstrated that diseases are culturally, socially, and legally constructed, invested with meaning beyond its etiology. At the same time, unlike other illnesses, the fear of Hansen's disease was bound up in ideologies of imperial medical practices. ${ }^{4}$ The biopolitics of Hansen's disease in Japan must be understood not only in terms of its dialogue with national hygienic policies, but within the broader discourse of socially and politically produced meanings and medical practices developed through imperial encounters. ${ }^{5}$

This essay centers on one of the most famous authors of a genre that came to be known as "leprosy literature," Hōjō Tamio (real name Shichijō Kōji). ${ }^{6}$ In addition to Hōjō's work, I examine the reactions of medical professionals to it - that is, I examine the way in which some doctors sought to limit patient writing according to medical and legal meanings of the illness and with a consequent reduction of the patient to a life devoid of political or social engagement. I demonstrate that writing by sufferers and its meaning became one of grounds in which the social meaning of the illness and its representations were constructed.

A narrow definition of patient experience was concomitant of the attempts to limit possibilities for patient communities and treatment that Waka 
Hirokawa traced in her contribution to this volume. Hirokawa has demonstrated the multiplicity of definitions of the disease in Japan, not only in epidemiological understandings of the illness but also in the fluidity of isolation policies targeting the illness. ${ }^{7}$ As relief organizations and doctors such as Takano Rokurō and Mitsuda Kensuke campaigned against multiple etiologies of illness, or what Hirokawa has described as "folk epidemiology," patient writing presented narratives that countered medical discourse and practices in ways that physicians sometimes saw as problematic. ${ }^{8}$ By providing alternative accounts of hospital experiences, such narratives opened a space that allowed for patient experiences outside of the frame proscribed by modern medical policies.

Patient writing contested the impulse to reduce patient experience to a clinical definition. Many doctors felt Hōjō's writing inaccurately represented an institution they believed was inherently benevolent and served the greater national good. Certainly, Hōjō challenged the official idea of the hospital and its quarantined life. With his publications, medical professionals lost some of the power to define what it meant to have Hansen's disease. Hōjō claimed for patients the power to represent their own experiences. In so doing, he resisted the "medical gaze" Michel Foucault described in The Birth of the Clinic that reduces patients to objects. ${ }^{9}$

Thus, doctors' reactions to Hōjō's works clarify another context for defining the meaning of Hansen's disease and shaping the stakes for patient experience. To highlight the dialogue between medical responses to Hōjō and his work, the final part of this essay examines one work, Hōjō's most famous novella, "Life's First Night." I show the ways his writing gave voice to varied experiences of the hospital and illness, threatening to undermine official representations of life in the sanatoria.

Reading his work in the context of the hospital has become the dominant response to Hōjō's work, creating a kind of quarantine for his literature in which Hōjō's short stories are mined for historical data about life in the hospital or biographical data about Hōjō's personal hospital experiences only. In such readings, Hōjō's writing is stripped of its power to represent the illness and death of patients from their point of view; instead, there is implicit acceptance of the meanings that the hospital assigned to patient suffering and death. Yet isolation was never absolute, and patient writing was always in dialogue with broader conceptualizations of the illness and society outside of the hospital, including literature.

\section{The colonial encounter with Hansen's disease in Japan}

Colonial-imperial encounters initially reinforced the idea that Hansen's disease was an affliction of primitive cultures since it was seen as part of the Western historical past. As Susan Burns and Waka Hirokawa have demonstrated, responses to Hansen's disease in Japan were always in dialogue with Western discourse about the illness and as such were tied up in ideologies of nation, race, and empire. ${ }^{10}$ The disease had largely disappeared in Europe after the 


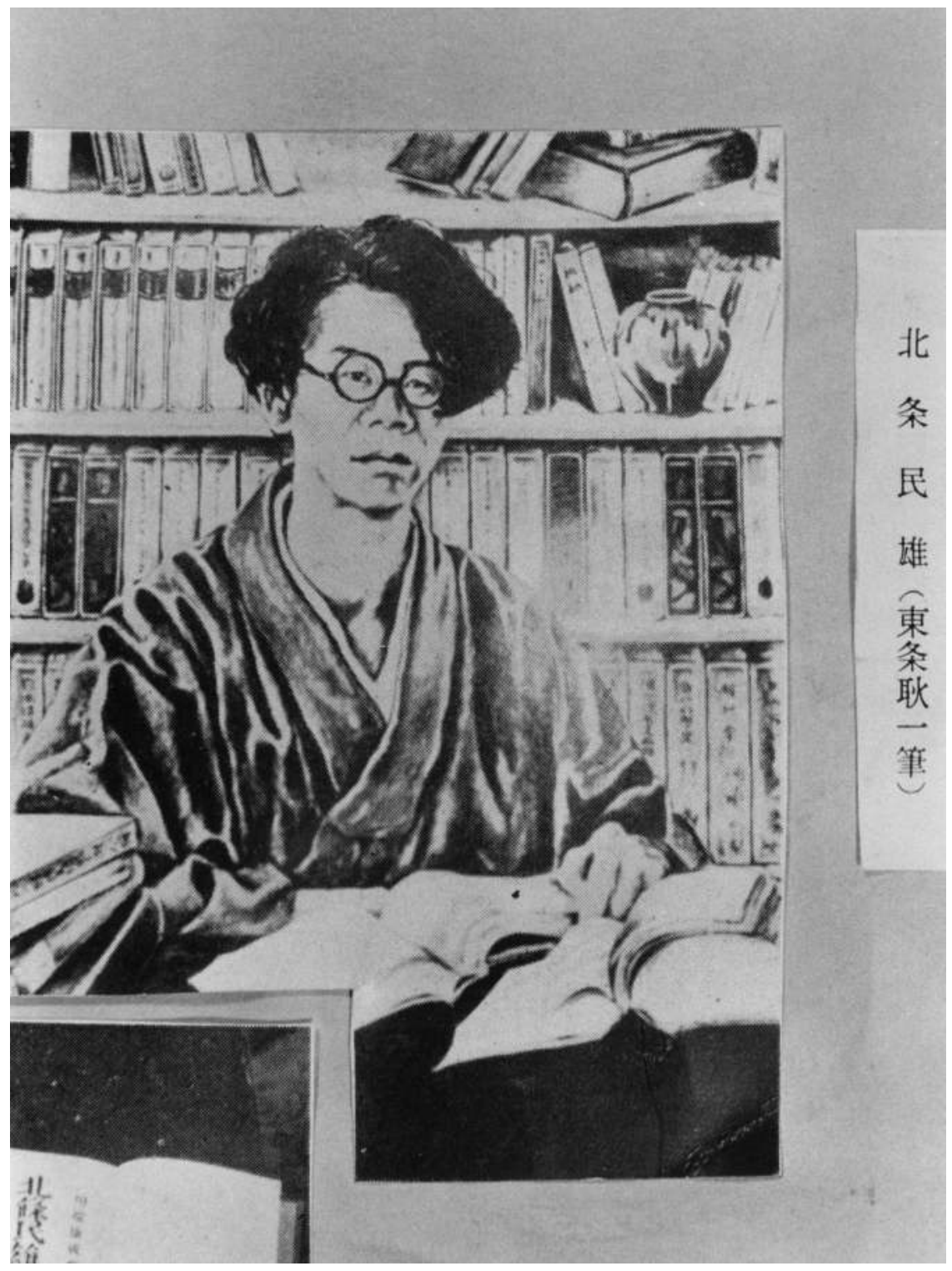

Figure 8.1 Hōjō Tamio, by Tojo Koichi (1936)

Source: Image courtesy of the National Hansen's Disease Museum, Tokyo, Japan. 
medieval period, and it was assumed that with the development of "civilization" Europeans had acquired immunity. By implication, places where it remained were thought inferior.

Conversely, popular medics often pointed out that Hansen's disease was "the sole major disease that 'inferior' peoples could bestow on the 'civilized' West."11 As Rod Edmund pointed out, "leprosy ... has had extraordinary potential for becoming more than itself;" again and again the illness acted as a prism to reflect symbolic threats from "natives" or fears about internal social threats. ${ }^{12}$ The discourse of tropical medicine associated Hansen's disease with the threat of contagion from non-European populations, specifically mapping the disease as indigenous to certain colonial bodies.

At the turn of the twentieth century, Japanese imperial engagement with Western ideologies of empire and medicine had serious implications for the Japanese treatment of Hansen's disease. First, medical policy was partly a response to Western imperialist threats against the emergent Japanese empire. At the same time, medical practices targeting Hansen's disease were transmitted to its own colonial possessions, as the colonial governments opened Hansen's disease hospitals in Korea (1916), in Taiwan (1930), and in Manchuria (1939). The treatment of Hansen's disease should be understood as a demonstration of mastery of medical modernity within this complicated matrix of imperial ideologies and signification of Japan's civilized status.

The fear of contagion was itself a hallmark of medical modernity. Microbial etiology redefined health and subsumed individual liberty under governmental protection of the health of its citizens: "no one had the right to contaminate others ... . Disease was no longer a private misfortune but an offense to the public order." ${ }^{13}$ In Japan, germ theory won fairly wide acceptance within the medical establishment, which became a basis for the linkage of individual health status with national well-being. ${ }^{14}$ Hansen's disease was an unusual case in that its etiology remained beyond absolute proof, feared in part precisely because it was so little understood.

The acceptance of germ theory meant that the battleground for fighting microbes were medical - the hospital and the laboratory. The laboratory was a sign of civilization and medical achievement - a demonstration of mastery of the microbe and regulation of unruly bodies. The laboratory was a place of "white coats, hand washing, strict hierarchy, correct training, isolation, inscription - in short, a place of somatic control and closure, organized around the avoidance of contamination." 15

Hansen's disease became an important arena in which to demonstrate somatic control. Many Japanese doctors espoused the idea of Western medical authorities that "the incidence of leprosy was a barometer of the state of civilization ... [and] civilized people everywhere shunned lepers." 16 This was the logic underpinning the push some made for stricter isolation policies and facilities within Japan.

Doctors' understandings of Hansen's disease and patient writing should be understood within the rubric of microbial medicine, the laboratory in service 


\section{Kathryn M. Tanaka}

to public health, and Hansen's disease categorized as a threat to national health. As in the Molokai sanitarium in the United States, Japanese Hansen's disease hospitals functioned simultaneously as isolation facilities and active laboratories - a distinctly colonial practice of medicine. ${ }^{17}$ Indeed, the English term "leper colony" suggests a logic of interior colonization based on modern medicine and a bacteriological disease etiology. A diagnosis of Hansen's disease often meant a forfeiture of legal protection and rights. Sufferers were vulnerable to expulsion from their community and institutionalization. The hospital was also an interior colony in the sense that it became the ruling apparatus governing patients' daily lives and their ability to have a voice was limited by the institution's boundaries. ${ }^{18}$ Spatially and conceptually, the hospital in Japan simultaneously reinforced the idea of the Hansen's disease sufferer as a pathological body poised to infect healthy citizens.

While the medical and legal construction of Hansen's disease was informed by the discourse of tropical medicine, it is important to note that even under germ theory Hansen's disease remained an uncertain, contested etiology. Indeed, as Waka Hirokawa discussed in her contribution to this volume, Hansen's disease has a long history in Japan, and even in the modern era, laws targeting those suffering from it were not evenly applied and quarantine was never absolute. The varied responses to Hōjō were part of the contestation of the meaning of Hansen's disease and the debates about the way in which patients should be treated.

\section{Doctors reading Hōjō Tamio}

Hōjō Tamio was diagnosed with Hansen's disease and entered Zensei Hospital in Tokyo in 1934; he became active in the hospital writing circle soon after, and in 1935 he began to publish in magazines outside the hospital with the help of his mentor, Kawabata Yasunari (1899-1972). While doctors encouraged patient writing as therapeutic, they did not recognize the potential dangers of a popularization of patient writing until Hōjō began to attract the attention of literary coteries. ${ }^{19}$ Once his work gained attention from the literary establishment, medical professionals re-examined the purposes of patient writing, an unsurprising turn as medical authorities were invested in a narrative of medical hegemony and somatic control of the ill.

Hōjō's representations contradicted medical representations of the hospital; in his work it was a place that was anything but orderly and controlled. His writing was populated with patients leaving the hospital on furlough, babies being conceived or born in the institution, insane sufferers, and patients with unruly bodies who could not be controlled. Hōjō's promotion by Kawabata and his notice by the literary coteries brought all of these elements of hospital life into the public domain.

Widespread recognition of Hōjō's work drew doctors to examine patient writing and to publish their own reviews. Two men, Dr. Nitto Shüichi, a doctor who worked briefly at Zenshō-en (1908-?), and Takano Rokurō (1884-1960), 


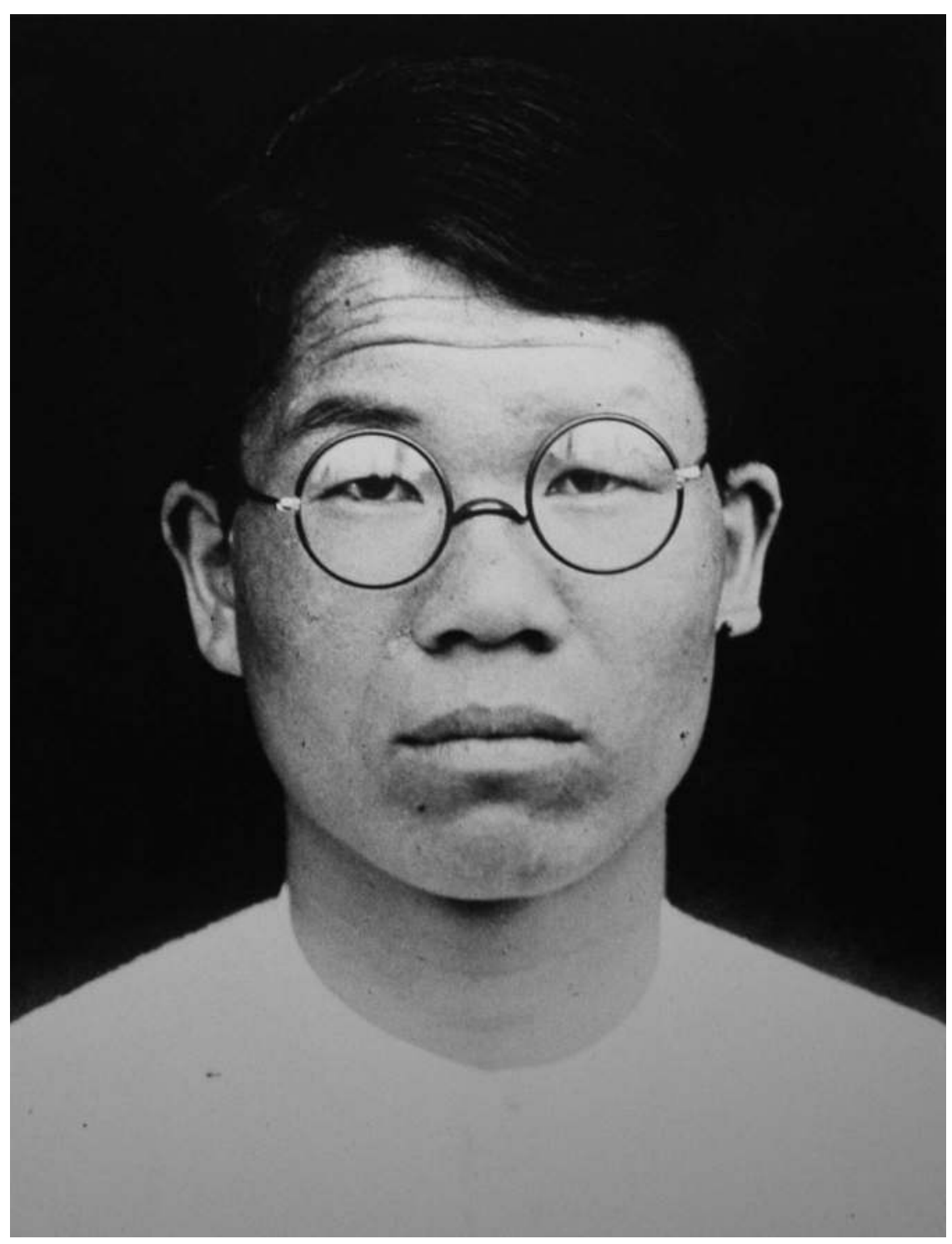

Figure 8.2 Hōjō Tamio upon institutionalization (1934)

Source: Image courtesy of the National Hansen's Disease Museum. ${ }^{20}$ 


\section{Kathryn M. Tanaka}

chief of the Prevention Agency in the Ministry of Health, represent varied responses. Their discussions of patient writing appeared in medical publications such as Iji kōron (Review of Medical Matters), Shakai jigyō (Social Services), Shakai jigyō no tomo (Companion to Social Services), and Kōshū eisei (Public Hygiene). ${ }^{21}$ Takano's attitude was common, while Nitto's evaluation represented an unparalleled extreme. To both of these doctors, Hōjō's work was a record of a very particular experience, one not representative of patient experience, and thus not true literature.

The focal points of the opinions of these men framed patient writing as narrowly defined "leprosy literature." They insisted that patient writing was simply therapeutic and had no broad social or historical significance outside the context of the hospital. To such doctors, patient writing was a journalistic record of a very particular kind of experience, one that had no relevance to humanity in general and therefore not true literature. Nitto and the doctor quoted in the beginning of this piece clearly believed that patients were in the hospital for treatment and believed that treatment and the eradication of the illness should be the focus of patient energies, with literature a distant priority. It is worth noting that while Nitto argued against its use in public health campaigns, even he was not entirely against the therapeutic use of literature.

In a 1937 introduction to a volume of patient writing and one of the earliest medical responses to "leprosy literature," Takano Rokurō supported patient

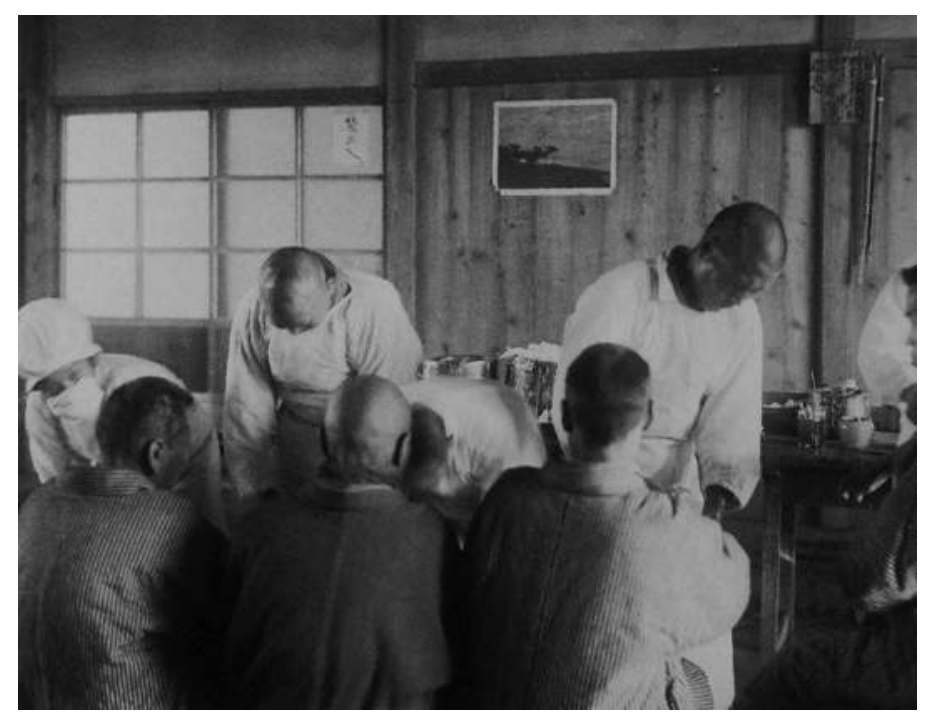

Figure 8.3 Medical staff and sufferers who were light cases provide care for seriously ill sufferers, Zensei Hospital (1919). Note the nurse's mask and head covering to prevent contagion

Source: Image courtesy of the National Hansen's Disease Museum. 
writing as therapy, noting that patients who come for treatment could nurture their psyches as well as their bodies through writing. Takano underscored the point that, for doctors, patient writing could first, raise support for quarantine and urge patients to voluntarily enter the hospital by including patient work in pamphlets or in short-story collections published by relief organizations, and second, serve as a therapeutic tool helping sufferers come to terms with their diagnosis and quarantine. ${ }^{22}$

Takano's discussion of the purpose of patient writing was a clear articulation of doctors' views that patient writing should be contained within the hospitals, or at most read by an audience of sufferers undergoing treatment at home, in a community, or in a facility of the type discussed by Hirokawa. As Hirokawa notes, isolation policies of the central government were weak and largely unenforceable locally. Institutionalization frequently remained voluntary, and some doctors believed literature could be a powerful tool to encourage sufferers to admit themselves to a facility.

Hōjō Tamio's frank and macabre depictions of illness and life in the hospital disrupted any clear reading of his work as supportive of quarantine policies. While he may not have openly rebelled against hospital policies, his writing certainly exposed the darker reality of life within the hospital system. Few sufferers who read his work would voluntarily seek admission to the institution he describes. Even doctors sympathetic to patient writing, such as Takano, had reservations about Hōjō's work and its impact outside of the hospital.

Doctors like Takano supported patient writing only within the parameters they defined. To give another example, in an article on patient writing published in Companion to Social Services, Takizaka Yōnosuke (dates unknown) described patient writing as follows: "[T]here is leprosy literature, which partakes of journalism. It is a part journalism, and its point is probably not to ultimately be literature; instead, leprosy literature has the hidden goal of being an important part of leprosy relief work ... ." ${ }^{, 3}$ For some medical professionals, then, patient writing could be useful in documenting patient experience journalistically as part of the Hansen's disease relief movements, but they remained reluctant to accord such writing the cultural cachet of being literature.

Other doctors did not approve of publication of patient writing outside the hospital in any format at all. Most vehement in his denunciation of patient writing as anything other than therapeutic was Nitto Shüichi. In the special issue on Hansen's disease published by the Review of Medical Affairs, Nitto argued for the importance of separating Hōjō the author from Hōjō the human being. Yet for Nitto, that human being was reduced to a patient, with no social value or authority to represent his experience of the hospital. ${ }^{24}$

In Nitto's opinion, the focus of Hōjō's writing was wrong: "His agony should have been the agony of 'life,' [his] tragic fate. Instead, he ... shouts his curses of society, his curses of the hospital, his overconfidence in himself, his conceit." ${ }^{25}$ Hōjō egoistically wrote for fame and had no talent as a writer and no value as a person. Consequently, Nitto criticized Kawabata for giving patient writing undeserved attention: "The sanatorium is not a cultural 


\section{Kathryn M. Tanaka}

institution," and it should not have been promoted as such. ${ }^{26}$ Indeed, patients should silently endured quarantine as their national duty in vanquishing the disease; there was no need for "leprosy literature."27

Nitto insisted that patient writing had no value as promotional material for government isolation policies; it had no value at all outside of the hospital. Hōjō's writing about the darker side of hospital life did a disservice to other patients; he was little more than mocking his fellow sufferers. While other doctors saw educational and advertising value in patient writing, Nitto concluded: "In the work of leprosy eradication, literature is worth about as much as a fart. In the case of [negative and resistant] literature like Hōjō's, then ... I think the [hospital] censorship system is necessary." 28 The country, he argued, provided shelter, clothing and food for the patients, so the aim of doctors and patients should be support of government policies and disease eradication. Doctors, patients, and the public should support the Leprosy Prevention Association, and the Association should stop using patient literature in their pamphlets. ${ }^{29}$

Nitto's extreme devaluation of patient writing reveals his concern about the impact Hōjō's work might have on medical professionals and institutions. Other physicians share this concern; even prominent proponents and editors of patient writing such as Uchida Mamoru (1900-1982) did so with the supposition it was written primarily for therapeutic purposes. Uchida was unusual in his encouragement of patient writing and his support of the circulation of literature within and outside the hospital; in general the medical leaned toward Nitto's views. Writing disrupted their narrative of the hospital as under firm yet helpful medical control. Even supportive doctors saw it as primarily therapeutic or propagandistic and as problematic when presented outside hospitals.

Horiguchi Ei'ichi (dates unknown), a doctor at the Tokyo hospital, supported Hōjō. He noted that Hōjō and his experience were exceptional among sufferers, even patient writers. While he praised Hōjō's work, he nonetheless pointed to the tension created by his writing. On the one hand, Hōjō's work had global importance because of its unique perspective; at the same time, its existence demonstrated the failures of social policy:

The majority of civilized countries have completely conquered leprosy; to say there is a shortage of materials in our laboratories is also to say that we are at the starting point. Rauche has written that patients writing works themselves is almost unheard of in civilized countries. Thus, Hōjō's works are a global phenomenon. Such works are a gift that was born in Japan, a civilized country lagging far behind in the business of social welfare. If Hōjō's works are translated into English and shown to the people of civilized nations, before they rave about his work, without a doubt they will first express shock that there are still leprosy patients in Japan. ${ }^{30}$

Horiguchi stressed the fact that Japan was a "civilized" country, while at the same time noting that Hōjō's presence indicated a contradiction: "civilized" 
countries had "conquered leprosy," but not Japan. Horiguchi attempted to resolve this by stating that civilized Japan still "lagged behind." The passage brings into sharp focus the ways in which concerns about Japan's status as a "civilized" (imperial) nation was embedded in responses to patient writing.

For doctors to praise Hōjō's writing as literature was a tacit acknowledgement of its potential to critique the hospital or medical representations of patient experience; Hōjō reclaimed his experiences from a medical narrative of unavoidable patient sacrifice. Furthermore, if Hōjō's work was recognized as literature, Hōjō's writing would have a cultural cachet that doctors were loath to accord patients: when a patient entered the hospital they were subsumed within its medical narrative. To acknowledge Hōjō as a literary author would acknowledge his ability to represent his own experience. By refusing to accept his work as literature, doctors underscored their belief that patients should accept medical definitions and meanings of the illness. Doctors viewed journalistic records as a valuable part of Hansen's disease relief work, but few were willing to accord a social cachet to Hōjō that they did not possess themselves: the ability to write literature.

\section{Patient experience in "Life's First Night"}

Hōjō believed his writing was literature and rejected the label "leprosy literature." In a posthumous, unfinished essay he wrote:

I do not believe there is such a thing as leprosy literature, but if there were such a genre, by no means do I want to write such a thing ... . I have not written it in the past, and ... I doubt I will write it hereafter. People can call what we write whatever they like ... . I simply want to write about humanity. Leprosy is nothing more than one case in writing about humanity. ${ }^{31}$

For Hōjō, categorizing his literature reduced its potential to be read and understood as literature representative of humanity. The evocation of a category of "leprosy literature" situated patient writing "within the medical narrative of illness and patient treatment. Hōjō resisted the way that usurpation of his experience." 32

In fact, Hōjō's work was directly at odds with imperial medical narratives represented the illness. Under the newly imported rubric of modern medicine, treatment facilities and laboratories for the treatment and study of Hansen's disease depersonalized bodies, controlled, organized, and displayed them in museums. ${ }^{33}$ Hansen's disease hospitals were organized around similar principles and displayed patient bodies in ways similar to Western colonial institutions. Hospitals opened for medical and relief work tours, and museums and laboratories were attached to them.

The medical control of Hansen's disease is implied in a visit to the museum attached to the hospital: 
The preserved sections showing the extirpated nerves of lepers, full of nodules, are regularly enlarged [and] deserved all our attention ... . [Also on display were] (f)ine pieces of the facial bones showing the various phases of lesions of the nasal septum ... [and] parts of the throat showing pharyngeal and laryngeal lesions. [There were] (e)xcellent models in wax of typical cases of leprosy of various forms. [There were also] (a)mplified photographs of various patients who profited by the treatment ... to be compared with the lesions and to verify the clinic cure. Six microscopes were mounted with excellent histologic preparations: sections of skin with leproma or infiltration or initial erythema and others showing the progressive disappearance of bacilli in the cases treated. They showed us also excellent preparations of nerves, glandes, and nervous centers with bacilli. ${ }^{34}$

Here we see the exhibition of the bodies of Japanese Hansen's disease sufferers, informed by colonial medical practices and put on display to foreign visitors as a demonstration of the Japanese mastery of Western medical discourse, and positioning of Japan as an equal of Western nations. As in the West, the normal and pathological were displayed to reinforce bacteriology as authenticating medical authority through its capacity to protect the national body, identify and control infectious elements within the Empire. Containment and control of Hansen's disease was a key to defining how Japanese nationhood would be constructed within the colonial hegemonic order. ${ }^{35}$

Contrast descriptions of the display of bodies undergoing cure with Hōjō's description of sufferers in "Life's First Night." For Hōjō the hospital was disorderly, full of disruptions and unruly behavior. His short story depicted Oda, a young man just admitted to Zensei Hospital, as he spent his first night in a ward for serious cases. The gaze Oda turns upon the inmates of the ward was very different from a doctor's; while the patients were still anonymous and the following is certainly a description of their condition, their suffering is not medicalized:

The serious cases that he couldn't bear to look at earlier were sleeping in the two rows of beds, gasping for breath .... Oda's neighbor ... was a sleeping man with hands that looked like the rounded ends of a wooden pestle hung over the edge of his bed. Across from him was a young woman, whose turned-up face was destroyed by countless nodules ... . Her appearance was cruelly disfigured, yet voluptuous.

As Oda studied the next man, he couldn't help avoiding his face. His ... entire body was wrapped in bandages ... . Oda held his breath and terrified, fearfully moved his eyes over the form, as a chill swept over his body. Can I believe that this is even human? Even the man's genitals, exposed under the electric light, [revealed] countless nodules, appearing like black insects... . Even at that point, they don't die - Oda ... could not help but feel the ghastly perseverance of life's vital energy. ${ }^{36}$ 


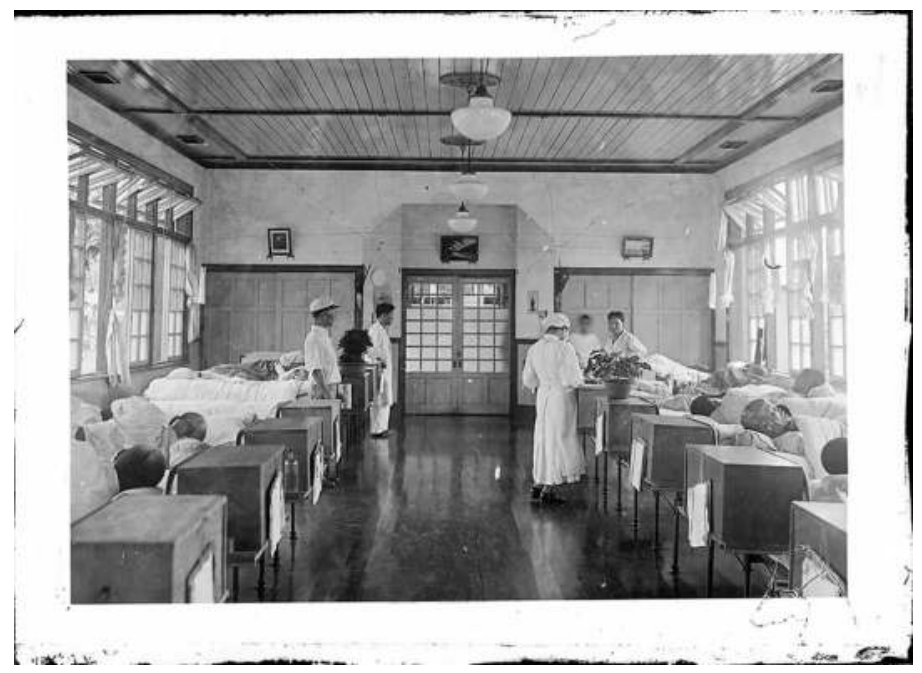

Figure 8.4 A ward for seriously ill cases, Zensei Hospital (1933)

Source: Image courtesy of the National Hansen's Disease Museum.

Hōjō's depiction is at odds with the idea of a hospital as an orderly, wellmaintained place where patients went for cure and rest. The bodies in Hōjō's work are not cured: their grotesque nature is fully displayed. The ravages of the illness, beyond the control of medicine, are on full display. Furthermore, as Saeki noted in response to Oda's inquiry about why a sobbing man is not receiving medical attention: "The only treatment is, well, just giving him a shot of anesthetic, which only helps for a short time ... . At best, if we could give morphine it would be better, but they don't allow that at this hospital." ${ }^{37}$ Hōjō presents the limits of medical technology and the disintegration of patient bodies through the gaze of the sufferers.

Hōjō also described the way in which the patients were inscribed as sufferers within the institution. A conversation between Oda and Saeki, a patient writer assigned to introduce Oda to life in the hospital, has often been cited as demonstrating how patients found and accepted a new life within the hospital:

"Oda-san, do you think these people are human?"

"They're not human. It's life. Only life, it's just life. Can you understand what I'm saying, Oda-san? The 'human' in these people has already died. All it is is life, flickering life ... . The moment a person gets leprosy, their humanness perishes ... . It's not just that his humanness as a social being dies ... . It's not a crippled soldier, it's a crippled person. But, Odasan, we're phoenixes. When we have new thoughts, when we have new eyes, when we completely accept the life of lepers, then we are revived as 
human ... . A new human lifestyle starts there. Oda-san, now you're dead. And being dead, you're not human. Think about where your agony and despair come from. Isn't it because you're seeking the person you were in the past who is now dead?"38

Rather than rebirth into life in the leprosarium, the above describes the social death of a person, or an introduction to a state of exemption, a condition of duress in which human rights are superseded as the government extends its power. ${ }^{39}$ Patients' bodies underwent a process of colonization as admission to hospital redefined what it meant for them to be "human." Many human and social rights were suspended, their bodies were subject to medical control, their voices were silenced as they were subsumed into the hospital structure.

Voices like Hōjō's that resist silence were of immense importance as a counter-narrative. The true survivor of extreme experience is not the writer. It is the voices of those silenced by death or those reduced to bare life-life controlled and categorized by modern biopolitics, a life barred from a meaningful social or civic existence. ${ }^{40}$ Those reduced to bare life did not have a voice: "With its every word, testimony refutes precisely this isolation of survival from life." $" 41$

While the above scene has often been read as a rebirth into life in the leprosarium and adjustment to the hospital, it does not merely represent rebirth, but also resistance to the hospital's attempts to reduce patients to bare life. Hōjō depicted biopolitics operating directly upon the sufferer. He described those who could no longer speak for themselves. Thus, rather than accept the death of their social beings, Saeki, also a patient writer, explained that he and Oda would find a new way, not just to live, but also to speak. Oda, in turn, had to accept the fact that despite his suicide attempts he must bear witness. Through bearing witness, Hōjō revealed the ways in which life continued in the hospital, and this, in turn, was a kind of politics that refused to be silenced or accept the meanings ascribed to Hansen's disease sufferers: it resisted biopolitical categorizations.

Hōjō depicted bare life in the hospitals not only by refusing to be silent but also by bearing witness on behalf of patients who could not speak. Both Oda and Saeki occupy a liminal space between sickness and health, but as patients they have the power to represent the experience of the seriously ill. It was precisely this liminal space of being not very ill yet no longer healthy that gave Hōjō an arena from which to question the meaning of patient experience and to offer counter-narratives of hospital life. In the context of these blurred boundaries, Hōjō's writing became dangerous to the hospital: it could not be defined or contained.

The porous, liminal space Oda inhabited is marked throughout by references to the minimal effects he suffers from the illness. Although Oda underwent a medical examination that was like a police interview, the only hint that Oda's body has been affected by the disease is his pulling a hat over his eyes to cover his thinning eyebrows on route to the hospital. Although showing more signs of the illness than Oda, Saeki is also relatively healthy. The grotesque 
bodies of serious cases stand in sharp contrast to the relative health and youth of both characters.

The divide between the ill and the healthy was apparent from the moment that Oda is hospitalized. One of the first scenes depicts Oda undergoing one of the processes of institutionalization, a disinfectant bath supervised by female nurses clothed from head to toe in white protective garb, in a tub used by all the hospital residents - driving home to Oda that he was now a member of the patient community, cut off from society. The setting humiliated the patient and reinforced their separation from the outside world. As Oda bathed, his luggage was confiscated and searched. The description of such rituals was intended to evoke the despair Oda felt. ${ }^{42}$

As the illness became more severe, patients experienced not only an increase in physical impairments but also a loss of the ability to speak, making Hōjō's representation of patient experience still more powerful. The slow decline of health and the impact of loss of speech are clear:

"atten ... en."

Oda heard a hoarse voice from the bed at the other end of the room and he closed his mouth. Saeki quickly stood up and walked over to the man. It was then Oda understood the man had called "Attendant," for Saeki.

"i wanna pee."

"Urinate, huh. OK, OK. Do you want to go to the bathroom, or do you want to use the bedpan?"

"go to the bathroom." 43

Hōjō rendered the italicized phrases entirely in hiragana, a Japanese syllabary. The appearance of the speech represented entirely in hiragana, without the inclusion of Chinese characters in the text, has several effects. First, on a visual level, Hōjō's use of hiragana separated Oda from more seriously afflicted patients. Second, the strangeness of the speech was based in the physical experience of the disease. Hansen bacilli affects the voice box, and the voice becomes increasingly difficult to understand. Hōjō used hiragana to highlight the strangeness of the patient's voice, rendering it unfamiliar to Japanese readers.

That Oda does not initially understand the patient's utterance hints at why patient writing read as testimony and fiction could be threatening: just like a person without the illness who is horrified by the description of patients, Oda also did not identify with Hansen's disease patients. His inability to understand patients' speech again marked him as inhabiting a liminal space. The existence of a liminal space where one was not yet sick but no longer healthy implies that the boundary between the two was blurred, opening up a space to challenge official hospital narratives.

Other examples of blurred boundaries between sickness and health, fiction and testimony lace the text, but in all the most serious cases patients lacked a voice. They spoke with giggles, screams, cries, or short utterances. Bathing, 


\section{Kathryn M. Tanaka}

Oda for the first time comes face to face with a man suffering from the same illness as himself.

In a moment, the glass door at the entrance to the bath was opened, and a face like a rotten pear abruptly appeared ... . It was a grotesque face. It was not just the mud-like complexion, or the face so swollen it looked as if pus would burst out with the lightest touch; on top of that, there was not a single hair in the brows of the man's face, making him look suspiciously like a nopperabo, both grotesque and idiotic. ${ }^{44}$ His breathing was excited and he was panting, perhaps because he had been running. He stared at Oda with festering yellow eyes .... It was the first time [Oda] had seen so closely a patient with the same illness as himself. So while he was scared - terribly scared - he was also moved by curiosity ... . His expression was so strange that Oda began to get the ominous feeling that this was a madman. ${ }^{45}$

Throughout his story Hōjō insists on ambiguity rather than clear meaning, and nowhere is this more evident than in his depiction of voiceless sufferers. Hōjō did not attempt to ascribe meaning to their cries or shouts: he left the meaning open. There was no meaningful resolution of the contradictions Hōjō introduced in his text.

Hōjō's resistance to ascribing meaning to patient experience was echoed at the end of "Life's First Night," often read as a reluctant acceptance of life in the hospital and an affirmation of patient identity.

"Ah, day is already dawning, isn't it?"

Saeki spoke as he looked outside.

"Even though I'll undeniably go blind, Oda-san, I'll still write. If I become blind, I expect there will be another way to live. I'd ask you, too, to start a new way of living. Accept that you are a leper, and then discover a path to move forward. I'll work hard until I can no longer write."

$\cdots$

As the darkness around them slowly sank into the earth, the brilliant sun appeared above the woods, rays of light streaking the sky and flowing over the treetops, then flooding the strong trunks. Oda still had deep misgivings — as to whether he could attain Saeki's world, but while he looked at the streaming rays of sunlight he determined he would try to live. $^{46}$

Oda's reaction is not an unequivocal acceptance of patient identity but a resolve to find a way to live in the hospital in which he found himself, a way to live for himself, to define his own experience. Note that Oda's resolution was not to live, but to try to live, with death still a possibility. Furthermore, he resolves to enter Saeki's world, which was not just the world of the seriously 
ill but also the world of patients who had the "talent" to describe their experiences on their own terms. The end of the story is Oda's insistence on creating his own meaning for life in the hospital - that is, not accepting the narrative that life in the hospital was his duty as a Japanese citizen diagnosed with leprosy, expressing gratitude to the Japanese state, à la Nitto.

Saeki and Oda predicated adjustment to life within the hospital on finding a way to define their experiences for themselves and being heard. Life was tied to their ability to document their circumstances on their own terms. In the final lines of "Life's First Night," Oda resolves to continue to fight death; in doing so, he joined Saeki as one bearing witness through his writing. Through his writing, Hōjō survived positively, "a person who, in fighting against death, survived the inhuman." 47

\section{Conclusion}

Medical professionals and many literati reacted to Hōjō by arguing that such writing should be read not as literature but as therapy or documentary only relevant within the context of the hospital. This was an attempt to silence and control patients' representation of their own experiences, in part because such narratives challenged the presentation of the hospital as a place of control and medical containment. In the hospitals, patients were reduced to bare life and were not supposed to have a voice. Published expression of their experiences contradicted the medical establishment and the push by doctors such as Mitsuda for stricter isolation policies. Hōjō blurred the strict dichotomies that were to guide patient life, but he also obscured the boundaries between fiction and journalism, making it difficult to contain or respond to his writing. Hōjō's work insisted on the importance of patient experience. When writing threatened to give patients the autonomy to create their own narrative, the medical authorities pushed understandings of patient writing towards the "therapeutic" and away from the "literary."

The opportunity for patients to create a history of their own experience through fiction, exemplified by Hōjō's writing, was constrained after his death. Hospital officials realized the power of literature to provide a counter-narrative of hospital life. When patients were recognized as authors, their writing achieved greater cultural cachet, with the power to question medical control and expose its limits.

By dismissing its literary value and promoting it as a journalistic element of relief work, hospitals and relief groups were able to use depictions of patient experience to support government policies and encourage patients to seek treatment in the hospital; this reading imposed by doctors on patient writing dominates today. Hōjō's work is often read as accepting of life within the hospital and his legacy was defined by these reactions to his work, but in fact Hōjō provided an alternative narrative of the biopolitics of Hansen's disease and revealed their human cost. He refused to accept the usurpation of his experience by the hospitals and doctors, by visions of civilization and 
modern scientific-medical expertise that the emerging imperial state promoted in its competition with other powers. He insisted on telling his own story. As Hōjō puts it, it is through literature that "a flickering, living life has attained a physical body. A new human lifestyle starts there." 48

\section{Notes}

1 I wish to thank our editors, Philip Brown and David Wittner, for their generous insights into this paper. Further, I would be remiss if I did not acknowledge my profound debt to Professor James R. Bartholomew.

2 Fujimoto Toshi, “Jimen no soko ga nuketan desu," in Hansen-byō bungaku zenshū, 10 vols, ed. Ōoka Makoto et al. (Tokyo: Koseisha, 2002-2010), 4: 31.

3 Hansen's disease is the term preferred today for the disease also known as leprosy.

4 Three examples of scholarship on the influence of imperial ideologies targeting Hansen's disease: Zachary Gussow, Leprosy, Racism, and Public Health: Social Policy in Chronic Disease Control (Boulder, CO: Westview Press, 1989); Michelle T. Moran, Colonizing Leprosy: Imperialism and the Politics of Public Health in the United States (Chapel Hill, NC: The University of North Carolina Press, 2007); and Rod Edmund, Leprosy and Empire: A Medical and Cultural History (Cambridge: Cambridge University Press, 2006).

5 Susan L. Burns, "Rethinking 'Leprosy Prevention': Entrepreneurial Doctors, Popular Journalism, and the Civic Origins of Biopolitics," Journal of Japanese Studies, 38: 2 (2012), 301-27.

6 For more on "leprosy literature" and "Hansen's disease literature" as genres, see Kathryn Tanaka, "Through the hospital gates: Hansen's disease and modern Japanese literature," Ph.D. dissertation, University of Chicago, 2012, and "Rois Jonsson Erikkson fujin to Nagata Honami: Kirisutokyō senkyōkyoshi to rai bungaku no fukyū," Otemae daigaku ronshū 15 (Nishinomiya: Otemae University, 2015), 119-47.

7 For parallels elsewhere, see Moran, Colonizing Leprosy, 9.

8 Hirokawa Waka, "A Colony or a Sanitarium? A Comparative History of Segregation Politics of Hansen's Disease in Modern Japan," this volume.

9 Michel Foucault, The Birth of the Clinic: An Archaeology of Medical Perception (New York: Vintage Books, 1993).

10 Susan L. Burns, "From 'leper villages' to leprosaria: Public health, nationalism, and the culture of exclusion in Japan," in Isolation: Places and Practices of Exclusion, ed. Carolyn Strange and Alison Bashford (Oxford: Routledge, 2003), 104-18; Burns, "Rethinking 'Leprosy Prevention"”; Hirokawa, "A Colony or a Sanitarium?," this volume; and Kindai Nihon no Hansen-byō mondai to chiiki shakai (Osaka: Osaka Daigaku Shuppan-kai, 2010).

11 Gussow, Leprosy, Racism, and Public Health, 112.

12 Rod Edmund, Leprosy and Empire: A Medical and Cultural History (Cambridge: Cambridge University Press, 2006). For more on imperialism and Hansen's disease, see Moran, Colonizing Leprosy; and Kerri I. Inglis, Ma'i Lepera: Disease and Displacement in Nineteenth-Century Hawai'i (Honolulu, HI: University of Hawaii Press, 2013).

13 Bruno Latour, The Pasteurization of France, Alan Sheridan and John Law (trans.), (Cambridge, MA: Harvard University Press, 1988), 123.

14 Michael K. Bourdaghs, The Dawn that Never Comes: Shimazaki Tōson and Japanese Nationalism (New York: Columbia University Press, 2003), 52. 
15 Warwick Anderson, Colonial Pathologies: American Tropical Medicine, Race, and Hygiene in the Philippines (Durham, NC: Duke University Press, 2006), 111.

16 Sheldon Watts, Epidemics and History: Disease, Power and Imperialism (New Haven, CT: Yale University Press, 1997), 81.

17 Moran, Colonizing Leprosy, 33.

18 Anderson, Colonial Pathologies, 111.

19 Tanaka, "Through the Hospital Gates"; see also Uchida Morita (Mamoru), "Bungei ni yoru raikanja no seishin kaihō undo," Shakai jigyō kenkyū, 25: 9 (August, 1937), 122-7.

20 The different images of Hōjō presented here are poignant visual representations of Hōjō as he presented himself and the way the hospital identified him as a patient. Tanaka, "Life's First Night."

21 Medical magazines in the late 1930s often published articles on patient writing together with commentary on disease etiology and treatment in special "leprosy issues." See: Kagaku Pen, 3: 3 (March, 1938); Kagaku chishiki, 19: 12 (December, 1939); Shinri, 6: 4 (April 1940); and Iji Kōron, 1390 (March, 1939).

22 Takano Rokurō, "Jobun," in Raijin bungaku, ed. Nagami Yutaka (Takamatsu: Oshima Ryōyōjo kanja isha kai, 1937), i. See also Kathryn Tanaka, "Contested Histories and Happiness: Leprosy Literature in Japan," Health, Culture and Society, 5: 1 (2013), 99-118.

23 Takizaka Yōnosuke, "Raisha no tanka," Shakai jigyō no tomo, 149 (April, 1941), 78.

24 Nitto Shūichi, "Ningen Hōjō Tamio," in Iji Kōron, 1390 (March, 1939), 47.

25 Ibid.

26 Ibid.

27 Ibid.

28 Ibid.

29 Ibid.

30 Horiguchi Ei'ichi, "Raii no mita Hōjō-kun no bungaku," Kagaku Pen, 3: 3 (1938), 93.

31 Hōjō Tamio Zenshū (hereafter HTZ) 2: 138-9. Quoted in Tanaka, "Life's First Night."

32 Tanaka, "Life's First Night," n.p.

33 Anderson, Colonial Pathologies, 111.

34 Ibid., 112-13.

35 Fujino Yutaka, "Hansen-byō to kin-gendai Nihon," in Hansen-byō: haijo, sabetsu, kakuri no rekishi, ed. Kazuteru Okiura and Susumu Tokunaga (Tokyo: Iwanami Shoten, 2001), 55.

36 HTZ, 1: 42; Tanaka, "Life's First Night," n.p.

37 Ibid., 44; ibid.

38 Ibid., 46; ibid.

39 Giorgio Agamben, Homo Sacer: Sovereign Power and Bare Life, Daniel Heller-Roazen (trans.) (Stanford, CA: Stanford University Press, 1998), 1-14.

40 Ibid.

41 Giorgio Agamben, Remnants of Auschwitz: The Witness and the Archive, Daniel Heller-Roazen (trans.) (New York: Zone Books, 2002), 157.

42 HTZ, 1: 18-9; Tanaka, "Life's First Night," n.p.

43 Ibid., 35; ibid.

44 A nopperabo is a ghost in human form, but without a face.

45 HTZ, 1: 21-2; Tanaka, "Life's First Night," n.p.

46 Ibid., 50; ibid.

47 Agamben, Remnants of Auschwitz, 133.

48 HTZ, 1: 46; Tanaka, "Life's First Night," n.p. 


\title{
9 Dr. Baelz's Mongolian spot German medicine, discourse of race in Meiji Japan, and the local response
}

\author{
Rotem Kowner
}

East Asia did not escape the taint of scientific racism. From the 1860s it witnessed the arrival of Western scholars who subscribed to this approach and promulgated its tenets. The idea that humanity is broadly divided into large groups that inhabit different geographical habitats and are characterized by distinct corporeal and mental characteristics dates back to classical Greece, Rome, and the Middle Ages. ${ }^{1}$ However, during the late eighteenth century and especially around the mid-nineteenth century, this idea gained an aura of scientific validity. It was used to justify territorial expansion and the subjugation of vast native populations. Leading the quest for measuring human diversity were the medical practitioners who filled the ranks of recently established ethnographic and anthropological societies. Quite a few of them ventured overseas to observe the Other in its own habitat.

One of the most prominent Western scholars with a racial edge to anthropological and medical practice was the German physician Erwin Baelz (1849-1913), whose fin-de-siècle theories on the Japanese population's composition, origins, and medical peculiarities are of special concern (Figure 9.1). These theories exerted a long-term impact not only on Westerners' attitudes toward Japan but also on the way in which the Japanese themselves began to construe their own national identity and history. Baelz's importance in shaping racial discourse in Japan notwithstanding, he represents a certain strain of European scholarship on Japan that reached a cul-de-sac by the late Meiji era. By then, Japan had become the first nation in the non-Western world to have capitalized upon anthropological research performed on its own population. By so doing it had begun to also dominate the racial discourse on its origins and composition. This academic achievement was not fortuitous. It reflected the spectacular rise and capacity of the indigenous academic and scientific community as well as the fields that the new Japanese state believed to be important.

Questions of race were cardinal issues since they were related to national status and affected Japan's public image within and outside the country. Moreover, since contemporary Japan was coveting and building an empire of its own, the construction of a racial worldview had substantial implications on the treatment of colonial populations. By focusing on a seemingly trivial phenomenon - the passing appearance of a blue spot on a newborn's body - this chapter will 


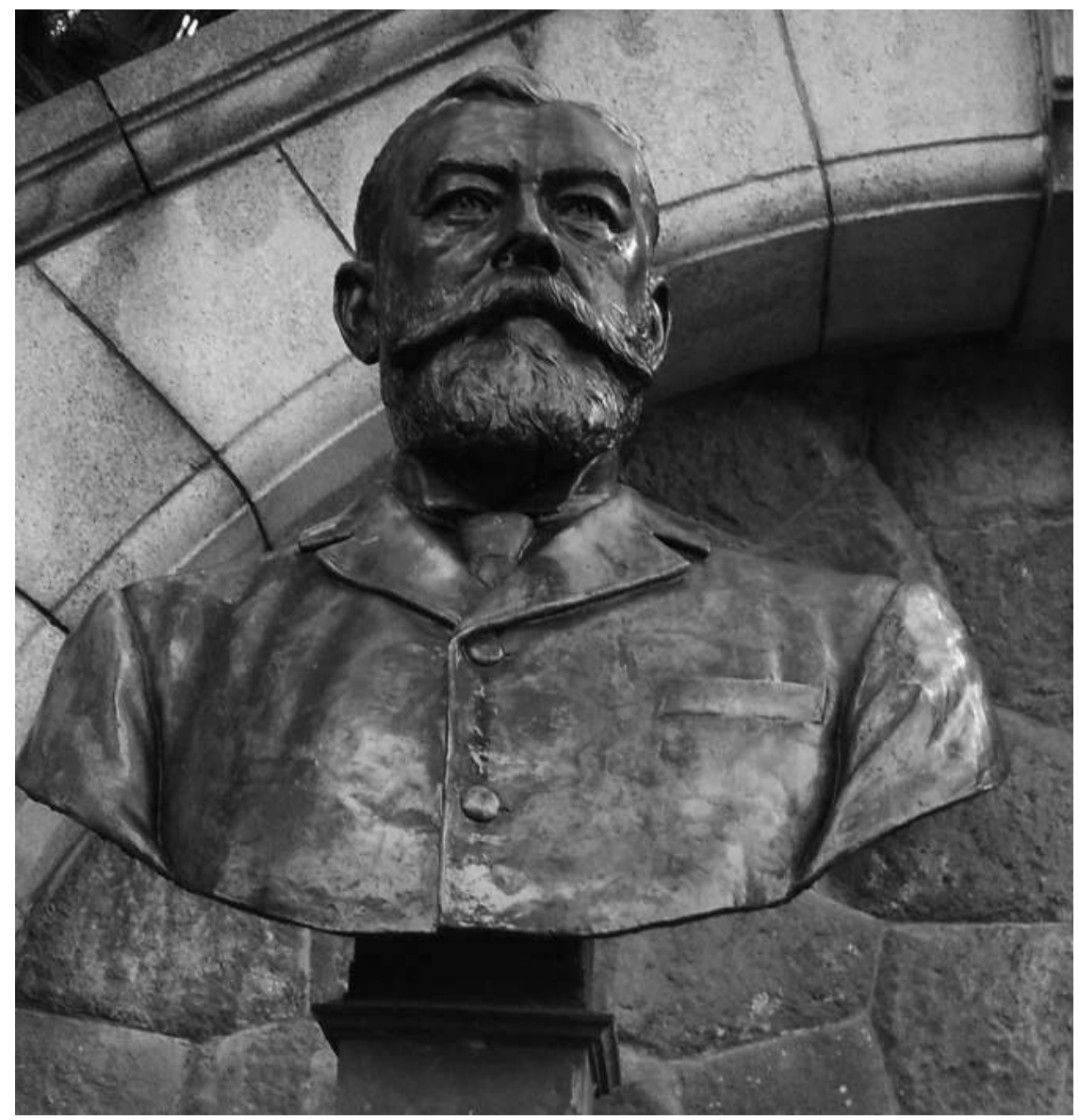

Figure 9.1 Erwin Baelz: a bust at the University of Tokyo

Source: Wikipedia Commons: http://commons.wikimedia.org/wiki/File:Erwin_Bellz.tif.

discuss Baelz's racial theories on the Japanese and the reactions it caused among Japanese scholars during a crucial period of scientific transition. Altogether, this chapter seeks to illuminate the distinctive, and apparently also unique, interaction between foreign and Japanese scientists in the construction of racial theories during the late-Meiji era and early stages of Japanese imperialism.

Born near Stuttgart, there was very little in Baelz's early biography that could suggest his personal and professional destiny. ${ }^{2}$ Apart from his admission to medical school at Tübingen University, the most remarkable event in his early adulthood was the Franco-Prussian War (1870-1), in which he served as a surgeon-major's assistant. During this conflict he contracted near-fatal dysentery but managed to complete his studies at the University of Leipzig and began teaching there. Fluent in French and English and possessing a great deal of 
interest in traveling to foreign countries, he accepted-following a chance encounter with a Japanese patient - the offer of a professorship at the Imperial University of Tokyo's School of Medicine. While the invitation was personal, it was part of a broader framework. By then, the German approach to science, as James Bartholomew has demonstrated, became a model for the way the Japanese state intended to organize its own scientific research in general, and medicine in particular. ${ }^{3}$

Arriving in Japan in 1876, the 27-year-old Baelz began a long and successful career at the local leading medical school, teaching pathology and subsequently internal medicine for the next 29 years. Baelz soon became personal physician to many members of the Japanese elite - including the imperial family, and especially the young and sickly crown prince (the future Emperor Taishō). While his support for Japan throughout his career is evident in his personal diary, his ties with this nation were further reinforced by his marriage to a Japanese woman who bore him two children.

Baelz had additional interests alongside his profession. Akin to other German physicians stationed overseas - and especially in Japan — at this period, Baelz engaged in anthropological pursuits. Anthropology, and to a lesser extent ethnology, was associated with the imperial expansion that characterized all major Western nations. Imperialism was not the raison d'etre of anthropology, but more than in any subsequent period the relations between the two were symbiotic. The German Anthropological Association had been established seven years before Baelz's departure to Japan, but soon became a juggernaut of research in which physicians took the lead as theorists and fieldworkers. ${ }^{4}$

During his work in Japan, Baelz observed that local infants displayed bluish patches and spots on the spine, buttocks and loins that sometimes persisted for the first two or three years of life but that usually left no trace later. These patches, which Baelz called dark blue or blue spot and later Mongolian spot (Figure 9.2), were far from an original discovery. ${ }^{5}$ They were widely known in Japan, and had also been observed earlier among Inuit infants in Greenland. Baelz was nonetheless the first to mention them in the scientific literature. ${ }^{6}$ Published in 1885 , his observation initially attracted very little attention, but at the turn of the century it suddenly turned into a sort of scientific sensation. ${ }^{7}$ Passionate interest in this "peculiar phenomenon," as one contemporary scholar referred to it, is hardly surprising. ${ }^{8}$ It partly derived from Europe's long-standing folk fascination with birthmarks but also reflected the growing Western interest in the rising powers of East Asia — Japan in particular - alongside a rising fear of the "yellow peril.",

Additional studies soon revealed that similar spots could also be found in Chinese, Koreans, and Burmese infants and so erroneously confirmed they were characteristic of Mongolian peoples. ${ }^{10}$ Some argued they were racial stigmata, but the idea of atavism seemed far more appealing. Followers of Darwin tended to regard them as a case of arrested development akin to rare occurrences of a rudimentary tail in newborns, which in turn led to the appearance of characteristics shared with earlier and more remote ancestors, 


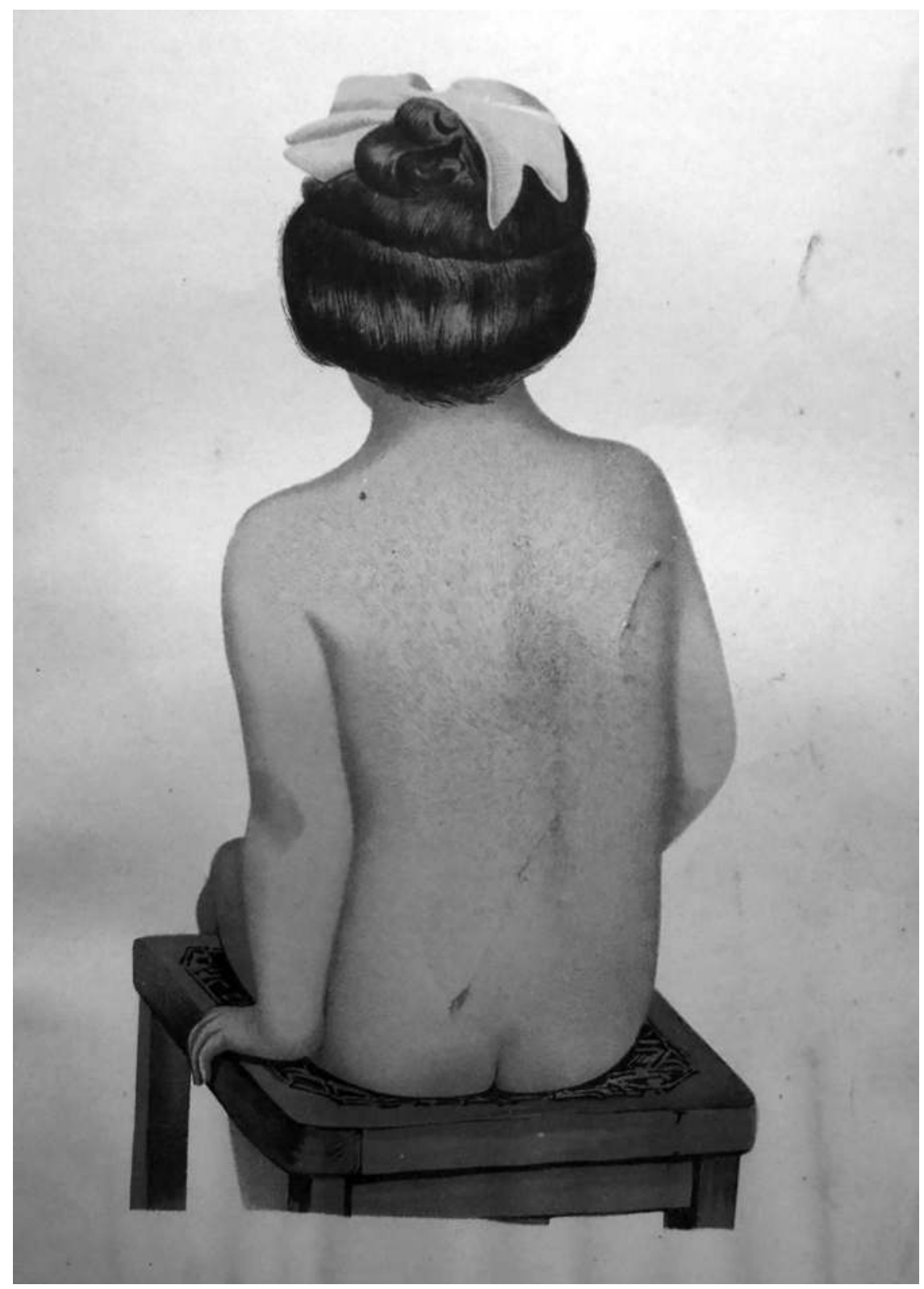

Figure 9.2 "The Mongol spot seen in a seven-year old Japanese girl" Source: Erwin Baelz, "Menschenrassen Ostasiens mit spezieller Rücksicht auf Japan," Zeitschrift für Ethnologie, 33: 2 (1901), 189. Courtesy of the University of Leiden Library. 


\section{Rotem Kowner}

both human and animal. Some scholars did not miss this link. In 1905, for example, the American physician Albert Sidney Ashmead (1850-1911) interpreted the spots as an indication of Japanese "Negro ancestry." 11 Serving as a foreign director of the Tokyo prefectural hospital in the mid-1870s, Ashmead was at least acquainted with Japan. Others who had no familiarity at all went even further and argued that the spots were no less than a trace of a simian ancestor. $^{12}$ These radical views were not novel. Contemporary racial theorists who subscribed to the Darwinian approach were also inclined to embrace scientific racism and vice versa. The majority of these considered non-Europeans racially inferior and physically unattractive. Attraction to Darwinian theories was particularly strong in Germany, albeit not unopposed. ${ }^{13}$

Fascinated by birth defects and staunchly opposed to Darwinian theory, physician and anthropologist Rudolph Virchow (1821-1902), for example, regarded the spots as pathological. ${ }^{14}$ Baelz followed Virchow's line and considered the spots as nothing more than over-pigmentation. They were transmitted genetically, he found, and there was nothing abnormal about them. Having spent the majority of his professional career in Japan and married to a Japanese woman (their two children were born after the "discovery" of the spot), Baelz obviously had a vested interest in such a view. This does not mean that he dismissed the spots: quite the opposite. In 1901, he stated that if the spots were indeed unique to the Mongol race they embodied the most important difference between this and other races. ${ }^{15}$ A year later he conceded that the spots are found in all races except for Europeans but still insisted they were a very important racial criterion. ${ }^{16}$ This was a minority view Baelz did not maintain for long and which, in any case, did not undermine his ultimate authority on the broader racial issues related to Japan.

\section{Baelz's integrative perspective on the Japanese "race"}

Baelz's note on the Mongolian spot was not the outcome of chance observation. He was one of the most experienced and devoted of the scholars and observers of Meiji Japan among the "hired foreigners" (oyatoi gaikokujin). In addition, he benefited from a long stay in the country, an increasingly wide network of human relations, and a profound interest in racial issues. More than any of his predecessors, his physical anthropological research was also characterized by meticulousness and persistence. Yet, Baelz's overall contribution to the racial discourse on the Japanese and East Asians is usually overlooked. His impeccable reputation as a medical practitioner and pioneering professor at the University of Tokyo is usually what comes to mind first among present-day Japanese. This, alongside his intimate ties with many towering figures of the Meiji era, his humanism, occasional criticism of European conceit and the admiration he often expressed for the nation, have all helped to obscure his pivotal role in fin-de-siècle discourse on the Japanese "race." Instead, most references to him mention his medical studies, his interest in Japanese ethnography, and his devotion to Japan. 
However, Baelz was unquestionably the most important figure in the late nineteenth-century Western quest to assess Japanese racial origin and composition and his views lingered long after his death. He was not a blatant racist - at least not consciously - but his views nonetheless contributed to the Western image of Japan as a "colored" country, and - especially after the war with Russia (1904-5) — the epitome of the "yellow peril." At least as important were his views on Ainu origins and their contribution to the racial constitution of modern Japanese. These aboriginal inhabitants of Hokkaido, Baelz believed, held the key to understanding the prehistory of the Japanese archipelago and thereby to solving the intriguing mystery about the origin and racial affiliation of the entire population of Japan. Reviewing various studies on the subject, Baelz determined that the Ainu did not belong to the Mongolian race. At first, he admitted having only a vague idea of their origins and suggested that they came to Japan through either Sakhalin or through an ancient land mass connection to the mainland. In subsequent decades, however, he continued to reconstruct the Ainu past and modified his view of their racial origins. By the 1890 s, he clearly favored the Caucasian link. ${ }^{18}$

Leading theorists of race in Europe and the United States followed suit. For many of them, the issue of Ainu racial origins probably had greater importance than the parallel racial discourse on the Japanese. The Ainu, they felt, contained subtle clues to the origins of Europeans themselves. In contrast, for those interested in the racial origins of the Japanese, the debate on the affinity between the Ainu and the Japanese, and the Ainu and Europeans, was marginal. Many of them paid little attention to the close association between the two discourses, and - critically - their conclusions about Ainu origins could not alter the intellectual tide relating to the racial position of the Japanese. Nonetheless, for a brief period and partly owing to Baelz's theories, the minor debate on Ainu origins seemed to eclipse the discourse on the Japanese as the primary racial discourse on the region. Paradoxically, this interference took place in contradictory ways. For some, the possibility of Caucasoid Ainu blood being injected into the Japanese genetic pool throughout history provided a sound account for Japan's successful modernization, as well as a pretext for supporting Japan's cause in international affairs throughout the early twentieth century. For others, the existence of an oppressed Caucasoid minority in Japan's periphery only exacerbated their animosity toward the Japanese. For some years the discourse and research on Ainu origins was more intensive than that about the Japanese, but Baelz's prevailed. By the early twentieth century, his outlook helped situate the dwindling Ainu as the last remnants of by-then extinct East Asian Caucasians but also partial ancestors of the Japanese majority. ${ }^{19}$

Given the consolidation of ideas about Ainu origins, Baelz was able to postulate an all-inclusive theory regarding the origins of the Japanese race. Influenced by earlier theories advanced by several of his compatriots who had recently sojourned in Japan, notably the physician Friedrich Karl Wilhelm Doenitz (1838-1912) and the geographer Johannes Justus Rein (1835-1918), 


\section{Rotem Kowner}

Baelz presented his theory at the German Anthropological Congress in 1885 and modified it slightly several times in subsequent years. Unlike most of his contemporaries, he measured living people indefatigably and thus could substantiate his assumptions. In an 1885 article, he depicted two "Japanese" types, which he referred to as "the fine" (der feine Typus) and "the coarse" (der plumpe Typus). ${ }^{20}$ Like his predecessors, and in accordance with European trends outside Germany, he associated these with the higher and lower classes, respectively, but also with different racial origins (in line with German distinctions). In addition, Baelz employed affinity to Europeans as another useful parameter for distinguishing between the two types. Even a limited genetic portion, or a few grains of high-grade racial origins, could reflect upon the whole type.

By the turn of the century, Baelz could crystalize a theory that also took the Ainu people into account. It depicted three basic types representing the sources of ancient invasions of Japan. The first, the Manchu-Korean or true Mongolian type (formerly the "fine" type) was characterized by a mature figure, dolichocephalic skull, long face, broad and high forehead, and a fine aquiline nose. These features, he argued, were common among members of the Japanese upper classes, who were more related to Europeans than the second or Malayan-Mongol type. Formerly the "coarse" type, Baelz characterized the Malayan-Mongol type by less slanted and often round eyes, a broader nose, and a brachycephalic round skull with a tendency toward prognathism. These features, he contended, were more common among people living in East Japan and among the lower classes. The third was the Ainu type (Aino Typus). The bodies of these people were even smaller but more strongly built than the average Japanese. The Ainu type has round eyes, a short nose, a big mouth with swollen lips, and a wide jawbone. It was also characterized by hirsuteness on the face and body. People of this type were mainly found in northern Japan and made the least genetic contribution to the modern Japanese population (Figure 9.3). ${ }^{21}$

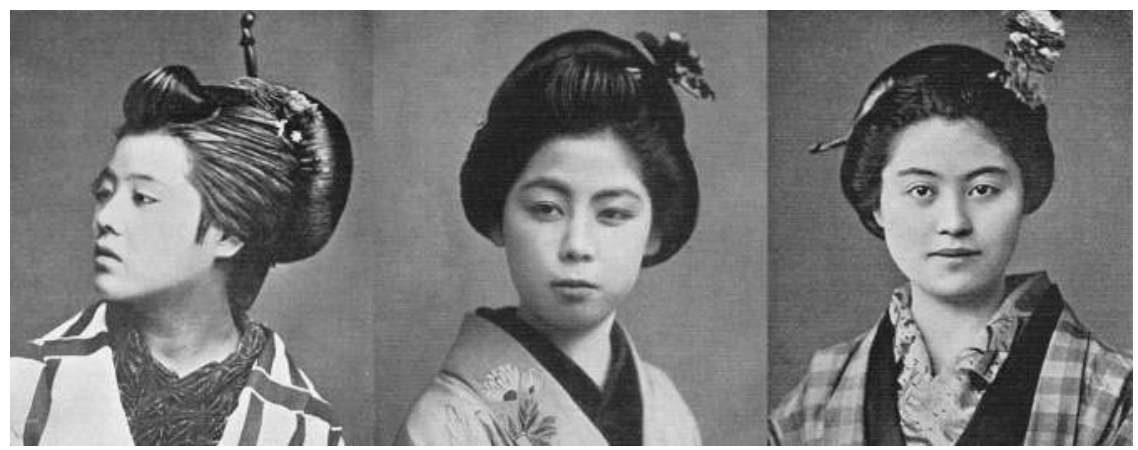

Figure 9.3 Baelz's typology of the Japanese "race": the Manchu-Korean type, the Malayan-Mongol type, and the Ainu type (from left to right)

Source: Carl Heinrich Stratz, Die Korperformen in Kunst Und Leben Der Japaner, 2nd edn (Stuttgart: F. Enke, 1902), 28, 30, 26 [private collection]. 
Based on his measurements, Baelz argued that the oldest inhabitants of Japan were the Ainu, who were gradually pushed northwards by invading peoples. $\mathrm{He}$ assumed that the natural path for the invading population's migration to the Japanese archipelago had been through Korea. This was confirmed, he claimed, by ancient Japanese traditions and by prehistoric-era findings. These migrants landed in Kyushu and on the southern part of the western coast of the main island Honshu and brought the first elements of civilization to the island. Linguistic similarity between Japanese, Turkish, Hungarian, and Finnish indicated that these peoples originated in central Asia. The north Mongolian element had therefore played a critical role in shaping the modern Japanese population, as in China and Korea. A second wave of migrants, Baelz suggested, were of southern Mongolian extraction and came through either Korea or along the islands south of Japan. These migrations, and particularly the latter, probably occurred throughout the first millennium BC. ${ }^{22}$ The issue of Mongol spots was a rather trivial detail in this elaborate scenario. But because they were common among members of the first two groups, they could serve as an unequivocal living testimony for racial linkages and for their affiliation to other native Mongol groups in the mainland. On the other hand, the supposed absence of spots among pure-blooded Ainu proved that the Ainu were indeed Europeans and of limited genetic contribution to the Japanese.

\section{German medicine and the question of race in Japan}

Although Baelz's emergence as an expert on the natural history of the Japanese was rather coincidental, the fact that it was a German physician who offered this observation was not. The chronicles of European contacts with Japan are full of examples of certain groups having an advantage, and at times even a virtual monopoly, on the acquisition of knowledge on the local population. Although Jesuits made the greatest contribution to the construction of the early modern European idea of the Japanese during the sixteenth century, it was a small group of employees of the Dutch East India Company who followed suit in the subsequent two centuries. ${ }^{23}$ Such a relative monopoly was no longer possible in late nineteenth-century Japan and it was the turn of German scholars - the majority medical doctors - to make the greatest impact. Admittedly, German physicians were not new to this field, as demonstrated by Kaempfer and Siebold in Edo, Japan. Yet, since the 1870s, a growing number of scholars representing the newly unified German empire took an unequivocal lead in researching the ethnological, anthropological and racial aspects of the Japanese. ${ }^{24}$ This collective hegemony was not predestined since Germany was not an evident candidate for such a lead. It only had some minor colonial holdings that were associated with the explosion of ethnological research in other cases and Germany's expatriate community in Japan was relatively small. ${ }^{25}$

Germany was a newcomer to the realm of colonial expansion outside Europe, but its rising military power shortly before, and especially after, unification, spectacular growth of its industrial exports and international commerce, 


\section{Rotem Kowner}

and its hectic quest for overseas colonies in the late nineteenth century stirred a great deal of domestic interest in foreign cultures, Asian and African in particular. Insofar as Japan is concerned, German hegemony was more the outcome of local demand than German desire. Well informed on matters of national development, Japanese decision makers of the late 1860s were convinced that German higher education in general and medical science in particular were the world's best and should thus serve as a model for the budding local discipline. ${ }^{26}$ In subsequent years they also found that authoritarian relations and remnants of feudalism that characterized German academics were also adequate for Japan's newly established university and health systems, as well as legal reforms. ${ }^{27}$ No less important was the timing. After unification and considering its growing international ambition, Germany was willing to cooperate with Japan as much as the latter was willing to follow its guidance. Medicine and scientific knowledge were a few ways by which Germany projected status and acquired influence.

The subsequent hiring of German physicians as harbingers of modern medicine in Japan facilitated the arrival of highly qualified experts over a long period. As these physicians presided over the most important positions reserved for foreigners in either medical schools or hospitals, they had better access to research resources, as well as greater professional status and scientific prestige than any other group of foreigners. ${ }^{28}$ The dominance of German scholars in Japan and their contribution to anthropological, ethnological, and racial research on Japan was not unique. Germans were prominent in the contemporary study of race in other geographical regions too. Britain and France did not become true centers of physical anthropology or the study of racial issues during the late nineteenth century, while America focused racial research inwards. ${ }^{29}$ In Germany, however, medicine, physical anthropology, and racial theorization became strongly linked, creating a model of scientific unity. German medicine made use of anatomical measurements such as craniometry to assess human performance and pathology, as well as questions relating to human diversity, racial origins, and atavism more than in any other nation. ${ }^{30}$ This is not to say that German racial science was sui generis, but there is no question that it constituted, possibly like the entire German experience of this period, "a heightened version of what occurred elsewhere." 31

Although not all German physicians were anthropologists, the vast majority of anthropologists in Japan, at least initially, were physicians. ${ }^{32}$ The close association between the two disciplines had long roots. As in earlier decades, turn-of-the-century medical science still provided a basic knowledge of botany and taxonomy and facilitated an interest in anthropology and questions relating to the essence of race. This predominance of physicians inevitably resulted in the medicalization of anthropology and channeled its members to issues on the periphery of the medical discipline. Despite its liberal bent and initial tendency to oppose colonial ventures, the German anthropological community gradually embraced contemporaneous human racial theories and was highly receptive to Darwinian ideas from the outset. ${ }^{33}$ German enthusiasm for evolutionary 
theory impressed Darwin so much that in 1868 he regarded it as his "chief ground for hoping that our views will ultimately prevail." 34 Nonetheless, he was also wary of the dangers to which such zeal could lead and by in as much as a year earlier he had, cautioned that his views were taken "much stronger than ... intended." ${ }^{35}$ Darwin's concerns were correct for another reason. German fascination with anthropology and racial theorization partly had deeper sources. One apparently was the nation's struggle with its own problematic self-image.

A few decades later, the eminent American sociologist Frank Hankins would argue that the German "consciousness of the utter falseness of their claim to be Teutonic type par excellence" was the very reason for their leadership in physical anthropological research on racial typology. In other words, German anthropologists exerted a great deal of effort to study others, but consciously avoided extensive research on their own population. ${ }^{36}$ While there is a kernel of truth in Frank Hankins' observation, he was wrong about the order of things. The Germans first generated a great deal of internal research and then "exported" it abroad. More than anything, argues Paul Weindling, German anthropology "constituted a type of national cultural anatomy." ${ }^{37}$ This is not to say that German anthropologists were inactive abroad. In 1897, for instance, Germany took over Rwanda and its colonialists and missionaries soon became engaged in a typological study of the local population. They distinguished between the Tutsi ruling class and the Hutu majority, identifying the former as a separate racial group of superior qualities, such as paler skin and a more dolichocephalic skull. Above all, the Tutsi considered to have a certain racial affinity with Europeans due to their supposed Hamitic Caucasoid origins which entitled them to serve as German intermediaries. ${ }^{38}$ Some of this typology is reminiscent of Baelz's work, although the latter did not have any immediate political repercussions. If any, his views prompted Westerners to see positive racial elements among the Japanese, especially during the Russo-Japanese War, due to his emphasis on the European-like aristocratic, dolichocephalic and magnificent (Manchu-Korean type) and Caucasoid (Ainu type) elements. ${ }^{39}$

\section{The Japanese reaction and Baelz's racial legacy}

This flattering view of the Japanese - at least in European eyes - did not have many local followers. While Baelz was very much praised in Japan for his medical contributions, his racial observations appealed to only a few of his local followers. Some of them, in fact, did their utmost to refute such theories even while Baelz was still in Japan, and certainly after his return home in 1905. The issue of the Mongolian spot was perhaps trivial but nonetheless representative. The idea that the spots were a characteristic shared solely by the "Mongolian" race or even by the "dark races" was unattractive to Meiji-era intelligentsia. The suggestion that Negro blood was present among the Japanese was even worse, since it put the Japanese in an immutably inferior position compared to Europeans. Between 1894 and 1899, Japan was at last successful in annulling the unequal treaties the shogunal regime had signed with the 
Western powers several decades earlier, and at about the same time it also proved its invincibility by winning two wars. Japan's quest for equality was no longer confined to legal and military spheres but spread to the vague domain of national status and racial standing. The urge for amending racial inequalities with the West, which would so incense Japanese representatives at the establishment of the League of Nations in 1919, had been burning in Japan for a while. ${ }^{40}$

In such an atmosphere, it was none other than Meiji Japan's leading anatomist, Adachi Buntarō (1865-1945), who took up the gauntlet. Mirroring Baelz's Japanese scientific endeavors, he examined the bodies or cadavers of dozens of European infants during a stay in Munich in an attempt to uncover the presence of dark pigments among "Caucasians" too. His efforts were fruitful. He found traces of spots in a few German infants and thus concluded they might appear in all races and individuals, albeit to different degrees. ${ }^{41}$ Adachi's findings were certainly not far-fetched. Although a few Western scholars rejected them, ${ }^{42}$ several others verified them in subsequent years. ${ }^{43}$ This does not mean that Baelz's term "Mongolian spot" fell completely out of favor. Unlike the term Mongolism (Down's syndrome), it has survived in medical literature to this very day. ${ }^{44}$

The question of Japanese origins and racial composition was more complex. Here the activity of a single native scholar such as Adachi could not erode the mountain of foreign works to the contrary. Moreover, the local scientific community did not reach consensus. As early as 1879 , two years after the American zoologist Edward Morse's (1838-1925) seminal excavation of a shell mound in Ōmori, two of his students, Iijima Isao and Sasaki Chūjiro, conducted their own excavations of similar mounds in Ibaraki. ${ }^{45}$ Soon, a growing number of Japanese joined the fray. One might imagine that their initial participation in meetings of the British and German Asiatic Societies in Tokyo drew some sentiments of paternal conceit from the senior members. However, the claim of these foreign sojourners "to be tribune of the unheard," as Clifford Geertz referred to modern anthropologists facing decolonization, was soon "increasingly difficult to sustain." ${ }^{46}$ Japanese academic self-confidence was on the rise. In 1883, the number of Japanese members in the faculty of medicine at the University of Tokyo exceeded the number of Germans for the first time, and a year later, a small group of Japan's first anthropologists in the modern sense of the word joined to establish its own anthropological association under the name Jinruigaku no Tomo (the Friends of Anthropology). ${ }^{47}$ In 1888, the new association included no less than 217 members who constituted the first generation of noteworthy Japanese scholars of either domestic or foreign training. It did not take long for these scholars to voice their own views on Japanese racial origins and composition and to dominate the discourse on this issue several decades later. ${ }^{48}$

In an 1887 article published in Japanese, Tsuboi Shōgorō (1863-1913) reiterated Milne's speculations that the early race of pit-dwellers residing in Hokkaido were ancient pigmoids known in the Ainu tradition as Koropokguru ("family 
of black dwarfs"). ${ }^{49}$ Tsuboi, one of the founders of the new association and the first chair of the Anthropological Institute at the University of Tokyo nine years later, was hostile to Morse's legacy. His unfounded analysis, nonetheless, did not contribute much to the debate, and Tsuboi was soon challenged by Koganei Yoshikiyo (1898-1944), professor of anatomy at the University of Tokyo, who returned from extensive anatomical studies in Germany in 1885 and was uninfluenced by Baelz. ${ }^{50}$ Koganei introduced some fresh data and displayed a sound scientific approach. Based on comparative examinations of skeletal morphology, he found that the Ainu were similar to the prehistoric population of the mainland, known by then as the Jomon population. In two lengthy reports written in German, Koganei asserted that the Ainu were the direct descendants of that prehistoric population. Geographically, he concluded, the Ainu once resided all over the Japanese archipelago but were replaced at a later stage by the population that gave rise to the modern Japanese in every one of the islands apart from Hokkaido. ${ }^{51}$

Koganei's thesis constitutes the core of our present view of the Ainu. ${ }^{52}$ The real local bone of contention, however, was whether the Japanese as a people were pure-blooded or a hybrid nation of mixed blood, as Baelz and other foreign scholars contended. For some, the discussion of origins reinforced the sentiment of pan-Asianism. In later years, Japan would witness the emergence of theories suggesting common ancestry with the Chinese and Koreans (Nissen dōso ron). ${ }^{53}$ Suffice it to say that at the time Baelz retired to Germany, native scholars constituted the majority of participants in the racial discourse on Japan and within several years prevailed in the production of new knowledge in this field. For those who follow the rise of Imperial Japan closely, there was nothing exceptional about this. After all, Japan commissioned its first domestically built battleship by 1910 . Yet, in dominating the local discourse on race, Japan was the first non-European nation to seize a European intellectual domain, however partially it may have done so.

All in all, Baelz's contribution to racial discourse in Japan should be seen not only within the context of Western imperial project but also through the lenses of Japanese rising scientific discourse. During the three decades of his activity at the Imperial University of Tokyo, Baelz was able, together with many foreign scholars, to stimulate, and to some extent shape, indigenous research on the origins of the Japanese and their affinity to other East Asian peoples. The cadre he helped train soon capitalized upon anthropological research and gradually dominated the racial discourse on Japan, in a manner and scale unparalleled in other non-Western countries at that period.

\section{Notes}

1 See Benjamin Isaac, The Invention of Racism in Classical Antiquity (Princeton, NJ: Princeton University Press, 2004), passim.

2 For Baelz's life and medical activity, see editor's preface in Erwin Baelz, Awakening Japan: The Diary of a German Doctor (New York: Viking Press, 1932), xi-xvii, 3-4, 
as well as his diary in the above book. See also Otto Schmiedel, Die Deutschen in Japan (Munich: C. Kuhn, 1920); Felix Schottlaender, Erwin Von Baelz, 1849-1913 (Stuttgart: Ausland und Heimat Verlags-Aktiengesellschaft, 1928); Gerhard Vescovi, Erwin Baelz, Wegbereiter der Japanischen Medizin: Ein Lebensbild (Stuttgart: Gentner, 1972); Teijiro Muramatsu, Westerners in the Modernization of Japan (Tokyo: Hitachi Ltd, 1995), 129-34; Ishibashi Chōei and Ogawa Teizō, Oyatoi Gaikokujin: Igaku (Tokyo: Kajima Kenkyūjo Shuppankai, 1969), 106-37.

3 James R. Bartholomew, The Formation of Science in Japan: Building a Research Tradition (New Haven, CT: Yale University Press, 1989), 4, 51, 65-7, 71-82.

4 Notable examples of other German physicians who conducted anthropological research in Meiji Japan are Albrecht Agaton Wernich (1843-1896) and Friedrich Karl Wilhelm Doenitz (1838-1912). Together with Baelz they became heirs to a long tradition of prominent German physicians and ethnologists such as Engelbert Kaempfer (1651-1716) and Philipp Franz von Siebold (1796-1866), who served at the Dutch factory during the Edo period. On the predominance of physicians at the Yokohama OAG, see Hoi-eun Kim, "Physicians on the Move: German Physicians in Meiji Japan and Japanese Medical Students in Imperial Germany, 1868-1914.” Ph.D. dissertation, Harvard University, 2006, 146-7.

5 The first reference to the spots which Baelz referred to as blaue Pigmentfleck is found in Erwin Baelz, "Die Körplichen Eigneschaften Der Japaner (Zweiter Teil)," Mittheilungen der Deutschen Gesellschaft für Natur- und Völkerkunde Ostasiens (Yokohama), 4: 32 (1885), 35-103, 40-1.

6 See Adachi Buntaro, "Hautpigment beim Menschen und bei den Affen." Zeitschrift für Morphologie und Anthropologie, 6: (1903), 1-131. For observations of spots among Inuit infants, see Joseph Brennemann, "The sacral or so-called 'Mongolian' pigment spots of earliest infancy and childhood, with especial reference to their occurrence in the American Negro," American Anthropologist, New Series, 9: (1907), 12-30, 14.

7 See H. Newell Wardle, "Evanescent Congenital Pigmentation in the Sacro-lumbar Region," American Anthropologist, New Series, 4: (1902), 412-20; A. F. Chamberlain, "Pigment Spots," American Anthropologist, New Series, 4: (1902), 796; Herman F. Ten Kate, "Die Pigment Flecken de Neugeborenen," Globus, 81: (1902), 238-40; idem, "Die blauen Geburtsflecken," Globus, 87, (1905), 53-8; idem, "Neue Mitteilungen über den blauen Geburtsfleck," Zeitschrift für Ethnologie, 37: (1905), 756-8; Brennemann, The Sacral or So-called "Mongolian” Pigment Spots, 24.

8 Ibid., 24.

9 See Karl Jaberg, "The Birthmark in Folk Belief, Language, Literature, and Fashion," Romance Philology, 10: (1956/7), 307-42.

10 See Brennemann, The Sacral or So-called "Mongolian” Pigment Spots; L. G. Fink, "Mongolian Birth-marks: An Anthropological Study," Journal of Tropical Medicine and Hygiene, 15: (1912), 227-30.

11 Albert. S. Ashmead, "The Mulberry-colored Spots on the Skin of the Lower Spine of Japanese," Journal of Cutaneous and Genito-Urinary Diseases, 23: (1905), 203.

12 See Francis Graham Crookshank, The Mongol in Our Midst: A Study of Man and His Three Faces, 3rd rev. edn (London: Kegan Paul, Trench, Trubner \& Co., 1931), 139-40.

13 For German attraction to Darwinian theory, see Richard Weikart, From Darwin to Hitler (New York: Palgrave Macmillan, 2004), 114; Paul Weindling, Darwinism and Social Darwinism in Imperial Germany (Stuttgart: Gustav Fischer, 1991), 15-22, 24.

14 On Virchow's opposition to the idea of atavistic reversion, see Frederick B. Churchill, "Rudolf Virchow and the Pathologist's Criteria for the Inheritance of Acquired Characteristics," Journal of the History of Medicine, 31: (1976), 117-48. 
For his interest in congenital deformities and his view of them as pathological, see Zimmerman, 73-85.

15 "Wenn es zutreffen sollte—was ich glaube-dass solche Flecke ausschliesslich bei den Mongolen vorkommen, dann muss man sagen, dass dies das wichtigste Unterscheidungs-Merkmal zwischen den Mongolen und den übrigen Rassen ist." In Baelz, "Menschen-Rassen Ost-Asiens mit specieller Rücksicht auf Japan," Zeitschrift für Ethnologie, 33: (1901), 166-90, 188.

16 Erwin Baelz, "Noch einmal die blauen 'Mongolen-Flecke," Centralblatt für Anthropologie, Ethnologie und Urgeschichte, 7: (1902), 329-31.

17 See Suzanne L. Marchand, German Orientalism in the Age of Empire (Cambridge: Cambridge University Press, 2009), 383.

18 See Rotem Kowner, "Lighter Than Yellow, But Not Enough: Western Discourse on the Japanese 'Race, 1854-1904," The Historical Journal, 43: (2000), 103-31.

19 On Ainu origins, see Josef Kreiner, "European Images of the Ainu and Ainu Studies in Europe," in European Studies on Ainu Language and Culture, ed. Josef Kreiner (Munich: Iudicium Verlag, 1993), 13-60; Kirsten Refsing, "Lost Aryans? John Batchelor and the Colonization of the Ainu Language," Interventions: International Journal of Postcolonial Studies, 2: (2000), 21-34; and Rotem Kowner, "European Aborigines in Japan? Physiognomy and Racial Affinity in the discourse on the Ainu, 1548-2000," Historia, 18: (2006), 5-31. [In Hebrew].

20 Baelz, Die Körplichen Eigneschaften, 57-8. For Baelz's earlier theory, see Baelz, "Die körplichen Eigenschaften der Japaner," Mittheilungen der Deutsche Gesellschaft für Natur- und Völkerkunde Ostasiens, 3: (1883), 330-49, 337.

21 Baelz, Die Körplichen, 57-8. In later years, Baelz changed his typology to the fine Manchu-Korean type and the Malayan-Mongol type, e.g. Baelz, Menschen-Rassen Ost-Asiens, 172-4; idem, "Prehistoric Japan." In Annual Report of the Board of Regents of the Smithsonian Institute (Washington, DC: Government Printing Office, 1907), 523-47, 523; Carl H. Stratz, Die Korperformen in Kunst und Leben der Japaner (Stuttgart: F. Enke, 1902), 27-35.

22 See Baelz, Die körplichen, 337-46; Erwin Baelz, "Über die Rassenelemente in Ostasien, Speciell in Japan," Mittheilungen der Deutsche Gesellschaft für Natur- und Völkerkunde Ostasiens, 8: (1900), 227-35; Erwin Baelz, Die Ostasiaten (Stuttgart, 1901), 11-20.

23 See Rotem Kowner, "Skin as a Metaphor: Early European Racial Perspectives on Japan, 1548-1853," Ethnohistory, 51: (2004), 751-78.

24 See John Z. Bowers, "The Adoption of German Medicine in Japan: The Decision and the Beginning," Bulletin of the History of Medicine, 53: (1979), 57-80. On the broader context of the Japanese adoption of Western medicine, see John Z. Bowers, When the Twain Meet: The Rise of Western Medicine in Japan (Baltimore, MD: Johns Hopkins University Press, 1980). On Germans and German institutions in early twentieth-century Japan, see Akira Kudō, Japanese-German Business Relations: Cooperation and Rivalry in the Inter-War Period (London: Routledge, 1998), 30-1.

25 The German community in Meiji Japan was far smaller than the British. See Hazel J. Jones, Live Machines: Hired Foreigners and Meiji Japan (Vancouver: University of British Columbia Press, 1980), 145, 148-9.

26 For the rise of German medicine in the second half of the nineteenth century, see Thomas Hoyt Broman, The Transformation of German Academic Medicine, 1750-1820 (Cambridge: Cambridge University Press, 1996).

27 Bowers argues that the Japanese were especially attracted to the similar mindset that characterized German teachers. Bowers, When the Twain Meet, 158.

28 For activity of Germans in Meiji Japan, see Meissner, Deutsche in Japan, 1639 1960, 9-63. For the contribution and dominance of German medicine in the early 
stages of Japanese modernization, see Hermann Heinrich Vianden, Die Einführung der deutschen Medizin im Japan der Meiji-Zeit (Düsseldorf: Triltsch, 1985); Kim, Physicians on the Move, 20-80.

29 For the weakness of Britain in physical anthropology, see Stocking, Victorian Anthropology, 67.

30 For the latter assertion, see Paul Weindling, Health, Race, and German Politics between National Unification and Nazism, 1870-1945 (Cambridge: Cambridge University Press, 1989), 50.

31 David Blackbourn and Geoff Eley, The Peculiarities of German History: Bourgeois Society and Politics in Nineteenth-Century Germany (Oxford: Oxford University Press, 1984), 292.

32 All participants who took part in the 1861 meeting were professors of medicine. See Weindling, Health, Race, and German Politics, 50, 134. For the predominance of physicians in the Deutsche Gesellschaft für Natur- und Völkerkunde Ostasiens (OAG) of Yokohama, see Kim, "Physicians on the Move," 146-7.

33 For German interest in Darwinist theory, see Weindling, Health, Race, and German Politics, 55.

34 Quoted in Richard Weikart, "The Origins of Social Darwinism in Germany, 18591895," Journal of the History of Ideas, 54: (1993), 471; Weikart, From Darwin to Hitler, 10.

35 In a letter to Ernest Haeckel. See Darwin, The Life and Letters of Charles Darwin, III: 68 .

36 Frank Hamilton Hankins, The Racial Basis of Civilization: A Critique of the Nordic Doctrine (New York: Knopf, 1926), 94.

37 Weindling, Health, Race, and German Politics, 54.

38 Cf. Edith R. Sanders, "The Hamitic Hypothesis; Its Origin and Functions in Time Perspective," The Journal of African History, 10: (1969), 521-32.

39 See Joseph M. Henning, "White Mongols? The War and American Discourses on Race and Religion," in The Impact of the Russo-Japanese War, ed. R. Kowner (London: Routledge, 2007), 153-66.

40 See Naoko Shimazu, Japan, Race, and Equality (London: Routledge, 1998).

41 Adachi, Hautpigment beim Menschen; Adachi and K. Fujisawa, "Mongolen Kinder Fleck bei Europäern," Zeitschrift für Morphologie und Anthropologie, 6: (1903), 132-3.

42 See A. Epstein, "Ueber den blauen Kreuzfleck und andere mongoloide Erscheinungen bei Europäischen Kindern," in Jahrbuch für Kinderheilkunde (1906), 60-73.

43 See Brennemann, The Sacral or So-called "Mongolian” Pigment Spots, 29.

44 For later references to Mongolian spots as a medical phenomenon see, "Beauty Spot or Blemish?" The British Medical JournaI, 1: 6054 (1977), 126-7. After 1945 the spots did not completely lose their role as a racial marker. James Patrie, The Genetic Relationship of the Ainu Language (Honolulu, HI: University of Hawaii Press, 1982); Deborah Posel, "Race as Common Sense: Racial Classification in Twentieth-century South Africa," African Studies Review, 44: (2001), 87-113, 96.

45 See Isao Iijima and Chūjiro Sasaki, "Okadaira Shell Mound at Hitachi," Memoirs of the Science Department, University of Tokio, 1: (1883).

46 Clifford Geertz, Works and Lives: The Anthropologist as Author (Stanford, CA: Stanford University Press, 1988), 131.

47 For the number of Japanese and German faculty members from 1877 to 1898 , see Kim, "Physicians on the Move," 78.

48 The group changed its name to Tōkyō Jinrui Gakkai and became the Nippon Jinrui Gakkai in 1941. For discourse of race in late Meiji Japan, see David Askew, "Debating The "Japanese" Race in Meiji Japan: Toward a History of Early Japanese Anthropology," in The Making of Anthropology in East and Southeast Asia, ed. 
Shinji Yamashita et al. (New York: Berghahn Books, 2004), 57-89. Many of the main themes of the discourse are discussed also in Oguma Eiji, Tan'itsu minzoku shin'wa No kigen: Nihonjin no jigazō no keifu (Tokyo: Shin'yōsha, 1995).

49 Tsuboi Shōgorō, "Koropokkuru Hokkaidō ni sumi shinarubeshi," Tokyo jinruigaku hōkoku, 12: (1887), 93-7.

50 For Tsuboi's attitude to Western anthropological scholarship, see Shimizu Akitoshi, "Colonialism and the Development of Modern Anthropology in Japan," in Anthropology and Colonialism in Asia and Oceania, ed. Jan Gerhard van Bremen and Shimizu Akitoshi (Richmond: Curzon, 1999), 115-71, 125. For Tsuboi's antagonism toward Morse, see Kudo Masaki, "Tsuboi Shōgorō to sono shūhen," Kōkogaku Kenkyū, 24: 3-4 (1977), 190-208. For Koganei's limited acquaintance with Baelz's racial theories, see Suzuki Hisashi, "Koganei Yoshikiyo sensei to Erwin von Baelz hakushi." Jinruigaku zasshi, 82: 1 (1974), 1-6.

51 Koganei Yoshikiyo, "Beiträge zur physichen Anthroplogie der Ainu: I. Untersuchungen am Skelet," Mittheilungen aus der Medicinischen Facultät der KaiserlichJapanischen, 2: (1893), 1-249; "Beiträge zur physichen Anthroplogie der Ainu: II. Untersuchungen am Lebenden," Mittheilungen aus der Medicinischen Facultät der Kaiserlich-Japanischen, 2: (1894), 251-403. For the controversy between Tsuboi and Koganei and subsequent development of the debate over Japanese prehistoric research, see Hanihara Kazurō, "Dual Structure Model for the Population History of the Japanese," Japan Review, 3: (1991), 1-33; Imamura Keiji, Prehistoric Japan: New Perspectives on Insular East Asia (Honolulu, HI: University of Hawaii Press, 1996), 39-52.

52 For present day views on the Ainu, see, e.g., Hanihara Kazurō, Ainu wa gen nihonjin ka: Atarashii nihonjinron no tameni (Tokyo: Shōgakukan, 1982); idem, "Emishi, Ezo and Ainu: An Anthropological Perspective," Japan Review, 1: (1990), 35-48; Michael Pietrusewsky, "Multivariate Comparisons of Female Cranial Series from the Ryukyu Islands and Japan," Anthropological Science, 112: 3 (2004), 1-13; Noboru Adachi et al., "Mitochondrial DNA Analysis of Jomon Skeletons from the Funadomari Site, and Its Implication for the Origins of Native American," American Journal of Physical Anthropology, 138: (2009), 255-65.

53 For a comprehensive overview of the local discourse on racial origins, see Oguma, A Genealogy of "Japanese" Self-Images. 


\section{When precision obscures Disease categories related to cholera during
the Sino-Japanese War (1894-1895)}

Roberto Padilla

\section{Introduction}

In the nineteenth century Japanese physicians embraced a dizzying array of terms to describe cholera. These include: mikka kokori, kaku-ran, Asiatic cholera, cholera and gastro-intestinal catarrh. The changes in how the Japanese medical field conceptualized the disease reflected a change in both broader understandings of the illness within the context of advances in medicine and Japan's understanding of its place in the nineteenth century world. In particular, the Japanese medical community perceived cholera as an external illness consistently associated with the Asian continent. This is not surprising considering cholera's origins in India's Ganges Delta region. What is surprising are the shifting definitions of cholera that created disease categories drawing distinctions between Japan and Asia, an effort at precision in classification and naming that simultaneously obfuscated the epidemiological realities of the disease.

This confounding of cultural-geographical and medical concerns about cholera are well illustrated by how the Japanese army medical bureau, an organization that embraced Western scientific medicine, classified cases of cholera during the Sino-Japanese War (1894-1895) and the medical and social consequences of those disease classifications. Here scientific medicine refers to the type of medicine that emerged in the nineteenth century in hospitals, universities, and laboratories of Western Europe, which sought to understand the origins of infectious illnesses through the application of rational methods and protocols designed to demonstrate a causal relationship between a specific microbial pathogen and a particular disease. By the latter half of the nineteenth century, the Japanese envisioned Germany as the world leader in medicine and German instructors came to Japan to teach medicine in the army and universities, while the Japanese and Japanese universities sent their best and brightest students to study in German universities. In the 1870s and 1880s, when German researcher Robert Koch, through extensive field work and laboratory testing, isolated the microbial pathogens responsible for anthrax, tuberculosis, and cholera and demonstrated the cause and effect relationship between a specific disease and a single microbe, he confirmed the import of germ theory. ${ }^{1}$ 
Koch's efforts engendered a new method of assessing the onset of disease that was at once precise and definitive and shifted the view of the physician from simply observing symptoms, which could be misleading, to the use of the microscope that allowed the physician a view of the illness at the microbial level. This diagnostic revolution ushered in a new way of understanding disease causation grounded in rational scientific method. It should have brought an end to the wide array of disease categories associated with cholera rooted in a physician's imprecise diagnosis based on visible manifestations of the disease. The Japanese army medical bureau, with its close links to German research institutes and university laboratories, was a repository of this new knowledge, and the new perspective became the primary lens through which medical officers in the Japanese army during the Sino-Japanese War viewed disease in general and more specifically cholera. The precision inherent in germ theory should have enabled the Japanese army medical bureau to accurately diagnose and account for all cases of cholera during the war. Contrary to the end result we could anticipate from the use of germ theory the application of this new knowledge obscured and obfuscated issues of disease in profound and poignant ways by combining modern medical understandings with pre-existing methods of disease classification based on ethnicity.

The ability of the Japanese army medical bureau to adapt this new understanding of disease causation underscores the highly advanced nature of the field of medicine in Japan by the end of the nineteenth century. In The Formation of Science in Japan, James Bartholomew notes that medicine was the most developed scientific field in Japan at this time, evidenced by the large number of Japanese researchers and physicians who held a doctorate in medicine. ${ }^{2}$ Bartholomew's work on the development of the field of science in general is a foundational study that charts the growth of science in Japan from the end of the Tokugawa period up to the early years of the 1920s by focusing on key individuals and institutions that both shaped and determined the overall trajectory of Japanese science and medicine.

During the war the relationship between cholera and society was skewed in multiple ways because of the contexts in which the Japanese army chose to apply new understandings of infectious illnesses within the framework of bacteriology. They adopted an inconsistent policy of classifying an illness as cholera based, in part, upon ethnicity, an emphasis that ultimately proved more confusing than elucidating. For example, medical officers were to determine a soldier was stricken with cholera only after the disease had been confirmed in laboratory tests, but this policy created another circumstance that obscured the presence of cholera. When there was no laboratory test undertaken for a patient's illness, the Japanese army medical bureau classified cases as some form of catarrh, even though the disease appeared to be cholera based on observed symptoms. This led to a vast under-reporting of the disease in the army. In addition, another facet of the army's policy further complicates our understanding of cholera during the war in two ways. The army did not extend its emphasis on laboratory confirmation to the Chinese civilian population. Thus, Chinese in 
Manchuria, Shandong and Taiwan were often identified as having contracted cholera through first and second-hand accounts based on the observation of symptoms, which in Japan and the West had been a pre-germ theory method of determining the illness. These decisions, effectively created two modes for diagnosing cholera, which meant that while Japanese cases of cholera went under-reported, Chinese cases were largely over-reported. A second unintended consequence of this policy was that both forms of classifying cholera drew distinctions between Japanese and other Asians and contributed to the view in Japan that the Asian mainland was a dangerous epidemiological place rife with cholera. The Japanese medical communities' continued association of cholera with Asia and Asians, as well as the under-reporting of cholera in the army, resulted in a delay in quarantine efforts that, in part, tragically prevented the army from halting the spread of the illness to Japan.

In sum, this study engages a complex of medical, policy and social issues germane to Japan's experience during the Sino-Japanese War, in addition to the racially differentiated categorization of similar symptoms that fostered the spread of disease to Japan during the Sino-Japanese War, including awareness of advanced medical knowledge, the ability to employ it in the field, and related issues. Broadly speaking, this essay examines Japan's imperialist enterprise within the context of Western scientific medicine by focusing on the spread of cholera on the Asian continent during the conflict and the decisions the leadership of the Japanese army medical bureau made that prevented an early, clear identification of the epidemic in its initial stages. The Japanese army embraced a rigid policy that meant many cases of cholera in the army went unreported even as the disease was over-reported among the Chinese populace. Both errors obscured the characteristics of the epidemic that spread throughout the war zone.

\section{The Japanese}

By the mid-1880s, advances in bacteriology represented a paradigm shift in the underlying causes of infectious diseases and provided physicians with the ability to accurately determine the nature and origin of certain illnesses. In 1884, Robert Koch isolated a comma shaped bacterium, cultured the microbe, and demonstrated it was the pathogenic agent for cholera by injecting it into laboratory animals, which then developed symptoms consistent with the disease. Koch's discovery of the cholera vibrio changed the focus of medical researchers from a reliance on symptoms of the body, which due to their observational nature were inherently imprecise, to the more discerning and definitive microscopic examination. This new diagnostic tool associated with bacteriology provided medical practitioners with a way to clearly identify cases of cholera. The Japanese government's Home Ministry 1886 and 1887 reports on cholera in Japan underscored the importance of Koch's discovery. The first report based on the work of Kitasato Shibasaburō, a medical officer of the Home Ministry, who investigated the 1885 outbreak of cholera in Japan, confirmed the existence of Koch's comma bacillus in patients and in Osaka's sewage system. ${ }^{3}$ The second report explained in detail why 
Osaka suffered year round from cholera beginning in the previous year, arguing the city's waterways and sewers provided the pathogen with a clear path of transmission:

The situation of Osaka is such that it undoubtedly favors the propagation of an epidemic ... for the water of the Yodo River being conducted through the city by canals in various directions ... receives the contents of the drains of the city, while at the same time it supplies the city with drinking water. ${ }^{4}$

In Japan, even though bacteriology offered Japanese medical practitioners new tools to more precisely identify cholera, the view persisted that cholera was primarily an external illness. The introduction to the 1886 Home Ministry report challenged the position held by many in the West that cholera was endemic throughout much of the Far East. The denial was strongly worded and called the statement "an assumption for which, we believe, there is no foundation in fact." ${ }^{5}$ Here, without specifically mentioning China, the report was essentially concerned with demonstrating that cholera existed as a persistent threat on Japan's periphery. "Each new outbreak of cholera in Japan, renders it more clearly evident that here, as in Western countries, the disease is always imported and traceable to but one and the same origin, the burning plains of India."6

What makes the Japanese Home Ministry's position all the more intriguing is that it was written the same year the disease was endemic in Osaka and when it had already been persistent in Japan since the late 1870s. The report is significant because it highlighted the Home Ministry's central concern regarding cholera - that Japan be seen in the same light as Europe and the United States. That is, the government sought to continue to identify cholera as an external phenomenon even when its own studies showed the disease had become a persistent year-long presence within Japan's epidemiological landscape.

\section{Cholera during the war}

The Japanese army's use of the catarrh classification for patients exhibiting symptoms of cholera during the war was based on existing medical practice that predated hostilities. In the nineteenth century, physicians of Western scientific medicine employed the general catch-all disease "catarrh," which referred to a wide array of ailments sharing the common symptoms of irritated and inflamed mucous membranes marked by edema and the increased flow of mucous, fluids, and any manner of discharges. In essence, catarrh described a panel of symptoms whose origins remained unclear and therefore served as a flexible disease category to describe the unknown. This practice was clear in Arima Taro's description of a contagious illness that worked its way through the 8th Infantry Regiment while it was stationed in Osaka in 1892. Arima called the malady a type of catarrhal jaundice and suggested it resulted from tainted food and water or poor-quality air. ${ }^{7}$ 
During the Sino-Japanese War, the Japanese army medical bureau employed a dual standard for classifying cholera in Japanese soldiers as either cholera or some form of catarrh. In the army's official medical history of the war, soldiers exhibiting cholera-like symptoms were not recorded as having contracted cholera unless the pathogenic agent had been identified by bacteriological examination. Without the examination they were classified as having a type of intestinal catarrh. Soldiers with light diarrhea and mild vomiting were said to have intestinal or gastrointestinal catarrh. ${ }^{8}$ During the war it was often extremely difficult and time consuming to test every case under a microscope, so many cholera cases were simply classified as some form of intestinal catarrh. The army medical bureau was fully aware of the resultant cholera under-reporting, noting that:

Among the various contagious diseases dysentery and malaria were the most prevalent followed by what is called acute gastrointestinal catarrh, even though it had only become epidemic late in the war. In truth it cannot be doubted that those afflicted with cholera must be far greater in number than is currently recorded. ${ }^{9}$

During the war dysentery, malaria, and acute gastrointestinal catarrh accounted for 10,000 patients each, while the number of patients stricken with cholera only numbered slightly more than $8,000 .^{10}$

A part of the army's official report on the outbreak of cholera during the war on the Liaodong peninsula in southern Manchuria focused on cholera among the local Chinese population. Here it is clear the army applied more relaxed standards in reporting cholera among Chinese. The army's report is based on the work of medical officer third class Nagae Tosaburo, who following the war, filed a report about an outbreak of cholera that occurred in the last year of the war in Dalian in southern Manchuria. Nagae interviewed local people and found they referred to the disease as shanghanbing (傷旱病) and reported it appeared annually in the summer and autumn months. Chinese physicians identified the illness by its symptoms, which included frequent vomiting and diarrhea and a sudden loss of strength, followed by a collapse into lethargy, with the stricken often dying in one to seven days. According to the army's report during the war, the villages around Dalian suffered from a particularly virile cholera epidemic that wiped out entire families. With a flair for the dramatic, Nagae wrote, "[t]he dead were temporarily piled in heaps here and there and were ultimately buried in nearby graves. Now scattered throughout the vicinity of Dalian there are a number of cemeteries, which are remnants of last year's epidemic." 11 It is evident Nagae identified the illness as cholera based on the description of symptoms gleaned from interviews with the local Chinese who survived the outbreak. Accordingly, the report did not classify the disease as a form of acute gastrointestinal catarrh, which would have been the case had the victims been Japanese soldiers.

The army's rigid system of classifying cases of cholera among its rank and file meant medical officers were slow in recognizing that the army was in the 
midst of a cholera epidemic. As early as January and February of 1895, during the conflict on the continent, Japanese troops began to develop symptoms consistent with cholera. The first report of an epidemic enteric illness came from medical officer Nakamura, the commander of the reserve hospital at Kokura. In January he cabled Mori Rintarō, the commander of the medical bureau of the line of communications for the Second Army, and warned that wounded aboard transports from the Liaodong peninsula to army hospitals in Japan were sick with severe vomiting and diarrhea. ${ }^{12}$ In early February, six soldiers on board the Seihō maru out of Dalian developed severe cases of diarrhea; four of them died within a day. Later, two more patients aboard the Seihō maru came down with severe diarrhea. ${ }^{13}$ In addition, in February, medical officer Tateyama, attached to the Second Army's supply bureau in the area of Jinzhou, recorded that a construction worker in the town and another laborer developed symptoms resembling cholera. ${ }^{14}$

The disease spread very rapidly throughout every region in which the Japanese army operated. In March, following the outbreak on the Liaodong peninsula, Mori cabled the army medical bureau about further outbreaks in the Dalian area. In the morning of March 3, 1895, two soldiers from the 5th Reserve Infantry Regiment arriving at Dalian aboard the Seihō maru were stricken with severe vomiting and diarrhea. Later in the evening, part of the same regiment, traveling from Weihaiwei in Shandong province, entered the port of Dalian aboard the Tōei maru, with soldiers sick from similar symptoms. By the time the transport vessel made landfall, one soldier had already died.

The sick soldier's symptoms should have raised concerns about a cholera epidemic; unfortunately the precision inherent in scientific medicine was only as precise as the physicians tending to the sick and it is apparent that none of the sick were tested for cholera. Based on reports by medical officers in the field, Mori attributed the vomiting and diarrhea to food poisoning from Chinese buns eaten by the troops. The army issued a warning that instructed soldiers to refrain from purchasing and eating Chinese food items. However, not all medical officers were convinced that the outbreak was the result of local foods. Maeda, the commander of the line of communications hospital at Lushun, placed the remaining 32 soldiers from the Tóei maru in isolation for observation. ${ }^{15}$ Maeda's decision was the first attempt to limit the spread of the disease that would later be confirmed as cholera.

By March 8 it became apparent that the epidemic was in full swing. Commander Tōki, the director of the Second Division's medical bureau, telegrammed Mori and frantically described a full-blown outbreak of cholera in his unit in Jinzhou, southern Manchuria. According to Tōki, more than 200 troopers were ill with vomiting and diarrhea, which they contracted while being transported from Japan to the Liaodong peninsula. With Tōki's cable in his hand, Mori became convinced that the problem was not Chinese baked goods: these troops developed symptoms before setting foot on the continent. Rather, Mori concluded, the water on board Japanese transport vessels must have been the cause of the outbreak. He immediately called for an investigation of the 
outbreak and simultaneously issued instructions to all transport vessels to supply troops with boiled, not fresh, water. ${ }^{16}$

The Japanese navy, which had its own medical service, did not strictly adhere to Mori's instructions, so as the fighting spread from China to Taiwan the disease continued to spread through the ranks of the Japanese army, which, in turn, brought cholera to Taiwan. At the end of March, the Japanese army carried out a brief campaign on the Penghu Islands (Pescadores) near Taiwan. During the operation it took the Japanese army only two days to occupy the island chain. On March 28 a telegram from the islands described a severe outbreak among the troops of an illness that would later be identified as cholera, which began during the trip from Japan to the islands. The unit in question was transported to the war zone on the Kagoshima maru out of Sasebo, where members of the crew developed a vomiting and diarrheal illness before the voyage. In addition, soldiers transported aboard the Kinshu maru, also out of Sasebo and bound for the Penghu Islands, developed cholera-like symptoms. According to the cable, 49 soldiers contracted the illness and 32 of them were already dead. ${ }^{17}$

Another barrier to diagnosing the illness was simply that the field of bacteriology was relatively new and hence an under-developed field of study in Japan in the 1890s, with few practitioners, military or civilian, who could test for cholera bacteria. After all, the seminal discoveries that laid the groundwork for the import of bacteriology within the field of medicine had only recently occurred with the advent of germ theory in the early and mid-1880s. Since most of the physicians in the Japanese army during the conflict had been trained prior to germ theory, there were few physicians in the Japanese army who were trained in the use of microscopes and capable of engaging in bacteriological inquiries. Furthermore, there were few medical installations in the warzone or in Japan able to carry out bacteriological studies to determine and confirm disease causation. By the end of the war only permanent hospitals in Japan and the isolation facility established in Taiwan were equipped with the personnel and the microscopes to conduct microscopic examinations of the bodily fluids of soldiers who presented with symptoms consistent with cholera. Even in 1885, as Japan's universities embraced the new medical science of bacteriology, naval medical officer Takagi Kanehiro, trained in epidemiology, questioned the practical application of microscopic inquiry to determine disease because it would necessitate that all physicians have access to and training in the use of microscopes. ${ }^{18}$ Essentially, bacteriological inquiry was the purview of medical researchers in the mid-to-late-1880s and this had changed little by the Sino-Japanese War a decade later.

The limited number of medical researchers who held a Ph.D. in bacteriology further underscores the newness of the field of bacteriology in Japan in the 1890s. Ph.D.s in a given field of knowledge are one way of discerning the maturity and development of a research community, because the Ph.D. functions in two essential and complimentary roles: as a producer of research and knowledge, and as a mentor for those wishing to study the field. From the 
mid-1880s to the early 1920 s, the formative period of this field of medical inquiry, there were only 25 holders of a Ph.D. in bacteriology in Japan. Prior to the Sino-Japanese War, Japan had only four bacteriologists, one of whom had received the advanced degree. After the conflict there was a flowering of researchers who became bacteriologists. From 1885 to 1904, the short decade between the Sino- and Russo-Japanese Wars, an additional 15 Ph.D.s in bacteriology were added to Japan's medical scientific community; significant, but hardly an overwhelming number of degree holders. ${ }^{19}$

\section{Quarantine efforts}

The efforts of the Japanese army and navy to contain the outbreak were entirely inadequate and stemmed from two factors: an inability to recognize the epidemic in its earliest stages (noted above), and a focus on disinfection with isolation limited to soldiers and sailors with symptoms consistent with cholera. In the 1880s, the Japanese army and navy issued comprehensive regulations for the prevention of contagious illnesses. In 1886, the navy published a detailed list of rules related to quarantining naval personnel who contracted cholera. The regulations, which mirrored those of the Home Ministry, called for the isolation of the cholera patient, disinfection of the ship they were on, proper disposal of the patient's vomit and diarrhea, and the disinfection of any items the patient used. ${ }^{20}$ In 1889 , the army published its rules for the prevention of contagious illnesses, which focused on how to liaison effectively with local officials during the crisis, as well as instructions for the prevention of contagious illnesses similar to those of the navy and the Home Ministry. ${ }^{21}$ Neither the army nor the navy emphasized isolating people who had come in contact with an infected individual. This was largely because incubation periods for infectious illnesses were not understood this early in the bacteriological study of disease. Instead, the Japanese military medical services focused on isolating the patient and disinfecting and sterilizing vessels and personal effects. These procedures, while thorough in light of the limited knowledge medical practitioners had regarding the disease, led to dire consequences for the Japanese military in its war with China.

By late March, the army itself was fully aware of the two-month-old epidemic's severity. Army reports set off alarm bells in Tokyo and led to consideration of some sort of quarantine planning. The Home Ministry made clear it was illprepared to quarantine large numbers of soldiers returning from the continent, so the army medical bureau took responsibility for quarantining symptomatic soldiers and disinfecting the asymptomatic (but still potential carriers). In April the army established quarantine stations at Moji in Fukuoka prefecture, Nitadori in Hiroshima prefecture, Tenpōzan near Osaka, and Otaru in Hokkaido, but the stations were not fully operational until early summer because it took a few months to construct the facilities and purchase the disinfection equipment from Germany. ${ }^{22}$ By the time the facilities were in place the epidemic had spread from the Liaodong peninsula in China to Shandong province, Taiwan, the 


\section{Roberto Padilla}

Penghu Island chain, and a number of bases in Japan. While the facilities were impressive and at the time represented the most advanced effort to eradicate a microbe, it was too late to retard the epidemic.

Despite its practical limitations, quarantine work also offered the Japanese army medical bureau an opportunity to present itself as a modern organization in line with Western standards. On May, 13 Ishiguro Tadanori, the directorgeneral of field hygiene during the war, issued instructions related to the army's quarantine efforts, which he presented as a necessity because "disinfecting an entire triumphant army upon its return is the hope of any civilized nation." $\mathrm{He}$ began by stressing the Herculean nature of the task. Then he admonished the soldiers working in the quarantine stations to be diligent and thorough in their disinfection procedures, because failure would "sully the good name of the Japanese army." ${ }^{\text {"3 }}$ For Ishiguro and the army, the key to disease prevention stemmed from a central feature of scientific medicine - the killing of microbes. This was the logical progression that formed the basis of the microbial gaze: identify the pathogen that caused the particular illness and prevent the illness by destroying the microbe.

An excerpt from the diary of Hamamoto Risaburō, an infantryman in the Japanese army during the conflict, provides a glimpse of the work of the Japanese army quarantine stations. Hamamoto's unit boarded a transport at Dalian on July 15,1895 , and arrived at the quarantine station at Moji the following morning. During the one-day voyage a private in Hamamoto's company fainted and was diagnosed with cholera by the unit's medical officer. The soldier died that evening before the transport reached Moji. ${ }^{24}$ Hamamoto gave a detailed description of the five-step disinfection process his unit underwent. The men were directed to walk down a long corridor with a large rectangular wooden box, about 60 feet in length, filled with a carbolic acid solution, in the center of the hallway. After walking through the disinfectant they stripped down, placing their uniforms, shoes, and caps in a basket and filled out a name card to identify their items. The men then entered the bathing area that was complete with a large saltwater and a large freshwater bath. After bathing, attendants ushered the men into a refreshment area where they received a haircut, read newspapers, and were provided with tea, cakes, and fresh fruit. Once their personal items had been disinfected they were directed to a receiving room where they dressed and re-boarded their ship, which had also been cleaned and disinfected. The entire process took the better part of a morning. ${ }^{25}$ In the summer of 1895 , more than 230,000 Japanese military personnel aboard 687 transport vessels experienced the disinfection process Hamamoto described in his diary. ${ }^{26}$

The quarantine work of the Japanese army was extensive but flawed, and doomed to failure for the following reasons. First, the quarantine system was put in place too late to seriously impact the spread of cholera. The epidemic began in early January and was in full force by the time the quarantine stations were operational in June. Second, it is clear from Hamamoto's account that the quarantine stations were primarily disinfection and sterilization centers, with quarantine imperfectly carried out. The quarantine stations had the policy of 
only isolating those soldiers, crewmen, and personnel who exhibited symptoms consistent with an infectious illness, and did not separate everyone who came in contact with the sick individuals. This reflected the limits of medical knowledge in disease etiology in the 1890s. Medical professionals did not understand that infectious illnesses had an incubation period, specifically that an individual could be infected with a disease and show no visible symptoms for a period of time. Hamamoto and his unit were not isolated after undergoing the disinfection and cleansing process because they had not developed full-blown cholera, even though they had contact with a member of their unit who died from cholera during the passage to Japan.

\section{Conclusion}

During the Sino-Japanese War, the Japanese army's use of a rigid standard of classifying cholera based solely on laboratory testing had a number of significant and unintended consequences. The selective use of the system of disease classification essentially created two forms of the illness for the Japanese army: cholera and gastrointestinal catarrh. Since most soldiers who actually contracted cholera were classified as having gastrointestinal catarrh, there was a significant underreporting of cholera among the rank and file of the Japanese army. Likewise, cholera was over-reported in the Chinese civilian population because the army did not use the category of intestinal catarrh with Chinese. They were reported as having cholera if they developed observable symptoms that mirrored the illness. This disparity in reporting skewed the epidemiological reality throughout the warzone and reinforced the Japanese view that cholera was primarily an Asian illness. In addition, in the final months of the Sino-Japanese War the army medical bureau did not establish quarantine stations until six months after the first cases of a cholera-like enteric illness was reported in the army. This was the result of the army's policies related to cholera identification, policies which were unrealistic considering the resources and limitations of the army medical bureau in diagnosing the illness based on the new field of bacteriology. Since the army medical bureau was unable to determine the earliest cases to be cholera, the initial outbreaks in January and February were attributed to either gastrointestinal catarrh or Chinese food items, so there was no effort to prevent the spread of cholera. Furthermore, once the Japanese army responded to the epidemic it established a system of quarantine that emphasized disinfection and sterilization and, because of the limits of medical knowledge of the period, limited quarantining to those individuals who exhibited symptoms consistent with cholera and did not isolate those who had been in contact with the sick. The failure of the army medical bureau to recognize the cholera outbreak in its early stages and to put in place a proper system of quarantine and isolation had dire consequences for Japan. In 1895, a particularly virulent form of cholera became epidemic in Japan, claiming 40,154 lives out of a total of 55,144 confirmed patients, largely because of an over-reliance on a new tool, bacteriological analysis, that was 
poorly understood and had limited availability, as the sole means of identifying cholera among the Japanese population. ${ }^{27}$

\section{Notes}

1 Arno Karlen, Man and Microbes: Disease and Plagues in History and Modern Times (New York: Simon and Schuster, 1995), 138-9.

2 James Bartholomew, The Formation of Science in Japan (New Haven, CT: Yale University Press), 51.

3 A Brief Review of the Operations of the Home Department in Connection with the Cholera Epidemic of the 18th Year of Meiji, 1885 (Tokyo: The Home Ministry, 1886), 4. Hereafter Brief Review.

4 Ibid., 2-3.

5 Ibid., 2.

6 Ibid.

7 Arima Tarō, "Katōjisei ōdan no ryūkō ni tsuite," Rikugun guni gakkai zasshi, 55, (October 1892), 46-9.

8 Meiji 27-28 neneki rikugun eisei jikō: dai 3 kan densenbyō oyobi kakke, dai 3 hen koreri, dai 1 shō kanja sōkei oyobi ryūkō no jōkyō, sono 1 kanja sōkei (Tokyo: Igakubu rikugunsho), 1-2. Hereafter Meiji 27-28 neneki rikugun eisei jikō.

9 Ibid.

10 Rikugun guni gakko gojūshünenshi (Tokyo: Rikugun Guni Gakko, 1937), 36.

11 Meiji 27-28 neneki rikugun eisei jikō, 5.

12 Meiji 27-28 neneki jinchü, chü 2, Daihonei yasen eisei chokanbu (Tokyo: Rikugunsho, 1896), 823. Hereafter Meiji 27-28 neneki jinchū, chū 2.

13 Ibid., $1,018$.

14 Ibid., $1,024$.

15 Ibid., $1,097$.

16 Ibid., 1,115-6. This document is also significant because it implies that as early as March cholera was evident in camps in Japan.

17 Yamamoto Shunichi, Nihon korerashi (Tokyo: Tokyo University, 1982), 98.

18 Christian Oberlander, "The Rise of Scientific Medicine in Japan: Beriberi as the Driving Force in the Quest for Specific Causes and the Introduction of Bacteriology," Historia Scientarium: International Journal of the History of Science Society of Japan, 13: 3 (March 2004), 195. Here, Takagi Kanehiro questions the application of bacteriology inquiry in relation to beriberi in the 1880s. His concerns regarding the practical aspects of the scientific study to examine body fluids were well founded.

19 Who's Who Hakushi in Great Japan, 1888-1922: Biographical Dictionary, vol. 2, ed. Kuro Ieski (Tokyo: Hattensha, 1922).

20 Yamamoto, Nihon korerashi, 528-32.

21 Ibid., 523-26. The army's regulations stressed the need for commanders of units to notify local authorities about the outbreak of an illness and establish a committee to address the emergency.

22 Ibid., 97.

23 Ibid., 588-9.

24 Jinushi Aiko, Nisshin sensō jūgun hiroku: 80-nenme ni kōkai suru, sono inga kankei (Tokyo: Seishun Shuppan, 1972), 193.

25 Ibid., 193-4.

26 Kabe Sumio, "Nihon no korera-sono rekishi to genjō," Bōei eisei: gijutsu shirizu, 51: 200 (March/April 2004), 4.

27 Yamamoto, Nihon korerashi, 96. 


\title{
11 Kampō in wartime Sino-Japanese relations \\ The Association of East Asian Medicine and the search for a tripartite medical partnership
}

\author{
Mizuno Norihito
}

Kampō or Kampō igaku (Kampō medicine) is the popular term that refers to traditional Japanese medicine, including the prescription of crude drugs, acupuncture, moxibustion, and traditional regimens and eubiotics. It is a neologism which the Japanese used to distinguish their indigenous medicine from Ranpo (Dutch medicine) in the late Tokugawa period (1603-1868). However, the usage of the term is also not unanimous among the Japanese. The term is used to refer exclusively to traditional Japanese medicine but also to refer to Chinese medical traditions. ${ }^{1}$ The Kampo professionals who appear in this chapter were the latter. ${ }^{2}$ Kampo sometimes includes traditional Korean medicine and is synonymous with or as a constituent of Tōyō igaku (Eastern or Oriental medicine) or Tōa igaku (East Asian medicine). ${ }^{3}$ Before the end of World War II, inspired by nationalistic sentiment, the alternative term $K \bar{o}-K a n$ igaku (Imperial Japanese-Chinese medicine) sometimes replaced Kampō to emphasize Japanese uniqueness or originality. ${ }^{4}$

Regardless of vocabulary or definition, traditional Japanese medicine owed much to Chinese medicine. The continual medical exchange was the unilateral outflow of medical wisdom from China to Japan. Although $k \bar{o}$ seems to have become an obsolete term after World War II, popular understanding of traditional Japanese medicine, usually called Kampō today, still tends to stress its unique or different aspects as some use Nihon Kampō to distinguish Japanese from traditional Chinese medicine. ${ }^{5}$ The continued presence of Kan demonstrates, however, that the Japanese recognize Chinese medicine's historical influence.

In the late nineteenth century, Sino-Japanese medical relations began an unprecedented phase shift. The long-time mentor-protégé relationship between the two countries was no longer a fixture due to Western inroads into East Asia, drawing China and Japan into more intimate communications. Soon after diplomatic relations were re-established in the early 1870s, the Chinese discovered that the Japanese had preserved missing Chinese medical classics and recognized that traditional Japanese medicine was worth their study. Particularly after their humiliating defeat in the First Sino-Japanese War (1894-5), the Chinese started learning from the Japanese 


\section{6}

\section{Mizuno Norihito}

modernization experience. ${ }^{6}$ After the war, the Qing dynasty invited Japanese advisors and instructors to reform administrative, educational, and military institutions, as did the Republican government and local warlords after the Xinhai Revolution (1911-12). ${ }^{7}$ There was a wave of Chinese studying in Japan around the Russo-Japanese War (1904-5), and thousands of Chinese students came to Japan in the first decade of the twentieth century. ${ }^{8}$ Chinese also sought medical knowledge from Japan. Japanese medical professionals were invited to China and introduced Japanese-style medical education. ${ }^{9}$ Young Chinese such as Lu Xun and Guo Moruo came to Japan to study modern medicine. The Japanese medicine to which the Chinese paid attention also included Kampō. In the early Republican period China witnessed a publication boom in works on traditional Japanese medicine and numerous Chinese studied traditional Japanese medicine in Japan. ${ }^{10}$

This chapter focuses on an unprecedented and virtually unknown modern episode of Sino-Japanese medical intercourse: in the midst of the Second Sino-Japanese War (1937-45), a group of Japanese Kampō professionals founded the Association of East Asian Medicine. The proclaimed mission of the Association was to pursue a partnership of the traditional medicines of Japan, China, and Manchukuo as an effective means to attain "amity and partnership" between the three East Asian neighbors toward the ultimate goals of creating "eternal peace" in East Asia and "true East Asian medicine" to guide the coming new post-war era. ${ }^{11}$ Previous studies, except for some brief narratives and biographical sketches, have paid little or no attention to the wartime activities of the Association, which still exists. ${ }^{12}$

I focus on how the Association was involved in the war that became the final episode in Imperial Japan's continental expansion. The Association neither necessarily blindly supported government propaganda nor did it unconditionally believe that Japan was entirely righteous vis-à-vis China. ${ }^{13}$ However, it by no means firmly denied the efficacy of either the war itself or wartime state policy. The search for a medical partnership was the Association's manifestation of support for the war and propagated war objectives, i.e., the creation of peace under a "New East Asian Order." 14 The Association simultaneously found that the ongoing war on the neighboring continent provided a great opportunity to realize the dream which Kampō professionals, including Association members, shared at that time. The Association expected the creation of a tripartite medical partnership to promote the "great strides" of Kampo medicine and as a result contribute to the Kampo revival movement from the late 1920s, after several decades of adversity under medical Westernization. ${ }^{15}$ The Association was thus encouraged to contribute to the war effort by wartime propaganda and simultaneously tried to use the war for its own sake. The Association prepared various partnership projects and actually launched some of them. The search for a partnership could escape neither the hard fact of the military conflict nor being at the mercy of the war's progress. 


\section{The Association of East Asian Medicine and tripartite medical partnership}

In the midst of protracted war with China, a group of Japanese Kampō professionals and others in related professions established a new Kampō organization named the Association of East Asian Medicine. The inaugural ceremony took place at Takushoku University, Tokyo, on November 25, 1938. ${ }^{16}$ The Kampō faculty, placed in the university a year earlier, was chosen as the headquarters, and the secretariat was placed in Kaikō Academy, a private Kampō academy within the Onchidō Kampō clinic in Ushigome. Membership was opened to all who supported the Association's mission; the annual subscription fee of one yen twenty sen for the bulletin of the Association Tōa igaku (East Asian Medicine) doubled as the membership fee. ${ }^{17}$

The founding members of the Association, all Japanese, were Yakazu Dōmei, his younger brother Yakazu Yūdō, Ishihara Yasuhide, Ōtsuka Noriyoshi, Tatsuno Kazuo, Yanagiya Sorei, Kimura Chōkyū, and Shimizu Tōtarō. The Yakazu brothers, Ōtsuka, and Kimura were Kampō physicians belonging to different schools, such as the schools of Classical Formulas (Kohōha), Later Development (Goseiha), and Eclecticism (Setchüha), all of which had emerged during the Tokugawa period. ${ }^{18}$ Shimizu was a pharmacist, Yanagiya was an acupuncturist, and Ishihara was a medical historian. They were the founding members and instructors at the Kaikō Academy established in 1935 for the purpose of restoring Kampō, training a younger generation of Kampō practitioners, and holding the Kampō workshop, the precursor to the aforementioned Kampō faculty. ${ }^{19}$ The founders entered their names as the directors of the Association. The position of president was not established at the beginning but later assigned to Ōtsuka. ${ }^{20}$

The Association's prospectus stated that its objective was to contribute to the materialization of a tripartite partnership between Japan, China, and Manchukuo which should lead to the ultimate goal, peace in East Asia, by exploiting traditional medicine of the three countries to form a tripartite medical partnership:

This Association is to foster mutual amicable companionship and to attempt to promote East Asian culture in order to contribute to the accomplishment of eternal peace in East Asia through the exchange and study of East Asian medicine between the three countries_-Japan, China, and Manchukuo. $^{21}$

After emphasizing the significance of amity between the three countries as the basis of regional peace, the prospectus claimed that traditional medicine could function as a "shortcut" to reach that goal. It explained what the Association meant by "exchange" and "study." Japanese Kampō professionals would engage in medical services for the local Chinese and Manchurian populace and collaborate with traditional medical professionals. Under such a tripartite partnership, the Association intended to strive for the "rapid 
progress" of Kampō medicine and to create "true East Asian medicine," which should then play a leading role in "East Asia's new era" after the war. ${ }^{22}$

The Association's expectation that traditional East Asian medicine would become a "shortcut" and "pillar in the construction of a new East Asia" came out of its confident view of the state of traditional medicine in China. ${ }^{23}$ The Association considered that traditional medicine enjoyed some advantages vis-àvis Western medicine in China and Manchukuo, especially regarding ease of access. The prospectus pointed out that the several thousand-year-old medical tradition was overwhelmingly superior to its Western counterpart in terms of general public confidence and the number of medical practitioners in the two neighboring countries. ${ }^{24}$ Yakazu Dōmei noted that about 80 percent of medical professionals practiced traditional medicine in China and Manchukuo, and that Western medicine accounted for a mere 2,048 professionals compared with 9,227 in traditional medicine in Manchukuo in $1935 .{ }^{25}$ Otsuka also referred to the presence of over a million traditional medical practitioners in China and pointed out that the unchallenged status of traditional medicine rested on popular support behind which there was ever-present Sinocentrism. Ōtsuka observed that the traditional self-image as the "Center of Civilization" had prevented Western medicine from penetrating the country and argued, "We ought to think about which would contribute to Sino-Japanese goodwill, making one million Chinese Kampō physicians, supported by 400 million people, our friends or enemies." ${ }^{26}$ The anonymous foreword of the second issue of the monthly bulletin Tóa igaku in March 1939 claimed that philosophical and remedial superiority was a further reason for the qualification of traditional medicine as a mainstay in constructing a "New East Asian Order," which would morally outdo liberalism and communism. ${ }^{27}$

Assuming that the language appearing in Tōa igaku expressed what the Association and its members, especially the pivotal ones, truly thought and intended to do, it is perhaps possible to argue that the Association - a group of Japanese nationals - supported and were eager to contribute to the wartime policy which drew broad support among the Japanese populace. ${ }^{28}$ The ideas of tripartite partnership and "eternal peace" in fact coincided with the state's propaganda. On 3 November 1938, about three weeks before the inauguration of the Association, Premier Konoe Fumimaro proclaimed Japan's wartime objectives:

The Empire seeks the construction of a new order that will secure eternal stability in East Asia. This is the objective of the war at this time. The construction of this new order will accomplish international justice, anti-Communist cooperation, the creation of new culture and economic unity, with the establishment of mutual cooperation in various fields such as politics, the economy, culture, and so on through a partnership between the three countries-Japan, Manchukuo, and China. ${ }^{29}$ 
Yakazu Dōmei furthermore identified the goal of the Association with the "will of the emperor" by quoting the following phrase of the imperial edict in the opening ceremony of the $72^{\text {nd }}$ Imperial Diet on 4 September 1937, about two months after the Marco Polo Bridge Incident: "To implement co-prosperity by securing the stability of East Asia through partnership and cooperation between the Empire (of Japan) and the Republic of China is that with which we have always been concerned." 30

The Association was not so naïve as to blindly believe in Japanese infallibility vis-à-vis China. Despite the rise of military authority and the 1938 National Mobilization Act, some latitude for free speech still remained in wartime Japanese society in the late 1930s, and some intellectuals openly criticized Japanese perceptions of, and policies toward China. ${ }^{31}$ In a statement issued on 15 August 1937, the Japanese government justified the war as "chastisement," alleging that military operations, although inevitable and to be regretted, were countermeasures to hostile and insulting Chinese attitudes toward Japan, which desired peace in East Asia and the coexistence and co-prosperity of the two countries. The Association, however, refused to place full responsibility for the SinoJapanese military confrontation on China. The foreword to the bulletin's second volume contended that Japanese education, including medical education, had sunk into the depths petty idealism and was one of the causes of the war. The idealism they meant was the construction of a "truly peaceful world." The forward claimed that the foundation for attaining the ultimate goal should be the realization of both Chinese and Japanese people's enjoyment of life through mutual trust, understanding, and respect. The Association asserted that Japanese education, which worshiped and mimicked the West, caused Japan's disdain of China, their culture's ex-mentor, and engendered the current idealism. ${ }^{32}$ The editorial note warned that those who, as victors, looked down on China and its people, would understand neither a Sino-Japanese partnership through Kampō nor the significance of mutual understanding, respect, and trust as the basis for the construction of a new East Asian order. ${ }^{33}$

Despite such critical views, the Association seemed on the whole to swallow state propaganda. From the very beginning, the Konoe cabinet attributed the outbreak of war to Chinese attitudes toward Japan. The Imperial Army published a booklet titled Chōkisen ni taisuru kokumin no kakugo (The Nation's Determination vis-à-vis a Protracted War) on the $33^{\text {rd }}$ commemoration of the victory in the Battle of Mukden (March 10, 1905), blaming the Nationalist government, which collaborated with communists, for causing the war and for disturbing peace in East Asia. ${ }^{34}$ Likewise, the foreword of the third volume of the bulletin (April, 1939) also identified Chiang Kai-shek's "anti-Japanese education" as an obstacle to Chinese understanding of Japan's true objectives, which were designed to serve the common welfare of East Asians. ${ }^{35}$

Anti-Western tones found in the bulletin also indicate that the Association accepted state propaganda. The government had outlined the reasons for denouncing such major Western powers as the United Kingdom, the United States, and France, in addition to the Soviet Union, for supporting China's 
anti-Japanese policy and disturbing the realization of new order and peace in East Asia. ${ }^{36}$ The army pamphlet stated that Western powers and the international communist movement were behind Chinese attitudes. ${ }^{37}$ In his November, 1938 inauguration speech, Yakazu Dōmei insisted that warfare would have to be pursued until the expulsion of the "puppeteers," i.e., the United States and Great Britain, which manipulated Chiang Kai-shek. ${ }^{38}$ Yakazu continued, quoting a classical Chinese anecdote, warning that without partnership, Japan and China would be reduced to sharing the same fate as the quarreling snipe and mussel caught by the fisherman. ${ }^{39}$ This editorial note sounded even more hostile, advocating a Sino-Japanese joint struggle against all Western thought and domination. ${ }^{40}$

Leading Association members furthermore interpreted the war on the Chinese continent as a clash of civilizations and stressed the potential role of traditional medicine in promoting the ultimate goal of the wartime state policy. In his "fisherman" metaphor, Yakazu Dōmei considered the "fisherman" to be an interloper, in this case the West, which made the Sino-Japanese conflict a struggle between Eastern and Western civilizations. ${ }^{41}$ Ötsuka, who defined medical partnership as cultural, stated that ongoing warfare in China would dissolve the "old culture" and engender the "new culture." For him, the former meant "Western Europe-centered culture," the latter being "East Asia-centered culture." ${ }^{42}$ For Ōtsuka, the regulations and the prospectus proved that the Association expected Kampo medicine to play a role in the rise of the new culture he expected the war to bring about, and Ötsuka argued that Kampō could pioneer a new East Asian civilization and unite the three countries to sustain the East. ${ }^{43}$ Yanagiya Sorei insisted that further development of acupuncture and moxibustion could contribute to the completion of a new East Asia. ${ }^{44}$

Devotion to the state also sprang from the Association's concern about selfinterest, namely the advancement of the Kampō revival movement. Kampō professionals' collective struggle against medical Westernization since the Meiji Restoration resulted in near-fatal defeat in the 1890s. Those who wanted to be licensed physicians were required to study Western medicine, and as a result, traditional medicine was on the verge of extinction. ${ }^{45}$ However, grassroots-level support and a small number of surviving Kampo professionals just managed to save traditional medicine from being buried in the annals of history. ${ }^{46}$ Some Kampō professionals and scholars of schools such as the schools of Classical Formulas, Later Development, and Eclecticism began "reviving" the endangered medical tradition. The emerging ethos of restorationism (fukko shugi) and chauvinistic nationalism (kokusui shugi) in the early Showa era (1926-89) possibly inspired the rise of the revival movement, along with increasing popularity of the term "Kō-Kan igaku" among traditional medical professionals. ${ }^{47}$ In 1934, different Kampo groups sharing the common objective of "revival" established the Japan Society for Kampō Medicine in Tokyo. ${ }^{48}$ Six of the founding members of the Association (Yakazu Yūdō and Tatsuno Kazuo were the exceptions), shared the position of director. ${ }^{49}$ As mentioned 
previously, the establishment of the Kaikō Academy and workshop at Takushoku University in 1935 was the basis for founding the Association four years later.

The Association considered that a medical partnership would promote "rapid progress" in "Kampō medicine as part of a revival." 50 For the Association, "revival" meant more than a mere literal revival of the endangered medical tradition. Yakazu Dōmei, for example, believed in the necessity of innovation in a "new Japanese medicine." 51 With the emphasis on clinical advantage, Takeyama Shin'ichirō, an ex-journalist and acupuncturist, rejected the mere revival of tradition and the compromise between Kampō and Western medicine. As an argumentative member of the Association who joined the communist party after the end of World War II, Takeyama instead advocated for "innovation in modern clinical medicine" through the critical examination of modern medicine. ${ }^{52}$ According to the prospectus, innovative medicine would materialize through a medical partnership between the three countries sharing the same or similar medical traditions and should ultimately be elevated to the status of a "new East Asian medicine."

The "revival" was not intended, however, to eliminate Western medicine despite Kampō's alienation from the tide of Westernization and the Association members' anti-Western sentiments. Members contended rather, that Western medicine was stagnating because of its clinical impotence, which they thought was evident in such urgent medical concerns as the spread of tuberculosis and the decline of national physique in Japan at that time. ${ }^{53}$ However, the Association did not exclude foreign medicine from making wartime medical contributions to the "historical great enterprise" 54 _ indeed, it envisaged that collaboration between the two medicines would be fruitful. ${ }^{55}$ Kimura Chōkyū recognized some pathological, preventive and surgical advantages of Western medicine, advocating for the "synthesis of Eastern and Western medicines." 56 The new medicine that Yakazu envisioned similarly meant the "fusion" of the two medicines. For the Association, however, the uncompromising point was that indigenous East Asian medicine must be the basis of the new medicine in the post-war era.

\section{Programs and activities for a tripartite partnership}

The Association introduced eight programs to implement its tripartite medical partnership:

1 publication of a journal, Tōa igaku;

2 a journal exchange from each country;

3 an exchange of books and articles from each country;

4 an exchange of each country's superior medicines;

5 an exchange of research students and groups of inspectors;

6 the establishment of Kampō hospitals, Kampō libraries, a JapaneseChinese medicine ( $W a-K a n ' y a k u$ ) research institute and Kampō educational institutes; 
7 other undertakings recognized as necessary for the accomplishment of the objective;

8 the holding of a regular monthly meeting. ${ }^{57}$

The Association published Tōa igaku and held fairly regular monthly meetings in Tokyo, mostly at Takushoku University to share and deepen the members' professional knowledge and understanding of medical conditions in China and Manchuria. ${ }^{58}$ At a very early stage the Association founded a pharmaceutical corporation, the Research Institute of the Association of East Asian Medicine, to popularize Kampō drugs and meet the growing demand for quality Kampō merchandise in China. ${ }^{59}$ With Ishihara Yasuhide's donation of 600 titles and others' donations, the Kampo library, named the Ishihara Library, was established inside the Takushoku University Library in February $1941 .{ }^{60}$ For educational purposes, the Kampo faculty continued to be housed at Takushoku University until 1944, and all lectures were published. The Kampo Medicine Workshop for Youth and the Kampo Acupuncture Workshop for Youth were opened. ${ }^{61}$ The Association also held, sponsored, and published open lectures. ${ }^{62}$ Furthermore, the Association planned to establish a professional school, Kampō hospital and an herbal garden, though neither came to fruition. ${ }^{63}$

The Association and its individual members attempted to promote exchange programs. In Japan, the Association made efforts to disseminate information and knowledge of traditional medicine in the "partner" countries. The bulletin repeatedly published articles introducing the activities of Chinese traditional medical professionals, including their publications and translations of Chinese works and reports on and discussions about medical practices and conditions in Manchukuo and China under Japanese occupation. ${ }^{64}$ The Association used its monthly meetings and the Kampo faculty at Takushoku University to introduce the subject of Chinese medicine. ${ }^{65}$ The organ of the Japan Association for Kampō Medicine, Kampō to Kan'yaku (Kampō and Kampō Drugs) was another important place to discuss and introduce Chinese traditional medicine to its members. ${ }^{66}$

Building a bridge between Chinese and Manchurian professionals of traditional medicine was not quite a new endeavor for the Association. Ötsuka and Yakazu noted that before the outbreak of the Marco Polo Bridge Incident (July 1937), Chinese Kampo professionals had approached them to form a research partnership, donating 18 Chinese medical journals in which Japanese Kampō works were translated and introduced. ${ }^{67}$ Before the outbreak of the war, nearly twenty Chinese organizations had been affiliated with the Society of Japanese Kampō Medicine, founded in 1934, to promote the revival of Kampō in China. ${ }^{68}$ At least some Chinese traditional medicine professionals looked for a chance to associate with the Japanese in the prewar years but a series of anti-Japanese actions at that time, including violence against individuals, indicated mounting Chinese indignation against Japanese imperial encroachment. ${ }^{69}$ Despite the anti-Japanese atmosphere Chinese professionals of traditional medicine maintained their interest in Japanese traditional medicine. The number of publications 
introducing Kampō to a Chinese audience published before and after the Meiji Restoration consistently increased, and this phenomenon became more conspicuous in the 1930s, ironically in parallel with the intensification of tension between Japan and China. Mayanagi Makoto argues that domestic controversy over traditional medicine perhaps gave rise to the boom in Japanese Kampō works in China because Chinese professionals of traditional medicine tried to find wisdom in Japanese publications with which to counter their opponents. A proposal to abolish traditional medicine submitted to the Republican government in 1929 prompted this dispute. In the end, traditional medicine obtained legal status in 1936. The Chinese likely approached Japanese Kampō professionals to protect traditional Chinese medicine. $^{70}$

The Association's attempt to promote friendship with Chinese and Manchurian professionals of traditional medicine meant an effort to rehabilitate exchanges obstructed by the war. Soon after its establishment in late 1938, the Association started to donate teaching materials used by the Takushoku University Kampō faculty and medical exchanges interrupted by the military clash since the summer of 1937 were resumed. ${ }^{71}$ In March 1939, the Association dispatched Koyanagi Ken'ichi, Tōa igaku's editor, to major cities in northern and central China to investigate local medical conditions, propagate the establishment of the Association, and associate with local Kampō professionals. ${ }^{72}$ Members on duty in China were in a better position to have closer contact with the local profession. ${ }^{73}$ A pharmacist, Nakajima Torao, a junior lieutenant in northern China, had conversations with 15 local Chinese physicians and $\mathrm{Fu}$ Ruqin, the director of health and hygiene of Tianjin, in $1939 .^{74}$ Honda Seiichi, an army surgeon and first lieutenant, found an opportunity to meet Ye Juquan, director of Suzhou National Medical Hospital (Suzhou Guoyi yiyuan). Based on Ye's introduction, Honda also had a conversation with Shi Yire, the publisher of the medical journal Fuxing zhongyi (The Revival of Chinese Medicine) and the organizer of the Shi Yiren National Medicine Program in Shanghai. ${ }^{75}$

Even during a state of belligerency, the Association's appeal for medical exchange intrigued some Chinese. Yang Yiya was an acupuncturist and moxibustionist and ran a publishing house in Beijing. Yang started to donate his medical journal, Guoyi dizhu (National Medical Fortitude), to the Association in May 1939 and kept introducing Japanese Kampō works to Chinese readers. ${ }^{76}$ Qin Bowei, the owner of a Kampō clinic in Shaghai, also sought exchanges with the donation of his journal, Zhongyi liaoyang zhuangang (Professional Journal of Chinese Medical Treatment). ${ }^{77}$ Tianjin ribao (The Tianjin Daily) introduced Ötsuka's study of a remedy for dysentery, which had appeared in the sixth volume of $T \bar{o} a$ igaku in July $1939 .{ }^{78}$ The eleventh volume of the bulletin published in December 1939 reported that the Association had seven Chinese members and had received additional membership applications from China and Manchukuo. $^{79}$

Ye Juquan of Suzhou seems to have been the most active Chinese Kampō professional with whom the Association interacted. The Association officially counted him, as well as Yang Yiya of Beijing, as partners in China. ${ }^{80}$ Ye had 
paid attention to traditional Japanese medicine from before the outbreak of the war. He found the translation of Ötsuka Yoshinori's article in the Chinese journal Mingri yixue (Future Medicine, May 1937) and started communicating with Ōtsuka. After finding that Ye was still alive following the outbreak of the war, Ötsuka sent him a letter, along with the bulletin and Kampō to Kan'yaku in late 1939. ${ }^{81}$ Ye wrote back and asked Ötsuka to donate all the back volumes of Kampō to Kan'yaku plus Japanese medical plants and Kampō drugs in exchange for his work and samples of new Chinese drug products. ${ }^{82}$ Ye's clinical reports were translated by Ōtsuka and published in Tōa igaku in $1940 .{ }^{83}$ Ye dispatched two of his students (a married couple) to Japan and they participated in the Kampo faculty at Takushoku University from April until July $1941 .{ }^{84}$ After the war, his wartime affiliation with the Japanese likely became the cause of years of hardship during the Cultural Revolution until his rehabilitation in 1973.

The Manchukuo government gave the Association official opportunities to be involved in the process of making medical policy in the newborn state. In March 1940, Zhang Jiyou, chief of the epidemic prevention section of the Department of Home Affairs visited Japan to consult with the Association on the treatment of traditional medicine in the Manchukuo medical system, which reform was in progress. ${ }^{85}$ In the July issue of the bulletin, Kurihara Kōzō, a pharmacist who had returned from a trip to Manchukuo one month earlier, argued that the re-education of Manchurian professionals of traditional medicine and the adoption of Western anatomical physiology would be required to re-examine and systematize traditional local medicine and ultimately to create a new medicine which could contribute to the "New East Asian Order." 86 Two directors, Yakazu Dōmei and Tatsuno Kazuo, were invited to Manchukuo on Kurihara's recommendation to the Department of Home Affairs and attended a council meeting on medical reform in the Manchurian capital, Shinkyō (Changchun), on July 17, 1940. Tatsuno later reported that the meeting concluded that traditional medical practices should be preserved with re-education and a license examination system. ${ }^{87}$ Two of the Association directors were appointed to be temporary department heads and members of the committee on license examination in September. ${ }^{88}$ Tatsuna thereafter continued to work on the examination system, which the Manchukuo government eventually implemented in $1941{ }^{89}$ Together with two other Association members, Kurihara and Kimura Yūshirō, Tatsuno further participated in preparing regulations on traditional medicine. ${ }^{90}$

\section{Limitations and frustration in the wartime search for a tripartite partnership}

The Association's search for a tripartite medical partnership appeared to have reached fruition by early 1941 with the bulletin of the Suzhou National Medicine Clinic (Suzhou guoyi yiyuan), published in 1939, marking clear progress toward a medical partnership between Japan and China. The Suzhou National Medicine Clinic had been founded by order of the governor of Jiangsu province 
in April 1939, and Ye Juquan worked as one of its ten doctors. ${ }^{91}$ Probably published months after the clinic opened, the bulletin's preface was written by Yumoto Kyūshin, ${ }^{92}$ the Kampō doctor who had gained a reputation for his work, Kō-Kan igaku (1927), which was also translated and published in China. ${ }^{93}$

In the foreword of the 25th volume of Tōa igaku, published in February 1941, Yakazu Dōmei boasted of the Association's two years of achievements and asserted that exchanges between Japanese and Chinese professionals of traditional medicine had been growing stronger since the temporary disruption of their prewar communications by the clash in July $1937 .{ }^{94}$ The bulletin unprecedentedly received five contributions to this special issue and subsequent issues from China, Inner Mongolia and Manchukuo, and this engendered the impression that the Association's efforts at medical partnership had borne fruit. ${ }^{95}$ Ye Juquan's students - the married couple — arrived in Tokyo the same month. ${ }^{96}$ The volume's announcement of Tatsuno Kazuo's attendance at the preparatory meeting for license examinations for Manchurian professionals of traditional medicine and the participation of the three directors of the Association, Shimizu Tōtarō, Kurihara Kōzō, and Kimura Yūshirō, in establishing the Bureau of Kampō Medicine in Manchukuo the following month would further the impression of the Association's successful trajectory. ${ }^{97}$

Nevertheless, in the search for medical partnership, some members found problems within the Association itself. The inspection report on the medical and hygienic situation in China pointed to the Association's lack of basic preparation for cultivating medical partnerships. The anonymous author, apparently the editor of the bulletin Koyanagi Ken'ichi, stated that the members lacked sufficient Sinological background, deeming language learning in particular an urgent matter. He further pointed to the absence of articles written by Chinese physicians in the bulletin as another problem. ${ }^{98}$ Takeyama Shin'ichirō's comments on the issue of the "survival" of traditional medicine in the three East Asian countries were accurate regarding another problem. Takeyama contended that Kampō professionals should form an affiliated organization based on the unity of government and private supporters, with a firm financial footing and ability to take proper political and academic actions. Takeyama then criticized several Japanese Kampō organizations that were, in his view, isolated from the rest of society and impotent politically, financially, and academically. ${ }^{99}$ Although Takeyama did not specify which organizations he targeted, the problems he identified were recognized in the Association.

The Association also failed in lobbying the political and military figures who influenced wartime medical policy. Decades after the war, Yakazu Dōmei concluded that the Association intended to shape its activities to favor the government at home and to promote itself overseas as a political movement, but could not in the end win the support of the government or military and political circles. ${ }^{100}$ Some individual government leaders and officials, however, expressed positive views of traditional medicine and admitted its possible contribution to the wartime state enterprise. At the Imperial Diet in early 1939, the 
secretary-general of the East Asian Development Board (Kōain), Yanagawa Heisuke, expressed his expectation that Japanese medical activities in China, combining with traditional and Western medicine, would contribute to the placation of the local populace. ${ }^{101}$ In July 1941, in a conversation with Kampo faculty lecturers at Takushoku University, Director General of the Cultural Affairs Division of the Ministry of Welfare Matsumura Susumu said that the ministry planned the establishment of Kampo educational and research institutes in Japan and on the continent for the sake of nurturing talent to serve an intraregional partnership. ${ }^{102}$ Other state agencies, however, did not seem to regard traditional medicine as serving national interests, nor did they assist its "revival." 103

Kampo professionals felt that traditional medicine remained alienated and marginalized in Japanese medical policy. The government banned Kampo clinics' public use of the title "Kampo (Kampōka)" in 1933. The use of the title (or word) was furthermore banned as an "enemy word" in 1944. Ötsuka felt that the true intention of government regulation was to suppress traditional medicine. ${ }^{104}$ Some individual army officers, such as Honda Seiichi, participated in the Association, and their reports to the bulletin from the continent indicate that their superior officers permitted them to practice traditional medical techniques. ${ }^{105}$ Struggling desperately with an unexpectedly protracted war in China, the army — or at least its expeditionary forces to China - came to expect "the reconstruction of Eastern culture" to bring the two countries into a partnership. ${ }^{106}$ Such an awareness of the usability of traditional medicine was not shared by the upper echelons of the Imperial Army. Lieutenant Surgeon General Shimose Kentarō denied the raison d'être of Kampō. He labeled traditional medicine "abolished medicine" and refused to admit to its potential role in medical policy toward China. ${ }^{107}$

The activities of the Association were inseparably subordinate to the nature and progress of the war. Japanese Kampō professionals had already been communicating with some of their Chinese counterparts from before the outbreak of the war; yet Tóa igaku revealed that the Association was able to associate with only a few Chinese medical organizations while the war was ongoing. Despite its eagerness to form partnerships, only a handful of Chinese joined the Association. ${ }^{108}$ Exactly two years after its establishment, the Association could consider only two Chinese Kampō professionals-Ye Juquan and Yang Yiya- "communication partners." 109 Japanese Kampō professionals' lack of competency in Chinese likely prevented them from finding and communicating with their Chinese counterparts. ${ }^{110}$ Nevertheless, the sharp decline in the number of Chinese traditional medical practitioners who approached Japanese Kampo professionals after the two countries plunged deeper into war indicated that hostilities impeded the Association's cultivation of broader association with Chinese professionals. It is not surprising that the search for a medical partnership failed to spread beyond the territories under control of the Japanese military and Japanese puppet regimes. Even within these territories, where Japanese military control was limited to urban areas and the railways 
connecting them, it was not easy for the Association to search for partnerships without official support. Another factor may have been that the Chinese professionals had fled the cities to escape the Japanese invasion following the outbreak of war. ${ }^{111}$ Finally, it would be quite understandable if Chinese wrath against the Japanese military presence impeded the Association's attempts to find more Chinese partners. In his report to Tōa igaku during his stay in Shanghai in the summer of 1939, Shimizu Tōtarō testified that he encountered difficulties in seeing local Kampō professionals because of local anti-Japanese sentiments and fear of terrorism against "pro-Japanese traitors." 112

Growing complications brought by the war undermined and frustrated the Association's plans. Forced by the government's tightening grip on publication and paper consumption, the Association suddenly decided to discontinue Tōa igaku in March 1941, only one month after the 25th volume was published. It was merged with the bulletin and became Kampō to Kan'yaku. ${ }^{113}$ Articles, including policy proposals and reports on topics related to Chinese and Manchurian medicine and medical conditions thereafter faded from the journal's pages. ${ }^{114}$ The departure of such prominent members as the Yakazu brothers and Kimura Chōkyū for the battlefront before and after Pearl Harbor weakened the Association's activities. ${ }^{115}$ Other Association members remaining at home found themselves swamped by the worsening conditions of their daily lives, especially in the very final years of the war with increased air raids and shortages of the commodities and crude drugs indispensable for Kampo professionals. ${ }^{116}$ Ōtsuka became the last of the original eight founding members of the Association remaining in Tokyo in 1944, the last year of the Kampo faculty at Takushoku University. ${ }^{117}$ The search for a tripartite medical partnership, as a contribution to wartime state policy and as a means to facilitate the Kampō Revival Movement, shrank, ultimately doomed to follow the fate of the Japanese wartime empire.

\section{Conclusion}

This chapter explored Japanese Kampō professionals' quest for medical exchange through traditional medicine during the Sino-Japanese Conflict. The Association placed the attainment of a medical partnership between Japan, China and Manchukuo as its primary mission, contributing to peace under the new Japanese regional international order. The Association did not intend to become a blind tool of continental expansion, which marked the final stage of Japanese imperialism. Some prominent members even vocally refused to believe Japan's absence of fault vis-à-vis China despite government propaganda. It is quite evident, nevertheless, that the Association was still an active supporter of national wartime policy under the sway of wartime state propaganda, a pattern unexceptional among its contemporaries. The Association simultaneously sought to benefit from the war with China for the sake of the revival of traditional Japanese medicine, a goal for which the Association's leading members had strived Long before hostilities. Several years of 
activities and efforts at home and in China and Manchuria generated limited results. The Association was insufficiently prepared for foreign exchange. A lack of official and private support at home, and escalating hostilities on the continent, and later in the Pacific and Southeast Asia, were contributing factors. Frustrated by the dream of a "New East Asian Order," the Association's search for a tripartite medical partnership came to an abortive end.

\section{Notes}

1 Furuta Makoto, "Kampō wa Nihon de dokuji no hattatsu o shita rinshō igaku," online at: http://kampo-ikai.jp/kampo_towa (accessed September 18, 2011); Ishino Shōgo, "Rijichō goaisatsu," online at: http://japan-kampo.com/corporation/topm essage.html (accessed September 18, 2011); "Kampō no kaisetsu," online at: www.nikkankyo.org/kampo/guide_kampo (accessed September 18, 2012); Onda Hiromasa, Kindai Kampō sōron (Tokyo: Idō no Nihonsha, 1998), 4; "Kampō towa: Kanjasama no koko no jōtai o jushishita iryō desu," online at: www.tsumura.co.jp/ kampo/museum/index.htm (accessed September 15, 2011).

2 Mayanagi Makoto, "Seiyō igaku to Tōyō igaku," online at: http://mayanagi.hum. ibaraki.ac.jp/paper04/sinica97-11.html (accessed September 15, 2011). The Chinese use the terms "Zongyi" or "Guoyi" rather than "Hanfang" (Kampo in Chinese).

3 Mayanagi, "Kampō ya Tōyō igaku to yobu iware," online at: www2.tokyoweb. or.jp.secom-Kampōu/dangi.html (accessed September 15, 2011); Kosoto Hiroshi, Kampō no rekishi: Chūgoku, Nihon no dentō igaku (Tokyo: Tiashūkan Shoten, 1999); "Henshū kōki," Tōa igaku (hereafter TI), 1: (1939): 8.

4 Furuta; Ōtsuka Yoshinori, "Kampō igaku no chiryō to sono seikaku," TI, 17: (1940), 11; Yakazu Dōmei (ed.), Tōa Igaku Kyōkai 60-nen no ayumi (hereafter 60-nen no ayumi) (Tokyo: Tōa Igaku Kyōkai, 1998), 55. Yakazu discovered that the use of the term $K \bar{o}-K a n$ was overwhelmingly popular in the early Showa period.

5 For example, see note 3. Regarding Nihon (or Nippon) Kampō, see Terasawa Katsutoshi, Yoshimasu Tōdō no kenkyū: Nihon Kampō sōzō no shisō (Tokyo: Iwanami Shoten, 2012); "Nihon Tōhō Igakkai ni tsuite," online at: www.jptoho. or.jp/zaidan/gakkai/index1.html (accessed September 15, 2011).

6 Mayanagi, "Shinkoku makki ni okeru Nihon Kampō igaku shoseki no dennyū to hensen," in Yakazu Dōmei sensei kiju kinen bunshū, ed. Hosokawa Kiyoji and Kudō Kunimasa (1983), 643-61.

7 Wang Lan, "Kindai Chūgoku shōgyō kyōiku seido no seiritsu," Kōbe Daigaku Kyōiku Gakkai kenkyū ronshū, 8: (2001), 18-9.

$8 \mathrm{Li}$ Xiejing and Tabuchi Isoo, "Chūgokujin no Nihon ryūgaku no hyakunen: Rekishiteki kiseki to genzai no ryūgaku jijō ni tsuite," Nara Kyōiku Daigaku kiyō, 46: 1 (1997), 22-3.

9 Ding Lei, "Kindai Nihon no tai-Chū iryō bunka katsudō: Dōjinkai kenkyū 1," Nihon igakushi zasshi, 45: 4 (December 1999), 543-62, online at: http://mayana gi.hum.ibaraki.ac.jp/students/98ding1.htm (accessed March 18, 2015)

10 Kosoto, 170-6; Mayanagi, "Shinkoku makki ni okeru Nihon Kampō igaku shoseki no dennyū to hensen," 643-61; "Kindai Chūgoku dentō igaku to Nihon: Minkoku jidai ni okeru Nihon isho no eikyō," Kampō no rinshō, 46: 12 (December 1999), 1928-44; Liang Yongxuan and Mayanagi, "Okada Kōshō to Shinmatsu no Nitchū igaku kōryū shiryū," Nihon ishigaku zasshi, 51: 1 (2005), $25-49$.

11 "Tōa Igaku Kyōkai seritsuri shuisho," (Hereafter Shuisho), in Tōa Igaku Kyōkai no setsuritsu ni tsuite, Tōa igaku: Kōki 2600-nen Kaikō Gakuen 5-shūnen kinen ji dai 1-go shi dai 16-go gappon (Tokyo: Tōa Igaku Kyōkai, 1940), n.p. 
12 Kosoto, 177; Ōtsuka, Kampō hitosuji: 50-nen no chiryō taiken kara (Hereafter Kampō hitosuji) (Tokyo: Nihon Keizai Shinbunsha, 1976), 62-3; Yakazu, 60-nen no ayumi, 55.

13 "Kantōgen: Tairiku iryō taisaku no sekkyokuteki igi," TI, 2: (1939), 1. On government propaganda, see the Konoe Cabinet's statement justifying the war as "chastisement (yōchō)" of "atrocious China (bōrei Shina)." "Seifu seimei," Shūhō, 44, (1937), 2.

14 For example, see ibid.; "Takudai Tōa Igaku Senmonbu setsuritsu shuisho," TI, 2: 4; Yanagiya Sorei, "Tairiku to Nihon ni okeru shinkyū no hensen," Kampō to Kan'yaku (Hereafter referred to as KK), 6: 6 (1939), 37.

15 "Shuisho," 2.

16 Yakazu, 60-nen no ayumi, 60, 118.

17 "Tōa Igaku Kyōkai kaisoku," in Tōa Igaku Kyōkai no setsuritsu ni tsuite, Tōa igaku: Kōki 2600-nen Kaikō Gakuen 5-shünen kinen ji dai 1-gō shi dai 16-gō gappon, 3.

18 Regarding the history of Kampō during the Tokugawa period, see Kosoto, 145-68.

19 "Tōa Igaku Kyōkai kakubu shunin kettei," TI, 1: (1939), 7.

20 "Shōwa 15-nen ni okeru kyōkai kankei shuyō jigyō keika," TI, 23: (1940), 5. Ōtsuka assumed the position of president in February 1940, although his title was referred to as "riji daihyō" in the $22^{\text {nd }}$ volume of TI. See "Tōa Igaku Kyōkai shin kikō," TI, 22: (1940), 1.

21 Yakazu, 59; "Shuisho," 2.

22 "Shuisho," 2.

23 "Kantōgen: Tairiku iryō seisaku no sekkyokuteki igi," 1.

24 Ibid.

25 Ibid.; Yakazu, "Tōa Igaku Kyōkai hakkaishikii kaikai no ji," TI, 1: (1939), 7.

26 Ōtsuka, "Kantōgen: Kagaku no senrei o hetaru Kampō o yōseiseyo," TI, 1: (1939), 1; "Chūgoku Kampō ikai no genkyō to Nikka teikei ni tsuite 2," TI, 2: (1939), 4.

27 "Kantōgen: Tairiku iryō taisaku no sekkyokuteki igi," 1.

28 Koyasu Nobukuni, "Ajia" wa dō katararete kita ka: Kindai Nihon no orientarizumu (Tokyo: Fujiwara Shoten, 2003), 140-1.

29 "Tōa Shinchitsujo kensetsu no seimei," in Konoe Shushō enjutsushū, 2, ed. Atsuchi Morishige (Tokyo: Atsuchi Morishige, 1939), 5.

30 Yakazu, "Tōa Igaku Kyōkai hakkaishiki kaikaai no ji," 7; "Dai 72-kai Teikoku Gikai kaiinshiki no chokugo," in Kokuritsu Kōbunshokan Ajia Rekishi Shiryō Sentā, online at: www.jacar.go.jp/DAS/meta/image_C11110812100?IS_STYLE=default\& IS_KIND $=$ SimpleSummary\&IS_TAG_S1 $=$ InfoD\&IS_KEY_S1 $=\%$ E5 $\%$ B $8 \% 9$ D $\%$ E5\%9B $\%$ BD $\%$ E $8 \%$ AD $\%$ B0 $\%$ E4\%BC $\% 9 \mathrm{~A} \% \mathrm{E} 3 \% 80 \% 8072 \% \mathrm{E} 3 \% 80 \% 80 \% \mathrm{E} 5 \% 8 \mathrm{~B}$

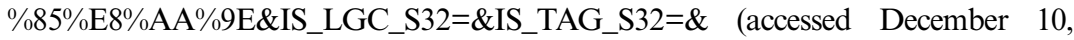
2011).

31 Inoue Toshikazu, Ajiashugi o toinaosu (Tokyo: Chikuma Shōbo, 2006), 152-5, $159-65$.

32 "Kantōgen: Tairiku iryō taisaku no sekkyokuteki igi," 1.

33 "Henshū kōki," TI, 2: (1939), 8.

34 Rikugunshō, Chōkisen ni kansuru kokumin no kakugo (Tokyo: Rikugunshō Shinbunhan, 1938), 1, 3.

35 Kanōogen: Tairiku shinshutsu niwa yakuzaishi o dōinseyo, TI, 3: (1939), 1.

36 "Tōa Shin Chitsujo kensetsu ni kansuru senden hōsaku taikō," in Kokuritsu Kōbunshokan Ajia Rekishi Shiryō Sentā, online at: www.jacar.go.jp/DAS/meta/ image_B02030556700?IS_KIND=RefSummary\&ISKEY_S1 $=$ B02030556700\& IS_STYLE=default\&IS_TAG_S1=reference_code\& (accessed December 11, 2011).

37 Chōkisen ni kansuru kokumin no kakugo, 3. 
38 Yakazu, "Tōa Igaku Kyōkai hakkaishiki kaikai no ji," 7; Yakazu, 60-nen no ayumi, 76.

39 Yakazu, "Tōa Igaku Kyōkai hakkaishiki kaikai no ji," 7. The mussel or clam and snipe refer to a Chinese fable which says that when two sides argue both lose.

40 "Henshū kōki," TI, 2: (1939), 8.

41 Yakazu, "Manshū kenkoku no risō to warera no shimei," TI, 19: (1940), 1.

42 Ōtsuka, "Kantōgen: Kagaku no senrei o hetaru Kampōi o yōseiseyo," 1; "Sensō wa bunka no haha," TI, 2: (1939), 5.

43 Ōtsuka, "Chūgoku Kampō igaku no genkyō to Nikka teikei ni tsuite 3," TI, 3: (1939), 6.

44 Yanagiya, 37.

45 Fukagawa Shin'yo, Kan-Yō igaku tōsōshi: Seiji tōsō hen (Tokyo: Iseisha, 1981).

46 Takeyama Shin'ichirō, Kampō ijutsu fukkō no riron kaikoban (Tokyo: Sekibundō Shuppan, 1971), 9; Ōtsuka, "Chūgoku Kampō ikai no genkyō to Nikka teikei ni tsuite 2," TI, 2: (1939): 4.

47 Yakazu, Zōho kaitei Meiji 110-nen Kampō igaku no hensen to shōrai: Kampō ryakushi nenpyō (hereafter Meiji 110-nen), (Tokyo: Shun'yōdō, 1979), 116; 60-nen no ayumi, 51-56; Matsunaga Shōzan, "Kohō igaku fukkō e no kibō," KK, 5: 2 (1938), 66; “Tōa Igaku Kyōkai kaiki kizō no kito ni tsuite,” TI, 16: (1940), 6; Takeyama, 86.

48 Meiji 110-nen, 12.

49 Ibid.

50 "Shuisho," 2.

51 Yakazu, "Susumunomi," KK, 7: 1 (1940), 1.

52 Takeyama, 120-1.

53 Ayukawa Shizuka, "Kokumin taii teika o sukuu michi: Kōsei daijin ni tatematsuru," KK, 5: 8 (1938), 24; "Kokumin kenkō no kōjō kakuho ni Kampō ihō o saiyōseyo," TI, 5: (1939), 3; Takeyama, 118-19.

54 "Jihen 2-shūnen to Tōa igaku no kibō," TI, 6: (July 1939), 1; Takayama, 88.

55 "Shuisho," 2.

56 Yakazu, "Igaku no tenkanki," TI, 1: 3; Kimura Chōkyū, "Tōa Igaku no hakkan ni saishite," TI, 1: (1939), 5.

57 “Tōa Igaku Kyōkai kaisoku,” 2; Yakazu, 60-nen no ayumi, 60.

58 See the advertised contents of the meetings in several volumes of $T I$, especially the volumes published in 1939 and 1940. It is unknown whether or not the Association continued regular meetings from 1941 and until the end of the war in August 1945 - certainly no advertisement is found in the three final volumes of $T I$, published in the first three months of 1941, and the series of volumes of $K K$, published after TI's merger into KK in April 1941.

59 "Kyōkai kenkyū no Kampōyaku: Shin keishiki no moto ni hanbai saru Tōa Igaku Kenkyūjo yori hatsubai," TI, 2: (1939), 7; 60-nen no ayumi, 64-5.

60 "Tōa Igaku Kyōkai Takudai Kampō Kōza Ishihara Bunko Kampō Toshokan no tanjō," TI, 21: (1940), 6; "Kaikō Gakuen Sōritsu Kinen Dai Kōenkai Takudai Kampō Toshokan kaikaishiki," TI, 26: (1941), 7.

61 "Tōa Igaku Kyōkai shin kikō," 1; "Kampō Igaku Seinen Shidōkai no ugoki," TI, 23: (1940), 7-8.

62 For example, see volumes 15, 16, 17, 20, and 26 of TI.

63 "Tōa Igaku Kyōkai shin kikō," 1.

64 Only volumes 9, 15, 22, 23, 24 of Tōa igaku do not contain articles and reports on the medical conditions and practices in China and Manchukuo and policy.

65 "5-gatsu reikai tairiku shisatsu hōkokusho," TI, 4: (1939), 6; "Tōa Igaku Kyōkai 10-gatsu reikai,” TI, 9: (1939), 7; “Takudai Kampō Igaku Kōza reikai!,” TI, 14: (1940), 7; Tōa Igaku Kyōkai 8-gatsu reikai," TI, 3: (1939), 8; "Tairiku no kenkō," TI, 4: (1939), 5. 
66 For example, see $K K, 6: 6$. The issue has a special title, Tairiku igaku shōkaigō.

67 Ōtsuka, "Kantōgen," 1; Yakazu, "Nikka Kampō tokushūgō hakkan ni tsuite," TI, 25: (1941), 1.

68 Ōtsuka, "Chūka Minkoku ni okeru kokui gakkai kanken," KK, 4: 3 (1937), 1; Yakazu, "Genka ni tekiōsuru Kampō igaku fukkō shian," TI, 2: (1939), 2; "Nikka Kampō igaku tokushūgō hakkan ni tsuite," 1.

69 "Shina no hai-Nichi bu-Nichi ni tsuite: Rikugunshō Chōsahan chōsa," Naigai Shiryō Chōsa, 4: 1 (January 1932), 72-129; "Shina Jihen no keii," Taiwan jihō (September 1937), 166-81.

70 Mayanagi Makoto, "Kindai Chūgoku dentō igaku to Nihon: Minkoku jidai ni okeru Nihon isho no eikyō," Kanpō no rinshō, 46: 12 (1928), online at: http://ma yanagi.hum.ibaraki.ac.jp/paper01/minkoku.htm (accessed May 14, 2015).

71 "Takudai kōza kyōzai zōtei," TI, 1: (1939), 7.

72 "Hokushi Chūshi tokuhain o hasu," TI, 2: (1939), 6. For Koyanagi's reports, see "Shina iyaku eisei jijō shisatsu hōkokusho," TI, 4: (1939), 2; "Pekin Kokui Gakuin hōki," TI, 4: (1939), 3.

73 Ōtsuka, "Nihon Kampō igakkai no genkyō to Nikka teikei ni tsuite 1," TI, 1: (1939), 5.

74 Nakajiima Torao, "Senjin nikki," TI, 1: (1939), 8; "Tenshin Shigai Eisei Kyokuchō Kampō ni tsuite katararu," TI, 3: (1939), 8; "Tairiku no kenkō," TI, 4: (1939), 5.

75 Honda Seiichi, "Shanhai no meii, Ji Itsujin sensei o tazunete," TI, 19: (1940), 3.

76 Memo," TI, 5 (1939): 8; "Memo," TI, 6, 8; "Honkyōkai ate kizō tosho," TI, 8: (1939), 7; "Memo," TI, 12: (1940), 8; "Tōa Igaku Kyōkai shin kikō," 1.

77 "Memo," TI, 6: (1939), 8.

78 "Henshū kōki," TI, 7: (1939), 8; Ōtsuka, "Kampōi no mita sekiri to sono ryōhō," TI, 6: (1939), 3 and 6.

79 TI, 11: (1939), 5. Later, three more Chinese, Chen Kangsun, Chen Jigao, and Zhou Ruilin became members. See TI, 12: (1939), 8; TI, 15: (1940), 8; TI, 22: (1940), 8.

80 Tōa Igaku Kyōkai shin kikō," 1.

81 "Yō Kitsusen-shi no kinsei naika kokuyaku shohōshū o yomu: Chūi no kaishin mondai," TI, 10: (1939), 2.

82 "Yō Kitsusen-shi yori no shokan," TI, 12: (1939), 3.

83 "Chiryō jitsurei," TI, 13: (1940), 5; "Chiryō jitsurei 2," TI, 14: (1940), 7.

84 Kimura Chōkyū, "Chūgoku ryūgakusei no inshō," KK, 9: 12 (1942), 32-5.

85 60-nen no ayumi, 68.

86 Kurihara Kōzō, "Manshūkoku Kan'i to sono shōrai oyobi kyōiku mondai," TI, 18: (1940), 5-6.

87 Tatsuno Kazuo, "Manshū no tabi," TI, 19; (1940), 7; 60-nen no ayumi, 68-9. Kurihara recommended that the department invite Yakazu and Ötsuka. Because Ötsuka was unable to accept the invitation, Tatsuno attended the meeting instead. See also the Japanese translation of Zhang Jiyou's letter to Yakazu on June 26. "Manshū yori," TI, 18: (1940), 6.

88 "Yakazu, Tatsuno ryō riji Manshūkoku Minseibu shokutaku to naru," TI, 21: (1940), 7; 60-nen no ayumi, 14.

89 "Manshūkoku Kan'i shiken jisshi," TI, 26: (1941), 7; “Tōa Igaku Kyūkai kaihō," KK, 8: 4 (1941), 98; 60-nen no ayumi, 70. Regarding the exam, see "Manshūkoku Kan'i kōshi kokoroe," KK, 8: 10 (1941), 42-5; "Manshūkoku dai 1-kai Kan'i kōshi mondai," KK, 9: 1 (1942), 61.

90 "Manshūkoku Kampōhō Yakkyokuhō seitei," KK, 8: 3 (1941), 7.

91 "Dōdō 200 yo pēji no Soshū Kokui Iin Inkan sōkansaru," TI, 13: (1940), 4.

92 Ibid. 


\section{Mizuno Norihito}

93 Hirama Naoki, "Nihon Kampō igaku fukkō no kōrōsha: Ōtsuka Yoshinori sensei to Yakazu Dōmei sensei," online at: www.jtcma.org/news/img/2014-4-1.pdf (accessed March 21, 2015).

94 Yakazu, "Nikka Kampō igaku tokushūgō hakkan ni tsuite," 1.

95 Bai Yishan, "Shuhuo rehuo zhi bieshuo," TI, 25: (1941), 3-4; Gao Qixiang, "Zhonguo zhi yixue luohou," TI, 25: (1941), 4; Qian Jianting, "Hanyi zhenduan yu diaojifa," TI, 26: (1941), 4-7; Ye Juquan, "Cunji Yilu Zhiyanji," TI, 25: (1941), 2; "Cunji yilu zhiyaanji: chengqian," TI, 26: (1941), 4; Zhang Zhuan, "Luetan Hanyi zhi xuanli," TI, 25: (1941), 2-3.

96 "Kaikō Gakuen sōritsu kinen daikōenkai Takudai kampō Igaku Toshokan kaikanshiki," TI, 26: (1941), 7.

97 "Manshūkoku Kan'i shaken jisshi, TI, 26: (1941), 7; "Manshūkoku Kampō yakkyokukata seitei," TI, 26: (1941), 7.

98 "Shina iyaku eisei jijō shisatsu hōkokusho," TI, 4: (1939), 2-3.

99 Takeyama, "Tairiku ni okeru shin iryō taisei no seitei to Kampō ijutsu no mondai," TI, 18: (1940), 5.

100 60-nen no ayumi, 59.

101 "Yanagawa chōkan kō-A no dōdōtaru hōfu o senmeisu," TI, 2: (1939), 3.

102 60-nen no ayumi, 77. Regarding Matsumura's comment on Kampō, Honda Seiichi, "Tairiku ni okeru saikin no Kampō mondai," KK, 8: 10 (1939), 19.

103 For example, Minister of Welfare Hirose Hisatada revealed in January 1939 that his ministry had no intention of reconsidering the reintegration of Kampō medicine into the active medical system. See "Senkakusha Inoge daigishi Tairiku iryō hōsaku o senmeisu,” TI, 2: (1939), 2.

104 Ōtsuka, Kampō hitosuji, 118-23.

105 Besides Nakajima and Honda, Major Surgeon General Watanabe Atsuyuki was a member. See Watanabe Onko, "Kanpai no itari” TI, 1: (1939), 4. Regarding examples of the use of Kampo know-how on the front, see Nakajima Torao, "Senjin nikki," 6; “'Mararia' no Kampō ryōhō," TI, 22: (1940), 4-6; "Shien ni tsuite," TI, 22: (1940), 6-7. Nakajima's reports on clinical practice are summaries of his lectures in the military hospital in Ichigaya, Tokyo. See also Nakajima, "Senchi dayori: dai 1-shin," TI, 9: (1939), 8; "Senchi dayori dai 2-shin, dai 3-shin," TI, 10: (1939), 5; "Henshū kōki," TI, 22: (1940), 8; "Sensen dayori," KK, 9: 9 (1942), 54-5. See also Ryū Sei, "Shina Chōkō yoteki 1," TI, 7: (1939), 5; "Shina Chōkō yoteki 2," TI, 8: (1939), 6-7.

106 Inoue, 196-7.

107 Henshū kōki," TI, 1: (1939), 8.

108 See notes 80,81 and 83 .

109 "Tōa Igaku Kyōkai shin kikō," 1.

110 "Shina iyaku eisei jijō shisatsu hōkokusho," 2.

111 "Shanhai no meii, Ji Itsujin sensei o tazunete," TI, 19: (1940), 3.

112 Shimizu Tōtarō, "Chūshi no iyaku jijō kenbunki," TI, 10: (1939), 2-3.

113 Meiji 110-nen, 2; “'Idō no Nihon' oyobi 'Tōa igaku' honshi e gōdō: kitaru 4-gatsugō yori," 80-1. An acupunctural and moxibustional journal, Id̄̄ no Nihon, founded in October 1938, was simultaneously merged into the journal.

114 See volumes of $K K$ published after the merger in April 1941.

115 Meiji 110-nen, 15, 20.

116 Ötsuka, Kampō hitosuji, 68; Takeyama, Kampō ijutsu fukkō no riron kaikoban, 342-3. Takeyama and his fellow acupuncturists continued medical activities in China until at least late 1943.

117 Ōtsuka, Kampō hitosuji, 137. 


\title{
12 The question of research in prewar Japanese physics
}

\author{
Ito Kenji
}

\section{Introduction}

A primary challenge that James Bartholomew addressed in The Formation of Science in Japan: Building a Research Tradition was the establishment of a tradition of scientific research in Japan, an issue that this chapter revisits by examining some of the problems that confronted noted prewar physicists in their efforts to integrate their research activities within the international scientific community and subsequently to develop their own tradition of physics research. ${ }^{1}$ Here the word research means methodical and institutional activities conducted to produce new knowledge, not learning established knowledge from others. Shaped by various characteristics of the time and debated among its historical actors, what actually constitutes research is contingent and contentious. Nonetheless, physicists' research efforts can be examined from an historical perspective.

Physics research in Japan was not necessarily part of empire building. Since research is an activity to produce knowledge, its relevance to empire building was not inherent, even if it was contingent on that process. As many Japanese in the late nineteenth and first half of the twentieth century, physicists in Japan did not necessarily have all aspects of their work immersed in empire building. As was the case with other imperial powers, however, imperialism and colonialism shaped the social contexts in which research activities took place. The question might be how the context of empire building affected physics research in Japan and vice versa.

Sociologists and historians have discussed the relation between science and its social contexts for half a century. ${ }^{2}$ The ways by which scientific research affected society constitutes a prevalent theme in popular accounts of the history of science. ${ }^{3}$ Various attempts have been made since Robert K. Merton's and Paul Forman's seminal work to show how social contexts shaped scientific contents and research activities. ${ }^{4}$ For example, there is a renewed attempt to explain scientific content through social context during the Cold War. ${ }^{5}$ It is, however, problematic to separate scientific content and social context, and to attempt to explain the former by the latter, because such dichotomous reductionism is groundless. This applies to science and empire building, too. 


\section{Ito Kenji}

Analyzing empire building and science in Japan, the temptation to reduce scientific activities to things related to empire building is strong. As Bartholomew suggests in his afterword, Westerners often impute uniqueness or particularity to Japan as a society. Seeing Japanese scientists as loyal servants of Japan's empire building might appeal to some readers who approach this genre with Orientalistic curiosity, intending to see Japanese science as different, peculiar, or even unique, and forgetting the complicated relation between science and colonialism in Europe.

By contrast, this chapter approaches the issue of physics research and empire building with extreme caution. In particular, I avoid the semiotic topography to include scientific activities within empire building. Basic physics research and empire building were separate activities with separate goals. At the same time, they were intertwined with various, and significant, intersections. This chapter tells a more ambiguous story than some might expect.

As symbolized by several Nobel laureates, physics is one of the fields in which Japan has displayed impressive strength in scientific research. One can safely say that Japanese physicists started producing strong research before World War II. I have discussed elsewhere the rise of quantum physics in Japan, which marked the creation of a strong research tradition in the country. My focus was on how scientific cultures in Japan received and adapted to the research culture of quantum physics. ${ }^{6}$

Here, I attempt a rough illustration of a different approach to locate physics research in Japan in historical contexts. My assumption is that establishing a research tradition was not simply a process of achieving a pre-defined goal, but a resolution to a set of questions and problems confronting physicists. These questions are partially constructs of the analyzer since the historical actors did not consciously formulate or endeavor to solve them. They also reflect the actual problems that confronted scientists. These questions might well be within the personal and individual spheres of each physicist. Then again, they might be in the external spheres, which concern time, space, and society. Here I examine Japanese physicists who contributed to the establishment of Japan's research tradition and how they responded to these questions. Weaving a historical narrative through such questions and the physicists who confronted them, I eschew asking the simplistic question of how the "context" affected the "content" of research.

Without pretending to be comprehensive, I focus on four questions: the questions of possibility, legitimacy, strategy, and originality of research.

The question of possibility concerns whether it was possible to conduct physics research in Japan, either for Japan as a society or for individuals. This was an especially valid question during the Meiji era. When racial prejudice was common, a lack of observable evidence that the Japanese were capable of research could also be considered sufficient to assume they were incapable. Moreover, even if the Japanese were inherently capable of research in physics, whether it was possible for Japanese physicists to compete with researchers in Europe and North America was another matter. While Japan's socio-cultural 
environment may have not been nearly so encouraging of research, Japan is geographically separated from Europe and, at the time, journals took at least two weeks to arrive. ${ }^{7}$ The question of possibility is thus not only a matter of personal capacity but also a matter of social conditions, broadly defined.

The question of legitimacy concerns how research initially became a legitimate activity in Japan. Since research seeks new knowledge, it is often an exploration of the unknown and a quest for new ideas. The content of new knowledge is by definition impossible to predict and can have unexpected results. Results might be insufficiently beneficial to justify the expense or might have undesirable impact. Researchers often challenge the orthodoxy when they produce new knowledge. They develop an ethos to challenge orthodoxy, and new ideas can shake established social norms. Consequently, research is potentially risky, costly, and subversive. For an individual, therefore, conducting research requires a certain mindset that incorporates their own sense of the legitimacy of their work. Whether society even allows and/or supports research activities as legitimate is a socio-cultural question. For a country, supporting research activities may not be a reasonable allocation of national resources. Because doing research was not the norm in pre-Meiji Japan, the emergence of research as a legitimate activity requires an explanation. In this context, the question of legitimacy was often tied to Japan's empire building. Although Japanese scientists were not necessarily mindless minions of the empire, the cause of empire building and its associated goals of industrial development and military research were rationales that research-oriented scientists could use to justify their activities. It was not simply because research could produce scientific weapons, but also because research could enhance the status of the empire in industry, commerce, and prestige.

The question of possibility is connected to what I tentatively call the question of strategy: what strategies could Japanese physicists employ to produce research? Of what opportunities (and resources) could and should they take advantage? I do not assume Japanese physicists always made conscious decisions in choosing their strategies. Instead, this line of analysis attempts to examine possible options allowed by the scientists' socio-cultural situation, such as the state of the scientific community, the status of research organizations, other available resources, and the tangible choices that individual scientists made.

The question of originality pertains to the question of strategy - and points to the fundamental question of introducing Western science. In the Japanese context, conducting scientific research was a potentially contradictory enterprise. On the one hand, modern scientific research came to Japan from Europe and North America. Conducting research involved the use of conceptual and practical tools invented in Europe, which might encourage the imitation of Western practices and thoughts. On the other hand, conducting research was supposed to produce new knowledge, which critically hinged on the researcher's creativity and originality. How to achieve originality is the apparent dilemma. 


\section{Kitao Diro (Jirō) and local science}

Among early Japanese scientists, Kitao Diro (1854-1907) has received little attention from historians. In 1869, at age 16, Kitao went to Germany to study medicine. After spending two years at a gymnasium, he entered the University of Berlin, switched his major to physics, and studied under Hermann Helmholtz and Gustav Kirchhoff until he returned to Japan in 1883. During his unusually long stay, Kitao was immersed in the Helmholtzian tradition of physics and physiology. In 1878, he wrote and published a doctoral thesis, Zur Farbenlehre, in which he described his invention of Leukoskop, an optical instrument for diagnosing color blindness. ${ }^{8}$ After his return to Japan, Kitao obtained a position at the College of Science, Tokyo University. ${ }^{9}$ His scholarship, however, did not take root in Japan's physics. A confrontation with Kikuchi Dairoku, a mathematician trained in Britain and a member of the powerful Kikuchi-Mitsukuri family, led to Kitao's departure from the College of Science in 1886. He subsequently became a professor of "agricultural physics and meteorology" at the College of Agriculture of the Imperial University of Tokyo, where in 1887 he published a three-part paper on typhoons. ${ }^{10}$ Demonstrating Kitao's mastery of late nineteenth-century mathematical physics, the study involved a rigorous application of fluid dynamics in a meteorological phenomenon. Highly regarded by meteorologists outside Japan, this original study was one of the earliest theoretical treatments of the typhoon. ${ }^{11}$

Three aspects of Kitao's work pertain to the question of strategy. First, he was able to learn his skills in mathematical physics during his extended stay at a prime research circle in Berlin. Kitao's training was scarcely distinguishable from that of contemporary German scientists. Second, Kitao specialized in theory, which suffered relatively little from the lack of a physical infrastructure, making it possible for him to do noteworthy work even after his return to Japan. Third, he chose a local phenomenon, typhoons, as his topic. Although it is not certain how much it mattered in Kitao's theoretical work, Japanese scientists have used this strategy repeatedly in order to turn their inherent geographical marginality into an asset. Therefore, earth science was an area to which European and American physicists hired by the Meiji government paid particular attention. Early physicists in Japan (Japanese and non-Japanese) achieved early success in this field. In addition to meteorology, seismology was another good example of an area representing early research success. ${ }^{12}$

Topics of local scientific interest may have provided an advantage relative to the question of legitimacy. Scientific understanding of typhoons appeared to be especially useful and socially legitimate in a country where typhoons cause serious damage. This, however, led to the development of another discipline separate from physics. Consequently, this work did not lead to Kitao's legitimization as a mathematical physicist. He is typically considered a precursor of Japanese dynamic meteorology. 


\section{Nagaoka and the Japanese capability for research}

After Kitao, and representing the struggle to conduct research in Japan, was Nagaoka Hantarō (1865-1950). Nagaoka was a wide-ranging research-oriented physicist. His most important work, the Saturnian model of the atom, was one of the earliest scientific achievements by Japanese scientists relevant to mainstream physics. Mentoring younger researchers and serving as an administrator at scientific institutions, Nagaoka was a towering figure in Japan's physics community. ${ }^{13}$

Nagaoka's research orientation was not the norm and he appeared to be deeply unhappy about the circumstances of physics research in Japan. After World War II, remembering the environment of physics departments in the early twentieth century, Nagaoka criticized his colleague, Tanakadate Aikitu, for not conducting research. When a younger physicist, Fujioka Yoshio, later asked whether Japanese physicists had started doing research when new issues of physics journals had arrived in Japan, Nagaoka laughed and declared that that would have been impossible when Tanakadate had been in charge. ${ }^{14}$

As a student, Nagaoka was seriously concerned with the question of possibility. He held fundamental doubts regarding Japanese capabilities for scientific research. In 1883, after finishing the first year at Tokyo University, he took a oneyear leave of absence and turned to the Chinese classics for evidence of scientific research by Asians. He found a number of examples of how ancient Chinese scholars investigated natural phenomena, such as Zhuangzi, which provided both a description and explanation of lightening based on the theory of yin and yang. Nagaoka considered that explanation essentially correct and in the same vein as the modern scientific theory of positive and negative electricity. To his surprise, Zhuangzi also raised the question of the sky's blue color, a question later answered by the British scientist John Strutton (Lord Rayleigh). Similarly, Nagaoka claimed that there were various descriptions of natural phenomena in the Chinese classics of the Warring States period. Hui Sui, a logician who often appears in Zhuangzi, for example, discussed the issue of the infinitesimal, asking the question of repeating the operation of breaking a stick into two halves. From these examples, Nagaoka concluded that Asians were indeed curious and capable of systematic scientific research. ${ }^{15}$

Nagaoka was aware of the question of legitimacy and was keen on connecting physics with practical applications. For him, atomic physics was not an abstract scientific theory devoid of practical utility. In early twentiethcentury atomic physics, the electron was probably the most important and most studied object. This was also the case with quantum mechanics, which was, in practice, mostly a theory of electrons. As a theory of electrons, atomic physics was considered especially relevant to the rapidly developing discipline of electrical engineering, which people widely thought would rebuild the modern urban landscape. Thus, Nagaoka and other physicists of his generation wrote popular accounts and textbooks of electron theory, which naturally included atomic theory. ${ }^{16}$ 
For Nagaoka, the link between physics and its practical applications was not limited to electrical engineering. Spectroscopy, for example, was an experimental sub-discipline of physics important to atomic physics and to Japan's optical industry. Nagaoka's later interest in the transmutation of elements was at least partially legitimized by its practical value, in particular the transmutation of mercury into gold, in which Nagaoka toiled for years to no avail. ${ }^{17}$ Nonetheless, this idea of the transmutation of elements resurfaced when Nagaoka endorsed and called for support for Nishina Yoshio's efforts to construct cyclotrons. $^{18}$

As for the questions of strategy and originality, Nagaoka was inclined to reduce these issues to the question of mentality and personal traits. He ascribed his success with the Saturnian model to his "rashness" in publishing his workin spite of criticism from colleagues. He described later generations (and implicitly his contemporaries) as "too timid" in comparison to himself. ${ }^{19}$

\section{Nakamura Seiji on the Imperial Institute for Physical Research and RIKEN}

Nakamura Seiji (1869-1960) was an experimental physicist at Tokyo Imperial University. He is of interest primarily because of his justification for research, not his own research. In March 1908, Nakamura published an article in Jiji shinpō calling for the establishment of a "Teikoku Rigaku Kenkyūjo" (Imperial Institute for Physical Research). ${ }^{20}$ According to Nakamura, the most important measure for the survival of the nation was fukoku kyōhei ("rich nation, strong army"). The best way to achieve this, Nakamura argued, was to be progressive and to develop commerce and industry. He argued that fundamental to the development of commerce and industry was establishing an imperial research institute. Nakamura also argued that a research institute would enhance Japan's standing internationally. Nakamura supported his argument by providing the example of Physikalische Technische Reichsanstalt, the German research institute for physics and engineering, funded by donations from Werner Siemens. Nakamura praised Siemens as a "true patriot" and sought donations from the rich to establish such an institute in Japan. ${ }^{21}$

Although Nakamura's idea did not materialize at the time, other scientists, especially chemists Takamatsu Toyokichi and Takamine Jokichi, repeated his argument in subsequent years, emphasizing the utility of chemical research for a newly developing chemical industry. ${ }^{22}$ As a result of the experience of World War I, an institute was eventually established as the first research-oriented organization in Japan, the Institute for Physical and Chemical Research, or RIKEN, in 1917.

RIKEN was originally established as a research institute for chemistry and physics, with the hope that its research results would contribute to the development of heavy industry in Japan. It was a non-government organization, originally funded by donations from the imperial household and the industrial 
sector, as well as annual grants from the government. ${ }^{23}$ Its functions soon multiplied.

RIKEN's third director, Ōkouchi Seibin, appointed in 1921, made it an institution where pure scientific research and empire building coexisted. He solved the problem of funding by industrializing research results through RIKEN itself and later RIKEN Sangyōdan, the industrial concern under Rikagaku Kōgyō, a stock-holding company that he created in 1927. A specialist in military engineering and a prominent member of the House of Peers, Ōkouchi obviously had Japan's empire in mind and considered research in physics and chemistry a scientific basis for developing Japan's heavy industry, an important source of national wealth, and a necessary step for modernizing Japan's armaments. ${ }^{24}$

RIKEN was successful in producing scientific knowledge, but not so much for the development of Japan's heavy industry. RIKEN was able to industrialize some of its scientists' research. A large portion of the profit was returned to RIKEN. One early example was industrialization of vitamin A. Because of this funding, researchers at RIKEN were able to enjoy abundant funds and freedom, a research environment far better than what was to be found at the imperial universities. Ironically, because of the assumed utility of its research, RIKEN created an ideal place for pure research, viewed as a "free paradise of scientists." 25

Ōkouchi was less successful as an industrialist. Compared to other newly emerging industrial concerns such as Nissan, Nicchitsu, Shōden, or Nissō, RIKEN's interests and impact on society were much more limited, consisting of very small companies specializing in one product with a fragile financial base, many of which stopped producing profits. In 1939, Ōkouchi was removed from power and RIKEN underwent reform to separate profitable and unprofitable companies. $^{26}$

\section{Terada Torahiko and experimental physics}

Even if being Asian did not actually prevent the Japanese from being capable of conducting scientific research, it obviously did not guarantee research abilities. Furthermore, there were other disadvantages and obstacles, such as the geographic separation of Japanese scientists from European scientific centers and the stimulus of close professional contacts. Distance prevented them from receiving the latest scientific news in a timely manner and keeping in touch with colleagues overseas.

Overwhelmed by these difficulties, Terada Torahiko (1878-1935) sought an alternative strategy. Terada was a professor of experimental physics at the Imperial University of Tokyo as well as chief scientist at RIKEN. Although he was one of the best-known scientists in Japan, Terada is recognized more for his literary essays based on science than for actual scientific research. Early in his career, Terada sought success in mainstream physics topics. Inspired by Max von Laue's work, in the 1910s Terada conducted research on X-ray diffraction. ${ }^{27}$ While von Laue used photography, Terada found a way 


\section{Ito Kenji}

to observe diffraction patterns using a fluorescent screen. In 1913, he published two short articles in Nature and one long article in Proceedings of the Tokyo Mathematico-Physical Society. ${ }^{28}$ Around the same time, however, William Lawrence Bragg, along with his father William Henry Bragg, developed the famous work that has come to be known as Bragg's law and the idea of net planes. Their work laid the foundation for X-ray crystallography, which resulted in their Nobel Prize in $1915 .^{29}$

While the Bragg's work overshadowed Terada's, Terada was at least able to choose the right scientific problem and make progress toward an important finding. Had he been given a better research environment, he might have produced results comparable to Bragg's. In this sense, the kind of question that Nagaoka asked, namely the question of whether the Japanese possessed the inherent ability to do scientific research, was no longer as pressing as the external disadvantages from which Japanese physicists suffered. If geographic isolation made communication with European and American research centers difficult, the lack of experimental facilities and equipment was equally confounding. Terada used a second-hand X-ray tube donated by the Faculty of Medicine, which was apparently better funded and equipped than the Faculty of Science. $^{30}$

These difficulties compelled Terada to give up competing with European and American physicists. Instead, he opted to find research topics that European scientists would not think of, or with which they would have a disadvantage, such as local natural phenomena. In Terada's case, it was geophysics, especially seismology. The other research category involved various artifacts and everyday natural Japanese phenomena. While his 1907 doctoral thesis was an acoustic study of the traditional Japanese bamboo flute, he studied topics such as small fireworks, the expulsion of wisteria seeds, and the falling motion of the camellia flower. ${ }^{31}$

Choosing such non-mainstream and somewhat eccentric topics was probably Terada's answer to the question of originality. One of his students, Uda Mititaka (Michitaka), reported that Terada encouraged them not to imitate foreigners but instead attempt to find rare phenomena, explaining, "In physics, too, we don't have to imitate Westerners. There must be a kind physics suited to the Japanese." 32 Terada simultaneously created a tradition of scientist-literati, who not only produced scientific research but also literary work based on scientific knowledge.

Positioning himself in this situation, Terada created a niche for his own variety of Japanese physics. Ultimately, Terada's combination of scientific research and literary skill provided the means to legitimize research in physics quite differently from the legitimation of physics in engineering. Research could be valued from literary, and aesthetic perspectives could be further justified by a wider readership outside the scientific community.

Whether Terada's research activities were completely unrelated to Japan's empire building is debatable. After all, Terada belonged to RIKEN, and some of his research had relevance to military technology and industrial applications. 
Yet, conceptually, Terada opened a space for research in which physicists were able to justify their work without resorting to the rhetoric of empire building.

\section{Ishiwara Jun and modern physics}

Unlike experimentalists like Terada, theoretical physicists did not require a significant material environment for research. Nonetheless, to be successful and have access to up-to-date information on developments in the field, theoretical physicists needed to have intellectual interaction with research centers. Japanese physicists could visit international research centers. Another strategy was to choose a novel research topic for which such a research center did not yet exist (e.g. the work of Terada Torahiko and Kitao Diro).

Ishiwara Jun's (1881-1947) strategy was similar. Ishiwara was one of the most successful theoretical physicists in the generation immediately after Nagaoka. Upon graduating from the Imperial University of Tokyo in 1906, he studied relativity and quantum theory, publishing a paper on the former in 1909, the latter in $1911 .^{33}$ These publications appeared before he spent time abroad studying in Europe from 1912 to 1914. During his stay in Europe, Ishiwara visited and studied with important theoretical physicists, including Arnold Sommerfeld in Munich, Max Planck in Berlin, and Albert Einstein in Zurich. ${ }^{34}$ In 1915 Ishiwara produced his most important paper, a study on quantum conditions. ${ }^{35}$ After returning to Japan, he was appointed professor of theoretical physics at the newly founded Tohoku Imperial University, which was intended to be a new research center in science and technology. In 1921, however, Ishiwara resigned the post because of repercussions from a scandal caused by his extramarital love affair.

Although Ishiwara's shortened scientific career failed to create a strong research tradition of theoretical physics at Tohoku Imperial University, he thereafter became a prominent science writer. Through popular lectures, articles, and books, he promoted the new physics, relativity theory, and quantum theory. $\mathrm{He}$ also facilitated Einstein's 1922 visit to Japan. These activities were extremely important in popularizing modern physics in Japan and enhancing its legitimacy. Indeed, Ishiwara's writings generated support for physics and lured young people, including future physicists such as Tomonaga Sin-itiro and Yukawa Hideki, into the field. ${ }^{36}$

Einstein's high regard for Ishiwara's 1909 relativity theory paper suggests that Ishiwara was already able to produce significant research before his trip to Europe $^{37}$ Ishiwara's quantum conditions turned out to be similar to Arnold Sommerfeld's findings, a generalization of Niels Bohr's quantum conditions. ${ }^{38}$ Of note, Ishiwara published his paper in Japanese half a year before Sommerfeld, yet historians of physics indicate this particular work had only limited impact. ${ }^{39}$ It, however, indicates that Ishiwara had the ability to participate in the mainstream development of quantum theory and produce first-rate research in theoretical physics and to contribute substantially to major developments in physics, yet remained hampered by slow communications. As was the 


\section{Ito Kenji}

case with Kitao, research in theoretical physics required less physical infrastructure; therefore, its lack or deficiency caused fewer problems than in experimental physics. A lack of access to timely information and intellectual stimulation could still cause difficulties. This disadvantage was mitigated somewhat by the novelty of relativity theory and quantum mechanics. Because they were both still relatively new, even in Europe, researchers were similarly dispersed and conducting their research independently. Ishiwara's study abroad should have helped him to make closer contacts with European theorists but he failed to have much influence on European physicists partly because Ishiwara published in a Japanese journal, and partly because World War I severed communications between Germany and Japan. Ultimately, Ishiwara was not successful in raising the visibility of his work.

Like Terada, Ishiwara had the qualities of a literary person and was known for his tanka poetry. Ishiwara's biographer and historian of science, Nisio Sigeko, points to Ishiwara's early interests in the aesthetic aspects of nature and suggests that they might have actually been what led him to become a theoretical physicist. Being from the relatively poor Christian pastor's home, physics was a good compromise for Ishiwara, satisfying his literary and aesthetic proclivities, while simultaneously conveying potentially more useful training for finding a remunerative job. ${ }^{40}$

\section{Nishina Yoshio and atomic physics in Japan}

Nishina Yoshio (1890-1951) is arguably the most important physicist in preWorld War II Japan. Originally trained as an electrical engineer, he turned to physics after graduating from the Imperial University of Tokyo and entering RIKEN. Nishina stayed in Europe, mostly in Copenhagen, between 1921 and 1928. As a theoretical physicist, he is known for his 1929 Klein-Nishina formula, one of the earliest contributions to quantum mechanics by a Japanese scientist. ${ }^{41}$ He led a team of experimentalists and initiated cosmic ray and accelerator physics in Japan. ${ }^{42}$ Most importantly, he trained young physicists, both in theory and experimentation, contributing significantly to the creation of a strong research tradition. During World War II, he led the Japanese Army's nuclear bomb project, Ni-go kenkyü. ${ }^{43}$ After the war, he became RIKEN's director (renamed KAKEN in 1948) and served as a statesman of science, working to rebuild science in Japan until his death in $1951 .^{44}$

In terms of his research in theoretical physics, Nishina used strategies similar to Kitao and Ishiwara. During his long stay in Europe he acquired the requisite skills to conduct research in the emerging tradition of quantum physics. One difference was that Nishina's stay in Copenhagen coincided with a period of fundamental change in physics, the birth of quantum mechanics This was soon followed by radical developments in experimental physics, including the use of radioactive substances and accelerators that represented tremendous opportunities for physicists attempting to "catch up" with European research. ${ }^{45}$ Simultaneously presenting new problems and new methods, Japanese physicists 
were able to reduce the advantage that European researchers enjoyed over physicists in the periphery. An added difference is that Nishina not only acquired the requisite skills to do theoretical physics, he also brought back a way to develop a community of physicists in Japan. ${ }^{46}$

Even greater than his contributions to theoretical physics, Nishina is credited with creating a strong tradition of experimental nuclear physics in Japan. Nishina was particularly quick to adopt the new methodologies of experimental physics, namely cosmic ray research and the use of cyclotrons. Nishina laid groundwork that eventually led to a tradition of cosmic ray and high-energy physics in Japan. Initially, his strategy was most likely designed to overcome Japan's geographic disadvantage. When experimental physics methods were changing radically, Japanese physics could gain a clear advantage by having one of the most powerful experimental devices in the world. He could have chosen to employ clever experimental approaches or to promote superb experimental techniques. However, Nishina probably considered training experimentalists would be even more difficult than gathering the resources to build a large device. He apparently underestimated the difficulty of building a cyclotron. While its construction required significant material resources and proprietary components, what mired construction was Japanese physicists' lack of experience with cyclotrons. ${ }^{47}$

Regarding legitimacy, even more than Nagaoka, Nishina represented the connection between physics and engineering. Coming from a locally prominent but declining farmer's family, in a region where land reclamation continued for centuries, a career in engineering was a natural path to restore the family fortune. Two of his elder brothers entered engineering-related careers and his eldest brother inherited the family's salt-making business. Therefore, it was natural for Nishina to pursue engineering. Completing undergraduate studies, his interests shifted to atomic physics and Nishina entered graduate school (and a paid position at RIKEN). Nishina's choice of atomic theory was justified because atomic physics included studies of electrons, which also provided a foundation for electrical engineering. ${ }^{48}$

To legitimate constructing larger or better scientific instruments necessitated developing social justifications. As Nishina's team required greater resources, he had to spend increasingly more time on fundraising. His students subsequently complained that he spent too much time writing popular accounts, while neglecting their collaborative drafts for academic journals. ${ }^{49}$ Japan's nation building provided room for fundraising. Famously, the Japan Society for Promotion of Science funded Nishina's nuclear physics research, because, according to Hirosige Tetu, meteorologists believed cosmic ray research might contribute to aerology, deemed important for aviation. ${ }^{50}$ Similarly, the atomic bomb project provided Nishina's group with funding to build a larger cyclotron. A cyclotron could be used purely for scientific research; it could also be used to obtain essential data for atomic weapons. By connecting research with military utility, scientists were able to use empire building to legitimize their expensive research. 


\section{Ito Kenji}

Nishina's attitude toward empire building was ambivalent. Elsewhere I discussed the dilemma he faced. Nishina was a socially responsible scientist in his own way, who took seriously his obligations to family, country, teachers, students, and science. He was a firm believer in scientific cosmopolitanism, which his mentor Niels Bohr strongly advocated and from which Nishina greatly benefited. At the same time, Nishina had obligations to his country. He did his best to pursue nuclear research within the material and financial constraints of wartime Japan and had to reconcile multiple and contradictory obligations. He probably tried to achieve this reconciliation by attempting to keep research activities alive during the war as much as he could. Nishina understood that he needed to be ready to resume international competition and collaboration in science at the end of the war. He believed that, if unable to show high standards for his research activities in Japan, he would disgrace the country. ${ }^{51}$

\section{Yukawa Hideki and Tomonaga Sin-itiro}

The generation of physicists after Nishina successfully produced first-rate research. Yukawa Hideki (1907-81) and Tomonaga Sin-itiro (1906-79) are two representative examples. Various historians have discussed and contrasted Yukawa and Tomonaga. Olivier Darrigol, in particular, provides a succinct account of their styles. Yukawa was bold and ambitious, whereas Tomonaga was careful and patient. Yukawa attempted to solve problems by radically departing from the basic premises, even by mobilizing Eastern thought (or so he claimed). Tomonaga attempted to solve problems through innovation within existing theoretical frameworks. ${ }^{52}$ While I agree with Darrigol's skepticism toward Yukawa's self-fashioning as an East Asian scientist, I interpret Yukawa's references to Chinese and Japanese philosophical traditions as his own perception of how he solved the question of originality and his way of showing this perception to others, especially Westerners (what I call "self-Orientalism”). Tomonaga's style as a "non-reactionary conservative" was another answer to the same question. ${ }^{53}$ Their differences appear in their means of connecting with the network of contemporary physicists. Whereas Tomonaga was in the tradition of theoretical physics stemming from Niels Bohr, Yukawa had little direct connection with European research centers. He relied on foreign-trained Japanese physicists such as Hori Takeo, a spectroscopist who spent time in Copenhagen and taught physics to Yukawa and Tomonaga at the Third Higher School. ${ }^{54}$ Nishina also encouraged Yukawa and supported his meson theory before Yukawa published in English. ${ }^{55}$

Rather than re-examining differences between Yukawa and Tomonaga, I examined their commonalities in earlier work. In addition to their family origins (both had university professors as parents), they grew up in the same socio-cultural environment. In short, they lived in the modernist culture of the Taishō and early Shōwa eras. Engineering that legitimized physics through practical value produced a new material environment in the urban space of 
modernist culture. Featuring writers such as Edogawa Rampo, Yumeno Kyūsaku, Inagaki Taruho, and Unno Jūza, the movement was represented by the magazine Shinseinen (New Youth), first published in 1920. Inspiring writers of detective stories and science fiction alike, science and technology were important elements in this cultural movement personified by "modern girls" and "modern boys." much less integrated into the social elite and Japanese empire building. From 1919 to 1929, the number of college students sextupled. Coupled with a crippled economy, however, this resulted in high unemployment for college graduates, as symbolized by Ozu Yasujirō's 1929 film Daigaku wa deta keredo. Unlike students at imperial universities during the Meiji era, Japanese college students were no longer expected to be pillars of the state. This situation radicalized some of them politically, leading to left-wing activism. ${ }^{57}$ Although science students were less prone to politics, this cultural and occupational situation must have affected their way of evaluating the question of scientific legitimacy.

To science students, a revolution of a different kind was more directly relevant. The historian of science Kaneko Tsutomu called Einstein's 1922 visit to Japan an "Einstein Shock." A national relativity theory fervor and popular writings on relativity theory by the likes of Ishiwara Jun inspired some young future physicists. Einstein represented a revolution, and that revolution was directly connected to science and technology, which both impressed and thrilled young intelligent minds. ${ }^{58}$

Reality did not match anticipated opportunity, however. Tomonaga was excited by the expectation that he would be able to learn physics when he entered the Imperial University of Kyoto. When he arrived, he found that "In laboratories, people were doing second-hand experiments with dirty and dusty old-fashioned machines. Lectures on theories were flooded with dry equations. How boring it was to copy those equations one by one!" 59

In response to this uninspiring university environment, Yukawa, Tomonaga, and other young physicists at the Imperial University of Kyoto formed a study group to read literature on quantum mechanics (c. 1927). Tomonaga later described themselves as "ambitious modern boys." ${ }^{60}$ Similar groups formed in Tokyo as well. ${ }^{61}$

In 1929, Werner Heisenberg and Paul Dirac came to Japan. Although their visit lacked the popular fervor of Einstein's, it had tremendous impact on young physicists like Tomonaga. Heisenberg and Dirac were only in their late twenties at the time, but they were already immortals in the history of physics; their youthfulness made a tremendous impression on Japanese students. The students were further impressed when Nagaoka, the patriarch of Japanese physics who was more than 60 years old, addressed them as "sensei." ${ }^{2}$ More importantly, Tomonaga was able to understand exactly what they were talking about. ${ }^{63}$

By the end of the 1920s, young physicists in Japan at least had answers to the questions of legitimacy and possibility. Modernism provided them with the cultural legitimacy that motivated and encouraged them to produce new knowledge in a subject to which few of their teachers paid attention. Empire 


\section{Ito Kenji}

building was much less important to this generation of cultural elite, who were disenfranchised, politically indifferent, and endowed with cultural capital from their families. Institutionally, they were protected by established organizations like RIKEN or imperial universities, and by leading figures like Nagaoka and Nishina. Hence, internally and externally, they no longer needed to tie justification for research related to empire building. Simultaneously, seeing Heisenberg and Dirac, they realized that first-rate research in physics was not entirely out of their reach.

\section{Conclusion}

The question of possibility, whether the Japanese were capable of doing research in physics, found a tentative answer in Nagaoka's personal inquiry into the Chinese classics. Nagaoka proved the point by his own achievement in physics. Other physicists, such as Terada and Ishiwara followed, eventually leading to Yukawa's work on meson theory in 1935.

How to answer the question of legitimacy depended on individual scientists and their socio-cultural circumstances. Earlier generations socially legitimized research in physics by connecting it to engineering. There were also individuals, such as Terada and Ishiwara, whose literary interests constituted at least part of the values they personally saw in physics research. Much less integrated into the elite class of the Japanese establishment, later generations of physicists could more easily legitimize research activities in the personal and cultural sphere, such as the context of the modernist cultural movement of the Taishō and early Shōwa eras.

Depending on the subject and the stage of its development, the answer to the question of strategy varied. A common problem was Japan's geographic marginality. Experimentalists had the added challenge of requiring experimental facilities and equipment. For theorists, a lack of communication with foreign scholars represented another dilemma. It was generally difficult to gain visibility among scientists overseas, and Japanese researchers' results often failed to exert significant influence even when their work was noteworthy.

There were two contrasting approaches to the question of originality in Japan. Terada and Yukawa attempted to emphasize a unique Japanese or Asian approach. Nishina and Tomonaga tried to be original within the same framework as Western scientists. The latter was not simple mimicry. In the case of Kitao, we cannot say he was imitating Western scientists when this classification did not apply to his classmates at the University of Berlin with whom he studied. Similarly, when Tomonaga studied quantum electrodynamics, he probably had more in common with Heisenberg and Dirac, at least scientifically and most likely culturally, than with earlier Japanese physicists, or than Heisenberg and Dirac had with European scientists before quantum physics. As the natural world was described by the newly developing quantum physics, the social world of modernist culture engendered by technological developments was new to both Europeans and Japanese. In this 
environment, the question for Japanese physicists was not how to introduce Western science to Japan, but how to adapt to the emerging physics, which was new to both the Europeans and Japanese.

The question of how Japanese physicists established their tradition of research in physics and integrated it within the international network of researchers involves various sub-questions. While I do not claim that these four questions exhaust the relevant possibilities, they represent at least some of the important issues that need to be addressed. In addition, they are useful in highlighting the various options of historical actors with different specialties at different times.

Empire building and physics research were separate yet intertwined activities. As we saw with Nakamura and the establishment of RIKEN, physicists could use empire building to justify the research activities that they envisioned. There were also overlaps, where the same activities had both meanings. For example, Nishina's wartime nuclear weapons project can be seen as pure scientific research and as a part of military effort. But it is a mistake to simply subsume physics under imperial agendas.

\section{Notes}

1 James Bartholomew, The Formation of Science in Japan: Building a Research Tradition (New Haven, CT and London: Yale University Press, 1989).

2 For a review of sociology of science, see Steven Shapin, "Here and Everywhere: Sociology of Scientific Knowledge," Annual review of Sociology, 21: (1995), 289-321.

3 For a recent prominent example in this genre, see Thomas Hager, The Alchemy of Air: The Jewish Genius, a Doomed Tycoon, and the Scientific Discovery that Fed the World but Fueled the Rise of Hitler (New York: Broadway Books, 2009).

4 Robert K. Merton, Social Theory and Social Structure (New York: Free Press, 1968), especially Chs XVIII and XIX; Paul Forman, "Weimar Culture, Causality, and Quantum Theory: Adaptation by German Physicists and Mathematicians to a Hostile Environment," Historical Studies in the Physical and Biological Sciences, 3, (1971), 1-115; Paul Forman, "Kausalität, Anschaulichkeit, and Individualität, or How Cultural Values Prescribed the Character and Lessons Ascribed to Quantum Mechanics," in Society and Knowledge, ed. Nico Stehr and Meja Volker (New Brunswick, NJ: Transaction Books, 1984), 333-47.

5 Naomi Oreskes and John Krige (eds), Science and Technology in the Global Cold War (Cambridge, MA: MIT Press, 2014).

6 Kenji Ito, "Making Sense of Ryōshiron (Quantum Theory): Introduction of Quantum Mechanics into Japan, 1920-1940” (Ph.D. dissertation, Harvard University, 2002).

7 Tomonaga Sin-itiro, Oda Minoru, Takeuchi Masa, Kumagai Hiroo, Yamazaki Fumio, Sugimoto Asao, Ishii Chihiro, and Fujimoto Yōichi, "Nishina sensei to kakubutsuri no hatten: Nishina Yoshio sensei no 10 shūnen o mukaete 1 \& 2," Shizen, 26: 4 (1971), 55-76, 73.

8 Diro Kitao, Zur Farbenlehre (Berlin: G. Lange (Paul Lange, 1878).

9 Founded in 1877, Tokyo University took various names through its history. In 1886 , it became the Imperial University. When Kyoto Imperial University was established in 1897, it was renamed Tokyo Imperial University. In 1949, it was reorganized and renamed Tokyo University. 


\section{Ito Kenji}

10 Hirota Isamu, "Kitao Diro no shōzō: Kishōgaku no idai na sendatsu," Tenki, 57: (2010), 909-16; Diro Kitao, "Beiträge zur Theorie der Bewegung der Erdatmosphäre und der Wirbelstürme," Journal of the College of Science, Imperial University, Japan, 1: (1887), 113-209; 2: (1889), 229-412; 3: (1895), 293-402.

11 Hirota, "Kitao Diro," 913-4.

12 See Kim Boumsoung, Meiji Taishō no Nihon no jishingaku: Rōkaru sainesu o koete (Tokyo: University of Tokyo Press, 2007).

13 Itakura Kiyonobu, Kimura Tōsaku, and Yagi Eri, Nagaoka Hantarō den (Tokyo: Asahi Shinbunsha, 1973).

14 Nagaoka Hantarō, Fujioka Yoshio, and Watanabe Nei, "Genshiryoku jidai no akebono," in Nagaoka Hantarō, Genshiryoku jidai no akebono, Ningen no kiroku (Tokyo: Nihon Tosho Sentā, 1999), 181-207, 187.

15 Ibid., 192-5; Itakura et al., Nagaoka Hantarō den, 39-44.

16 Kenji Ito, "Superposing Dynamos and Electrons: Electrical Engineering and Quantum Physics in Nishina Yoshio," in Traditions and Transformations in the History of Quantum Physics, ed. Shaul Katzir, Christoph Lehner, and Jürgen Renn, Edition Open Access (Berlin: Max Planck Research Library for the History and Development of Knowledge, 2013), 183-208.

17 Itakura et al., Nagaoka Hantarō den, 473-508.

18 Nagaoka et al., "Genshiryoku jidai," 135-6.

19 Ibid., 191.

20 I note that in this context, rigaku can be either physics or science. I tentatively translate this as physics because Nakamura's idea came from Physikalische Technische Reichsanstalt.

21 Nakamura Seiji, "Teikoku rigaku kenkyūjo setsuritsu no hitsuyō," in Seikatsu, kagaku, kyōiku (Tokyo: Kawade Shobō, 1938), 10-30.

22 Kamoi Takeshi (ed.), Kōgaku hakushi Takamatsu Toyokichi den (Tokyo: Kagaku Kōgyō Jihōsha, 1932).

23 Saito Satoshi, Shinkō kontsuerun RIKEN no kenkyū (Tokyo: Jichōsha, 1987), 361-3.

24 Ibid.

25 Tomonaga Sin-itiro, "Kagakusha no jiyū na rakuen," in Tomonaga Sin-itiro chosakushū, vol. 6 (Tokyo: Misuzu Shobō, 1981, 2001), 224-35.

26 Saito, RIKEN no kenkyü, 358-61.

27 Paul Forman, "The Discovery of the Diffraction of X-rays by Crystals," Archive for History of Exact Sciences, 6: (1969), 38-71.

28 Torahiko Terada, "On the Transmission of X-rays Through Crystals," Proceedings of the Tokyo Mathematico-Physical Society, 7: (1913), 60-71.

29 William, L. Bragg, "The Diffraction of Short Electromagnetic Waves by a Crystal," Proceedings of the Cambridge Philosophical Society, 17: (1913), 43-57.

30 Nishikawa Shōji, "Raue hanten," Shisō, 16 March, (1936), 103-6.

31 Torahiko Terada, "Acoustical Investigation of the Japanese Bamboo Pipe, syakuhati," The Journal of the College of Science, Imperial University of Tokyo, Japan, 21: (1907), 1-34.

32 Uda Mititaka, "Umi no butsurigaku no chichi: Terada sensei no omoide," Shisō, 166, (March 1936), 61-7.

33 Jun Ishiwara, "Zur Optik der bewegten ponderablen Medien," Proceedings of the Tokyo Mathematico-Physical Society, 2nd Series, 5: 10 (1909), 150-80; Jun Ishiwara, "Beiträge zur Theorie der Lichtquanten," Tohoku Science Report, 1: (1912), 67-104.

34 Nisio Sigeko, Kagaku jānarizumu no senkusha: Hyōden Ishiwara Jun (Tokyo: Iwanami Shoten, 2011), 145-56.

35 Jun Ishiwara, "Die universelle Bedeutung des Wirkungsquantums," Proceedings of the Cambridge Philosophical Society, 2nd Series, 8: 4 (1915), 106-16.

36 Nisio, Ishiwara, v-ix.

37 Ibid., 69. 
38 Arnold Sommerfeld, "Zur Quantentheorie der Spektrallinien," Annalen der Physik, 51: (1916), 1-94.

39 Helge Kragh, Niels Bohr and the Quantum Atom: The Bohr Model of Atomic Structure (Oxford: Oxford University Press, 2012), 154.

40 Nisio, Ishiwara, 18-9.

41 Oskar Klein and Yoshio Nishina, "Über die Streuung durch freie Elektronen nach der neuen relativistischen Quantendynamik von Dirac," Zeitschrift für Physik, 52: (1929), 853-68.

42 Dong-Won Kim, "Yoshio Nishina and Two Cyclotrons," Historical Studies in the Physical and Biological Sciences, 36: 2 (2006), 243-73.

43 See for example, Yamazaki Masakatsu, Nihon no kakukaihatsu, 1939-1955: Genbaku kara genshiryoku e (Tokyo: Sekibundō Shuppan, 2011), 3-66; Walter E. Grunden, Secret Weapons and World War II: Japan in the Shadow of Big Science (Lawrence, KS: University Press of Kansas, 2005), Ch. 2; Keiko Nagase-Reimer, Forschungen zur Nutzung der Kernenergy in Japan, 1938-1945 (Marburg: Japan-Zentrum Philipps-Universität Marburg, 2002).

44 One biography of Nishina available in English is Dong-Won Kim, Yoshio Nishina: Father of Modern Physics in Japan (New York: Taylor and Francis, 2007).

45 I owe this insight to Takabayashi Takehiko, who applied a similar idea to the developments in the 1930s. See Takabayashi Takehiko, Variete: Butsuri hito kotoba (Tokyo: Misuzu Shobō, 1998).

46 I discuss this aspect of Nishina's role in Japan in detail elsewhere. See Ito, "Making Sense of Ryōshiron"; Kenji Ito, "The Geist in the Institute: The Production of Quantum Physicists in 1930s Japan," in Pedagogy and the Practice of Science: Historical and Contemporary Perspectives, ed. David Kaiser (Cambridge, MA: MIT Press, 2005), 151-84.

47 Kim, "Yoshio Nishina and Two Cyclotrons"; Hinokawa Shizue, Saikurotoron kara genbaku e: Kakujidai no kigen o saguru (Tokyo: Sekibundō Shuppan, 2009), Ch. 2 .

48 Ito, "Superposing Dynamos and Electrons," 185-7.

49 Tomonaga Sin-itiro, Yamazaki Fumio, Takeuchi Masa, Sakata Shoichi, Nakayama Hiromi, and Tamaki Hidehiko, "Nishina sensei o shinonde," Shizen, 6: 4 (1951), 64-76, 71.

50 Tetu Hirosige, "Social Conditions for Prewar Japanese Research," in Science and Society in Modern Japan: Selected Historicla Sources, ed. Shigeru Nakayama, David L. Swain, and Eri Yagi (Tokyo: University of Tokyo Press, 1971), 202-20.

51 Kenji Ito, "Values of 'Pure Science': Nishina Yoshio's Wartime Discourse Between Nationalism and Physics, 1940-1945," Historical Studies in the Physical and Biological Sciences, 33: (2002), 61-86.

52 Olivier Darrigol, "Yukawa, Tomonaga, and the Japanese School of Theoretical Physics," in Seimitsu kagaku no shisō (Tokyo: Iwanami Shoten, 1994), 211-30.

53 Ibid., 227.

54 Okamoto Takuji, "Sankō jidai no Yukawa Hideki to Tomonaga Sin-itiro," Butsuri, 57 (2002): 419-20.

55 Yukawa Hideki, "Nishina-sensei no omoide," in Yukawa Hideki chosakushū, ed. Katō Shūichi (Tokyo: Iwanami Shoten, 1989 [1951]), 96-100.

56 Ito, "Making Sense of Ryōshiron," 151.

57 Ibid., Ch. 3. For student activism in prewar Japan, see Henry DeWitt Smith, Japan's First Student Radicals (Cambridge: Harvard University Press, 1972).

58 For Yukawa, see Yukawa Hideki, Tabibito: Aru butsurigakusha no kaisō (Tokyo: Kodansha, 1966). For Tomonaga, Tomonaga Sin-itiro, "Wagashi wagatomo," in Tomonaga Sin-itiro chosakushū, vol. 1 (Tokyo: Misuzu Shobō, 2001), 193-202. For general cultural impacts of Einstein's visit to Japan, see Kaneko Tsutomu, Ainshutain shokku (Tokyo: Kawadeshobō Shinsha, 1991), especially vol. 2, 220ff. 


\section{Ito Kenji}

59 Tomonaga, "Wagashi wagatomo," 193.

60 Ibid., 196.

61 The activities of this group of young physicists are studied in Katsuki Atsushi, Ryōshirikigaku no shokkō no nakade (Tokyo: Seirinsha, 1991). See also Ito, "Making Sense of Ryōshiron," Ch. 3.

62 Katsuki Atsushi, Sone Take: Wasurerareta butsurigakusha (Tokyo: Sekibundō Shuppan, 2007), 206.

63 Ito, "Making sense of Ryōshiron," 261. 


\title{
13 Architects of $\mathrm{ABC}$ weapons for the Japanese empire
}

\section{Microbiologists and theoretical physicists}

\author{
Tomoko Y. Steen
}

\section{Introduction}

The countries of the Japanese empire, like the Allied and other Axis nations, joined the race to develop atomic, biological and chemical (ABC) weapons during the Second World War. Japanese ABC weapons projects received substantial support from the government of the Japanese empire, with members of the imperial family taking a lot of interest in the programs. ${ }^{1}$ We see different motivations for participation between the scientists - physicists and biologistsinvolved in ABC weapons development. Similarly, the fate and attitudes of these scientists at the end of the war and during the post-war period differed depending on wartime rank, where they were at the end of the war, and whether they were physicists or biologists. Interestingly, their moral values as they pertained to their wartime scientific activities appear to have remained near constant at an individual level throughout the trans-war period. In other words, imperial wartime rhetoric and pressure failed to change these scientists' pre-war moral standards.

The attitudes of biologists and physicists during the war were different from the start. Japanese biologists involved in bioweapons projects during the Pacific War enthusiastically initiated scientific research to create and test weapons using available technologies prior to the war and maintained enthusiasm for their projects throughout and after the war. Top-ranked bioweapons officers such as Ishii Shirō and Naitō Ryōichi actively sold their agenda to the military and ran bioweapons projects, which often included human experimentation. They protected themselves at the war's end while sacrificing a number of their junior colleagues. After successfully returning to Tokyo from Manchuria, where operations were headquartered prior to the collapse of the Japanese empire, they directly negotiated with SCAP (Supreme Commander for the Allied Powers) officials such as Lt. Colonel Murray Sanders to obtain immunity from prosecution as war criminals. ${ }^{2}$ To cover their tracks, officers such as Yamada Otozō remained in Manchuria to oversee destruction of evidence related to the Kwantung army's biological weapons programs. Yamada and others were captured by the invading Soviet Army and put on trial in Khabarovsk to live out their lives under hard labor in Soviet prison camps. 


\section{Tomoko Y. Steen}

In contrast, physicists who worked on nuclear weapons projects were brought to work for the government by the Japanese military; they were not enthusiastic supporters of the military's agenda and only continued their efforts to build nuclear weapons for the sake of advancing science and protecting young physicists from being drafted. ${ }^{3}$ Noted physicists, such as Nishina Yoshio and Arakatsu Bunsaku, were chosen by the military to run Japan's atomic bomb projects. They were keen to pursue basic physics research, treating their missions as extensions of pre-war (government) funding for basic research, especially at the beginning of the war. It was Ito Yoji, for example, a naval officer and engineer, who returned from Germany and persuaded Nishina to start a nuclear weapons project early in the summer of $1942 .{ }^{4}$ Other naval officers were interested in pursuing the project and contacted Hagiwara Sakutarō at Kyoto Imperial University, a physicist who had close ties to the navy, to hold an information session. With Hagiwara's recommendation, Arakatsu was approached by the navy and recruited for its project. As with scientists working on nuclear weapons project elsewhere during the war, Japanese physicists were not quite aware of the degree of devastation caused by atomic weapons. In contrast to bioweapons scientists who continued to defend their wartime activities, Nishina and Arakatsu and their closest colleague Yukawa Hideki became anti-nuclear activists in the post-war era, joining international physicist colleagues from former enemy countries such as Frédéric Joliot-Curie, Linus Pauling, and Albert Einstein. In fact, Yukawa was one of the co-signers of the Russell-Einstein Manifesto issued in London on July 9, $1955 .^{5}$

During the Pacific War, science and technology were used by the government as important tools for the Japanese Empire's war effort. ${ }^{6}$ As in the United States where Vannevar Bush headed the US Office of Scientific Research and Development (OSRD) to oversee military-oriented research, Japan established its counterpart agency. Japan gathered its best scientists to pursue the military's dream of establishing and advancing the Great East Asia Co-Prosperity Sphere. In Japan's case, however, scientific efforts for the war were not as centralized as in the United States under the OSRD. Typical of pre- and wartime Japanese government and politics, there were rivalries between the Imperial Japanese Navy and Army which divided scientific research efforts and funding.

While physicists were aware of Japan's research limitations and cautious about Japan's prospects for developing nuclear weapons, biologists were less well informed of international developments and were less reticent about their research prospects. The Japanese government's wartime activities were not enthusiastically supported by physicists. Having studied abroad and understanding that world-class science was closely associated with physicists from enemy countries, they were aware of the scientific capabilities in the United States and European countries and Japan's limitations for developing weapons such as atomic bombs. Biologists, however, actively promoted their research for inclusion with a view of further enhancing the development of effective, albeit inhumane biological weapons. The leader of the bioweapons project, Ishii Shirō, never had the opportunity to study abroad nor to associate closely with foreign 
scientists until after the war when he wanted to use such friendships for personal advantage. He was unaware of the limitations he faced for scientific research on biological weapons.

This chapter illustrates the differences between biologists and physicists who worked on developing ABC weapons throughout the Pacific War, focusing on their background, ethical values, and enthusiasm for developing ABC weapons under the Japanese government's plans for imperial expansion. I will discuss whether or not wartime rhetoric truly influenced either group of scientists. ${ }^{7}$ Although not presented in detail in this chapter, underpinning the story of bioweapons research and development is the racial bias of some Japanese biologists toward the Chinese population and prisoners of war who served as their test subjects. As seen in earlier chapters in this volume, Kowner and Padilla's for example, Japanese scientists distinguished between Japanese and "other Asians" often to the detriment of the latter.

This study is based on a wide range of sources, which include interviews by the author and other historians with surviving scientists and witnesses involved in ABC activities during the war, as well as newly declassified or discovered documents both in the United States and Japan. ${ }^{8}$ To situate the material being discussed, I will provide background from a broader chronological period and extend my discussion beyond the Pacific War; specifically, from the 1920s through the end of the Allied occupation period in 1951

\section{A case of biological and chemical weapons development}

Ishii Shirō (1892-1959), microbiologist and medical doctor, led the Epidemic Prevention and Water Purification Unit, in reality a biological and chemical weapons unit, widely known as Unit 731. ${ }^{9}$ Ishii had grand plans for bioweapons operations long before Japan initiated the Pacific War with the attack on Pearl Harbor on December 8, 1941. To understand fully why and how this infamous operation was established and implemented, it is important to know Ishii's childhood and educational background.

Ishii was born the fourth son of a wealthy landlord and merchant family in the small village of Kamo (near present-day Tokyo Narita International Airport). The family was able to provide important financial support for their children, including Shirō, while they were growing up. Among Ishii's critical advantages, two stand out: growing up in a small village and being considered sufficiently bright that his financially well-off family supported his educational career. When Ishii was 13, his eldest brother was killed in the Russo-Japanese War. Ishii, considered to be the brightest of the family's three remaining sons, received the full attention of his parents. ${ }^{10}$ As a result, Ishii was able to study medicine and microbiology at two of Japan's top schools. Ishii earned his undergraduate degree at Kyoto Imperial University in 1920, enlisted in the army less than a month later, and went on to the Army Medical School (Rikugun Gunni Gakkō). ${ }^{11}$ Upon completing his medical degree, Ishii was chosen for so-called "domestic study abroad [kokunai ryugakü]" but did not 


\section{Tomoko Y. Steen}

receive a foreign placement, returning instead to Kyoto Imperial University in 1924 for his doctorate as one of the superior graduates of the Army Medical School. Although rumored to have a photographic memory, Ishii's parents financed his studies at the Army Medical School and Graduate School at Kyoto Imperial University because he was not at the top of his class as an undergraduate. $^{12}$

Ishii was considered "an eccentric individual" or "mad scientist" by his professors and fellow students at Kyoto Imperial University and the Army Medical School. ${ }^{13}$ Despite his reputation, he was excellent at persuading others to support his ideas and was able to easily ingratiate himself with people in powerful positions. This was perhaps due to his physical presence, standing taller than the average Japanese and having a commanding voice. ${ }^{14}$ While studying at Kyoto Imperial University, he invented a water purification unit and named it the "Ishii-shiki rokasuiki" [Ishii-style water purification unit]. During the early 1900s, water purification units were crucial tools when countries went to war in underdeveloped and insanitary areas or jungles. According to Major General Matsumura Tomokatsu's memoirs, Ishii was indeed an eccentric individual and this was demonstrated in his efforts to persuade his superiors of his plans for water treatment. "He (Ishii) was always full of unusual behaviors." Matsumura noted:

When I was assigned to lead the headquarters involved in the establishment of new units in the Army, Ishii came to me and colleagues and insisted that we help establish a water purification unit/group under [his leadership] ... . In order to convince us of his extraordinary skills, Ishii tasted salt in front of us that he claimed he extracted from human urine, or drank water that he claimed was purified from a sewer using his water purification unit. ${ }^{16}$

Ishii shocked the officers at headquarters with his demonstration.

Germany produced a parallel genius, who, however, took a different path with his military research. A leading chemical weapons scientist in Nazi Germany, Kurt Gerstein also developed a water purification unit before he was unwillingly involved in managing production of hydrogen cyanide gas that was used in Nazi concentration camps. ${ }^{17}$ The big difference between the two was that while Ishii conducted and encouraged others for this inhumane operation, Gerstein tried to stop such operations. Considering both scientists were under similar military pressure during World War II, Ishii's inhumane behavior cannot be explained simply by saying that he faced unusual circumstances, i.e. being under the pressure of "total war.", 18

After completing his medical degree and doctorate, Ishii took the opportunity to travel around Europe and the United States, first with his parents' financial support and later with government funding. During this two-year trip, he obtained information about chemical and biological weapons developments and the use of them in the countries he visited. Chemical and biological 
weapons were developed and used during World War I in Europe, and Ishii was keen to learn about them. In some cases, Ishii used trusted assistants to visit labs in Europe and the United States asking for specific strains of bacteria useful to develop biological weapons. Ishii admired pioneering chemical weapons experts at the Army Medical School and was aware of Japan's earlier use of these weapons. However, the news of the Japanese diet's failure to ratify the Geneva Protocol of 1925 excited Ishii and made him enthusiastic about going abroad. Among other things, the Geneva Protocol outlawed the use of biological and chemical weapons and Japan's refusal to accept the international agreement is indicative of the government's attitudes towards national security. Traveling abroad presented Ishii with important opportunities: his travels to the United States and Europe allowed him to gain greater insight into foreign bioweapons programs, which he then used to convince the military, government, and his opponents of the need for Japan to develop such a program in the name of national security.

On returning to Japan in 1930, Ishii immediately started an active campaign to establish biological and chemical weapons programs for the Japanese military. With the support of the influential Colonel Koizumi Chikahiko, Ishii passionately persuaded his professors and high-ranking army officers that biological and chemical weapons were less expensive and possibly the only effective weapons that a country of extremely limited resources like Japan could use to take over Asia and potentially the world. ${ }^{19}$ Though many were initially skeptical about Ishii's idea, they were eventually convinced and top military leaders, including Tōjō Hideki, agreed. Ishii successfully obtained funding from the Japanese government and private companies to establish his biological and chemical weapons programs. ${ }^{20}$ Despite the overseas investigations and contacts he made, Ishii appears to have made little or no effort to maintain contact with his overseas colleagues.

Unlike its formal name, the Epidemic Prevention and Water Purification Unit, the main goal of Unit 731 was to produce weapons with various infectious agents for use in the war. Ishii knew that such an idea would not be popular among the Japanese population and thought it better to run the operation outside of Japan to maintain secrecy. Ishii proposed that the army establish the larger operation in Manchukuo after learning about the establishment of the puppet state there as Japan's most recent imperial annexation in China. ${ }^{21}$

This large bioweapons facility was established in Pingfang, Manchukuo. The army also established a Mukden POW camp at Shenyang (Hoten) and another at Liaoning Pingfang, near the factory. These camps became the source of human test subjects for experiments with biological weapons. ${ }^{22}$ Pingfang became the headquarters of what became known as the Ishii Agency and stayed active until toward the end of the Pacific War when the Russians invaded on August 9, 1945.

While the Ishii Agency's operation officially began in August 1936, the actual use of weaponized infectious agents by the Japanese did not occur until the border conflict with Russia during the summer of 1939, known as the 


\section{Tomoko Y. Steen}

Battle of Khalkhyn Gol or the Nomonhan Incident (Nomonhan jiken). ${ }^{23}$ Between 1940 and 1942, the Agency used biological weapons extensively in central China, according to Tsuneishi Keiichi who interviewed various Ishii Agency employees and biological weapon victims, as well as studying court records of witness testimonies in law suits against the Japanese government after the war. $^{24}$

Because Ishii believed that biological weapons research should remain a top-secret operation until the end of the war and beyond, he needed to recruit staff scientists and technicians discretely. According to Aoki's interviews with Kamo village residents, a large number of people from Kamo, including married couples and entire families, were recruited to work in Manchuria to support the operation. The people of Kamo trusted and respected Ishii because he came from an influential family in the village. They were loyal to Ishii throughout the war, and in most cases, remain so to the present. ${ }^{25}$ Ishii and other officers in the Ishii Agency also visited leading imperial medical schools such as those at Tokyo, Kyoto, Kyushu, and Tohoku imperial universities to recruit young doctors and scientists, persuading them that they could conduct top-level research with an "abundance of resources." It was, however, simply rhetoric, as members of Ishii's group knew nobody would have willingly joined such an inhumane operation if they knew their real plans. ${ }^{26}$

Ishii established several other units for different types of biological and chemical weapons development and testing throughout China and Southeast Asia and even on mainland Japan. In fact, the main operation for chemical weapons development was managed on a small island in Hiroshima prefecture called Okuno-shima or Okuno Island. ${ }^{27}$ I should mention here that the socalled Ishii Unit, or Unit 731, actually consisted of a number of units with different missions. ${ }^{28}$

As soon as Japan's defeat was obvious, Ishii left a skeleton crew at Pingfang to destroy evidence of biological weapons development and human experimentation. He ordered his staff to swear to take their knowledge of the top-secret biological weapons and testing programs to the grave; if captured, they were expected to commit suicide. Ishii distributed cyanide tablets to his staff, although there is little evidence of its use. Some members were captured by the Soviet Army in August 1945 and gave evidence at their trial. Other former Unit 731 members escaped to Japan where they were thought to have used the cyanide tablets for another crime, the so-called 1948 Teigin Incident in which 12 people were administered poison disguised as an inoculation. ${ }^{29}$

The officers who returned to Japan with Ishii safely resumed their careers at medical school or in private companies or government offices after the war; those who stayed behind in Manchuria, however, were not so lucky. ${ }^{30}$ General Yamada Otozō, commander-in-chief of the Kwantung Army, and others who, like him, remained in the Pingfang area were captured by the Soviets and brought to the now infamous war crimes trials at Khabarovsk. The Soviets had been developing biological weapons at Khabarovsk before World War II so it was considered an ideal place to try these Japanese bioweapons POWs. 
The 12 men who were captured and tried received prison sentences ranging from two to 25 years. Several died or were killed in prison; those who survived were repatriated to Japan in $1956 .{ }^{31}$

In contrast to the fate of these men, Ishii's diaries, which describe his journey back to Japan from Manchuria and post-war negotiations with the occupation army, are highly revealing about his attitudes at the end of the war and the efforts he made to survive the transition from war to peace. ${ }^{32}$ Ishii stated that he originally planned to use bioweapons when the Allied Military Force landed in Japan. However, he was strongly discouraged by his direct subordinates. They suggested, rather, that he should become friendly with the army of occupation. Ishii stated that he invited top-ranked officers from SCAP for fancy meals at his residence, where he wined, dined and negotiated with the occupiers. He also explained how he planned the entire bioweapons organization, including recruitment. The diary entries show Ishii's efforts to avoid trial. After much negotiation, Ishii successfully achieved immunity and avoided being tried at the International Military War Crimes Tribunal for the Far East; he was also given the opportunity to run a small hotel for GHQ officers to support himself financially.

Other officers in Unit 731 also tried to negotiate immunity from prosecution at the war crimes trials by developing close relationships with SCAP officers. Lt. Colonel Murray Sanders, a microbiologist from Camp Detrick, and Lt. Colonel Arvo Thompson, a veterinarian also from Camp Detrick, were the first two officers assigned to interrogate key personnel in Japan's biological weapons unit, and those they interrogated were mostly top officials such as General Ishii Shirō, General Wakamatsu Yujirō, Major General Kitano Masaji, and Lt. Colonel Naitō Ryōichi. ${ }^{33}$ Naitō, having studied at the University of Pennsylvania, was fluent in English. He and Sanders developed a close relationship over the years. Sanders and Thompson's work was followed by that of Norbert Fell, another microbiologist from Camp Detrick; Fell was often included in the invitation list to Ishii's house. ${ }^{34}$ Thompson did not develop a close relationship with these top-ranked members of Unit 731. After completing his assignment in Tokyo, he was promoted to the rank of general upon return to the US. However, he committed suicide at the Daiichi Hotel in May 15, 1951. ${ }^{35}$

By following the details of interrogations by SCAP representatives, one can understand the ethical background of senior officers involved in the operation and how these leaders of Unit 731 established immunity from prosecution. Ota Masakatsu describes these details based on information he obtained from interviews with some of the high-ranking officers of Unit 731 who were interrogated by SCAP officials. Ota also obtained key information from Niizuma Seiichi, who orchestrated the destruction of evidence of Japan's ABC weapons operations. Ota also received a note in which Niizuma recorded his operations at the end of the war. ${ }^{36}$

According to Ota's sources, most of the top players involved in Unit 731 were not only given immunity for their crimes, they became highly successful in a variety of fields. ${ }^{37}$ For example, Niki Hideo and Miyamoto Kōichi became company executives. And Ishikawa Tateo became a professor and 


\section{Tomoko Y. Steen}

then president at Kanazawa University Medical School without apparently facing any obstacles. Naitō founded the Japan Blood Bank, later to become the Green Cross Corporation, a successful Osaka-based pharmaceutical manufacturer dealing in blood products.

Under GHQ protection, these Unit 731 doctors' immoral behaviors were buried; those who were able to broker deals with SCAP resumed their pre-war career paths, their wartime actions seemingly having no consequences. A few unexpected incidents, however, brought some of these individuals' connections to biological weapons operations to light and, though none faced prosecution, they were subjected to the shame of public revelation. The most recent of these was the 1998 blood contamination scandal involving the Green Cross Corporation (Midori Jyuji). The company sold HIV-contaminated blood to hemophiliac patients and infected the patients with HIV. The initial report for this contamination was covered up by officials at Japan's Ministry of Health who were part of the biological weapons unit during the Pacific War. Newspapers eventually disclosed that executives at this company-including Naitō Ryōichiwere also all former biological weapons unit members. Naitō studied freeze drying techniques for blood serum while studying at the University of Pennsylvania before the Pacific War; he became Ishii's right-hand man at Unit $731{ }^{38}$ Like others, Naitō had been successful after the war in hiding his wartime identity from the Japanese public until this scandal broke. As a result of this scandal, not only Naitō's background but also that of other former members of Unit 731 was disclosed. General information related to Unit 731 was further publicized. $^{39}$

\section{Atomic weapons development}

While biological weapons scientists were extremely secretive regarding their research from before the Pacific War, physicists freely exchanged information both nationally and internationally. Many were educated and conducted research in Europe and the United States. In fact, leading Japanese physicists for Japan's atomic bomb projects such as Nishina Yoshio and Arakatsu Bunsaku had actively collaborated with European and American scientists. Arakatsu Bunsaku was born in a castle town, Himeji, in Hyogo prefecture. ${ }^{40}$ Arakatsu first went to Kobe Normal School (now Kobe University) to become a science teacher. He taught at a high school in Saga prefecture on Kyushu Island, but decided to pursue higher education at Kyoto Imperial University in the Faculty of Science, majoring in theoretical physics. Graduating in 1918, Arakatsu was given a position as lecturer and then as assistant professor at Kyoto Imperial University. In 1926, he was offered a professorship at Taihoku (Taipei) University in Taiwan. He decided to defer this offer for two years and instead went to study abroad in Europe. Arakatsu studied at the Kaiser Wilhelm Institute in Berlin, then at the Eidgenössische Technische Hochschule Zürich (ETH Zürich), and finally in the Cavendish Laboratory at Cambridge University in the UK. Returning to Japan in 1928, Arakatsu assumed his full professorship at Taihoku University. ${ }^{41}$ In his 
memoir, Arakatsu recalls that he had many bright students at this university with whom he remained acquainted for the rest of his life. In 1936, Arakatsu was offered a full professorship at Kyoto Imperial University and returned to Japan. Several of the students that he brought back to Japan from Taiwan became leading physicists (internationally) and established advanced physics laboratories in Taiwan or the United States following the end of the Pacific War. Arakatsu was a leading nuclear physicist before and during the Pacific War and along with Nishina Yoshio and Yukawa Hideki was considered to be among the top physicists in the world. ${ }^{42}$

Yoshio Nishina was born in a small town, Satoshō-chō Hamanaka, in Okayama prefecture. He was the fourth son in a wealthy family. Although he had a weak constitution throughout childhood and was often sick during his school years, he was skilled in various sports and known to be extremely intelligent. He was a top student throughout his educational career and in 1914 entered Tokyo Imperial University's Faculty of Engineering, specializing in electrical engineering. In 1918, Nishina graduated top of his class from Tokyo Imperial University and went to the Institute for Physical and Chemical Research (Rikagaku Kenkyūjo, also known as Riken) as a research assistant while starting his graduate work at the Faculty of Engineering at Tokyo Imperial University. In 1920, Nishina became a research associate, then in 1921 was offered a two-year fellowship to study abroad. He became affiliated to the Cavendish Laboratory at Cambridge University and in 1922 moved to the University of Göttingen. In 1923, Nishina heard Niels Bohr lecture and became fascinated by Bohr's research. He moved to Copenhagen where he spent five and a half years in Bohr's lab as a research associate. In 1928, he proposed what became the wellknown Klein-Nishina formula with Oskar Klein who also worked at Bohr's lab. That same year, Nishina decided to return to Japan after seven years abroad. Back in Japan, Nishina first worked at Riken under Nagaoka Hantaro, then Japan's leading nuclear physicist. He invited Werner Heisenberg and Paul Dirac, Nobel laureates, to visit Japan to deliver lectures. Nishina had become acquainted with them while he was abroad. Throughout his life, Nishina contributed to the advancement of physics in Japan through association and collaboration with top scientists. These two brief biographical statements are intended to demonstrate the international nature of Japanese physicists.

In 1931, Nishina established his own laboratory at Riken. He worked on new areas of physics, including quantum theory and cosmic rays. In 1937, he successfully built a cyclotron at Riken with advice from Ernest Lawrence of Berkeley National Laboratory, and several of his assistants, including Sagane Ryōkichi, were sent to study with Lawrence in $1935 .{ }^{43}$ During this period, Nishina enjoyed a great deal of communication and collaboration with physicists at Berkeley. 44

Once the Pacific War started, scientists were in general prohibited from continuing their collaboration with scientists abroad, with the exception of some collaboration with German physicists such as Werner Heisenberg. Nishina in particular was both disappointed at this restriction and strongly opposed to 
Japan's war with the United States as he knew of their advanced skills in science and technology, as well as their seemingly unlimited domestic resources and funding. Although Nishina and Arakatsu shared similar professional trajectories and strong international connections, they were destined to work for two different, potentially competitive, organizations: Nishina became affiliated with an army project and Arakatsu with a navy endeavor.

In April 1940, Takeo Yasuda, director of the Army Aeronautical Engineering Research Institute, learned of the existence of nuclear fission through science journals and ordered his subordinate, Tatsusaburō Suzuki, to look into a possible research project to develop uranium-powered weapons. The military's interest in obtaining uranium predated the Pacific War as it had learned about development of so-called "uranium bombs" in Germany and the United States. Top Japanese officials started to investigate the possibility of uranium mining during the Pacific War for use in an atomic bomb project. Receiving a special request from Yasuda on the new project, Suzuki secretly contacted the director of Riken on the subject. Because of Nishina's advanced knowledge of nuclear physics, the Nishina Research Laboratory at Riken was selected to work on this project in the spring of 1941. This project was called the Stage 2 project (Ni go $k e n k y \bar{u}$ ) and in January 1942, Nishina's group started its work on separating uranium-235 by thermal fusion. In May 1943, Nishina's group reported to the army that by isolating purer uranium-235 from uraninite or pitchblende uranium they could develop atomic bombs. The army's top officials were excited to hear the news and decided to continue financially supporting Nishina's group; they also gave Nishina permission to exempt skilled young physicists from the draft to continue their research. By March 1944 they had developed a thermal diffusion tower; the extraction of purer uranium-235 began. ${ }^{45}$

Meanwhile, in May 1941, Arakatsu Bunsaku was assigned to develop atomic weapons using nuclear fission with the support of the navy. The project was called the Stage F-Project (F-go kenkyū). The navy, independent of the army, considered establishing an atomic bomb project after learning about German and American atomic bomb project prospects in 1940 through a New York Times article. Navy officers such as Mitsui Futao, who had a background in physics, began considering establishing a parallel atomic bomb project in Japan. The key events in actualizing this plan were when navy officers invited Hagiwara Sakutarō from Kyoto Imperial University to lecture on an explosive atom, U-235, on May 23, 1942, and then subsequently learned that Japan had the capability and scientific abilities to develop atomic bombs. ${ }^{46}$ The navy moved ahead to fund the atomic bomb project and invited Arakatsu to take charge.

The establishment of two major theoretical physics laboratories to develop atomic weapons, funded and managed by separate entities, had little success in furthering large-scale uranium mining and purification in Japan. Mining began as a small operation at Ishikawa city in Fukushima prefecture. However, the ore was very impure and not enough uranium could be extracted to develop atomic bombs. As an alternative, attempts were made to purchase 
$130 \mathrm{~kg}$ of uranium on the Shanghai black market in China, while Japan also tried to import uranium from Germany, which had access to a uranium mine in Czechoslovakia (however, the submarine transporting the uranium from Germany surrendered to Allied forces before it reached Japan in 1945). The extraction technique developed at Riken was not very efficient and could not produce large enough amounts of uranium to be useful. While the focus of the Riken group was on slow neutrons, the Kyoto group focused on fast neutrons. (The fast neutron mechanisms were at the heart of the Hiroshima-style atomic bomb.) The Kyoto group organized a meeting to which they invited navy officials, explaining their theoretical achievement in developing the atomic bomb at Lake Biwa on July 21, 1945, but concluded that they did not have enough uranium to build an actual atomic bomb. The Kyoto project funded by the navy ended at this point. ${ }^{47}$ For both projects, obtaining uranium was extremely difficult. Furthermore, large-scale bombing of Tokyo on May 15, 1945, destroyed most of the facilities for atomic bomb research at Riken. For these reasons, in June 1945 the Ni-go project was abandoned. In July 1945, Arakatsu's group also gave up their project, largely due to a shortage of sufficiently purified uranium. ${ }^{48}$

Financial and underlying resource limitations stymied both projects; Japan did not have sufficient resources to advance two separate research projects. Japan's total funding for the atomic bombs was a fraction of that available to the Manhattan Project in the United States: Japanese funding was \$5 million, American funding was $\$ 20$ billion. $^{49}$

Nishina and Arakatsu knew that their work would not go very far. Interviews with their former students revealed that as long as the labs carried the name "atomic weapon development laboratory," young physicists could avoid being sent to the war and this in part appears to have motivated Arakatsu and Nishina to continue their efforts. Heisenberg had already stated in his 1939 speech that the project required massive funding, a large number of individuals, and an abundance of raw materials, i.e. uranium, and this was common knowledge among physicists internationally, including in Japan. The US was probably the only country that could meet these conditions. Studying abroad, most leading Japanese physicists knew this. ${ }^{50}$

While Japanese physicists realized the improbability of completing their atomic bomb projects, they were also not aware of the devastation such a weapon would produce. Following the atomic bombing of Hiroshima and Nagasaki, they were mentally unprepared to examine what their research could have produced. When the first atomic bomb was dropped on Hiroshima on August 6, 1945, the Japanese government quickly organized an expert team to examine the bomb site as they suspected it was indeed an atomic bomb. The team members included two physicists from Kyoto Imperial University Theoretical Physics Laboratory who worked under Araktasu Bunsaku: Shimizu Sakae and Uemura Yoshiaki, as well as two scientists from Riken, including Nishina. Although the team planned to visit Hiroshima the day after the bomb, their plane had engine trouble and the visit was delayed for four days, during which time the second bomb was dropped on Nagasaki on August 9. Following their delayed arrival, 


\section{2}

\section{Tomoko Y. Steen}

the team was shocked by the devastation that greeted them. Nishina stated in his memoir that he never thought the bomb would be so destructive to humankind. ${ }^{51}$ After examining the sites, the Kyoto and Riken groups identified the weapons as atomic bombs. Correspondingly, the Japanese government immediately ordered a number of physicists and nuclear medicine physicians to collect data from the two cities. The late Sasamoto Ikuo, a leading historian of the atomic bombing and activist for civil rights for atomic bomb survivors, argued that the data gathered by the Japanese government at that time was actually prepared to give to the incoming occupation army as a gift. ${ }^{52}$

As the Pacific War ended, SCAP sent skilled US intelligence units with scientists and a support team to each key research lab in Japan to capture useful materials for the Tokyo trials, and when they visited physics labs they were greeted by men with very different attitudes to those displayed by bio-chemical weapons specialists. The Americans investigated both Nishina's laboratory at Riken and Araktsu's labs in Taiwan and Kyoto, as well as Nobel Laureate Yukawa Hideki's laboratory at Kyoto Imperial University. While Ishii considered his research as a way to avoid prosecution as a war criminal, Nishina and especially Arakatsu looked to the scientific merit of their work and wanted to share it with the Americans for its scientific value. This shows the differences in the way these scientists viewed their work. ${ }^{53}$

Nishina was very much aware of the political sensitivity of his research and dealings with SCAP. Arakawa, however, was anxious to preserve, show, and share the results of his theoretical research on fission mechanisms. This was, in part, an effort to preserve his accomplishments as he thought the SCAP team had limited understanding of his research and would not value the materials he could provide, such as research notebooks. He was concerned about the loss of his scientific knowledge, and that concern was well justified. Thomas Smith, a translator for the US investigative team and later professor of Japanese history at Stanford and Berkeley, in a letter to Masaike Akira (professor emeritus at Kyoto University's Theoretical Physics Laboratory and director of the Japan Society for the Promotion of Sciences) described a visit with Arakatsu. While Arakatsu tried unsuccessfully to explain the importance of all the data he had gathered, the SCAP team was impatiently collecting materials from his lab, tossing them into canvas sacks. According to Smith, Arakatsu asked the leader of the SCAP team if he could keep the data notebook to translate for them and show the further development of his research, but this proposal was rejected. The cyclotron run by a team of scientists from Osaka University and Arakatsu's laboratory was thrown into Osaka Bay. Smith stated that the SCAP team did not understand the utility of the cyclotron and mistook it for part of an atomic bomb project. Araktatsu, at age 55, lost a lifetime of research. Over the years, Arakatsu made multiple requests to the US government to return his research notes, but to date, most of the notes have not been found. ${ }^{54}$ Despondent, Arakatsu lost any enthusiasm to continue his research. 


\section{Conclusion}

In this chapter I compared the motivations of biologists who worked on biological weapons projects and physicists who worked on atomic weapons projects under the Japanese imperial government's wartime rhetoric. All worked under the pressure and expectations of developing "useful" weapons for Japan's total war. As I stated at the beginning of this chapter, one defence of their participation during the war could be unavoidable circumstances and pressure from the imperial government. However, these scientists seem to have maintained the same attitudes to their research throughout the pre-war through post-war eras. In particular, physicists at Kyoto Imperial University and Riken involved in atomic weapons projects used the Japanese empire's financial support to pursue purely scientific research; in general, developing weapons was not their primary goal as they knew it was unlikely to succeed given Japan's limited resources, but it did help them protect promising young physicists. Their discussion never focused on the effect of atomic bomb as a weapon of war. Biological weapons scientists, on the other hand, used the Japanese empire's enthusiasm and funding to pursue their desired projects of developing and testing biological and chemical weapons. The biological weapons scientists discussed here were part of the military and apparently shared its ideologies from early on in their scientific and medical careers. They were able to persuade higher officials of the importance of biological and chemical weapons development based on Japan's lack of natural resources, and thus obtained much of the necessary funding and property to establish research sites. All of these biochemical projects were top secret and undisclosed as scientists and top officials were aware of the unethical nature of their research but pursued it nonetheless. The military's belief in the inferiority of the Chinese Asian "other" allowed army scientists, physicians, and nurses to carry out their experiments on human subjects.

Given the significantly greater costs of nuclear research, the comparatively modest funding of biological and chemical weapons had greater potential impact than the development of weapons-grade uranium. The atomic weapons projects were discontinued before the end of the Pacific War because of limited financial resources, lack of raw materials, destruction of laboratory spaces, and the perceived inability to develop a "usable" bomb. In contrast, Ishii tried to pursue the use of his weapons through to the end of the war, even planning to use them against the US army of occupation when it landed. ${ }^{55}$

Scientists from both sectors moved on to successful careers. ${ }^{56}$ Arakatsu continued his work with radiation, this time with agriculture, as did Nishina. The latter died in 1951. Most physicists renewed friendships with their international counterparts and collaborations both in peace activism and scientific research. Among them, Yukawa Hideki earned a Nobel prize in 1949 for his work in physics. Escaping prosecution for wartime activity, biologists took up positions as university professors or company executives. Although there were later some embarrassing moments for some individuals involved in bio-chemical 


\section{4}

Tomoko Y. Steen

weapons development (or their heirs), many prominent individuals were not punished for their involvement in morally suspect research activities. Information about their projects was sealed by the army of occupation as part of their being given immunity from prosecution. Once the occupation period was over, physicists and biologists again developed important scientific knowledge during the post-war reconstruction period, contributing to Japan's period of advanced economic development (kodo seichō ki) under the guidance of the Japan Society for the Promotion of Science, much as OSRD research was publically released to develop American industry during the post-war period.

\section{Notes}

1 See Yoshimi Yoshiaki, 731 butai to tennō. Iwanami Bukureeto, 1995.

2 Ishii Shirō’s diaries, "1945-8-16 Shūsen tōji memo" and "Shūsen memo 1946-1-11," were discovered by Aoki Fukiko in 2005. Copies in author's possession.

3 Author's interview, Masaike Akira, Professor Emeritus, Kyoto University's Department of Theoretical Physics, July 1, 2006.

4 See Yamazaki Masakatsu and Hinokawa Shizue, Zōho: Genbaku wa kōshite kaihatsu sareta (Aoki Shoten, 1997), 23; Shina Takeo, "Z kenkyū: Satsujin kōsen hiwa" in Ichioku nin no shōwa shi: 10 Fukyoka shahin shi (Tokyo: Mainichi Shinbunsha, 1977), 239-41.

5 See Yamazaki Masakatsu, "Nihon ni okeru 'heiwa no tame no genshi' seisaku," Kagakushi kenkyū, (2009), 11-21.

6 Fukui Shizuo et al. (eds), Kimitsu heiki no zenbo: Waga gunji kagaku gijutsu no shinsō to hansei (II) (Tokyo: Kyōyōsha, 1952), 165, 304-5.

7 Ibid., 162-3.

8 See Tsuneishi Keiichi, Kagakuheiki hanzai (Tokyo: Kodansha, 2003).

9 Unless noted otherwise biographical information on Ishii is from Aoki Fukiko, 731 (Tokyo: Shinchōsha, 2005) and interviews with the author.

10 Aoki, 731, 46.

11 Sheldon H. Harris, Factories of Death: Japanese Biological Warfare, 1932-45, And the American Cover-up (New York: Routledge, 1994), 15.

12 Kokunai ryūgaku, i.e. "domestic study abroad," as opposed to kaigai ryūgaku "study abroad." See Aoki, 47, 51.

13 Ibid., 47.

14 Harris, Factories of Death, 14-7.

15 Matsumura Tomokatsu, Kanton gun sanbō fukuchō no shūki (Tokyo: Fuyō Shobō, 1977), 104-106. Author's translation.

16 Ibid., 35.

17 Gerstein was a German SS officer and member of the Institute for Hygiene of the Waffen SS; as head of Technical Disinfection Services he developed water purification units as well as chemical gas to exterminate pests. After witnessing exterminations he provided information to a Swedish diplomat and the Catholic church to inform the international public about Nazi activities. In 1945, he wrote the Gerstein Report explaining his involvement in the Holocaust. See Saul Friedländer and Kurt Gerstein, The Ambiguity of Good (New York: Alfred A. Knopf, 1969).

18 Aoki interviewed people from Ishii's home town, Kamo, and his former classmates from Kyoto Imperial University, the Army Medical School, and colleagues in the Japanese army. Aoki also discovered valuable original documents, several volumes of diaries by Ishii himself, held by a family that worked for Ishii's household. Personal communication with Aoki. July 12, 2006. 
19 Ishii mentions this in his diary: "1945-8-16 Shusen memo." Koizumi, a chemical weapons advocate, met Ishii in 1930 at the Army Medical College and became an avid supporter. Koizumi became dean of the medical college, the army's surgeon general in 1934, and minister of health two years later in 1936. To say he was influential is an understatement. See Daniel Barenblatt, A Plague Upon Humanity: The Secret Genocide of Axis Japan's Germ Warfare Operation (New York: Harper Collins Publishers, 2004), 14-20.

20 Yamada Otozō, Saikinsen yō heiki no junbi oyobi shiyō no ken de kiso sareta moto Nihongun gunjin no jiken ni kansuru kōhan shorui (Moscow: Gaikokugo Tosho Shuppansho, 1950).

21 The trial record from Khabarovsk includes a series of interrogations of Yamada Otozō. Ibid.

22 Author interview with Mukden POW camp survivors in 2001.

23 Tsuneishi Keiichi, Senjō no ekigaku (Tokyo: Kaimeisha, 2005).

24 Tsuneishi Keiichi, Igakushatachi no soshiki hanzai: Kantōgun dai 731 butai (Tokyo: Asahi Shinbunsha, 1999).

25 Aoki, 731, 62. Aoki investigated the role of Kamo villagers' involvement in Ishii's operation at Unit 731. An alternate interpretation was that Ishii's family held near feudal control over the village and the villagers feared Ishii as much as they may have respected him. See Barenblatt, A Plague Upon Humanity.

26 Ishii talks about the details of recruitment in Shüsen memo 1946-1-11.

27 Okuno-shima was not on Japanese maps until the end of the Pacific War because it was a site for top secret operations. Chemical weapons operations were not as active as biological weapons operations and were abandoned quickly.

28 The biological weapons operations units were Unit 691, controlled by the Kwantung Army, the central office of which was Unit 731, and Unit 516 (Qiqihar), a chemical weapons division operated secretly under Unit 731. Sub-units that primarily focused on water purification were units $643,162,673,543$, and 319 . In addition, there were four other units: Unit 1855 (Beijing), controlled by the Japanese Northern China Area Army, Unit Ei 1644 (Nanjing), controlled by the Japanese Central China Area Army, Unit 8604 or Nami Unit (Guangzhou), controlled by the Japanese Southern China Area Army, and Unit 9420 or Oka Unit (Singapore), controlled by the Southern Expeditionary Army Group.

29 For literature on "Teigin jiken," see Takezawa Tetsuo and Watada Susumu (eds), Teigin jiken no kenkyū (Tokyo: Banseisha, 1998).

30 See Tsuneishi, Igakushatachi no soshiki hannzai.

31 Russian trial records were translated into several languages. See Yamada Otozo, Saikinsen yō heiki.

32 The notebooks are still in private hands.

33 Tsuneishi, Igakushatachi no soshiki hanzai, 122.

34 Among SCAP reports on biological weapons, the three most valuable are the Sanders Report, Thompson Report, and Fell Report held in the National Archives of Japan II.

35 According to William Jack Schull, this news was quite shocking at the same time quite mystifying. Interview with author, April 23, 2011. See also "An Army Medical Officer's Body Discovered," Stars and Stripes, May 18, 1951.

36 Author interview with Masakatsu Ota, August 12, 2010.

37 See Tsuneishi, Igakushatachi no soshiki hanzai.

38 Being fluent in English, Naito also greeted Sanders and Thompson who conducted interrogations of Unit 731 members.

39 Sanders continued his friendship with Naitō throughout his life without knowing Naitō's true history. For details of the interrogations, see the Thompson Report, Sanders Report, and Fell Report. Naitō died in 1982, escaping personal shame for his wartime behavior.

40 Arakatsu Bunsaku (1890-1973), private collection. Copy in author's possession. 


\section{Tomoko Y. Steen}

41 Taihoku University was considered to be an elite colonial university by the Japanese.

42 James Bartholomew, The Formation of Science in Japan: Building a Research Tradition (New Haven, CT: Yale University Press, 1989).

43 J. L. Heilbron and Robert W. Seidel, Lawrence and His Laboratory: A History of the Lawrence Berkeley Laboratory, vol. 1 (Berkeley, CA: University of California Press, 1989), 318.

44 Lillian Hoddeson, "Establishing KEK in Japan and Fermi lab in the US: Internationalism, Nationalism and High Energy Accelerators," Social Studies of Science, 13: 1 (February 1983), 1-48.

45 Yamazaki, Nihon no kaku kaihatsu, 37-43.

46 See Takutato Hagiwara, "Liberation of Fast Neutrons in the Nuclear Explosion of Uranium Irradiated by Thermal Neutrons," Memoirs of the College of Science, Kyoto Imperial University, Series A, 23: 1 (1940), 19-32.

47 Shōwa ki no tennō, 4: 204.

48 According to newly declassified documents at the National Archives of Japan II, United States government officials knew that Japanese physicists had the necessary skills in theoretical physics to build atomic bombs, but lacked financing, resources, and manpower. Interview with author, Masaike Akira, May 21, 2004.

49 Yamazaki Masakatsu, Nihon no kaku kaihatsu: 1939-1955 (Tokyo: Sekibundo, 2012), 4.

50 Interviews with author, Masaike Akira and Konuma Michio, October 3, 2012. Correspondence between V. Bush and OSRD officials. NARA II, declassified SCAP document series.

51 Arakatsu Bunsaku, Hiroku genshibakudan, n.p.

52 Author interview (May 12, 2002). Unfortunately Sasamoto's archival materials were discarded upon his unexpected death. On SCAP censorship see Monica Braw, The Atomic Bomb Suppressed: American Censorship in Occupied Japan (Armonk, NY: M. E. Sharpe, 1991).

53 Dong-Won Kim, Yoshio Nishina: Father of Modern Physics in Japan (New York: Taylor and Francis, 2007). Masaike was keen to learn about Arakatsu's work and SCAP's visit to Arakatsu's laboratory. He obtained a letter from the late Stanford professor Thomas Smith regarding Smith's work as a SCAP translator explaining their visit to Kyoto University. After retiring from Kyoto University, Masaike became director of the Japan Society for the Promotion of Science (JSPS) and wrote a series of articles on Arakatsu and the SCAP team's visit to Arakatsu's and Yukawa's labs. Interview with author, Masaike Akira, August 3, 2008.

54 Masaike Akira, "Rekishi no shōkei: Senryōgun ni yoru Nihon no genshikaku kenkyū chōsa (III) - Beikoku Kokuritsu Kōbunshokan nado no hozonbunshō yori," Nihon butsuri gakkai shi, 65: 7 (2010), 567-9.

55 "Ishii note," 1945-8-16 Shüsen tōji memo.

56 See Tsuneishi, Igakushatachi no soshiki hanzai; biographies of Nishina and Arakatsu in Asaike Akira, "Senryōgun ni yoru Nihon no genshikaku kenkyū no chōsa," Japanese Journal of Physics Society, 65: 5 (2010), 362-4; Dong-Won Kim, Yoshio Nishina. 


\title{
14 The science of population and birth control in post-war Japan
}

\author{
Aya Homei
}

\section{Introduction}

After World War II, the Japanese government adopted a different method of tackling population growth. Whereas the pre-war government was comfortable with relieving Japan's surplus population by emigration and territorial expansion, the post-war government relied on birth control to slow the population growth. ${ }^{1}$ Despite the change in population management technique, one theme remained consistent: population scientists acted as policy advisors.

This essay examines the entanglement between population science and population governance immediately after World War II. It analyzes debates on population and birth control research that contributed to the state-endorsed birth control campaign. Drawing on the existing works on the campaign as well as coproduction theory proposed in science and technology studies (STS), this essay depicts how the Japanese state's post-war birth control policy was coproduced with a particular kind of population science that insisted on the necessity of birth control for Japan's post-war reconstruction. ${ }^{2}$

While focusing on the science of population that developed within the Japanese state, my central argument is that transnational exchanges among population and birth control experts also shaped the nexus between state population governance and the making of population science in post-war Japan. I argue that the perspectives adopted so far implicitly privilege the nation-state as a primary category for analysis and undervalue the interaction among various nodes of population governance, including scientists who existed not just within but also beyond a given national border. Twentieth-century population governance was more than just a story of nation building precisely because the problem of population was seen as dovetailing with spatial issues such as food, land and environment, which contemporaries claimed required inter- and transnational cooperation. ${ }^{3}$ This discourse of population engaged international and non-governmental institutions to participate in population governance exercises at national and local levels. In post-war Japan, the Allied Occupation (1945-52), in which the US exercised preponderant power over Japan, facilitated the transnational dialogue between American and Japanese population advocates and experts. This transnational element affected the trajectory of the state-endorsed birth control campaign and 


\section{8}

Aya Homei

indicates that the campaign - which has been presented as a quintessentially Japanese and national project - was interlocked with global history. ${ }^{4}$

To highlight these points, I first analyze how the debate on population, predicated on the Malthusian argument, shaped perceptions of population growth and provided foundations for the state birth control campaign after 1945. ${ }^{5}$ I focus on Edward A. Ackerman and Warren S. Thompson, American scientists who participated in the disputes over Japanese population issues as scientific consultants to the occupation's general headquarters (GHQ). I describe how the occupation gave non-Japanese scientists an opportunity to participate in state population governance through their science. Consequently, Ackerman's and Thompson's transnational perspective, which regarded Japanese demography as inherently tied to global politics and highlighted Japan's critical position within world population, became a foundational narrative for understanding the population of Japan.

The second part of the essay studies how the theoretical debate on population was translated into concrete medical research on birth control in Japan, and indicates that the transnational element was even integrated into the applied scientific project that allegedly accounted for state population policy. I analyze birth control research organized by Koya Yoshio (1890-1974), director of the National Institute of Public Health. Koya defined his research within the framework of the state's birth control policy yet simultaneously sought financial help from sympathizers of population control from the United States, namely Clarence J. Gamble and the Rockefeller Foundation. Koya's arrangement eventually permitted non-Japanese, non-governmental actors to contribute to running the Japanese state apparatus addressing population policy. By clarifying agency in Koya's birth control research, I demonstrate that inter- and transnational vectors affected not only the theoretical debate over the state's participation in population control but also the medical practice sustaining state efforts to discipline and manage its population. These case studies therefore challenge the assumption of the state monopoly over population control.

The theme of empire acted as a critical backdrop to transnational exchanges on population, prevailing in the disputes over Japan's population management. Specifically, discussions of the population problem in post-war Japan built on the transnational dialogue were predicated on the narrative of Japan's lost empire as well as an imperialistic perspective engrained in the burgeoning discourse of transnational population control that labelled parts of Asia, Africa and Latin America as "underdeveloped." This international context conferred a special status to post-war Japan: its demographic trend and sociopolitical state made Japan an archetype for "underdeveloped areas." According to Ackerman, 1940s Japan had become a hungry, poor, overcrowded, and "underdeveloped" country because it had lost colonies after the collapse of its empire. Ackerman and Thompson suggested Japan should no longer resort to the familiar trope of territorial expansion or emigration precisely because these measures were associated with Japan's aggressive imperial past. Under these circumstances, they understood birth control to be one appropriate policy for post-war Japan. They 
proposed birth control to replace pre-war methods to support a growing population that hinged on the notion of lebensraum. ${ }^{7}$ Thus, the image of Japan's lost empire, coupled with a perspective rendering Japan "underdeveloped," acted as a critical backdrop to the promotion of birth control, creating an intersection between the domestic scientific discourse of population, the geopolitical narrative of colony and empire, and the post-war world that shaped population governance in post-war Japan.

\section{The "population problem" and the state birth control campaign in the immediate post-war period}

Shortly after the end of World War II, Japan's population started to grow very quickly, and birth control came to the fore as an answer to a perceived "population problem." Repatriation and a post-war baby boom were assisted by a moderate death rate of 14.6 per 1,000 , resulting in population growth of 31 per 1,000 population. ${ }^{8}$ The population surge was, however, a temporary phenomenon; the birth rates gradually began to dwindle after 1948, and slowed further after 1951.

Yet demographic trends within the first three years after the war convinced policymakers that Japan was confronted with a "population problem" and that the government should tackle it. After much discussion, the government eventually resorted to birth control. In 1949, the government issued the Pharmaceutical Law that explicitly allowed the sales of condoms and diaphragms for contraception, and on October 26, 1951, the prime minister's Cabinet Council formulated a fundamental policy to popularize birth control across the country and the government began a nationwide campaign. With guidance from central government, local authorities assigned existing female health practitionersmidwives and public health nurses - the additional role of "birth control instructors" and retrained them to educate ordinary men and women about the idea and practice of contraception. In consultation with doctors, these instructors visited individual households and hosted seminars and marriage counseling clinics, teaching the benefits of birth control and making contraceptives available in their communities. Thus, the state birth control campaign in postwar Japan unfolded almost in tandem with the rise in the discourse around "population problem."

The deployment of the birth control campaign as a policy response to the perceived population problem was in no way predetermined. First, intellectuals from diverse backgrounds made many suggestions other than birth control: emigration, reindustrialization, and agricultural reform were all discussed as preferred options. Minoguchi Tokijirō, who approached the population problem from an economics/resources perspective, argued that policymakers should focus on rebuilding Japan's economic and industrial capacity, not birth control. ${ }^{9}$ Furthermore, while birth control was a subject of discussion from the onset, some were also resistant to birth control as a national policy partly because they feared that it would promote what eugenicists and doctors called 
"reverse selection," or the "lowering" of the quality of the Japanese populace via differential fertility - that is, the "biologically unfit" or those in lower socioeconomic classes would bear multiple children, while others regarded more "biologically fit" would regulate fertility ${ }^{10}$ Finally, even when birth control had become a realistic policy in the late 1940s, the most urgent objective of the campaign was allegedly to tame the surge in abortion rates that had occurred after the amendment of the Eugenic Protection Law in 1949 that created a legal loophole for women seeking abortions. ${ }^{11}$ Thus, the path from the ascendancy of "population problem" discourse to the implementation of the birth control campaign was neither unidirectional nor predetermined.

Despite competing ideas about the solution to the imminent population crisis, the argument that Japan's loss of colonies after World War II constituted a critical factor in the post-war population problem ran through the debate on Japanese population. After 1945, Japan lost its empire and its territory shrank drastically, to the extent that Aki Köichi implied the country had lost nearly 45 percent of its pre-war territory. ${ }^{12}$ The idea of lost colonies fed into the view that Japan was now flooded with repatriates. The image of overcrowded Japan consolidated claims similar to one made by the prominent obstetrician, gynaecologist, and politician Taniguchi Yasaburō, that overpopulation would trigger hunger, poverty, and the infestation of diseases in crowded spaces and eventually lower the quality of the Japanese population. ${ }^{13}$ At the same time, leading commentators on resources such as Minoguchi problematized overpopulation in relation to Japan's access to natural resources and capital, now severely hampered by the loss of colonies. ${ }^{14}$ This view held wide currency during the post-war period precisely because the country was also confronted by obvious food shortages. ${ }^{15}$ Policy intellectuals' gloomy forecasts regarding the consequences of overpopulation for the country's socioeconomic and political future suggested a post-war Malthusian dilemma might preclude war-torn, US-occupied Japan from achieving economic reconstruction and even national independence. ${ }^{16}$ Therefore, the post-war "population problem" was derived from the issue of space unique to Japan's recent past, its lost empire.

Since the period when population growth was problematized largely overlapped with the period of the Allied occupation (1945-52), leaders within the occupation's governing body were compelled to react. General Douglas MacArthur, the supreme commander of the Allied Powers (SCAP), chose to proclaim publicly that the GHQ would take a hands-off approach to birth control. ${ }^{17}$ Nevertheless, population growth itself remained a high priority within the GHQ, in part because countless non-Japanese studies on Japan's demographic trend during the occupation agreed with the prognosis made by Japanese policy intellectuals. ${ }^{18}$ Consequently, the GHQ, in parallel to the Japanese government, embarked on research that explored possible solutions to the population problem. It assigned the three sections dealing with population issues - the Economic and Scientific Section, Natural Resources Section and Public Health and Welfare Section - to investigate the current population problems confronting Japan. ${ }^{19}$ 
In the late 1940s, as an extension of population concerns within the GHQ, SCAP invited noted population experts from the US as scientific consultants. The list of invited experts was impressive, and included prominent demographer Frank W. Notestein of the Office of Population Research at Princeton University who led the "population establishment," the amorphous group that laid the foundation for the transnational population control movement from the 1950s onwards. ${ }^{20}$ These expert consultants visited Japan for brief periods to look into population issues and were asked to produce reports that gave specific policy advice to the respective sections within which they served.

Among those invited by GHQ were noted geographer Edward A. Ackerman and sociologist Warren S. Thompson. Ackerman visited Japan from July 1946 to February 1948 and from August 1948 to January 1949 and on both occasions served in GHQ's Natural Resources Section. ${ }^{21}$ Likewise, Thompson worked for the same section while he stayed in Japan for several months from January 1949. ${ }^{22}$ The two stood out as recognized authorities on birth control in occupied Japan. Their Japanese colleagues, including Koya Yoshio, came to advocate birth control after becoming acquainted with Ackerman and Thompson. ${ }^{23}$ Furthermore, the two came to have a high public profile for statements they made on birth control and Japan's population problem. Ackerman came to the public's attention when a newspaper article caricature of his report to SCAP (December 30, 1949) "urg[ed] birth control as a 'workable solution"” to Japan's overpopulation. ${ }^{24}$ In turn, Thompson, who was credited with persuading Prime Minister Yoshida Shigeru to adopt birth control as Japan's policy, was more forthcoming in expressing his support publicly. ${ }^{25}$ To be sure, they gained fame in Japan less because the Japanese themselves paid attention to their actions than because the American Catholics residing in Japan were scandalized by their comments. ${ }^{26}$ Nevertheless, their media presence assisted acceptance of birth control as a justifiable technology of population control in Japan.

While both men promoted birth control as a solution to the population problem, the ways each considered the problem of population differed, reflecting their distinctive fields of expertise. Ackerman, a geographer whose interest in population derived from his long-lasting engagement with issues of resources, understood Japan's population problem in a manner similar to Japanese Malthusian economists - i.e. that it was caused by the collapsing balance between population growth and economic growth. ${ }^{27}$ Noting that over 80 million people, or "more than half as many as the total population of the entire United States," lived on the now much smaller landmass of Japan, Ackerman thought the Japanese situation exemplified "the fundamental problem of balancing production against demand." 28 What concerned Ackerman was that this "fundamental problem" would erode Japan's limited land resources and cause a drastic rise in mortality rates if current international food aid were terminated. ${ }^{29}$ Furthermore, as a specialist in issues of development and resource availability, Ackerman considered the population problem particularly in relation to Japan's poor and hungry. He thought the loss of colonies and the warobliterated economy transformed Japan into a "have not" country and drove it 


\section{Aya Homei}

"backward" on the scale of industrial development. He further argued that population growth exacerbated the socioeconomic situation to such a degree that he classified Japan as one of the "underdeveloped areas." ${ }^{30}$ For geographer Ackerman, Japan's population problem posed what was primarily a Malthusian dilemma and denoted issues of land, resource, and development.

In contrast, sociologist Thompson discerned the population problem in terms of world security. ${ }^{31}$ Since the pre-war period, Thompson had been leading international debates on population by warning that socioeconomic crises, such as poverty, food shortages and unemployment, were brought on by population pressure, and therefore surplus population could destabilize people politically. He had also participated in the dispute over Japan's population growth that surged after the Rice Riots (1918), and stated in 1929 that population pressure would push Japan into a war, and consequently the Japanese situation jeopardized world peace. ${ }^{32}$ In the post-war period, too, Thompson stressed the imminent ramifications of overpopulation on geopolitics, specifically concentrating on the position of the United States in the burgeoning Cold War. Thompson commented that if population growth was not moderated and if the United States stopped current food aid, Japan might fall back on militarism or succumb to communism, compromising the geopolitical balance in the Cold War. ${ }^{33}$ Thompson, therefore, discussed population principally in regard to the politics of space.

Ackerman and Thompson's articulation of population issues indicated that however different their emphasis, they were fundamentally in agreement and considered the population problem essentially an issue of space. Convergence of their views should come as no surprise, especially when we take into account that this conceptualization of population was in no way uncommon among world population scientists during the period. Because the population problem dovetailed with issues such as land, migration, territory, colonization, and settlement, the pre-war debate on world population emphasized geography and population policy was predicated on the logic of shifting lebensraum and redistributing people. ${ }^{34}$ This line of argument was so prevalent that Thompson in the 1920s endorsed Japan's colonial pursuit by claiming that territorial expansion, e.g., the cession of Pacific Islands to Japan, could act as an alternative to war. ${ }^{35}$ Even after the war, the idea of regarding population as part of the problem of space and security did not disappear; as Thompson's articulation of population and the Cold War geopolitics implies, it remained a significant undercurrent in the discussion of population during the period. ${ }^{36}$ Ackerman and Thompson's characterizations of the Japanese population problem mirrored international trends in population science.

At the same time, in the context of the international politics of sex, birth control was long considered obscene, and here Ackerman and Thompson diverged from the international currents by presenting birth control as a viable method for population control; yet, one could also argue that their attitude toward birth control ironically reflected a new trend within the field of population science that gradually shifted its focus from geography toward biology to 
manage surplus population. Reasons for the change varied, but the rise of demographic transition theory that stressed the importance of fertility for population statistics and the realization that the earth was no longer free living space - that there was no such thing as flight to "virgin land" to relieve population pressure - were among critical perspectives underlying the shifting argument. ${ }^{37}$ Thus, from the 1950 s onwards, population experts increasingly looked to fertility reduction for population management. Thompson was a forerunner in advocating these measures. In the pre-war period he championed manipulating space and shifting people to solve the population problem, but having witnessed Japan's population problem and the bloody Partition of Pakistan and India, Thompson reappraised his underlying assumptions. He concluded that opening land to a large population could provide only temporary relief, and began to campaign for birth control. ${ }^{38}$ This shift within population science encouraged Thompson, and to some extent Ackerman, to endorse birth control for Japan.

Ackerman's and Thompson's endorsement of birth control cannot be explained solely by international developments in population science; Japan's status as a former colonial power also underlay their claim. In assessing various population measures for post-war Japan, Ackerman thought that although previous scholars had regarded expansion of territory as effective, and although some Japanese intellectuals were still discussing the possibility of emigration as a countermeasure to overpopulation, the decision of whether or not the Japanese government could opt for these measures was beyond Japan's control precisely because past Japanese leaders used such rationales to justify aggression. ${ }^{39}$ Similarly, Thompson commented, regarding emigration as a population control measure, "[o]wing to the aggressiveness of the Japanese in the past, no country is willing to admit any appreciable number of them ...."40 Ackerman concluded that fertility reduction through birth control, which he euphemistically labeled "stabilization of the population," was the only "adequate" measure left for post-war Japan. ${ }^{41}$ Ackerman's statement appears as though he reached this conclusion through the process of elimination; however, one could also argue that his characterization of birth control as an "adequate" method - and implicitly characterizing emigration and territorial expansion as inadequate - for population management could not have been made without his interpretation of Japan's aggressive military and colonial past. ${ }^{42}$ The image of Japanese colonial power exploiting the idea of lebensraum buttressed the two American scientist consultants' rationale for birth control.

As the abovementioned analysis suggests, the specific political context of the occupation allowed international influence to shape the debates over solutions to Japan's post-war population problem. Under the circumstances, non-Japanese population scientists willingly participated in the debates, but because they felt that the Japanese case was more than just one example out of many that would further their knowledge of world population, they also paid special attention to Japanese demography because it represented a unique experience with the politics of space (gain and loss of empire) - in other words, they reckoned that study of the Japanese population could lead 


\section{Aya Homei}

to an understanding of global population governance as it intersected geopolitics. Japanese policy intellectuals, like the American scientists, agreed that Japan's "shrunken" territory was the source of the "population problem" and this specific understanding of Japan's geographical and geopolitical position helped present the Japanese population problem as a unique case. Equally, the American scientists' understanding shaped the population debate within Japan and ultimately exhorted Japanese policymakers to replace the colonizing motivation of lebensraum with birth control as a domestic medical/public health solution.

\section{Birth control in public health, Japanese demography, and American population controllers}

Although the abovementioned arguments on population control had constituted a strong undercurrent for birth control as fundamental policy in 1951, the government officially proclaimed that the policy was not a response to population expansion but intended to curb the imminent health crisis among mothers resulting from the growing popularity of abortion. The official stance regarding abortion and birth control was temporary and the government quickly shifted its argument to favor birth control for the purpose of population control. The initial definition of the 1951 policy, however, determined its position within the public health administration. Thus, public health institutions took charge of implementing birth control policy with the National Institute of Public Health (NIPH) playing a critical role. The NIPH became an officially recognized training center for the popularization of birth control. In consultation with the Ministry of Health and Welfare (and the Public Health and Welfare Section of GHQ until the occupation ended in 1952), the institute ran the program under which local public health leaders and healthcare professionals were trained in the most up-to-date methods of conception control. NIPH thus linked the central authorities and public health institutions in local governments to establish and maintain birth control services nationwide. ${ }^{43}$

NIPH director Koya Yoshio was the force behind the government's birth control program. Koya, a graduate of the elite Medical Department of the Imperial University of Tokyo and a noted racial hygienist, had long advised the government on matters of reproductive health. ${ }^{44}$ During the war he worked for the Ministry of Health and Welfare and participated in drafting the 1940 National Eugenic Law. ${ }^{45}$ Even after SCAP moved him to NIPH in 1946, he helped draft the 1948 Eugenic Protection Law. Finally, Koya occupied center stage when the government adopted birth control as national policy. Koya first approached health minister Hashimoto Ryūgoro and persuaded him to consider adopting birth control as a policy for protecting maternal health. ${ }^{46}$ Koya also sat on the Cabinet's Japanese Population Problem Council (established 1949) and contributed to draft recommendations that formed the basis for the 1951 birth control policy. ${ }^{47}$ Thus, Koya's elite 
academic background, as well as his proximity to political authorities, made him a credible scientific advisor on matters of reproductive health, and birth control in particular.

Koya's interest in promoting birth control was motivated by his preoccupation with population quality, in contrast to Ackerman and Thompson whose support for birth control chiefly arose from concerns over population quantity. As mentioned above, Koya was initially reluctant to endorse birth control because he believed it would promote "reverse selection." After issuing the Eugenic Protection Law, however, Koya changed this view and became an avid promoter of birth control. ${ }^{48}$ Immediately after implementation of the law, Koya learned that the rate of unchecked abortions was on the rise and seemed to promote differential fertility. ${ }^{49}$ Koya concluded that abortion had a dysgenic effect on overall population quality and suggested it should be replaced by the guided use of birth control, specifically targeting the lower socioeconomic class. ${ }^{50}$ Thereafter, he actively dedicated himself to the birth control movement and lobbied the government to promote birth control. ${ }^{51}$ Koya's birth control advocacy was, therefore, grounded in his long-lasting involvement to maintain and improve the quality of the Japanese populace.

Koya used multiple channels to spread birth control into various policy arenas, but his research with the demographic team at the NIPH's Department of Public Health Demography was the most important. In the early 1950s, Koya's team embarked on the so-called Three Model Village Study, in which the government tested its birth control service. For seven years a team surveyed 6,936 participants in three "typical Japanese villages" deemed representative of rural Japan. ${ }^{52}$ The team distributed to the participants contraceptives of their choice at a low price (initially free) and investigated the relation between contraception practice and declining birth and abortion rates. ${ }^{53}$ The study proved the project's success. After seven years, contraceptives - most preferred was the condomwere used by 75 percent of the families that had experienced pregnancies in the past and by 95 percent of families with four or more children. Moreover, these figures correlated with the decline in birth and abortion rates. The crude birth rate fell from 26.7 to 13.6 per 1,000 and after the end of the sixth year, the rate of induced abortions per 1,000 dropped to 1.4, much lower than the nationwide rate of reported abortions for that year. ${ }^{54}$ Koya used the study's results to validate the government's birth control policy and demonstrated the efficacy of the particular birth control initiative that he believed was the most suitable and acceptable, as it would not only reduce population size but ensure the high quality of the Japanese populace.

While Koya's birth control research was officially presented as a government project, in reality, American advocates of birth and population control also supported his research. The Three Model Village Study was funded by Clarence J. Gamble, heir of the Proctor and Gamble soap company fortune, birth control activist, and self-professed medical researcher based at the Harvard School of Public Health. Since the 1930s, Gamble had endeavored to institute contraceptive services in public health programs in America's Deep South 


\section{Aya Homei}

specifically aimed at women from lower socioeconomic backgrounds. ${ }^{55}$ Viewing his mission abroad as an extension of his experiments in the United States, Gamble approached Koya and proposed a collaborative effort. ${ }^{56}$ The two shared professional attributes and interests: both were public health specialists working on birth control. Moreover, by SCAP order, Koya once visited the American South to observe birth control programs in public health services, part of which Gamble helped to establish. ${ }^{57}$ For Gamble, Koya appeared to be the ideal individual with whom to work. Koya was happy to accept Gamble's offer and Gamble's personal donations consequently helped to maintain NIPH demographic research during the 1950s.

In addition to Gamble, Koya's research group at the NIPH was endowed by the Rockefeller Foundation (RF), whose related organization, the Population Council, was known as a pillar of the US-led transnational population control effort from the 1960s onward. The tie between the RF and the NIPH was long-standing, dating back to 1939. In the immediate post-war era, the RF began to support demographic study at the NIPH. This was partly due to Koya's initiative; he continually applied for RF funds. The RF also paid attention to Koya's research proposals because it was interested in the East Asian population. ${ }^{58}$ In September 1948, its International Health Division dispatched two noted demographers from the Office of Population Research at Princeton University, Notestein and Irene B. Taeuber, along with two RF officers, Marshall Balfour (Far East regional director of the International Health Division) and Roger Evans (assistant director for the Social Sciences Division) to Japan. The delegates' advice encouraged the RF to see its mission as fostering "pioneering research ... through the cooperation of private scholars and institutions in the United States and Japan." "59 In Tokyo, Oliver R. McCoy, RF representative in Japan stationed at the NIPH and a consultant to the GHQ's Public Health \& Welfare Section, pushed the RF's idea of "[d]irect help to such agencies as ... the Department of Public Health Demography of the Institute of Public Health ... ." ${ }^{60}$ McCoy believed that "Koya's projects" would provide "points of interest" for his organization. ${ }^{61}$ Consequently, the RF funded Koya's projects on reproductive behavior impacts on the demography of Japan. ${ }^{62}$

The American benefactors did more than just aid Koya and his team's research financially; they actively participated in it. However, the RF retained its policy of distancing itself from birth control research. ${ }^{63}$ Birth control was still a controversial cause in some quarters of American society, and the RF was reluctant to be seen as collaborating with birth control proponents anywhere. Under the circumstances, Koya's RF-funded research principally focused on population statistics rather than projects assessing birth control methods. In contrast, Gamble used his benefactor status to advance his cause: establishing clinical trials in Japan investigating the effectiveness of emerging birth control methods. ${ }^{64}$ Gamble shipped foam powder to Koya and asked him to promote his sponge and powder method. He further suggested that Koya "can test the clinical effectiveness of a sponge using 10 percent sodium chloride solution," and also encouraged the jelly and syringe method, a kind of barrier method. ${ }^{65}$ From the mid-1950s 
onward, when Gamble was acquainted with the foam tablet, he advised Koya to conduct an experiment on Sampoon, a variation of the tablet produced by Japan Eizai Pharmaceutical Company in Tokyo. ${ }^{66}$ Gamble was keen to establish the clinical trials he had so far been unable to conduct, and expected Koya to play the role of local confidante who performed clinical trials on his behalf.

Koya was a cooperative collaborator for the most part. Koya closely monitored the use of the sponge method, which he believed would suit Japanese users. ${ }^{67}$ Furthermore, Koya even asked for Gamble's advice whenever he was about to change directions in his research or embark on a new project. ${ }^{68}$ However, Koya was never simply docile when responding to Gamble's requests. ${ }^{69} \mathrm{He}$ was motivated by his sense of mission to solve Japan's population problem and by his desire to expand the field of demography in Japan, in particular the field of public health demography that specialized in the correlation between reproductive behaviors and demography. ${ }^{70}$ Koya believed he could achieve his goals with the additional foreign funds and the networks forged by that funding. Gamble and the RF's offers of support arrived just at that moment, and he accepted their offers because he foresaw benefits in collaborating with the American philanthropists for his own projects. With regard to Koya's birth control research, the amicable collaboration between Koya and Gamble eventually influenced its trajectory.

This collaborative aspect of Koya's research highlights the important role local and global population science played in formulating population policy in post-war Japan. Population science provided a site that allowed transnational interests to participate in population management exercises that were sanctioned by the Japanese state. Although Koya designed his research to benefit state planning by providing data for the government's birth control policy, by allowing Gamble to influence his research, Koya-however unintentionallyfacilitated the process by which transnational elements were integrated into state machinery whose purpose was solely domestic. This in turn meant that the state-endorsed birth control campaign was partially undergirded by nongovernmental and non-Japanese forces, even though it was situated within the Japanese government's structure and derived from statist discourse of national independence and economic recovery. The story of Koya's research confirms how the practice of population management, which is chiefly presented with the framework of the nation-state, also involved interactions with vectors, local and international, beyond the state.

\section{Conclusion}

To the degree that population issues affect vast areas of human endeavor, debates on population have embraced diverse perspectives and wide-ranging views of the population problem. The process of making the state's birth control campaign embodied this complexity domestically and internationally. To date, studies of the topic have focused attention on the biopolitical aspect of the campaign. 


\section{Aya Homei}

This essay presented a multi-level response to a historiography focused on the nation-state. We have seen the influence of international scientific debates involving Ackerman and Thompson that underscored issues of space and spatiality related to Japan's colonial past. I have demonstrated that the campaign was not only a story about sex, reproduction, or biopolitics, but that geographical topics - e.g. land, food, emigration, colony, and security - buttressed debates leading to the campaign. This concern was also reflected in domestic Japanese debates.

Another central question analyzed was the relationship between science and state sovereignty and I have indicated that development of a particular trend among Japanese population scientists played a critical role outside the state apparatus. In order to complement the historiography that has hitherto largely assumed the existence of scientists within the policy-making process, the second part of the essay analyzed Koya's birth control research that directly responded to the state's population governance effort and also to nongovernmental influences. The case study pointed out the significant role Japanese population scientists played in population policy, thereby showing that the development of a particular type of population science emphasizing birth control was interlocked with the vector within the modern state that insisted on population management involving fertility reduction.

However, I also demonstrate that interactions between population science and population governance in post-war Japan centering on birth control were buttressed by the transnational flow of ideas and people that transcended state sovereignty. This flow was in part facilitated by the political structure of Japan under the occupation. The occupation paved the way for American population experts to partake in Japanese population governance exercises as consultants to the GHQ. Likewise, the occupation helped transnational population actors of the RF and Gamble to connect with Koya's policy-oriented research. The occupation was not the sole reason why this transnational flow occurred: ongoing transnational interest in Japanese demography since the prewar period stimulated the movements of actors and ideas across national borders. Thompson served the GHQ partly because he had been closely watching over Japanese demography even before the war and because he believed it would directly influence issues of world peace. For Thompson, Japanese population trends provided a case study that enabled him to further his analysis of the links between world demography and security. Similarly, Gamble supported and even guided Koya's research because he saw Koya's birth control research as a compelling experimental case study that would benefit global population governance. In sum, occupied Japan, as well as the ongoing international interest in Japanese demography, enabled the vectors that shaped the transnational exchange of ideas and people in the arena where population science and state population governance intersected. Consequently, Japanese population management was embedded in the broader network of global population governance. 
This formulation of state population governance compels us to reappraise our sense of the state. The post-war state was never a neat and self-contained category but rather a porous entity allowing space for transnational elements to exist within its workings. Simultaneously, the image of the modern Japanese state as an aggressive empire was pivotal in the course of population governance in post-war Japan. It shaped arguments about the specific ways in which the state should pursue population management.

Finally, an undercurrent in this essay has been the pivotal position of population science in the Japanese state's pursuit of population governance at sites where reality and rhetoric intersected. The population grew and birth control was used by the Japanese state for the sake of population control during the post-war period. Yet at the onset of population debates it was evident neither that population growth would constitute an imminent crisis nor that policymakers must resort to birth control to alleviate the crisis. Amidst uncertainties, population science problematized demographic trends and presented birth control as a desirable option. In other words, population science provided a rhetorical device with which population governance actors could seize convoluted, open-ended, and at times less intangible phenomena and translate them into something pertinent to, and workable within, the framework of the Japanese state. Although there were countless possibilities among the perceptions of population trends and in the solutions to the perceived demographic crisis, what reigned over Japanese population governance was the ontologically coherent narrative that contended that Japan immediately after the war was confronted with overpopulation to which the state responded by replacing discredited colonial motivations with a domestic birth control policy. Population science helped construct the rhetoric of population and state governance and transformed it into tangible reality involving birth control.

\section{Acknowledgement}

I would like to express my sincere appreciation to the editors of the current volume as well as the Wellcome Trust [085926/Z/08/Z], whose generous grant supported this work.

\section{Notes}

1 See Ryoko Nakano, Beyond the Western Liberal Order: Yanaihara Tadao and Empire as Society (Basingstoke: Palgrave Macmillan, 2013), 41-63.

2 For recent examples of work on the post-war history of birth control in Japan, see Ogino Miho, "Kazoku keikaku" e no michi (Tokyo: Iwanami Shoten, 2008); Tama Yasuko, "Kindai kazoku" to bodī poritikkusu (Kyoto: Sekaishisosha, 2006); and Hiroko Takeda, The Political Economy of Reproduction in Japan: Between NationState and Everyday Life (London: RoutledgeCurzon, 2005). Susan Greenhalgh, Just One Child: Science and Policy in Deng's China (Berkeley, CA: University of California Press, 2008) best represents STS studies of the population field. 
3 Alison Bashford, Global Population: History, Geopolitics, and Life on Earth (New York: Columbia University Press, 2014); Matthew Connelly, Fatal Misconception: The Struggle to Control World Population (Cambridge, MA: Belknap Press of Harvard University Press, 2008); Matthew Connelly, "Seeing beyond the State: The Population Control Movement and the Problem of Sovereignty," Past and Present, 193: (2006), 197-233.

4 Nick Cullather, The Hungry World: America's Cold War Battle against Poverty in Asia (Cambridge, MA: Harvard University Press, 2010), 13-42; Susan Greenhalgh, "The Social Construction of Population Science: An Intellectual, Institutional, and Political History of Twentieth-Century Demography," Comparative Study of Society and History, 38: (1996), 22-66; Peter J. Donaldson, Nature Against Us: The United States and the World Population Crisis, 1965-1980 (Chapel Hill, NC: University of North Carolina Press, 1990).

5 Scott O'Bryan, The Growth Idea: Purpose and Prosperity in Postwar Japan (Honolulu, HI: University of Hawaii Press, 2009), 144-60; Ogino Miho, "Jinkō seisaku no sutoratejī 'umeyo fuyaseyo' kara 'kazoku keikaku e'," in Tekuno/baio poritikkusu: kagaku iryō gijutsu no ima, ed. Kaoru Tachi (Tokyo: Sakuhinsha, 2008), 145-59; Eric Gordon Dinmore, "A Small Island Nation Poor in Resources: Natural and Human Resource Anxieties in Trans-World War II Japan” (Ph.D. diss., Princeton University, 2006).

6 Edward A. Ackerman, Japan's Natural Resources and Their Relation to Japan's Economic Future (Chicago, IL: University of Chicago Press, 1953), 566.

7 For lebensraum and its significance to Japan during the pre-war period, see e.g. Li Narangoa, "Japanese Geopolitics and the Mongol Lands, 1915-1945," European Journal of East Asian Studies, 3: (2004), 45-67.

8 “Jinkō no suii B, Taishō 9 nen kara heisei 21 nen' and 'Shussei, shibō, shizan, kon'in oyobi rikonsū' (Taishō 14 nen Heisei 20 nen)," Statistics Bureau, DirectorGeneral for Policy Planning (Statistical Standards) \& Statistical Research and Training Institute, Ministry of Internal Affairs and Communications of Japan, online at: www.stat.go.jp/data/nenkan/02.htm (accessed September 19, 2011). Also see Deborah Oakley, "American-Japanese Interaction in the Development of Population Policy in Japan, 1945-52," Population and Development Review, 4: 4 (1978), 617-43, 619.

9 Dinmore, "A Small Island Nation," 112, 136.

10 Ogino Miho, “Umeyo fuyaseyo' kara 'kazoku keikaku’ e: Jinkō kanri no seijigaku," in Sei to seishoku, kokka no seisaku, ed. Namihira Emiko (Tokyo: Frontiers of Gender Studies, Ochanomizu University, 2006), 127-36, 133; Matsubara Yoko, "Nihon ni okeru yūsei seisaku no keisei-kokumin yūseihō to yūsei hogohō no seiritsu katei no kentō" (Ph.D. diss., Ochanomizu University, 1997).

11 Yoshio Koya, "A Study of Induced Abortion in Japan and its Significance," Milbank Memorial Fund Quarterly, 32: (July 1954), 282-93, 282; Koseishō Jinkō Mondai Kenkyūjo, Yūsei hogohō shikōgo no jinkō ninshin chūzetsu no jōkyō ni kansuru kenkyū (dai ippō), November 10, 1950.

12 Dinmore, "A Small Island," 118.

13 Yamamoto Kiyoko, "Seishoku wo meguru seiji to kazoku hendō," Sonoda Gakuen Joshi Daigaku ronbunshü, 45: (2011), 1-18, 2-3.

14 Dinmore, "A Small Island Nation," 112.

15 Steven J. Fuchs, "Feeding the Japanese: Food Policy, Land Reform, and Japan's Economic Recovery," in Democracy in Occupied Japan: The US Occupation and Japanese Politics and Society, ed. Mark E. Caprio and Yoneyuki Sugita (London: Routledge, 2007), 26-47, 28.

16 Dinmore, "A Small Island," 123, 133.

17 Memorandum for The Catholic Woman's [sic] Club, June 6, 1949, Record Group 5, Box 13, Folder 1 "OMS, CAS-CHAM," MacArthur Memorial Library \& 
Archives, Norfolk, VA (hereafter MMLA). For more details, see Ogino, "Kazoku keikaku," 145; Oakley, "American-Japanese Interaction," 625.

18 Crawford F. Sams, "Medic": The Mission of An American Military Doctor in Occupied Japan and Wartorn Korea (New York: M. E. Sharpe, 1998), 184. See also Norgren, Abortion Before Birth Control, 164, (Japanese ver.); Dinmore, "A Small Island Nation," 123.

19 Dinmore, "A Small Island Nation," 124.

20 On the population establishment, see Connelly, Fatal Misconception, 155-94.

21 On Ackerman, see Trevor Barnes and Jeremy Crampton, "Mapping Intelligence: American Geographers and the Office of Strategic Services and GHQ/SCAP (Tokyo)," in Reconstructing Conflict: Integrating War and Post-war Geographies, ed. Scott Kirsch and Colin Flint (London: Ashgate, 2011), 227-51; Donald J. Patton, "Obituary: Edward A. Ackerman (1911-1973)," Geographical Review, 64: (1974), 150-3; Gilbert F. White, "Edward A. Ackerman, 1911-1973," Annals of the Association of American Geographies, 64: (1974), 297-309.

22 For Thompson in Japan, see Bashford, Global Population, 310-17.

23 E.g. Oliver R. McCoy diary, May 3, 1949, RG 12.1, Officers' Diaries, FA266-7, Rockefeller Foundation records, Rockefeller Archive Center (hereafter RAC); Norgren, Abortion Before Birth Control, 166 (Japanese ver.).

24 "US Officials Promote Birth Control in Japan," The Witness, 5 January 1950, Record Group 5, Box 4, Folder 1 "OMS Comesp, A," MMLA.

25 Oakley, "American-Japanese Interaction," 631.

26 The Catholic Women's Club of Tokyo to General Douglas MacArthur, 3 May 1949, Record Group 5, Box 13, Folder 1 "OMS, CAS - CHAM," MMLA; Sister Mary Aloyne to Douglas MacArthur, n.d. c. February 1950, Record Group 5, Box 4. Folder 1 "OMS Comesp, A," MMLA.

27 Dinmore, "A Small Island Nation," 125-32. See also Jin Sato, "Formation of the Resource Concept in Japan: Pre-War and Post-War Efforts in Knowledge Circulation," Sustainability Science, 2: (2007), 151-8; Ishimitsu Toru, "Akkāman hakase to Nihon no shigen seisaku," Kokumin keizai zasshi, 153: (1986), 1-18.

28 Edward A. Ackerman, Japan's Natural Resources, 1: 559.

29 Ibid., 161; Ishimitsu, "Akkāman hakase," 10-11.

30 Ackerman, Japan's Natural Resources, 566. Greenhalgh, "The Social Construction," 36-7.

31 This did not mean Thompson refused to consider population pressure from the economic perspective. Warren S. Thompson, "Future Adjustments of Population to Resources in Japan," The Milbank Memorial Fund Quarterly, 28: (1950), 191-202.

32 Warren S. Thompson, The Danger Spots in World Population (New York: Knopf, 1929).

33 Norgren, Abortion Before Birth Control, 87.

34 Bashford, "Nation, Empire, Globe: The Spaces of Population Debate in the Interwar Years," Comparative Studies in Society and History, 49: (2007), 170-201, 173.

35 Thompson, Danger Spots, 43-5.

36 Alison Bashford, "World Population, World Health and Security: 20th Century Trends," Journal of Epidemiology and Community Health, 62: (2008), 187-90; John Sharpless, "World Population Growth, Family Planning, and American Foreign Policy," Journal of Policy History, 7: (2005), 72-102.

37 Matthew Connelly, "To Inherit the Earth: Imagining World Population, from the Yellow Peril to the Population Bomb," Journal of Global History, 1: (2006), 299-319.

38 Bashford, Global Population, 312; Thompson, "Future Adjustments," 199-202.

39 Ackerman, Japan's Natural Resources, 161.

40 Thompson, "Future Adjustments," 200. 
41 Ackerman, Japan's Natural Resources, 161; Ishimitsu, “Akkāman hakase," 10-11.

42 For Japanese policy intellectuals' view of the population of colonial subjects, see Jin-kyung Park, "Corporeal Colonialism: Medicine, Reproduction, and Race in Colonial Korea" (Ph.D. diss., University of Illinois at Urbana-Champaign, 2008), 55-70; Takashi Fujimura, Race for Empire: Koreans as Japanese and Japanese as Americans during World War II (Berkeley, CA: University of California Press, 2011), 35-40.

43 Birth control activists increasingly found themselves allying with health professionals. See Norgren, Abortion Before Birth Control, 36-52. For the resurgence of birth control movement post-war, see Takeda, The Political Economy, 77-97, 103-15.

44 Matsumura Hiroyuki, "Kokubō kokka' no yūseigaku: Koya Yoshio wo chūshin ni," Shirin, 83: (2000), 102-32; Nakamura Mari, "Koya Yoshio to minzoku seibutsugaku," Seibutsugakushi kenkyū nōto, 12: (1967), 8-14.

45 Matsubara, "Nihon ni okeru," 33-8.

46 Yoshio Koya, "The Program for Family Planning in Japan," November 1952, folder 671, box 80, series 1.5, RG 5 John D. Rockefeller 3rd Papers, Rockefeller Family Archives, RAC.

47 General Headquarters Supreme Commander for the Allied Powers, History of the Nonmilitary Activities of the Occupation of Japan: Population (1945 through 1951), 1951, 115-6.

48 Ogino Miho, "Umeyo fuyaseyo," 132.

49 Koya Yoshio, "Keikaku shussan moderu mura no kenkyū," Archives of the Population Association of Japan, 1: (1952), 1-11, 2.

50 Oliver R. McCoy diary, May 16, 1949, RG 12.1, Officers' Diaries, FA266-7, Rockefeller Foundation records, RAC.

51 Because of his prewar position Koya's relationship with some birth control activists was awkward. Toyoda Maho, "Sengo nihon no bāsu kontorōru undō to Kurarensu Gyanburu: dai 5-kai kokusai kazoku keikaku kaigi no kaisai wo chūshin ni," Jendā shigaku, 6: (2010), 55-70, 57.

52 Yoshio Koya, H. Kubo, Shu Yuasa, and H. Ogino, "Seven Years of a Family Planning Program in Three Typical Japanese Villages," The Milbank Memorial Quarterly, 36: (1958), 363-72.

53 Ogino, "Kazoku keikaku," 184-5.

54 Koya et al., "Seven Years," 371-2.

55 Johanna Schoen, Choice \& Coercion: Birth Control, Sterilization, and Abortion in Public Health and Welfare (Chapel Hill, NC: University of North Carolina Press, 2005), 29-34, 41-4.

56 Oliver R. McCoy diary, December 13, 1949 and March 18, 1952, RG 12.1, Officers' Diaries, FA266-7, Rockefeller Foundation Records, RAC. For Gamble's involvement, see Toyoda, "Sengo Nihon," 59-62.

57 Aiko Takeuchi-Demirci, "The Color of Democracy: A Japanese Public Health Official's Reconnaissance Trip to the US South," Southern Spaces, 18: (March 2011), 1-22.

58 Aiko Takeuchi-Demirci, "From Race Biology to Population Control: The Rockefeller Foundation's 'Public Health' Projects in Japan, 1920s-1950s," in Science, Public Health and the State in Modern Asia, ed. Liping Bu, Darwin H. Stapleton, and Ka-che Yip (London: Routledge, 2012), 113-28.

59 "A Reconnaissance of Demography and Public Health in Japan," n.d. c. 1948, p. 53, folder 10, box 2, series 600, RG 1.1, Rockefeller Foundation Archives, RAC.

60 McCoy to Marshall C. Balfour, May 28, 1951, folder 44, box 6, series 609, RG 1.2, Rockefeller Foundation Archives, RAC.

61 Ibid.

62 "Grant In Aid to the Institute of Public Health, Tokyo," January 14, 1953, folder 44, box 6, series 609, RG 1.2, Rockefeller Foundation Archives, RAC. 
63 Aiko Takeuchi, "The Transnational Politic of Public Health and Population Control: The Rockefeller Foundation's Role in Japan, 1920s-1950s," RAC, Research Reports, online at: www.rockarch.org/publications/resrep.takeuchi.pdf (accessed December 15, 2009).

64 Gamble to Koya, May 29, 1952, Japan files, folder 1538, Clarence Gamble papers, 1920-1970s (inclusive): 1920-1966 (bulk). HMS c23. Harvard Medical Library, Francis A. Countway Library of Medicine, Boston, MA [hereafter CGPJF].

65 Gamble to Koya, December 6, 1951, Clarence Gamble papers Japan files, folder 1535; Gamble to Koya, January 16, 1952 and February 7, 1952, CGPJF, folder 1538.

66 Gamble to Koya, June 18, 1952, CGPJF, folder 1538.

67 Koya et al., "Seven Years," 369.

68 Koya Yoshio to Gamble, September 12, 1952, CGPJF, folder 1538.

69 Koya to Gamble, March 4, 1955, CGPJF, folder 1553.

70 Nihon Jinkō Gakkai Sōritsu 50-shūnen Kinen Jigyō Iinkai (ed.), Nihon jinkō gakkai 50-nenshi (Tokyo: Nihon Jinkō Gakkai, 2002), 4-24. 


\title{
Afterword
}

\section{Is there anything unique about modern Japanese science?}

\author{
James R. Bartholomew
}

Japan in the mid-nineteenth century was what today one would call an "emerging nation." After a long period of relative detachment it was beginning an active reengagement with the world on a large scale. The impetus for reengagement was partly involuntary. Japanese leaders had to contend with pressures from Britain, France and other countries during an era of "high imperialism." "Imperialism" meant then and still refers to the "extension by one country of its authority over other lands by political, military or economic means." ${ }^{1}$ Japan avoided the full force of direct imperial domination by carrying out many internal reforms: industrialization, legal changes, economic restructuring, military expansion, and others. At the time, such reformism was not widely evident in other nonWestern countries, so historians have debated what characteristics distinguished Japan from other countries that faced similar pressures.

Though this is now changing, scientific developments in Japan have largely been absent from conversations on Japan's adjustment to imperialist pressures. It is appropriate to consider how the Japanese were able to achieve success not only in the realms of the reforms mentioned above, but also in medicine and natural science. My purpose here is to consider just two features of Japanese scientific activity that were highly unusual within the context of science done elsewhere. One of them was "Japanische Geduld" (Japanese patience), well displayed in the world of the pathologist, Yamagiwa Katsusaburo, who founded the entire field of chemical carcinogenesis by creating cancer in the laboratory for the first time ever. Another feature of Japanese science was the Buddhist cosmological framework of Yukawa Hideki, the theoretical physicist who upset the entire European framework for explaining the forces of nature at the most basic level, forever changing high-energy physics.

Yamagiwa in the 1920s and Yukawa about 15 years later were both candidates for the Nobel Prize in physiology or medicine, and physics, respectively. The second was successful; the former was not. The prizes (in physics, medicine, chemistry, peace and literature) were first awarded in 1901 following the probate of Alfred Nobel's 1895 will. Nobel was Swedish and except for the Peace Prize, appropriate Swedish academic bodies were assigned the annual task of selecting appropriate awardees. The year 1901 was perhaps the high-water mark of modern imperialism; and as one might expect, early prizes were nearly 
all awarded to people from the leading imperialist powers. Alfred Nobel was not an imperialist, Sweden was not an imperialist power, and prize-awarding bodies made an effort to be objective. ${ }^{2}$ Nonetheless, evidence of the imperialist outlook of many Europeans lies in the inevitable politics of nominators for the prizes, and, less frequently, in the activities of some prize committee members. Within this institutional, cultural, and political context we consider the question of possible Japanese uniqueness and how unique cultural traditions may have influenced Japanese achievement in science. We also consider how Japan as an emerging power in science was regarded by the imperial nations of the day before the middle of the century.

$* * * * *$

Since the early 1980s, Japanese have expressed intense interest in all the Nobel Prizes. This attitude reflects many things, including a growing nationalism reminiscent of prewar sentiments, but also a sense that the number of Nobel awards received to date-21 altogether, including 18 in science-does not accurately reflect the country's actual accomplishments. ${ }^{3}$ (By way of comparison, France-with a far smaller population - has received 36 Nobel prizes in science). Whether or not one agrees with the claim of incommensurability in this connection is in some sense immaterial; attitudes are what they are, and historians have to pay attention to them.

Nor does it even matter whether or not we think that the number of Nobel Prizes in and of itself is really a significant indicator of anything. (There is a school of thought that inclines toward a full-throated debunking of the Nobels.) I have no preference, but what I do want to insist on is that the Nobel Prizes - at least in the context of Japan - are an example of what Emile Durkheim a century ago called a "fait sociaux," a "social fact." " The prizes for various reasons have become invested with a degree of influence, prestige, glory, affect, reputation that does actually influence behavior, whether of scientists, journalists, politicians, or others, and has done so for some time. A casual reading of J. D. Watson's The Double Helix from almost 50 years ago offers just one piece of evidence. $^{5}$

Let me mention recent indications of this phenomenon in Japan. In 1981 the late Fukui Ken'ichi became the first Japanese scientist to win the Nobel Prize in Chemistry, in his case with his close friend, Roald Hoffmann. This event prompted the president of the Nobel Foundation, Sune Bergstrom, to state at the Nobel banquet that he expected more Japanese (and European) scientists to win in the future, meaning that the Americans should not expect to monopolize the prizes to the extent that they had after $1945 .{ }^{6}$ Fukui himself was surprised by Bergstrom's remarks; but in fact, the number and percentage of Nobel awards to the Japanese has increased since 1981. While he himself was the fourth Japanese scientist to win (after three in physics), other Japanese won in physiology or medicine in 1987 and 2012; in chemistry 
in 2000, 2001, 2002, 2008 and 2010; and again in physics in 2003 and 2014. ${ }^{7}$ organisation

One could argue, though not convincingly, that this improved performance owes something to the heightened Japanese interest in the prizes and to initiatives that have actively been taken. Roald Hoffmann once stated that Japan now has one of the two most active, most efficient set-ups in the world for bringing deserving nationals to the attention of the right people in Stockholm (France being the other). ${ }^{8}$ Then in 1987, the Japanese organized the "Japan Forum of Nobel Prize Recipients." It is held every November, a few weeks after the October announcements of the Nobel prizes and brings foreign Nobel laureates to Japan for press conferences, lectures, seminars, photo opportunities and so on, while also prominently featuring Japan's own Nobel laureates. Many of the public events are aimed at young people. The organizers, originally several private firms but now including the Ministry of Foreign Affairs and the Ministry of Education and Science, candidly acknowledge that helping Japan to win more Nobel prizes is one of the objectives. ${ }^{9}$ Perhaps the most audacious initiative was an official government declaration in the year 2000 that over the next half century, Japan expects to win some 30 Nobel prizes in science. This declaration has been controversial, both abroad and in Japan itself, and harkens back to Okubo Toshimichi's suggestion that Meiji Japan would industrialize in 20 years given that it took the British 50. One Japanese Nobel laureate denounced it as "absurd" but another thought it might have merit. ${ }^{10}$

An important historical point in considering this entire phenomenon is that the Nobel prizes have definitely not offered a "level playing field" to all scientists. Japan was not part of what we can call the "Nobel system" when the prizes were first awarded in 1901, although a Japanese scientist was nominated that year. ${ }^{11}$ As Kenji Ito and others in this volume have shown, the Japanese had to overcome racial stereotypes and demonstrate the validity of Japanese science before being considered for a Nobel Prize. The first invitation to nominate reached Japan in 1907, a date that immediately followed the country's admission to the pre-World War I International Association of Academies of Science in 1906, which in turn was a direct result of Japan's defeat of Russia in the RussoJapanese War (1904-1905). This invitation came from the Nobel Committee in Physiology or Medicine, a fact that reflected Japan's considerably greater strength in these fields as opposed to the physical sciences. The first invitation to nominate in physics came in 1910, but in chemistry not until $1927 .^{12}$ Japan was at a considerable disadvantage in terms of its geographic location in an era before jet airplanes, fax machines, and email. Even in the interwar period, travel between Japan and Europe took two to three weeks, and even that was an improvement over the 1880s when five to six weeks were required. Moreover, Japan's culture was and is different from that of Europe, a point I will return to later. The cumulative effect was to create a situation in which it was considerably more difficult for Japanese scientists to make the kind of impact on international science that their work might warrant than it was for scientists from Europe or North America. The Hungarian chemist István Hargittai believes 
that problems remain for the Japanese vis-à-vis the international scientific community even now. In 2002, he wrote that the Japanese "do not get their fair share of recognition for their work in science." He then quoted remarks by a former editor of Nature, John Maddox: "I think people are bothered by the language and the culture, and most Westerners find Japan strange. The consequence is that Japanese scientists are not highly enough regarded."13

\section{Case studies: Yamagiwa Katsusaburō and Yukawa Hideki}

The Nobel Prizes in chemistry and physics are awarded by the Royal Swedish Academy of Sciences, while the Nobel Prize in Physiology or Medicine is awarded 3by the Karolinska Institute. Both observe a 50-year rule of access to archival materials. This means that one cannot investigate recent Nobel candidacies using these sources. For this reason, I am only studying candidacies from Japan that took place between 1901 and 1950. During that half-century, a total of 17 Japanese were nominated for a Nobel Prize. Of that number, 15 were proposed in physiology or medicine and just two in physics. However, of the 15 in medicine, two were also recommended in chemistry. These numbers reflect a number of things, including the fact that in that period there was simply far more Japanese activity in medicine than there was in the physical sciences. This pattern itself, of course, has an historical explanation. ${ }^{14} \mathrm{I}$ am investigating a select six Japanese candidacies in medicine, one in chemistry, and one in physics. One could debate which of these candidacies were the most meritorious. Few would argue, however, that those of Yamagiwa Katsusaburō in physiology or medicine and Yukawa Hideki in physics belong on the short list. Yukawa actually won, in 1949; Yamagiwa should have won, in 1927, but did not. Those familiar with the Nobel Prizes can readily offer a list of candidates who "should have won" but did not. Yamagiwa's case was different because we have a paper trail showing that those involved were made quite familiar with the basic facts but simply gave the award to the wrong man. This is a point now rather widely acknowledged. ${ }^{15}$

\section{Uniqueness, particularity, and culture}

I have long been deeply suspicious of social science or historical explanations of anything in Japan that derive from either "culture" or claims about Japan's supposed "uniqueness." In this regard I have been reacting against the approach of an earlier generation of anthropologists whose explanatory paradigms smacked to me of essentialism or hypostatization. ${ }^{16}$ Anthropological studies of Japan these days are vastly more sophisticated than was once the case. Moreover, it is surely appropriate to ask whether there are or have been features or aspects of science - including medicine - as practiced in Japan that are either statistically unusual, or even unique.

At the conceptual level, one might begin by noting that - China and Korea notwithstanding _Japan is the world's only major contributor to scientific 
knowledge whose cultural, philosophical, or religious traditions are heavily indebted to Buddhism and Confucianism, not Judaism and Christianity. This is likely to have had some important — if unspecified — consequences for science. There is a large literature dealing in the European or American contexts with such topics as the relative impact on scientific endeavors of Judaism, Calvinism, other forms of Protestant Christianity, or Catholicism. ${ }^{17}$ Fifty years ago Joseph Needham published various speculations about the importance for science of Confucianism and Taoism in the Chinese context. ${ }^{18}$ But his comments at the same time were too general to be really useful to later historians. As for Japan, there has been some discussion about the importance of Confucianism for science but very little about the possible importance of Buddhism. ${ }^{19}$ It explains nothing to observe, for example, that Buddhism seems more compatible with modern science - by which people usually mean physics - than does Christianity or Judaism. In fact, I think that both the Buddhist and Confucian traditions in Japan have probably had some important consequences for science at a conceptual or other level. But it is necessary to demonstrate this explicitly, not simply assert the idea. ${ }^{20}$

We can also engage this issue of uniqueness or particularity at an institutional, behavioral, or phenomenological level. For example, did at least some important Japanese active in science behave in a professional context differently from American, European, or other non-Japanese colleagues? In this instance, I think the claim is at least arguable that they have done so. While it will not be my principal focus here, I can mention the oft-noted tendency toward extreme factionalism that many believe to be rampant among Japanese academics, including scientists, in the past or today.

In fact, I do believe that factionalism- - gakubatsu ishiki-has been more prominent in Japan than elsewhere. I do, however, dissent strongly from the belief that this is either a) nearly universal or b) always destructive of good scientific work. If the claims of Japanese and others to this effect were universally true, the Japanese would never have accomplished anything in science, whereas they can boast of many important achievements.

Relentlessly repeated characterizations of Japanese society and the Japanese academy as faction-ridden, and the supposed ill effects of this behavior well illustrate Dennis Wrong's important observation years ago about the intellectual dangers of accepting an "over-socialized" view of man. ${ }^{21}$ Let us remember that Japanese can act as idiosyncratically as other people when it suits their purpose.

Here I describe two cases of particularity or uniqueness in Japanese science, one operating primarily at a behavioral level, one at a conceptual level. The first is the research career of Yamagiwa Katsusaburō (1863-1930) in pathology. The other is Yukawa Hideki (1906-1981), the theoretical physicist. Each exemplified a quality or intellectual perspective in his scientific work that was arguably "unique" or particular within the framework of world science but somewhat more typical in Japan. In Yamagiwa's case, the unique feature was a matter primarily of behavior, whereas Yukawa's case was more a matter of 
perspective, attitude, or cognition. (I concede that the distinction between "behavior" and "cognition" is somewhat vague or inchoate.)

\section{Yamagiwa Katsusaburō and the founding of chemical carcinogenesis}

Yamagiwa Katsusaburō, a professor of pathology at Tokyo University from 1894 to 1925, and his younger colleague Ichikawa Köichi (1888-1948) are widely credited with founding chemical carcinogenesis as an organized field of study. $^{22}$ They accomplished this task by creating cancer artificially in the laboratory during World War I and thereafter. By painting coal tar on the epithelial tissue of rabbits' ears or injecting it into the animals, they generated both carcinoma and sarcoma. Challenged by skeptical Japanese colleagues, they went on to demonstrate metastasis and even, by 1921, succeeded in transplanting the tumors between animal hosts. The work was seen to prove an influential hypothesis about cancer set forward by Yamagiwa's German mentor, Rudolph Virchow, in the 1860 s that a so-called "chronic irritation" of cellular tissue might induce tumors.

The achievements eventually made Yamagiwa world famous as well as a leading - if unsuccessful — candidate for the 1926 Nobel Prize in Physiology or Medicine. When Yamagiwa died, rather prematurely, in March 1930, William Cramer, a German émigré professor at Washington University, St. Louis, wrote in The Lancet that it was "impossible to overstate the importance of Yamagiwa's achievement for the study of cancer." 23 However, some colleagues not only denied him appropriate recognition for a time but also ridiculed him mercilessly. ${ }^{24}$

To understand why recognition was delayed and - equally important — why Yamagiwa and Ichikawa succeeded, we need to consider the historical and scientific context within which they worked. At least from the late eighteenth century there had been a suspicion that certain kinds of chemical exposure might be linked to human tumors. Beginning in 1775, Sir Percival Pott (St. Bartholomew's Hospital, London) published clinical observations about chimney sweeps, teenagers or young men, who contracted cancer, especially of the skin and scrotal tissue, seemingly as a result of their work. Pott noted that the tumors rarely appeared while the chimney sweeps were actually employed but rather only became evident years after they had discontinued the work, often as much as ten years later. ${ }^{25}$

Although Pott made his observations in Britain, the first nation to undergo industrialization, as industrialization expanded on the European continent, similar reports were published to the effect that workers in certain industries seemed especially prone to cancers of various kinds. There was never certainty in the matter, only inference or speculation. As a result, a number of investigators in several European countries from the 1860s began trying to provide scientific proof of a link between cancer and chemicals. Typically they subjected various kinds of laboratory animals (often dogs, rats or mice) to some regimen of chemical application, by cutting the animals' skin or by combining these 
methods. But prior to the outbreak of World War I, all of these attempts to create cancer artificially in the laboratory setting had failed. ${ }^{26}$

Yamagiwa and Ichikawa succeeded for a number of reasons, and oneperhaps more - of the factors in their success one could attribute to the particular Japanese social or cultural environment within which they were working. For one, they operated as a very effective team. Yamagiwa, following the Virchow paradigm, provided the intellectual framework and research design for the project. However, because he had contracted tuberculosis before they actually began the work, he had to follow a strict regimen of bed rest and only occasionally appeared in the laboratory. This meant that Ichikawa-25 years younger - had day-to-day control of the actual procedures. He applied the coal tar or administered the injections and oversaw the results. Years later when asked why the Tokyo University team succeeded with the coal tar, Ichikawa explained that he had used ordinary brushes for writing Chinese characters but had cut the brushes short with scissors so he could better control how much tar was applied. ${ }^{27}$

The choice of a suitable animal host, though long controversial among researchers in the field, seems also to have mattered. Yamagiwa chose rabbits, partly because they were not susceptible to cancer in their natural environment and partly because of the convenience that the epithelial tissue in their long ears afforded to the investigator. But once the Tokyo scientists proved that tumors could be generated with coal tar, later researchers, even in Japan, usually adopted mice. Their reason was that the coal tar could be painted efficiently on the backs of the mice and because the time required for tumors to appear was shorter than with rabbits. The rabbits still had advantages: "Mice are very sensitive [to coal tar]," Ichikawa pointed out. "[In fact] they are too sensitive, such that if tar is applied to the ears, the site where tar is applied experiences necrosis and the ears fall off much of the time." ${ }^{28}$ Rabbits as animal hosts were sturdier than mice; and it is quite likely that the entire procedure could only have been demonstrated in the first instance with rabbits.

Another factor that may have been even more fundamental: sheer persistence. Prior to the experiments in Tokyo, investigators in Europe never continued chemical applications to the skins of laboratory animals for more than six months - and most gave up before then. By contrast, Yamagiwa and Ichikawa continued their applications for about twenty-two months. And depending on how one understands the expression "creating cancer," the project could be seen to have lasted about ten years! "Creating cancer" is not an entirely straightforward concept. Does it refer only to carcinoma? Sarcoma? The appearance of keratomas? Metastasis? Or what? So challenging was the entire project and so marked with failure was the path to success, Yamagiwa and Ichikawa faced great skepticism both at home and abroad and were forced to expand their efforts well beyond their original parameters. Once their success became widely accepted, some European colleagues offered as an explanation what they called "Japanische Geduld" or "Japanese patience."29 This view 
lent credence to a kind of cultural explanation that-however limited or flawed - may not be entirely far-fetched.

"Japanese patience" is also subject to further analysis. In Yamagiwa's case it seems to have derived from certain experiences, beliefs, and firm convictions. These in turn reflect some of his samurai background. The Tokyo pathologist was the scion of a deeply impoverished family and undertook to repay all of his father's considerable debts in full. (By the 1860s, a large number of the samurai class lived in the same condition.) Yamagiwa did not complete the task of paternal debt repayment until 1917 when he was $54 .{ }^{30}$ It is also noteworthy that in this period his income was the smallest of the entire university medical faculty. We know this because the Asahi shinbun newspaper published an exposé article on medical professors' incomes as part of a complaint that they were shirking their duty to the country in wartime by concentrating on the treatment of private patients, not their teaching and research. ${ }^{31}$ As a professor of basic - not clinical - medicine, Yamagiwa was forbidden to treat private patients, a pattern Japan borrowed from the German academic system. ${ }^{32}$

Yamagiwa also believed devoutly in the Virchow theory of cancer, expressing thereby an attitude of near reverence to the views of a European mentor that was rather typical of Japanese academics who studied in Europe during this period. Colleagues in Japan also described Yamagiwa as possessed of an iron will, an archetypal feature of the samurai code of manly behavior. ${ }^{33}$ Beyond these traits, the Tokyo cancer pioneer was profoundly impressed by Percival Pott's observations from the eighteenth century. Noting the time lag of as much as ten years between chimney sweeps' exposure to soot in their work environment and the appearance of skin tumors, Yamagiwa was prepared - as no one in Europe was - to continue the tar applications for a decade if necessary.

The Tokyo pathologist's Nobel candidacy was a complicated business that I only briefly describe here. By 1921 his work was sufficiently recognized for the Dutch to organize a small conference in Amsterdam largely based on his work. For reasons of health Yamagiwa was unable to attend. Shortly after this event, Gustave Roussy, the eminent Swiss-French pathologist, invited Yamagiwa to travel to Europe in order to attend a conference in honor of the centennial anniversary of the birth of Louis Pasteur. Yamagiwa could not make this trip either, but the result was that Roussy agreed to invite Ichikawa to his laboratory, where the younger Japanese worked for two years. A series of eight papers that Ichikawa wrote in French, together with replications of the Japanese work in Paris, Berlin, and London made it patently apparent to everyone in Europe that the results were genuine. In 1924 the eminent German pathologist Ludwig Aschoff actually traveled all the way to Tokyo and visited Yamagiwa. Deeply impressed by what he saw, Aschoff formally nominated Yamagiwa for the Nobel Prize. The Danish pathologist Johannes Fibiger was nominated for the same prize (by Aschoff and others) for supposedly generating tumors in the stomachs of rats in a Copenhagen sugar mill by feeding them cockroaches that harbored parasites. This work was also taken by some as a proof of the Virchow hypothesis and had been published two years before Yamagiwa and Ichikawa began 


\section{2}

James R. Bartholomew

their work. It was crucially important that Fibiger worked in Europe, was well known to European colleagues, and had many friends in Stockholm. ${ }^{34}$

Two reports went to the Nobel committee. One favored a shared prize for Fibiger and Yamagiwa; the other opposed a prize for either one. The opponent wrote of Yamagiwa's work that the pathologist had achieved little more than the "confirmation of a well-known clinical experience." Translation: We always knew chemicals cause cancer: so what? Nor did it help that the two Swedish referees loathed one another. Ultimately the one favoring the shared prize withdrew his endorsement of Yamagiwa because he discerned that doing so would enhance the prospects for success of his friend, Fibiger. The other referee gave up the fight and the unshared prize to Fibiger was approved. Six months after receiving the Nobel Prize, Fibiger died and critics began attacking his work relentlessly, eventually discrediting it altogether. Yamagiwa's one-time proponent in Stockholm belatedly realized his mistake, but too late because Yamagiwa also died prematurely.

\section{Yukawa Hideki, Buddhism, Confucianism, and quantum physics}

In 1934, a lecturer at Osaka University, Yukawa Hideki, took up the fundamental question in physics of what it was that held the atomic nucleus together. Consisting as it did of protons and neutrons, there was no widely accepted explanation for the stability of the structure. Moreover, the arrival of quantum theory seemed to imply a fundamental instability in the basic laws of nature associated with classical mechanics, and many physicists found that situation disturbing. Albert Einstein in particular never fully embraced quantum mechanics. "God does not play dice," was one of his comments on the matter. ${ }^{35}$ Thus, while any attempt to answer the question of nuclear forces based on quantum mechanics was certain to attract attention, it was also likely to inspire debate.

Yukawa proposed a new theory of nuclear forces that postulated "a new sort of quantum" or particle intermediate in mass between an electron and a proton and exchanged within the nucleus by the nucleons, that is, neutrons and protons collectively. "It was known that the electromagnetic field explained the long-range forces between charged particles. Using the idea that a proton and neutron were different states of a nucleon, and modifying the electromagnetic field to obtain short-range forces, he discovered a relation that connected the mass of the field particles with the range of the force between the nucleons. Since the range of the force was approximately known, he was able to calculate the mass of these particles to be about two hundred times the mass of the electron." ${ }^{36}$ After considerable debate and over some years, the particle was eventually termed the meson. Yukawa noted that mesons would not be emitted in ordinary nuclear transformations but suggested that they could materialize in nuclear processes like those occurring in cosmic ray interactions. ${ }^{37}$

In historical context Yukawa's proposal was highly original and controversial. Since the early part of the twentieth century, physicists had generally embraced H. A. Lorentz's classical electron radius formulation. Later some tried to 
explain the new phenomena of nuclear physics as a breakdown of existing dynamics, rather than accept the existence of new particles or forces. ${ }^{38}$ Among the prominent critics was Niels Bohr. In 1937 Bohr accepted a longstanding invitation to visit Japan. A famous anecdote tells of Yukawa's summertime visit to Bohr at his Japanese-style inn in Kyoto. Yukawa wore a business suit and knelt like a suppliant on the tatami floor in front of Bohr. The Danish physicist, by contrast, wore the bathrobe-like yukata while lounging in a wicker chair and puffing on his pipe. After Yukawa finished explaining his theory of nuclear forces, Bohr responded merely by saying, "So, you like new particles, do you?" 39 Not surprisingly, critics of Yukawa like Enrico Fermi and Robert A. Millikan would later invoke the authority of Bohr in urging that Yukawa be denied the Nobel Prize that he finally received, in 1949.

Yukawa's path to the prize was circuitous - though it also showed that formal scrutiny and professional deliberations worked a bit differently in physics than they sometimes did in medicine! Ignored for the first two years after its publication in 1935, his radical proposal suddenly attracted attention when Seth Neddermeyer and Carl Anderson of Cal Tech - initially unaware of Yukawa's work - discovered a new particle while conducting cloud chamber experiments. ${ }^{40}$ The new particle was shown to have a mass between that of an electron and a proton, calculated to be somewhere between 130 and 240 times the mass of an electron; it seemed a strong candidate for the exchange particle that Yukawa had predicted. From this point the Japanese physicist's theoretical prediction entered the spotlight, and in 1938 and 1939 physicists' prior interest in Fermi's competing theory of nuclear forces shifted more toward the Yukawa proposal. In 1939, Yukawa left Japan for the first time, having been invited to the very exclusive Solvay Conference in Brussels. While the conference was aborted due to Hitler's invasion of Poland on September 1, Yukawa stayed longer in Europe where he gave seminars in Germany and Switzerland. He then returned to Japan via the United States. In Pasadena he met Anderson and Neddermeyer, who invited him to dinner.

As theoretical formulations and cosmic ray studies accumulated, it became clear that the Anderson-Neddermeyer particle was not the one predicted by Yukawa. Their particle-later termed the mu meson or muon - did not participate in the strong nuclear force and was found to decay with a mean life of 2.2 microseconds, much too long for the lifetime expected of Yukawa's particle. When research on elementary particles resumed after World War II, other findings also began to point away from the significance of the Yukawa theory, although the theory itself had been modified along the way. What finally changed the balance of evidence in Yukawa's favor was the discovery of the pi meson or pion by Cecil Frank Powell and Giuseppe Occialini in 1947.

Between 1939 and 1945, these two experimentalists developed a new apparatus, in some degree replacing the cloud chamber, for recording the tracks of particles found in cosmic radiation. This photographic emulsion device made possible the discovery of the pi-meson which exactly matched the features of the particle that Yukawa had predicted a dozen years earlier. It was then shown that the muons were 


\section{James R. Bartholomew}

the decay product of Yukawa's pions. The pions had not been detectable by older methods because of their short lifetimes and propensity to decay in flight. The Bristol triumph set the stage for two Nobel prizes, one for Yukawa in 1949 and one for Powell in 1950.

Was there something culturally "unique" or particular about Yukawa's triumph in nuclear physics from the vantage point of European science? One possible answer is to say that there was not. The meson particle theory of nuclear forces could be regarded as simply the triumph of an outstanding mathematician and theorist who applied quantum mechanics and relied on the highest level of scientific insight or inspiration. On the other hand, Yukawa's proposal was revolutionary at the time. It set aside several decades of theorizing by physicists in Europe, seemed compatible with views of nature that were definitely not part of the classical European tradition, and in some respects changed the face of physics for the long term. Whereas physicists were once reluctant to accept the idea of previously unknown particles, since Yukawa's time, few of the major problems encountered by high-energy physics in recent decades "have not been solved by the introduction of new particles." One might argue the Yukawa proposal set the stage for the appearance of the "Standard Model."

Does it matter that a Japanese physicist put forward the meson particle theory of nuclear forces as opposed to a scientist from some Western country? There is reason to think so. Yukawa personally gave some credit for his work to the East Asian cultural traditions in which he grew up. His father, Ogawa Takuji, a professor of geology at Kyoto University, came from a long line of Confucian scholars and Chinese-style physicians. (Father and son have different surnames because Yukawa was formally adopted into his wife's family, the Yukawas.) Yukawa liked the natural philosophy of the Taoist founders, Lao-tze and Chuang-tze, especially their notion of chaos and eternal flux, and said that this had helped to shape his thinking about physics. ${ }^{41}$ However that may have been, Taoism never established a clear, distinctive cultural identity in Japan as opposed to China where the tradition originated. Indeed, Yukawa was well aware that Taoist attitudes and thought were introduced to Japan through the medium of Buddhism. Thus, it is to the Buddhist traditions of Japan that we should have recourse if we are to argue that Yukawa's natural philosophy was unique against European science.

While it is not my purpose to present a detailed argument, the evidence of an explicitly Buddhist influence - with its ideas of chaos, flux, and eternal transformation - on Yukawa is fairly strong. Unlike Einstein, he was completely comfortable with the possibility that nature possessed these features. Moreover, the influence of East Asian religions in his family was considerable. One brother-Kaizuka Shigeki — became a famous Sinologist (again, the surname changed on the occasion of marriage, a common pattern in Japan). Yukawa's father became ever more interested in East Asian religion and philosophy in his later years. As a university student Yukawa came under the influence of Nishida Kitaro, a professor of philosophy who was deeply committed to Zen Buddhism in his professional life and personal values. Finally, in one of the 
many essays Yukawa wrote about his life after receiving the Nobel Prize, he reports that he agonized over a career choice between natural science and life as a Buddhist priest.

\section{Conclusion}

However one may feel about the issue of uniqueness or particularity in Japanese science, Westerners have often imputed such characteristics to Japan as a society. When Yukawa and his wife Sumiko traveled to Stockholm in December 1949 to attend the Nobel ceremonies, the new physics laureate casually mentioned at a cocktail party that his wife performed traditional Japanese dance as a hobby. This led to a vigorous demand from the other Western guests that she should perform for the assembled company. Yukawa protested a lack of preparation and musical accompaniment but finally had to yield. In the end, Sumiko, wearing a kimono and accompanied by Yukawa's singing at a microphone, entertained the group. ${ }^{42}$ Was this event not suffused with more than a little Orientalism? How many other Nobel laureates have been asked to perform in such a setting? It does bring to mind the observations of István Hargittai I mentioned earlier to the effect that Westerners "find Japan strange" in a way that is not entirely helpful to an appropriate acceptance of their contributions to science.

\section{Notes}

1 Webster's Dictionary of the English Language (New York: Lexicon Publications, 1990), 485.

2 Elisabeth Crawford, Nationalism and Internationalism in Science, 1880-1939 (Cambridge: Cambridge University Press, 1992).

3 Totals as of 2014. For prizes received before 1950, see Elisabeth Crawford (ed.), The Nobel Population 1901-1950: A Census of Nominators and Nominees for the Prizes in Physics and Chemistry (Tokyo: Universal Academy Press, 2002); for after 1950, see Karolinska Institute and Nobel Prize official website, online at: www. nobelprize.org/.

4 Émile Durkheim, The Rules of Sociological Method, trans. and ed. Steven Lukes (New York: Free Press, 1982).

5 James D. Watson, The Double Helix: A Personal Account of the Discovery of the Structure of DNA (New York: Atheneum, 1968).

6 Sune Bergstrom, "Opening Address," The Nobel Foundation: Les Prix Nobel, 1981 (Stockholm: Almqvist \& Wiksell International, 1982), 19.

7 See www.nobelprize.org.

8 Personal communication, Roald Hoffmann to James R. Bartholomew, April 18, 1995.

9 "Forum: 'Creativity in the 21st Century' with Nobel Laureates," Nōberu-shō jushōsha o konomu fuōramu "21 seiki no sōzō," online at: http://info.yomiuri.co.jp/yri/ n-forum-en/index.htm; see also James R. Bartholomew, "How to Join the Scientific Mainstream: East Asian Scientists and Nobel Prizes," EASTM, 31: (2010), 25-43, 27; and Association of Research Libraries, Minutes of the Meeting: Association of Research Libraries, 122: (May 1993), 41. 
10 David Cyranoski, "Nobel Officials Recoil from Expenses Offer," Nature, 414: 6865 (December 13, 2001), 676. Noyori Ryoji was critical of the government proposal; Tanaka Koichi was somewhat supportive. See Mainichi Interactive for their comments: 10/12/05 for Tanaka and 2/13/06 for Noyori.

11 James R. Bartholomew, "Japanese Nobel Candidates in the First Half of the Twentieth Century," in Morris Low (ed.), "Beyond Joseph Needham: Science, Technology, and Medicine in East and Southeast Asia," Osiris, 13: (1998), 238-284, 240.

12 Bartholomew, "Japanese Nobel Candidates," 240.

13 István Hargittai, The Road to Stockholm: Nobel Prizes, Science, and Scientists (Oxford: Oxford University Press, 2002), 34.

14 During the Tokugawa period medicine progressed significantly more than chemistry and physics.

15 Bartholomew, "Japanese Nobel Candidates," 253.

16 See for example, Thomas Rohlen, Japan's High Schools (Berkeley, CA: University of California Press, 1983): a classical example is Ruth Benedict, Chrysanthemum and Sword (New York, Meridian, 1974 [1946]).

17 See Robert K. Merton, "Science, Technology, and Society in Seventeenth Century England,"Osiris, 4: (1938), 360-632; and Joseph Ben-David, The Scientist's Role in Society (Englewood Cliffs, NJ: Prentice Hall, 1971).

18 Joseph Needham, The Grand Titration (Toronto: University of Toronto Press, 1969).

19 On Confucianism, Albert M. Craig, "Science in Confucianism in Tokugawa Japan," in Changing Japanese Attitudes to Modernization, ed. Marius Jansen (Princeton, NJ: Princeton University Press, 1965), 133-60.

20 For a general discussion of Buddhism and science, see Gary Zukav, The Dancing Wu Li Masters: An Overview of the New Physics (New York: William Morrill, 1979).

21 Dennis H. Wrong, "The Oversocialized Conception of Man in Modern Sociology," American Sociological Review, 26: 2 (April 1961), 183-93.

22 The best source for biographical information on Yamagiwa Katsusaburō is Nagayo Matarō (ed.), Yamagiwa Katsusaburō sensei shoden, Tokyo Teikoku Daigaku Byōigaku Kyōshitsu 50-nen shi, vol. 1 (Tokyo: Tokyo Teikoku Daigaku Byōigaku Kyōshitsu, 1939), 221-81.

23 William Cramer, "The Late Prof. Yamagiwa," The Lancet, 218: (1930), 1155.

24 For example, Torikata Ryūzō, "Hakusei Shuyō no kesseigakuteki kenkyū hōshin ni tsuite," Chūgai iji shimpō, 938: (April 20, 1919), 440-3.

25 Pott's observations were originally published in 1775 in Chirurgical Observations Relative to the Cataract, the Polypus of the Nose, the Cancer of the Scrotum, the Different Kinds of Ruptures and the Mortification of the Toes and Feet (London: Hawes, Clarke \& Collins). The chapter titled "Cancer Scroti" described the relationship between exposure to soot and cancer. His work is considered the first to recognize industrial carcinogens.

26 James R. Bartholomew, "The Nobel Candidacy of Katsusaburō Yamagiwa, 1863-1930," unpublished manuscript.

27 Kobayashi Tadatsugu, Gan kotohajime (Tokyo: Maininichi Shinbunsha, 1965), 148.

28 Koichi Itchikawa, "Sur la Production Experimentale du Cancer du Goudron," in Congres du Cancer: Strasbourg, 23-24 juillet 1923, rapports, vol. 1, ed. Gustave Roussy (Paris: Association Française pour Étude du Cancer, 1924), 29-43, 37.

29 Archibald Lake, "The Specificity of Carcinogenic Agents," in Congres du Cancèr: Strasbourg, 23-24 juillet 1923, rapports, vol. 2, ed. Gustave Roussy (Paris: Association Française pour Étude du Cancer, 1924), 39-45, 40-1.

30 James R. Bartholomew, The Formation of Science in Japan: Building a Research Tradition (New Haven, CT: Yale University Press, 1989), 85 and 302, n. 207.

31 See ibid., 333, n. 14. 
32 Ibid., 85.

33 Tashiro Yoshinori, "Ko Yamagiwa-kun o kataru," in Tokyo Teikoku Daigaku Byōrigaku Kyoshitsu 50-nen shi, ed. Nagayo Matarō (Tokyo: Tōkyō Teikoku Daigaku Igakubu, Byōrigaku Kyōshitsu Gojū Shūnen Kinen Kai, 1939), 2, 125.

34 For all details about Yamagiwa unless otherwise indicated, see James R. Bartholomew, "Katsusaburo Yamagiwa's Nobel Candidacy: Physiology or Medicine in the 1920s," in Historical Studies in the Nobel Archives: The Prizes in Science and Medicine, ed. Elisabeth Crawford (Tokyo: Universal Academy Press, 2002), 103-31.

35 William Hermanns (ed.), Einstein and the Poet: In Search of the Cosmic Man (Wellesley, MA: Branden Press, 1983), 58.

36 M. F. Soto, "Hideki Yukawa, 1949," in The Nobel Prize Winners, vol. 2, Frank N. Magill (Pasadena, CA and Englewood Cliffs, NJ: Salem Press, 1989), 563-9, 563.

37 Hideki Yukawa, Tabibito: The Traveler, trans. Laurie Brown and R. Yoshida (Singapore: World Scientific, 1982); and Laurie M. Brown, "Yukawa's Prediction of the Meson," Centaurus, 25: 1/2 (1981), 71-132.

38 Brown, "Yukawa's Prediction," 82.

39 Watanbe Masao, Tokinaosu Aoki, and Asou Hajime (eds), Yukawa Hideki \& Tomonaga Shinichiro: Futatsu Noberu butsurigakusho (Tokyo: Maruzen Comics, Maruzen Kabushikaisha, 1994), 116-9.

40 Brown, "Yukawa's Prediction," 132, n. 122.

41 Yukawa Hideki, Creativity and Intuition: A Physicist Looks at East and West, trans. John Bester (Tokyo, New York, and San Francisco, CA: Kodansha International, 1973), 52.

42 Watanabe Masao, Tokinosu Naoki, and Aso Hajime, Yukawa Hideki to Tomonaga Shin'ichiro (Tokyo: Maruzen Komikku, 1994). 


\section{Bibliography}

\section{Archives}

Ajia Rekishi Shiryō Sentā, Online

Clarence Gamble Papers, Harvard Medical Library, Francis A. Countway Library of Medicine, Boston, MA, USA

Library of Congress, East Asia Section

MacArthur Memorial Library \& Archives, Norfolk, Virginia, USA

Rockefeller Archive Center, Sleepy Hollow, New York, USA

Shimomura Kōtarō Papers, Dōshisha University Archives

Stafford Leak Warren Collections, UCLA

Worcester Polytechnic Institute Archives, Worcester, Massachusetts, USA

\section{Newspapers}

Kyodo News Online

Nihon keizai shinbun

Osaka asahi shinbun

Tokyo asahi shinbun

Yomiuri shinbun

\section{Primary and archival sources}

Abe Isō, Diary of Isō Abe. Kyoto: Doshisha Archives, 2009.

Ackerman, Edward A., Japan's Natural Resources and Their Relation to Japan's Economic Future. Chicago, IL: University of Chicago Press, 1953.

Adachi, Buntaro, "Hautpigment beim Menschen und bei den Affen," Zeitschrift für Morphologie und Anthropologie, 6: (1903), 1-131.

Adachi, Buntaro and K. Fujisawa, "Mongolen Kinder Fleck bei Europäern," Zeitschrift für Morphologie und Anthropologie, 6: (1903), 132-133.

Arakatsu Bunsaku, Hiroku genshibakudan. Private collection.

Arima Tarō, "Katōjisei ōdan no ryūkō ni tsuite," Rikugun guni gakkai zasshi, 55: (October 1892).

Ashmead, Albert S., "The Mulberry-Colored Spots on the Skin of the Lower Spine of Japanese," Journal of Cutaneous and Genito-Urinary Diseases, 23: (1905), 203.

Baelz, Erwin, "Die körplichen Eigenschaften der Japaner," Mittheilungen der Deutsche Gesellschaft für Natur- und Völkerkunde Ostasiens, 3: (1883), 330-349.

Baelz, Erwin, "Die Körplichen Eigneschaften Der Japaner (Zweiter Teil)," Mittheilungen der Deutschen Gesellschaft für Natur- und Völkerkunde Ostasiens, 4: 32 (1885), 35-103. 
Baelz, Erwin, "Über die Rassenelemente in Ostasien, Speciell in Japan," Mittheilungen der Deutsche Gesellschaft für Natur- und Völkerkunde Ostasiens, 8: (1900), 227-235.

Baelz, Erwin, Die Ostasiaten. Stuttgart: Verlag von Konrad Wittwer, 1900.

Baelz, Erwin, "Menschen-Rassen Ost-Asiens mit specieller Rücksicht auf Japan," Zeitschrift für Ethnologie, 33: (1901), 166-190.

Baelz, Erwin, "Noch einmal die blauen 'Mongolen-Flecke," Centralblatt für Anthropologie, Ethnologie und Urgeschichte, 7: (1902), 329-331.

Baelz, Erwin, "Prehistoric Japan," in Annual Report of the Board of Regents of the Smithsonian Institute. Washington: Government Printing Office, (1907), 523-547.

Baelz, Erwin, Awakening Japan: The Diary of a German Doctor. New York: Viking Press, 1932.

Ban, Tadayasu. Tekijuku to Nagayo sensai: Eiseigaku to shōkashishi (Tekijuku and Nagayo Sensai: The Study of Hygiene and Nagayo's Memoirs). Osaka: Shōgensha, 1987.

Bartels, Max, "Culturelle und Rassenunterschiede in Bezug auf die Wundkrankheiten," Zeitschrift für Ethnologie, 20: (1888), 169-183.

“Beauty Spot or Blemish?” British Medical Journal, 1: 6054 (1977), 126-127.

Bragg, William L., "The Diffraction of Short Electromagnetic Waves by a Crystal," Proceedings of the Cambridge Philosophical Society, 17: (1913), 43-57.

Brennemann, Joseph, “The Sacral or So-called 'Mongolian' Pigment Spots of Earliest Infancy and Childhood, with Especial Reference to Their Occurrence in the American Negro," American Anthropologist, New Series, 9: (1907), 12-30.

Chamberlain, A. F., "Pigment Spots," American Anthropologist, New Series, 4: (1902), 796. Chujō Suketoshi, Rai densen no keiro. Tokyo: Zaidan Hōjin Rai Yobō Kyōkai, 1935.

Circular of the Dōshisha Collegiate and Theological School, Kyoto. Yokohama: R. Meiklejohn \& Co, 1885.

Crookshank, Francis Graham, The Mongol in Our Midst: A Study of Man and His Three Faces, 3rd rev. edn. London: Kegan Paul, Trench, Trubner \& Co, 1931.

"Dai-jūni shidan shotai no ichibu shisatsu ni kansuru shoken (Tōjō Taii)," Bōeishō Bōei Kenkyūjo, Rikugunshō Dainikki. Seimitsu-uke, sei-uke dainikki, Taishō 7-nen 12-gatsu (December1918). Sei-uke Dainikki (C07060610100). Ajia Rekishi Shiryō Sentā.

Dainippon Seiyaku (ed.), Dainippon seiyaku rokujūnenshi (The Sixty-year History of Dainippon Pharmaceutical Company). Osaka: Dainippon Publishers, 1958.

Doi Masanori and Kōzō Kuji, "Dairen ni okeru seishinbyō no tōkeiteki kansatsu: (1) Nihonjin seishinbyō ni tsuite," Tōkyō iji shinshi, 2999 (1936), 36-37.

Doi Masanori and Kōzō Kuji, "Dairen ni okeru seishinbyō no tōkeiteki kansatsu: (2) Manshūjin seishinbyō ni tsuite,” Tōkyō iji shinshi, 3001 (1936), 29-30.

Donnan, Frederick G., "Baron Joji Sakurai," Nature, 44: (August 5, 1939), 234-235.

Dosha ryūkō ji goyōjo korera yōyaku kokoroe, manuscript. Tokyo: Yamazaki Bunko, Juntendō University, 1858.

Epstein, A., "Ueber den blauen Kreuzfleck und andere mongoloide Erscheinungen bei Europäischen Kindern,” Jahrbuch für Kinderheilkunde, (1906), 60-73.

"Fink, L. G., "Mongolian Birth-marks: An Anthropological Study," Journal of Tropical Medicine and Hygiene, 15: (1912), 227-230.

Fujimoto Toshi, "Jimen no soko ga nuketan desu" (vol. 4), in Hansen-byō bungaku zenshu, 10 vols, ed. Makoto Oka et al. Tokyo: Koseisha, 2002-2010.

Fuller, Homer T., "Kotaro M. Shimomura," Journal of the Worcester Polytechnic Institute, 7: (1903/4), 312. 
Furukawa Seiichi, Korori no fusegikata. Tokyo: Furukawa Seiichi, 1877.

Gakujutsu Kenkyū Kaigi (ed.), Scientific Japan: Past and Present, prepared in connection with the Third Pan-Pacific Science Congress, Tokyo, 1926. Kyoto, 1926.

General Headquarters Supreme Commander for the Allied Powers, History of the Nonmilitary Activities of the Occupation of Japan: Population (1945 Through 1951). Tokyo: SCAP, 1952.

Goodell, J. M. and C. L. Griffin et al. (eds), The Log of '88 Published by the Senior Class of the Worcester Polytechnic Institute. Worcester, MA, 1888.

Gragg, William. F., A Cruise in the U. S. Steam Frigate Mississippi, Wm. C. Nicholson, Captain, to China and Japan, from July 1857 to February 1860. Boston, MA: Damrell \& Moore, 1860.

Hankins, Frank Hamilton, The Racial Basis of Civilization: A Critique of the Nordic Doctrine. New York: Knopf, 1926.

Hattori Unokichi (ed.), Kanbun taikei, vol. 1, Daigaku setsu, Chūyō setsu, Rongo shū, Mōshi teihon. Tokyo: Fusanbō, 1972.

Hidaka Minoo, Gunki hogo hō. Tokyo: Hata Shoten, 1937.

Hōjō Tamio, Hōjō Tamio zenshū, 2nd edn., 2 vols, ed. Kawabata Yasunari and Kawabata Kaoru. Tokyo: Sogen-sha, 2003.

Hoken Eisei Chōsa-kai, Hoken eisei chōsakai dai 3 kai hōkoku-sho. Tokyo: Hoken Eisei Chōsa-kai, 1919.

Home Department, A Brief Review of the Operations of the Home Department in Connection with the Cholera Epidemic of the 18th Year of Meiji, 1885. Tokyo: The Home Department, 1886.

Ichikawa Koichi, "Sur la Production Experimentale du Cancer du Goudron," in Congres du Cancer: Strasbourg, 23-24 Juillet 1923, vol. 1, ed. Gustave Roussy. Paris: Association Française pour l'Étude du Cancer, 1924, 29-57

Iijima Isao and Chûjiro Sasaki, "Okadaira Shell Mound at Hitachi," Memoirs of the Science Department, University of Tokio 1. Reprinted as Okadaira Shell Mound at Hitachi. Tokyo: Dai-ichi Shobō, 1983.

Irisawa Tatsukichi, "Yamagiwa kun no omoide," in Tokyo Teikoku Daigaku Byorigaku Kyoshitsu 50-nen shi, vol. 2, ed. Nagayo Mataro. Tokyo: Teikoku Daigaku, 1939, 114-121.

Ishiguro Tadanori, Korera ron. Tokyo: Daigaku Tōkō, 1871.

Ishii Shirō, "1945-8-16 Shūsen tōji memo" and "Shūsen memo 1946-1-11".

Ishiwara Jun, "Zur Optik der bewegten ponderablen Medien," Proceedings of the Tokyo Mathematico-Physical Society, 2nd Series, 5: 10 (1909), 150-180.

Ishiwara Jun, "Beiträge zur Theorie der Lichtquanten," Tohoku Science Report, 1: (1912), 67-104.

Ishiwara Jun, "Die universelle Bedeutung des Wirkungsquantums," Proceedings of the Cambridge Philosophical Society, 2nd Series, 8: 4 (1915), 106-116.

Jaberg, Karl, "The Birthmark in Folk Belief, Language, Literature, and Fashion," Romance Philology, 10: (1956/7), 307-342.

"Japanese War Crimes," Interagency Working Group (IWG), National Archives. Online at: www.archives.gov/iwg/japanese-war-crime.

"Jinkō no suii B, 'Taishō 9-nen kara Heisei 21-nen' and 'Shussei, shibō, shizan, kon'in oyobi rikonsū' (Taishō 14-nen-Heisei 20-nen," Statistics Bureau, Director-General for Policy Planning (Statistical Standards) \& Statistical Research and Training Institute, Ministry of Internal Affairs and Communications of Japan, online at: www.stat.go.jp/data/nenkan/02.htm (accessed September 19, 2011). 
Kanagaki Robun, Ansei korori ryūkō ki gairyaku. Edo: Tenshudō, 1858.

"Kampō to Kan'yaku, 20 vols. Tokyo: Shogakukan, 1939-.

Katō Susumu, "Korera kokoroe," Tokyo iji shinshi, 443: (1886), 1302.

Kenpei Shireibu, Nichi-Doku sen-eki kenpeishi. Tokyo: Kenpei Shireibu, 1914.

Kenpei Shireibu, Shiberia shuppei kenpeishi furoku. Tokyo: Kenpei Shireibu, 1928.

Kirisutosha retsuden: shinkō sanjūnen. Tokyo: Keiseisha shoten, 1921.

Kitao Diro, "Beiträge zur Theorie der Bewegung der Erdatmosphäre und der Wirbelstürme," Journal of the College of Science, Imperial University, Japan, 1: (1887), 113-209.

Kitao Diro, Zur Farbenlehre. Berlin: G. Lange (Paul Lange), 1878.

Klein, Oskar and Yoshio Nishina, "Über die Streuung durch freie Elektronen nach der neuen relativistischen Quantendynamik von Dirac," Zeitschrift für Physik, 52: (1929), 853-868.

Koganei Yoshikiyo, "Beiträge zur physichen Anthroplogie der Ainu: I. Untersuchungen am Skelet," Mittheilungen aus der Medicinischen Facultät der Kaiserlich-Japanischen, 2: (1893), 1-249.

Koganei Yoshikiyo, "Beiträge zur physichen Anthroplogie der Ainu: II. Untersuchungen am Lebenden," Mittheilungen aus der Medicinischen Facultät der Kaiserlich-Japanischen, 2: (1894), 251-403.

Kokuritsu Kōbunshokan Ajia Rekishi Shiryō Sentā, online at: www.jacar.go.jp/DAS/ meta/image_C11110812100?IS_STYLE=default\&IS_KIND=SimpleSummary\&IS_

TAG_S1 $=$ InfoD\&IS_KEY_S1 $=\% \mathrm{E} 5 \% \mathrm{~B} 8 \% 9 \mathrm{D} \% \mathrm{E} 5 \% 9 \mathrm{~B} \% \mathrm{BD} \% \mathrm{E} 8 \% \mathrm{AD} \% \mathrm{~B} 0 \% \mathrm{E} 4 \%$

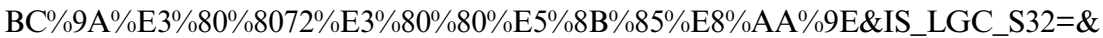

IS_TAG_S32=\& (accessed December 10, 2011).

Korera yobō no satoshi, Tokyo: Ikebe Kōzō, 1880.

Kōseisho Imukyoku (ed.), Koseishō gojūshūnenshi. Tokyo: Gyōsei, 1976.

Koya Yoshio, "Keikaku shussan moderumura no kenkyū," Archives of the Population Association of Japan, 1: (1952), 1-11.

Koya Yoshio, "The Program for Family Planning in Japan," November 1952. Folder 671, box 80, series 1.5, RG 5 John D. Rockefeller 3rd Papers, Rockefeller Family Archives, Rockefeller Archives Collection.

Koya Yoshio, "A Study of Induced Abortion in Japan and its Significance," Memorial Fund Quarterly, 32: (1954), 282-293.

Koya Yoshio, H.Kubo, ShuYuasa, and H. Ogino, "Seven Years of a Family Planning Program in Three Typical Japanese Villages," Milbank Memorial Quarterly, 36: (1958), 363-372.

Kozaki Hiromichi, Reminiscences of Seventy Years. Tokyo: Christian Literature Society of Japan/Kyo Bun Kwan, 1933.

Kraepelin, Emil, Manic-Depressive Insanity and Paranoia. Edinburgh: E. \& S. Livingstone, 1921.

Kretschmer, Ernst, Physique and Character: An Investigation of the Nature of Constitution and of the Theory of Temperament, 2nd rev. edn rev. with Appendix by E. Miller. [Originally published in English in 1936] New York: Cooper Square Publishers, 1970.

Kubo Kiyoji and Rokurō Hattori, "Chōsen ni okeru seishinbyō ni kansuru (sono ichi) Sōutsubyō mahiseichihō tankan no ribyōritsu tōkei ni yoru hikaku seishinbyōgaku kōsatsu," Seishingaku zasshi, 32: 8 (1930), 32-52.

Kure Shūzō, "Henshitsu-sōutsubyō," Shinkeigaku zasshi, 14: 9 (1916), 22-27.

Kure Shūzō shōden. Tokyo: Kure Hakushi Denkihen Sankai, 1933. 


\section{Bibliography}

MacNeal, Ward J., "The Influenza Epidemic of 1918 in the American Expeditionary Forces in France and England," Archives of Internal Medicine, 23: 6 (June 1919), $657-688$.

Majima Toshiyuki (Rikō), "Waga shōgai no kaiko," Kagaku no ryōiki, 8: (1954), 1-11 and $137-146$.

Matsumoto Ryōjun (ed.), Kanpan ekibyō yobō setsu. Edo: Yōsho Shirabesho, 1862.

Matsumura Hidehisa, "Sōutsubyō no ippanteki tōkei," Seishin shinkeigaku zasshi, 41: 1 (1937), 195-207.

Matsuo Katsuzō, Shiberia shussei nikki, ed. Osamu Takahashi. Nagoya: Fūbaisha, 1978.

Meiji 27-28 neneki jinchū nisshi: chü II, Daihonei yasen eisei chōkanbu. Tokyo: Rikugunsho, 1896.

Meiji 27-28 neneki rikugun eisei jikō: dai 3 kan densenbyō oyobi kakke, dai 3 hen koreri, dai 1 shō kanja sōkei oyobi ryūkō no jōkyō, sono 1 kanja sōkei. Tokyo: The Medical Bureau of the Ministry of the Army, 1896.

Midoro Masuichi, Meiji Taishō shi, vol. 1. Genron-hen. Tokyo: Asahi Shinbunsha, 1930.

Midoro Masuichi, "Sōkōgeki o mae ni taikyo meirei," in Nihon sensō gaishi: Jūgun kisha, ed. Okamoto Kōzō. Tokyo: Shinbun Jidaisha, 1965.

Military Archives. Tokyo: National Institute for Defense Studies, Ministry of Defense.

Minami Manshū Tetsudō Kabushiki Kaisha jūnenshi. Dairen: Minami Manshū Tetsudō Kabushiki Kaisha, 1919.

Ministry of Health, Reports on Public Health and Medical Subjects No. 4: Report on the Pandemic of Influenza, 1918-1919. London: His Majesty's Stationery Office, 1920.

Mukasa Hiroji, "Sōutsubyō no byōzen seikaku ni tsuite," Seishin shinkeigaku zasshi, 45: 6 (1941), 42-44.

Munemoto Naotoku, "Taiwan ni okeru sōutsubyō no hikaku tōkeigakuteki kenkyū," part 1, Seishin to kagaku, 17: 1 (January 1943), 1-13.

Munemoto Naotoku, "Taiwan ni okeru sōutsubyō no hikaku tōkeigakuteki kenkyū," part 2, Seishin to kagaku, 17: 2 (February 1943), 1-9.

Nagayo Sensai, "Hakkai shukushi," Dai Nihon eiseikai zasshi, 1: (1883), 1-10.

Nagai Nagayoshi Shiryō Iinkai Hensū (ed.), Nagai Nagayoshi Berurin tsūshin. Tokushima: Tokushima School of Pharmaceutical Science, Tokushima University, 2006.

Nagaoka Hantarō, Fujioka Yoshio, and Watanabe Nei, "Genshiryoku jidai no akebono," in Genshiryoku jidai no akebono, Nagaoka Hantarō. Tokyo: Nihon Tosho Sentā, 1999, 181-207.

Naimushō Eiseikyoku, Eiseikyoku nenpō Taishō 7-nen. Tokyo: Naimushō Eiseikyoku, 1918.

Naimushō Eiseikyoku (Hoken Eisei Chōsakai Mitsuda Kensuke Jyutsu), Rai yobō ni kan suru iken. Tokyo: Naimushō Eiseikyoku, 1921.

Naimushō Eiseikyoku, Ryūkōsei kanbō: "Supein kaze” dai ryūkō no kiroku. Tōyō Bunko, 1922; Tokyo: Heibonsha, 2008.

Naka Shūzō, "Nettai shinkei suijaku oyobi seishinbyō mondai," in Taiheiyō igaku ronsō. Dai isshū, ed. Taiheiyo Kyōkai. Tokyo: Nankōdō Shuppan, 1944, 199-232.

Naka Shūzō, Hōsei Okamoto, Kunihiro Yamagata, Kuiei Hamasaki, Kōkichi Gōhara, and Katsushi Sakakibara, "Hainantō ni okeru nettai shinkei suijaku no kenkyū," Taiwan igakkai zasshi, 40: (December 1941), 32-58.

Nakamura Seiji, "Teikoku rigaku kenkyūjo setsuritsu no hitsuyō," in Seikatsu, kagaku, kyōiku. Tokyo: Kawade Shobō, 1938, 10-30.

Nitto Shūichi, "Ningen Hōjō Tamio," Iji Kōron, 1390, (March 1939). 
Nitto Shūichi, "Seinen raii no shuki," in Bōkyōka, ed. Shikiba Ryūzaburō. Tokyo: Sangabō, 1939, 352-374.

Nishikawa Shōji, "Raue hanten,” Shisō, III (March 1936), 103-106.

Ogata Kōan, Korori chijun. Osaka: Tekiteki Saizō, 1858.

Okudaira Hiroshi, Kōshū eisei sankō yōsho. Tokyo: Kyōeidō, 1885.

Okumura Nichiki, "Taiwan ni okeru nettai baidoku no mondai (hontōjin no hikaku seishinbyōgakuteki kenkyū I),” Seishin shinkeigaku zasshi, 15: 11 (November 1941), $650-657$.

Okumura Nichiki, "Taiwan in okeru shinkishō (shinkeishitsu) no tōkei (Hontōjin no hikaku seishinbyōgakuteki kenkyū II)," Seishin shinkeigaku zasshi, 45: 11 (November 1941), 658-667.

Ōta Kiyoyuki, "Kuretchumeru shi santaikei no shisūteki hyōgen to honpō naichijin no taikei," Shinkeigaku zasshi, 36: 5 (1933), 393-431.

Ota Kōsaku, Korera yobō kokoro egusa, Tokyo: Tokyo Shinto Jimu Bun Kyoku, 1880.

Prince Kotohito of Kan-in, "Opening Address," in Proceedings of the Third PanPacific Science Congress, ed. National Research Council of Japan. (Tokyo, October 30-November 11, 1926). Tokyo, 1928, 65-66.

Rikugun Daijin Kanbō, Rikugun Seiki ruijū dai jūsan rui basei, dai jūyon rui un'yu, tsūshin, dai jū-go rui keiho, chōhatsu. Tokyo: Rikugun Daijin Kanbō, 1929-1940.

Sakurai Jōji, "Kokka to rigaku,” Tōkyō Gakushi kaiin zasshi, 21: (1899), 1-20.

Sakurai Jōji, "Inaugural Address," in Proceedings of the Third Pan-Pacific Science Congress, ed. National Research Council of Japan. (Tokyo, October 30-November 11, 1926). Tokyo: National Research Council of Japan, 1928, 68-75.

Sakurai Jōji, Omoide no kazukazu: Danshaku Sakurai Jōji ikō. Tokyo: Kyūwa Kai, 1940.

Sams, Crawford F., "Medic": The Mission of an American Military Doctor in Occupied Japan and Wartorn Korea. New York: M. E. Sharpe, 1998.

Sanbō Honbu, Shiberia Shuppeishi: Taishō 7-nen ri itaru 11-nen, 3 vols. (1924). Tokyo: Shinjidaisha, 1972.

Sankyō Hyakunenshi Henshū Iinkai (ed.), Sankyō hyakunenshi. Tokyo: Dainippon Publishers, 2000.

Shiberia Shuppei eisei shi, vol. 1. Eisei kinmu. Tokyo: 1924.

Shikiba Ryūzaburō, "Raisha no igaku to bungaku," in Bōkyōka, ed. Shikiba Ryūzaburō. Tokyo: Sangabō, 1939, 293-312.

Shikiba Ryūzaburō, Shukumei no geijutsu. Tokyo: Shōwa Kankō Kai, 1943.

Shimizu Sakae, "Oboegaki Arakatsu ken" [Notes: Arakatsu Lab], 1944.

Shimomura Kōtarō, Fallen Leaves. Kyoto: William Blackwood \& Sons, 1914.

Shimomura Kōtarō, My View of Religion. Tokyo: Minyusha, 1931.

Shimomura Kōtarō, Reikon fumetsukan. Tokyo: Dairinsha, 1939.

"Shina Jihen no keii," Taiwan jihō, (September 1937), 166-181.

"Shina no hai-Nichi bu-Nichi ni tsuite: Rikugunshō Chōsahan chōsa," Naigai shiryō chōsa, 4: 1 (January 1932), 72-129.

"Shinbun kiji torishimari no ken," Bōeishō Bōei Kenkyūjo, Rikugunshō Dainikki. Dai nikki kōshū, Taishō 11 nen (December 1922). Dai nikki kōshū (C02031073800). Ajia Rekishi Shiryō Sentā.

Shina Takeo, "Z kenkyū: Satsujin kōsen hiwa," in Ichioku nin no Shōwa shi: 10 Fukyoka shahin shi. Tokyo: Mainichi Shinbunsha, 1977, 239-241.

Shionogi Pharmaceutical Company (ed.), Shionogi hyakunen. Osaka: Shionogi Seiyaku, 1978. 


\section{Bibliography}

de Souza-Araujo, H. C., Leprosy: Survey Made in Forty Countries (1924-1927). Rio de Janerio: Oswaldo Cruz Institute, 1929.

Stratz, Carl H., Die Korperformen in Kunst und Leben der Japaner. Stuttgart: F. Enke, 1902.

Sugawara Sagae, Shiberia shuppeishi yō. Tokyo: Kaikōsha, 1925.

Sugihara Manjirō, "Taikei to seishin to no kankei ni tsuite no chiken," hoi dai ikkai hōkoku, Shinkeigaku zasshi, 31: 4 (1931), 457-498.

Sugihara Manjirō, "Taikei to seishin to no kankei ni tsuite no chiken," hoi dai nikkai hōkoku (Jukeisha ni okeru taikei to seishin ni tsuite no kansatsu), Shinkeigaku zasshi, 34: 3 (1932), 255-294.

Sugihara Manjirō, "Taikei to seishin to no kankei ni tsuite no chiken," hoi dai sankai hōkoku (hanzai to taikei narabi ni seishin to no kankei), Shinkeigaku zasshi, 34: 5 (1932), 423-465.

Taishō Nyūsu Jiten Henshū Iinkai (ed.), Taishō nyūsu jiten, vol. 3, Taishō 6-nen-Taishō 7-nen, Tokyo: Mainichi Komyunikēshonzu, 1987.

Taishō Nyūsu Jiten Henshū Iinkai (ed.), Taishō nyūsu jiten, vol. 4, Taishō 8-nen-Taishō 9-nen. Tokyo: Mainichi Komyunikēshonzu, 1987.

Takase Kiyoshi, "Sōutsubyō no ippanteki tōkei" (1-5), Seishin shinkeigaku zasshi, 22: 2-5 (1922), 37-41, 9-20, 2-24, 20-32, 51-56.

Takeda Pharmaceutical Company (ed.), Takeda nihyakunen. Osaka: Takeda Yakuhin Kōgyō Kabushiki Kaisha, 1984.

Takano Rokurō, “Jobun,” in Raijin bungaku, ed. Nagami Yutaka. Takamatsu: Oshima Ryōyōjo Kanja Isha Kai, 1937.

Takano Rokurō, "Sannin no onna," Iji kōron, 1390, (March 1939).

Takano Rokurō, Isha no kuroyaki. Tokyo: Kibundō Shobō, 1943.

Takizaka Yōnosuke, "Raisha no tanka," Shakai jigyō no tomo, 149: (April 1941), 78-81.

Tanabe Seiyaku Shashi Hensan Iinkai (ed.), Tanabe Seiyaku Sanbyaku-gojūnenshi. Osaka: Tanabe Seiyaku Kabushiki Kaisha, 1983.

Ten Kate, Herman F., "Die Pigment Flecken de Neugeborenen," Globus, 81: (1902), 238-240.

Ten Kate, Herman F., "Die blauen Geburtsflecken," Globus, 87: (1905), 53-58.

Ten Kate, Herman F., "Neue Mitteilungen über den blauen Geburtsfleck," Zeitschrift für Ethnologie, 37: (1905), 756-758.

Terada Torahiko, "Acoustical Investigation of the Japanese Bamboo Pipe, syakuhati," Journal of the College of Science, Imperial University of Tokyo, Japan, 21: (1907), 1-34.

Terada Torahiko, "On the Transmission of X-rays Through Crystals," Proceedings of the Tokyo Mathematico-Physical Society, 7: (1913), 60-71.

Thompson, Warren S., The Danger Spots in World Population, New York: Knopf, 1929.

Thompson, Warren S., "Future Adjustments of Population to Resources in Japan," Memorial Fund Quarterly, 28: (1950), 191-202.

Tōa Igaku, vols. 1-25, 1939-41.

Tōa Igaku Kyōkai no setsuritsu ni tsuite, Tōa Igaku: Kōki 2600-nen Kaikō Gakuen 5-shūnen kinen jidai igo shi dai 16-go gappon. Tokyo: Tōa Igaku Kyōkai, 1940.

Tomita Pharmaceutical Company (ed.), Tomita Seiyaku Hyakunenshi no ayumi. Naruto: Tomita Seiyaku Kabushiki Kaisha, 1992.

Tomonaga Sin-itiro, "Kagakusha no jiyū na rakuen," in Tomonaga Sin-itiro chosakushū, vol. 6. Tokyo: Misuzu Shobō, 1981, 2001, 224-235.

Tomonaga Sin-itiro, "Wagashi wagatomo," in Tomonaga Sin-itiro chosakushū, vol 1. Tokyo: Misuzu Shobō, 2001, 193-202. 
Tomonaga Sin-itiro, Yamazaki Fumio, Takeuchi Masa, Sakata Shoichi, Nakayama Hiromi, and Tamaki Hidehiko, "Nishina sensei o shinonde," Shizen, 6: 4 (1951), 64-76. Tomonaga Sin-itiro, Oda Minoru, Takeuchi Masa, Kumagai Hiroo, Yamazaki Fumio, Sugimoto Asao, Ishii Chihiro, and Fujimoto Yōichi, "Nishina sensei to kakubutsuri no hatten: Nishina Yoshio sensei no 10 shūnen o mukaete 1 \& 2," Shizen, 26: 4 (1971), 55-76.

Toyama Mikio, Iryōfukushi no so Nagayo Sensai. Kyoto: Shibunkaku, 2002.

Tsuboi Shōgorō, "Koropokkuru Hokkaidō ni sumi shinarubeshi," Tokyo jinruigaku hōkoku, 12: (1887), 93-97.

Uchida Morita (Mamoru), "Bungei ni yoru raikanja no seishin kaihō undo," in Shakai jigyō kenkyū, 25: 9 (August 1937), 122-127.

Uda Mititaka, "Umi no butsurigaku no chichi: Terada sensei no omoide," Shisō, 166: (March 1936), 61-67.

Uemura Masaaki, "Oboegaki: Arakatsu ken” [Notes: Arakatsu Lab], 1943.

Wardle, H. Newell, "Evanescent Congenital Pigmentation in the Sacro-Lumbar Region," American Anthropologist, New Series, 4: (1902), 412-420.

Watase Tsuenekichi, Ebina Danjō sensei. Tokyo: Ryūginsha, 1938.

Yakazu Dōmei (ed.), Tōa Igaku Kyōkai 60-nen no ayumi. Tokyo: Tōa Igaku Kyōkai, 1998.

Yamada Otozo, Saikinsen yō heiki no jumbi oyobi shiyō no kado de kisosareta moto Nihongun gunjin no jiken ni kansuru kōhan shorui. Moscow: Gaikokugo Kokusho Shuppansho, 1950.

Yukawa Hideki, "Nishina sensei no omoide," in Yukawa Hideki chosakushū, ed. Katō Shūichi. Tokyo: Iwanami Shoten, 1989 [1951], 96-100.

Yukawa Hideki, Tabibito: Aru butsurigakusha no kaisō. Tokyo: Kodansha, 1966.

Yukawa Hideki, Creativity and Intuition: A Physicist Looks at East and West, trans. John Bester. Tokyo, New York and San Francisco, CA: Kodansha International, 1973.

"Zen sensen ni akueki ryūkō: Shōsotsu kanja issen yomei ni tassu," Fukuoka nichinichi, October 24, 1918.

Zenkoku Ken’yūkai Rengōkai Hensan Iinkai (ed.), Nihon kenpei seishi. Tokyo: Zenkoku Ken'yūkai Rengōkai Honbu, 1976.

\section{Secondary sources}

731 Butai Kokusai Shinpojiumu Jikko Iinkai (ed.), Nihongun no saikinsen, dokugasusen: Nihon no Chūgoku shinnryaku to sensō hanzai. Tokyo: Akashi Shoten, 1996.

Abel, Jonathan E., Redacted: The Archives of Censorship in Transwar Japan. Berkeley, CA: University of California Press, 2012.

Adachi Noboru et al., "Mitochondrial DNA Analysis of Jomon Skeletons from the Funadomari Site, and its Implication for the Origins of Native American," American Journal of Physical Anthropology, 138: (2009), 255-265.

Agamben, Giorgio, Homo Sacer: Sovereign Power and Bare Life, trans. Daniel Heller-Roazen. Stanford, CA: Stanford University Press, 1998.

Agamben, Giorgio, Remnants of Auschwitz: The Witness and the Archive, trans. Daniel Heller-Roazen. New York: Zone Books, 2002.

Anno Kazuyuki, "Itsu, dare ga, nan no tame ni ken'etsu shita no ka," Makuhari, Japan: Kanda Zatsugaku Daigaku. Online at: www.kanda-zatsugaku.com/110128/ 0128.html (accessed June 25, 2012). 


\section{Bibliography}

Anderson, Warwick, Colonial Pathologies: American Tropical Medicine, Race, and Hygiene in the Philippines. Durham, NC: Duke University Press, 2006.

Aoki Fukiko, 731. Tokyo: Shinchōsha, 2005.

Aoki Hiroshi, "Dai niji sekai taisen chū no kagaku dōin to Gakujutsu Kenkyū Kaigi no kenkyū han," Shakai keizai shigaku, 72: (2006), 331-353.

Arai Ikuzō, Hōkoku shoshū: Naichi ni okeru Chōsenjin to sono hanzai ni tsuite, Shihō kenkyū, dai 5 shū. Tokyo: Shihōshō Chōsaka, 1927.

Arai Yuki, Kakuri no bungaku: Hansen-byō ryōyōsho no jiko hyōgen shi. Tokyo: Shoshi Arusu, 2011.

Ariyama Teruo, Kindai jānarizumu no kōzō: Osaka Asahi shinbun hakkō jiken zengo. Tokyo: Tokyo Shuppan, 1995.

Ariyama Teruo, Senryō-ki media shi kenkyū. Tokyo: Kashiwa Shobō, 1996.

Askew, David, "Debating The 'Japanese' Race in Meiji Japan: Toward a History of Early Japanese Anthropology," in The Making of Anthropology in East and Southeast Asia, ed. Shinji Yamashita, Joseph Bosco, and J. S. Eades. New York: Berghahn Books, 2003, 57-89.

Ballhatchet, Helen, "Confucianism and Christianity in Meiji Japan: The Case of Kozaki Hiromichi," Journal of the Royal Asiatic Society of Great Britain and Ireland, 2: (1988), 349-369.

Barenblatt, Daniel, A Plague Upon Humanity: The Secret Genocide of Axis Japan's Germ Warfare Operation. New York: Harper Collins, 2004.

Barnes, Trevor and Jeremy Crampton, "Mapping Intelligence: American Geographers and the Office of Strategic Services and GHQ/SCAP (Tokyo)," in Reconstructing Conflict: Integrating War and Post-War Geographies, ed. Scott Kirsch and Colin Flint. London: Ashgate, 2011, 227-251.

Bärnighausen, Till, Medizinische Humanexperimente der japanischen Truppen für biologische Kriegsführung in China 1932-1945. New York: Peter Lang, 2002.

Barry, John M., The Great Influenza: The Story of the Deadliest Pandemic in History. New York: Penguin Books, 2005.

Bartholomew, James R., "The Nobel Candidacy of Katsusaburō Yamagiwa, 1863-1930," unpublished manuscript.

Bartholomew, James R., The Formation of Science in Japan: Building a Research Tradition. New Haven, CT and London: Yale University Press, 1989.

Bartholomew, James R., "Science and Technology as Cognitive Domains in Japan: A Comparative Perspective," Senri Ethnological Studies, (1998).

Bartholomew, James R., "Japanese Nobel Candidates in the First Half of the Twentieth Century," Osiris, Second Series, 1: 3 (1998), 238-284.

Bartholomew, James R., "Katsusaburo Yamagiwa's Nobel Candidacy: Physiology or Medicine in the 1920s," in Historical Studies in the Nobel Archives: The Prizes in Science and Medicine, ed. Elisabeth Crawford. Tokyo: University Academy Press, 2002, 103-131.

Bartholomew, James R., "Towards a History of Meiji Scientists in Japan," in Xavier's Legacies: Catholicism in Modern Japanese Culture, ed. Kevin M. Doak. Seattle, WA: University of Washington Press, 2011.

Barzun, Jacques, Race: A Study in Modern Superstition. New York: Harcourt, Brace, 1937.

Bashford, Alison, "Global Biopolitics and the History of World Health," History of the Human Sciences, 19: (2006), 67-88. 
Bashford, Alison, "Nation, Empire, Globe: The Spaces of Population Debate in the Interwar Years," Comparative Studies in Society and History, 49: (2007), 170-201.

Bashford, Alison, "World Population, World Health and Security: 20th-Century Trend," Journal of Epidemiology and Community Health, 62: (2008), 187-190.

Bashford, Alison, Global Population: History, Geopolitics, and Life on Earth. New York: Columbia University Press, 2014.

Bay, Alexander R., Beriberi in Modern Japan: The Making of a National Disease. Rochester, NY: University of Rochester Press, 2012.

Bergstrom, Sune, "Opening Address," The Nobel Foundation: Les Prix Nobel, 1981. Stockholm: Almqvist \& Wiksell International, 1982.

Beveridge, Allan, "A Brief History of Psychiatry Through the Arts," in Mental Health, Psychiatry and the Arts: A Teaching Handbook, ed. Victoria Tsichler. London: Radcliffe Publishing, 2010, 11-24.

Bevis, W. M., "Psychological Traits of the Southern Negro with Observations as to Some of his Psychoses," American Journal of Psychiatry, 78: (1921/2), 69-78.

Blackbourn, David and Geoff Eley, The Peculiarities of German History: Bourgeois Society and Politics in Nineteenth-Century Germany. Oxford: Oxford University Press, 1984.

Bourdaghs, Michael K., The Dawn that Never Comes: Shimazaki Tōson and Japanese Nationalism. New York: Columbia University Press, 2003.

Bowers, John Z., Medical Education in Japan, from Chinese Medicine to Western Medicine. New York: Hoeber, 1965.

Bowers, John Z., "The Adoption of German Medicine in Japan: The Decision and the Beginning," Bulletin of the History of Medicine, 5: 3 (1979), 57-80.

Bowers, John Z., When the Twain Meet: The Rise of Western Medicine in Japan. Baltimore: Johns Hopkins University Press, 1980.

Bragg, William. L., "The Diffraction of Short Electromagnetic Waves by a Crystal," Proceedings of the Cambridge Philosophical Society, 17: (1913), 43-57.

Bratfosand, Ole and John Otto Haug, "The Course of Manic-depressive Psychosis: A Follow Up Investigation of 215 Patients," Acta Psychiatrica Scandinavica, 44: 1 (1968), 89-112.

Braw, Monica, The Atomic Bomb Suppressed: American Censorship in Occupied Japan. Armonk, NY: M. E. Sharpe, 1991.

Brody, Howard, et al., "Map-Making and Myth-Making in Broad Street: The London Cholera Epidemic, 1854," The Lancet, 356: 9223 (2000), 64-68.

Broman, Thomas Hoyt, The Transformation of German Academic Medicine, 1750-1820. Cambridge: Cambridge University Press, 1996.

Brown, Julie V., "Revolution and Psychosis: The Mixing of Science and Politics in Russian Psychiatric Medicine, 1905-1913," The Russian Review, 46: (1987), 283-302.

Brown, Laurie M., "Nuclear Forces, Mesons, and Isospin Symmetry," in Twentieth Century Physics, vol. 1, ed. Laurie M. Brown et al. New York: American Institute of Physics Press, 1995, 357-419.

Brown, Laurie M., et al. (eds), "Yukawa's Prediction of the Meson," Centaurus, 25: 1/2 (1981), 71-132.

Brown, Laurie M., et al. (eds), Elementary Particle Theory in Japan, 1930-1960, Progress of Theoretical Physics Supplement no. 105. Kyoto: Yukawa Institute for Theoretical Physics, 1991. 
Brown, Philip C., "Never the Twain Shall Meet: European Land Survey Techniques in Tokugawa Japan," Chinese Science, 9: (1989), 53-79.

Burns, Susan L., "From 'Leper Villages' to Leprosaria: Public Health, Nationalism, and the Culture of Exclusion in Japan," in Isolation: Places and Practices of Exclusion, ed. Carolyn Strange and Alison Bashford. Oxford: Routledge, 2003, 104-118.

Burns, Susan L., "Rethinking 'Leprosy Prevention': Entrepreneurial Doctors, Popular Journalism, and the Civic Origins of Biopolitics," Journal of Japanese Studies, 38: 2 (2012): 301-332.

Byerly, Carol R., Fever of War: The Influenza Epidemic in the U.S. Army during World War I. New York: New York University Press, 2005.

Bynum, W. F., Science and the Practice of Medicine in the Nineteenth Century. Cambridge: Cambridge University Press, 1996.

Chaiklin, Martha, "A Miracle of Industry: The Struggle to Produce Sheet Glass in Modernizing Japan," in Building a Modern Japan: Science, Technology, and Medicine in the Meiji Era and Beyond, ed. Morris F. Low. New York: Palgrave Macmillan, 2005, 161-182.

Chaiklin, Martha, "Traditional Japanese Footwear: Purity and Pollution," in Shoes: A History from Sandals to Sneakers, ed. Peter McNeil and Giorgio Riello. Oxford and New York: Berg Publishers, 2006, 160-181.

Chaiklin, Martha, "Up in the Hair: Strands of Meaning in Ornamental Hair Accessories in Early Modern Japan," in Asian Material Culture in Context, ed. Elizabeth Bedford, Marianne Hulsbosch, and Martha Chaiklin. Amsterdam: University of Amsterdam, 2009, 37-64.

Chin, Hsien-Yu, "Colonial Medical Police and Postcolonial Medical Surveillance Systems in Taiwan, 1895-1950s," Osiris, 13: (1998), 326-338.

Churchill, Frederick B., "Rudolf Virchow and the Pathologist's Criteria for the Inheritance of Acquired Characteristics," Journal of the History of Medicine, 31: (1976), 117-148.

Clancey, Gregory K., Earthquake Nation: The Cultural Politics of Japanese Seismicity, 1868-1930. Berkeley, CA: University of California Press, 2006.

Clunan, Anne L., Peter R. Lavoy, and Susan B. Martin (eds), Terrorism, War, or Disease? Unraveling the Use of Biological Weapons. Stanford, CA: Stanford University Press, 2008.

Cohen, Paul A., History in Three Keys: The Boxers as Event, Experience, and Myth. New York: Columbia University Press, 1997.

Coleman, Samuel, Japanese Science: From the Inside. London: Routledge, 1999.

Colwell, Rita, "Global Climate and Infectious Disease: The Cholera Paradigm," Science, New Series, 274: (1996), 2025-2031.

Colwell, Rita, "Infectious Disease and Environment: Cholera as a Paradigm for Waterborne Disease," International Microbiology, 7: (2004), 285-289.

Connelly, Matthew, "Seeing Beyond the State: The Population Control Movement and the Problem of Sovereignty," Past and Present, 193: (2006), 197-233.

Connelly, Matthew, "To Inherit the Earth: Imagining World Population, from the Yellow Peril to the Population Bomb," Journal of Global History, 1: (2006), 299-319.

Connelly, Matthew, Fatal Misconception: The Struggle to Control World Population. Cambridge, MA: Belknap Press of Harvard University Press, 2008.

Crawford, Elisabeth, Nationalism and Internationalism in Science, 1880-1939. Cambridge: Cambridge University Press, 1991. 
Crosby, Alfred, America's Forgotten Pandemic: The Influenza of 1918, 2nd edn. New York: Cambridge University Press, 2003.

Cullather, Nick, The Hungry World: America's Cold War Battle Against Poverty in Asia. Cambridge, MA: Harvard University Press, 2010.

Cyranoski, David, "Nobel Officials Recoil from Expenses Offer," Nature, 414: 6865 (December 13, 2001), 676.

Darrigol, Olivier, "Yukawa, Tomonaga, and the Japanese School of Theoretical Physics," in Seimitsu kagaku no shisō. Tokyo: Iwanami Shoten, 1994, 211-230.

Darwin, Charles, The Life and Letters of Charles Darwin, 3 vols. London: John Murray, 1987.

Davis, Kingsley, "The Theory of Change and Response in Modern Demographic History," Population Index, 29: (1963), 345-366.

Ding Lei, "Kindai Nihon no tai-Chū iryō bunka katsudō: Dōjinkai kenkyū 1," Nihon igakushi zasshi, 45: 4 (December 1999), 543-62.

Dinmore, Eric Gordon, "A Small Island Nation Poor in Resources: Natural and Human Resource Anxieties in Trans-World War II Japan,” Ph.D. diss., Princeton University, 2006.

Doak, Kevin M., A History of Nationalism in Modern Japan: Placing the People. Leiden: Brill, 2007.

Donaldson, Peter J., Nature Against Us: The United States and the World Population Crisis, 1965-1980. Chapel Hill, NC: University of North Carolina Press, 1990.

Donnan, Frederick G., "Baron Joji Sakurai," Nature, 44: (August 5, 1939), 234-235.

Dreq, Edward (ed.), Researching Japanese War Crimes Records: Introductory Essays. Washington, DC: Nazi War Crimes and Japanese Imperial Government Records Interagency Working Group, 2006.

Eckart, Wolfgang Uwe, Deutsche Ärzte in China 1897-1914: Medizin als Kulturmission im Zweiten Deutschen Kaiserreich. Stuttgart: G. Fischer, 1989.

Edgerton, David, The Shock of the Old: Technology and Global History Since 1900. London: Oxford University Press, 2006.

Endō Takahisa et al., "Kyōsei no ba to shite no ryōyōjo no 'syakai-ka' wo kangaeru tame ni," Hansen-byō shimin gakkai nenpō 2008, Osaka, 2009.

Forman, Paul, "The Discovery of the Diffraction of X-rays by Crystals," Archive for History of Exact Sciences, 6: (1969), 38-71.

Forman, Paul, "Weimar Culture, Causality, and Quantum Theory: Adaptation by German Physicists and Mathematicians to a Hostile Environment," Historical Studies in the Physical and Biological Sciences, 3: (1971), 1-115.

Forman, Paul, "Kausalität, Anschaulichkeit, and Individualität, or How Cultural Values Prescribed the Character and Lessons Ascribed to Quantum Mechanics," in Society and Knowledge, ed. Nico Stehr and Meja Volker. New Brunswick, NJ: Transaction Books, 1984, 333-347.

Foucault, Michel, The Birth of the Clinic: An Archaeology of Medical Perception. New York: Vintage Books, 1993.

Francks, Penelope, Technology and Agricultural Development in Pre-War Japan. New Haven, CT: Yale University Press, 1984.

Freeman, Christopher, Technology, Policy, and Economic Performance: Lessons from Japan. London and New York: Pinter Publishers, 1987.

Fritz, Stephen G., "Frankfurt," in The 1918-1919 Pandemic of Influenza: The Urban Impact in the Western World, ed. Fred R. van Hartesveldt. Lewiston, NY: Edwin Mellen Press, 1992, 13-32. 
Frühstück, Sabine, Colonizing Sex: Sexology and Social Control in Modern Japan. Berkeley, CA: California University Press, 2003.

Fuchs, Steven J., "Feeding the Japanese: Food Policy, Land Reform, and Japan's Economic Recovery," in Democracy in Occupied Japan: The U.S. Occupation and Japanese Politics and Society, ed. Mark E. Caprio and Yoneyuki Sugita. London: Routledge, 2007, 26-47.

Fujimura Takashi, Race for Empire: Koreans as Japanese and Japanese as Americans during World War II. Berkeley, CA: University of California Press, 2011.

Fujino Yutaka, Nihon fashizumu to iryō: Hansen-byō o meguru jisshōteki kenkyū. Tokyo: Iwanami Shoten, 1993.

Fujino Yutaka, Nihon faashizumu to yūsei shisō. Kyoto: Kamogawa Shuppan, 1998.

Fujino Yutaka, "Hansen-byō to kin-gendai Nihon," in Hansen-byō: Haijo, sabetsu kakuri no rekishi, ed. Kazuteru Okiura and Susumu Tokunaga. Tokyo: Iwanami Shoten, 2001, 51-71.

Fujino Yutaka, Hansen-byō to sengo minshu shugi. Tokyo: Iwanami Shoten, 2006.

Fukagawa Shin’yo, Kan-Yō igaku tōsōshi: Seiji tōsō hen. Tokyo: Iseisha, 1981.

Fukui Shizuo et al. (eds), Kimitsu heiki no zenbo: waga gunji kagaku gijutsu no shinso to hansei, (II). Tokyo: Kyōyōsha, 1952.

Furuta Makoto, "Kampō wa Nihon de dokuji no hattatsu o shita rinshō igaku," Online at: http://kampo-ikai.jp/kampo_towa (accessed September 18, 2011).

Gakujutsu Kenkyū Kaigi (ed.), Scientific Japan: Past and Present, prepared in connection with the Third Pan-Pacific Science Congress, Tokyo, 1926. Kyoto, 1926.

Gates, Reginald R., "Studies in Race Crossing: IV. Crosses of Chinese, Amerindians and Negroes, and Their Bearing on Racial Relationships," Zeitschrift für Morphologie und Anthropologie, 47: 3 (1956), 233-315.

Geertz, Clifford, Works and Lives: The Anthropologist as Author. Stanford, CA: Stanford University Press, 1988.

George, Timothy S., Minamata: Pollution and the Struggle for Democracy in Postwar Japan, Harvard East Asian Monographs. Cambridge, MA: Harvard University Asia Center, 2002.

Gerschenkron, Alexander, Economic Backwardness in Historical Perspective: A Book of Essays. Cambridge, MA: Belknap Press of Harvard University Press, 1962.

Gluck, Carol, Japan's Modern Myths: Ideology in the Late Meiji Period. Princeton, NJ: Princeton University Press, 1985.

Gomer, Robert, John W. Powell, and Bert V. A. Röling, "Japan's Biological Weapons: 1930-1945," Bulletin of the Atomic Scientists, (1981), 43-53.

Goodwin, Frederick K. and Kay Redfield Jamison, Manic-Depressive Illness: Biopolar Disorders and Recurrent Depression. Oxford: Oxford University Press, 2007.

Gordon, Andrew, Labor and Imperial Democracy in Prewar Japan. Berkeley, CA: University of California Press, 1991.

Gordon, Andrew, A Modern History of Japan: From Tokugawa Times to the Present. New York: Oxford University Press, 2003.

Gordon, Andrew, "Managing the Japanese Household: The New Life Movement in Post-War Japan," in Gendering Modern Japanese History, ed. Barbara Molony and Kathleen Uno. Cambridge, MA: Harvard University Asia Center, 2005, 423-451.

Gould, Tony, A Disease Apart: Leprosy in Modern World. New York: St. Martin's Press, 2005. 
Greenhalgh, Susan, "The Social Construction of Population Science: An Intellectual, Institutional, and Political History of Twentieth-century Demography," Comparative Study of Society and History, 38: (1996), 22-66.

Greenhalgh, Susan, Just One Child: Science and Policy in Deng's China. Berkeley, CA: University of California Press, 2008.

Greenhalgh, Susan, and Edwin A. Winckler, Governing China's Population: From Leninist to Neoliberal Biopolitics. Stanford, CA: Stanford University Press, 2005.

Grob, Gerald, The Deadly Truth: A History of Disease in America. Cambridge, MA: Harvard University Press, 2002.

Grunden, Walter E., "Science Under the Rising Sun: Weapons Development and the Organization of Scientific Research in World War II," Ph.D. diss., University of California, Santa Barbara, 1998.

Grunden, Walter E., Secret Weapons and World War II: Japan in the Shadow of Big Science. Lawrence, KS: University Press of Kansas, 2005.

Guillemin, Jeanne, Biological Weapons: From the Invention of State-Sponsored Programs to Contemporary Bioterrorism. New York: Columbia University Press, 2005.

Gunji Yoko (ed.), "Shōgen” 731 Ishii butai. Tokyo: Tokuma Shoten, 1982.

Gussow, Zachary, Leprosy, Racism, and Public Health: Social Policy in Chronic Disease Control. Boulder, CO: Westview Press, 1989.

Haensch, Stephanie, et al., "Distinct Clones of Yersinia Pestis Caused the Black Death," PLoS Pathogens, 6: 10 (2010), 1-8.

Haga Shōji, Meiji Ishin to shukyō. Tokyo: Chikuma Shobo, 1994.

Hager, Thomas, The Alchemy of Air: The Jewish Genius, a Doomed Tycoon, and the Scientific Discovery that Fed the World but Fueled the Rise of Hitler. New York: Broadway Books, 2009.

Hamlin, Christopher, Cholera: The Biography. Oxford: Oxford University Press, 2009.

Hanihara Kazurō, Ainu wa gen nihonjin ka: Atarashii nihonjinron no tameni. Tokyo: Shōgakukan, 1982.

Hanihara Kazurō, "Emishi, Ezo and Ainu: An Anthropological Perspective," Japan Review, 1: (1990), 35-48.

Hanihara Kazurō, "Dual Structure Model for the Population History of the Japanese," Japan Review, 3: (1991), 1-33.

Hanke, Christine, "Zwischen Evidenz und Leere," in Der Gesellschaftskörper: Zur Neuordnung und Geschlecht um 1900, ed. H. Bubliz et al. Frankfurt: Campus Verlag, 2000, 179-235.

Hanley, Susan, "Urban Sanitation in Preindustrial Japan," Journal of Interdisciplinary History, 18: (1987), 1-26.

Hara Teruyuki, Shiberia shuppei: Kakumei to kanshō 1917-1922. Tokyo: Chikuma Shobō, 1989.

Hardin, Garrett, "The Tragedy of the Commons," Science, New Series, 162: 3859 (1968), 1243-8.

Hargittai, Istvan, The Road to Stockholm: Nobel Prizes, Science, and Scientists. Oxford: Oxford University Press, 2002.

Harris, Sheldon H., Factories of Death: Japanese Biological Warfare 1932-1945 and the American Cover-Up. New York: Routledge, 2002.

Harootunian, Harry, D., "The Economic Rehabilitation of the Samurai in the Early Meiji Period," Journal of Asian Studies, 19: 4 (August 1960), 433-44.

Hata Ikuhiko (ed.), Nihon riku kaigun sōgō jiten, 2nd edn. Tokyo: Tokyo Daigaku Shuppankai, 2005. 
Hayami Akira, Nihon o osotta Supein Infuruenza: Jinrui to uirusu no Dai-ichiji Sekai Taisen. Tokyo: Fujiwara Shoten, 2006.

Hayashi Takeshi, The Japanese Experience in Technology: From Transfer to SelfReliance, Technology Transfer, Transformation, and Development. Tokyo: United Nations University Press, 1990.

Healy, David, Mania: A Short History of Bipolar Disorder. Baltimore, MD: Johns Hopkins University Press, 2008.

Hearn, Lafcadio, The Writings of Lafcadio Hearn. 16 vols. Boston, MA: Houghton, 1922.

Heilbron, J. L. and Robert W. Seidel, Lawrence and His Laboratory: A History of the Lawrence Berkeley Laboratory, vol. 1. Berkeley, CA: University of California Press, 1989.

Hempel, Sandra, The Strange Case of the Broad Street Pump: John Snow and the Mystery of Cholera, Berkeley, CA: University of California Press, 2007.

Henning, Joseph M., "White Mongols? The War and American Discourses on Race and Religion," in The Impact of the Russo-Japanese War, ed. Rotem Kowner. London: Routledge, 2007, 153-166.

Hermsen, Lisa M., Manic Minds: Mania's Mad History and its Neuro-Future. New Brunswick, NJ: Rutgers University Press, 2011.

Hidaka Minoo, Gunki Hogo hō. Tokyo: Hata Shoten, 1937.

Hinokawa Shizue, Saikurotoron kara genbaku e: Kakujidai no kigen o saguru. Tokyo: Sekibundō, 2009.

Hirama Naoki, "Nihon Kampo igaku fukko no korosha: Otsuka Yoshinori sensei to Yakazu Domei sensei." Online at: www.jtcma.org/news/img/2014-4.1.pdf (accessed March 21, 2015).

Hirokawa, Waka, Kindai Nihon no Hansen-byō mondai to chiiki shakai. Osaka: Osaka Daigaku Shuppankai, 2011.

Hiroshige Tetsu, Kagaku no shakaishi: Kindai Nihon no kagaku taisei. Tokyo: Chūō Kōronsha, 1973.

Hirosige Tetu, "Social Conditions for Prewar Japanese Research," in Science and Society in Modern Japan: Selected Historical Sources, ed. Nakayama Shigeru, David L. Swain, and Eri Yagi. Tokyo: University of Tokyo Press, 1971, 202-220.

Hirota Isamu, "Kitao Diro no shōzō: Kishōgaku no idai na sendatsu," Tenki, 57, (2010), 909-916.

Hirota Kōzō, Mantetsu no shūen to sono go: Aru chūō Shikenjo shoin no hōkoku. Tokyo: Seigensha, 1990.

Hoddeson, Lillian, "Establishing KEK in Japan and Fermi Lab in the US: Internationalism, Nationalism and High Energy Accelerators," Social Studies of Science, 13: 1 (February 1983), 1-48.

Hoshi Shin'ichi, Jinjin wa yowashi, kanri wa tsuyoshi. Tokyo: Shinchōsha, 1978.

Howell, David, "Fecal Matters: Prolegomenon to a History of Shit in Japan," in Japan at Nature's Edge: The Environmental Context of a Global Power, ed. Ian Jared Miller, Julia Adeney Thomas, and Brett L. Walker. Honolulu, HI: University of Hawaii Press, 2013, 137-151.

Huffman, James L., Creating a Public: People and Press in Meiji Japan. Honolulu, HI: University of Hawaii Press, 1997.

Huntington, Ellsworth, Civilization and Climate. New Haven, CT: Yale University Press, 1915.

Hwang Min Gi, Tadaima sensō hajime sōrō: Meiji 10-nen no sukūpu gassen. Tokyo: Yōsensha, 2006. 
Iinuma Nobuko, Takamine Jōkichi to sono tsuma. Tokyo: Shin Jinbutsu Ōraisha, 1993.

Iinuma Nobuko, Nagai Nagayoshi to Therese: Nihon yakugaku no kaiso. Tokyo: Yakugakkai, 2003.

Ikai Takaaki, "Sei no kakuri (sex segregation)" to kakuri seisaku: Hanna Rideru (Hannah Riddell) to Nihon no sentaku. Kumamoto: Kumamoto Shuppan Bunka Kaikan, 2005.

Ikeda Yoshimasa, Nihon shakai fukushi shi. Kyoto: Hōritsu Bunkasha, 1986.

Imamura Keiji, Prehistoric Japan: New Perspectives on Insular East Asia. Honolulu, HI: University of Hawaii Press, 1996.

Inglis, Kerri I., Ma’i Lepera: Disease and Displacement in Nineteenth-Century Hawai'i. Honolulu: University of Hawaii Press, 2013.

Inkster, Ian, Japan as a Development Model? Relative Backwardness and Technological Transfer. Bochum: Studienverlag Dr. N. Brockmeye, 1980.

Inoue Toshikazu, Ajia shugi o toinaosu. Tokyo: Chikuma Shōbo, 2006.

Isaac, Benjamin, The Invention of Racism in Classical Antiquity. Princeton, NJ: Princeton University Press, 2004.

Ishibashi Chōei and Ogawa Teizō, Oyatoi gaikokujin: Igaku. Tokyo: Kajima Kenkyūjo Shuppankai, 1969.

Ishimitsu Toru, "Akkāman hakase to nihon no shigen seisaku," Kokumin keizai zasshi, 153: (1986), 1-18.

Ishikawa Masakichi, "Seishinbyō ippan koto ni sōtsubyō no yogo ni tsuite," Seishingaku zasshi, 18: 2 (1919), 28-34.

Ishino Shōgo, "Rijichō goaisatsu." Online at: http://japan-kampo.com/corporation/ topmessage.html (accessed September 18, 2011).

Itakura Kiyonobu, Kimura Tōsaku, and Yagi Eri (eds), Nagaoka Hantarō den. Tokyo: Asahi Shinbunsha, 1973.

Ito Kenji, "Making Sense of Ryōshiron (Quantum Theory): Introduction of Quantum Mechanics into Japan, 1920-1940,” Ph.D. diss., Harvard University, 2002.

Ito Kenji, "Values of 'Pure Science': Nishina Yoshio's Wartime Discourse Between Nationalism and Physics, 1940-1945," Historical Studies in the Physical and Biological Sciences, 33: (2002), 61-86.

Ito Kenji, "The Geist in the Institute: The Production of Quantum Physicists in 1930s Japan," in Pedagogy and the Practice of Science: Historical and Contemporary Perspectives, ed. David Kaiser. Cambridge, MA: The MIT Press, 2005, 151-183.

Ito Kenji, "Superposing Dynamos and Electrons: Electrical Engineering and Quantum Physics in Nishina Yoshio," in Traditions and Transformations in the History of Quantum Physics, ed. Shaul Katzir, Christoph Lehner, and Jürgen Renn. Berlin: Edition Open Access (Max Planck Research Library for the History and Development of Knowledge), 2013, 183-208.

Iwamoto Hiromitsu, "Japanese Southward Expansion in the South Seas and its Relations with Japanese Settlers in Papua and New Guinea, 1919-1940," South Pacific Study, 17: 1 (1996), 29-81.

Izao Tomio, Shoki Shiberia shuppei no kenkyū: "Atarashiki kyūseigun” kōsō no tōjō to tenkai. Fukuoka: Kyūshū Daigaku Shuppankai, 2003.

Izao Tomio, "Shinbun no naka no Shiberia shuppei," Yamaguchi kenritsu daigaku kokusai bunka gakubu kiyō, 12: (2006), 1-12.

Izumi, Yasuhiro, Ai no gōshō-keiei senryaku to seisui. Tokushima: Tokushima Shinbunsha, 1991. 


\section{Bibliography}

Izuo, Masaru, "Medical History: Seishu Hanaoka and His Success in Breast Cancer Surgery Under General Anesthesia Two Hundred Years Ago,” Breast Cancer, 11: 4 (November 2004), 319-324.

Jannetta, Ann Bowman, "From Physician to Bureaucrat: The Case of Nagayo Sensai," in New Directions in the Study of Meiji Japan, ed. Helen Hardacre and Adam L. Kern. Leiden, New York, Köln: Brill, 1997.

Jannetta, Ann Bowman, The Vaccinators: Smallpox, Medical Knowledge, and the "Opening” of Japan. Stanford, CA: Stanford University Press, 2007.

Jinushi Aiko, Nisshin sensō jūgun hiroku: 80-nenme ni kōkai suru, sono inga. Tokyo: Seishun Shuppan, 1972.

Johnson, Jeffrey Allan, The Kaiser's Chemists: Science and Modernization in Imperial Germany. Chapel Hill, NC: University of North Carolina Press, 1990.

Johnson, Steven, The Ghost Map: The Story of London's Most Terrifying Epidemic and How it Changed Science, Cities, and the Modern World. New York: Riverhead Books, 2006.

Jones, Hazel J., Live Machines: Hired Foreigners and Meiji Japan. Vancouver: University of British Columbia Press, 1980.

Josephson, Jason Ananda, The Invention of Religion in Japan. Chicago, IL: Chicago University Press, 2012.

Kabe Sumio, "Nihon no korera-sono rekishi to genjō," Bōei eisei: gijutsu shirizu, 51: 200 (March/April 2004).

Kamoi Takeshi (ed.), Kōgaku hakushi Takamatsu Toyokichi den. Tokyo: Kagaku Kōgyō Jihōsha, 1932.

"Kampō no kaisetsu." Online at: www.nikkankyo.org/kampo/guide_kampo (accessed September 18, 2012).

"Kampō towa: Kanjasama no koko no jōtai o jushishita iryō desu." Online at: www. tsumura.co.jp/kampo/museum/index.htm (accessed September 15, 2011).

Kan Osamu, "Honpō ni okeru seishinbyōsha narabini kinsetsu seru seishinijōsha ni kansuru chōsa," Seishin shinkeigaku zasshi, 41: 10 (October 1937), 793-884.

Kaneko Tsutomu, Ainshutain shokku. Tokyo: Kawadeshobō Shinsha, 1991.

Kaneo Seizō, Nagai Nagayoshi den. Tokyo: Nihon Yakugakkai Hachijūnen Kinengyōji, 1960.

Karlen, Arno, Man and Microbes: Disease and Plagues in History and Modern Times. New York: Simon \& Schuster, 1995.

Kasza, Gregory J., The State and the Mass Media in Japan 1918-1945. Berkeley, CA: University of California Press, 1988.

Katsuki Atsushi, Ryōshirikigaku no shokkō no nakade. Tokyo: Seirinsha, 1991.

Katsuki Atsushi, Sone Take: Wasurerareta butsurigakusha. Tokyo: Sekibundō Shuppan, 2007.

Kawaguchi Kōfū, Meiji zenki Sōtōshū no kenkyū. Kyoto: Hōzōkan, 2002.

Kawakami Kiyoshi Karl, Jokichi Takamine; A Record of His American Achievements. New York: W. E. Rudge, 1928.

Ketelaar, James, Of Heretics and Martyrs in Meiji Japan. Princeton, NJ: Princeton University Press, 1990.

Kevles, Daniel J., “'Into Hostile Political Camps': The Reorganization of International Science in the First World War," Isis, 62: (1971), 47-60.

Kevles, Daniel J., The Physicists: The History of a Scientific Community in Modern America, rev. edn. Cambridge, MA: Harvard University Press, 1995. 
Kikuchi Yoshiyuki, "Joji Sakurai and His British Connections," Kagakushi, 31: (2004), 239-267. [In Japanese.]

Kikuchi Yoshiyuki, "World War I, International Participation and Reorganisation of the Japanese Chemical Community," Ambix, 58: (2011), 136-149.

Kikuchi Yoshiyuki, Anglo-American Connections in Japanese Chemistry: The Lab as Contact Zone. New York and Basingstoke: Palgrave Macmillan, 2013.

Kikuchi Yoshiyuki, "Sakurai Jōji (1858-1939): Leading Chemist and Nō Drama Specialist,” in Britain \& Japan: Biographical Portraits, vol. 9, ed. Hugh Cortazzi. Folkestone: The Renaissance Book, 2014, 425-437.

Kim Boumsoung, Meiji Taishō no Nihon no jishingaku: "Rōkaru saiensu” o koete. Tokyo: Tokyo Daigaku Shuppankai, 2007.

Kim Dong-Won, "Yoshio Nishina and Two Cyclotrons," Historical Studies in the Physical and Biological Sciences, 36: 2 (2006), 243-273.

Kim Dong-Won, Yoshio Nishina: Father of Modern Physics in Japan. New York: Taylor \& Francis, 2007.

Kim Hoi-eun, "Physicians on the Move: German Physicians in Meiji Japan and Japanese Medical Students in Imperial Germany, 1868-1914,” Ph.D. diss., Harvard University, 2006.

"Kindai Chūgoku dentō igaku to Nihon: Minkoku jidai ni okeru Nihon isho no eikyō," Kampō no rinshō, 46: 12 (December 1999), 1928-1944.

Kitanaka Junko, Depression in Japan: Psychiatric Cures for a Society in Distress. Princeton, NJ: Princeton University Press, 2012.

Knightley, Phillip, The First Casualty: The War Correspondent as Hero and MythMaker from the Crimea to Iraq, rev. edn. Baltimore, MD: Johns Hopkins University Press, 2002.

Kobayashi Hideo and Zhang Zhi Qiang (eds), Ken'etsu sareta tegami ga kataru Manshūkoku no jittai. Tokyo: Shōgakkan, 2006.

Konoe Fumimaro, "Tōa Shinchitsujo kensetsu no seimei," in Konoe Shushō enjutsushū, vol. 2, ed. Atsuchi Morishige. Tokyo: Atsuchi Morishige, 1939.

Koseishō Jinkō Mondai Kenkyūjo, Yūsei hogohō shikōgo no jinkō ninshin chuzetsu no jōkyō ni kansuru kenkyū (dai ippō). Tokyo: Koseishō Jinkō Mondai Kenkyūjo, November 10, 1950.

Kosoto Hiroshi, Kampō no rekishi: Chūgoku, Nihon no dentō igaku. Tokyo: Tiashūkan Shoten, 1999.

Kowner, Rotem, "Lighter Than Yellow, But Not Enough: Western Discourse on the Japanese 'Race', 1854-1904,” The Historical Journal, 43: (2000), 103-131.

Kowner, Rotem, "Skin as a Metaphor: Early European Racial Perspectives on Japan, 1548-1853,” Ethnohistory, 51: (2004), 751-778.

Kowner, Rotem, "European Aborigines in Japan? Physiognomy and Racial Affinity in the Discourse on the Ainu, 1548-2000," Historia, 18: (2006), 5-31. [In Hebrew.]

Kowner, Rotem (ed.), The Impact of the Russo-Japanese War. London and New York: Routledge, 2007.

Koyasu Nobukuni, “Ajia” wa dō katararete kitaka: Kindai Nihon no Orientarizumu. Tokyo: Fujiwara Shoten, 2003.

Kragh, Helge, Niels Bohr and the Quantum Atom: The Bohr Model of Atomic Structure. Oxford: Oxford University Press, 2012.

Kreiner, Josef, "European Images of the Ainu and Ainu Studies in Europe," in European Studies on Ainu Language and Culture, ed. J. Kreiner. Munich: Iudicium Verlag, 1993, 13-60. 


\section{Bibliography}

Kudō Akira, Japanese-German Business Relations: Cooperation and Rivalry in the Inter-War Period. London: Routledge, 1998.

Kudo Masaki, "Tsuboi Shōgorō to sono shūhen," Kōkogaku Kenkyū, 24: 3/4 (1977), 190-208.

Kure Shūzō, "Monbushō shitei gakkō kisoku o yomu," in Kure Shūzō chosakushū, dai ni kan, ed. Okada Yasuo. Tokyo: Shibunkyaku Shuppan, 1982, 109-118.

Kure Shūzō and Kashiba Gorō, "Seishinbyōsha shitaku rangoku kanchi no jikkyō oyobi sono tōkeiteki kansatsu (shō)," in Kure Shūzō chosakushū, dai ni kan, ed. Okada Yasuo. Tokyo: Shibunkyaku Shuppan, 1982, 164-186.

Kuro Ieski (ed.), Who's Who Hakushi in Great Japan, 1888-1922: Biographical Dictionary, vol. 2. Tokyo: Hattensha, 1922.

Kuryū Rakusen'en Jichikai (ed.), Fūsetsu no mon: Kuryū Rakusen'en kanja 50-nenshi. Gunma: Kuryū Rakusen'en Jichikai, 1982.

LaFleur, William R., Gernot Böhme, and Susumu Shimazono (eds), Dark Medicine: Rationalizing Unethical Medical Research. Bloomington, IN: Indiana University Press, 2007.

Latour, Bruno, The Pasteurization of France, trans. Alan Sheridan and John Law. Cambridge, MA: Harvard University Press, 1988.

Latour, Bruno, "Where Are the Missing Masses? The Sociology of a Few Mundane Artifacts," in Technology and Society: Building Our Sociotechnical Future, ed. Deborah G. Johnson and Jameson M. Wetmore. Cambridge, MA: MIT Press, 2009, 151-180.

Law, John, "Actor Network Theory and Material Semiotics," in The New Blackwell Companion to Social Theory, ed. B. S. Turner. Chichester: Wiley-Blackwell, 2009, $141-158$.

Li Xiejing and Tabuchi Isoo, "Chūgokujin no Nihon ryōgaku no hyakunen: Rekishiteki kiseki to genzai no ryūgaku jijō nit suite," Nara Kyōiku Daigaku Kiyō, 46: 1 (1997), 22-23.

Liang Yongxuan and Mayanagi Makoto, "Okada Kōshō to Shinmatsu no Nitchū igaku kōryū shiryū," Nihon ishigaku zasshi, 51: 1 (2005), 25-49.

Liu, Michael Shiyung, Prescribing Colonization: The Role of Medical Practices and Policies in Japan-Ruled Taiwan, 1895-1945. Ann Arbor, MI: Association for Asian Studies, 2009.

Low, Morris, Science and the Building of a New Japan: Studies of the Weatherhead East Asian Institute, Columbia University, 1st edn. New York: Palgrave Macmillan, 2005.

Majima Toshiyuki (Rikō), "Waga shōgai no kaiko," Kagaku no ryōiki, 8: (1954), 1-11 and 137-146.

Marchand, Suzanne L., German Orientalism in the Age of Empire. Cambridge: Cambridge University Press, 2009.

Maruyama Kōsaku, "Ayamari data 'kiseichu hatsugen setsu' de jushō," in Noberusho hikari to kage, ed. Kagaku Asahi Henshū Bu. Tokyo: Asahi Shinbunsha, 1981, 17-26.

Martin, Emily, Bipolar Expeditions: Mania and Depression in American Culture. Princeton, NJ: Princeton University Press, 2009.

Marx, Leo and Merritt Roe Smith (eds), Does Technology Drive History? Cambridge, MA: MIT Press, 1994.

Masaike Akira, "Rekishi no shōkei: senryōgun ni yoru Nihon no genshikaku kenkyū chōsa (IIl) Beikoku Kokuritsu Kōbunshokan nado no hozonbunshi 6 yori," Nihon butsuri gakkaishi, 65: 7 (2010), 567-9. 
Masaike Akira, "Senryōgun ni yoru Nihon no genshikaku kenkyu no chōsa" (part 1), Japanese Journal of Physics Society, 65: 5 (2010), 362-364.

Masaike Akira, "Senryōgun ni yoru nihon no genshikaku kenkyu no chōsa" (part 2), Japanese Journal of Physics Society, 65: 6 (2010), 467-469.

Masaike Akira, "Senryōgun ni yoru nihon no genshikaku kenkyu no chōsa" (part 3), Japanese Journal of Physics Society, 65: 7 (2010), 567-569.

Matsubara Yoko, "Nihon ni okeru yūsei seisaku no keisei - kokumin yūseihō to yūsei hogohō no seiritsu katei no kentō," Ph.D. diss., Ochanomizu University, 1997.

Matsumoto Miwao, Technology Gatekeepers for War and Peace: The British Ship Revolution and Japanese Industrialization, St. Antony's Series. Basingstoke, New York and Oxford: Palgrave Macmillan (in association with St. Antony's College), 2006.

Matsumura Hiroyuki, "Kokubō kokka' no yūseigaku: Koya Yoshio wo chūshin ni," Shirin, 83: (2000), 102-132.

Matsumura Tomokatsu, Kanton gun sanbō fukuchō no shūki. Tokyo: Fuyo Shobo, 1977.

Matsusaka Yoshihisa Tak, The Making of Japanese Manchuria, 1904-1932. Cambridge, MA: Harvard University Asia Center, 2001.

Matsushima Eiichi, "Shiberia shuppei, Kome Sōdō, sekai taisen shūketsu," in Taishō nyūsu jiten, vol. 3, Taishō 6-nen-Taishō 7-nen, ed. Taishō Nyūsu Jiten Henshū Iinkai. Tokyo: Mainichi Komyunikēshonzu, 1987, 28-33.

Mayanagi Makoto, "Kampō ya Tōyō igaku to yobu iware." Online at: www2.tokyoweb. or.jp.secom-Kampōu/dangi.html (accessed September 15, 2011).

Mayanagi Makoto, "Kindai Chūgoku dentō igaku to Nihon: Minkoku jidai ni okeru Nihon isho no eikyō," Kanpō no rinshō, 46: 12 (1928). Online at: http://mayanagi. hum.ibaraki.ac.jp/paper01/minkoku.htm (accessed May 14, 2015).

Mayanagi Makoto, "Seiyō igaku to Tōyō igaku." Online at: http://mayanagi.hum. ibaraki.ac.jp/paper04/sinica97-11.html (accessed September 15, 2011).

Mayanagi Makoto, "Shinkoku makki ni okeru Nihon Kampō igaku shoseki no dennyu to hensen," in Yakazu Dōmei sensei kiju kinen bunshū, ed. Hosokawa Kiyoji and Kudo Kunimasa. Aizuwakamatsu: Onchikai, 1983, 643-661.

Meissner, Kurt, Deutsche in Japan, 1639-1960. Tokyo: Deutsche Gesellschaft fur Natur- und Volkerkunde Ostasiens, 1961.

Merton, Robert K., Social Theory and Social Structure. New York: Free Press, 1968.

Miki Kinji, "Hōkoku shoshū: Naichi ni okeru Chōsenjin to sono hanzai ni tsuite," Shihō kenkyū, Dai 17 shū. Tokyo: Shihōshō Chōsaka, 1933.

Mimura, Janis, Planning for Empire Reform Bureaucrats and the Japanese Wartime State. Ithaca, NY: Cornell University Press, 2011.

Mishima Yūichi, Kusuri no Osaka Doshōmachi. Osaka: Izumi Shoin, 2006.

Mitchell, Richard H., Censorship in Imperial Japan. Princeton, NJ: Princeton University Press, 1983.

Miura Un'ichi, "The Problem of Acclimatization of the Japanese in Manchuria," The China Medical Journal, (1927), 794-797.

Miura Un'ichi, Waga kokumin no manmō imin to fūdo tekigō mondai. Mukden, 1933, n.p.

Mizoguchi Hajime, "The Population Problem and the Birth Control Program During the Occupation," in The Occupation Period 1945-1952, vol. 1, A Social History of Science and Technology in Contemporary Japan, ed. Nakayama Shigeru, Gotō Kunio, and Yoshioka Hitoshi. Melbourne: Trans Pacific Press, 2001, 395-410.

Mizuno Hiromi, Science for the Empire: Scientific Nationalism in Modern Japan. Stanford, CA: Stanford University Press, 2009. 


\section{Bibliography}

Moore, Aaron Stephen, Constructing East Asia: Technology, Ideology, and Empire in Japan's Wartime Era, 1931-1945. Stanford, CA: Stanford University Press, 2013.

Moore, Ray A. and Donald L. Robinson, Partners for Democracy: Crafting the New Japanese State Under MacArthur. Oxford: Oxford University Press, 2002.

Moran, Michelle T., Colonizing Leprosy: Imperialism and the Politics of Public Health in the United States. Chapel Hill, NC: The University of North Carolina Press, 2007.

Mori Masataka and Yoshia Kasukawa (eds), Chūgoku-gawa shiryō Chūgoku shin'ryaku to 731 butai no saikinsen. Tokyo: Asahi Shoten, 1995.

Morris-Suzuki, Tessa, The Technological Transformation of Japan: From the Seventeenth to the Twenty-First Century. Cambridge, New York: Cambridge University Press, 1994.

Morris-Suzuki, Tessa, "Debating Racial Science in Wartime Japan," Osiris, 13: (1998), 354-375.

Motsuki Akimoto, "Seishu Hanaoka, a Japanese Pioneer in Anesthesia," Anesthesiology, 32: 5 (May 1970), 446-49.

Muramatsu Teijiro, Westerners in the Modernization of Japan. Tokyo: Hitachi Ltd, 1995.

Murashima Shigeru, “Anglo-Japanese Alliance, 1895-1923," in History of AngloJapanese Relations, 1600-2000, ed. Ian Nish and Yoichi Kibata. Basingstoke: Palgrave Macmillan, 2000, 159-196.

Murayama Satoshi, Chōsenjin no shisō to seikaku. Chōsa shiryō, dai nijū shū. Keijō: Chōsen Sōtokufu, 1927.

Nagase-Reimer, Keiko, Forschungen zur Nutzung der Kernenergy in Japan, 1938-1945. Marburg: Japan-Zentrum Philipps-Universität Marburg, 2002.

Nagayo Mataro, "Yamagiwa Katsusaburo sensei shoden," in Tokyo Teikoku Daigaku Byōrigaku Kyōshitsu 50-nenshi, vol. 1, Tokyo Teikoku Daigaku Byōrigaku Kyōshitsu gojūnenshi, ed. Nagayo Matarō. Tokyo: Tokyo Teikoku Daigaku, 1939, 223-281.

Nakamura, Ellen Gardner, Practical Pursuits: Takano Chōei, Takahashi Keisaku, and Western Medicine in Nineteenth-Century Japan. Cambridge, MA: Harvard University Asia Center, 2005.

Nakamura Mari, "Koya Yoshio to minzoku seibutsugaku," Seibutsugakushi kenkyū nōto, 12: (1967), 8-14.

Nakamura Shigeru, Kusatsu "yorokobi no tani” no monogatari: Kon'uōru-rī (Cornwall-Leigh) to hansen-byō. Tokyo: Kyōbunkan, 2007.

Nakane Ryōhei, Nishina Yūichiō, Nishina Kōjirō, Yazaki Yūji, and Ezawa Hiroshi (eds), Nishina Yoshio Ōfukushokanshū, 3 vols. Tokyo: Misuzu Shobō, 2006-2011.

Nakano Ryoko, Beyond the Western Liberal Order: Yanaihara Tadao and Empire as Society. Basingstoke: Palgrave Macmillan, 2013.

Nakaoka Tetsuro, Science and Technology in the History of Modern Japan: Imitation or Endogenous Creativity? Tokyo: U.N. Press, 1980.

Nakayama Shigeru, A History of Japanese Astronomy; Chinese Background and Western Impact. Harvard-Yenching Institute Monograph Series 18. Cambridge, MA: Harvard University Press, 1969.

Nakayama Shigeru, Science, Technology, and Society in Postwar Japan. London: Kegan Paul, 1991.

Nakayama Shigeru, Gotō Kunio, and Yoshioka Hitoshi, A Social History of Science and Technology in Contemporary Japan. Japanese Society Series. Melbourne: Trans Pacific Press, 2001.

Nanasanichi Kenkyukai (ed.), Saikinsen butai. Tokyo: Banseisha, 1996. 
Narangoa Li, "Japanese Geopolitics and the Mongol Lands, 1915-1945," European Journal of East Asian Studies, 3: (2004), 45-67.

National Taiwan University, "The History Wall of the College of Public Health of Taiwan National University Inaugurated," 2006. Online at: www.ntu.edu.tw/engv4/ spotlight/2011/e110823_1.html.

Newman, Barclay M., Japan's Secret Weapon. New York: Current Publishing Co., 1944.

Nie Jing-Bao (ed.), Japan's Wartime Medical Atrocities: Comparative Inquiries in Science, History, and Ethics. London: Routledge, 2010.

Nie Lili, Chūgoku minshū no sensō kioku: Nihongun no saikinsen ni yoru kizuato. Tokyo: Akashi Shoten, 2006.

Nihon Jinkō Gakkai Sōritsu 50-shūnen Kinen Jigyō Iinkai (ed.), Nihon Jinkō Gakkai 50-nenshi. Tokyo: Nihon Jinkō Gakkai, 2002.

"Nihon Tōhō Igakkai ni tsuite." Online at: www.jptoho.or.jp/zaidan/gakkai/index1. html (accessed September 15, 2011).

Nishikawa Takashi, Kusuri no shakaishi: Jinbutsu to jiji de yomu 33 wa. Tokyo: Yakuji Nippo-sha, 2010.

Nishimura Hidekazu, "Kaisetsu," in Ryūkōsei kanbō: "Supein kaze" dai ryūkō no kiroku, ed. Naimushō Eiseikyoku. Tōyō Bunko, 1922; Tokyo: Heibonsha, 2008.

Nisio Shigeko, Kagaku jānarizumu no senkusha: Hyōden Ishiwara Jun. Tokyo: Iwanami Shoten, 2011.

Nohara Hiromu, Roman to jōnetsu ni ikita yakugaku no chichi, Kono hito Nagai Nagayoshi. Tokyo: Creative Books, 2008.

Norgren, Tiana, Abortion Before Birth Control: The Politics of Reproduction in Post-War Japan. Princeton, NJ: Princeton University Press, 2001.

Notehelfer, Frederick G., "Ebina Danjō: A Christian Samurai of the Meiji Period," in Papers on Japan from Seminars at Harvard University, vol. 2. Cambridge, MA: Harvard University East Asia Center, 1963, 1-56.

Nye, Joseph S. Jr., Soft Power: The Means to Success in World Politics. New York: Public Affairs, 2004.

O'Bryan, Scott, The Growth Idea: Purpuse and Prosperity in Post-War Japan. Honolulu, HI: University of Hawaii Press, 2009.

Oakley, Deborah, "American-Japanese Interaction in the Development of Population Policy in Japan, 1945-1952,” Population and Development Review, 4: (1978), 617-643.

Obayashi Michiko, Josanpu no sengo. Tokyo: Keisō Shobo, 1989.

Obayashi, Michiko, "Sengo nihon no kazoku keikaku fukyū katei ni kansuru kenkyū," Ph.D. diss., Ochanomizu University, 2006.

Oberlander, Christian, "The Rise of Scientific Medicine in Japan: Beriberi as the Driving Force in the Quest for Specific Causes and the Introduction of Bacteriology," Historia Scientarium: International Journal of the History of Science Society of Japan, 13: 3 (March 2004).

Odagiri Hiroyuki and Akira Gotō, Technology and Industrial Development in Japan: Building Capabilities by Learning, Innovation, and Public Policy. Oxford: Clarendon Press; Oxford University Press, 1996.

Ogawa Teizō and Sakai Shizu (eds), Matsumoto Jun jiden, Nagayo Sensai jiden. Tokyo: Heibonsha, 1980.

Ogino Miho, "Kazoku keikaku eno michi," Shisō, 925: (2001), 169-195.

Ogino Miho, "Hanten shita kokusaku: kazoku keikaku undō no tenkai to kiketsu," Shisō, 955: (2003), 175-195. 
Ogino Miho, “'Umeyo fuyaseyo' kara 'kazoku keikaku' e: Jinkō kanri no seijigaku,” in Sei to seishoku, kokka no seisaku, ed. Emiko Namihira. Tokyo: Frontiers of Gender Studies, Ochanomizu University, 2006, 127-136.

Ogino Miho, "Kazoku keikaku” eno michi. Tokyo: Iwanami Shoten, 2008.

Ogino Miho, "Jinkō seisaku no sutoratejī 'umeyo fuyaseyo' kara 'kazoku keikaku e," in Tekuno/baio poritikkusu: kagaku iryō gijutsu no ima, ed. Kaoru Tachi. Tokyo: Sakuhinsha, 2008, 145-159.

Oguma Eiji, Tan'itsu minzoku shin'wa No kigen: Nihonjin no jigazō no keifu. Tokyo: Shin'yōsha, 1995.

Oguma Eiji, A Genealogy of "Japanese” Self-Images, trans. David Askew. Melbourne: Trans Pacific Press, 2002.

Okamoto Takuji, "Sankō jidai no Yukawa Hideki to Tomonaga Sin-itiro," Butsuri, 57: (2002), 419-420.

Okudaira Yasuhiro, Hyōgen no jiyū, vol. 1. Tokyo: Yūhikaku, 1983.

Olin, Saul C., Finlandia: The Racial Composition, the Language, and a Brief History of the Finnish People. Hancock, MI: The Book Concern, 1957.

Onda Hiromasa, Kindai Kampō sōron. Tokyo: Idō no Nihonsha, 1998.

Oreskes, Naomi and John Krige (eds), Science and Technology in the Global Cold War. Cambridge, MA: MIT Press, 2014.

Ōta Masakatsu, 731 menseki no keifu: Saikinsen butai to hizōno fairu. Tokyo: Hyōronsha, 1999.

Otsubo Sumiko, "Feminist Maternal Eugenics in Wartime Japan," US-Japan Women's Journal, English Supplement, 17: (1999), 39-76.

Otsubo Sumiko, "Fighting on Two Fronts: Japan's Involvement in the Siberian Intervention and the Spanish Influenza Pandemic, 1918-1920," in The Decade of the Great War: Japan and the Wider World in the 1910s, ed. Tosh Minohara, Tze-ki Hon, and Evan Dawley. Leiden: Brill, 2014.

Otsubo Sumiko and James R. Bartholomew, "Eugenics in Japan: Some Ironies of Modernity, 1883-1945," Science in Context, 11: 3/4 (1998), 545-565.

Ōtsuka Yoshinori, Kampō hitosuji: 50-nen no chiryō taiken kara. Tokyo: Nihon Keizai Shinbunsha, 1976.

Ozawa Terutomo, Japan's Technological Challenge to the West, 1950-1974: Motivation and Accomplishment. Cambridge, MA: MIT Press, 1974.

Park Jin-kyung, "Corporeal Colonialism: Medicine, Reproduction, and Race in Colonial Korea,” Ph.D. diss., University of Illinois at Urbana-Champaign, 2008.

Patrie, James, The Genetic Relationship of the Ainu Language. Honolulu, HI: University of Hawaii Press, 1982.

Patton, Donald J., "Obituary: Edward A. Ackerman (1911-1973)," Geographical Review, 64: (1974), 150-153.

Pekkanen, Saadia M., Picking Winners? From Technology Catch-Up to the Space Race in Japan. Stanford, CA: Stanford University Press, 2003.

Phillips, Howard and David Killingray (eds), The Spanish Influenza Pandemic of 1918-19: New Perspectives. London: Routledge, 2003.

Pickering, Andrew (ed.), Science as Practice and Culture. Chicago, IL: The University of Chicago Press, 1992.

Pietrusewsky, Michael, "Multivariate Comparisons of Female Cranial Series from the Ryukyu Islands and Japan,” Anthropological Science, 112: 3 (2004), 199-211.

Posel, Deborah, "Race as Common Sense: Racial Classification in Twentieth-Century South Africa," African Studies Review, 44: (2001), 87-113. 
Rasmussen, Anne, "Prevent or Heal, Laissez-Faire or Coerce? The Public Health Politics of Influenza in France, 1918-1919," in Influenza and Public Health: Learning from Past Pandemics, ed. Tamara Giles-Vernick and Susan Craddock. London: Earthscan, 2010, 69-83.

Reed, Christopher, "The United States and the Japanese Mengele: Payoffs and Amnesty for Unit 731 Scientists," Japan Focus. Online at: www.japanfocus.org/products/ details/2177 (accessed September 14, 2012).

Refsing, Kirsten, "Lost Aryans? John Batchelor and the Colonization of the Ainu Language," Interventions: International Journal of Postcolonial Studies, 2: (2000), 21-34.

Rehbock, Philip F., "Organizing Pac Sci: Local and International Origins of the Pac Sci Association," in Nature in its Greatest Extent: Western Science in the Pacific, ed. Roy MacLeod and Philip F. Rehbock. Honolulu, HI: University of Hawaii Press, 1988, 195-221.

Rice, Geoffrey W., "Japan and New Zealand in the 1918 Influenza Pandemic: Comparative Perspectives on Official Responses and Crisis Management," in The Spanish Influenza Pandemic of 1918-19: New Perspectives, ed. Howard Phillips and David Killingray. London: Routledge, 2003, 73-85.

Rice, Geoffrey W. and Edwina Palmer, "Pandemic Influenza in Japan, 1918-1919: Mortality Patterns and Official Responses," Journal of Japanese Studies, 19: 2 (Summer 1993), 389-420.

Rikagaku Kenkyūjo (ed.), Riken gojūnen. Tokyo: Rikagaku Kenkyūjo, 1967.

Rikugun Guni Gakkō (ed.), Rikugun guni gakkō gojūnen shi. Tokyo: Funi Shuppan, 1937.

Rikugunshō, Chōkisen ni kansuru kokumin no kakugo. Tokyo: Rikugunshō Shinbunhan, 1938.

Roberts, Gerrylynn K., “'A Plea for Pure Science’: The Ascendancy of Academia in the Making of the English Chemist, 1841-1914," in The Making of the Chemist: The Social History of Chemistry in Europe, 1789-1914, ed. David Knight and Helge Kragh. Cambridge: Cambridge University Press, 1998, 107-119.

Rosenberg, Charles E., "Foreword," in Mania: A Short History of Bipolar Disorder, ed. David Healy. Baltimore, MD: Johns Hopkins University Press, 2008, xi-xiv.

Rubin, Jay, Injurious to Public Morals: Writers and the Meiji State. Seattle, WA: University of Washington Press, 1984.

Saitō Satoshi, Shinkō kontsuerun RIKEN no kenkyū. Tokyo: Jichōsha, 1987.

Sakano Tōru, Teikoku Nihon to jinruigakusha: 1884-1952-nen. Tokyo: Keisō Shobō, 2005.

Salloum, Ihsan M. and Juan E. Mezzich (eds), Psychiatric Diagnosis: Challenges and Prospects. Chichester: Wiley \& Blackwell, 2009.

Sanders, Edith R., "The Hamitic Hypothesis: Its Origin and Functions in Time Perspective," The Journal of African History, 10: (1969), 521-532.

Sasamoto Ikuo, Hiroko Takahashi, and Masakatsu Yamazaki et al. (eds), Beyond Differences: International Symposium on Nuke Histories in Japan and Korea. Tokyo Institute of Technology, March 7-8, 2009.

Sato Jin, "Formation of the Resource Concept in Japan: Pre-War and Post-War Efforts in Knowledge Circulation,” Sustainability Science, 2: (2007), 151-158.

Sawada Kayo, Sengo Okinawa no seishoku wo meguru poritikkusu: beigun tōchika no shusseiryoku to onnatachi no kōshō. Tokyo: Otsuki Shoten, 2014. 


\section{Bibliography}

Sawai Minoru, "Research and Development in Wartime Japan: Mobilization of Science and Technology and Intensification of Joint Research," Osaka Daigaku Keizaigaku, 54: (2004), 383-409. [In Japanese.]

Schmiedel, Otto, Die Deutschen in Japan. Munich: C. Kuhn, 1920.

Schoen, Johanna, Choice \& Coercion: Birth Control, Sterilization, and Abortion in Public Health and Welfare. Chapel Hill, NC: University of North Carolina Press, 2005.

Schottlaender, Felix, Erwin Von Baelz, 1849-1913. Stuttgart: Ausland und Heimat Verlags-Aktiengesellschaft, 1928.

Sebaly, Kim P., "The Tatas and University Reform in India, 1898-1914," History of Education, 14: (1985), 117-136.

Seligman, C. G., "Anthropological Perspective and Psychological Theory," Journal of the Royal Anthropological Institute of Great Britain and Ireland, 62: (July-December 1932), 193-228.

Seth, Michael J., A Concise History of Modern Korea: From the Late Nineteenth Century to the Present. Plymouth: Rowman \& Littlefield Publishers, 2009.

Shapin, Steven, "Here and Everywhere: Sociology of Scientific Knowledge," Annual Review of Sociology, 21: (1995), 289-321.

Sharpless, John, "World Population Growth, Family Planning, and American Foreign Policy," Journal of Policy History, 7: (2005), 72-102.

Sherwin, Martin J., A World Destroyed: Hiroshima and its Legacies. Stanford, CA: Stanford University Press, 2003.

Shibuya Masayuki, Yakugaku to yakurigaku no bun'ya niokeru Nagai no yakuwari to jūyōsei: Tokuni Nihon nioite. Nichidoku Ishizuze no Rekishi. Tokyo: Nihon Yakugakkai, 2000.

Shimazu Naoko, Japan, Race, and Equality. London: Routledge, 1998.

Shimizu Akitoshi, "Colonialism and the Development of Modern Anthropology in Japan," in Anthropology and Colonialism in Asia and Oceania, ed. Jan Gerhard van Bremen and Akitoshi Shimizu. Richmond: Curzon, 1999, 115-171.

Shimizu Katsuyoshi, Seibutsu heiki bōgyo kenkyū. Tokyo: Fuji Shuppan, 2005.

Smith, Henry DeWitt, Japan's First Student Radicals. Cambridge, MA: Harvard University Press, 1972.

Snail, David, "The Actual Test Was a Success!” The Atlanta Constitution, October 3, 1946.

Snail, David, "Scientists Doubt That A-bomb Story," The Atlanta Constitution, October 4, 1946.

Sommerfeld, Arnold, "Zur Quantentheorie der Spektrallinien," Annalen der Physik, 51: (1916), 1-94.

Soto, M. F., "Hideki Yukawa," in The Nobel Prize Winners: Physics, vol. 2 (19381967), ed. Frank Magill. Pasadena, CA and Englewood Cliffs, NJ: Salem Press, 1989, 563-569.

Speck, Reinhard S., "Cholera," in The Cambridge World History of Human Disease, ed. Kenneth Kiple. Cambridge: Cambridge University Press, 1993.

Stanley, Amy, "Enlightenment Geisha: The Sex Trade, Education, and Feminine Ideals in Early Meiji Japan,” Journal of Asian Studies, 72: 3 (August 2013), 539-562.

Statistics Bureau, Director-General for Policy Planning (Statistical Standards) and Statistical Research and Training Institute, Ministry of Internal Affairs and Communications of Japan, "Jinkō no suii B, Taishō 9 nen kara Heisei 21 nen' and 'Shussei, shibō, shizan, kon'in oyobi rikonsū' (Taishō 14-nen-Heisei 20-nen).” Online at: www.stat.go.jp/data/nenkan/02.htm (accessed September 19, 2011). 
Stegewerns, Dick (ed.), Nationalism and Internationalism in Imperial Japan: Autonomy, Asian Brotherhood, or World Citizenship? London: Routledge Curzon, 2003.

Steinberg, John W., Bruce W. Menning, David Schimmelpenninck van der Oye, David Wolff, and Shinji Yokote (eds), The Russo-Japanese War in Global Perspective: World War Zero, vol. 1. Leiden: Brill, 2005.

Stocking, George W., Victorian Anthropology. New York: Free Press, 1987.

Strachan, Hew, The First World War. New York: Penguin Books, 2003.

Sugita Nozomu, Mantetsu chūō shikenjo: Tairiku ni yume o kaketa otokotachi. Tokyo: Kōdansha, 1990.

Suzuki Akihito, "Family, the State and the Insane in Japan 1900-1945," in Psychiatric Confinement in International Perspective, ed. Roy Porter and David Wright. Cambridge: Cambridge University Press, 2003, 193-225.

Suzuki Hisashi, "Koganei Yoshikiyo sensei to Erwin von Baelz hakushi," Jinruigaku Zasshi, 82: 1 (1974), 1-6.

Swanger, Andrew J., "Undercover: Japanese Unit 731 Used Human Test Subjects to Conduct Biological Warfare Research," World War II, 13: (1998), 62.

Sweeney, Michael S., The Military and the Press: An Uneasy Truce. Evanston, IL: Northwestern University Press, 2006.

Takabayashi Takehiko, Variete: Butsuri hito kotoba. Tokyo: Misuzu Shobō, 1998.

Takeda Hiroko, The Political Economy of Reproduction in Japan: Between Nation-State and Everyday Life. London: RoutledgeCurzon, 2005.

Takahashi Hiroko, Fūinsareta Hiroshima, Nagasaki: Bei kakujikken to minkan bōei keikaku. Tokyo: Gaifusha, 2008.

Takaoka Hiroyuki, Sōryokusen taisei to "fukushi kokka": senjiki nihon no "shakai kaikaku" kōsō. Tokyo: Iwanami Shoten, 2011.

Takeuchi-Demirci, Aiko, "The Transnational Politic of Public Health and Population Control: The Rockefeller Foundation's Role in Japan, 1920s-1950s," Rockefeller Archive Center, Research Reports. Online at: www.rockarch.org/publications/resrep. takeuchi.pdf (accessed December 15, 2009).

Takeuchi-Demirci, Aiko, "The Color of Democracy: A Japanese Public Health Official's Reconnaissance Trip to the US South," Southern Spaces, 18: (2011), 1-22.

Takeuchi-Demirci, Aiko, "From Race Biology to Population Control: The Rockefeller Foundation's 'Public Health' Projects in Japan, 1920s-1950s," in Science, Public Health and the State in Modern Asia, ed. Liping Bu, Darwin H. Stapleton, and Ka-che Yip. London: Routledge, 2012, 113-128.

Takeyama Kyōji, Hōdō denpō ken'etsu hishi: Marugame yūbin kyoku no Nichiro Sensō. Tokyo: Asahi Shinbunsha, 2004.

Takeyama Shin'ichirō, Kampō ijutsu fukkō no riron kaikoban. Tokyo: Sekibundō Shuppan, 1971.

Takezawa Tetsuo and Watada Susumu (eds), Teigin jiken no kenkyū. Tokyo: Banseisha, 1998.

Tama Yasuko, "Kindai kazoku” to bod̄̄ poritikkusu. Kyoto: Sekaishisosha, 2006.

Tamaki Hidehiko and Ezawa Hiroshi (eds), Nishina Yoshio: Nihon no genshi kagaku no akebono. Tokyo: Misuzu Shobō, 2005.

Tamura Yukio, "Manshū ni okeru shusei chūdoku no tōseiteki rinshōteki kansatsu" [originally in Seishin shinkeigaku zasshi, 41: 11 (1937), 129-143], in Chügoku tōhoku kyū manshū ni okeru minzoku to seishinbyō: kyū manshū ika daigaku seishin shinkeika kyōshitsu gyōsekishū, ed. Yukio Tamura. Aomori: Tamurayukio, 1983, 229-244. 


\section{Bibliography}

Tanaka, Kathryn, "Through the Hospital Gates: Hansen's Disease and Modern Japanese Literature," Ph.D. diss., University of Chicago, 2012.

Tanaka, Kathryn, "Contested Histories and Happiness: Leprosy Literature in Japan," Health, Culture and Society, 5: 1 (2013), 99-118.

Tanaka, Kathryn, “Life's First Night' and the Treatment of Hansen's Disease in Japan," The Asia-Pacific Journal, 13: 4 (2015), n.p.

Tanaka, Kathryn, "Roisu Jonsson Erikkson fujin to Nagata Honami: Kirisutokyō senkyōkyoshi to rai bungaku no fukyū," Otemae daigaku ronshū, vol. 15. Nishinomiya: Otemae University, 2015, 119-147.

Tanaka Katsuhito and Masayoshi Masayoshi, Jifuteria yobosetsyu jiken. Tokyo, Kamokame Shuppan, 2011.

Tanaka Yuki, Hidden Horrors: Japanese War Crimes in World War II. Boulder, CO: Westview Press, 1996.

Tanaka Yasuo, "Sakurai Jōji sensei kara kiita koto nado,” Kagakushi, 18, (1991), 232-234.

Tanimoto Masayuki, The Role of Tradition in Japan's Industrialization: Another Path to Industrialization. Japanese Studies in Economic and Social History. Oxford: Oxford University Press, 2006.

Tashiro Yoshinori, "Ko Yamagiwa-kun o kataru," in Tokyo Teikoku Daigaku Byōrigaku Kyōshitsu gojūnen shi, ed. Nagayo Matarō. Tokyo: Teikoku Daigaku Igaku Bu, Byōrigaku Kyōshitsu Gojū Kinen Kai, 1939.

Tatsukawa Shōji, Kinsei yamai zōshi. Tokyo: Heibonsha, 1979.

Tatsukawa Shōji, Meiji iji ōrai. Tokyo: Shinchōsha, 1986.

Terasawa Katsutoshi, Yoshimasu Tōdō no kenkyū: Nihon Kampō sōzō no shisō. Tokyo: Iwanami Shoten, 2012.

Thal, Sarah, Rearranging the Landscape of the Gods: The Politics of a Pilgrimage Site in Japan, 1573-1912. Chicago, IL: Chicago University Press, 2005

Tierney, Robert Thomas, "Introduction," in Tropics of Savagery: The Culture of Japanese Empire in Comparative Frame, Robert Thomas Tierney. Berkeley, CA: University of California Press, 2010, 1-37.

Tōa Shin Chitsujo kensetsu ni kansuru senden hōsaku taikō, in Kokuritsu Kōbunshokan Ajia Rekishi Shiryō Sentō. Online at: www.jacar.go.jp/DAS/meta/image_B02030556 700?IS_KIND=RefSummary\&ISKEY_S1=B02030556700\&IS_STYLE=default\&IS_ TAG_S1=reference_code\& (accessed December 11, 2011).

Tokumaru Tateo and Chūichi Nishimura, "Manshū Ika Daigaku Seishin Shinkeika ni okeru mahisei chihō (shinkō mahi) no rinshōteki, tōkeiteki kansatsu" [originally published in 1940 in Ōnari Kiyoshi kyōju tsuitō ronbunshū], in Chūgoku Tōhoku kyū Manshū ni okeru minzoku to seishinbyō: kyū Manshū Ika Daigaku Seishin Shinkeika kyōshitsu gyōsekishū, ed. Tamura Yukio. Aomori: Tamurayukio, 1983, 260-285.

Toyoda Maho, "Sengo nihon no bāsu kontorōru und̄̄ to Kurarensu Gyaburu: dai 5 kai kokusai kazoku keikaku kaigi no kaisai wo chūshin ni," Jendā shigaku, 6: (2010), 55-70.

Tsuji Tetsuo, Nihon no kagaku shisō: Sono jiritsu eno mosaku. Tokyo: Chūō Kōronsha, 1973.

Tsuneishi Keiichi, Igakushatachi no soshiki hanzai: Kantōgun dai 731 butai. Tokyo: Asahi Shinbunsha, 1999.

Tsuneishi Keiichi, Kagakuheiki hazai. Tokyo: Kodansha, 2003.

Tsuneishi Keiichi, Senjo no ekigaku. Tokyo: Kaimeisha, 2005. 
Tsuneishi Keiichi, "New Facts About US Payoff to Japan's Biological Warfare Unit 731," trans. James Orr, Japan Focus. Online at: www.japanfocus.org/-Tsuneishi-Kei_ ichi/2209 (accessed September 14, 2012).

Tsuneishi Keiichi and Tomizō Asano, Saikinsen butai to jiketsushita futarino igakusha. Tokyo: Shinchōsha, 1982.

Tuge Hideomi, Historical Development of Science and Technology in Japan. Series on Japanese Life and Culture. Tokyo: Kokusai Bunka Shinkokai, 1961.

Tyler, Ian, Reforming the World: the Creation of America's Global Empire. Princeton, NJ: Princeton University Press, 2010.

Uchikawa Yoshimi, Masu media tōsei, 2 vols. Tokyo: Misuzu Shobō, 1973-1975.

Uchikawa Yoshimi, "Terauchi naikaku no genron tōsei," in Taishō nyūsu jiten, vol. 3, Taishō 6-nen-Taishō 7-nen, ed. Taishō Nyūsu Jiten Henshū Iinkai. Tokyo: Mainichi Komyunikēshonzu, 1987, 33-37.

Ushiba Tomohiko (ed.), Tōa Shin Chitsujo to Nihon gaikō seisaku, in Taiheiyō mondai shiryō, vol. 6. Tokyo: Nihon Kokusai Kyōkai, 1939.

Vescovi, Gerhard, Erwin Baelz, Wegbereiter der Japanischen Medizin: Ein Lebensbild. Stuttgart: Gentner, 1972.

Vianden, Hermann Heinrich, Die Einführung der deutschen Medizin im Japan der Meiji-Zeit. Düsseldorf: Triltsch, 1985.

Wakamatsu Usaburō (ed.), Shimomura Sensei Tsuioku roku. Kyoto: Wakamatsu Usaburō, 1938.

Wakatsuki, R., "Welcome Address," in Proceedings of the Third Pan-Pacific Science Congress Tokyo, ed. National Research Council of Japan (Tokyo, October 30-November 11, 1926). Tokyo, 1928, 66-68.

Walker, Brett L., Toxic Archipelago: A History of Industrial Disease in Japan. Weyerhauser Environmental Books. Seattle, WA and London: University of Washington Press, 2010.

Wang Lan, "Kindai Chūgoku shōgyō kyōiku seido no seiritsu," Kōbe Daigaku Kyōiku Gakkai kenkyū ronshū, 8: (2001), 18-19.

Wang, Zuoyue, "Saving China Through Science: The Science Society of China, Scientific Nationalism, and Civil Society in Republican China," Osiris, 2nd Series, 17: (2002), 291-322.

Watanabe Masao, Tokinosu Naoki, and Aso Hajime, Yukawa Hideki to Tomonaga Shin'ichiro. Tokyo: Maruzen Komikku, 1994.

Watts, Sheldon, Epidemics and History: Disease, Power and Imperialism. New Haven, CT: Yale University Press, 1997.

Weikart, Richard, "The Origins of Social Darwinism in Germany, 1859-1895," Journal of the History of Ideas, 54: (1993), 469-488.

Weikart, Richard, From Darwin to Hitler. New York: Palgrave Macmillan, 2004.

Weindling, Paul, Health, Race, and German Politics Between National Unification and Nazism, 1870-1945. Cambridge: Cambridge University Press, 1989.

Weindling, Paul, Darwinism and Social Darwinism in Imperial Germany. Stuttgart: Gustav Fischer, 1991.

White, Gilbert F., "Edward A. Ackerman, 1911-1973," Annals of the Association of American Geographies, 64: (1974), 297-309.

White, Paul, "Ministers of Culture: Arnold, Huxley and Liberal Anglican Reform of Learning," History of Science, 43: (2005), 115-138.

Wilcox, Robert K., Japan's Secret War. New York: William Morrow \& Co., 1985. 


\section{Bibliography}

Williams, Peter and David Wallace, Unit 731: Japan's Secret Biological Warfare in World War II. New York: Free Press, 1989.

Wittner, David G., Technology and the Culture of Progress in Meiji Japan. Routledge/ Asian Studies Association of Australia East Asia Series. London and New York: Routledge, 2008.

Wolff, David, Steven G. Marks, Bruce W. Menning, David Schimmelpenninck van der Oye, John W. Steinberg, and Yokote Shinji (eds), The Russo Japanese War in Global Perspective: World War Zero, vol. 2. Leiden: Brill, 2007.

World Health Organization Cholera Fact Sheet no. 107, July 2012. Online at: www.who.int/mediacentre/factsheets/fs107/en/index.html (accessed August 15, 2012).

World Health Organization Regional Office for South-East Asia, Guidelines for Strengthening Participation of Persons Affected by Leprosy in Leprosy Services. New Delhi: World Health Organization Regional Office for South-East Asia, 2011.

Wrong, Dennis H., "The Oversocialized Conception of Man in Modern Sociology," American Sociological Review, 26: 2 (April 1961), 183-193.

Yakazu Dōmei, Zōho kaitei Meiji 110-nen Kampō igaku no hensen to shōrai: Kampō ryakushi nenpyō. Tokyo: Shun'yōdō, 1979.

Yamamoto Akio, Nihon no kagaku no rekishi, Kagaku aakaibusu - kagaku sōgō shiryōkan no setsuritsu e. Kagakukyōiku Kyōgikai, Kagaku Archive Working Group. Tokyo: Chemical Society of Japan, 2004.

Yamamoto Kiyoko, "Seishoku wo meguru seiji to kazoku hendō," Sonoda gakuen joshi daigaku ronbunshū, 45: (2011), 1-18.

Yamamoto Shun'ichi, Nihon korera shi. Tokyo: Tokyo Daigaku Shuppankai, 1982.

Yamamoto Shun'ichi, Zouho Nihon rai shi. Tokyo: Tokyo Daigaku Shuppankai, 1997.

Yamashita Fumio, Taiheiyō Sensō-shi hiroku: Kakusareta daishinsai. Sendai: Tōhoku Daigaku Shuppankai, 2009.

Yamazaki Masakatsu, Nihon no kakukaihatsu, 1939-1955: Genbaku kara genshiryoku e. Tokyo: Sekibundō, 2011.

Yang Daqing, Technology of Empire: Telecommunications and Japanese Expansion in Asia, 1883-1945. Cambridge, MA: Harvard University Asia Center, 2010.

Yasue Masa'ichi, Kagakusha Nagai Nagayoshi no gyōseki saiginmi: Densetsuteki jinbutsu hyōron o hihansuru. Tokyo: Kagakushi Kenkyū, 1986.

Yonei Teruyoshi, "Kindaika to shūkyō," Tokyo Daigaku shūkyōgaku nenpō, 17: (2000), 47-55.

Yonekura Seiichiro, The Japanese Iron and Steel Industry, 1850-1990: Continuity and Discontinuity. New York: St. Martin's, 1994.

Yoshida Noriaki, Senji tōsei to jānarizumu. Kyoto: Shōwa-dō, 2010.

Young, Louise, Japan's Total Empire Manchuria and the Culture of Wartime Imperialism. Berkeley, CA: University of California Press, 1999.

Young, Louise, "Rethinking Race for Manchukuo: Self and Other in the Colonial Context," in Race, Ethnicity and Migration in Modern Japan, ed. Michael Weiner. New York: RoutledgeCurzon, 2004, 280-295.

Zimmerman, Andrew, Anthropology and Antihumanism in Imperial Germany. Chicago, IL: Chicago University Press, 2001. 


\section{Index}

abortion 129 n. 7, 230-5

Ackerman, Edward A. 228, 231-3, 235, 238

acrolein (chemical) 53-4

Allied Occupation 13, 46; and ABC weapons $213,217,222-4$; and population $227-8,230,233-4.238$

anatomy 157,159

Anglo-Japanese relations 27, 50, 52, 55 anti-contagionism 64

Arakatsu Bunsaku \& Japanese Atomic

Bomb Project 212, 218-23 ff.

Army Technology Review Board (Gijutsu Shinsabu) 53

Army, Imperial Japanese (IJA) 26, 53-4, 57, 169, 171, 173; and censorship 79, 79-80, 85, 86, 89-91; medical bureau 164-6, 168, 172; and traditional medicine 183, 186; see also atomic, biological and chemical weapons

Artillery Department (Ministry of War, Japan) 53

Atkinson, Robert William 51

atomic, biological and chemical (ABC) weapons 9, 13, 57; Army and 212; atomic weapons 218-22; biological and chemical weapons 213-23, 225 n. 19, n. 27

atomic bomb projects 203, 212, 218, $220-3$

bacillus 72,97 n. 51; cholera 63-4, 66-7, 166; leprosy 126; plague 66

Bayer 44

biological and chemical weapons, see atomic, biological and chemical (ABC) weapons

biopolitics 130, 142, 145, 238 birth control 13, 227-39, 242 n. 51; contraceptives 229, 235-7

"Black Dwarfs" (Koropokguru) 158-9

Bohr, Niels 204, 219, 253

Buddhism 242, 244, 252-5

Bureau of Hygiene (Eisei Kyoku) 65, 70

Bush, Vannevar 212

carbolic acid 34, 40, 68, 73, 76, 172 catarrh 12, 73, 164-5, 167-8, 173

Caucasians/Caucasian link 153

censorship 85-92; freedom of the press 82, 83, 93; Hakkō censorship incident 83; Military Secrecy Protection Law (Gunki Hogo hō) 85, 88, 92; Newspaper Act 83, 85; Newspaper Ordinance 83, 85; see also Army, Japanese Imperial, Navy, Japanese Imperial

chemical industry/production 25-7

chemical warfare see atomic, biological and chemical weapons

Christianity 17-24, 29-30, 248

cholera: Edo era 67; and First

Sino-Japanese War 8, 12

colonialism and imperialism 33, 39, 46, 178, 232; and Hansen's disease 131-4; Japan as colonial power 5, 7-9, 51, 58, 98, 111-12; and manic depression 102-8; manic depression and expansionist policy 108-10; medicine \& science in colonies 4, 7, 9-14, 51, $57-8$; and population policy 228,233 , 238-9; and physics 193-5, 207, 244; and race 148; and traditional medicine $187-8$

Confucianism 21, 24, 70, 73-4, 248, 252-5

cyclotron 198, 203, 219, 222 
Dainippon Pharmaceutical Company 34 4, 44-6

Darwin, Charles 150, 156-7

Darwinian theory 152,178

Darwinism 24

demography $228,233-8$

Down's syndrome 158

Einstein, Albert 201, 205, 252

emigration 106, 227-9, 233, 238

Epidemic Prevention and Water

Purification, Department of

(Kwantong Army) 184, 213

eugenics 100, 102, 111, 113 n. 15, 229;

Eugenic Protection Law 230, 234-5;

see also racial and ethnic hierarchies under "race"

Fell, Nobert 217

folk medicine 64

Gamble, Clarence J. 228, 235-8

General Headquarters, Supreme Commander Allied Forces in the Pacific (GHQ-SCAP) 217-18, 228, 230-1, 234, 238; and $\mathrm{ABC}$ weapons 211, 217-18, 222; Economic and

Scientific Section 232; Natural Resources Section 230-1; and population 230-1, 236

germ theory 63,97 n. 51, 133-4, 164-6, 170

German anthropology 157; German Anthropological Congress 154

German medicine 150, 152, 155-9

Gerstein, Kurt 214

Gerstein Report 224 n. 17

Hale, George Ellery 56

Hamitic Caucasoid origins 157

Hankins, Frank 157

Hansen's disease 11, 117, 125-6, 137-41, 145, 146 n. 3; etiology (germ theory); $130,133-4,147$ n. 21; fear of contagion 125-6, 130, 133, 140

Heisenberg, Warner 20, 25-6, 219, 221

Hirosige Tetu (Hiroshige Tetsu) 50-1, 58, 203

Home Ministry (Ministry of Home

Affairs) 65, 69, 74; and censorship 80, 82-3, 85, 89, 92; and cholera 166-7, 171

hospitalization 110, 122
Igakusho (Tokugawa "medical school") 62

Imperial Academy (Teikoku Gakushiin) 48

Imperial Rescript on Education 51

Imperialism see colonialism and imperialism

indeterminacy $80,89,92-3$

indigo industry $41-2,45-6$

influenza (flu, pandemic, and ryūkōsei kanbō) 11, 79-82, 85-6, 88-93, 97 n. 51

Institute for Physical and Chemical Research (Rikagaku Kenkyüjo or RIKEN) 50, 55-6, 198-200, 202-3, 206-7, 219-23

Inter-Allied Research Council 56

Ishiguro Tadanori 63, 194

Ishiwara Jun 201-2

Japan Society for the Promotion of Science (Nihon Gakujutsu Shinkōkai or GAKUSHIN) 50, 58, 222, 224

Japanese Army Medical Bureau 164-6, 168,172

Japanese Occupation (China, Korea, Manchuria) 115 n. 73, 182

Japanese Population Problem Council 234

Japanese, coarse type, fine type 154

Jinruigaku no tomo (Friends of Anthropology) 158

Kaiser Wilhelm Institute 44, 218

kampō 175-87; Kampō Revival Movement 176, 180, 187; Kampō to Kan'yaku (Kampō and Kampō Drugs) 182, 184, 187

Kitao Diro (Jirō) 196

Klein-Nishina Formula (for Compton Effect) 202, 219

Koch, Robert 64, 66, 164, 166

Koch's postulates 72

Korea 3, 5, 26, 98-9, 118, 128; character/ criminality and 102-3, 133; and Hansen's disease 133; and manic depression 101-2, 105-8, 111

Korera yobō no satoshi (Admonitions Regarding Cholera Prevention) 64, 69, 75,78 n. 32

korori, mikka korori (cholera) 62, 63, 68

Kōshū eisei sankō yōsho (Essential

Reference for Public Health) 65

$k \bar{s}$ shu eisei see "public health"

Koya Yoshio 228, 231, 234-8 
Kraepelin, Emil 99-101, 103, 110-11

Kretschmer, Ernst 103-4, 114 n. 37, n. 40

Kumamoto School 20-2

Law Concerning the Prevention of Leprosy 119

laws of nature (tennen no dōri) 71, 252

lebensraum 13, 229, 232-4

leper colony/village 118-19, 123-34

leprosy see Hansen's disease

leprosy literature 130, 136-9, 146 n. 6

Leprosy Prevention Law 119

Malayan-Mongol type 154

Malthusianism 228, 230-2

Manchu-Korean type 157

Manchukuo 58, 184, 215 and manic depression 99, 105-6, 108, 111, and traditional medicine $176-8,182,185$

Manchurian Incident 50

Manhattan Project 221

manic depression 11, 99-108, 110-12, 114 n. 40

maternal health 234

medical practices, imperial/colonial 130 , $133,140,182,184$

mikka korori see kororii, cholera

Ministry of Health and Welfare (Japan) 34,234

Ministry of War (Japan) 52-3, 86

Mitsuda Kensuke 126, 131, 145

Mongolian/Mongolian race 154-5, 157

Mongolism see Down's syndrome

Mukden (Shenyang) POW camp 215

Nagaoka Hantarō 197-8, 200-1, 205-6, 219

Nagayo Sensai 35-6, 48 n. 37, 65, 70

Nakamura, Seiji 198-9

Naikoku Pharmaceutical Company 34, $36,38-42,45,48$ n. 26

nanshin doctrine of expansion 115 n. 73; and manic depression 108-10

(Taiwan)

nation and illness $67,110,122,130-1$, 133-4, 181

National Institute of Public Health 228, 234

National Research Council of Japan (Gakujutsu Kenkyū Kaigi or GAKKEN) 50, 56, 57-9, 59 n. 3

Navy, Imperial Japanese 212; and atomic bomb project 220-1; and censorship 85; and cholera 170-1; and depression
109; see also atomic, biological and chemical weapons

New East Asian Order and traditional medicine 12, 176, 178, 184, 188

Nishina Yoshio 4, 198, 202-4, 206, 212, 218-23

Nissen dōso ron (Japanese common ancestry with the Chinese and Koreans) 159

Nobel Prizes: awards and nominations (Japan) 1-2, 244-7, 249, 251-5; Japanese struggles for recognition 246-7; in medicine or physiology 244, 249, 251-2; post-war investigation of 222 ; in physics $194,200,219,223$,

252-5; prominence in Japan; 13, 245-6

Nomonhan and chemical weapons 215-16 non-Caucasian 107

Notestein, Frank W. 231, 236

nuclear physics 203,220

Ōmori, Fusakichi 58, 61 n. 49

Osaka Pharmaceutical 38

overpopulation and poverty 14 n. 4,66 , $125,230-3,239$

pandemic (see influenza)

pathogen (byōdoku) 63, 68, 72, 164, 166-8, 172

Pettenkofer, Max von 63-4

pharmaceutical industry $33,35,38,46$

physical anthropology 156, 162 n. 29

population: control 13, 228, 231, 233-6, 239; governance 227-9, 234, 238-9; management $8,227-8,233,237-9$; policy 228, 232, 237-8; pressure 9, 232-3; problem 228-34, 237; reverse selection 230, 235; science 13, 227 , 232-3, 237-9

public health (kōshū eisei) 76, 80, 108, 134, 136, 229; and cholera 73; policy $\&$ infrastructure $62-7,92,120,228$, 234-7; Public Health \& Welfare Section, GHQ 236

quarantine hospitals $73,76,134,137$, $166,171-3$

race 155-7, 159; racial and ethnic hierarchies: degeneration $8,12,98-9$, 108; discourse on 9, 148, 152-3, 159; eugenics 102; Harry H. Laughlin 113 n. 15 ; stigmata 150 ; theorization 156-7 Ranpō (Dutch Medicine) 43, 175 
research: anthropological 148, 150, 152-3, 155-7, 159; and atomic, biological and chemical warfare $211,213,216,218$, 220-4; and industry 26, 44, 54-9; institutions of 50, 54-9, 182, 186; and leprosy 122; and manic depression 102-12; originality in Japanese research 9, 195, 197; and population 227-8, 231, 235-8; scientific research tradition and community 4-5, 170, 193-5

RIKEN (see Institute for Physical and Chemical Research)

Rockefeller Foundation 228, 236

Russo-Japanese War 10, and censorship 85; and chemistry 51-5; and Japanese Nobel nominations 246;

ryūkōsei kanbō see influenza

Sanders, Murray 211, 217, 225 n. 38, n. 39 Sanders Report 225 n. 34, n. 39

Sankyō Pharmaceutical Company 40, 41, 46

science (rigaku) 52, 208; Cold War and 8, 232; scientific diplomacy 56, 61 n. 54; scientific Japan 58; science, technology and science (STS) frameworks 15 n. 12, 51, 227, 239 n. 2; and social studies of science 193

scientific medicine 164, 166-7, 169, 172

scientific research see Research

Shimoyama Jun'ichirō 43-4

Siberia/Siberian intervention 11, 79-81, 86-92

Siemens, Werner 198

Sino-Japanese War (First Sino-Japanese War, 1894-5) 51, 175

smallpox 62, 64

South Manchuria Railway Central Laboratory 55, 60 n. 31, n. 33

Sugamo Mental Hospital 101, 110

Supreme Commander for the Allied Powers (SCAP) see General Headquarters, Supreme Commander Allied Forces

Suzhou National Medical Hospital (Suzhou Guoyi Yiyuan) 183-5

Suzuki Umetarō 46
Taeuber, Irene B. 236

Taiwan 105, 108-12, 118, 128, 133, 170

Takamine Jōkichi 2, 40, 46, 198

Takushoku University 177, 181-4, 186-7

Terada Torihiko 199-201

Thompson, Arvo 217, 225 n. 38

Thompson Report 225 n. 34, n. 39

Thompson, Warren S. 228, 231-3, 235, 238, 241 n. 22 , n. 31

Three Model Village Study 235, 242 n. 52

Tokyo Academy (Tokyo Gakushi Kaiin) 52

Tokyo Imperial University 43, 207 n. 9

Tomita Kyūzaburō 42-4

Tomita Pharmaceutical Company 34, 42-5, 48 n. 34

Tomonaga Sin-itiro 204-6

traditional medicine see kanpō

vaccination $62-4$

von Hofmann, August Wilhelm 36, 42

War Crimes Trials (Tokyo Trials, The International Military Tribunal for the Far East (IMTFE) 216, 217, 222; Khabarovsk War Crime Trials 211, 216

Water Purification Unit 213-14, 224 n. 17

Water sanitation 35

World War I 10, 51, 202; and ABC weapons 214-15; Koreans and 103; Sakurai Jōji and, 55-7; and news regulation 85; and RIKKEN 198

World War II (Pacific War) 5-6, 9, 13, 50; and $\mathrm{ABC}$ weapons 211-12, 215, 218-20, 223; Sino-Japanese Conflict (Second Sino-Japanese War, 1937-45) $59,180,187$; and population policy 227, 229-30

Yamagiwa, Katsusaburō 36, 240-52

Yellow Peril 150, 153

Yukawa, Hideki 204-6, 212, 244, 247-8, 252-5

Zensei Hospital (Zenshō-en) 130, 134, 140 